a

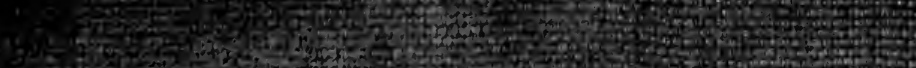
10.

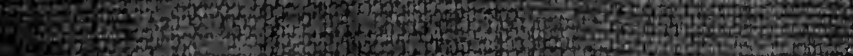

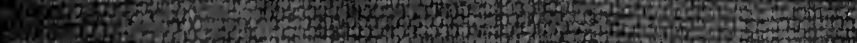
3.25

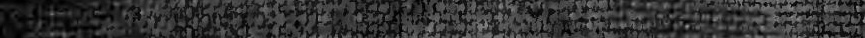
23-30

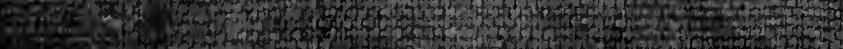

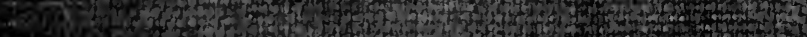

2.1.2.

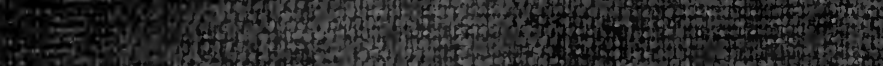
-

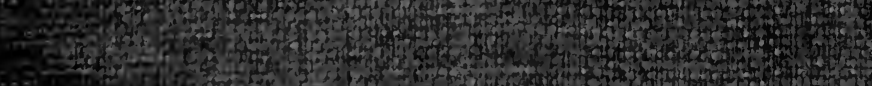

- 1 -

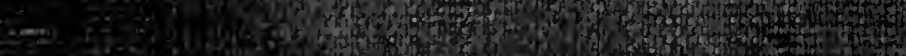

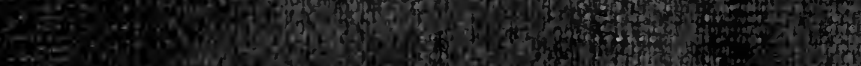
-

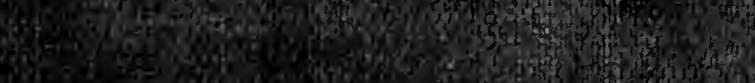

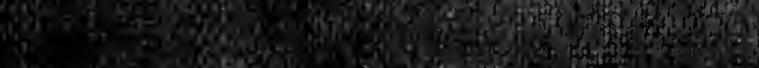

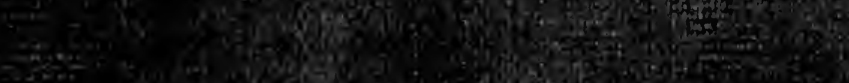

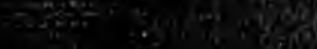

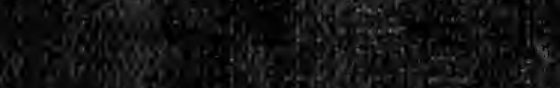

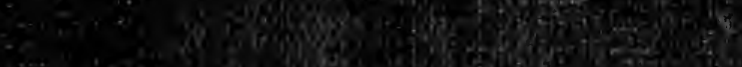

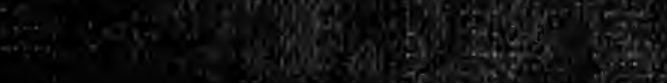

(5) thes

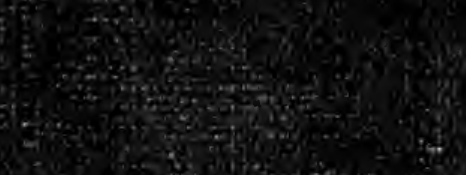
2.0.

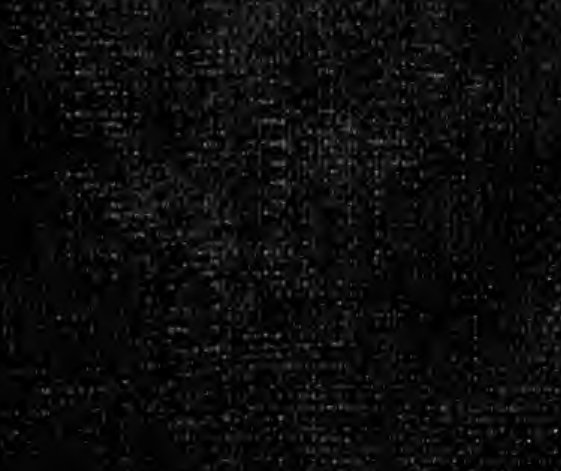




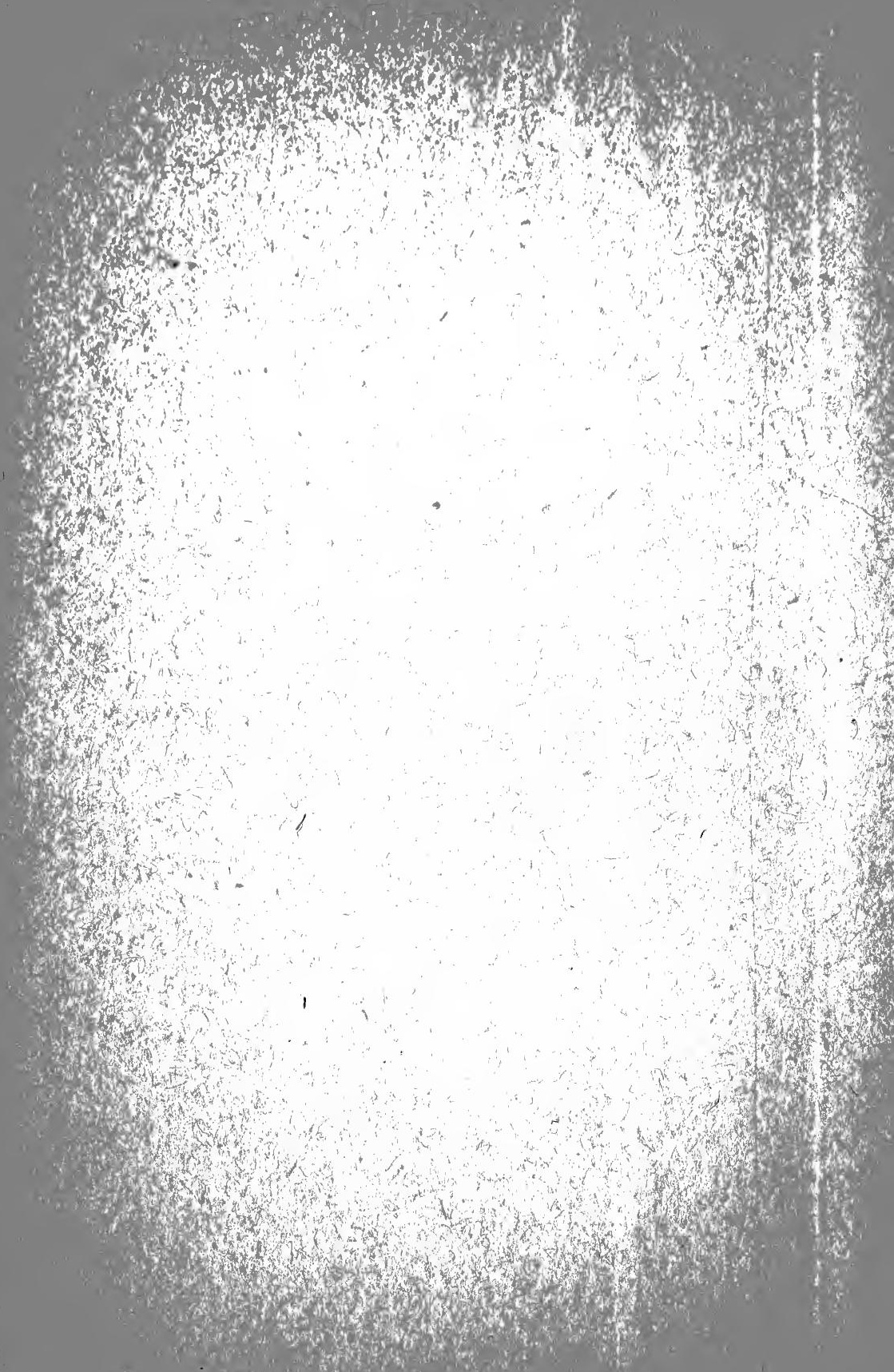




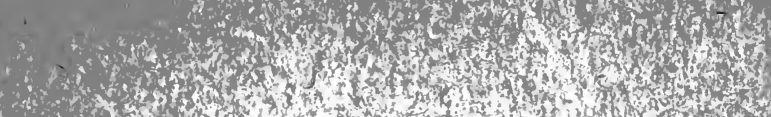

(1)

inting

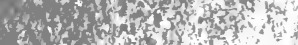

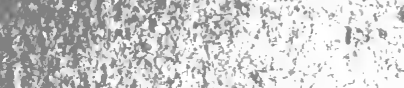

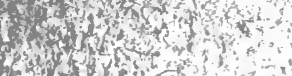

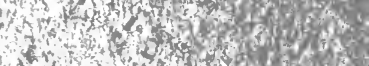

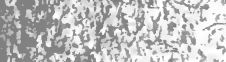

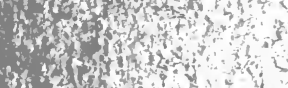

का

iftitis

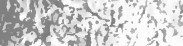

so 6 \%

a. $x+4$

w

$32.4 y^{2}$

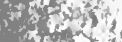

ind

ortiris

X.ting

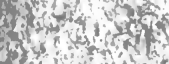

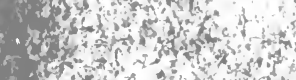

were and on

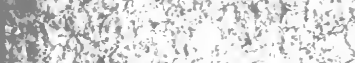

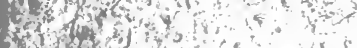

thes

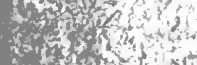

toth

conty

Hots

r.

Het

Qting

it

(t)

ins

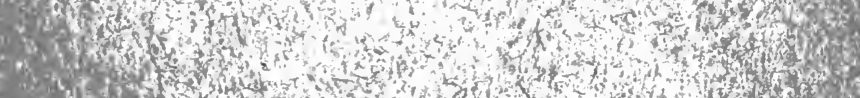

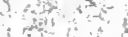

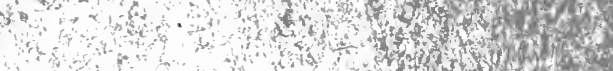

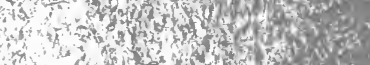
int 89 1 (f)

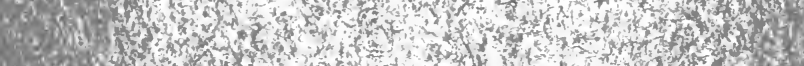

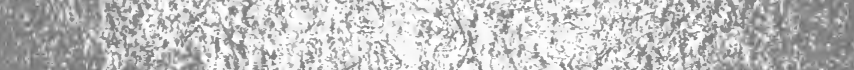

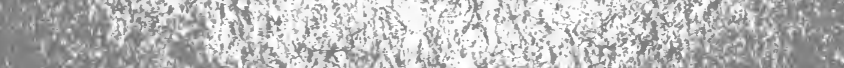

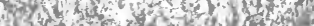

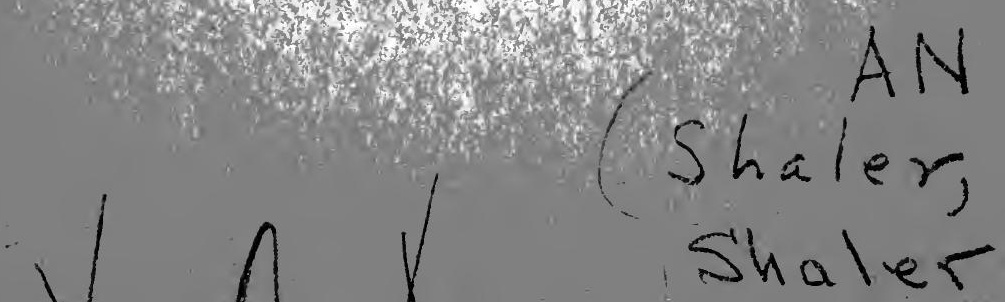





\section{THE AUTOBIOGRAPHY OF}

NATHANIEL SOUTHGATE SHALER 
Digitized by the Internet Archive in 2008 with funding from Microsoft Corporation 



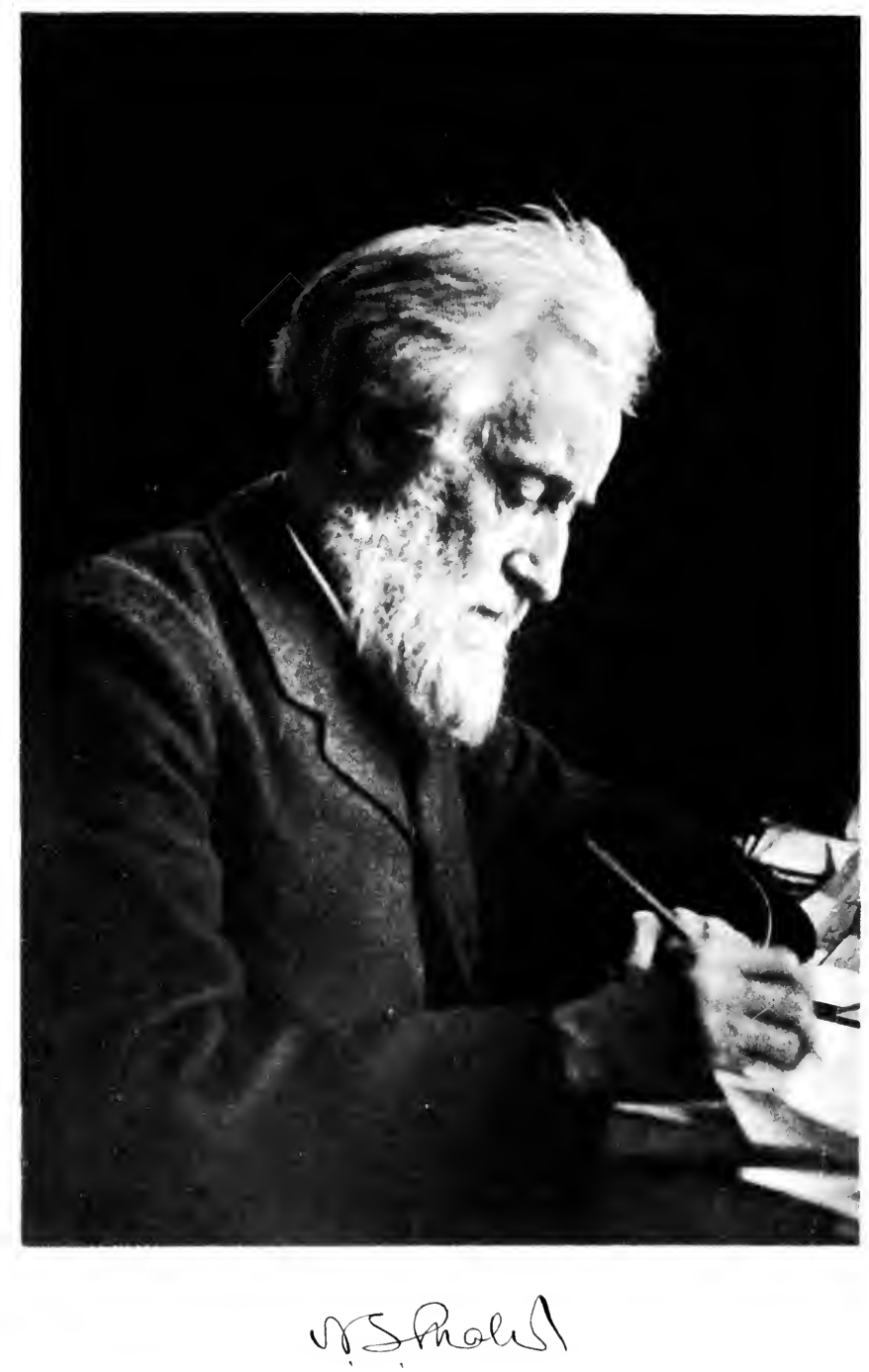




\section{THE AUTOBIOGRAPHY}

$\mathrm{OF}$

NATHANIEL SOUTHGATE

\section{SHALER}

WITH A SUPPLEMENTARY MEMOIR

BY HIS WIFE

WITH ILLUSTRATIONS

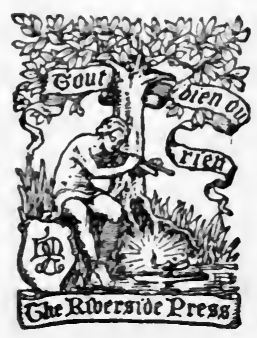

BOSTON AND NEW YORK HOUGHTON MIFFIN COMPANT The Riberside Press Cambrioge 1909 


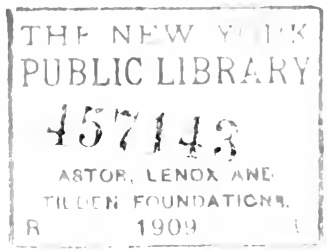

COPYRIGHT, I909, BY SOHHIA I. SHALER

ALL RIGHTS RESERVED

Published Fune roog

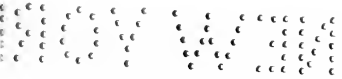

cc

с

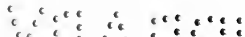

ध 


\section{NOTE}

- The autobiographical part of this volume is given almost exactly as Mr. Shaler left it on his tablet: one might almost say warm from his hands; the pencil with which he wrote it having been used to make the few corrections, - that is, here and there to rewrite a word that was illegible.

In the preparation of the memoir I gratefully acknowledge the aid of those kind friends who have furnished a fact, a letter, or a suggestion, but especially am I indebted to Mr. Ferris Greenslet for his generous interest and for his literary judgment exercised so greatly to the profit of the reader; also to Mr.William $R$. Thayer, ever faithful to the memory of his old teacher.

S. P. S. 


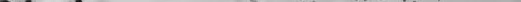




\section{CONTENTS}

\section{THE AUTOBIOGRAPHY}

I. My Ancestors and Parents . . . . . 3

II. Recollections of Childhood . • . • • • 26

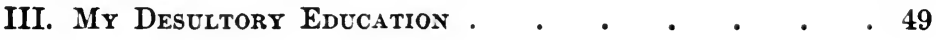

IV. First Visits from HoMe . . . . . . . . . 66

V. Some Kentucky Magnates . . . . . . . . 71

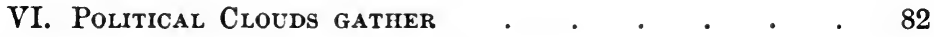

VII. I become Agassiz's Pupil at Harvard • • • • . 90

VIII. Some College Companions . . . . . . . 118

IX. Cruising and Camping $\quad . \quad$. $\quad . \quad$. $\quad . \quad 130$

X. Ax Expedition to the Gulf of St. Lawrence . . 139

XI. Anticosti and Labrador . . . . . . . 150

XII. The First Year of the War a . • • . 170

XIII. My Last Year at Harvard . . . . . . . 179

XIV. Cambridge and Boston Celebrities . . . . 193

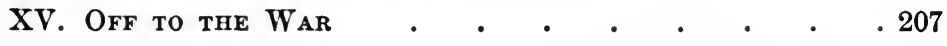

\section{THE MEMOIR}

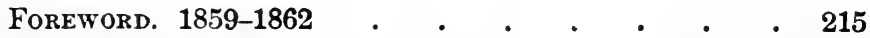

XVI. The War. $1862-1867$. $. \quad . \quad . \quad . \quad . \quad . \quad .219$

XVII. Walks and Talks Abroad. 1866-1868 . . . . 228

XVIII. Teaching and Exploring. 1869-1873 • $\quad$ • $\quad . \quad .247$

XIX. England. 1872-1873 • . . . • . • . 255

XX. Field Work. 1873-1879 • . . • • • • . 270 
viii CONTENTS

XXI. Italy. 1881-1882

299

XXII. Some Familiar Letters. 1882-1888 . . . . . . 325

XXIII. Mine Prospecting and Other Experiences. 1881-1891 334

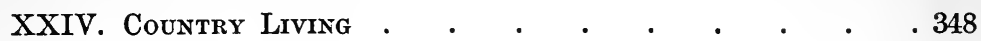

XXV. The Teacher. 1864-1905 • . . • . . 361

XXVI. Administratrve Work. 1891-1903 . . • . . . 386

XXVII. Last Years. 1904-1905 . . . . . . . 402

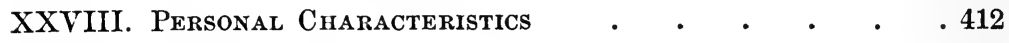

XXIX. LITERARY Work . . . . . • . . 424

List of Publications • • • • • • • • • . 447

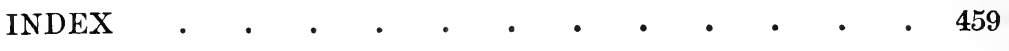




\section{ILLUSTRATIONS}

Nathaniel Southgate Shaler. Photogravure

Frontispiece

From a photograph by Prof. Charles R. Sanger, 1901

William Shaler, Consul of the United States at Algiers, $1815 \quad 6$

Richard Southgate, Mr. Shaler's grandfather . . . $\quad$ - 18

Nathaniel Southgate Shaler as a Child . . • . $\quad$. 28

From a daguerreotype

Mr. Shaler's Early Home in Newport, Kentucky. . . 44

Nathaniel Burger Shaler, Mr. Shaler's father . • • . 68

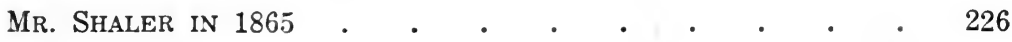

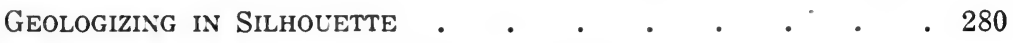

The Quincy Street House in Cambridge . . . • . 344

The House at Seven Gates . . . . . . . . 350

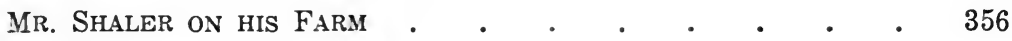

Hills of Martha's Vineyard . . . . . . . . . 360

From an etching by Philip Sawyer

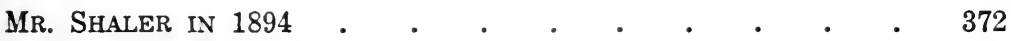

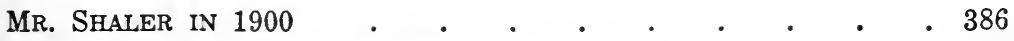

Portrait of Mr. Shaler by Joseph De CaMp . . . . 400

Presented to the Harvard Union "in affectionate memory" by the Harvard Class of 1908

BAS-RELIEF OF Mr. SHALER

By Leila Usher, 1908 


\section{THE AUTOBIOGRAPHY}

\section{CHAPTER I \\ MY ANCESTORS AND PARENTS}

IT is duly recorded in a family Bible, there being then and there no other means of recording such events, that I was born in the then village of Newport, Kentucky, on February 20, 1841. I was the second child of Nathaniel Burger Shaler and Ann Hinde Southgate, having had an elder brother who died in infancy. My parents had been married in 1834; at the time of my birth my father was thirty-six years of age and my mother twentyfive. Three other children survived to maturity, the one early death apparently having been due to accident.

Although the time when a man comes into the world and the place where he appears are in certain ways important and may well begin his story, the really weighty question concerns his inheritances and the conditions in which they were developed. That he brings with him something that is in a measure independent of all his progenitors, a certain individuality which makes him distinct in essentials from like beings he succeeds, is true - vastly true ; but the way he is to go is, to a great extent, shaped by those who sent him his life. I shall, therefore, do what I can to set forth the nature of the people through whom I came.

As is usual with Americans, I cannot clearly trace my ancestors beyond the sea, or for more than four or five generations back. On my name side it is fairly certain that the source was in central England, in the Warwickshire district, with folk who in the seventeenth century bore the name in the form of Shayler or Shaylor. Thence they seem to have moved 
to the island of Jamaica, in that time when England thought to make it a tropical Britain. They did not long remain there, but removed to Connecticut, where the first of them settled in Haddam. His descendants remained in that district and became rather numerous; some abide there to this day. For a time they seem to have maintained relations with Jamaica, since it is written that sundry of them were drowned in going to and fro. They seem to have been farmers with a propensity for fighting. It is told that they had some share as subalterns in the small military affairs of that and the following century. The only sign of peculiar enterprise was the beginning of the work of quarrying the red sandstone of the Connecticut valley, which business is credited to my great-great-great-grandfather.

Some time in the early part of the eighteenth century, my great-grandfather established himself at Berkenridge New Ferry, where he seems to have been a considerable landowner. During the Revolutionary War, he appears to have played a subordinate part as a soldier. He is said to have built the fortifications at Ocracoke Inlet at his own cost. As with most other families of that time of divisions, some went with the Rebels and some stayed with the King. In my youth, that ancient difference was still well remembered; certain of the clan were looked down upon, even denied the rights of hospitality, because they were the grandchildren of the Tories. I remember that when one of the name came to my father's house to claim kinship, he had to face a hard questioning about the politics of his ancestor.

My great-grandfather of Berkenridge died during the Revolutionary War, leaving what in that day and place was a considerable property, and a family of three sons and a daughter. A faithless trustee made away with the estate, leaving the children penniless. The lads, for they were all mere children, seem promptly to have betaken themselves to the sea for a livelihood, and two of them won to rather distinguished success 
and were soon able to care for their sister in a dignified way. Of these brave boys I have the full story of but one, the second in age, William, whose career was of some eminence, and in many ways noteworthy. The basis of my information is certain fragments of his diaries and some printed records of his service as consul of the United States to the Barbary powers and at Havana, as well as his published writings, which, though not extensive, are considerable. While they tell much, there is evidently much left untold concerning this.man, who had a touch of greatness in him which carried him well through an adventurous life.

William Shaler was born in 176-. At the age of thirteen he went to sea on a merchantman. Nine years thereafter, he was master of a ship which appears to have been engaged in foreign trade. From the beginning of his career as a seafarer he supported his sister. He was evidently a zealous student, for he became a good navigator, and gave himself a fair training in the classics as well as in French and Arabic. His English is a model of clearness and simplicity. He seems to have been successful as a trading shipmaster, but to have been in some way involved in the French Revolution. Just what part he took is not clear. After the close of this episode, he bought a ship in Copenhagen, provided it with stores for trading, and set forth with his friend, Cleveland, on a voyage about the world. Their cruise occupied several years. The story of it is told in Cleveland's narrative, a curious, yet forgotten, book. As fitted those times, the voyage led to diverse adventures, including an imprisonment by the Spanish authorities in Chili and the refusal of Mr. Shaler to go forth from the jail until there was a proper explanation concerning the reasons why he was put in, and an apology for the outrage to which he had been subjected. His exasperation led to a project for arming and leading the natives of southern Chili and Patagonia against the Spaniards. To carry out this plan the ship was sailed back to Europe in order to dispose of its cargo of furs, obtained on the western 
coast of North and South America, and to procure arms. The plan was chimeric and was not carried out.

We next find William Shaler engaged in government employment, apparently occupied in watching the actions of the River Company in the region of the lower Mississippi. While thus engaged, he recorded certain phenomena connected with the New Madrid earthquakes of 1811. He was upon a "broadhorn" boat which was carried some distance upstream by the reflux of the current due to the widespread subsidence of the alluvial plains, caused by the shocks and the movement of the river waters into the depressed areas. His steadiness under disturbance and his aptitude for seeing clearly at such times is well shown in his narrative of the event.

The most interesting part of William Shaler's life was the period when he was the consul of the United States at Algiers, to which post he was appointed by President Madison in 1815. At that time the Dey was still the "scourge of Christendom." Nothing so well shows the gain in the power of civilization as the fact that a century ago those malignant despots were allowed, as they had been since the Middle Ages, to exact tribute from all the maritime powers of Europe, to ravage their commerce and enslave their citizens captured on the high seas. At this moment there is sitting at Algeciras a convention of the civilized states to take action concerning the internal affairs of the last of the Mahometan states on the African shore. Now, as of old, it is not the strength of the petty despotism that limits action, but the rivalries and suspicions of the Western Powers and the fear of trouble with the Mussulman world.

When William Shaler went to Algiers as consul-general to the Barbary States, in effect as minister of his government, the Dey was still the insolent despot he had been for centuries. It is told that Mr. Shaler at his presentation at court, breaking through the ancient rule that the representatives of the Christian governments should come barefooted and uncovered before the monarch, made his appearance in jack-boots, with 


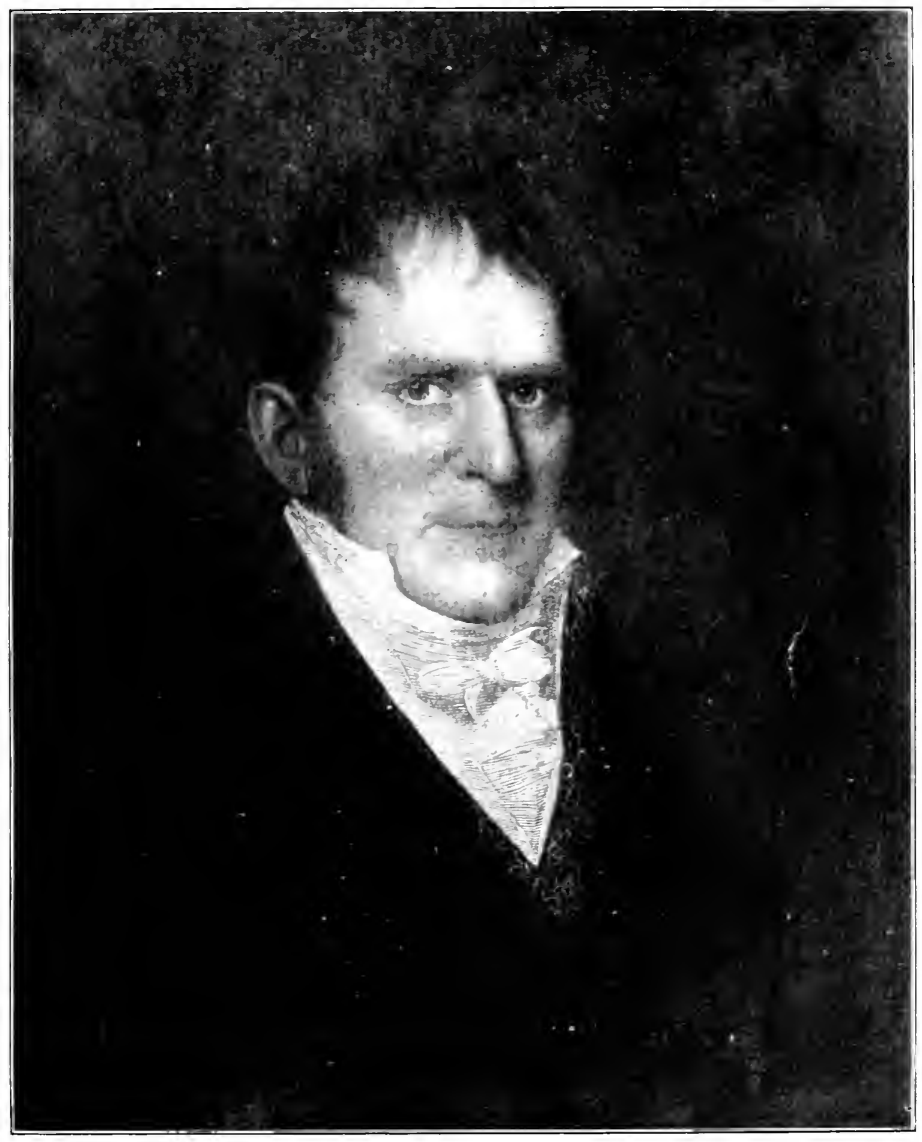

WILLIAM SHALER 


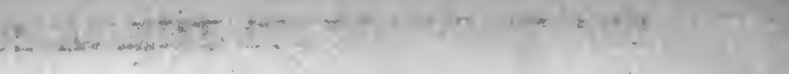

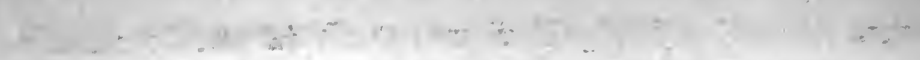

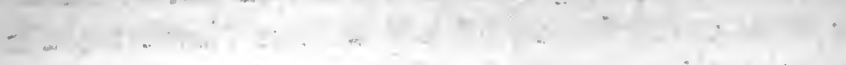
$n+$ 
pistols in his belt. In this guise he was received, and by his fearlessness he acquired a good deal of influence over the tyrant. Another example of his steady quality is given in the account of Abercrombie's bombardment of Algiers, where the landing parties, when the guns of the Algerines had been silenced and the water-front of the town was in ruins, found him at dinner in his arbor, he having compelled his servants to serve him through the action.

At the end of his service as consul-general, William Shaler, disgusted with the state of affairs in the principality, went to France and had much to do in persuading the French to invade and occupy the country, acting as the adviser of that government in its plans for the expedition, particularly in the operations which led to the capture of Algiers. For this service he received and refused the offer of a sum of money said to have been the equivalent of a hundred thousand dollars. Of his long residence in Algeria he left, as records, his sketches of Algiers and an account of the government, - both worthy essays, which show him to have had a certain observing power. He left behind him a memory of good service which is recorded by a tablet in the Episcopal Church at Algiers, placed there by those who never saw him but knew by tradition of his quality.

After his experience with the Algerines, William Shaler turned again to business with the sea, and, as seemed to be recurrent with him, made and lost much money, but saved out of the wreck enough to provide well for his sister and other dependents of the younger generation. His life ended as consul at Havana in 1832, where he died of cholera. When the end was near, he sent away his secretary and other attendants, telling them they needed their rest and that they could attend to his body in the morning. When they came back they found his body lying straight in shape for the grave. He was of the quality that dares to die alone in the dark.

The second son of this household seems to have been a daredevil ne'er-do-well, who wound up an adventurous career as a 
prisoner of war at Dartmoor in England, where he was shot leading a revolt against the jailers. Captives were not well treated in those days, and by all accounts those at Dartmoor fared hardly. The stories I heard in my youth of this man indicate that he was a person of ability but with little worth noting except a certain reckless valor.

The third of his generation, my father's father, like his brother William took to the sea when he was a lad and soon rose to the command of his own ship and just before the War of 1812 was a prosperous merchant dwelling in New York City. As the embargo and the war ruined him, he turned privateer, and in a succession of vessels was fortunate in his plundering work, so that he in a measure recouped his losses. The last of these vessels that he commanded was built for fast sailing and was for a time very successful in overhauling East Indiamen. From the many printed accounts of his adventures and from his letters, he appears to have been a man of courage, who kept his head in peril, and was withal of a simple generous nature. One of his letters tells of the bravery of certain black men among his crew who had been his slaves before they shipped. At the end of three years of this legalized buccaneering, Captain Shaler's ship vanished from the sea. To explain the disappearance there is the story of some East Indiamen sailing together for protection who were set upon by an American ship: at the outset of the attack came a squall, and when it cleared away the privateer was not to be seen. It is supposed that she "sailed under," which is made probable by the form of canvas she carried and the shape of her bows.

I have seen but one man who remembered my great-grandfather. He recalled him as a stately person who had very good horses in his carriage. Another remembered my grandfather as a very gentle man, with a delicate, womanish face, one side of which was blackened with gunpowder, as my informant said, from an adversary's pistol in a "boarding" fight. Of my greatuncle William Shaler I have had accounts from several persons, 
especially from the late George Ticknor, well remembered as the historian of Spanish literature, who knew him and bore his memory in high esteem. These agree in that they all described him as a singularly impressive personality of a great dauntless aspect, but at heart lovable.

Only one of that generation, the sister, Abigail Stilwell, lived to my day. Her brother William had established her in a rather stately place in Lancaster, Massachusetts, with her three children and the four left by his brother the privateer captain. Thereto I went in 1855 as a lad of fourteen years, in company with my father on his first return to his childhood home, after an absence of a quarter of a century. My great-aunt was then a venerable woman, over eighty years of age, and of a singular dignity, it may well be said splendor, of shape and manner. She was six feet in height, perfectly erect, clad in black silk, capped with a tall white turban, and armed with a gold snuffbox, to which she much resorted. I had seen several great dames of the Virginia stamp and have beheld them since in many lands, but none of them compared with that woman. I recall even now the fear of her which even her great kindness in no wise cleared away. She belonged to a variety, apparently now extinct, in which the sense of personal dignity and authority shaped the life. It is characteristic of this remarkable woman that she was found dead sitting upright in her chair with her snuff-box in her hand.

I remember that I was curiously interested in observing that my father, whom I had never seen awed by any one, was visibly cowed in the presence of his aunt; he seemed, indeed, almost as much in fear of her as I was myself. I also recall in the days of that visit much talk on the part of my great-aunt of matters which dated back to my father's youth; also of her trials with a certain Frenchwoman then dead, who had been entangled in the life of her brother William, and whom she had taken over with the rest of his estate. These family stories attracted me less than did the house and grounds of the old place. The dwell- 
ing was a rather massive brick structure, in large grounds sloping to the Nashua River. I recall that the doors were of mahogany and the hinges plated with silver. Since then the dwelling has been burned, and the grounds sold to the state for the use of a school. The considerable library of William Shaler, which seemed to my eyes very fine, - in fact, as I know from competent persons, was rich in the old standard editions of the classics, - went to the Boston Public Library.

My great-aunt had four children : a daughter Elizabeth, then recently dead, had been married to an interesting fellow who bore the name of David Stuart, a very attractive Scot who claimed to be of kingly blood and looked it thoroughly, but was otherwise rather worthless; there had been three sons, but one was killed in the Texan battle of San Jacinto. Another was a physician in Sag Harbor, New York; and the third, Elias Millard Stilwell, was yet with his mother, at the end of variegated experiments in the art of existing beautifully. Since my father and Elias Stilwell were double cousins, they were nearer akin than ordinary cousins german, and singularly alike in appearance. This likeness is indeed curiously common in those of my name stock, even when the common ancestor is four or five generations back. Partly for this reason, we soon came near to one another in spirit; furthermore he had an eminent capacity for saying things aptly. In fact, he had the greatest capacity for phrasing I have ever known in a man who was too lazy and contentious to acquire any fair semblance of an education. As a young man, he had been sent to West Point, but found a speedy exit because he thrashed one of his instructors. From France, where he went as clerk, he fought his way home again. Put to like work in this country, he had ended a brief career on a newspaper beating the life out of a man who had assailed him for some well-merited criticism. A curious thing about his troubles was that he attributed them all to his shyness, his inability to come into normal contact with men, which led him when in any way assailed to turn demon. I see him now 
as he would in his confidences wail to me of this curse of bashfulness, with the tears streaming down his face of old bronze. He was fit but for one business, that of the hunter and fisherman, and he found in middle life a suitable place as game commissioner in the state of Maine. In his declining years, I often visited him there, and had my pay in his comments on men and things as good in their way as Thomas Carlyle's. I have seen many wasted lives, but none where as much natural capacity as his was fruitless. As with many other self-indulgent men, his interests became in the end limited to the sports of hunting and fishing - activities which call on the primitive motives of men, and in a mature person indicate a degradation of the civilizing motives. So passionately was he devoted to such business, that he warned me that he would not make me heir to his property unless I would go with him for a month in search of salmon. I felt that the price of my refusal was not overmuch to pay.

My father had two brothers and a sister. The eldest brother, William, I never saw: he was a well-educated man, having been trained at the University of Upsala in Sweden, and in other European schools, at the cost of his uncle the consul. There was evidently a tincture of worthlessness in him, for with ability, a fine presence, and perfect health he died without leaving any sign of quality. The other brother showed a like inability to face the world. I knew him about my father's house when I was a lad, and found him a penetrating intelligence, a mind of a distinctly philosophic power, but hampered by indolence and self-indulgence. The sister, my aunt, though inheriting much of the presence of her aunt Abigail, had not her commanding character. She was married to a dominating brute who crushed out the considerable talent which was in her.

I have now to describe my father, who was a very singular man. I foresee that I shall not be able to set him forth in his true quality. Born in 1803, he was but a lad when his mother died of grief for her vanished husband. There was money enough 
to give him a good education; so he was sent to school in Lancaster, Massachusetts, where he was lodged in the establishment which his uncle had prepared for those of his generation. Thence he went, as all the boys were intended to go, to Harvard College, where he entered the class of 1827 . Although he had a large measure of ability, he was only moderately successful in his studies. Yet he gained and kept to old age a fair knowledge of Latin and Greek and of mineralogy as it was then taught. His combative humor led him into trouble with his teachers; he therefore withdrew at the beginning of his last year, and went to the Medical School, where he had as preceptors Drs. Channing and Jackson and was much influenced by Dr. Warren. In this school my father was successful; for he had a distinct aptitude for the tasks of a physician, and for a part of his life was devoted to his profession. After graduating, - the course was then a small affair, with most of the training given by preceptors, - he went to Havana, where his uncle was consul, with the intention of making his career in that place. He appears to have been successful as a practitioner and to have accumulated some money. But his combative motive was still upon him, and in two years he started in search of some other spot "to locate" in. This he found as by chance in Newport, Kentucky, then a little village with no educated physician and with the Asiatic cholera upon it. His success with this disease, due to his resourcefulness and intrepidity, quickly gave him place among the people. He there married in 1832 Anne Southgate, my mother, and ceased his wanderings.

I first distinctly remember my father when he wasabout fortyfive years of age. He was then of a singularly noble aspect. I recollect thinking at the time that the only other man to compare with him was Robert E. Lee, whom I first saw at about that time, - who had a like nobility of form and carriage, though my father was much the more powerful man. Six feet and an inch high, weighing about two hundred pounds, straight limbed, with regular Roman features and with a certain majesty 
of carriage, he has always remained with me as the type of what the shape of man should be. Though I have seen many the world about, I have never seen a better. When I came as a youth to Harvard, I found that the memory of his form abided not only with his classmates but with many of the common people, - as well as his propensity for fighting. The only trace of a physical defect was near-sightedness, which was not considerable enough to require the use of glasses; he did not indeed use them to the end of his life. Otherwise his body seemed perfect. He had been well trained in fencing and boxing, and he was a good horseman and an expert swimmer. Of his fighting habit, for which he had an unhappy reputation in his youth, I recall but one instance, when a huge negro sprang at him knife in hand; he struck the man one blow which threw him into a heap. Lad though I was, I still remember the change in the situation when my father in a moment was upon the fellow to see the measure of his hurts.

As regards the qualities of his spirit, my father was absolutely, almost brutally honest and straightforward, morally clean with no trace of vice or even bad habits except that he smoked tobacco in moderation. His intelligence was acute, though intellectual matters aside from natural science did not interest him. Indeed nothing interested him greatly; he seemed quite destitute of constructive imagination, and though in some measure enjoying poetry, never cared to read it except to seek a quotation. His talk related generally to superficial matters; when the conversation led to the deeps he would after mayhap a word or two, which often showed a singularly penetrating intelligence, leap back, as if affrighted, to the commonplace. In his medical practice he was successful in difficult cases, those which aroused his combativeness, and often very clever in ruses to gain his ends. Thus I have known him to help a stout man on the verge of a collapse in Asiatic cholera, by reviling him as a coward until the fellow's rage helped the reaction. Again, when a woman who was sinking needed in like manner to be aroused, 
he became interested in a supposititious dog-fight which he seemed to see from the window, hurried away to observe it, and shortly returned to find her in a fair way to recovery because of her indignation. In surgery he was dexterous. I have seen him when about sixty years of age remove an iron filing from a workman's eye with the point of a common needle, and this without glasses. His hand was as steady as it was nimble.

During a large part of my father's life he was employed by the government as surgeon at Newport Barracks. This was a convenient place whereto were forwarded the sick soldiers from a wide area. Especially during the Civil War it was a kind of dumping ground for the obstinate cases sent in from the field hospitals; yet, as I have been credibly informed, the proportion of recoveries was larger than in any other hospital of that time. His success was in great measure due to his distrust of remedies and his confidence in the use of tents, nutrition, and cheerfulness. He was among the first to put aside the singular custom of blood-letting, not having used the lancet after 1832. When Surgeon-General Hammond issued his order concerning the use of calomel in the army hospitals, he offered to return all the supplies of that drug which he had received, unopened.

My father had capacities for the making of a great physician and surgeon, yet for thirty years he remained content with a common village and country practice and that which the barracks afforded; with a capacity as great as I have ever seen for breaking new ground he left it untilled. The reason for this was an ineradicable indolence of spirit, a sense that nothing in this world was really worth striving for; there might be things worth doing because there was immediate duty in them, but it was not worth while seeking for duties not thrust upon him. There was money enough, which came through my mother, for comfortable living, so why should he strive? The Civil War roused him strongly. He went security for the first thousand muskets which came into the hands of the Kentucky Unionists, and sacrificed much for the cause in many ways, in friendships as 
well as in money: this at the outset, but with the advance of the war his interest in it as in all else gradually flagged - nothing held him permanently.

As I look back on him, I discern ever more clearly what I saw in a measure in his lifetime, a mark of the commonplace presented to the world, behind which the large-natured, able personality was well hidden even from himself. It was an instance of what I have found in many, found even in myself when the consciousness seems to be abnormally limited, when only a small and the lesser part of the intelligence comes into its illumination, the greater part remaining in the dark. It was my father's ideal to be a stoic, to put aside all things spiritual, to regard emotions and the speculations to which they lead as signs of weakness. His good measure of will power united with his lethargic humor enabled him to thrust back all the offerings of his spirit and to keep himself in the ordinary matters of every-day life.

After he was sixty years old my father gave up reading, and in a great measure withdrew from the small world of his activities. It was his wont to sit for hours looking out of the window, but evidently withdrawn from what passed before his sight. If brought back by a sudden question, he would sometimes reveal by a word or two that he had been far away on some speculation, but he would at once hide the trail of it with some commonplace remark. So far as I can remember, but once or twice in my contacts with him the deeps broke through the well-constructed barrier and revealed a part of what was habitually hidden. After those chance revelations he became at once more obstinately trivial than before, as if to protest against the momentary enlargement of his better but most artfully concealed self. Since I was often near him until he died in 1882 , I had a chance to see the strange workings of his complex personality, and to form the opinion that the basis of the suppression of his better part was an intense shyness, amounting to an incapacity to reveal himself, with the result 
that what was apparent in him was a mere screen contrived to hide the inner man. This shamefaced motive is in some measure so common among men that it is almost a human characteristic. We generally mask the best that is in us and find our modesty offended if we are found out. But my father's case was a most striking instance of this passion, for this solitude of the soul, combined with a lethargic quality, kept him from playing the part in the world for which his hidden capacities prepared him. He died in consequence of a fall, in the eightieth year of his age, after having apparently completely recovered from a ten years' siege of diabetes, his admirable body having won the fight with the disease.

So far as my limited knowledge goes, none of the collateral strains of blood on my father's side gave any strength to his stock. They appear to have been of pure English origin, with an intermixture of Welsh and a cross of Hollandish, which came from Van Dykes, some few generations before my own. On his mother's side, there seems to have been a breed of a placid quality, indolent, and with a tendency for the men to waste their lives and squander their estates.

My mother's family, the Southgates, shows in the five generations known to me much less evidence of capacity than my father's. Yet there is some sign of ability among them, and many of them were interesting people. The name of Southgate comes from the sunny side of London: it is said that the name is from the place. From all I can learn, these sunny-siders have long been a good kind of rather small folk. One or two of them have come to some intellectual station as clergymen; one, by the given name of Henry, as a very minor poet. From that stock which came to Virginia in the early part of the eighteenth century was Wright Southgate, my great-grandfather, who became a successful merchant and planter, amassing a share of wealth. He seems to have been a man of intellectual quality, for he was enlisted in the schemes of Thomas Jefferson and gave liberally to further them. He married a Miss Lush of Albany, New York, 
and had by her a son Richard, my grandfather, who being of a scholarly turn was sent to William and Mary College. When summoned thence to take his share in the management of his father's business, the young man rebelled and announced his intention of studying law. This was displeasing to the merchant father, who set great store by his ships and his shops, of which the principal was in Richmond, where the old Spottiswood Hotel stood. The young man and the old were alike obdurate; so they parted. The time was about 1790; the tide of life was flooding to the West, and it bore my grandfather with it. He had read law with the help of W [name illegible] and other able jurists, though he was but a youth when he came to Kentucky and after a time settled down in Campbell County, which then included what is now a number of counties in northern Kentucky. He was too late for the last chance of acquiring land of the best quality by the simple process that came to those who entered the country in the first twenty-five years of the colonization; so he had to set about his winning in the less desirable but still excellent fields near the Ohio, rather than in the marvellously fertile region about Lexington.

Though a late-comer, my grandfather was laborious and thrifty. He practised law with great success, took land for his fees, bought discerningly, and in sixty years amassed what was for the time and place a great fortune. Though he had given largely to his many children, and supported a host of imprudent kindred, his estate was valued at his death, in 1868, at a million and a half dollars, there being at that time probably not half a dozen such successes in the Ohio valley. All this gain was made not only honestly, but in a generous way. He was a good landlord; he deterred no man who tried to do his part, and even of ne'er-do-wells who swarmed about him all his days, he was wont to say that "the good will of a cur is better than his ill will." The worst comment he ever was known to make of any man was that he was "a pestiferous fellow." 
When I first remember my grandfather, in 1846 , he was about sixty-five years of age. His appearance and quality even then made a strong impression on me; thereafter until he died, for the twelve most impressionable years I was much with him, and he influenced me greatly. I was nearer to him than any other of his thirty or more grandchildren, partly because he was peculiarly attached to my mother, and partly because I was the only one of the lot by nature in sympathy with his strangely delicate quality, his abiding interest in literature, and his keen insight into men. In his aspect and manner Richard Southgate was an excellent sample of the old, long-vanished class of Virginia gentlemen. He was a small person, or at least so appeared among a folk who tended to hugeness of body. He was the last of the folk in his part of the world to hold to the "pig-tail," queue arrangement of his hair, which was always carefully braided and tied with a bit of ribbon, so that the end of it hung between his shoulders. Toward the end of his life he disused the smallclothes and stockings which were the fit accompaniment of the queue, but he kept to the buckled shoes and the round cloak of the ancient costume. His face, - with the white hair strained back like a girl's to her braid, - delicate, regularly featured, and smooth shaven, had a womanish look; but the keen alert eyes had all of a man's strength in them. Up to his death, in his eighty-third year, his face kept an unusual share of its youthful quality.

In his quality, Richard Southgate curiously united the efficiency of an adroit business man with an abiding everpresent interest in the other side of human affairs; in history and literature he was well read and abounded in judgments. $\mathrm{He}$ had the reputation of being little given to charity. My father, who was none too sympathetic with him, told me a story which well illustrates his curious ways of dealing with those about him. A tipsy teamster, one of the carriers who in the time before railways transported goods from the Ohio into the back country, while drunk, drove his horses into the river, 


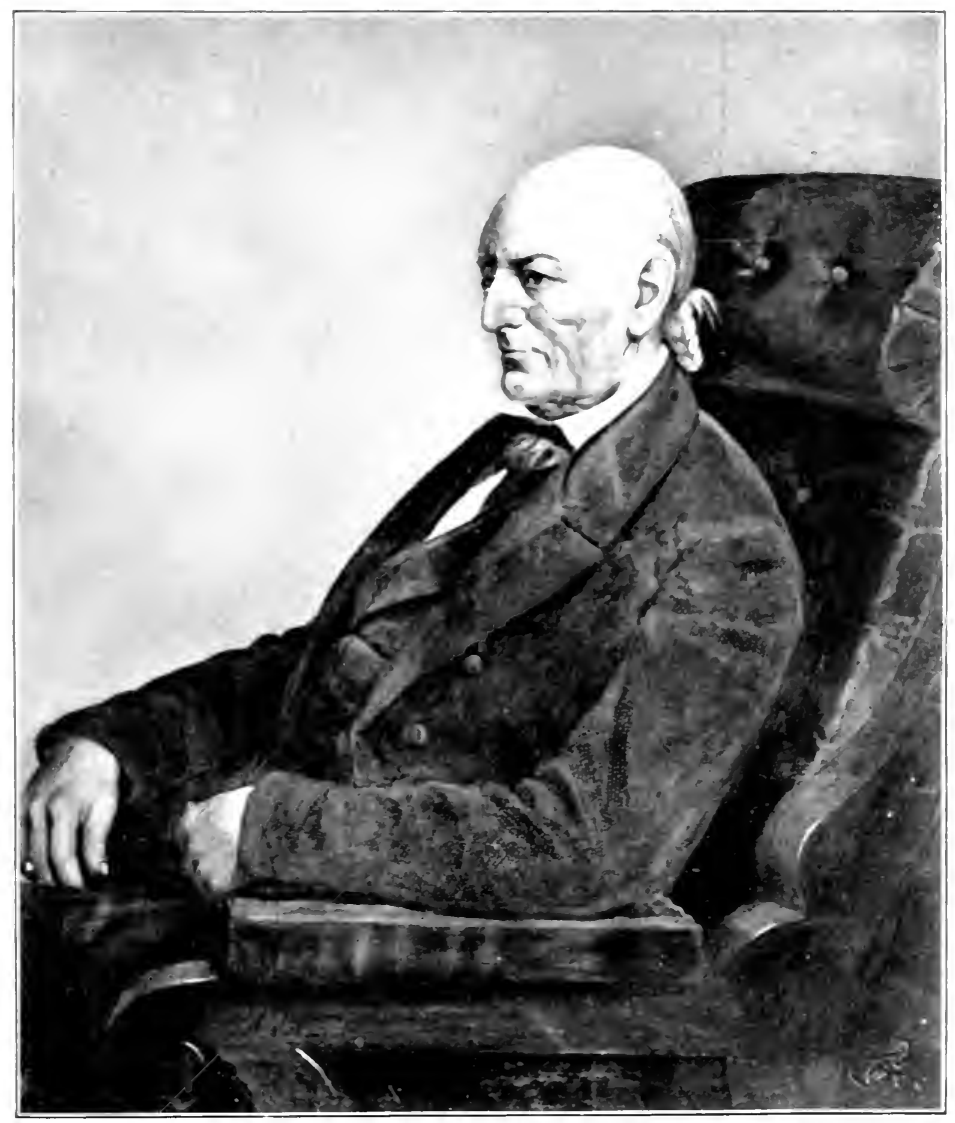

RICHARD SOLTHGATE 
1 1

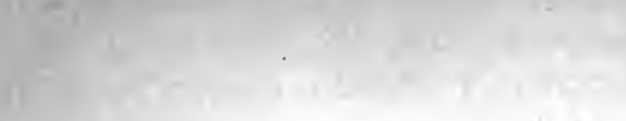

(1)

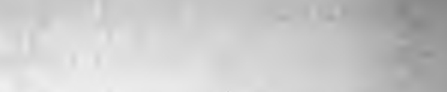

\section{,}

.

$\therefore$
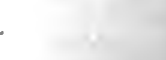

.

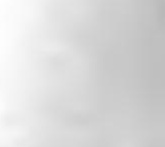

(n)

$=$

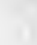

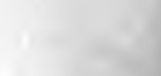

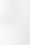

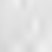

(1)

-

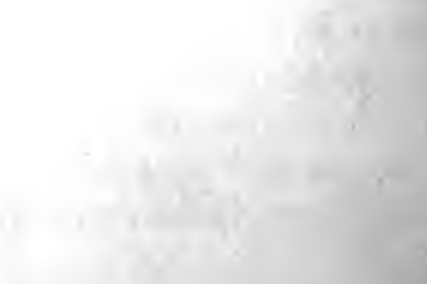


where they with the wagon were swept away and lost. An effort was made to raise a subscription to help the fellow out of his difficulties. My grandfather not only refused to give any money for this purpose, but dismissed the idea for the reason that it publicly approved the man's drunken ways. The subscription failed, yet to the surprise of the neighborhood the man was supplied with four horses and a wagon. It was found out that Richard Southgate had contrived in a round-about way, at his own cost, to make good the loss. By this adroit device he stuck to his principles of not rewarding negligence and his axiom of "not letting your right hand know what your left does." I should like to tell far more of this interesting man, but something of his unusual ways will be set forth in the slender personal narrative of my youth.

I have been unable to find anything concerning the collateral ancestors on my grandfather's side. What he had of distinction appears to have come through his father from the old country; though through his wife, my maternal grandmother, there came an interesting group of inheritances. This woman was evidently a person of more than usual fineness of character. She died of cholera ten years before I was born, but her name lived after, so that as a lad, going about in a wide range of northern and central Kentucky, I found a welcome as her grandchild, and a warm place in the hearts of all sorts of people whom she had cheered and befriended in the days when as the throng from Virginia to the frontier were coming in there was need of mutual help. She must have been a woman of uncommon vigor, for she was the efficient mistress of a great household, one that held many slaves, and a host of poor kin, who swarmed upon any successful pioneers who had made a place in the new land. She seems to have thought nothing of horseback journeys of fifty or a hundred miles to help those who needed her cheer.

The qualities which made my grandmother a large figure in her time and place, came from her father, Dr. John Hinde, a London man, long a surgeon in the British navy, who in middle 
age, with some little fortune to waste, settled in Virginia. In the course of his service he was with Wolfe at the capture of Quebec, and in the well-known picture of the hero's death, John Hinde is figured as the surgeon who seeks to aid him. I recall the account of an unsuccessful effort to recover a family portrait loaned to Benjamin West for use in his picture. John Hinde first appears in the family traditions as a merry if not a dissipated person, who gave more attention to riding after foxes and other follies than to his business as planter and country doctor, or to his growing family. His wife, who was born a Hubbard, seems also to have been rather a worldly person. But in the great wave of the religious revival which led to Methodism, the wife "experienced religion." Her husband, it is related, and I have seen an account of the incident in print, judged the symptoms as indicating trouble in her brain, and applied a fly blister to the back of her neck. When he came to dress the blister he had a like experience, which from all accounts must have been a striking visitation; for the man was at once changed in all his habits of thought and action. He became a deeply religious person, giving up his life to charitable work, going up and down the land as a physician and surgeon who took no pay. It is said that he was wont to pray at every bedside for the Lord's blessing on the help he sought to give. The accounts I have had of the few persons who remembered John Hinde make it clear that he was a singularly attractive person. His access of piety having left him if anything merrier than before it came, he went to the end of his life, at near one hundred years, in a frolicsome relation with his Maker. When he came to die, his last act was to feel the pulse of his wife, who was then a woman of ninety, and to tell her that they would have to be apart for some years.

Of the children of John Hinde I saw but one, a daughter - a widow whom I remember as Aunt C_- a most gracious presence. She was entirely blind, but her fine eyes were not clouded nor had her face taken on the impassive look so common when 
the sight has long been lost. She was always happy, a cheer to the fireside she adorned. I recall her love of children and the devotion to her of the negro servants, her attendants, whose services gave a certain stateliness to her life. I well remember her habit of smoking a single pipeful of tobacco in the evening, the bowl made of corn-cob and the stem of reed. It is the only instance in which I ever saw a woman of station use tobacco, except as snuff. Even in these modern days I have not encountered such, though I am told that it is common enough in some societies. My great-aunt explained to me that it was the custom of old ladies in her youth.

My grandfather had four sons and three daughters who came to mature age. Of these but one showed evidence of effective capacity, William Southgate, a lawyer, who made a considerable reputation as a popular speaker and a wit: he was for some time a member of Congress. He was singularly loved by the people, and with his good share of capacity should have made for himself a large place in political life, but he came to a premature end. Another brother, Henry, also famed as a wit, - a very Yorick in his humor, - commanded the love of men and women, but went the same rapid way. These brothers, with their rare charm, their trains of admiring followers, and their swift exit, made a great impression on my childish mind. From the social point of view they were essentially unlike anything our race breeds in this day. Their manners and mode of thought were those of the Stuart times, when men felt the life of their neighbors, and dwelt in their hearts.

I begin my memory of my mother when I was about five years old. Strangely enough, there are at least three of the slaves of the household whose faces were enduringly printed on my mind before my mother's found its place there. As with this, the first deliberate review I have ever made of my threescore years of memory, I recall my mother's qualities, it becomes clear to me that through her came the most of good and the least of evil of my life. For through her, probably more remotely through her 
mother and her grandfather, John Hinde, came that simple interest in my fellow human beings and a sense of duty to them, which she so eminently possessed. In person, as I recall her at the age of thirty, she was, with only moderate beauty, very attractive from her noble motherliness. She inherited from the Hinde stock the very English quality which came to perhaps half the descendants of the merry doctor; the characteristics which are summed up in the typical squire - that solid simplicity which is the foundation of all the best in the stock. Though blessed with a good mind, my mother was singularly without intellectual interests. She inherited nothing of her father's quick, wide-ranging intelligence; all her care, and it was great, went to her household, her numerous kindred, and her limited circle of friends. Her excellent, unbreakable judgment and keen discernment never penetrated beyond this seemingly narrow field which she made by her activities a great realm. Now and then a flash of intelligence showed that she had large possibilities of thought which in other social conditions would have awakened, but which were effectively repressed by the narrowing quality of the life of the time and place.

This task of sketching my ancestry is in some ways the most difficult that I have ever undertaken. To set forth what is germane without touching on what is essentially private, or perhaps is not illustrative, is hard to effect in a way to give the result any value. The writer essentially finds that the nearer he comes to his own time the greater his limitations; for whatever be his regard for history, he must have a thought for those now living, who may be offended by over-much detail concerning those who share with him in the lives he is depicting. I am glad to say that there is nothing in all I know of the direct and collateral kinship of my line, which I can fairly well trace for an average of six generations, that needs be hidden. In all the host there is not one, so far as I have learned, who has ever been connected or even charged with other vice than fighting in a fair kind of a way. There has been no instance of insanity or 
idiocy in the direct or collateral kindred. There has been some drunkenness in the collaterals, but, so far as I have been able to learn, none in the direct ascendants. So, too, they have been spared the more terrible maladies. In my large kinship there is no trace of cancer or tuberculosis. My father, who was curious in such matters, and had so far as possible informed himself concerning the diseases of my stock, told me that he believed that those ills had never visited any of my kindred, except in the case of one cousin, who inherited consumption from her mother, who was not of my blood. I have never known of any kindred who were deformed: they have often enough been goodfor-nothing, but their shapes testify to wholesome physical inheritances.

So far as I can judge what I have from my ancestors comes mainly from my mother's side of my house. I am evidently nearer akin in spirit to Richard Southgate than to any other of my forbears. His eager interest in men and things, his skill in memorizing, his love of the land and desiring of it, his taste for literature, especially for poetry, were clearly sent on to me. From my father's side I inherit a combativeness which curiously contends with the eminently peaceful humor which came through the Southgates, who were disinclined to any kind of warfare. Even before his people came to this country to settle, they appear in tradition as buccaneers on the Spanish Main; but among the Southgates of the direct line, or in my collateral ancestors of that side, I have not been able to learn of a soldier. As a whole, none of my ancestry ever came near to greatness, yet they sent on to me a good inheritance of sufficiency, both of body and of mind. The best of these gifts has been a capacity for an intense interest in tasks without much reference to personal comfort in doing them, along with a power for keeping at work, whatever might be the discouragement from illness or ill-success, and also a certain unconscious talent for seeing the situations in which I have been involved as parts of the whole of actions - a talent that may be termed the historic sense in 
immediate application; so that my doings, though of no great account in themselves, have been curiously related to large affairs. For this quality I am most indebted to my father's family ; it was not manifested in him, but somewhat in his father, and especially in his uncle William, there was the capacity for thought in action combined with that full share of will which carries purposes to their end.

In the foregoing pages I have briefly sketched the story of my ancestral life so far as it is known to me. I am aware of the fact that the history of even six generations does not provide an adequate background for a judgment as to the inheritances of an individual; for the reason that while we do not yet know for how long characteristics may remain latent, it is evident from the history of human stocks that they may inhere though they be not manifested for many generations. There is, however, a fair presumption that when half a dozen stages of a life are fairly well known, they afford a tolerable basis for reckoning as to what comes to the last stage in the way of birthright. What else there may be, can in some indefinite measure - if indeed the term measure can be applied to it - be charged to the account of personal quality and incentive. It is evidently impossible to determine the share of the individual in his actions. Some naturalists hold that he has none at all; but this is a preposterous view, because it not only denies human experience in the face of action, but it gives no room for the advance in the series such as has, so far as we can discern, come about through the personal incentive which appears to be characteristic of all organic forms. In my own case, the best analysis that I have been able to make indicates that all my intellectual capacities and emotional trends have reached me from my ancestors in the same way and about as dominatingly as my bodily parts. The use I have made of these transmittenda, the extent to which they have been developed, and especially their continuation in the whole of a life, are the results of that fundamental mystery, the individual will, controlled by and controlling the condi- 
tions which have helped to shape it. I am disposed to give to this personal power a value quite as great as to that shadowy domination that comes to me from the past: believing, indeed, that what I am in relation to myself and my fellows is far more my own than it is my ancestors'. What they sent me limited the bounds of my little part of the great field; what I have done in that field is my own. 


\section{CHAPTER II}

\section{RECOLLECTIONS OF CHILDHOOD}

I TURN now to the story of my own life, my own motives, and the environment of nature and men that shaped them. I foresee that the account will have to be somewhat jumbled and confused, for the reason that every life is a compound of what is within and what is without the personal quality and of the surroundings which shaped impulses and gave them chance of action.

Although my ancestors were wholesome in body and mind, I was at birth and through my youth rather weakly. The trouble seems to have been with the nervous system leading to imperfect digestion, so that in childhood I was what is called delicate. The pictures of me and the descriptions from my elders show up to twelve years of age a slender, retarded shape, with a pale face and rather frightened look. After that came a rapid growth, which led to a fair measure of bodily strength and reactive forces. The main point is that in the years that mould the man I was, because of innate weakness, left almost without schooling and with no other education than what came from contact with my surroundings. Up to that age I could barely read and write. In a dame school, kept by an ancient spinster, to which I was sent from time to time when I was well enough, I learned nothing and was regarded as a dunce. The fact seems to have been that in the bad air of the crowded little room my life wilted at once. Various tokens, especially the rough talk of the slaves of the household, led me to understand that I was not expected to live beyond childhood. I recall that this impression was not at all painful to me, for my weakness and the consequent isolation from other children made me a rather intense pessimist for one of my small size. 
My first memories are of a negro woman who was my nurse; the image of her is clear, though I could not have been more than three years old when it was formed, for I remember being much carried about in her strong arms. She was a large, wellshaped negress; something of her good face and dear soul is now before me. There are three other black faces which were printed on my memory before I find that of my mother. It is probably on this account that the African face has always been dear to me. It still seems, as it surely is, the more normal human face, that of our own kind appearing in a way exceptional. My father's face, though it was very striking, does not appear in my recollections until later, - until the time when I was five years old, - and none others seen before I was seven or eight abide with me.

Because I came just after the first-born died, and because I was frail, I was very tenderly cared for. Until I was five or six years old I had no playmates whom I remember. It is evident that I was for a time somewhat coddled, but there was probably need of unusual care to bring me through a troubled childhood. What scraps of memory I have of that time curiously do not relate to the house in which we dwelt, but to the open country whereto I went often on horseback with my father, to the Ohio River, a dear mystery, fearful yet enchanting, and to the government post a few hundred feet from my father's door, where with my nurse I spent the most of my days. The first recollection I have except of the few persons mentioned, is of the parade ground and the soldiers, above all of the music and the bugle calls. Those notes are so embedded in me that they seem a part of my substance and strangely move me to this far-off day. The earliest trace of any kind of activity that I recall is an adventure with the musician who beat the great drum of the barracks band. It was my delight to see the band march around the parade ground, and my cherished ambition to have a whack at the drum. So, craftily, stick in hand, I hid behind a boxed tree and managed to get in a stroke, only to be bowled over by the 
irate drummer. I could not have been more than four years old at the time, yet the delight of that deed stays by me.

When I was about five, the musterings for the Mexican War were going on, and the barracks were over-filled, so that considerable hordes of troops were encamped in the open fields which adjoined it. On those fields, then pastures, one of the horse batteries, I believe Ringgold's, was for some time drilled. I was then exempt from the care of a nurse and could run about afoot or on a pony. The movements of this command filled my little soul with wonder; there I gained my first sense of the power of men in action, that primitive might of war which impresses the primitive child and childish man as nothing else does. I well remember my longing for the unapproachable splendor of the commander of that battery, who seemed to me a supernatural being. Oddly enough, fifteen years thereafter I was in his place drilling a horse battery on the same field, to find it tedious drudgery, with moments of high life when by chance the work went well.

The newspaper reports of the battles in Mexico read aloud by my mother to the household made a great and enlarging impression on me. Though I could not read, I had the ability to understand a map, and I made a poor stagger at a description of the country over which the troops passed on their way to Mexico and of their movements in that country. As I had seen many of the officers and sundry of the commands on their way to the front, I had food for imagination, and of it I built a host of pictures of imaginary events. For two or three years about all the thoughts of my waking hours and all my dreams were of war or fighting of some kind. The interest was aroused at an even earlier time, for I remember my eagerness on court days to see from near by the brutal contests between the tipsy countrymen in the Court-House yard. So too, I recall, when about five years old, being in the midst of a riot on a race-track half a mile from my home - people in the judge's stand shooting down at a mob which was assailing them. While in the delight of the 


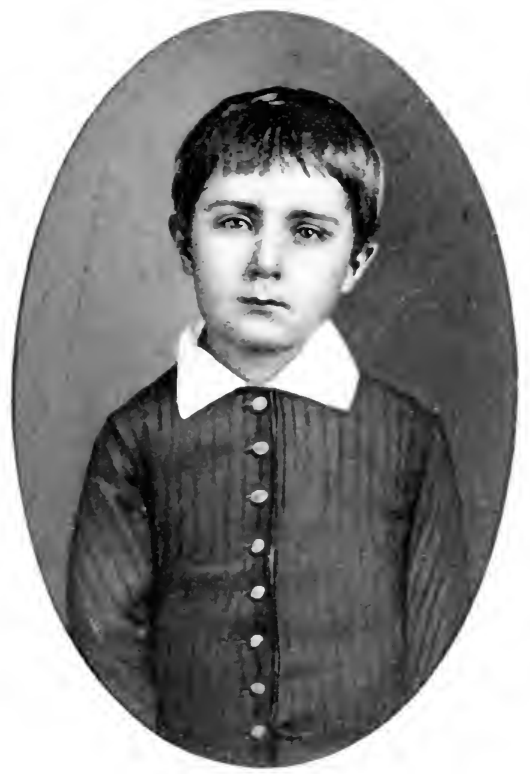

NATHANiEl SOUThGate SHALER AS A CHILD 


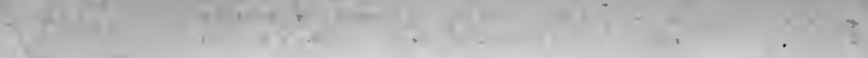

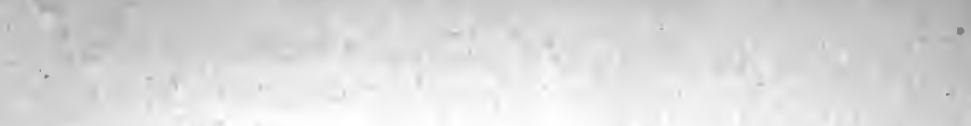

(1)
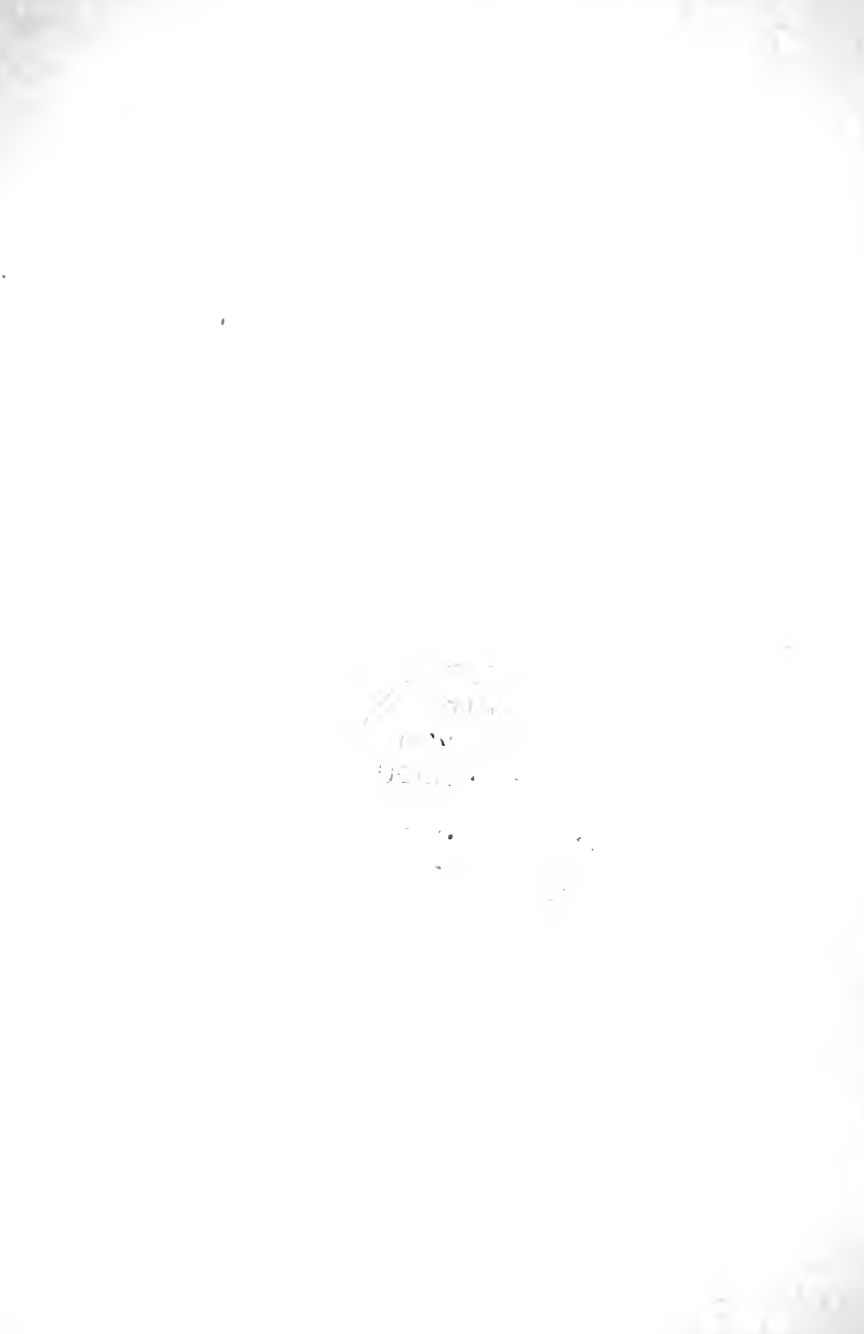

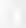
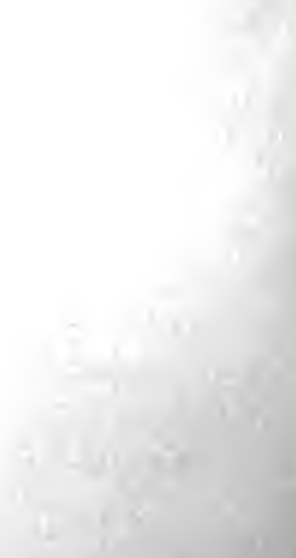

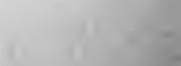


situation, for my dream of war was realized, I was caught up on the shoulders of a sturdy slave and carried home. This treatment remains the humiliation of my life.

As I had no playmates who satisfied my fancy of what a playmate should be, my time was passed in playing alone. As war was in my heart it expressed itself in endlessly building fortifcations of clay and arming them with guns laboriously made of keys, the wheels cut from spools, and the rest of the carriages whittled as best I could do. The old-fashioned large hollow key, with the hole a third of an inch in diameter, properly managed with a file, can be concocted into a miniature cannon which will "go off." My ambition not satisfied with these small affairs, I filched a pair of horse pistols from my father's office, razeed them with the file, and with no end of well-concealed labor done in my hiding-place in a barn, converted them into rather pretty diminutive field-pieces which were able to do real damage. My father, who had a fancy for developing new varieties of melons, had a new patch with sundry fine specimens nearly ripe. On these I turned my guns with such effect that they were all shattered.

Although I had no constant playmates in these years of imaginary war, I did not feel the need of them because my imaginary companions were numerous, and much more to my taste than the lads with whom I might have associated. They were all much older than myself, all for a time soldiers, great heroes who admitted me most graciously to share their mighty deeds, with the implicit understanding that I should not tell any one about it all. To have an ordinary, commonplace boy, even if he were years older than myself, imposed on this heroic society was revolting. So I played in company with an unseen host, as many children do, and got thereby much enjoyment.

It must not be supposed that because I lived in imaginary war I was naturally a brave lad; far from it. Up to my twelfth year I was absurdly timid. Alongside of this dream of war there dwelt a world of fear of the dark, of all beyond the field of view, 
of men and beasts, even of lads no bigger than myself. I doubt if a child ever suffered from immediate senseless fear as I did, while my whole soul was given to warlike projects. What I have seen in later life leads me to believe that this is a common human condition, and that the grown men who glory in the images of war are led thereto by their sense of their own timidity. This seems the likelier from an incident which ended my youthful dreams of battle. It has a certain psychologic interest and it is the first distinct turning-point in my mental state. So, though in itself a trifle, it needs be told.

Until I was about twelve years old, I was so far possessed by fear that I was much put upon by the lads of my own age. This cowardice seems to have related only to contacts with people, for as a tree-climber I was daring and successful. I remember the pleasure it gave me to scale a lofty beech and allow myself to fall through the boughs, trusting to make good my hold before I came to the ground. This I was accustomed to do alone, so that there was no vaunting in the performance. The sense of this childish pleasure was so fixed in memory that to this day I never see a tree well shaped for the hazard without desiring to try it once again. Whatever was the basis of the state of mind, it possessed me sorely until a crisis came. A negro servant, a mulatto belonging to a kinsman who dwelt near my home, amused himself by bullying me in a brutal manner so that my life became unsupportable. So with a newly awakened spirit I determined to end with him, fully expecting to be killed; be it said that my fear was not of death, a fear from which I have never suffered. I lay in wait for the fellow on the street on a moonlight night. When the bully, who was a sturdy fellow of twice my size and about twenty years old, tried to seize me, I managed with a quick unexpected rush to bring him down and to beat him on the head with a stone, so that he had to be carried off and was for some time in a bad state. It was thought that he would die, but he fortunately recovered. In this combat for the first and only time in my life I felt that strange 
bloodthirstiness, that demoniac fury, which is in all men. I had afterward in my boyhood and later a number of fights, but in no other instance has the slaying motive been aroused; so far as I can discern, the situations have provoked a rather intense sense of merriment, and the desire to do the antagonist no unnecessary harm. Another effect of this crisis was to make an end of all my fear of men and beasts. When in danger of assault there has always been a keen reckoning on the situation with a singular assurance that my wits would see me through.

My preposterous contest with "Bill Button" appears to have made an end of my fancy for war. As above noted, I am inclined to believe that this devotion of some years' duration was a natural device to support my spirit in its fear, an ideal of brave doing set over against the mastering sense of cowardice. In place of the old fear of external enemies there came to me a new terror lest the newly discovered fury should break out again. This secondary fear made no permanent impression, though its moral value to a growing lad was considerable. I am inclined to think that this trifling incident marks my passage from childhood to the youth in which the mind begins to feel the wider realm. So far as I can see, I thereafter began to look upon the world with a man's eyes, though it was with scanty intelligence. This seems therefore a fit place to set forth the conditions of the place and people where I was to take something like adult shape.

The village of Newport, Kentucky, at the time when I was born was a place of perhaps a thousand inhabitants. To a casual observer it would have seemed as a mere outskirt of the large and prosperous town of Cincinnati on the northern side of the Ohio River, with which it was connected by a ferry. Its only title to distinction was that it was the seat of a government military post, which occupied a few acres at the angle where the Licking River enters the larger stream. Although the measurable distance between the two places is not more than a third of a mile, they were in the old days much more widely separated 
in all the essentials of society than New York and New Orleans now are. There are sundry places in the world where bounds of no more geographic value separate people somewhat diverse in speech and tradition, but none known to me where neighboring folk are so absolutely parted as were these people during the first six decades of the last century. They had nothing in common but their joint share in the English blood and speech and a certain theoretical likeness of religion. Institutionally, they were widely parted. The one represented the motives of the nineteenth century, the other of the sixteenth. For there is essentially all that difference between the motives of free communities, where in the one all are of equal rights before the law, and in the other slavery holds.

The separation of the two communities on either side of the Ohio was intensified by certain accidents of the settlement of this part of the country in the eighteenth century. The northern section had been mainly sold by the United States to settlers coming from a wide range of country, mostly from the northeastern states. Although in some part owned by the government of Virginia and sold to settlers in its patent system, most of the territory had been laid out, in the usual manner, into townships, so that there were no large connected holdings; while in Kentucky the Virginia system of land grants or patents, without the preliminary sectionizing process, was adopted except for the small district to the west of the Tennessee River known as the Jackson Purchase, which was secured after the colony acquired its character and never had any influence on its social system. The result of this difference in the way in which the territory passed into private ownership was, that while in the district north of the Ohio River there were few holdings exceeding a square mile or six hundred and forty acres, and the normal size of farms was much less, being more commonly a half or a quarter of that amount, in Kentucky the larger part of the field had been distributed in tracts averaging several thousand acres. Under this patent system there grew up a form 
of proprietorship where the land was held by relatively few men, who let it to tenants. Even when the poorer class of original settlers acquired land, it was likely to pass to the richer holders by purchase or through law-suits based upon the claims of older patents. Boone became landless and emigrated to Missouri, complaining that at the end of his adventures he had no place in which to be buried. Kentucky inherited from Virginia the mediæval theory of a landed aristocracy resting upon a tenantry. North of the river, though there were here and there landowners, the conception of the relation of the people to the land was that of the free man working acres which he owned.

Another influence which tended to establish the Virginia method of proprietorship in Kentucky, and thus to fasten the feudal system, was the peculiar division in the quality of the settlers. These colonists were from the three very distinct classes into which the people of Virginia had from the beginning of its history been divided, viz.: the upper class of proprietors, their slaves, and the group of poor whites who were well accustomed to the station of tenants. They accepted the lot of the landless and were content to get what they could out of their station without striving for a higher. So it came about that in the first half of the nineteenth century relatively few of the landowners labored with their hands; they either let their holdings to their tenants, or, where they were themselves engaged in the business of farming, the labor was done by the slaves. If the holding was large, these slaves were generally controlled by an overseer; if so small that only a few negroes were employed, the owner would do the overseeing himself. Thus, while manual labor was not considered as in itself degrading, - - for, so far as I have seen, any landowner of that time would, without thought of his station, take hold with his slaves in any farming work, there grew up, or rather was perpetuated, the tradition of the three distinct estates, the proprietor, the tenant, and the slave.

In the county of Campbell, where I was born, by far the greater part of the land came by patents or by purchases from 
smaller holders into the possession of two families of common blood who migrated together from Virginia in the colonization period. These families, bearing the names of Southgate and Taylor, were from the first considerable slaveholders; they both aspired to form landed families. Unto them, as soon as they were established, there came, as usual, numbers of their poor kindred, those swarms of the unsuccessful - the landless of the Virginia families, who were ever fighting to save themselves from falling to the level of the "poor white trash," whom the slaves of the rich accounted as beneath their own station. These tenant whites came not to any extent in the first movement into Kentucky; that was made up of men of a higher social grade, and of the frontier class, generally shiftless people who had the habits of the frontier, living by hunting and trapping. They drifted out in search of new land to rent, or were imported by the large proprietors, so that their farms might be rented. In my boyhood, I knew this group of small farmers well. There were perhaps a hundred families of the class on the lands of my kindred. They were then mostly of the second generation, though many of the elder were born in Virginia or North Carolina - an excellent folk, curiously resembling the English cotter of the better class, as I came to know him in my walks in central England in the years 1867 to 1873 . Vigorous, honest, kindly, with good farming instincts, sexually wholesome, with no other vice than drunkenness, which was rarely continuous, but took the form of sprees on the quarterly pay-days or other festive occasions. They were, it is true, addicted to fighting, and were nursers of feuds, but they never murdered for money. Their feuds then, as now in the less advanced eastern section of the state, seem to have been due to the large share of the class motive among them. In this regard they did not differ from the higher-placed group of great landowners.

The most conspicuous feature of the cotter class, as I knew it, was its shiftlessness; it was not mere indolence, though the people were characteristically lazy; but rather an entire lack of all 
traditions as to the relation of labor to life. Thus they usually dwelt in commonplace small log cabins, when fifty days of labor would have given them good dwellings of the same easy construction. They put up with "stick chimneys," built of small round timbers daubed with clay, which were always taking fire or tumbling down, when a trifle of labor would build them of the stone which could be had by lifting it from the gullies of the worn fields. In many cases they were too shiftless to clear the dung from the log horse-stables; they would let it lie until it was no longer possible to get the animals out of the doors, then pull the logs apart and build the stable elsewhere. In my youth, I never knew of manure being put upon the land. When, about 1855, my father began the use of it, he was much laughed at. The plan was to till a field until it was worn out and then let it go to grass or bushes of a kindly nature, helped by chance sowing; commonly the soil washed away until the lava rock was exposed. The crops were mainly tobacco and grains, and as there was no system of rotation, the fields rapidly became exhausted. The more careful landlords required that their tenants should plant tobacco, a most exhausting crop, only for three or four years, and then set the land in grass; but generally there was no adequate enforcement of the rules, so that the cleared land rapidly became worthless. In the first sixty years of this atrocious process nearly one half of the arable soil of the northern counties of Kentucky, where most of the surface steeply inclined, became unremunerative to plough tillage.

My grandfather did what he could to contend against the evils of bad tillage; he knew of the métayer system and copied it, taking his rents in kind, that is, in a share of the crops. I well remember the times when the payments were made, including not only tobacco and grains but bags of wool, feathers, and even beeswax. To dispose of these goods, he had a store where other things were sold as well, the place giving occupation to the everpresent "poor kin."

The body of the people with whom I came in contact were the 
poor whites. The slaves were not numerous and were owned by not more than a score of families in the county. They were mostly house-servants; probably not as many as two hundred were regular field-hands. Probably not five hundred in all were owned in the county, partly for the reason that the table-land of the region, being all near the Ohio and the Licking rivers, was so deeply indented by the drainage channels that it was not suited for large plantations; but mainly for the reason that slaves readily escaped to the free country. What negroes there were belonged to a good class. The greater number of them were from families which had been owned by the ancestors of their masters in Virginia. In my grandfather's household and those of his children, who were grouped about him, there were some two dozen of these blacks, mostly pretty decent and fairly industrious people. They were well cared for; none of them were ever sold, though there was the common threat that "if you don't behave, you will be sold South." One of the com. monest bits of instruction my grandfather gave me was to remember "that my people had in a century never bought or sold a slave except to keep families together." By that he meant that a gentleman of his station should not run any risk of appearing as a "negro-trader," the last word of opprobrium to be slung at a man. So far as I can remember, this rule was well kept and social ostracism was likely to be visited on any one who was fairly suspected of buying or selling slaves for profit. This state of opinion was, I believe, very general among the better class of slave-owners in Kentucky. When negroes were sold, it was because they were vicious and intractable. Yet there were exceptions to this high-minded humor.

There is a common opinion that the slaves of the Southern households were subjected in various ways to brutal treatment. Such, in my experience, was not the case. Though the custom of using the whip on white children was common enough, I never saw a negro deliberately punished in that way until 1862 , when, in military service, I stayed a night at the house of a 
friend. This old man, long a widower, had recently married a woman from the state of Maine, who had been the governess of his children. In the early morning I heard a tumult in the back yard, and on looking out saw a negro man, his arms tied up to a limb of a tree, while the vigorous matron was administering on his back with a cowhide whip. At breakfast I learned that the man had well deserved the flogging, but it struck me as curious that in the only instance of the kind I had known the punishment was from the hands of a Northern woman.

In the households where I was intimate the slaves were on about the same social footing as the other members of the family; they were subjected to sudden explosions of the master's temper much as were his children. I well remember a frequent scene in my grandfather's house, whereto it was the custom that I should go every Sunday afternoon for counsel and instruction. These were at first somewhat fearsome occasions for a little lad thus to be alone with an aged and stately grandfather. I soon won his interest, in some measure by my fears, and came greatly to enjoy the intercourse, for he knew how to talk to a boy, and we became, in a way, boys together in our sense of the funny side of things. It was the custom, too, for him to divide the session of three or four hours with a brief nap taken in his chair. Meanwhile I had a picture-book, or, after I was about ten years old, when I could read, some work he deemed profitable, very often verses to commit, most commonly from Pope, while he slept. As his rooms were near the negro quarter, he would make ready for his siesta by sending forth the servant-man who waited on him, bidding him tell the people that they were to keep quiet during the performance. I can see him now with his pig-tail hanging down behind the back of the easy-chair and a handkerchief over his face as he courted slumber. For a minute or two it would be still, then the hidden varlets would be as noisy as before. Then the pig-tail would begin to twitch, and he would mutter: "Jim, tell those people they must be still." Again a minute of quiet, and once more 
the jabbering and shouting. Now with a leap he would clutch his long walking-staff and charge the crowd in the quarter, laying about him with amazing nimbleness, until all the offenders were run to their holes. Back he would come from his excursion and settle himself again to sleep. I could see that his rage was merely on the surface and that he used it for a corrective, for he evidently took care not to hurt any one.

There was one man in the community at the time, of some fortune, who had an evil reputation on account of his cruelty to his slaves. One of them, it was said with horror which evidently moved his neighbors greatly, owed his lamed state to his master's rage. With this slaveholder the others had little to do. They evidently regarded him as an outcast and told stories of how he had been a "negro-trader."

Among the negroes whom I remember there were sundry very old, who lived together in a building in the quarter and were well cared for. They were troublesome, because one of them, named Bristoe, had an ineradicable fancy for harboring lowdown whites, who would be found from time to time hidden away in his quarters, where they shared food with the blacks. Among these unhappy dependents was a certain aged drunken vagabond bearing the aristocratic name of Lee Sutherland. He was an ancient Virginian, with a gentleman's face and manner still showing through his debauched misery. He had no known kindred, and many efforts to keep him above utter degradation had failed. In that day there were no retreats where such folk could be stored away. Each time Sutherland turned up under Bristoe's bed there was a hubbub in the household. Bristoe was soundly rated, but he was too old for punishment or for the threat of "selling South" to have any effect on him. He enjoyed the situation, especially the peculiar dignity that came to him from protecting a man of quality. On one occasion when his quarters were watched, he harbored the man in the ice-house, where the wretch, in striving to crawl beneath the straw, had got over near the ice and was found nearly frozen to 
death; but recovered and lived to vex decent folk for long afterwards.

My grandfather's defence against the recurrent shame of having Sutherland among his negroes was ingenious. Each time he was found, after being cleaned up a bit he was put into a wagon and hauled away for a day or two of driving, and then left with a little money in his pocket. The creature would slowly work his way back, to be found again hidden under Bristoe's bed or in some near-by barn, where the old black cared for him. At length, after a distant deportation, he did not return, and no one knew whether he had died on his way back or had gone to fresh woods and pastures new.

The vagabond element in the life of the place was far more important than in a town of modern days. The idiots and the insane, as well as the ne'er-do-wells of all classes and both sexes, played their part in the comedy of life. The open market-house was the resort of all this loose life. There the houseless were wont to sleep until disturbed by the holders of the stalls. As a boy I liked to rummage among the lot with an inquiring interest in the odds and ends of folk. I remember one morning cottoning to an old man I had awakened, to get his story. It seemed that he was a Revolutionary soldier who had been wounded in the battle of Cowpens ("Cuppens" as he called it); he had come in from the up-country to draw his pension and had spent it on a spree. There was criticism when I brought the ancient home for breakfast, but when he was cleaned up and verified he had a welcome.

Of all the folk who were about me the survivors of the Indian wars were the most interesting. There were several of these old clapper-clawed fellows still living, with their more or less apocryphal tales of adventures they had heard of or shared. There was current a tradition - I have seen it in print - that there had been a fight between the Indians and whites where the government barracks stood, and that the wounded whites had been left upon the ground, where they were not found by the savages. 
One of these had both arms broken, the other was similarly disabled as to his legs. It was told that they managed to subsist by combining their limited resources. The man with sound legs drove game up within range of the other cripple's gun, and as the turkeys or rabbits fell, he kicked them within reach of his hands, and in like manner provided him with sticks for their fire. This legend, much elaborated in the telling, gave me, I believe at about my eighth year, my first sense of an historic past, and it led to much in the way of fanciful invention of like tales.

Among those men who in their youth, and even their boyhood, had been in tussles with the savages in the wars with the Illinois Indians, was a certain ancient of the name of Harris, who kept a small hardware shop which, because of his stories, I much inhabited. His exploits, more or less true, were summed up in certain rules as to how to "manage an Injun," which he used to exemplify, to my grinning delight, on my little body. Much as in the preparation for rabbit pie, you were first to catch your "Injun." The clutch was well prescribed with preliminary dissertation on the folly of "standing off and monkeying with him." Then he was to be laid face to the ground; your knees were to be planted in the small of his back; with the left hand you were to seize his scalp lock and pull up his head, and with the right holding the knife, taken from its sheath in your belt, you cut his throat. You were not to scalp him, as some uncultivated persons were wont to do, - Harris considered that to be bad form, "real Injun manners," - but proceed smartly to the next. I have never had occasion to "manage an Injun," but if such had come to me, I am quite sure that I should instinctively have essayed the task in the manner presented by my veteran instructor.

I recall that several of these old fighters, who had worked at the theory of battle with their savage enemies, held to the notion that any white man could "lay down" in the manner above described any Indian he could manage to clutch. I have 
found the same notion among the frontiersmen of the Far West in later days. It seems likely that there is truth in it; for such men are in the position of teachers, the handers-on of traditions of life and death, and do not speak as boasters. May it not be that in the white man, as a part of the predominance of his more highly organized nervous system, there is a greater capacity for yielding in a few seconds a larger amount of energy for use in the muscles? It may be that it all depends upon the intensity of the more highly trained will of the white.

When I was ten years old, and began to be attentive to the deeds and stories of men, there was still the chance to see many who had taken part in the War of 1812-15. It was less remote than the Civil War is from our time. St. Clair's defeat was only a little over half a century in the past, sundry fights with Indians were less remote, and just at hand were the tales from Mexico told by the returning troops, so that I breathed an air of combat, and of it moulded my day-dreams of valor.

The people with whom I first shaped my notions of life were, by their history, and inevitably, somewhat bloodthirsty. Their ancestors came largely from folk who had fought in England and Scotland, to fight Indians in Virginia and North Carolina, then the British in the Revolution, then more Indians and more British in the Mississippi Valley. As they had never been at peace for a generation, their ideal was naturally the warrior and his battles. This led to the feeling that combat was the fittest occupation of a man. Among the poor whites the fighting in that day was commonly without the use of fire-arms and usually of a good-natured brutality. At the county fairs, or the barbecues, a chap with the devil in him would throw up his cap and shout out that he was the best man on the ground. His nearest neighbor would dissent from that proposition; whereupon there would be a rough-and-tumble struggle even more unlimited in its conditions than a dog-fight. Sometimes the kinsmen or clansmen of the combatants would join in, but the ideal was that the two should be left to settle it in a ring of 
watching bystanders. To my father's office the wounded in these battles were often brought for treatment, and as even in childhood I often acted as his helper, it sometimes fell to me when he was absent to do what I could to mend their hurts. This gave me a sense of what to do in the way of surgical aid which afterward served me well. It also brought me near to human nature in the rough. Many of the incidents of this experience stay by me. Especially lasting are the memories showing the endurance and rude good-nature of these primitive men. At the moment, I recall a certain Sam McLaughlin, who was frequently brought for repairs; finally, he was lugged in on a shutter, with a knife slash across his abdomen which effectively disembowelled him. My father being away, I was washing his protruding entrails, which fortunately were not wounded, and returning them to the cavity, while he with his head propped up was scrutinizing the work. I said to him, "Sam, you ought to quit fighting - you are n't good at it." "My boy," said he, "I am the best fighter in this here county, but I ain't good at judging men."

With the people of the better class, fist fights were not uncommon; they were looked upon as amusing though perhaps somewhat undignified. These fist fights left no rancor: they seemed to be mere modes of expression. I remember one between an old kinsman, a man over seventy years of age, and his steward of like age, both of them needing spectacles to see at all. The rounds were ended on one side or the other with the cry, "Stop, I've lost my spectacles!" whereupon the man still provided with sight would help right neighborly to find and restore the glasses, and then they would battle again.

Serious matters between those who esteemed themselves gentlemen were supposed in all cases to be settled by the duel. For this social need much preparation was made in the way of training with arms and careful introduction into the laws and regulations of honor. My father, who thoroughly disbelieved in the business and privately ridiculed it, held, as I found, that it 
was inevitable that a man should accept a challenge in order to keep his station. He had me very carefully trained, saying that if you were a well-known expert with the pistol, rifle, and sword, ordinary decent behavior would keep you out of such trouble. I cannot remember when I began to shoot, but I recall, when not more than seven years old, a weekly exercise of some hours, partly because the light rifle used by its recoil made my shoulder very sore. By the time I was fifteen I was an expert rifleshot, including the varieties of "snap shooting" at bottles thrown in the air, flying birds, and the like. There were many who could beat me at the ancient tests of "candle snuffing," "nail driving," or other deliberate work, but I led in all such exercises when quickness was needed.

Fencing was not a common exercise among the youths of that time and place, but my father had me begin in Cincinnati with a fencing-master by the name of Scherer, a Frenchman, when I was about twelve years of age. Scherer, who claimed to be an exiled officer, but was most likely of the drill-master grade, was a great master, and having much aptitude for the work I was in five years reckoned very good in small-and broad-sword, sword and dagger, and French cane exercises, and I became passionately fond of them. The master claimed that I was the best amateur rapier fencer in this country and could hold my own with any one in France or Italy. I kept up this training assiduously until I went to Harvard, - somewhat later indeed, until the Civil War completed my distaste for arms and all that related thereto.

To keep together the story of Scherer, a character who deserves record, because he was most noteworthy of his kind, I shall here tell more of my relations with him, which were in a way intimate until my eighteenth year and continued until the beginning of the Civil War. He was a small man of the most intense Gallic quality, the human equivalent of a game-cock even to his tread. His eager little soul had but one idea, that of combat, an idea which shone from his livid face, which had a 
beautiful animal quality. All his talk was of fighting. His only treasures were half a dozen duelling-swords with blood-stains on them, and of each he had the most precise traditions as to the place of entry, the nature of the stroke, and the result. These he showed to those only whom he esteemed as successful pupils; they were to him sacred relics not to be looked at by unworshipful eyes. He was, indeed, the most perfect man of a trade I have ever known, in that he was absolutely nothing else.

To Scherer's salle d'armes came a good many well-bred lovers of fencing, among them Milton Sayles, afterwards known as a politician and jurist, a young man of much quality and of a large nature. Among them there were some reprobates, including a dissolute Britisher with the preposterous appellation of Captain Mars, who was a good hand with the broad-sword. It was the custom of the well-trained habitués of the place sometimes to fence with naked broad-swords, marking the strokes, as the phrase is, not sending them home. One day while I thus engaged with that son of Mars, he was attacked with a sudden visitation of mania and began a real assault on me. One of his strokes was effective enough to sting me so that it became a real duel, though my purpose was limited to disabling his sword-arm - which was not easy, because his madness made him insensible to the nips he received. Scherer, at the time in another room, detected by the sound of the steel that there was business needing his attention, looked in quickly, grasped the situation, and with a leap pinioned the wight and flung him on the floor. As a bit of stout daring of a little man dealing with one twice his size, I have never seen the like.

While I was in Cambridge, I saw Scherer only from time to time. When I returned home in vacation in the winter of 1860 61, I found him awaiting me with trouble upon him. It seemed that a rival had set up a competing school of fencing and had challenged him to a trial, which should include a contest between a selected pupil trained by each teacher. The contest was to take place in a hall or theatre in the part of Cincinnati known 


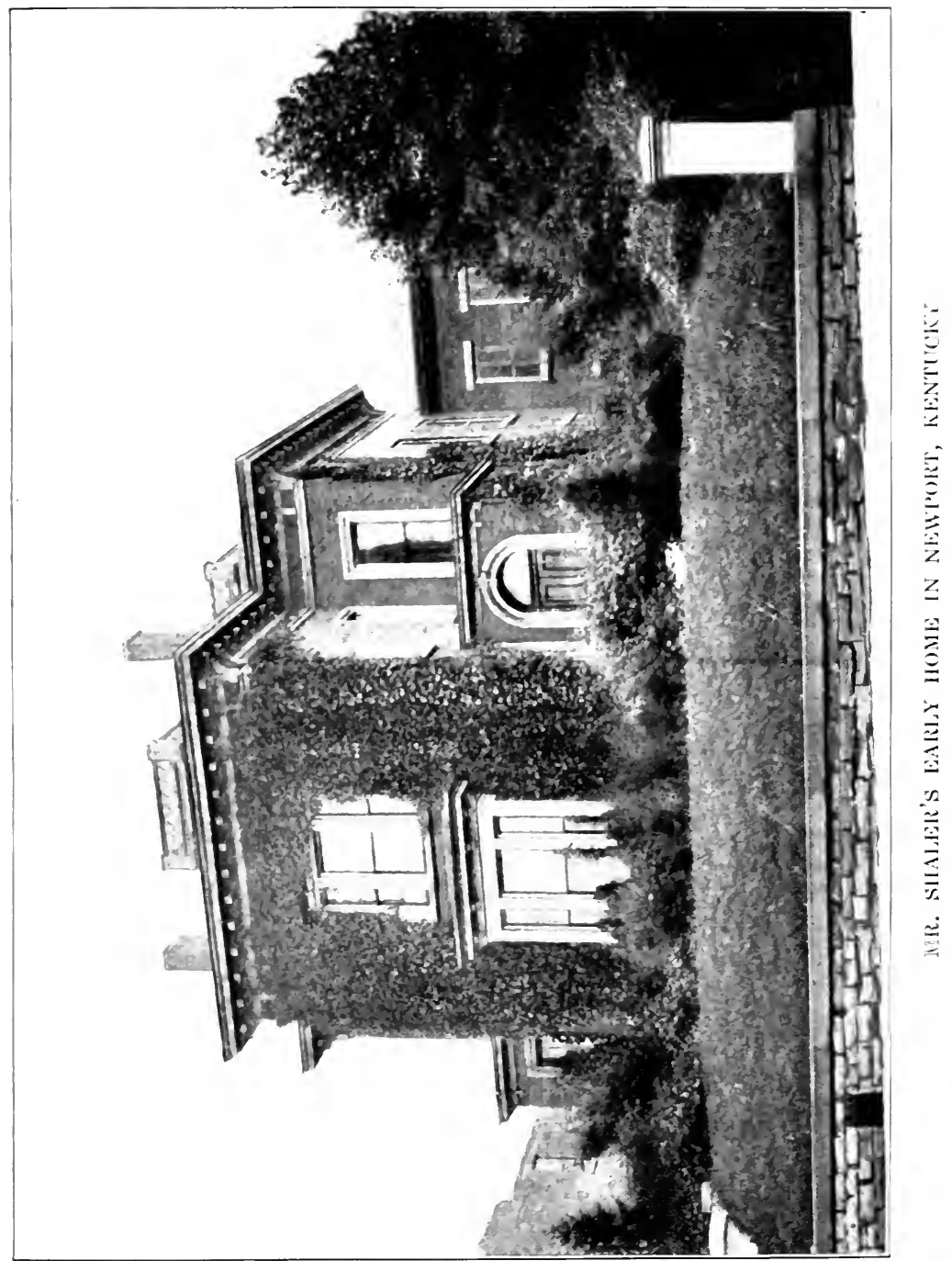


.

. 
as "over the Rhine." Scherer insisted that I should be his pupil; this I at first refused to do, but his tearful woe and imprecations led me in the end to overcome my reluctance to take part in such performances. There was a throng of spectators; for some reason the contest had aroused attention. Scherer's bout with his antagonist was only slightly to his advantage, for he was then about seventy years of age and no longer at his best. When it came my turn, I found myself opposed by another six-footer, most elegantly clad in white buckskin jacket with an embroidered red heart covering the place where his own was supposed to lie. After the ancient grand salute, we set about it. My plan was always to take the defensive and hold it with no returns until the quality of the antagonist was clear, his tactics evident, and his guard dropped - as it almost inevitably will drop, if there is no occasion to parry; then to take the offensive swiftly and with determination. I managed to protect myself for perhaps thirty passes, and had as I felt nearly used up my limit of retreat. I recall the white teeth of my vis-à-vis as he smiled in his amusement at a fencer who could only parry, however well he might do that part of his task. At length, his guard was low enough and I "stopped true" on him, that is, lunged out the instant he did, for the embroidered heart. To my horror, the blade entered to the hilt, and the fellow fell forward and sideways to the floor, pulling the foil out of my hand as he came down, and lay as if dead. Happily, it turned out when his clothes were cut open that the button on the foil had not broken off, but bent sideways; it had then ripped through the leather, padding, and inner clothes, then torn the skin and passed out beneath the arm. The hard blow had for the moment stopped the action of the heart. In a few moments the man was himself again. It is an ugly thing even in mere appearance to slay a fellow against whom you have no ill-will, so I had a very bad minute or so before the situation was evident; but the real horror of it was the demoniacal screech of joy and triumph from that old sinner Scherer 
as the wight went down. It had in it a bit of hell. I managed to get away without a word with him. From that day I have never held a foil or seen a fencing bout, except some of the preposterous things on the stage.

In 1865, after the Civil War was over, I met Scherer on the street. He had been an officer in a cavalry regiment, and the trials of service had brought him to the decrepitude of old age. To my greetings and inquiries as to his service, he said, "O Shaler, that was a coup - that was a coup!" All that had happened since seemed to have passed from his crapulous mind. I could not bring him back to his deeds as a soldier; the triumph of his pupil pursued him altogether. He was a real master.

From my curiously elaborate training in arms I had certain advantages in that it exempted me, as my father judged it would, from being put upon or bothered with challenges. I was but once thus troubled, and then most unreasonably. It happened that the person who supposed he was offended chose a sensible fellow for his second, who, as he explained to me, soon convinced his principal that he was playing the fool. On two occasions, before I was twenty years old, - boys took men's parts in those days, - I served as second to friends, and in both instances easily adjusted the troubles without much parley. The first occasion was when a silly cousin of mine with too much wine in him challenged a well-known duellist, James Jackson, who, as a general, fell at Perryville. Fortunately, I knew Jackson as well as a boy of eighteen may know a man of twice his years. I made my plea to him to give my kinsman an easy way out. At first he was obdurate, saying that he would have his life, - he had, indeed, reason to be vexed, - but in the end he told his second to "fix it up" with me. My good, I may say indeed affectionate, relations with Jackson had begun a year before in a like absurd business in a ball-room in Frankfort. I had accidentally stepped into the mess made on the floor by the breaking of a bottle of champagne, which he as manager was trying to have cleaned up. With a sharp word, he 
pushed me aside; my new-found manly dignity was offended; therefore, as usual in such cases, I asked him for his card. His answer was: "I beg pardon, my dear sir, I took you for a boy." We both saw the fun of the situation and became friends. He was one of the glories of this world; he lifted my sense of what it was to be a man - the ancient type of gentleman. The other instance, when I had to compose trouble between men, was more serious. In $1859 \mathrm{I}$ went with a party of young people to the Mammoth Cave. With me went Courtland Prentice, son of the once well-known George D. Prentice, editor of a Louisville paper, who, though some years my senior, was then my nearest friend. As the railway was not completed, we journeyed in stage-coaches privately hired. At a relay place a gentleman, a stranger to us all, mounted the stage and sat beside my friend, who was in an excited state and resented the intrusion in an improper manner. It quickly came to the point where he had to challenge the stranger, which he did on the spot. There being no one more fit, I had to serve Prentice as second. Fortunately, as the other principal knew no one in the throng at the Mammoth Cave, I had to help him to find a second, and so had a very reasonable person to deal with. The stranger, who turned out to be a well-known duellist from Mississippi, accepted the invitation to battle, choosing as weapons shot-guns with buckshot at twenty paces distant - which meant certain death to a novice. But once again the difficulty was easily arranged; in fact, they were with rare exceptions mere fooling.

The only good side of the system was certain features of the code which require that the antagonists should not dispute with one another, and that as soon as there was a grievance it should be put into the hands of disinterested persons; and the further theory that the seconds, with an arbiter if need be, should try to compose the matter, their decision being quite beyond appeal. One of the maxims - one often impressed on me by my grandfather and other elders - was that gentlemen sometimes fought, but they never quarrelled in the manner of 
the vulgar. There was an interesting old fellow in my town who instructed the younger generation in the code. This Major $\mathrm{H}$. had been an officer in the regular army and was then crippled as to his right leg. He had received his wound because of his strict adherence to one of the many peculiar rules which determined the process of duelling. Being second to a man who did not promptly meet his engagement, he took his principal's place at the appointed moment, and the bullet lamed him for life. This, to our modern sense, is something at once for laughter and for tears, but in that vanished time it was otherwise. The incident dignified the man and made him an authority in an important side of life.

I am glad to say that, even as a youth, the absurdity of the duel was plain enough to my mind; but it was an institution like slavery: when born in it, whatever one's views of the matter, it was not easy to get out without being disclassed.

The religious people of Kentucky, there, as elsewhere among our folk, the controlling element, shaped laws to make an end of duelling. All who took part in such affairs were disfranchised, unable to hold office, and liable to punishment, as if they were engaged in a conspiracy to commit murder. The result of this drastic legislation was to make an end of duelling and to bring in its place the more serious evil of "street fights," which were far more brutal than the ancient practice of regulated battles, when the friends of the disputants could almost always avoid serious results. In the time of my youth I recall but two deaths in duels; but since that custom was abolished more than thirty of my kindred and friends have been slain in these brutal encounters. It is all miserable business, but as a choice of evils, so long as men are bloodthirsty animals, the duel was the least. 


\section{CHAPTER III}

\section{MY DESULTORY EDUCATION}

THIS account of the fighting propensities of the people of Kentucky began with the story of my training in arms in my childhood and afterward. I now return to the process of my better education as a lad passing from childhood to youth.

At about ten years of age I began to be interested in animals. Rather oddly, this interest was at first awakened by spiders. It is likely that, being of a solitary humor, these lonely creatures aroused my sympathies. I quickly came to know the familiar species and their habits. I remember getting a number of large glass jars from my grandfather, a dozen or more, in each of which I kept some one kind, feeding them and watching their web-making and other habits. I also got into the way of collecting and hatching cocoons of various insects. Thence I went to studying ants, of which there were a half a dozen species. I remember, also, a great interest in the common beetles. These fancies were original, for there was no one about me with the least interest in these creatures. My father, though much given to minerals, paid no attention to the wild life except when they menaced his roses or other plants, and as a child I had no interest whatever in plants.

After a year or two of a rather wild devotion to "bugs," which was the subject of much ridicule, I transferred my affections to birds. I fancy that the change was due to the fact that when I was about eleven years old there were sundry extensive "flights" of the passenger pigeon, already becoming much reduced in number, but by some change in their migrating movements for a time a very conspicuous feature. For days at a time the sky would be flecked by these birds in endless flocks, moving this way or that in search of feeding or 
resting places. At their resorts where they bred they were mercilessly slain and fed to the droves of swine gathered there for that purpose. By 1855 they had disappeared from that part of the country. It is not unlikely that the species is now extinct. Although fond of climbing, I did not get into the habit of bird-nesting. From this boy's vice I was debarred by a keen sense of personal relation with the creatures. I had my satisfaction in watching their building work and in this followed through the construction of the orioles, swallows, and some other species. Naturally, I found my way to mating pigeons, and thence to the other domestic fowls. At this period, much of my time was spent on various farms, particularly on a place of about three hundred acres, two miles from the Ohio River, now the town of Southgate. There were extensive barnyards with numerous and varied fowl. I had at one time near a thousand pigeons, along with cocks and hens, geese, ducks of several species, and several varieties of turkeys. My love for these creatures became very great, but it gradually reverted to a fancy for game-cocks. This was caused by the fact that near-by was a farm altogether devoted to rearing male birds of this admirable breed for the West Indian markets, some thousand each year being sent on their way to distant adventures. It was a sight and sound I well remember, the passing of a huge wagon with a frame like a hay-rick, on which were hung hundreds of little basket coops, each holding a bird and with a little opening through which he could stretch his neck for the needed exercise of crowing. As the van crept down the way to the steamboat landing, it was to the noise of the united challenges of all the valiant cargo, a curious strident note that could be heard from a mile away.

For a time I was much interested in the battles of gamecocks. I never fought them with "gaffs," those detestable contrivances of steel shaped like lancets, which fit the cruel notion of Spaniards; in fact, I always blunted the spurs so that they could not give a deadly blow. What charmed me was the valor 
of the creatures and their curious antics and devices while in combat. All the eager fondness for war which had possessed me from five to twelve years of age, was at fourteen narrowed down to a delight in the capers of these cocks with blunted spurs. I remember being curious to find whether the creatures learned their art and acquired their combative motive from their elders. As an experiment I hatched one of them of a famous stock artificially, and brought him up "by hand," so that he did not have a chance to mingle with his kind until he was grown. I then turned him with his natural possession of spurs, which were keen instruments, into the above-mentioned barnyard, where there were a dozen males of his species of the ordinary degenerate breeds, bred for size and fecundity, as well as two male turkeys, a Muscovy drake and some ganders. It was but a moment before he was in battle with his natural enemies; these cocks he speedily dealt with; they seemed confused by his swiftness, and would soon turn tail : he easily daunted the drakes and ganders, but the turkey gobblers troubled him sorely. The last of his tasks and the most difficult was a very large white gobbler who, when attacked, would catch his small antagonist wherever it was convenient, oftenest by what was left of his comb, and carry him dangling in the air. For protection the cock invented a curious manœuvre: after each assault with his blow of spurs, he would move between the turkey's legs, hide his head in his feathers, and stay thus havened until he had regained breath and strength for another stroke. With leaps or short runs the turkey would try to have him out, but most dexterously would he manage to keep thus sheltered until again ready for an assault. The device was successful, so that in a few days the best adversary was fairly routed, and the little warrior was cock of the walk. I distinctly remember his forlorn appearance at the end of the hard campaign: he was almost stripped of feathers except those of the wings, his comb and wattles were gone, he had lost one eye, but the trumpet crow and the Scherer stride were still his. 
This bird was one of the most remarkable creatures with which I have ever become intimately acquainted, and I have been fortunate in such acquaintances - I may say friendships with birds and beasts. He seemed to have for me a measure of affection independent of any expectation of food, that I have never seen in any other bird. He would sit on my knee and let me stroke him as a dog would do, yet his instincts would lead him to attack me if I meddled with his hens. On one occasion I found a pullet of his harem imprisoned in a picket fence, where she had managed to get her wings through a space not wide enough for the pelvis to pass. It was a matter of some difficulty to release her, and she squawked lustily as I strove to do it. All the while the cock was near by, watching me with his one eye and dancing with excitement. At length, when the pullet gave a louder scream, his impetus carried him away and he planted his spur in the back of my hand, making a wound the scar of which I can faintly trace to this day.

I tell this seeming overmuch concerning game-cocks, in part for the reason that it is through them that I came to an intense interest in the actual life of animals, which has been to me a source of great enlargement, and in part that I may make again my plea for keeping what we can of our domesticated animals near the primitive stock. Those who know only the degradations of our supercivilized domesticated birds and beasts, have very little idea what a natural animal is. The game-cock is one of the few which retain a fair semblance of what the wilderness breeds; he is perhaps the most interesting of all birds.

On another occasion "the farm," so called to distinguish it from certain larger and more remote places, gave me a most instructive experience with animals. The owner of a menagerie placed there for a summer under a keeper a fine specimen of an elephant, named Hannibal, and also a camel. With the elephant I became promptly and most intimately acquainted. He was commonly chained to a tree on the edge of a wood, and thereto I went every day for many weeks. The noble beast had a rather 
bad reputation for his surly temper, but for me he had only kindness. It is true I came laden with gifts, bundles of clover and sweet corn for which he seemed duly grateful, but it was not all a matter of fodder. The great beast liked to play with me, lifting me with his trunk as if he would throw me a hundred feet away, and then searching my pockets for tid-bits. I can hear him now as he would trumpet and dance when I came in sight and when I went away. As for the camel, all my advances were rejected; the miserable brute spat at me. I have loathed camels ever since. I count that noble game-cock and that glorious elephant as among my teachers: they brought me to love animals and appreciate man's relation to them.

Like other lads, I had much to do with dogs. They abounded in the society in which I was reared; but then, as now, the dog was commonplace, not recognized as an outside animal, but taken rather as an integral part of man. It is the creatures which have their independent emotional life that give us the great lesson of our kinship with the lower stages of living. This lesson is sorely needed. I have known famous naturalists who had never come by either an intellectual or emotional understanding of their place in the chain of intelligence, and without this a man remains a stranger in this world.

The awakening which came to me at about twelve years of age, rapidly led, through my interest in animals, to a general interest in all the visible realm of nature. My father had some knowledge of mineralogy and a keen eye for all natural objects. He had in his study the remnants of what had been a really good private collection of minerals, made while he was a student under instruction from Warren, and in intimate connection with Charles T. Jackson, a brilliant man, afterward well known as a geologist. There were not more than a hundred specimens in this little cabinet, but they were all of kinds calculated to arouse the curiosity of a lad, beginning to awaken to the world about him. I remember rather suddenly turning to them, especially to the crystalline shapes. The ordinary dog-tooth spar, and 
the staurolites with polished ends showing the cross shape, set me to thinking as to what shaped them so. A specimen of "stinkstein," with its peculiar odor when struck or rubbed, gave me a sense of the hidden properties of things. I wore it out in repeating the experience, and for a time went about making like experiments on all the kinds of stone I could find, in which I detected a great variety of odors, and pleased myself with the notion that each variety had its own distinct smell. As there were practically no crystalline rocks in any place within three hundred miles of my abode, all these specimens of my father's collection were to me as from another world. I began to search for the like in my endless ramblings afield, and to my great joy found some gravel beds just to the east of the town of Newport, in which there were granitic and other pebbles from the Archæan rocks. The question as to what these pebbles meant came to me with its revealing power.

I well recall my father's explanation as to the origin of these bits of peculiar rock in the mill-bottom gravels, an explanation which shows that he had some knowledge of the general geology of the Ohio Valley. It was that they had been brought down from the mountains by the waters of the Ohio River and deposited where I found them, when the bed of the stream was higher than it now is. As a matter of fact, these gravel beds are a part of the frontal deposits made by a tongue of ice in the last glacial period, and the crystalline pebbles were brought from the Archæan district of Canada. Yet the explanation served me well; as a means of mental expansion more than any other concept, it led my mind to conceive of the far-reaching actions, of the world as a place where work was done. It was practically through this my first attention to rocks in the field, that I first came to discern that the plentiful fossils in the lower Silurian rocks about me had a meaning. I must have seen them from an early age, for they were everywhere in the fields, and I was by instinct a mouser after things in the earth. The first found to attract my attention was a common trilobite, the Calymene 
senoria; it is most often found rolled up, so that it distinctly resembles a gigantic oniscus, or sow-bug. This likeness caught my eye and led to the notion that there were such creatures turned to stone. My father knew in a general way what it was, and so I found the path to the idea that the strata of the country about me had been made on old sea floors and that the queer things they contained were the shapes of creatures which had of old been alive. This conception I came to when I was about fourteen years of age. It at once took a firm hold upon me. It was one of the shaping understandings of my life. I soon found access to certain geological books in the Mercantile Library in Cincinnati, and among them there was a two-volume edition of Murchison's "Silurian System," the first geological book I ever saw. Most of it came beyond my comprehension, but the figures gave me a clue to names of fossils, and at fourteen years a lad has enough of the primitive in him to set a great store by names.

Probably the most effective source of enlargement for me in these passage years was a series of events which turned me toward astronomy. Mitchel, the well-known astronomer, had established an observatory on the river bluff in the eastern part of Cincinnati, the buildings of which I saw, and the uses of which I had heard. I had also heard an interesting Irishman, by the name of Vaughan, ${ }^{1}$ who taught in the government school that I attended, kept at the barracks for the children of the

1 This guileless Irish dreamer excited the sympathy of the community, and my father invited him to spend several summer vacations at his house. During one of these visits he volunteered to teach my sister and me something of astronomy. The lessons were usually given outdoors under the grape arbor, the ground serving for blackboard; on it he drew with his cane diagrams commensurate with the sweep of his thoughts, so that before the hour closed his illustrations compelled us to perambulate the garden a good many times over. Although beginning simply enough, his talks soon became too abstruse for us to follow, and lured by the shade of a big tree it was our habit to steal away and amuse ourselves with terrestrial objects, while he, all unconscious of the desertion, would continue to wander alone in celestial spaces. At table he was so absent-minded that dishes would be passed before him unheeded, until some member of the family would put food upon his plate and tell him decidedly that he must eat, whereupon he would mechanically go through the process of filling his empty stomach. Now and then he would disappear, and after a search be found in some humble lodging where the only eridences of sustenance were a number of empty paper bags which originally held the peanuts that for days had kept body and soul together. - S. P. S. 
officers and soldiers. Vaughan knew much of astronomy and was a man of imagination and of great descriptive powers. His talks were beyond my understanding, but I had from them a dim sense of vastness which perplexed me. At this time, my father in some way obtained for the period of several months the use of a small reflector telescope which, as I remember it, had a mirror about ten inches in diameter; it was made, I believe, by a man named Barlow of Lexington, Kentucky, who made an orrery, or planetarium, showing the movements of several of the leaders of the solar system, which was kept in the Mercantile Library of Cincinnati, and in which I greatly delighted. The telescope, which I soon learned to manage, was good enough to open the heavens to me: up to that time only the sun and moon had in any way moved me. The lunar craters greatly excited my curiosity, as did also the satellites of Jupiter, but the great awakener was the ring of Saturn. I do not clearly see why it was so, but the sight of that ring system was intellectually the most important single incident of my life; this first impression and the memory of the startling effect of it on my mind, stays by me with a distinctness that belongs to nothing else of that time.

I have thus told in brief the conditions of my surroundings which served to awaken and in some measure to restrain the awakening of my mind. It is fit now to set forth the little I have to say concerning the effects of this desultory education, by noting certain states of my mind. First, as to what is termed religion. On this side I was little developed. My father never went to any church, and though he was always silent on the subject, I easily knew that he attached little importance to what was taught there. My mother was in a limited way a church-goer and kept a pew in the Episcopal church, though she often went to the Methodist meetings, taking me to one or the other. Of these churches, both of the orthodox type, I remember only the tedium of the performance and the development of an intense hatred of the being who, with the power to 
arrest Satan and his works, permitted him to torment men. This led to a wild desire to grow big enough to slay the pictured demon who would permit such iniquities. Against the devil himself I had no such rage, for it was clear that he was only a bigger kind of bad man, such as I saw about me. This was before my teens, when my fancies were proportionately valiant; after I passed twelve, came utter disbelief, or rather a turning away from the whole matter.

The concept of death came to me earlier than I can recall. In the barracks hospital men were constantly dying, and as I played in and about the building the performance went on under my eyes. The funerals with the covered bier, the band playing a dead march, and the escort, were my delight. I tagged on to it to see the brief but stately ceremonies, to hear the volley, and then the quickstep home. So death came to be accepted as the complement of life. With this went a curiously intense belief in immortality, altogether instinctive, for I had no teachings concerning it except in sermons which did not affect me. I was not at any time interested in the matter of a life after death, but accepted it as an absolute reality based on feeling.

The only movements of the spirit in the religious field which I can remember, came from two sources: my mother's singing she sang simply and sweetly - of the better hymns. "From Greenland's Icy Mountains" and "Jerusalem the Golden" would make me weep, I think because of the singing and not for the religious sentiment. Oddly enough, I had a curious kind of affection for Christ; I revolted at his submissiveness, but the sense of his love for all living creatures made him dear, despite that infirmity, in which he was so unlike the heroes with whom I still dwelt. The other spiritual influence came from the negroes. A number of them used to meet at night to talk religion beneath a shed which lay open to the northern sky. One of them, well named "Old Daniel," had a fervid imagination and excellent descriptive powers. He would picture the coming of the great. angel as if it were before his eyes; the path of light shooting 
down from about the North Star, - the majesty of his train. Then the rolling up of the heavens "like a scroll" - I did not know what this process was like, but it seemed vaguely fineand then the burning up of the world. I was always greatly moved while hearing these exhortations, which must indeed have been rather wonderful things, but they made no permanent impression upon me. In fact, I regarded them as "nigger talk."

Until I was twelve years of age I think that I had no sense whatever of natural beauty. I showed no disposition to draw or to model, except with my preposterous fortifications, which, as I recollect them, indicated a considerable ability to shape clay to my mind, and a decided ability for pop-gunning. But as I entered my teens, the sense of natural beauty suddenly, indeed remarkably, awakened. In less than a year I suddenly developed a temporary rage for drawing. Without any lessons or examples, I covered square yards of whitewashed walls with landscapes, in part copies from books, but as I recall with some trace of inventive power in them. People came much to see them, so that I found myself an infant prodigy. Then, alas, I was sent to a drawing-master in Cincinnati, a German by the name of Welsh. He set me to hard tasks, and the desire evaporated, so that in six months I detested it altogether. I have never since been able to draw in a way to give me any pleasure. I am inclined to think that I must have had some sense of pictures at that time, - they have always pleased me when the drawing was true, - for an incident shows that I was not blind to the expressions of nature. While with Welsh as a very inept pupil, some people came to look at a landscape he was painting. They admired it as a sunset; when they had gone away I asked him, to his great delight, if it were not a sunrise. That I saw the difference, which was plain enough to any seeing lad of fourteen, made him think that I would be an artist; but I was at this stage incapable of the needed labor.

My newly awakened love for the aspects of nature was shown 
by my eager search for points of view of the landscape, especially those which included the Ohio River, which from the first had been a source of movement to me, at the outset awaking the sense of mystery, which swiftly passed to that of beauty. The sense of mystery, that emotion which makes against the commonplace state of mind, was from the beginning strong in me, as I believe it is in most sensitive persons. At first it was mingled with the primitive fear, - fear of the dark, of the depths of the earth, of the great river, of men and animals. This sense of mystery appears to have been a kind of emboldened fear, and, with that of natural beauty, to have evolved itself from the feeling of awe before the great mystery of all things. At first this æsthetic sense seemed to relate only to the larger aspects of the world, to sunrise and sunset and the vistas of the great stream. Though my father was given to a love for flowers and I was in the habit of caring for them in the garden and greenhouse, they did not greatly delight me while I was a child; all emotional sense of the beauty of such things began to develop some time after puberty.

Turning now to my formal schooling, it may be said that I had none of any account until I was more than ten years of age. My father judged it well to let me go my way up to that time; all the slight efforts to cage me in a room and make me learn definite lessons seem to have made me ill. I suspect that a share of this illness was fictitious, contrived to avoid the hated caging in the school-room, but it had a real basis in a certain abnormal nervous sensitiveness which has always made the house a prison to me. That it was not from laziness is shown by my considerable zeal in following my vagarious activities. Between eleven and twelve, I was sent to the above-mentioned barracks school, which was under the charge of the government chaplain, an educated Virginian of high character and ancient lineage. The teaching was mainly in the hands of two men who were sergeants in the permanent garrison of the post, men of training and large quality, who, as was often the case in the old 
army, sought refuge there from the battle of the world, in which they had been beaten. It was a rough-and-tumble school, made up of some children from the garrison and a dozen or so lads from town families. There I learned the elements of Latin, Greek, and mathematics, acquired reluctantly with frequent long absences, due to nervous illness and general insufficiency of health. In my eleventh year these troubles began to take the form of megrim, commonly known as sick headaches, a torment which for fifty years sorely vexed my life. This malady, the opprobrium of medical science, came to me by double inheritance, and on both sides of my house it had affected my ancestors for at least three generations. For some years, until I trained myself to go on with my work while suffering, these visitations troubled me for at least two days in a fortnight. One of the compensations of age is that they greatly diminish in frequency and weight. After about three years in this school, where I learned very little except the art of dodging duties, in which I became fairly expert, in my fifteenth year my father found a tutor for me, a German-Swiss clergyman, who had wandered with his wife and children to this country in the movement of 1848 , and had been obdurately unsuccessful in his efforts to establish himself in charge of a church. As, next after my grandfather Southgate, this man had the most influence in shaping my mind, - in fact, the most of any in the passage from youth to manhood, - I shall now seek to give an account of him.

Johannes Escher was from eastern Zurich, of the wellknown family of that name. He was of moderate parts and had been well credited at Heidelberg and Tübingen. Though trained as a theologian, his bent was altogether towards philosophy: he was a Hegelian with the curiously intense devotion to the faith which characterized the followers of that master. His absorption in his philosophical creed withdrew him from the world, so that his interesting wife and attractive children seemed remote from him. His only keen interest that remained in his 
middle age was in the classics and in the poetry of his own language. All the rest of life appeared to be unreal to him. It was probably the admirable contrast of the quality of this dreamer with those about me that caused me to cleave to him; so that we were for three years very near to one another. Naturally curious about people and their ways, I found in Escher a revelation of a new genus of mankind; his ways of looking at matters curiously interested me. Moreover, in this my fifteenth year, I began to have some capacity for continuous work and did my hard lessons in Latin, Greek, and German under his tutorage with assiduity. His method of teaching was for me the best. As soon as I could read Latin with a little facility, he forced me to read aloud to him rapidly without rendering into English, he reading brief comments in that language and compelling me to ask my questions as best I could also in Latin. In this way he forced me to think in the language we had in hand. I had already been fairly trained in Latin grammar; I was now made to use Zumpt's more ancient but better work. In this way we went over a much larger body of literature than the ordinary student traverses, including all of Virgil, Cæsar, Ovid, Cicero, parts of Horace, Tacitus, etc. From the point of view of scholarship, this left much to be desired, yet as I was made to commit a large part of the Iliad and much of Cicero, I am inclined to think that I had more of value from my tasks than most students gain. In Greek his method was similar; but I went not near so far with him in that language as in Latin. I did some composition work in the way of written translations and a little of it in metric form, but this part of his teaching was ill done.

In German, Escher pushed me forward rapidly in speaking, writing, and reading, so that while with him I read practically all of the poetic work of Goethe and Schiller and parts of the other notable poets who have written in that language. At that stage of my life I had already gained some acquaintance with English poetry and had acquired the art of committing verse in such a measure that I had won a wager by committing Byron's 
"Siege of Corinth" and reciting it without error in one day. I was less successful with German, but memorized several thousand lines of its classics. Here I may turn aside to note the fact that this habit of committing to memory was very common, indeed fashionable, in the society in which I dwelt as a youth; it was held to be an index of culture, a necessary part of a gentleman's outfit. I recall an old kinsman, a man who seemed absorbed in a life made up of business cares and dissipations, who, when suddenly called on in a gathering, declaimed Manfred's soliloquy correctly and with vigor. I have heard many others of the same common stock do like feats. This fashion seems to have been a survival of the old English habit, when literature was taken more seriously than in this day. Thus it was that by the time I was eighteen years of age, in competition with the youths about me, I had stored away not less than fifty thousand lines of English, Latin, and German verse, a large part of which stays with me to this day and has been a helpful store.

With Escher I found my way to the society of Germans in Cincinnati, a most interesting group of men from whom I had much enlargement. Some of the ablest of these were accustomed to meet at a beer hall in the part of the town north of the canal. There were many of these men of quality, the best of the exiles of 1848. Of them I recall Stallo, - afterwards minister to Italy, - a newspaper editor, and a rabbi whose name has not abided with me though his admirable shape is still plain. These were strong men: their talk made a great impression on me, and their personal quality did much to lift me to a higher level of ideals than any our people supplied.

Gradually, probably with no purpose of teaching his philosophy, Escher inducted me into the mystery of Hegel, so that by the time I was seventeen I was deeply infected with his noble madness. The field of metaphysical speculation opened before me as a new universe; of all the vagarious devotions of my childhood and youth this took the firmest hold upon me. I began to read all I could of philosophers and their writings. 
The Mercantile Library in Cincinnati had many such books which I devoured. I recall the pleasure with which I bought a set of G. H. Lewes's "History of Philosophy," a rather poor book as I now see it, but then a treasure in my eyes. I had two German manuals, the titles of which I have forgotten. The curious thing about this prolonged excursion is that I really got something out of it. I appear even to have gained an adequate idea of Kant's "Critique," though I doubt if I could compass it to-day without much labor. With all this intense interest in the speculations of men and the history of the evolutions of their systems, I had no real belief in the essential verity of them. They charmed me as an exercise of wits much as did chess, to which at this time and at various later periods I became addicted. The sense of the difference between speculative and experimental inquiry was so far in my nature that when at about nineteen years of age I came in contact with the work of Auguste Comte, my interest in philosophic systems rapidly declined, to be roused in a limited way in after life, and then only as the means of rationalizing the evidence afforded by the phenomenal world.

While my youthful love of philosophy, though for two or three years very great, bore no immediate fruit, the ground on which the seeding fell was essentially strong, and it had certain secondary effects which have been of permanent value to me. No youth can be filled with that vast concatenation of semilogical deductions from an impossible postulate which makes up the system of Hegel, and in the end purge himself of it all, without very enlarging experiences. If he goes further, and sympathetically takes in the speculations of the Greek and German philosophers, and works himself through the main notions of the English and Scotch schools, even if at the end he casts it all away, he has a thought background for all his life. If one can be in the society of these futile giants and in the end escape from them, it is well for him. Intellectually there are, in my opinion, few things worse than to be cramped and kept in 
any kind of logical prison, but they are capital places for exercising the wits.

One effect of the study of philosophy was that I became very much interested in the history of Greece. I read several works on the subject and bought a set of Grote's great twelve-volume book and studied it with much care when about seventeen years of age. Long afterwards I found an abstract of these volumes which I had made. It was laboriously done, and with a measure of intelligence which gave me a certain respect for the vanished lad which I had not previously entertained.

As I look back on the stages of my life up to my eighteenth year, I have the curious impression that it was not a continuous existence, with a progressive intercalation of characteristics, but a number of disjointed personalities tagged with a common name. The child up to about ten years of age was not the father of the lad of twelve; nor was that rather ill-conditioned urchin gradually transformed at fifteen into the beginnings of a speculative philosopher. These individualities inhabited one unfolded body, but while there were links connecting them, they seem to have been curiously unrelated. This impression is doubtless partly due to the lack in this formative period of a continuous thread, such as is afforded by the usual uninterrupted process of schooling. I was left free to move with the natural currents of my inner life, so that heredity and what may be termed natural environment had free play. For long I thought that this lack of systematic training in my youth, though in some measure due to my frail health, was a wrong done me. As I have grown older, and seen some of the effects of our schooling in stunting the development of youths, I have come to the conclusion that in my case it was a piece of good fortune that I was thus left mainly to my native impulses. It cost me rather dear on some sides of my education, especially in the field of mathematics. Had I been properly ushered into that science in place of being left to my own devices, I should have gone forward to a fair measure of command of it as an instrument of inquiry, 
instead of being compelled to flounder with its methods or avoid them altogether. The lack of adequate knowledge of calculus has ever been to me a great hindrance in my work.

The lack of adequate training in the classics, which I suffered from the imperfection of my youthful training, has been a source of regret rather than inconvenience in my later life. I gained more than a fair scholarly sense of the value of Greek and Latin thought and phrase, so that I have been able to possess myself of its meaning and quality. As regards my own speech, in which I never had a lesson except from the proof-readers, the society in which I dwelt and some native capacity for appreciating men, served me fairly well; better, indeed, than the formal teaching which has been the share of those of my station. Of the other modern languages with which I have been thrown in close contact, German, French, Spanish, and Italian, my acquaintance has been limited to a capacity to speak and read them in an effective smattering way, which, though unscholarly, has sufficed to open books and the hearts of men at my need. Out of the jumble of experiences which served me as an education, came, above all, a capacity to find from time to time my bent and to follow it with a fair measure of determination; to be in effect my own master for my own purposes; to rest little on authority and to have a real love of the discoverable fact. Unlike the overtrained youth of the modern school, who is crowded for all his years of preparation so that his spontaneous impulses never have chance to take shape, I was allowed to evolve myself in a more normal way. Something of the very fair success of this experiment in my case was due to the fact that the life I shared, though rude, was that of very actual men, and to the combination of the effective environment which bore in upon me in a way fitted to the needs of my nature. 


\section{CHAPTER IV}

\section{FIRST VISITS FROM HOME}

THERE were certain experiences of my life between my fourteenth and eighteenth years which have not found their place in this story, but deserve telling, for they had their share in my shaping. Up to the age of fourteen I was kept within a narrow range of country, not wandering further away than twenty miles from my birthplace; the farthest, to certain large farms belonging to my grandfather about that distance up the Licking River, which were in charge of a kinsman by the name of Hinde, a large, simple-minded man, the type of the English squire. There I fell in with a more primitive folk than dwelt in and near the town, people essentially like those who were later discovered by literary folk in the mountains of eastern Kentucky and Tennessee and the adjacent parts of Virginia and the Carolinas. With them I learned the arts of the hunter. Deer were still to be found and wild turkeys were abundant. The men had the skill of the frontiersman and his traditions in tracking game. Two of these rustics stay in my mind: one was a gray-haired old man who had an amazing skill with the rifle then in use, the long, heavy-barrelled piece with a bore so small that a hundred or so spliced bullets were had from a pound of lead. As for shot-guns, he despised them utterly. I remember that when a friend of mine joined our hunting party armed with a double-barrelled fowling-piece, this ancient hunter, after examining it carefully, said, "Stranger, you ain't a-going to tote that ar thing with us; there's no knowing what it 'll do."

Among the lads near my age, was one of sixteen years who was a really marvellous shot, especially at wild turkeys on the wing, very difficult birds to hit with a rifle-ball. One day we started a flock in a wood where in their flight they were only 
visible in crossing a narrow roadway. The boy shot the first to appear, placed the bullet in the small space between the base of the wings and the top of the thighs where it needs to be placed so that the wounded animal can neither run nor fly; the distance was paced by the master of the hunt and determined to be two hundred and eight yards. It was not a fluke, for the fellow did much such shooting. He had that curious organic perfection which alone makes such deeds possible.

Because I came to know these countrymen and acquired that habit of dealing with the wilderness, I was often called on by my elders to take charge of the search for the "corners" of land held under the ancient titles when the only record was made in some such phrase as " beginning at a white oak by two sugar trees and a poplar on the upper waters of ten mile creek, thence running north-easterly 1600 poles to a red oak," etc. As in many cases it had been two or three score years since these corners were established, the axe-marks in the "corner" and "witness" trees were often extremely obscure, sometimes completely grown over; not infrequently one or more of the trees had fallen and gone to decay. On one occasion a land suit turned on the question of establishing a corner marked more than seventy years before. The only person who had ever seen it was a man nearly ninety years of age, who had been with the surveying party that first "ran out" the trail. In his dotage, the old fellow had only now and then command of his wits; but by staying with us for a fortnight while we rode through the woods, he slowly recovered his memory of the place and finally selected a tree as most likely the one we sought. The surface showed nothing that could be identified as an axe-mark; but by carefully scraping the bark and wood away we came upon ancient buried scars, which were evidently made by a tomahawk, such as the surveyors of the eighteenth century used; so the title was established. This case of slowly recovered memory interested me much and aroused in me a sense of the mystery of mind that has not passed away. I regard these experiences with a people of another age and 
quality as among the most enlarging that came to me in my youth.

In 1854, when a lad of thirteen, I made with my father a journey to Massachusetts and Long Island, - by railway to Cleveland, thence by steamer to Buffalo, and then on again by railway. To this day the sense of the breadth of the world which came with this seeing stays with me. Vast indeed was the impression afforded by the sky-line of water on Lake Erie. I knew that the northern shore lay not far beyond sight, yet the oceanic effect, the greatest the world has to give those who are from the depths of the land, entered my soul; no others of the manifold impressions I have had from the seas have been thus lasting. I must have been in a vivid state on this journey, for all the impressions of it remain startlingly clear. The wide stretches of the landscape and the peculiar waltzing effect which rapid motion gives to its features; above all, the sight of the first considerable hills, the glimpse of the far-off Catskills, and then the sight of Greylock as we neared Pittsfield, stay printed on my mind. Most interesting was the curiously strong sense that the land was not like what I had before known. This impression recurred every time I returned in after years to Massachusetts, though it was not long before I came to perceive that the meaning of this strangeness was that the surface of the ground in this part of the world had been shaped by glacial action, while the fields of my youth bore the stamp of free water.

Our first stopping-place was Lancaster, Massachusetts. Of my experience there at the home of my great-aunt Abigail Stilwell I have already told. Thence we went to Boston, where my father had many college friends, who thronged about him; he was evidently dear to them. Now for the first time I saw that the man of forty years had been a boy. For the first time in my life I heard him called by his given name, for my mother always addressed him as "Doctor." My surprise, mingled with a certain indignation at the freedom of these schoolmates with my father, shows clearly that he was a strangely withdrawn man. 


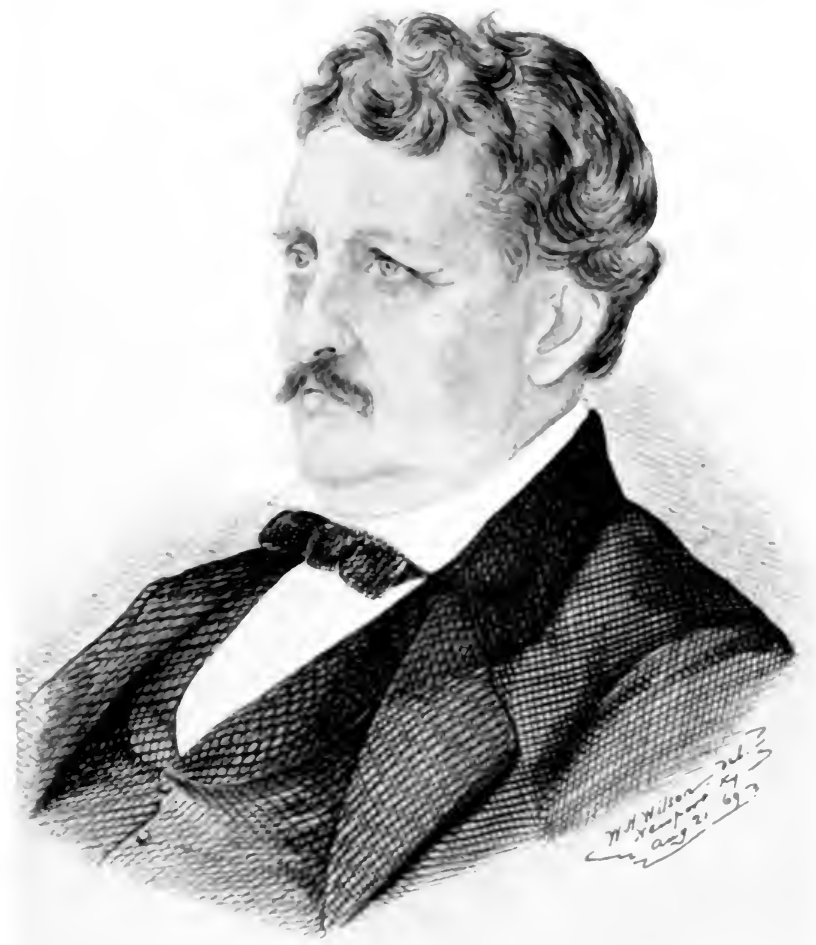

NATHANIEL BLRGER SHALER 


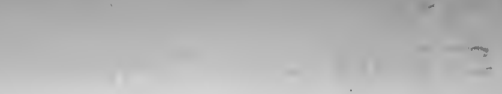

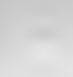

$=$

-

.

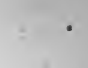

(n) 
Among these old familiars of my father were men who as persons interested me much. There was Cornelius C. Felton, professor of Greek in Harvard College, and afterwards its president, a large and large-hearted man; Horatio Greenough, who also dwelt in Cambridge; Epes Sargent Dixwell, a schoolmaster of renown; Charles T. Jackson, the chemist and geologist, and many others with whom I was afterwards to have relations. I recall in Jackson's house how he told my father the story of his relations to the discovering of ether and how Morton had cheated him out of his fame, and how he wept and raved in the telling. I had never before seen a man thus chagrined, and wondered greatly why he should be so about such a trifleas it seemed to me then - and ever since. When we came away, my father said to me that in his opinion Jaskson had been the discoverer, but that he was a rather timid person and did not venture to make the full trial of the agent himself, and so had turned to Morton as a person who would take the risk of the experiment.

At first sight, Harvard College greatly interested me. It was then a small affair, but to me, who had never seen anything of the kind, it seemed very great. From it I had the first sense of historic antiquity as it is embodied in edifices. There were then only what are now termed the old buildings of the Yard and the Divinity School and the old Medical School in Boston.

In 1857 , because I suffered much with ague, I was sent for three months to Sag Harbor on Long Island, where I stayed with a sister of my father's. I was then a lanky youth of a solitary, phlegmatic temper. I spent my time tramping the woods and keeping company with the sea. I had no congenial society, save that of certain rough sailors, some of them Lascars, a distinctly bad lot, but they interested me and taught me a bit of sea and ship lore that afterwards I had a chance to find serviceable. I remember best a sojourn on Montauk Point, then a solitary land where considerable herds of cattle wandered over the watery open country. They were wild, after the manner 
of the herds on the plains of the West, and would crowd about a stray huntsman. On one occasion while I was hunting plover, they crowded me over the edge of the sea cliff, till I had to stop them with bird-shot from my fowling-piece not in rage but from stupid curiosity. The noble solitude of the place was strangely attractive to me; there I first came to know the splendor of such isolation.

I have not been on Montauk since that visit of half a century ago. I have kept away from it because the memory is so rich and full that I have feared to disturb it by reseeing. The lighthouse, a great pond with an ancient house where I lodged between it and the sea, the cry of the plover, the air from the sea, are as yesterday in memory; above all, a startling feature when by chance the face of the moon rising above the ocean was crossed by a ship, so far away that for a moment it was framed in its round. It was here that the sea came to my soul. Save for that fortnight at Montauk, which did much for me, I have no pleasant recollections of my visit to Sag Harbor. I did not do well with the youth of the place; they treated me ill and did not take the consequences in good part. Among the older folk were some who were broadened by wide contact with the world. I saw that they were queer figures; they treated me kindly, but at that time I was a solitary - a bit misanthropic. The fact that I volunteered to serve some kind of a visit upon a bully who had threatened dire things to any one who would beard him in his den, - a lonely farmhouse, - finding him at the time very peaceable, seemed to convince the older folk that I was in some way dangerous; only with the sailors of the whaling ships did I find men after my mind. 


\section{CHAPTER V}

\section{SOME KENTUCKY MAGNATES}

ANOTHER set of chapters of my life were my visits to Frankfort, the capital of the state, where I had friends and kindred and whereto I resorted during the sessions of the Legislature, when in a small way the place was a brilliant centre of life, of a life that has long since passed away. Thereto came for a month or so in the winter some hundred people of local distinction, not a few of whom had made or were to make their marks in a wider circle of affairs. I generally lodged with an old kinsman, a Mr. Edmund Taylor, cashier of the State Bank, in those days a station of considerable dignity. At that time it was a law that the cashiers of such banks should severally dwell in the buildings where their business was done. This was with the idea, as I was told, that the domesticity of the work would ensure a greater measure of honesty in administration. These bank houses were solid, spacious mansions, with the business offices opening into the family quarters. In his way, the cashier who effectively had charge of the business was a magnate and a considerable figure in his little world. My kinsman was in years an old man past seventy when I remember him clearly, excellent in his business duties, but very merry, greatly addicted to dancing. I have seen him keep it up until dawn of a winter night.

The amusements of the people who congregated in Frankfort were dining, dancing, and card-playing for both sexes, getting drunk and sober for a large part of the young men, and a most endless discussion of politics by all the assembled multitude. It was a life of the ancient Stuart quality, quite unlike anything I have found elsewhere. The essence of it was an extraordinary sense of the value of the individual to himself and 
his neighbor; the people were more conscious of one another and of themselves than it seems possible for them to be now. In many ways, the relations of the folk were socially ideal; I never heard of any shame relating to any women of the assemblage. With a certain set of the youths it was the thing to pose as rakehells, but there was also a sober set, as I remember the larger part of the men old and young, who set their faces against all manner of filthiness. Getting drunk was not thought to be distinctly unmannerly, but the tipsy wight was led aside by his friends and given to the servants for safe-keeping. I have seen as many as a dozen of them thus in durance at a single ball. The effect of this habit was ruinous; about one in four of the young men I knew at this time went to ruin in that way.

There is a common notion that the men of the South were a licentious lot and that their relations with negro women was a feature of that time. My recollection is that by far the larger number of them were as continent as are men to-day in any part of the world known to me; that something like four fifths, perhaps nine tenths of them were wholesome, essentially clean-minded fellows, who had no habits of incontinence. As for intercourse with the negro women, while it doubtless occurred, I can say I never knew of an instance of it in those gatherings, and the whole of the life was so largely almost incredibly a matter of general knowledge that if common I surely would have known of it. In my observation of such matters, I know of but three instances where those entitled otherwise to the station of gentlemen had such relations.

As for card-playing with money, it was a very common habit, as common as it was in England forty years ago when I there played whist with clergymen of the Established Church for small points, so that if lucky you might win ten shillings at a sitting. Playing for money was a rather common vice, especially with the elderly men. One of them, a half great-uncle on my mother's side, was an admirable specimen of his class; a grave, dignified person of cultivated manners and much esprit, 
who would have perfectly fitted in the Bath of Brummel's time. $\mathrm{He}$ was a great master of the game of poker, for he was an uncommonly good judge of men, the highest compliment that was bestowed upon a man in those days, when judging men and women was the main business of life. This ancient worthy would have chastised his grand-nephew if he had found him in a game at his table.

Though I have been much thrown with gamblers, those of the green cloth in my youth and those of the stock market in later years, I have never been able to come into their state of mind. Even as a youth I had no fancy for the business, though I liked the American game of poker for the play of wits, and had some profit from that side of the experience. I particularly liked to watch skilful players when the stakes were high to see the human motive of the performance; there is no other game, save that of war, where there is so good an opportunity to see how minds work.

I count my visits to Frankfort as in a high measure educative. At home I had few associates of my own age who were in any way interested in matters which interested me. In the gatherings at the capital I found several youths of the Eugenia who were facing the same problems that I envisaged; who were setting themselves largely against life. Three of these young men were my kinsmen, of remote degree but near enough to make a bond between us. Two of them went down in the Civil War, and one, Sanford, was assassinated by Goebel, who afterward met like end on his way to his place as governor of the commonwealth. Now and then came to Frankfort some of the older men who had won distinguished place in public affairs John C. Breckenridge, then Vice-President of the United States; Crittenden, of the famous attempted compromise; Elder Breckenridge, then the head of that house of strong men; and many others of less note. In those days it was easy for a lad just nearing to man's estate to know his elders. They were on the watch for such as might serve them; moreover, in my case, they all 
had known my uncle William Southgate and had loved him dearly. I evidently had a great physical resemblance to him, though he was a small man, and at seventeen I was near six feet high. Countrymen would often accost me with the question, "Ain't you some kin to little Billy?" In this way my entrance among the leaders of that time was made easy.

Above the town of Frankfort, on the top of the steep bluff of the Kentucky River, is a burial-place where lie the bones of many heroes, sons the Commonwealth has lovingly gathered in one fold. It is a beautiful site for this simple Valhalla, with its wide outlook over the noble vale it crowns, to my eyes wondrously enriched by the sense of a people's care for the fame of its illustrious dead. Thereto was the usual walk of young and old, to take the sunset and whatever else came to them there. A wider outlook on varied temples of fame in Europe and elsewhere has not diminished my feeling for that simple place of graves. Even now it makes in me a larger impression than the cloistered dust of Westminster Abbey or the rows of busts on the Pincian Hill; most likely because of its simplicity, and the contrast between it and the very commonplace scenes about it.

In Frankfort I met many of those who had played their little parts as soldiers in Mexico and soon were to show themselves in larger action on the wider fields of the Civil War, as well as many near my own age who were to find a soldier's place, and the most of them their graves in that same deadly struggle. I recall John Hunt Morgan, then judged a man of small parts, who as a subaltern had done nothing at all distinguished in Mexico, but who was to win fame as a Confederate commander which would rank him with Wheeler and Stuart. This man, who became the type of a daring raider, seemed to me a commonplace person. He held a "poker hand" timidly, playing for certainties, and with little of that "knowledge of men" which was then and there held to be the sum of wits. There were the Marshalls, - Thomas, Humphrey, and John, - three 
very able men, who gave no fit account of themselves to their generation. Of the first of these I have a separate story to tell, for he has a special interest to me; they were all kinsmen of the great John Marshall. There are a score more of strong men who knew their strength and helped me to the station of manhood, though few of them helped themselves to their fit place in the world.

The impression made on me by the better people of Kentucky, as I saw them in the gatherings at Frankfort, an impression not lessened by later and wide intercourse with men, such as came soon thereafter, was that there was a singular development of power, one of those great openings of thought that is now and then, though rarely, offered to the world, in this case vainly. I am quite sure that this judgment is not colored by the enthusiasm or the ignorance of youth; for before my contact with these people was ended, I had been for a year or two a student in Harvard, associated with a very selected group of youths and mature men. Moreover, in that day even more than in this fifty years later, I was given to critical observation of the ways and nature of men. I question if in the history of our race there was ever a better presentation of varied power than in the generation that was matured and maturing at the outset of the Civil War in Kentucky. There were reasons why there should have been such development and why it should have come to naught, leaving the people on a lower plane than they have been since the foundation of this commonwealth. To see the meaning of this interesting social history, we must first note that the population of Kentucky, or at least of the central district which has given character to its society, was made up, in a measure not exhibited by the other secondary settlements of this country, of folk selected by circumstances for their vigor and capacity. So far as the whites were concerned, it may be doubted whether any plantation of men of a greater average of physical and mental vigor has been established in this country. This is shown 
by what is of record concerning the origin of the colonists, and is well attested by the history of the people in the first two generations of their life in this new field. By the middle of the last century, the trials of those who found a state in the wilderness were well by, the settlers were prosperous, the burthen of life was light, the climate admirable, so that they were ideally placed for further and high development in the intellectual field. Just such a flowering of strength and capacity as I saw in my youth was the natural, we may say the inevitable, outcome of such a history.

The failure of the Kentucky people to make good their promise; the fact that the youths of my time whom I judged to be my betters have left no sign, is in my opinion to be accounted for by a peculiar combination of circumstances, of which the Civil War was the most potent. In that trial a large part of the best of the youth perished, leaving no succession. There are no trustworthy statistics to show the numbers who owed their death or permanent invalidation to military service, but the total probably amounted to not less than twenty thousand. The whole number of men who stood in arms on the two sides was about one hundred and thirty-five thousand, and of these it is likely that at least one sixth were taken from the support of their society which then had a population of less than a million people. This sacrifice was in peculiarly large measure from the intellectual, the state-shaping class. In far larger proportion than the Northern states, this class contributed men to the armies, and the percentage of deaths of these natural leaders was very high. As I look back I count thirty lads and young men of this group whom I knew who thus passed before they came to their best years and left no children. More than half the expectancy of the state that I knew was thus swept away.

Not only did the Civil War maim the generation of Kentuckians to which I belonged, it also broke up the developing motives of intellectual culture of the commonwealth. Just 
before it I can see that while the ideals of culture were in a way still low and rather carnal, there was an eager reaching-out for better things; men and women were seeking, through history, literature, the fine arts, and in some measure through science, for a share in the higher life. Four years of civil war, which turned the minds of all towards what is at once the most absorbing and debasing interest of man, made an end of this and set the people on a moral and intellectual plane lower than that they occupied when they were warring with the wilderness and the savages. War is always degrading to the states that urge it, but it is most so when it is between brothers and hearthstones; therefore the tide which was setting towards the better life was stayed; the thoughts of men turned back towards the primitive. Many of those who might have led were slain; others sought homes elsewhere - for a society thus racked by civil war is no place for a man who seeks to make a career. In 1855 there were few communities holding more of promise for our race than that of the new commonwealth; in 1865 few that were less hopeful.

I have referred above to Thomas F. Marshall, a man of singular attractiveness and talents with whom I had a curious relation. I first met him when I was about fourteen years of age, when he, for some time a congressman, had through drunkenness fallen into a curious half-abandoned mode of life. He was then an oldish fellow, but retained much of his youthful splendor. He was about six feet three inches high, but so well built that he did not seem large, until you stood beside him. His face, even when marred by drink, had something of majesty in it. Marshall, when I knew him, picked up a scanty living as a lecturer. When sober, which he often was for months at a time, his favorite subject was temperance. On this theme he was as eloquent as Gough; in his season of spree, he turned to history. The gradations were not sharp, for he would, as I have seen him, preach most admirably of the evil of drink while he supported himself in his fervent oratory with whiskey from a silver 
mug. In matters of history, he had read widely. One of his favorite themes was the mediæval history of Italy. I recall with a distinctness which shows the impressiveness of his discourses his story of Florence, so well told that ten years after, when I saw the town for the first time, the shape of it and of the neighboring places was curiously familiar. Along with some other youths, I noted down the dates of events as he gave them and looked them up. We never caught him in an error, though at times he was so drunk that he could hardly stand up. I have known many historians who doubtless much exceeded him in learning, but never another who seemed to have such a capacity for living in the events he narrated.

I had no sooner met "Tom" Marshall than we became friends. $\mathrm{He}$ at once took a curious fancy to me, talked to me as though we were of an age, and gave me my first chance of such contact with a man of learning and imagination. The relation, while on one side largely profitable to me, became embarrassing, for the unhappy man got the notion that I could stop his drinking if I would stay with him. A number of times when he had his dipsomaniac fury upon him I found that by sitting by his bed and talking with him on some historical subject, or rather listening to his talk, he would apparently forget about his drink and in a few hours drop asleep and awake to be sober for some months.

Sometimes these quiet interviews were most interesting to me. I recall one of them when I found him in an attack of half delirium. His memory, always active, took him back to the days when he was in Congress and to a scene when he, a very young member of the House, had been chosen by some careful elders to lead an attack on John Quincy Adams. They, the elders, were to come to his support when he had drawn the enemy's fire. It all became so real to him, that he sprang out of bed and in his tattered nightgown gave, first his own speech with all the action of a young orator, and then the deliberate, crushing rejoinder of his mighty antagonist. At the 
end of it he fell back upon his bed, cursing the villains who led him into the fight and left him to take the consequences.

My relations with Marshall continued until I went to Cambridge, but my influence over his drinking gradually lessened as he sank lower, and his able mind began to be permanently clouded. When I had been some months at college, I espied the poor fellow in the street, carpet-bag in hand, evidently making for my quarters. I sent word by a messenger to my chum, Hyatt, to receive and care for him, but to say that I had left town, which was true, for I went at once to Greenfield, where I had friends. Hyatt was also to provide the wanderer with a suit of clothes and a railway ticket back to Kentucky. I stayed away until I learned that Marshall was on his way home. I have always been ashamed of my conduct in this matter, but the unhappy man was at that time of his degradation an impossible burthen for me to carry; once ensconced in my quarters it would have been impossible to provide him with a dignified exit, and there was no longer hope that I might reform him. Yet the cowardice of the action has grieved me to this day.

Two years afterwards, in 1862, I saw Marshall for the last time. I was with a column of troops going through the town of Versailles, Kentucky. He was seated in front of a bar-room, with his chin upon the top of his cane. He was so far gone that the sight merely troubled his wits without affording him any explanation of what it meant. His bleared though still noble face stays in my memories as one of the saddest of those weary years.

Among the interesting and in a way shaping incidents of my boyhood, was a brief contact with Abraham Lincoln about 1856. He was coming on foot from the town of Covington; I was on horseback, and met him near the bridge over the Licking River. He asked the way to my grandfather's house, which was about a mile off. Attracted by his appearance, I dismounted and asked him to get on my horse, which he declined to do; so 
I walked beside him. Probably because he knew how to talk to a lad - few know the art, and those the large natures alone - we became at once friendly. When I had shown him into the house, I hung about to find his name. As I had never heard of Mr. Lincoln of Illinois, it was explained to me that he was the man who was "running against" the Little Giant. We lads all knew Stephen A. Douglas, who was so popular that farm tools were named for him: the Little Giant this and that of cornshellers or ploughs. While Mr. Lincoln was with my grandfather, my mother dined or supped with him. When she came home she said: "I have had a long talk with Mr. Lincoln, who is called an Abolitionist; if he is an Abolitionist, I am an Abolitionist." I well remember the horror with which this remark inspired the household: if my mother had said she was Satan, it could not have been worse. The droll part of the matter is that all the reasonable people about me were in heart haters of slavery. They saw and deplored its evils, and were full of fanciful schemes for making an end of it. But the name Abolitionist was abominated.

I never knew what brought Mr. Lincoln to my grandfather's house. It is likely that he came because a certain doctor of central Kentucky, an uncle of Mr. Lincoln, a widower, had recently married an aunt of mine, a widow. This union of two middle-aged people, each with large families, brought trouble; since family traditions were against divorce, a separation was effected which had an amusing though tragic finish. When all other matters of property had been arranged and P. had betaken himself to his plantation in Mississippi, as an afterthought he set up a supplementary claim to a saddle mule belonging to my aunt which he had forgotten to demand in the settlement. This re-opened the question, and it was determined in family council that the grasping doctor should not be satisfied. We boys had the notion that Mr. Lincoln's visit related to this episode of the mule, for shortly after the "critter" was sent with a servant by steamboat, to be delivered to the claimant 
at the landing of his plantation on the Mississippi River. In due time the negro returned and made report: it was that the unworthy suitor came with a group of his friends to witness his success, mounted, and started to ride away, but the beast, frisky from its long confinement, "stooped up behind," as the darkeys phrase it, and threw his master and killed him. Whether Lincoln had a hand in the negotiations which led to this finish or not, I am sure that the humor of it must have tickled him. 


\section{CHAPTER VI}

\section{POLITICAL CLOUDS GATHER}

BEFORE taking up the story of my life as a student at Harvard, it is well to round out the necessarily rambling account of my boyhood life by telling something of the political life of the years immediately preceding the Civil War, especially of the endless discussions concerning the slavery question and the place of Kentucky in the war between North and South which all sagacious persons foresaw. From the time I was twelve years old, my grandfather in his Sunday afternoon lessons used often to say to me: "My lad, when this comes, you belong on the side of the Union." He, as others, knew the issue to be inevitable, and his exhortation did much to determine my eventual state of mind. He, too, was an Abolitionist, though he shaped the purpose on the lines of the Liberian colonization project, on which he abundantly discoursed to me.

In my boyhood, say from 1855 on, the idea of secession began to be discussed. It had but few advocates among the noted men, who were generally Henry Clay Whigs, with nothing but denunciation for Calhoun and all his works. I recall being held in my father's arms when I was perhaps eight years old to hear Clay make a short but impassioned speech. I cannot remember anything about it, but I can see that eager face and swaying body, and hear the cheers of his audience. In this period, from 1850 onward, the irritation between the slaveholding and the non-slaveholding sections became steadily more and more intense. Now and then negroes ran away. About 1857 , those belonging to my grandfather, my aunts, and my mother, all household servants, some of them old people, decamped in one night. I remember the excitement when at dawn a certain Sam Morton, who had also suffered from the 
exodus, roused the families. My grandfather at once ordered that they should not be pursued. In the course of three months there came a letter from the party, then in Canada, begging that they be allowed to return. This he refused to grant, saying that they had broken the bond that bound him to look after them, and that he would have nothing further to do with them. By threatening to "sell them South," the ancient threat which he never would have executed, he kept them from returning. This was one of several sudden migrations from my part of the country which were laid to the charge of "Underground Railroad" people, and served to increase that irritation of the folk, which was furthered by the failure of sundry efforts to have fugitive slaves returned by law.

It was the custom of the large householders in the early days of Kentucky to provide so far as possible for their needs by domestic work. This plan of "living within yourself," as it was called, was retained and carried very far by my grandfather, so that very little money was spent for any provisions. Flour, rice, soap, candles, most kinds of meat and all vegetables were prepared in the house or sent in from the farms; so, too, the cloth of various kinds, coarse cotton and linen, the woollen goods known as jeans for every-day wear. My grandfather even went so far as to undertake the manufacture of silk, having brought in an Italian family for that purpose. At that time some silkworms were grown in the neighborhood and the cocoons were reeled, spun, and woven in a little factory. This work was maintained up to about the time of his death with such success that the women of the family rejoiced in an abundance of excellent black silk. So good was it, indeed, that it took the premium in the so-called World's Fair held in New York about 1854. I recall my sense of importance when first clad in a suit of silk from "the factory." All the domestic arts attracted me much, especially the dipping of the candles, where the wicks were set in a frame so that they were alternately lowered into the hot tallow and lifted up to cool. The growth of 
the candles was a matter of wonderment, for the heated fat is nearly colorless while the candles are white. The reeling of the silk and the wonder of the grub inside concerned me most. I was allowed to see the living grubs feeding on mulberry leaves and spinning their cocoons and thereby came to know the stages of the creature's life up to the chrysalis. Oddly enough, for I was a prying lad and about eight years old, I had not noticed these changes among the wild insects. My infantile military mania must have closed my eyes as it shuts those of grown men.

From the many sturdy old men who were about me in my youth, I had many stories of the pioneer stages of the settlements of northern Kentucky and the neighboring parts of Ohio. These tales are all too dim for re-telling, but the quality of these brave old fellows stays with me. As is usually the case with the really valiant, they were very gentle. There was in them not a trace of the roistering cowboy who masquerades as "a terror," but is cowed by the silent, woman-faced "real thing." Of this group I remember best a certain Richard Taliaferro, a remote kinsman, a very gentle giant, who as a lad of fifteen had captained a party of women, children, and some slaves from eastern Virginia to their destination on the Kentucky shore just above Cincinnati. They travelled by horse and wagon to the Monongahela River and then built a broadhorn on which they floated down the Ohio, seeking for the sign of their landing-place, a white flag on a tree-top. They found it, and established near by the home of his long life. When I last saw him about 1888, he showed me over the place. Of his house, which he dearly loved, he said, "Here were raised eighteen children and there never was a quarrel among them." He was himself the embodiment of peace.

At this stage of the trouble between North and South, "Uncle Tom's Cabin" appeared. I well remember the excitement it created among my own people; the irritation was the greater because it was believed that Mrs. Stowe, who lived for a time 
in Cincinnati, had drawn her characters from people in some way known to her who dwelt on my side of the river. It was believed that her picture of St. Clare, the gentle slaveholder, was drawn from my grandfather, while Legree was sketched from a neighbor whose character and history fitted well to that villain. The incident of Eliza's flight across the river over the fields of floating ice probably came from a tradition which was current as far back as I remember, certainly as early as 1847 . In place of accepting these literary coincidences as a compliment, they were taken in high dudgeon. In that remote age there had been little experience with newspaper reporters, and while not much was private, it was esteemed a gross offence to put a man in print in that fashion.

At this time there were some indigenous Abolitionists, of whom Cassius M. Clay was the most conspicuous, but because they were natives of the state they were tolerated. Clay was, indeed, regarded as amusing. He was known as a furious person, a very fire-eater and no mean orator; it was therefore the private sport of the young men to send him a letter with many signatures stating that he would be killed if he ventured to preach his vile doctrine in their country. The expected result was that he would shortly enter the forbidden ground, seize the Court-House and, laying his pistols on the judge's desk, proceed with his furious harangue; thus affording an occasion for what the boys called a circus. So far as I knew, he was never harmed or even insulted on these excursions; he was taken as a joke. It is true that his press in Lexington was destroyed. All the serious people respected the man's courage and his willingness to stand by his principles. It was otherwise with Abolitionists who came into the state. One such, a man named Bailey, undertook to run an Abolitionist paper in Newport. He was said to be from New England and he had the shape of the Yankee of caricature. His press was looted by a mob of young men, and he was compelled to leave the state.

Gradually the friction concerning slavery bred up a strong 
party in favor of that institution. At first this group was insignificant; from what I remember, and what I have learned from the people of the generation before me, not one in ten of the men of Kentucky would have sided with South Carolina if the nullification doctrine had led to war; I very much doubt if five per cent of the voters in 1850 would have favored secession. It was the misfortune of the Civil War period that the preliminary stage of the combat lasted so long that there was a chance for the amazing hatred of the Abolitionists to develop. It knit the slaveholding states together, gradually breaking up the Emancipation Party, which up to about 1840 appeared to make steady growth in all the Border States. This new opinion came by the gathering of the young men about certain leaders of distinction, themselves youthful. John C. Breckenridge was the strongest of these strong men who adopted the "States'-Rights" view of the federal relation. They were not numerous, but they were able and their arguments strong. It was this theory of government, rather than any affection for slavery or sympathy with the plantation states, which led a large part of the people to become what was then called Southern sympathizers. In a way, it was a recrudescence of the old motive of independence which had led to the Kentucky Resolutions of 1798, a state of mind which had been to all appearance long dead.

I can just recall the excitement of the controversy as to the place of Kentucky in the struggle which was assumed to be inevitable in 1857. At that time I became a member of a debating society where the most of the members were lads of about my age, but older than the most I now see who count one and twenty years. Such societies were common throughout the state. All our interminable debates concerned the burning question as to the tenets of federal and state authority. We all came to know the Federalist, the Constitution, the great speeches and the court decisions almost by heart. In those contests I took a large part, and developed a capacity for pub- 
lic speaking which has been quite effaced. That I made a fair success of it is shown by the fact that I was chosen president of the society before I was eighteen years of age, though I was the youngest of its members. What surprises me as I look back on those exercises was that I had a swing of phrase and rationality of thought which attracted judicious elders and led them to believe that I was to be an orator.

It was my habit to make briefs of my little speeches and to rehearse the discourses in the neighboring woods. Long afterward I came across the plan of the argument for a speech on the secession question; it ran as follows: At the outset I gave a hearty assent to the principle of State Rights, by which system alone it was possible to secure the benefits of local government, of a government near to the people and adjustable to their needs. But to establish and maintain such a system it was necessary to preserve the Union as it existed; for if it were divided into a slaveholding section and a non-slaveholding section the inevitable consequence would be interminable war between those opposed nations, each of which would have to seek the strength consolidation only could give with the consequent destruction of state rights. This thesis was, doubtless, taken in part from the ancient debater, and the illustrations from what Marshall had taught me; but the judgment was, in effect, original and the argument good. I have never seen it set forth in just this form. It had at least the merit of clearing my mind as to the situation. It kept me on the Union side, though there were strong, almost mastering influences due to my youthful friends that inclined me to go South. Whether my arguments convinced others I do not know, although they had a rather wide currency, since they found their way into print and thus to speakers who were often heard.

The political debate which went on in Kentucky between 1858 and 1861 probably was the most universal and effective of any ever held by a commonwealth. Men, women, and children shared in it, with the result that I have noted elsewhere, 
that when the time for action came almost every person knew his mind. There was hardly a turncoat or a laggard in judgment. Moreover, the long study of the problem enabled the people to see how complicated it was, and how great was the room for diversity of opinion. To this was due the manfulness and dignity of the actual war, so far as it was shaped by the commonwealth, and the speedy reconciliation of the divided brethren when it came to an end.

It was generally accepted, as far back as I remember, that there would be an effort of the North to secede from the Union. As an instance of this, I may note that as a child I heard in the family a good deal of talk concerning Zachary Taylor, who was in some way a kinsman of my mother's people. This interested me, because he was one of the heroes of the Mexican War, - one of the imagined campaigns of my childhood, - as was also Jefferson Davis. Among the things told was Taylor's saying, that if the Union ever went to the devil, Davis would be in the lead. Shortly before my mother died in 1891, I asked her about this memory, taking pains not to lead up to the answer. She repeated this remark attributed to Taylor, telling me further that Davis had married Taylor's daughter without his consent, and that the remark was probably due to irritation on that account. I learned also that they were afterwards reconciled. It seems not unlikely that even at that early day Davis may have been among those who believed that the free and the slaveholding states should separate.

I also recall the fact that in 1857 , when my father planted a vineyard on a hill about two miles south of the Ohio River, I urged before the work was begun that the place would from its commanding position be a part of the fortifications for the defence of Cincinnati; it turned out to be the case, for the vineyard was ruined by the great earthworks erected in the centre of it in 1862. This incident was recalled to my memory by my father in about 1880, he attributing to me the remark that "it 
was too good for grape-shot, to be used for grapes." I much doubt the pun, but I well remember how I dreamed of the use of the site for a fortress as early as 1854. I had seen forts at various places on the seaboard. 


\section{CHAPTER VII}

\section{BECOME AGASSIZ'S PUPIL AT HARVARD}

IN 1858, when I was seventeen years old, it was determined that I should have a good education. My parents could well afford this, for my grandfather had left considerable property and besides that there were other means. The plan was that I should have a liberal training, and then make up my mind as to what profession I would adopt. It was at first proposed that I should go to West Point, but my fancy for war had passed, and not even the argument that there was war to come, and that soon, affected me. My desire, moved by my teacher Escher, was to go to Heidelberg; fortunately it was determined that I should begin my exploration of the realm of higher learning at Harvard College. We supposed that I was far enough along to enter the sophomore class in 1859 , and after graduating that I would go to Germany for further study. For my own part, I cared little where I went or what I did. There was need of enlargement, the resources about me were used up, and I was so shaped that if a change had not been made, I should have wandered away in search of adventures.

My father went with me to Cambridge, and as it was well on in the first term, I was placed under a tutor recommended by his classmate, Dixwell. I was then a lank fellow, six feet high, very slender, nimble from a good though limited physical training, still rather feeble from attacks of malaria and megrims. As for my training, what has been said before shows that it was from the schoolmaster's point of view a jumble of unrelated matters, - a very poor basis for collegiate study, which took no account of a training in arms and equitation, and as little of philosophy and geology or a knowledge of human nature. 
Still, on going me over, my tutor thought I could be put in the sophomore class in the autumn of 1859.

Although my studies interested me, - anything did, for I had then and ever since a capacity to be interested in anything put before me, - my tutor most commanded my attention. $\mathrm{He}$ was a senior in Harvard College, and had a well-deserved name for scholarship in the classics as well as for a miscellaneous assortment of talents and knowledge. He was reputed to be the best player of the game of checkers in the country; knew the political history of the United States amazingly well; was learned in pugilism, having at his tongue's end the story of all the prize fights of recent times; withal he was the merriest little man I have ever seen. His curly head and radiant visage charmed me at first, and remain as treasured recollections in a whole gallery of such memories. I well recall my first morning with him, when, after going over the best of what I could and could not do, he asked me if I could box. I pleaded guilty to some knowledge of that ignoble art. At that time I had not learned of his interest in it, and thought that I would be lowered in his eyes by the confession. To my surprise, indeed to my horror, for I had a swordsman's contempt for the business, he insisted on my having a bout with him at once. I had learned boxing in Scherer's school of arms, where it was taught by a competent man, but classed as a very degraded form of fighting, ranking below quarterstaff. It was regarded as an ignoble if sometimes necessary means of defence, only to be resorted to in extremity when you were contending with common people and had no blessed steel at hand. The eager little man proved very unskilful. At the very first tap he tipped over, his head going against a window-pane, smashing the glass but happily not harming him. I shall never forget my mingled wonder and exasperation at this incident. My training with the reverend philosopher Escher had set up in my mind a category of the tutor into which this new-found specimen by no means fitted. My work with my mentor went in a fair way for some months 
during the winter and spring in Cambridge, and during the summer in Keene, New Hampshire. In Cambridge, I found myself in an unhappy social position, for the reason that my station as a sub-freshman, as an inferior to the men of my own age already in college, was humiliating to my sense of self-importance, and in marked contrast to that I had won at home. In Keene, I found myself in a charming New England community, where the life resembled that to which I was native. There the fact that I could ride, shoot, act in theatricals, spout poetry, and descant on philosophy put me back into the class of men, so that I was myself again. While in Keene, there came an odd interest in my education which, though but a trifle, proved most telling. My tutor, with whom I had read much Latin verse in a manner which he approved, for my scanning was uncommonly good, - I had a natural ear for it, - one day asked me the rule for the quantity of a syllable, only to find that I was absolutely ignorant of such written prescriptions. The long list of these rules was then produced - they were to be learned at once. Now I cannot by any contrivance manage to fix in my mind a succession of irrelevances. If he had commanded me to commit all of Ovid, I should willingly have set about the task; as it was, I asked him if in his opinion Horace had learned those precious rules. He was sure that he had not, and equally certain that I must learn them if I had any expectation of getting into Harvard College. On that issue we parted. I refused to spend time on an unnecessary bit of purely formal work.

I was the more content to give up a training in Harvard College, for the reason that my stay in Keene had convinced me that I was more naturalist than humanist, in that I could not content myself with the book side of culture. The life of the fields, the brooks and rocks, was nearer to me than that of the men and thoughts of long ago. Moreover, in some way I had come across Agassiz's essay on classification, then just published, and in it I found something at once of science and 
philosophy. As I recall it, this essay was the introduction to Agassiz's series, never completed, of contributions to the natural history of North America, the volume concerning the Testudinata. These creatures had interested me in my childhood; I had one of them among my first "pets" when I was about ten years old, and fancied, I think with good reason, that he learned to know me and to come to my call. While at Keene, I became much interested in several aquatic species which were new to me. The essay and the descriptions in the memoir, along with the other contacts of nature in that lovely district, reawakened my enthusiasm for the world below man, so that the demand of my tutor that I should set me to learning rules for scanning Latin verse came most inopportunely for my college education.

At the time of my secession from the humanities, Agassiz was in Europe: he did not return, I think, until the autumn of 1859. I had, however, picked up several acquaintances among his pupils, learned what they were about, and gained some notion of his methods. After about a month he returned, and I had my first contact with the man who was to have the most influence on my life of any of the teachers to whom I am indebted. I shall never forget even the lesser incidents of this meeting, for this great master by his presence gave an importance to his surroundings, so that the room where you met him and the furniture stayed with the memory of him.

When I first met Louis Agassiz, he was still in the prime of his admirable manhood; though he was then fifty-two years old, and had passed his constructive period, he still had the look of a young man. His face was the most genial and engaging that I had ever seen and his manner captivated me altogether. But as I had been among men who had a free swing, and for a year among people who seemed to me to be cold and super-rational, hungry as I doubtless was for human sympathy, Agassiz's welcome went to my heart, - I was at once his captive. It has been my good chance to see many 
men of engaging presence and ways, but I have never known his equal.

As the personal quality of Agassiz was the greatest of his powers, and as my life was greatly influenced by my immediate and enduring affection for him, I am tempted to set forth some incidents which show that my swift devotion to my new-found master was not due to the accidents of the situation or to any boyish fancy. I will content myself with one of those stories, which will of itself show how easily he captivated men, even those of the ruder sort. Some years after we came together, when indeed I was formally his assistant, - I believe it was in 1866,- - he became much interested in the task of comparing the skeletons of thoroughbred horses with those of common stock. I had at his request tried, but without success, to obtain the bones of certain famous stallions from my acquaintances among the racing men in Kentucky. Early one morning there was a fire, supposed to be incendiary, in the stables in the Beacon Park track, a mile from the College, in which a number of horses had been killed and many badly scorched. I had just returned from the place, where I had left a mob of irate owners and jockeys in a violent state of mind, intent on finding some one to hang. I had seen the chance of getting a valuable lot of stallions for the museum, but it was evident that the time was most inopportune for suggesting such a disposition of the remains. Had I done so, the results would have been, to say the least, unpleasant.

As I came away from the profane lot of horse-men gathered about the ruins of their fortunes or their hopes, I met Agassiz almost running to seize the chance of specimens. I told him to come back with me, that we must wait until the mob had spent its rage; but he kept on. I told him further that he risked spoiling his good chance, and finally that he would have his head punched; but he trotted on. I went with him, in the hope that I might protect him from the consequences of his curiosity. When we reached the spot, there came about a marvel; in a 
moment he had all those raging men at his command. He went at once to work with the horses which had been hurt, but were savable. His intense sympathy with the creatures, his knowledge of the remedies to be applied, his immediate appropriation of the whole situation, of which he was at once the master, made those rude folk at once his friends. Nobody asked who he was, for the good reason that he was heart and soul of them. When the task of helping was done, then Agassiz skilfully came to the point of his business - the skeletons - and this so dextrously and sympathetically, that the men were, it seemed, ready to turn over the living as well as the dead beasts for his service. I have seen a lot of human doing, much of it critically as actor or near observer, but this was in many ways the greatest. The supreme art of it was in the use of a perfectly spontaneous and most actually sympathetic motive to gain an end. With others, this state of mind would lead to affectation; with him, it in no wise diminished the quality of the emotion. He could measure the value of the motive, but do it without lessening its moral import.

As my account of Agassiz's quality should rest upon my experiences with him, I shall now go on to tell how and to what effect he trained me. In that day there were no written examinations on any subjects to which candidates for the Lawrence Scientific School had to pass. The professors in charge of the several departments questioned the candidates and determined their fitness to pursue the course of study they desired to undertake. Few or none who had any semblance of an education were denied admission to Agassiz's laboratory. At that time, the instructors had, in addition to their meagre salaries, his was then $\$ 2500$ per annum, - the regular fees paid in by the students under his charge. So I was promptly assured that I was admitted. Be it said, however, that he did give me an effective oral examination, which, as he told me, was intended to show whether I could expect to go forward to a degree at the end of four years of study. On this matter of the degree he was 
obdurate, refusing to recommend some who had been with him for many years and had succeeded in their special work, giving as reason for his denial that they were "too ignorant."

The examination Agassiz gave me was directed first to find that I knew enough Latin and Greek to make use of those languages; that I could patter a little of them evidently pleased him. He did n't care for those detestable rules for scanning. Then came German and French, which were also approved: I could read both, and spoke the former fairly well. He did not probe me in my weakest place, mathematics, for the good reason that, badly as I was off in that subject, he was in a worse plight. Then asking me concerning my reading, he found that I had read the essay on classification and had noted in it the influence of Schelling's views. Most of his questioning related to this field, and the more than fair beginning of our relations then made was due to the fact that I had some enlargement on that side. So, too, he was pleased to find that I had managed a lot of Latin, Greek, and German poetry, and had been trained with the sword. He completed this inquiry by requiring that I bring my foils and masks for a bout. In this test he did not fare well, for, though not untrained, he evidently knew more of the Schläger than of the rapier. He was heavy-handed and lacked finesse. This, with my previous experience, led me to the conclusion that I had struck upon a kind of tutor in Cambridge not known in Kentucky.

While Agassiz questioned me carefully as to what I had read and what I had seen, he seemed in this preliminary going over in no wise concerned to find what I knew about fossils, rocks, animals, and plants; he put aside the offerings of my scanty lore. This offended me a bit, as I recall, for the reason that I thought I knew, and for a self-taught lad really did know, a good deal about such matters, especially as to the habits of insects, particularly spiders. It seemed hard to be denied the chance to make my parade; but I afterward saw what this meant, that he did not intend to let me begin my tasks by posing as a 
naturalist. The beginning was indeed quite different, and, as will be seen, in a manner that quickly evaporated my conceit. It was made and continued in a way I will now recount.

Agassiz's laboratory was then in a rather small two-storied building, looking much like a square dwelling-house, which stood where the College Gymnasium now stands. The structure is still extant, though in forty-six years it has three times changed its site and uses, having been first a club-house for his students on Divinity Avenue, where the Peabody Museum has been built; it went thence to a site on Jarvis Street, where it served as the club-house and theatre for the Hasty Pudding Club; from there a little further west to its present location, where, after being long the habitation for the department of French, it came to be a part of the little establishment for teaching students astronomy. Agassiz had recently moved into it from a shed on the marsh near Brighton bridge, the original tenants, the engineers, having come to riches in the shape of the brick structure now known as the Lawrence Building. In this primitive establishment Agassiz's laboratory, as distinguished from the storerooms where the collections were crammed, occupied one room about thirty feet long and fifteen feet wide - what is now the west room on the lower floor of the edifice. In this place, already packed, I had assigned to me a small pine table with a rusty tin pan upon it. Of other students, all somewhat older than myself, there were: Alpheus Hyatt, F. W. Putnam, A. E. Verrill, E. S. Morse, Richard Wheatland, Caleb Cook, and a person by the name of Lamb. Hereto also came from time to time but not regularly Theodore Lyman and Stimpson. There was also in some narrow quarters a translator, a Swede, whose name is gone from me, and a sterling old person, Gugenheimer, who served as a preparator. Agassiz's artists generally worked at his near-by dwelling or at his place at Nahant. One of the small rooms upstairs was a sleeping-place for Putnam, who served as keeper of the establishment. I have given what may seem unnecessary details 
concerning this primitive laboratory and museum, in part for the reason that there is, so far as I know, no record of it, and also that it may be set over against the existing conditions of what used to be called Natural History in the University.

When I sat me down before my tin pan, Agassiz brought me a small fish, placing it before me with the rather stern requirement that I should study it, but should on no account talk to any one concerning it, nor read anything relating to fishes, until I had his permission so to do. To my inquiry "What shall I do?" he said in effect: "Find out what you can without damaging the specimen; when I think that you have done the work I will question you." In the course of an hour I thought I had compassed that fish; it was rather an unsavory object, giving forth the stench of old alcohol, then loathsome to me, though in time I came to like it. Many of the scales were loosened so that they fell off. It appeared to me to be a case for a summary report, which I was anxious to make and get on to the next stage of the business. But Agassiz, though always within call, concerned himself no further with me that day, nor the next, nor for a week. At first, this neglect was distressing; but I saw that it was a game, for he was, as I discerned rather than saw, covertly watching me. So I set my wits to work upon the thing, and in the course of a hundred hours or so thought I had done much - a hundred times as much as seemed possible at the start. I got interested in finding out how the scales went in series, their shape, the form and placement of the teeth, etc. Finally, I felt full of the subject and probably expressed it in my bearing; as for words about it then, there were none from my master except his cheery "Good morning." At length on the seventh day, came the question "Well?" and my disgorge of learning to him as he sat on the edge of my table puffing his cigar. At the end of the hour's telling, he swung off and away, saying, "That is not right." Here I began to think that after all perhaps the rules for scanning Latin verse were not the worst infliction in the world. More- 
over, it was clear that he was playing a game with me to find if I were capable of doing hard, continuous work without the support of a teacher, and this stimulated me to labor. I went at the task anew, discarded my first notes, and in another week of ten hours a day labor I had results which astonished myself and satisfied him. Still there was no trace of praise in words or manner. He signified that it would do by placing before me about a half a peck of bones, telling me to see what I could make of them, with no further directions to guide me. I soon found that they were the skeletons of half a dozen fishes of different species; the jaws told me that much at a first inspection. The task evidently was to fit the separate bones together in their proper order. Two months or more went to this task with no other help than an occasional looking over my grouping with the stereotyped remark: "That is not right." Finally, the task was done and I was again set upon alcoholic specimens, - this time a remarkable lot of specimens representing, perhaps, twenty species of the side-swimmers or Pleuronectidx.

I shall never forget the sense of power in dealing with things which I felt in beginning the more extended work on a group of animals. I had learned the art of comparing objects, which is the basis of the naturalist's work. At this stage I was allowed to read and to discuss my work with others about me. I did both eagerly, and acquired a considerable knowledge of the literature of ichthyology, becoming especially interested in the system of classification, then most imperfect. I tried to follow Agassiz's scheme of division into the order of ctenoids and ganoids, with the result that I found one of my species of side-swimmers had cycloid scales on one side and ctenoid on the other. This not only shocked my sense of the value of classification in a way that permitted of no full recovery of my original respect for the process, but for a time shook my confidence in my master's knowledge. At the same time I had a malicious pleasure in exhibiting my find to him, expecting to repay in part the humiliation which he had evidently tried to 
inflict on my conceit. To my question as to how the nondescript should be classified he said: "My boy, there are now two of us who know that."

This incident of the fish made an end of my novitiate. After that, with a suddenness of transition which puzzled me, Agassiz became very communicative; we passed indeed into the relation of friends of like age and purpose, and he actually consulted me as to what I should like to take up as a field of study. Finding that I wished to devote myself to geology, he set me to work on the Brachiopoda as the best group of fossils to serve as data in determining the Paleozoic horizons. So far as his rather limited knowledge of the matter went, he guided me in the field about Cambridge, in my reading, and to acquaintances of his who were concerned with earth structures. I came thus to know Charles T. Jackson, Jules Marcou, and, later, the brothers Rogers, Henry and James. At the same time I kept up the study of zoölogy, undertaking to make myself acquainted with living organic forms as a basis for a knowledge of fossils.

Just after I entered with Agassiz, the construction of his museum was begun with the small part of the now great edifice which constitutes the end of the northern wing. There were four rooms on the ground floor, each with galleries, and a like number, similarly galleried, on the second floor. Early in 1860 the building was ready for use. Then came the work of transportation of the collections stored in the laboratory and elsewhere to their new domicile, and the effort to arrange them in some kind of order, so as to give to the public the semblance of a museum; for from a generous public came the money and placation was necessary. Into this work the students were in a way impressed; so for a year I was with others occupied in sorting and arranging a jumble of materials, odds and ends from all over the earth. In the old storage place there was no chance to exhibit any of the show specimens. So far as I can remember, the only thing that people came to see was a large glass jar containing several heads of Chinamen, which some one had 
brought from a place of execution. The sight of this was much sought after, especially by women in search of a sensation. In the course of a year a collection was installed which in certain ways was then the best in this country.

My share in the work of bringing a preliminary order into the new museum was considerable, and while for some months it broke all systematic study it was largely profitable. It gave me a chance to gain hard contact with a great range of animal forms, both recent and fossil, and to it I owe a general knowledge of organic forms which I could not have otherwise acquired. There was at that time no other means of finding one's way to such information. Agassiz's lectures gave us little. Though very interesting from their personal quality, the field they covered was curiously limited. In the first term he gave about twenty-five lectures on zoölogy and in the second about the same number in geology. The first series began with a very interesting sketch of the general principles of the science, which quickly passed to problems of classification and thence to questions of comparative anatomy, practically limited to the polyps, acalephs, and echinoderms. In the years from 1859 to his death in 1873 , whenever he gave these lectures, perhaps six or eight years, their form and contents remained unchanged. The geological series was practically altogether devoted to the simpler problems of stratigraphy or the succession of geological periods; about one third of the course was given to the glacial period. Except for the noble and marvellously contagious enthusiasm with which he approached the subject and the admirable pictures of the masters he had known, the lectures were not profitable to his students; in those regards - the weightiest possible - they were most valuable.

By far the greater part of the instruction I had from my master was in divers bits of talk concerning certain species and the arrangement of the specimens. He would often work with me for hours unrolling fossils, all the while keeping up a running commentary which would range this way and that, of 
men, of places, of Aristotle, of Oken. He was a perfect narrator, and on any peg of fact would quickly hang a fascinating discourse. Often when he was at work on wet specimens while I was dealing with fossils, he would come to me with, say, a fish in each hand, that I might search in his pockets for a cigar, cut the tip, put it between his teeth, and light it for him. That would remind him of something, and he would puff and talk until the cigar was burned out, and he would have to be provided with another.

As soon as Agassiz's collections were removed to the new museum, the old building (now to be known as Zoölogical Hall) was put on rollers and taken across lots to its second station on Divinity Avenue. It was then given over to what was called the Zoölogical Club, an association of about a dozen students who were working with him. It was so arranged as to provide bed-rooms, a dining-room, and a room in the centre of the upper story with which the bed-rooms connected, to serve as the meeting-place of the Zoölogical Club, which was organized at this time and became the centre of our life. I had the good fortune to receive in the allotment a sleeping-place and a study connected therewith. These, as I did not lack money, were well furnished. As my quarters lay on the path from his house to the Museum, my master got into the habit of coming for a bit of talk, not always on science, perhaps oftenest about people he had known, about politics, in which he was keenly interested, or about his plans and perplexities. It seemed to me, as it did to some of my mates, somewhat curious, for I was the youngest of the lot and a newcomer. I now see that it was probably owing to the fact that in some ways I was then a good deal more of a man in my knowledge of the world than my elders and betters of the association. Something was due to the fact that I had been trained by Escher, an educated fellow countryman of his, and had known some of the "forty-eighters," and profited by the enlargement that acquaintance offered; still more, perhaps, to the fact that I 
had become in a way intimate in the houses of some of his friends in Boston.

In my room my master became divinely young again. $\mathrm{He}$ would lie on the sofa, drink what I had to offer, - I brought with me the then Southern habit of offering wine to guests, take a pipe and return in mind to his student days, or to his plans for work, or to his scheme of a museum which should present the animal and vegetable kingdoms so plainly that he who ran would perforce read - and deeply. I have never known a mind of such exuberance, of such eager contact with large desires. I was in thorough sympathy with this museum and with his projects, so that I had large profit from these interesting meetings, for they awakened an enthusiasm for constructive work which I doubt if any other accident of life would have aroused. ${ }^{1}$

The meetings of the Zoölogical Club, at which all sorts of problems were discussed, were never attended by Agassiz. To our request that he would join us his answer was that we had better work alone, though he advised us to gather about us all who were interested in our problems, and to give our joint studies a wide range. I see now that, while much concerned for our advancement, his aim was to have us stand alone, or at least to lean only on our mates. Although he could not help shaping those about him to his mode of thought and was often indignant with them when they departed from his path, he had a sound practical sense of the danger of founding a school of followers; more than once he commented on this error of other masters.

It was Agassiz's habit to use his students to explore fields

1 In Mr. Shaler's note-book for April 7, 1860, is this entry: "Professor Agassiz in his lecture this morning dwelt upon the requirements of a scientific man who would be more than a mere species-describer. The great test, he said, was to be able to deal with your subject in different ways. In amplifying the idea he said it was well to be able to give in a single sentence the whole matter of months of labor, in a form so true that a scientific man could read in it not only the extent of your knowledge but also the habit of your mind. He declared he could learn all this from an answer couched in the most laconic form. He said he should require of us in our several departments first a monograph, second a scientific lecture, third a popular lecture, fourth a simple child's tale." - S. P.S. 
for him. This was an inevitable element in his method of teaching, and has been inevitably followed by all inquirers who have taught. In this process of exploration it was his custom to set one of us to work on a group of animals concerning which he had some knowledge, so that he could guide his inquirer, at least at the outset of his investigation. I recall that in this way I began a study of the family of the conchifers known as the Arcidx, including the fossil and recent trigonias. For a while I felt that I was following on the trail which he had broken, and then, as in the matter of the geographical and geological distribution of the genera and families, etc., I began to teach him a bit that he did not know. He was as eager to receive as to give, and what I supplied went into his memory as his own discoveries, which in a way they were, for the direction of the work came from his mind. In time, as will be noted hereafter, this plan of collaborative work gave him trouble, as it has given trouble to others who taught in the same way, - in that good old way that makes the pupil feel that he is the master and thereby wins to his powers.

At this time the relatively small community of scientific men about Boston contained a much larger measure of ability than it now does. Besides Agassiz, who by his wonderful personality held the foremost place, there were Jeffries Wyman, Charles T. Jackson, Asa Gray, William B. Rogers, William Cranch Bond, Benjamin Peirce, B. A. Gould, as well as a host of lesser yet able men, among whom I may name William Stimpson and later Jules Marcou. The most usual meeting-place of these men, or of most of them, was the Boston Society of Natural History. Of this society I soon became a member, and shortly was engaged in its then active life. Thence until about 1870, with the exception of the two years and a half from the early part of 1862 to the autumn of 1864 , this institution was much in my life. At first my efforts were limited to bringing about debates amongst the elders, by asking questions which were contrived to accomplish the end. Our particular aim was to set Agassiz 
and Rogers, who were chronic enemies, by the ears. When this could be accomplished, - and to that end there were many contrivings among the youngsters, - we were sure of good entertainment, often protracted over several successive meetings. Agassiz was admirable in discourse, - when at his best the most simply eloquent speaker I have ever heard, - but his capacity for debate was small. Rogers, on the other hand, was not only an able and learned geologist, but very skilful in argument, with a keen sense of the logic which should control statements. Oftenest these debates related to the theories of the glacial period, but they covered much ground. In 1860 and 1861 the Darwinian hypothesis was often in the field, though at this time and place it had little support from any one - except Asa Gray, who could rarely be induced to say anything about it.

At this stage of my life, about 1860 , I came into close relations with Jeffries Wyman, whose lectures I regularly attended, and in whose laboratory work I took a small share. In some ways he was the most perfect naturalist I have ever known. His physical weakness, combined with his exceeding modesty, - shyness is the better word for it, - kept him from winning a large place in science; but within the limits of his powers, he had the best-balanced mind it has been my good fortune to come into contact with. His work on the question of spontaneous generation, a part of which I saw, was a very model of how an inquiry should be made. Though he published but little, his store of knowledge of the whole field of natural history was surprisingly great, and, as I came to find, it greatly exceeded that of my master Agassiz in its range and accuracy. A part of his quality was his certainty and the balanced judgment which enabled him unerringly to attain to it. As a proof of this quality, I note an instance. From an Indian mound I had obtained two lots of bone which were evidently fragments of human tibix, though they were somewhat malformed. To make sure of this, though the determination seemed certain, I took 
them to Wyman, asking him what they were. To my surprise he said that he would examine them and let me know next week. When I said to him that he surely knew at a glance, he remarked that if I had brought him a human skull for inspection he would take time to it.

Jeffries Wyman's balance of mind was shown in his noble sense of justice, of which I had a curious example, after I had known him for a year or two. It was about 1860 that a student in the School, who had come thereto after my appearance, was seized by a fancy for making a journey to the far East. To provide himself with means for this venture, he went about among the patrons of Agassiz's work soliciting contributions. Some of the givers may have had an idea that they were giving to a project which had his approval, though he had not been consulted in the matter. The young man's action exasperated Agassiz and led him to an outbreak of rage, the first I had ever seen him in, for he was generally admirably composed in manner, even when inwardly troubled. He had the offender's effects put out of his room in Zoölogical Hall and summarily of his own authority dismissed him from the School. This expulsion he announced to a meeting of the students of the laboratory, giving his reasons for it. Knowing the purpose of the gathering I refused to attend it, for while I was not on good relations with the fellow, and regarded his conduct as improper, I refused to have any part in his punishment. I tried, indeed, to dissuade my master from his summary course, but without any other result than a berating.

The sense of even-handed rather formal justice which has always controlled in the discipline of Harvard University, and which requires that no student shall be expelled without a full hearing of the case before an unprejudiced board, was much shocked by the summary treatment which Agassiz gave to his pupil. Probably because I had refused to countenance the performance, Wyman, who appeared to have charge of the inquiry which the authorities made, came several times to ques- 
tion me about it, and our discussion of the matter brought us to the place of friends, though we were generations apart. His effort to form a judgment of this case, his inevitable fairness, made a great impression on my mind; it was the most beautiful exhibition of fairness and sympathy I have ever seen. Out of it came the conclusion that while the action of Agassiz was rash and illegal, the results were on the whole just. I distinctly recall how well Wyman weighed a suggestion of mine that it would not be right to judge Agassiz's course of action by the rules of the place where he was, but rather by those which held in the part of the world where he had acquired the standard of conduct which he brought with him when in middle life he came to this country; that the College in taking him took not only his learning but his habits as well; that these would not always happen to fit a New England school was to be expected.

Jeffries Wyman was one of three brothers who had a place in the life of their time. Morrill, the elder, was a physician of distinction who served the community of Cambridge, especially that of the College, for over sixty years. He had the same simplicity and honesty that characterized his brother Jeffries. $\mathrm{He}$ also knew most accurately the difference between knowledge and conjecture, and brought to his judgment of malady a rare penetration as well as an inventiveness in devising the means of help. Though successful by dint of his success, he lacked a full share of popularity because of his unwillingness to humor his patients. If he found nothing the matter with them he was likely, after looking at the pictures on the wall and making some irrelevant remarks about politics or the weather, to go away without any evident consideration of the case. If, however, there was reason for it, he would set about his task of helping with amazing devotion. When near eighty years of age, long by the time when he was willing to undertake any surgical work, he found himself in face of a case of strangulated hernia, when to save the life an immediate operation was necessary. $\mathrm{He}$ had no surgical instruments with him, but he at once and 
alone etherized the patient and with pen-knife and scissors did an entirely successful operation. Although by thrift and saving he amassed a considerable fortune, becoming as usual in such work somewhat close, he held obstinately to the low charges for his services, which were half a century ago a dollar for office advice, two dollars for a visit, and a like moderate scale for obstetric and surgical work. Moreover, he was given to the practice of refusing any compensation from people in stress for money. The only approach to a quarrel, in the forty years of our intimacy, was on an occasion when he asked me to tell an impecunious colleague of mine that he had no bill to pay for the long and devoted services rendered him in a grave illness. I refused to do this on the ground that such a communication should not pass through an intermediary, because even that slight amount of publicity would offend the recipient of the charity. After a time, finding that it was the curious family shyness that ailed the kind doctor, and that the matter was weighing on him, I bore his message, with the result that while the sick man accepted the grace it broke up our friendship.

My first contact with Wyman was in the winter of 1858-59, when there was much diphtheria about. Having a sore throat, I sent for him. Knowing that he was a busy man, and as it was in the night, I had ready a candle and a spoon which I handed him as soon as he came in. He looked at the offending throat, said it was not diphtheria, remarked that I had been well brought up, and went his way with no further word. When I sought him to pay for his services, he said that there was no charge, as I was a physician's son. He had apparently inferred this from the preparations I had made for his visit. It was only when I explained that though I was under age, I was supported by money which had come to me from generations beyond my father, and that my use of it in no wise affected his welfare, that he was willing to take his fee. The acquaintance thus begun soon ripened into friendship, which was ever a support and inspiration to me. His advice given in many perplexities was 
always wise and inspired by a wide-ranging knowledge of men and things. He was the very type of that best of all groups of men, the well-trained, devoted physician.

A third brother of this interesting family, Rufus Wyman, was personally little known to me, for he, too, shrank from any kind of publicity, and thus was hard to know. Like the others, he had the quality of devotion to his fellow-men with so complete a willingness to put aside all considerations of self that he never saw what his deeds meant in terms of sacrifice. An instance of this came to my attention, when an invasion of cholera slew a number of people in Boston and Cambridge, among them Gould, the zoölogist. Rufus Wyman saw several people looking at a house on the other side of Main Street, in Cambridgeport. Asking what was the matter, he learned that there were cases of cholera there, and that no one dared to go in. He went at once, stayed there and served as nurse until death or recovery made his help no longer necessary.

Next to Jeffries and Morrill Wyman, my relations were closest with Charles T. Jackson, a man of a totally different type; in fact, he and the noble brothers were at opposite ends of the great procession of my time. Jackson was a man of uncommon ability and of wide learning in chemistry and geology; most willing to help youths to their advancement but with an eager, most human, often pitiful hunger for applause. He could not rest on his solid accomplishments, on his for the time excellent geological work, and his full share in giving the greatest boon ever given to suffering men and beasts, but he must have a share of the approval of his fellows, for his mental digestion, so to speak, with every meal. Boston, with its chariness of praise and its unreasoning shallow contempt for demonstrative persons, afforded him no outlet for his great talents, which closely verged on genius. Had he lived in Paris, where a personality is appreciated for what it is worth, and not in the atmosphere of decaying Puritanism, where he was stifled, he would have won a great place for himself, and, what is better, 
happiness. From Jackson, whom I often saw at his house and oftener in the Society of Natural History, I had much in the way of information. I never went to him for help without finding it, but my errands related solely to matters of fact, of which he had a great store. He did not teach sympathy for his fellows, but he needed it overmuch himself.

Jackson had a great deal of divining power, with a limited amount of field observation - he was not zealous of seeing he could make safer inferences than any geologist I have ever known. This is shown in his work on the Narragansett Basin in Massachusetts and Rhode Island, as I discovered when I followed in his footsteps; he evidently saw but little, yet he correctly inferred the principal features of the structure of that interesting field. I have measured a large part of the work accomplished by my predecessors in this country and have found no instance where a difficult interpretation concerning the underground altitudes of a series of strata was so well done as in his report on this region. It is, so far as I have learned, the first piece of work in which a great syncline was adequately determined from only limited outcrops, for the most of the area is covered by the waters of the great inlet known as Narragansett Bay. The constructive imagination which led him to foresee the value of the anæsthetic properties of ether, was clear in all his geological work which I have traced in the field.

My contacts with Asa Gray were limited; he and Agassiz were in feud, so that except for hearing his lectures and now and then a word concerning some plant I had trouble in naming, I saw but little of him until after I had become a teacher in the School. Thenceforth until his death we were much together, for my grateful acceptance of Darwinism was a bond between us, as was also my general interest in botanical questions. My separation from him in the earlier days was, as I see it now, a misfortune, but inevitable; for in those primitive days when the students in the Scientific School were members of warring camps, each set against the others, in a desire to win 
this or that, it was dangerous for a student to be seen in parley with the enemy, and the leaders were not supposed to have much to do with the adversary's recruits. Coming as Agassiz did as a foreigner, successful in his efforts to get money for his large purposes, intense and outspoken as regards the ancient methods of teaching in the College, he naturally met with much opposition, which in his strong way he did not conciliate but overrode. The result was that his students found it well to herd together and have little to do with the followers of the other men. This, be it said, was not true in the case of Jeffries Wyman, with whom, despite incidental frictions as in the case above mentioned, Agassiz always retained friendly relations; he had indeed a great admiration for him. The fact that my master, who was the very antithesis of Wyman, understood and valued him, showed me that he had a rare capacity for judging men, and further that his conflicts with others were not due, as some thought, to his grasping desires.

Although in the curious system of instruction then existing in the Scientific School, essentially one of apprenticeship, the students of geology and zoölogy were not required to attend any other instruction, I went to certain courses of lectures, particularly to those given by Josiah P. Cooke in chemistry and to those of James Russell Lowell in literature. Cooke's lectures and experiments - there was no formal laboratory work gave an excellent outline of the subject as it was then known. At first, owing to a certain solemnity of speech combined with a nervous trembling which affected his voice as well as his hands, he made a somewhat unpleasant impression. Yet soon his earnestness, his willingness to help us to understand, made him valued for his real worth. From him I learned a little of chemistry and chemical physics, which has made me deplore my lack of real learning in that vast field.

Outside of natural science, the only teacher I listened to in my student days was Lowell, whose lectures I attended off and on for three years. I was first attracted to him by hearing that 
he was to lecture on Goethe, at that time an object of my worship, since unhappily relegated by what seems to me to be a better understanding to a secondary place, both as a humanist and as a naturalist. Lowell was then a fellow worshipper and that led me to hear him further. There was to me a peculiar fascination in his quality, though I did not then nor afterward when we were colleagues come to like him. As I saw it, he was the most perfect and most natural poser I have ever known. This acting was not of a purpose, he appeared to try to hide it even from himself, by contriving a garment of naturalness which he wore cleverly, but it did not hide the self-consciousness which tormented him. As I learned afterward, he had a devouring hunger for praise, which seemed necessary to lift him out of the self-critical humor which possessed him. While I felt this defect in the man in such a measure that at times it made me fairly ache to look at him, his lectures fascinated me: he gave me indeed my first contact with a man of high literary quality, with something of true genius in him. He read his lectures; they smell of the lamp, but he read them admirably; some of them stay with me after near half a hundred years. But none of his hearers seemed to come any nearer to him than I did, and I was kept at a distance. Any effort to get with him after his lectures led to failure. A few vague polite words made it plain that "those who did not leave when the performance was over would be put out by the police."

I particularly desired to know Lowell, for I had a hunger for the human quality that he knew, at least historically, so well. I desired to know him also because he was an Abolitionist and I was at that time curious as to the state of mind of cultivated men of that faith. I failed in this latter purpose with Lowell as I did with Edmund Quincy, the only other strong Antislavery man I hoped to approach. Quincy was my father's classmate and they for certain reasons had been thrown closely together, but he made it plain to me that he could not have relations with people who held slaves as my family did. This 
hint was so tactfully conveyed that I was neither vexed nor amused, but rather grieved at his preposterous state of mind. Whenever we met in after years, the dear old fellow always greeted me with a certain distinguished consideration such as you give and have from your enemy under a flag of truce. I shall have more to say of this curious state of mind of the Antislavery people further on in this narrative.

Of the other men who were in some measure my teachers while I was formally a pupil, I have the clearest and most delightful memories of Benjamin Peirce, professor of mathematics and astronomy. I was never in his classes, - they were reserved for college men, - but whenever there was a lecture to which I had access I heard him, with a greedy half-comprehension. He had a penetrating mathematical mind, compounded with a vigorous constructive imagination. I recall a course of lectures by him in which he dealt with a confounding variety of subjects, including curves and billiards, winding up with a drawing on the blackboard to which as a finale he with great effectiveness pointed, saying: "If an archangel had to make a universe he would do it in that formula." This made a vast impression on my mind at the time; it was long after that I came to see that your mathematical, like other mills, gives forth no more than you put into it, however changed in shape the product may be, and that the aforesaid formula held no more than certain human concepts of energy, matter, and law, so that even an archangel would find it a task to make anything whatever out of them. During my undergraduate days my relations with Peirce were limited, partly because I had no adequate preparation to follow his vast excursions, but more for the reason that he and Agassiz were enemies, with occasional intermissions of loving friendship, and as in the case of Gray I found it best to bide with my own lot. After I became a teacher, our relations were intimate and to me largely profitable in wide understandings.

Among those who came to Agassiz with the broadening of 
his prospects which the newly founded museum gave, were certain men who were in some measure my teachers. First of these I will note X., who had been trained by the master as a mineralogist and embryologist. Although he was a man of moderate parts, he had a decided capacity for the work assigned to him and taught it fairly well. From him I gained some skill in the relatively limited knowledge of those subjects which existed at that time, but no inspiration whatever. He was singularly affected by a notion that he was a genius who was in process of being discovered by Agassiz, and his whole mind went to securing his safety from that appropriation. While I saw that there was some slight basis for this idea, it was clear to me then as now that when a great and naturally avid personality comes in contact with a subordinate of mediocre talents, such a result is in some measure inevitable. I tried to make the sufferer see that for the ounce of value he gave he received a pound in return, but it was not in him to see it. Others who came in contact with Agassiz suffered from the same incapacity to understand the situation. The result in this case was a break which led to X.'s retirement from the university, and to his failure as a worker on his own account, which ended in his death a few years afterwards.

The other collaborator of Agassiz, who had far more influence on my life, was Jules Marcou, who had been his pupil, though the difference in their ages was but a few years. Marcou had already made a place for himself by his work on the Mesozoic rocks and his connection with the Mexican boundary survey. He was a native of Salins in the French Jura, but he had been in this country before and had married a Boston woman of distinguished family and considerable fortune. He was a characteristic Frenchman, of the especial type that marks the people of the region whence he came, so that they fit rather to our notions of Swiss than of French. He was some inches over six feet in height, slender, slightly stooped, with a handsome face that reminded me much of the portrait of Leonardo da 
Vinci. He never learned to speak English easily, to make it a second mother tongue as Agassiz did, and at that time his use of the language was most imperfect. Partly because I well understood him in French, but rather because of our common interest in geology, we soon came together and were long near friends. He was the first real geologist with whom I had a chance to take the field, and from him in 1860 in a prolonged excursion to Gay Head on Martha's Vineyard, I had my first lesson in actual exploration under the eyes of a trained man. Unfortunately, Marcou, though versed in the identification of horizons, had no sense of structural geology; so I was in no wise helped in the task of unravelling the complicated tangle of greatly disturbed strata which is there exhibited. In his opinion the folds and faults which are evident in the outcrop were altogether due to the slipping of the beds. Though these landslide movements have evidently had some effect in producing the tangle, I saw at the end of a week of work that this effect was but slight, and that other influences had been the main source of the complexity. This was my first piece of interpretation; it brought me no further than the stage of drilling, yet it was most profitable. Nearly thirty years afterward, on returning to the inquiry and setting about it with deliberation, the problem was solved.

I made a number of other shorter journeys with Marcou, all in the neighborhood of Boston. On these I learned from him more of the traditions of field work as he had received them from the various experts with whom he had been in contact. Yet he was little skilled in solving the riddles of geological structures and entirely inattentive to the meaning of physiographic forms. But as in that day few cared for those problems I was left to my own devices. I puzzled out some things in the structure of the Boston Basin by much footing over the ground and plotting sections and the dips of the strata; but it was years after, when I had a chance of help from the Swiss field workers, before I obtained any command of the methods I 
needed in my work. Marcou's main influence on me while I was a student came through his great knowledge of men and their deeds. He knew the work of the leaders of the science very well, and his intense interest in people, and delight in talking about them, helped me to get the traditions of the science. To him and afterwards to Lyell I owe a considerable amount of knowledge of what geologists have done and their quality not only as men of science but as men. I have never found any one else so rich in this important lore.

In 1860 I came in contact with the brothers Rogers, William and Henry, then famous for their work in Virginia and Pennsylvania. With the latter of these able men my personal contacts were limited, but I heard him expound his theory of mountain-building, which was in effect that mountains were great translation waves in the crust, made by earthquakes, essentially like those made by the wind on the surface of the sea, which had been arrested in their forward movement and remained as it were frozen as we now find them, except for the changes which erosion has brought about. I am glad to say that in the debates on this hypothesis in our club, I set myself against it, on the ground that we see no such waves attending earthquakes, and further that the rocks would be shattered by such movements and not folded as we find them. It was by such debates on every question which came up that I had much of the best training of my undergraduate time. Probably it was this proposition of Henry D. Rogers that fixed my interest on mountain structures and led me to read nearly all that had been written on the subject.

With William B. Rogers, as he had married in Boston and come to live there, my relations were nearer than with his brother Henry. We met in the Society of Natural History, where, as above noted, I was wont to contrive debates between him and Agassiz. I can see before me now the noble shape and brilliant countenance of my master, as he eagerly, often incautiously, set forth his hypothesis, while Rogers, keen-faced 
and alert, prepared himself for his attack. When his turn came, with an odd gesture by which he seemed to turn his eagle eyes "hard aport," he would launch on a task of mingled criticism and construction, in both of which he was most effective. While it was on, the contrivers of the fracas would rejoice in the profit of it; it was always large. They were both game-cocks, so that on a higher plane I had once again the pleasure of my boyhood in watching their evolutions. Much came to us from these debates.

It was well known even to Agassiz's students that Rogers desired to have a place in Harvard College as professor of geology. He was admirably well fitted for this position, a man of distinguished general ability, well informed in the science and an admirable teacher. Agassiz was at once professor of zoölogy and geology, though I believe that I was the only person who ever took the degree in geology while he taught at Harvard, and I had mainly to depend on outside help and fight hard for my training. It was not indeed until, after graduating, I spent two years in Europe and there had the help of half a dozen able teachers that I felt fairly well grounded on the dynamic side of the science; my training having been mainly biological. Large-minded as my master was in most of his contacts with men, he could not be persuaded to allow Rogers beside him. Presuming, it may be, on our relations, which had become rather those of man with man than pupil with teacher, I tried to debate the proposition with him, only to find that it was not debatable. It was a pity, for from this refusal to give him the place in the School to which he was entitled by his quality and station, Rogers was in a way compelled to turn his energy to the creation of a rival institution, the Massachusetts Institute of Technology, with the result that Boston supports two rival schools in a field which has fair place for but one. 


\section{CHAPTER VIII}

SOME COLLEGE COMPANIONS

NEXT to the elder men, my teachers, in the subjects which interested me, I have to rank as helpers a number of persons also a generation in advance of me who were only incidentally my instructors. Of these, two or three were in the entourage of Agassiz. One of them was Hansen, a Swede who served as a translator of Scandinavian languages, Russian, or any other foreign tongue save Latin, Greek, French, or German, which we were expected to deal with as best we might. He was a very interesting fellow, this Hansen, a huge blond Viking, with a rare spirit in him. A lover of music and poetry, good at a song, mingling gayly his age with our youths, all the day he was merry, but at night he had the most frightful dreams. His room was next to mine, and very often I had to go to his bed and wrestle him to consciousness. His visitations had a demoniacal fury and brought him a torment I have never known the like of. When awakened he was in a state of sorrow that wrung our hearts, but quickly he would cast his woe aside and be his merry self again. Gradually I learned from his unconscious speech, what I confirmed long afterwards from a person who knew his history, that his wife and children had been burned to death before his eyes. The daytime valor of this man taught me much.

We had as keeper of our club-house an interesting Scotchman, by the name of William Glenn, who was a preparator in the Museum. Though a mechanic, he had been much about museums and had known many naturalists in Great Britain. He was, moreover, a disputatious philosopher of rather wide reading in the Scotch school, concerning which we had endless debates. Glenn's wife, an attractive lower-class elderly Scotch- 
woman, was our housekeeper, an efficient matron of the young men who lodged in the hall, marvellously bitter of tongue, but full of motherly goodness. This couple interested me greatly, and we became near friends. I am sorry to say that they did not find favor with the other youngsters; so they fared ill, their life being made a burthen by certain reprobates of the rather ill-conditioned society.

Of the students who were with Agassiz, few of them became my friends, though I kept on good enough terms with all of them. At first, I was intimately associated with one of them from my part of Kentucky, whom I had known a bit in boyhood. So we naturally came at once together for the months before the club was set up in the Hall. We spent our evenings together, alternating in each other's rooms. Foley being by two or three years my elder and a masterful man, a while he was the leader of our doings. He was the most perfect specimen of a physical man I have ever known: six feet, two inches high, evenly built, weighing about two hundred pounds, and as nimble as a cat. After the manner of his Kentucky kind, he was a born fighter, rejoicing in battle in a most amicable way - whacking seemed to warm his heart. The memory of him always reminds me of somebody's picture of a gentleman in line of battle:-

And now he hummed a snatch of song: and now he smote a knave.

Foley bred about him an atmosphere of combat which led the toughs of all the neighborhood to try their hands on him. Looking one summer evening from my window, I saw him coming up the street. As he passed through the hedge two men jumped at him; in a flash he had knocked them down; straightway he picked them up and threw them over the hedge into the street, the whole process taking less than ten seconds. Then he came up to my room as if nothing unusual had happened. To my question as to who the chaps were, he said, "Dunno; never saw them before," and made no further reference to them. 
Beginning with the occupancy of Zoölogical Hall as a clubhouse, Foley was for some months my chum. We got on well together. He tried his best to take on studious ways and showed no little ability, so that the master had great hopes for his future, but fighting - and what goes with it - was too much for him. Some of his feats were in their time famous. One midnight he came home with a policeman's coat and billy under his arm. A huge member of the force known as the "Infant Hayes" had tried to arrest him, merely to be laid down and stripped of his uniform and club, which were returned the next day with Foley's compliments and address. Naturally, the vanquished giant held his peace. About the same time, coming out from Boston on the well-remembered "last car" of those days, he was set upon by a party of roughs; he kicked them off, and not liking the behavior of the conductor and driver he kicked them off also. He then drove the car to the stables, explaining that the men had stopped in the "Port" and would be up shortly. As my chum was never ill-humored or unfair, and especially as he was never vanquished, he became a privileged character, the idol of the gentlemanly and other villains of eastern Massachusetts. In six months I found the association unprofitable; so in all friendliness we dissolved partnership and he lodged elsewhere. At the end of the year, he left the School, to become afterward a distinguished officer of cavalry in the Union service. He stays in my memory as the best type of his class I have ever known.

My next chum was Alpheus Hyatt of Maryland, a man of different quality from Foley. He, too, was much my senior, and had a large place in my life. Although my experiences had been wider than his, he earlier developed maturity of mind; in fact, at nineteen I looked up to him, then about twenty-two, as an ancient. He had attained to a perfectly definite theory of life, while I was still an explorer. I well remember his arraignment of me as a dreamer and a vagarist who would drift through life doing what the moment bade me do, with no sense of a definite 
goal, such as he had set for himself. I felt that much of his denunciation was well founded - somehow I never cared for goals, - the mileposts have proved more interesting to me. What I had absorbed of philosophy, and had insensibly shaped into a plan of life, made me interested in thinking and doing for their own sakes and not for those accomplishments which bred fame. On this, as on most other matters, we had endless profitable quarrels, such as lead to firm friendship. We were together for a year, when we concluded that we were both naturally solitaries, and he moved to Divinity Hall just across the way. We parted to be even better friends and more helpful to each other than before. The bond lasted until his death in 1902.

After Hyatt left me I had no permanent chum. For a time Leslie Waggener, another Kentuckian, who was a student in the College, lodged with me, and we were very near to one another until he graduated (in 1861) and went directly to the Confederate army. The first Confederate uniform I saw, he had made in Boston and donned for our diversion just before he went away, he knowing that Hyatt and I were soon to be his official enemies. We thought nothing of this incident at the time, but seen across the years I see the pathos of it.

Waggener's name reminds me of another friend of those years; the reason for the reminder I shall tell below. This other was Philip Sidney Coolidge, a grandson of Thomas Jefferson. I met Coolidge when I first came to Cambridge. We ate at the same table, and though he was some six or eight years my senior we soon became intimate. He was then an assistant in the Observatory. The common ground was, as I recall it, a common longing for the width of the world. I have seen much of men, but never another who was as curiously interesting as this son of an ancient and staid Boston family. Coolidge was brought up in France, and spoke his English with a French accent, for which misfortune he berated his forbears who were responsible for it. He was a rather small, delicate person, with 
a soldierly courage, with a gentle pale face, and a large nose adorned with eye-glasses. Though soldierly in bearing, - he had been trained at a French military school, - he seemed to be physically a somewhat weak person. I was sufficiently experienced not to mistake that ancient sign of danger, the woman's look. He had led a strangely roving adventurous life as a soldier in the Franco-Italian-Austrian War of 1859, as engineer of a revolution in Mexico, and as a member of a government exploring expedition on the Pacific. He had roamed about afoot in various terrestrial wilds and was seeking celestial realms. Even then I knew something of Sir Philip and fancied in my friend there was something of his famous namesake: a like interior of valor, with a like outward insufficiency or what the unobservant take for such.

One short story will tell more of Coolidge's quality than all my inadequate description. I had been reading some book of travel in China, and, in the manner of a youth, was airing my knowledge in the talk that went round at our boarding-house table. I had spoken of the northern Chinaman as a well-developed man, saying he would average a certain height - whatever it was in the book. A chap questioned my statement. Knowing Coolidge had been in China, I asked his opinion. $\mathrm{He}$ assumed that he thought the estimate was right. The caviller said, "I should like to know, sir, what foundation you have for your opinion"; having for answer, "I saw a hundred of them beheaded, and I measured them afterwards." I have heard sundry "sockdologers," but this was the most perfect of all, quite ideal in its efficiency. At the moment, and for long afterward, I supposed that the statement was an invention well contrived to silence the troublesome fellow - so indeed all probably took it. But thirty years afterward, on telling it at my own table, as a sample of apt invention, another friend said, "That statement was no invention; I saw Coolidge do it." He went on to explain that they together had witnessed the execution, and that when it was over Coolidge, with a curious fancy for 
exact fact which marks the true idealist as distinguished from the mere dreamer, had, with the permission of the authorities, proceeded with his measurements. Some time after the Civil War began, Coolidge found his place as Major of the Sixteenth Infantry of the Union army. At Chickamauga he commanded the regiment and, holding his place when the line broke, was killed. So I needs must go forward ten years and complete here the story of my Philip Sidney's end.

From a captured officer who was not, as I remember him, from his regiment, I learned shortly after the battle of Chickamauga that Waggener had been killed on that field. My informant had seen him dead upon the ground at the close of the action. As was the way in those days, I bade him farewell with but a fanciful grief and thought little more about him. In 1874, being then state geologist, I happened to be in Kentucky. It came to my mind that my friend was from that place, and that he had kindred there. With this memory came a grief for his loss I had not felt before. Thus moved, it occurred to me to seek his family. I was directed where to find some of them, and set out for the place. On the way, I encountered a man whose shape led me to say, "Sir, are you a kinsman of Leslie Waggener?" To which he answered, "That's my name, sir." "But," I said, "the Leslie Waggener I have in mind was killed at Chickamauga." "No," he rejoined, "he was n't killed, though he was left as dead. There's no other Leslie Waggener and never has been." While I silently stared at him, for once in my life quite nonplussed, he in turn said, "You look like Nat Shaler." I told him that was my name, but as if repeating my words, he said, "The fellow I mean was killed at Stone River; Jim —, who knew him well, saw him lying dead." I answered him that there were two good reasons why that was n't true; first, that I was not at Stone River, and, second, that I was very much alive. At this stage of our strange business, we sat down on a box in front of a store and gaped at one another. The odd part of it was, as we afterward remarked, that there was in our hearts no trace 
of our old mutual affection. The situation was almost disgustingly odd. Each had long accepted the other as dead and the sometime love did not find its way back. Waggener was the first to recover his balance enough to start conversation. $\mathrm{He}$ began by asking me something about Coolidge, who was killed at Chickamauga. Then he told me the reason for his question. The story ran as follows. Waggener was with the force that broke the Federal line where the Sixteenth Infantry was stationed; as the shattered remnant went back, he saw Coolidge standing in his place with the point of his sword up, making what the soldiers called a "defy." Waggener recognized him, knew that his signal of no surrender would quickly lead to his being shot, and ran toward him. When he was a few score feet away, he was himself shot, and did not recover consciousness for some days thereafter. I should hesitate to tell this improbable story but for the fact that I wrote down what passed at that strange meeting. It should be said that the dead friendship between Waggener and myself quickly revived and lasted to the end of his beautiful life, in 1896. He became President of the University of Texas, but was finally borne down by the wound he received while trying to save his friend from the death he strangely sought.

Last of the list of those students with whom I was intimate, and on some accounts the nearest to me, I name George Emerson. He was not of Agassiz's lot, but was engaged in chemistry under Horsford and mineralogy with Cooke. He came about the time I did; and though he was my elder by several years, he soon became a near friend; along with Hyatt he was, until the time of parting, in the centre of my life. Probably the bond between us was in part due to his delicate health and to the care I felt called on to give him. He already had tuberculosis, and was, as I saw, doomed to a speedy death. Emerson had the quality which has gone with many of his name whom I have known. Of all the youths of my time he was in spirit the nearest to the front. The fact, well known to himself, as well as to 
us, that he was soon to die, may have had much to do with his journeys to the spaces; but this sense of the finish did not make him sorrowful ; as the phrase has it, he "burned his own smoke." I doubt if there was much to burn, for his was a brave soul. In shape he was small, rather shrunken, - for the malady clutched him in his adolescence, - but he had the Cæsar nose, that cleaving prow of a nose which is the only feature of the face which in my experience tells of true valor.

I talked much of high things with Emerson in our rooms in Cambridge and our walks about the town. He could not range far, for his breath was scant; but I was glad to go slowly with him and to rest often, for we always went far in these short farings. We were most together on the occasions, rather frequent, when he took me to his home in Greenfield, in the Connecticut valley. Here he had some property and a lot of interesting people, his kindred and friends. My memory of those good folk is now faint, save for the abiding impression that they were living the quiet, deep, unsignifying life of the New Englander, that Puritanic life so different from the housetop-shouting mode of living I had been accustomed to. One of these figures is still vivid - that of an old gentleman with a soldierly figure and a noble face, who had been much about the world, having spent long years in India amid rich experiences. This dear man was mildly insane, and because of his occasional perturbations shunned by the people of the town, even by his kindred. I was accustomed to deal with such unfortunates, because in the community where I began the task of dealing with neighbors, his like were allowed to go about getting what they could from human intercourse, and their capers were looked upon as amusing. So I took many long walks with this sturdy madman, and greatly enjoyed what he gave me from his ample store of memory and the simple kindly philosophy which was mingled with it. When once in an hour or so he would "fly off the handle," I would not notice the aberration, but steer him back to himself with some question concerning his experi- 
ences in the far East; once back into his reminiscences of his sane life, he would run on for a while, a most delightful companion. The dear fellow soon saw the way I managed to keep hold of his sound remainder, and his dumb gratitude, told in look and tone in the way only the gentle soul can tell it, moves me as I write these lines. I have long forgotten his name, but his face stays with me, the brave face of a man who was fighting to save his remnant from the deep, so that I would know it at a glance if it came again to view.

The last time I was with Emerson over a Sunday at Greenfield, - it must have been in the autumn of 1861, - we talked over the matter of his end, which was then evidently not far off. His regret seemed to be not for the early passing of his life, but for the failure of his plans for work that would remain undone. He turned to the disposition of his little patrimony, some twenty thousand dollars, which he desired to leave for scholarships in the Scientific School, to which he was attached by the sense of its large purposes and certain future, but he desired to mingle his care for the unknown with benefaction to those who had been near to him by giving a life estate on his property to $\mathrm{H}$. or myself. It was decided that it should be $\mathrm{H}$., who had least in the way of expectations. So it was thus arranged. Our mutual friend had the benefit of the trust until his death thirty years after Emerson passed. That the money, which now helps to support poor students in the University, will perpetuate George Emerson's name for ages is my hope. All else of him, the infinite else of his great nature, the world will never know.

I never saw Emerson after our last meeting in Greenfield, but in the autumn of 1862 I had a letter from him which came to me in active campaign while Bragg was in Kentucky, in which he told me that his disease was making progress, that he could not die in peace with the sense that Hyatt and I were in the lines, and he crawling about his home. He begged me to find for him the chance to stand up for a punch in the good cause. I took time to write him that this was impossible; that it needed 
all of a well man's strength to keep one's feet long enough to take the stroke; and that he would add one more to our cumbered hospitals. I never heard from him again; after this last lashing out against fate, he sank into the repose that usually comes to those who die of consumption, and passed quickly.

One of my neighbors, rather than comrades, of Agassiz's train, was - , an interesting fellow who went about his tasks nimbly and merrily, but with an utterly commonplace motive which made him quite uninteresting to our small hyperphilosophical coterie. He was of my age to a year, but seemed to me hopelessly young, I suppose for lack of the aforesaid philosophy. Had — stuck to zoölogy he would have made a great dissector of species, for he took to that dismal task as a duck does to water. Withal he was frolicsome; he played a large part in the rackets which went on in our hall and was much in society, where his eminent physical beauty made him welcome. At the first tap of the war drum, he was away and by the time he was twenty-two he commanded a brigade. I have heard it said that he was the youngest man in the service to earn a star for his shoulder. In 1865 he found no place in the regular army, but fell into avocations where he won no credit and died. It is the fashion to say that arms make a man fit for citizenship; that is in some measure true of the material which finds a place in the ranks; in my experience it is quite otherwise with youths of the higher order there. In our Civil War the effect was usually destructive of purpose, and the training that fits man for it.

There were two men much older than my set who were to be connected with Agassiz's pupils who gave me a share of their store, William Stimpson and Richard Wheatland. Wheatland was a Salem man who came often to the laboratory and at times worked with us for months, then would be away, - for he too was a consumptive, as were so many of the better sort in those ancient days. From him I had a sense of the fundamental measurement of the real Puritan stock of the Salem Colony; through his eyes I first saw past the appalling solemnity which 
marked the real nature of the Yankee life. He had not much to give, but he revealed to me that things were "not as deep as a well nor as wide as a church door"; and this gift helped much to reconcile me to a society which, seen on its face, was to one of my breeding by no means inviting. He soon passed out of my sight, but not from memory, which holds him dear. His was the common fate of Yoricks - to be forgotten before they are dust; in certain ways, high ways, they are the best of their times, but because a laugh cannot be perpetuated, they fall into quick forgetfulness, or at best they have an echo in the hearts of those who knew them.

William Stimpson was a naturalist of no mean capacity. If he had not been turned to species-describing, a task akin to "gerund grinding," he would have come to largeness. As it was, his keen interest in animals of all kinds, his real love for them, made him something much better than his printed work. It was his affection for creatures as well as his general wit that quickly brought us together. Stimpson was much my senior, probably by ten years or more. He had rather cut loose from Agassiz, for he had a fierce independence of spirit which did not allow him to profit by mastery. Yet he now and then worked in the laboratory, at that time on molluscs. We used to debate the Darwinian hypothesis privately, for to be caught at it was as it is for the faithful to be detected in a careful study of a heresy. We had both read the "Vestiges of the Natural History of Creation," Lamarck's "Philosophie Zoölogique," and first the Darwin-Wallace papers and then the newly published "Origin of Species." Agassiz had given a large part of his lectures in one term to denouncing these works, and to the assertion that species were absolute creations. He never even suggested how the special creation came about, and when, at the end of a lecture, I pressed him for some conception of how a species first appeared, he stated that it was a "thought of God," thereby showing the curious mysticism which lay at the foundation of his nature. The logic of these views bothered Stimpson less than 
it did me, because he was a man of facts and not fancies. He was puzzled by the transitional varieties between many of the species of molluscs he was studying, especially those occurring among the freshwater gasteropods. On one occasion I saw him throw one of these vexatious shapes on the floor, after he had studied it for a long time, put his heel upon it and grind it to powder, remarking, "That's the proper way to serve a damned transitional form." 


\section{CHAPTER IX}

\section{CRUISING AND CAMPING}

MY first experience with dredging was with Stimpson in the summer of 1860 along the coast of Maine. This art of searching the bottom was then in its infancy, but what there was of it he knew well by much very intelligent practice. We never worked at a greater depth than about a hundred fathoms, and at that depth, by using a large sand-boat, drifting with the strong tides; practically all our work was in the lateral belt. It was in general our practice to use a rowboat with a sail to get to and from our ground; but we trusted to our oars for dragging the apparatus over the bottom, two of us pulling while the third - Hyatt was with us for a time, and for the rest a boatman - "tended dredge." Since he was not strong, having, like so many others, consumption, Stimpson did little of the pulling, so that I had a season of hard work, enlivened and more than repaid by the joy of the deep and its riches. I well remember the enthusiasm with which Stimpson would greet a good haul. When the dredge came up well-laden, it was his custom to drirk to it in rum which was always aboard, and of which he partook greatly. Filling a glass, he would dextrously stand with one foot on either side of the boat, swaying with it as he sang:-

"I was born upon the water and had ne'er a mother fairer, And for mother's milk my father gave me only old Madeira;

So following out my early training I wander still upon the sea, But water yet I ne'er have tasted; water is no drink for me.

Water, no, no, no, water, no, no, no,

Water is no drink for me."

Then with "Here's to the haul" and a gulp, we would turn to the business of picking out the treasures. A month of this dredging took us pretty much the length of the Maine sea-front. 
We lodged where we chanced to be, generally with some farmer or fisherman. There comes back to me the memory of a good overnight place on Ironbound Island, in Frenchman's Bay. We landed there at sunset of a summer day, memorable to me because there had been a partial eclipse of the sun, which we had seen through bits of smoked glass taken with us for that purpose. The house, as seen from a distance, was a curious structure set against a hill, two stories in front and none behind, where it came against the steep slope. I was sent to parley for food and lodging. On the way, seated apart on a stone, I came upon an old, bareheaded man, who was reading in a loud reverential voice from a book in a language which at first seemed a jargon unknown to me. I went slowly near to him, waiting for him to look up, or at least to make a pause, in order that I could speak to him without being rude; but he kept steadily on in his preacher's tone and I had a chance to find out what he was up to. He was reading Greek, without having learned the sounds that fit the signs. When the letters could not be guessed, he gave them a sound which he had devised for each. Where the letters were much like the Roman form, he was right enough, but there were enough that he could not interpret to make the whole effect very odd. At last, the good man came to the end of his chapter, when I told him who we were, and what we were about. He handed me the book, asking if I could read it. I read him the first verses, to which he listened most intently. When I stopped, he said we might stay as long as we pleased. Then he added, "See the old woman, and don't tell her I said you can stay." I found the dame somewhat difficult. I had to dissemble concerning my interview with the old man, laying the accent on the Greek, but we lodged there for three days, of which nearly every waking moment spent ashore was of necessity given to teaching my eager pupil how to pronounce Greek. If I had been a tenth part as zealous a student as he was, I should have been a great scholar. It was interesting to see that he really knew the New Testament Greek; he had fairly worked out the gram- 
mar and syntax in his simple way, so that he appeared not to render it into English as he read, but to think in the language. His joy in acquiring the pronunciation was affecting; it was the crown of his life.

My note-book of this dredging expedition was burnt years ago; thus I have lost the name of this dear fellow whose friendship I acquired through the Greek alphabet, but I remember his story as he told it me. He had been to sea until he was too old for that labor. He was entirely self-taught, but he had an apt pupil in himself, for he had much sound learning, including rather difficult mathematics. He had devised and made an interesting lot of instruments for nautical observations, novel forms of sextants and queer contrivances for observing and computing, and, what was more remarkable, tools for graduating the various circles he needed in his constructions. He was a religious enthusiast and for all his active life had longed for a chance to study Greek in order to read the Christian part of the Scriptures in the original ; he was skeptic enough to distrust the translations. So when, at about seventy-five, he had leisure, he possessed himself of the text of the New Testament in the original, and without grammar or dictionary set to work by a process of comparison with the English version to learn the language - it was amazing to see how well. As we sailed away, I saw the old man in the place where I found him, and heard him fairly shouting his Greek in the letters and sounds he had learned.

Our voyage along the coast was replete with incidents of contact with the then remote and primitive people who dwelt there. It was the richer for Stimpson's rough art in dealing with their curiosity as to our purpose, which must have seemed strange enough to folk who thought they knew all manner of dealings with the sea. Between Grand Manan and Eastport, while we were pulling in a rough sea as for dear life towards the shore, a fisherman sailing in one of the sharp-sterned, high-pooped schooners of the time, found his curiosity too much for him. 
So he bore down on us, caught up, and called out, "Some kind of fishing?" "No," said Stimpson, "we ain't fishing"; whereupon the skipper pays off, and sails away a mile. When overcome again, he turns about, runs up to us, lays to awhile in silence, then, "Lost your anchor?" to have for brief answer, "No, have n't lost no anchor." Forth once more, but lest he burst with ignorance, he comes about very near and in a pleading tone calls, "Wall, what be ye doin'?" Stimpson, in his favorite attitude of one foot on either gunwale, explains. "Don't you see, skipper, we are turning Grand Manan over to fill up Eastport Harbor." "Shough," roars the skipper like a blowing whale, pays off, and sails away. When we arrived in Eastport, we found that our fame as "naturals" had preceded us.

After we parted with Stimpson, I went with a companion to Trenton Point in Frenchman's Bay and spent a month in further dredging and roaming about with one or two companions whose names I have forgotten. We stayed in an interesting family, the master being an old sea-captain of rough, unsympathetic, almost brutal outside, which was a mask for a very tender, sympathetic nature. He affected to despise us and our occupation; but one stormy night when the three of us had been caught out in the bay, and came near losing "the members of our mess," getting home only at break of day, I thought I saw his boat reach the wharf just ahead of us, and his hulky shape slip into the house just before we entered. In the morning, he affected utter unconcern whether we had been in danger or no; but I found from others that he had gone forth in the storm alone in his boat to search for us.

At Trenton Point, I fell in with an interesting Englishman, who was a country teacher of music. I believe his name was Ramsbottom or some such queerness. He was a well-trained musician, oddly out of place in the hamlet where he dwelt; I fancied a man with a history, such as may be found here and there in corners. He had trained a very good voice, which rendered high-grade music admirably well. This chap was a mas- 
terful fellow indeed, for he made me play on the violin in his orchestra. I had had a year's training at it, and he made me sing solos which I had never done before or since. Therefore I fairly judged him a master. He certainly was mightily entertaining.

From Trenton Point we took by boat a tent and simple camp "outfit" to where Bar Harbor now stands; tied the boat in the bushes about where the steamboat wharf is; and spent some days exploring the island of Mount Desert, then very little known. We camped for the most of the time on Green Mountain, where, boy-fashion, we amused ourselves by starting boulders down the steep to hear them crash into the woods below. Thence we went to Eagle Lake, built a raft and with our shelter tent managed to sail the length of it; but near the end of the voyage there came a stout wind, and the waves broke the raft to pieces, so that we lost our effects and had to swim ashore, and make our way ignominiously to our boat and back to our boarding-place.

This trifling bit of a camp journey in Mount Desert was a great event in my life, for it brought my feet for the first time upon a mountain-top. It is true that the height was trifling, but a matter of fifteen hundred feet or so, - and I had seen greater elevations in the distance; but the way to experience a mountain is to climb it with a pack on your back; you then sense its mass in a way that sight does not enable you to do. I have never had this sense of mass so borne in upon me as in this climbing of Green Mountain. I remember how the uniform structure of the elevation corresponded with my text-book knowledge, which led me to seek the outward dip of strata from an axis as the essential feature of such edifices. I came to a fair idea of the truth that it and the associated hills were the remains of the crystalline material which had been thrust up into the folded stratified rocks, which had at one time covered the country and had since been eroded by streams and glaciers. Some remnants of this ancient covering I found in the schists about the north shore of the island. 
Two other very diverse memories of impressions had on this journey remain with me. One is of a great fire which ravaged a primeval forest of pines near the shore, which I saw from our boat. The flames rose for at least fifty feet above the tops of the tall trees, and, fanned by a strong wind, marched with great rapidity, so that in an hour or two an area of some hundred acres was swept away, leaving only the headless charred trunks standing amid the smoke. Since then I have seen the fire of battlefields and a city in flames, but there was a solemnity in this burning of a great wood, a sense of personal loss, keener than they aroused.

The other impression is that of a preposterous fleet of ancient ships, locally called "bounty-catchers," sheltered from all the dangers of the deep in a well-landlocked harbor. It was a strange-looking lot of archaic craft, some of them of obsolete shapes, that could only by care be kept from falling to pieces. In good weather these queer things would be led forth into the more open water, but not to the deep sea, to go through the pretence of fishing, all this in order to earn the bounty then paid to fishing vessels, - so much for each ton of their incapacity. This was the first of the many processes of cheating the government I had ever seen. For at the government post whereabout my early days were passed, there was always a strict economy and diligent care for the mint the officers had in their hands.

During the autumn of the same year, in the Thanksgiving recess which then existed in the University, I went with Foley to the Umbagog Lakes in Maine, a journey of ten days or so. Many of the incidents of this outing stay clearly in mind. In Portland, where we had to wait for some hours, we bethought ourselves that we might need some whiskey. There being no evident bar-rooms, we went into an apothecary's and asked for a little of it, to be told that we needed a physician's prescription to obtain any kind of alcoholic stuff. Not to be balked, we entered another shop, where I handed the attendant the needed 
bit of paper with the usual $\mathrm{R}$ and with the Latin for whiskey, "spiritus frumenti," adding thereto a trifle of iron oxide. This prescription was at once filled.

Stopping over night at a little inn in Andover, on the way into the wilderness, I found an old man seated by the fire in the public room. He asked me whence I came, and on learning that it was from Cambridge, near Boston, he said that he had been there, but that it was quite a while ago. I asked when it was, and learned that it was on the day of the Battle of Bunker Hill, when he was a lad. He had nothing to do with the fighting, but seemed to retain a clear memory of the battle and the anxiety of the people in the village. Although in my boyhood I had seen men who claimed to have been soldiers in the Revolutionary campaigns and to have fought at Cowpens, King's Mountain, and Yorktown, this was the only ancient I ever encountered who had memories of the earlier stages of the Revolution.

In the then conditions of transportation in the Umbagog country we had to have a guide and pack our camp effects and canoe over portages. Our guide was a half-breed, a drinking fellow, who proved very insolent at the outset of our journey with him. We came to bettered relations through a trifling incident. In packing over a carry, he in the lead, a spruce partridge stood in the path, so that he halted, looking at it. I saw my chance to show him that we were not so green as we looked, and with a small revolver which he did not know I had, I fired at the bird and killed it; the bullet went within half a foot or so of the brute's ear. There was no risk of harming him, for I was so close that the shot could not go wild. He walked on, picked up the bird, and put it in his pocket; did not even look at me, but was afterwards very friendly. It was not that he was frightened that he became more amiable; the fact that I had shot by his head and hit the mark put me in the class of respectable persons - those who knew something of the wilderness and its ways. A part of the rather absurd but effective training of the lads with whom I had been brought up was to 
practise shooting under these conditions, when we would graze the neighbor. It was a rather risky thing to do; I do not remember that it was countenanced by our elders, nor do I recall any accident arising from it. No doubt it helped to that quality of steadiness which the marksman needs and does not easily acquire.

One day's fishing at a logging-camp, where we lodged by a dam which parted the upper and the lower lakes, satiated me with this sport. We caught more lake trout than the settlement could consume; a lot of the fish had to be thrown away. It was evident that fishing was not to my mind; so I borrowed a shotgun, and went after spruce partridges in some near-by clearings. The stupid birds permitted themselves to be slain with astonishing ease, and as they were in great plenty I soon wearied of this sport and lugged my bag back to the camp with the conviction that butchering animals was no longer amusing to me as it had been in my boyhood. I have never been able to reawaken the motive, which was innately strong. I am inclined to think that it is a primitive emotion, which normally does not survive the passing of the childish state of mind, which in many ways is savage in its propensities. When men retain the ancient cruel spirit which leads them to slay with pleasure, the reasonable conclusion seems to be that they have failed to grow to the stature of the civilized man.

Winter came upon us in a great storm, which broke just as we were setting out in a canoe for a sail down the longest of the lakes in the Umbagog chain. The wind was so strong that we could not return to the camp, nor could we keep the little sail. The only manœuvre was to run before it, paddling as hard as we could. The snow fell so thick that we could not see the shores; we therefore steered by the direction of the waves, and at the end of the voyage came ashore with such momentum that we were cast beyond the beach up into the woods, our craft being wrecked and all three of us somewhat the worse for the sudden landing. 
Although in its prime object this little expedition was a failure, - for I did not enjoy what most would have called excellent sport, - the touch of hardship of a character I had never found in the Kentucky woods was grateful to me, and the beauty of the New England wilds was entrancing. I also enjoyed the contacts it gave me with a new kind of man, the Maine lumberman. In that day, these men of the axe were all bred on the soil, and a more vigorous set of fellows could not have been found on the planet. The camp where we lodged, near the dam, was occupied by about threescore of them. Not all of them were in it every night, but all gathered there on a Sunday, when the most of them had a spree, not much else but animal spirits in it, but plenty of those, which their hard work seemed in no wise to lessen. The camp consisted of a single great square structure built of logs, perhaps sixty feet on a side; around the margin was a sleeping-bench some eight feet wide; within that tables and in the centre a great altar-like fireplace, with a dependent sheet-iron chimney with a great hood to catch the smoke. Here the cook did his simple business of preparing meats in early morning and at night. There were cabins for stores and great stables for the oxen, which were to haul the logs to the lakes and streams as soon as the snow came in plenty. Altogether it was a rude life, but it strongly appealed to me, though then, as ever since, it was painful to me to see the noble woods slain and fields where they had grown made a bitter desolation by fire. 


\section{CHAPTER X}

AN EXPEDITION TO THE GULF OF ST. LAWRENCE

THE last of all the journeys I made while a student was a considerable expedition to the Gulf of St. Lawrence in 1861. This was rather carefully planned so as to fit into the scheme of our training. It came about in this way. My small experiences in going about had awakened in me a great desire for a longer coastwise journey, which would give an extended contact with both sea and land. Since I was then studying the Silurian system in my vacations in Kentucky, and knew the points fairly well, the publications of the Canada Survey on the island of Anticosti interested me greatly. The report of the explorer and the writings of Billings showed that forms existed there which differed from those of the Ohio valley or those of Great Britain and Scandinavia, which I knew from the collections in the Museum. In the autumn of 1860 I met Lord Head, then Governor-General of Canada, at Professor Ticknor's house in Boston, and talked with him of my plan of studying that island. He was a very kindly old gentleman, and was so good as to interest himself in my project and to promise help in the way of a letter to all the government officers of the St. Lawrence district. So all at once it was decided, with my master's approval, that three of us should the next summer find some craft that could be chartered for the voyage as cheaply as might be, for we had to pay our own charges.

The adventurers, consisting of Hyatt, Verrill, and myself, managed through a good friend, a Captain Treat of Eastport, to charter a little schooner of that port. We found a pretty-looking little craft in the glisten of new paint; a skipper had been found in a splendid giant, who bore the picturesque name of 
Mariner Small - prophetically so dubbed in his christening, and, despite his surname, one of the mightiest of men. He was an oldish fellow, who had made his comfortable retiring fortune on the far seas, where he won also fame as a navigator and for divers other qualities. I fell in love with him at sight, and though we had many bad quarter-hours together, he is still near my heart. On shore I found him almost ridiculously urbane, a mild-mannered, soft-voiced giant. It was told that he was a deacon and uncommonly pious since he had given up the sea. All this interested me vastly, for I thought I saw else in Mariner Small. We learned that he was going with us for a little vacation and for our good company, to a corner of the seas - one of the few - where he had not set keel. There was one able seaman, named Upton Treat, a good fellow of the seafaring class, but of rather better standing than the most of those who go before the mast, whom we found most helpful and companionable; and there was a cook, a chap known as George, to make a fair number for a crew. The passengers were to act as hands and were to make out the watches and at times - when the need came - to keep the craft afloat by steady pumping.

As we did not know where else we might seek to go after Anticosti in the four months we expected to be away, and having some designs even on Greenland and Iceland, we provisioned the craft largely, so that if seabound we could have managed to feed for a year. Though we had to be economical, we were well found in such matters as guns and ammunition, as well as in enthusiasm - enough of that, indeed, to have dared for the North Pole. Among our miscellaneous stores I had as a private venture, on the recommendation of a friend who had summered in Labrador, a gross of clay pipes and a keg of tobacco and also a lot of sugar, and remedies for scurvy, a disease which, I was told - and truly enough - I should find rife among the sailors we should encounter. We had no whiskey or other spirits, but, oddly enough, my father had sent me a tengallon keg of wine from the Kentucky vineyards, which we took 
along for possible festive occasions. One of my comrades, who was full of chemical lore, contrived an expedient for preventing the wine from turning to vinegar, which consisted in putting in it some form of lime warranted not to affect the taste and to keep it perfectly sweet. He probably made some mistake in the kind or quantity of lime he used, for the result was to convert what was before a very agreeable drink into a weak acid whitewash, for which the only use was to dose the cook by means of a funnel when it was decided that his cooking was altogether too bad. The remark in his hearing that, "George would have to have some more wine," would always better the diet for some days.

We set forth on our journey, as will be seen by the date, after the Civil War had begun. Hyatt and I had much debate concerning the wisdom of our going, but we concluded that the struggle would probably last for many years, and that we would go through with our training and graduate before going to the task of arms. Neither of us had the least hunger for the business, which we foresaw would probably break up our careers. My own commonwealth, Kentucky, had determined to remain neutral in the struggle, and it was then believed that it would be some years - if at all - before she would be involved in it. At any rate, we determined to have a good time in the wilderness and forget the discords which had made our days miserable. I remember being thankful as we sailed out of Eastport, that we should hear no more of it for months to come.

The outset of our seagoing in the Bay of Fundy was tempestuous. For some days we had a wild, hard sea, which tried our stomachs sorely, and, what was worse, proved our nice-looking craft to be unseaworthy. We then heard from Skipper Small that the craft was old and had been a bad sailer, so that the owners had put her upon the stays, cut the hull in two, separated the parts and put in a piece to increase her length by ten feet. This had made her swift, but the job was ill done, with the result that in a heavy sea the joints were strained open. We 
had to pump continuously to stay afloat, and it was an oldfashioned pump - one without a lever handle, so that you have to stand over the pipe and take hold of a crosspiece. I remember the details of the business mighty well, for my back aches again as it comes to my mind. Off Liverpool, Nova Scotia, after a week of pumping, we found the water gaining on us; so we ran into the port for repairs. On the way in we were hailed by an officer of customs and bidden to lay to; but as the sea was heavy and the situation bad, we kept on until we found a friendly mud bank on which we ran. Swift after us came the irate official, who boarded us. He was a self-important fellow, and, despite our explanations, full of threats and abuse. $\mathrm{He}$ was the first of the provincials who in their manner showed their delight that the Union was breaking up, in the contumely they poured upon its unhappy citizens. When the situation became intolerable, I bethought me of the document which Lord Head had sent me, - a most imposing charter-like affair, with a huge seal and ribbons attached thereto, as I remember, from the Admiralty, - which in effect placed all the officers of customs at our disposition. I see now the awestruck look of the chap as he read it over. He wonderingly asked where the gentlemen were who were named in the paper. When I told him that he had been blackguarding them for half an hour his reconciliation was harder to bear than his previous insolence.

After a week of delay for the needed oakum in our joints and some bracing at the splices, we again set to sea to take another whack of storm on our way to the Gut of Canso, the passage into the Gulf of St. Lawrence. When the wind died out, we rested "hawse hole and scupper hole" for two days, the first of my several experiences in this tedious business. The monotony was broken by an incident which made so strong an impression that I feel it now. An ocean steamer passed near us, swaying in the sea as if she would roll over; a sailor was working aloft; I was watching him through a glass, for I felt his peril. Suddenly he was thrown as a stone from a sling, striking the water far 
from the ship. At once the ship was put about, stopped, and boats by a marvel were lowered, but the man did not, so far as I could see, come to the surface. We youngsters were eager to get out a boat, but the skipper said "no," that the place was about a mile away and the steamer's people would be there long before us; besides the chance of getting a boat away from our dancing craft was small. He was properly careful of his men - as he said he could n't go home unless he had us on deck. After the first waiting for the sailor to make his appearance, the steamer's whistle sounded, the boat's crew by a second marvel went back to their davits, and she swung on her course. I have seen much of sudden death, but this stays as the type of such good ending - duty, up aloft, and then the deep sea.

We went into the Gut of Canso, to find it packed with a vast huddle of fishing schooners, several hundred sail, partly from Cape Ann and other parts of the New England shore, and partly from the southern ports of Nova Scotia and New Brunswick, all held by head winds and mad with the delay. Here again the irritation between the Yankees and the provincials was bitter. There were reports, probably all false, of outrages on ships done here and there by the Federal or British authorities. Almost the worst of war is in the rumors it breeds. These stories, added to the ancient rivalry of the fishermen, bred hatred, so that our three days or so spent in this fleet was as in an ancient naval battle. An exchange of marine courtesies, though the tempest ran high, was commonly followed by the Gloucester men insisting on closer acquaintance; they would take to their boats and board the offender. I saw then what subsequent experience has confirmed, that the Yankee when loosed from the bonds of peace is about the most dangerous animal now on the planet. Fortunately, as all about us soon learned that we were not fishermen, we got out of the shindy except as spectators. Fortunately, too, there came a sudden change of the wind from northeast to southwest, followed at once by shouting, tugging at windlasses, clanking of chains, and creaking of blocks as the 
sails went up before the anchors were turned. The "Americans," as the provincials then termed them,- Yankee was only a term of contempt, - were the swifter to be under way. I expected to see a regular fight in the exit, but all else seemed to be forgotten save the dead race for the fishing-grounds. It was as silent as a vast regatta, with a marvellous skill in steering, so as to have every bit of advantage, to blanket and keep from being blanketed. In an hour or two after we had broken into the open water of the Gulf, the thing had parted into two fleets, those of the Cape Ann group and those of the Province ports, with unbroken water between them, and by night they had the round of sea between them. I have never seen such a striking difference between the works of kindred men.

The difference between the New England and colonial ships which I saw exhibited in the sailing fleets which were gathered in the Gut of Canso and went forth to the Gulf interested me greatly. I studied the shapes, the size, and the seamanship of each without getting much light on the matter. It was then as now easy to see the difference, as specimens of the two varieties of boats lay near each other; it was indeed plain enough when they were sailing miles apart; but I have never been able to state the difference in a way that would enable a builder to profit by the analysis. Taken separately, the forms, ritns, and sides of the hull, the spars and masts, the sails and the men, are indistinguishable, but in the assemblage they are both as diverse as wild and tame beasts of the same species. While on the Labrador shore, I met a Nova Scotia skipper who was also a shipbuilder, and asked him why they did not build their boats after the Cape Ann model. "We do," he said, "we have been doing it for fifty years or more; what we build are exactly like the Gloucester men - until the damned Yankees come again." I came to the conclusion, which may be true, that the difference is due to the way in which the work is done. In the Provinces it was, and I believe is, the custom for the fishermen to build their own vessels alongside of their houses, using their 
spare time in winter for this work. I have often seen the growing ships of perhaps sixty tons in their dooryards half a mile from the water and a hundred feet above its level. When completed, they would be slid down movable ways to the destined place. The New England craft were built in yards by men who did nothing else, who were selected and trained for their work, and who developed the qualities of artists, where only such qualities can be developed, in schools shaped by approved masters. A high-grade ship is in its way the product of a fine art and can only be made where traditions have been insensibly gathered and transmitted by masters.

Our first goal in the St. Lawrence was the Elizabeth Islands, where we were to see the Triassic sandstones of that basin. There we spent a day or two. I recall the problem as to the origin of the rocks in the interesting sections of those shores. There I first felt that problem as a large matter. What most interested me were the sea caves, especially those of Entry Island; into one of these I paddled my boat until almost out of light of day. I was familiar with caverns of the limestone type, such as abound in Kentucky, and had explored them much; those structures are far more varied than any shore caves cut by the waves can be, but those sea caverns of Entry Island had a quality of majesty, a weirdness, I had never dreamed of, perhaps because they combined the mysteries of the deeps, - the under earth and the sea.

From Entry Island we bore away for Bird Rock, that wonderful rookery of the St. Lawrence. We came to it in a fortunate time, when the sea was smooth enough for landing. When so far away that the lone isle was not visible, we noted that it was coming nearer by the steady increase in the number of marine birds - gannets, gulls, and sea-pigeons - which were feeding on the waters, or in flight to and from their nesting-places. The rock itself proved to be a little isle, perhaps two miles long, with its cliffs rising a hundred feet or so above the water, made of protruding horizontal layers of a hard Triassic rock with inter- 
vening beds of shale, which had retreated under the action of frost and rain. These shales made an admirable place for birds to nest, and there they were by myriads, the din of their cries and the vast sense of wingedness which seemed to be in the air making another world of it all.

After rowing about the island to take in the scene, we landed. Two of my companions set to work with their guns, while I undertook to scale the cliffs and gather eggs, easily mounting from shelf to shelf, admiring the vast congregation of sedate, brighteyed mothers perched in every place of vantage. I gained a broad ledge, favored by the large gannets, whose eggs I wanted. It was a rather clay-covered slope, wet with the rain that had just fallen. As I advanced, the gannets would rise unwillingly and whirl about me, screaming their rage as I gathered their eggs in my basket. When I had made a good collection, my feet slipped, and in an instant I was down on my back and gliding towards the edge of the cliff. Neither heels nor fingers could be planted deep enough to stop me, so I had to turn to clutch my fisherman's knife. This brought me up, with nothing to spare in the way of manœuvring ground. Motion arrested, I managed to dig the heels in, and then to cut places for hands so as slowly to work to a place of safety. It must have been nigh half an hour before I was well out of the fix. After the first moment, the danger of going over the precipice was by, but there was another nearly as serious from the attacks of the gannets. These creatures seemed to recognize my helplessness, as they showed by their vigorous attacks on me. I was several times struck by their bills, fortunately not in the face, which I managed to protect by my knife, with which I struck several birds which came at that part of me. At the end of the fight, I had had enough of bird-nesting, which I have always looked upon as a mean business. The gunners had a plenty of birds and a great lot of eggs of the sea-pigeon; they had shot a large male gannet, which seemed dead when thrown into the boat, but revived as we rowed toward our ship, and was disposed to have vengeance for his 
wounds by attacking us. Since the sea was rising and the ship drifting away, we had no time to kill him, so I offered him my foot to bite; he seized it and held so firmly as to pain me through the thick leather until we came aboard.

At this stage of our expedition, having been for some time without fresh meat, we learned to eat sea-fowl; and we found the sea-pigeon excellent eating. Gulls of the several kinds were very palatable, if the precaution was taken to parboil them before they went into the stew-pot. Our skipper had the usual horror of the real sailors for eating sea-fowl; the sight of us when thus engaged would drive him from the table to pace the deck, where he relieved his mind by a volcanic burst of his complicated and marvellous profanity before he came to the cabin again. Though we admired the fellow, - he was indeed a noble man, - after the manner of youths on a lark we were given to tormenting him as well as the cook. One act of meanness comes back to me. After we had been out a month or so, the skipper, who had with disgust disdained as rations gulls and the like, was lucky enough to shoot two black ducks. Over them he gloated, saying that he would eat them all himself, - he was capable of the feat, for his huge carcass had storage like a ship's hold, - while we should make our meal on gulls. As the cooking went on he presided over the galley, as if he saw the possibilities of substitution; he even saw his private victual dished up and put on the table before him. But we had, by threatening the cook with "more wine" and other inflictions, compelled him to make up our mess in a similar dish so that the two looked alike. Then at the last moment we contrived that the skipper should take a look on deck while the dishes were changed. He ate the gulls (and we the ducks) with many remarks on their sorry quality and much abuse of our dirty habit and its inevitable consequences in the way of bad weather and shipwreck. When we were sure that good digestion had sufficiently attended on appetite to make the success complete, we told the skipper the game we had played on him in order to clear off the score 
we owed him for his criticism of our diet and other indignities. He would have slain us, but that he was at heart a very good man, though subject to magnificent rages, which were as often against the order of nature as against man. He was built for hard fighting, to command a fleet in battle, and was out of place with his troublesome crew, and in the uncomfortable situation where he was teased by the men he was supposed to command.

I am glad to say that the process of disciplining Skipper Small seems on the whole to have been skilfully conducted by the crew. We determined that we would promptly and in silence obey every order he gave; we would as far as in us lay disregard his rather rare outbreaks, taking them as we did the weather. Only once did I reprove him for his wondrous profanity, which, as I found out afterward, was famed the seas about. I was on the middle watch with him one bad night when the weather was most vexing. After a long whack at the earth and sky, he turned the torrent on me. To give him a lesson, I woke up the cook and told him to report to the skipper, who was at the wheel. When he asked why I had done this, I told him that the cook was the only person on the craft who by custom was expected to take abuse, for he was the only hired man except the skipper. There is a saying that "those who go down to the sea in schooners see hell"; that there is truth in the adage I can testify. It is evident that even a good high-grade captain can breed a lot of it. I am glad to say that when we had been out a month or so our troubles with Skipper Small were over. He was large of heart and mind; he seemed to like our venturesome humor, and became much interested in what we were about, and we fell quite in love with his superb manliness. We taught him something of natural history, and he in turn taught me a good bit of the sailor's arts, so that at the end of it I could hand, reef, and steer as well, or make and work up observations - except by the methods of "lunar intervals," which he did not know how to use.

From Bird Rock, we made our way towards Anticosti, as 
usual through hard weather. We came upon the island at the east end, where we found a "one-sided harbor," which we were told was safe even in the heaviest easterly gales, to which it lay wide open. We were advised to trust it, for about the time when we were scared to death we should find that it was safe. This we had a quick chance to prove, for we were hardly anchored before the testing storm came. Fortunately we had good ground tackle, three anchors, and chain enough for a ship of three times the size. With them on a good bottom we rode on a mountain of sea until it seemed that the craft must drag under or pull her nose off. I remember wondering that a pint of water poured out at six feet above the deck at the foremast would all be blown over the stern. Just as the situation seemed about as bad as a sea-storm can bring, the sea began to break on a bar outside of us and almost in a moment we were in water so still that we could easily launch a boat and go to the shore a cable's length away. I have seen this beautiful process when a very slight increase in the height of the waves would thus create calm on other occasions, but never before or since when it brought so sudden a reprieve from what seemed to be very imminent danger. 


\section{CHAPTER XI}

\section{ANTICOSTI AND LABRADOR}

THE island of Anticosti proved to be mightily interesting to us, and as we spent the summer along its shores it merits a brief general description. It is about one hundred and twenty miles long, with a maximum width of about forty miles; it has nearly the land area of Connecticut. The whole of the field is composed of strata of the Ordovician and Silurian age, practically altogether of rather thin-bedded limestones or limy shales, which lie in less disturbed altitudes than any equally extensive deposits of that age. They have not indeed yielded perceptibly to compressive strains or been otherwise disturbed by organic action since they were laid down. So far as I have been able to find, there are no dykes on this area, and the trifling local discolorations or departures from horizontality can be explained by slight dips in the sea-bed on which they were formed, or by the solution of the strata by the action of underground waters, in some instances perhaps when the sea was lower than it is at present. The surface of this field is singularly regular in contour; along the south coast it is prevailingly low, none of the cliffs rising above a few feet in height and much of the front being marked by recent ice installations. From this face, the land rises rather gradually at the rate of five to ten feet to the mile to the northward, so that on the north shore the island is continuously bordered by cliffs which have a height of from two to three hundred feet.

The greater part of this surface of Anticosti is covered with a dense, rather low forest of spruces and firs; we saw no trees over sixty feet in height, though we did not succeed in penetrating more than three miles from the shore. Along the south coast there is frequently a broad belt of swamps composed 
mainly of sphagnum, which has evidently displaced and is still destroying the forest-covered area. The whole surface shows a system of low valleys with broad divides. The valleys have evidently been in part filled with drift. This glacial coating is not thick and is chiefly composed of the waste of the subjacent rocks; though I saw some areas where the drift material was mostly from the rocks on the mainland. There were no large boulders such as I had been accustomed to find in New England. As a whole, it was a region of good soil, so that I wondered that it was not peopled. When we saw the place there were not a dozen habitations upon it, these being occupied by the three lighthouse-keepers, one at each end and one at the centre of the south shore, with one or two houses at Ellis Bay near the west end, where dwelt two lonely men who were in a small way trading with the fishermen who resorted to that miserable one-sided harbor. It was the loneliest land I had as yet seen, the most of a wilderness; for though it lay on the path of two hundred years of activity, - by it passed all the movements of French and British to the river St. Lawrence, and thence to the interior of the continent, - it seems never to have been the seat of human endeavors. Save the lighthouses, set to warn the seafarers of its dangerous coast, and the multitudinous wrecks which showed the futility of these warnings, the place was deprived of human interest; it appears, indeed, not to have been tenanted by any tribe of Indians.

The wreckage on the southern shore of Anticosti was astonishing in amount. There were places for miles in length where fire would have run in the heaps from one to the other. This was due to the fact that the number of castaway ships was large, but more to their cargoes of lumber, which supplied a vast quantity of débris. A foggy shore, together with the sudden gales that visited it, made the island a very graveyard for sailing vessels.

While the first impression of Anticosti was forbidding, we learned to love it for the richness of its fossils. Probably no- 
where else in the world is there a like length of coast where the sea has done its work of dissolution on rocks so rich in the remains of ancient life of the Silurian age. Something of the plenty was due to the fact that only one collector had been there before us, and though he had made a good bag, the field was unexhausted, - we nowhere found a mark of his collecting. We had trouble in getting to the shore because of the lack of harbors. The only way was to take a chance of a wetting and pounding by driving our light whale-boat right through the surf and dragging it quickly out of the reach of the breakers. When we had gathered our treasures, we watched for a chance, shoved the boat through the breakers and jumped into it when we had passed their line. This often limited our load and was sometimes a bit risky; but we became fairly skilful in the business: moreover, we were of an age to be reckless. In such a life danger seems to be an insignificant matter.

Only once or twice so far as I can remember were we in serious peril. At the west end of the island we anchored the schooner without sounding to find the goodness of the ground for anchoring, and four of us, including the skipper, went ashore in search for fossils. Toward sundown we suddenly discovered that the ship had dragged her anchor and was drifting off-shore before a strong wind. When this was noticed, the party were scattered along a mile of the cliff-front; so by the time we had all got to the boat, the craft was three miles away and drifting rapidly before the gale that had sprung up. Since there was no one but the cook aboard, we started in chase. In a little while we were in a heavy sea-way and with the night coming on, and our goal, though nearer, growing dimmer and dimmer in the fading light. Our boat took so much water from the splash of the waves that it was all we could do to keep it bailed. To make the matter worse, the cook, who had managed, by the exercise of more energy than he expended in all his other days on the voyage, to get in his anchor, now hoisted sail to work his way back to the shore; our only chance was to guess his tacks, for if we 
ran by him we were pretty surely lost: we could not recover the shore against the heavy chop of sea, and the wide gulf was before us. Luckily, our skipper guessed right - he had the seaman's sense of situation - and we came near enough for his mighty shout to reach the cook; the craft luffed up and after much manœuvring we managed to get aboard, all but the skipper pretty well worn out by the toil at the oars. He was of the tireless kind, and, although sixty years of age, still a man of marvellous endurance. We found that the cook, who was left on watch, had turned in for a sleep, and that when he discovered the craft adrift he had got up his anchor, - a good job for two men, - hoisted jib and mainsail, and set out for the place where he belonged. He did right, but his activity brought us into grave peril.

For six weeks we amassed and stored fossils and what of living things came to hand. The wealth to naturalists was mostly in the ancient life. The shores were so wave-swept that there was little life in the shallow waters; on the land, too, it was scanty. Few birds nested near the shore, and when we tried to penetrate inland, the thick, low scrub woods defeated us. We found one or two nesting-places of the eider ducks, but they were not plenty. We tried for the interior across the bogs. To go with safety it was necessary to have an oar under each arm, so that in case one broke through it would be possible to climb out, for one often went up to the armpits in the cold swamp water. So we gave up the attempt, and the interior remained to us unknown, - no very tempting mystery, however, for looking from the open sea the eye ranged far across it and showed a dull monotonous expanse of northern woods.

There were no traces of deer, caribou, or moose; black bears, however, seemed to be plenty. At one place near the centre of the south shore we found the ruins of a large whale, which had been wrecked like a ship. On this mass of flesh many bears had been feeding, as was shown by their plentiful tracks. None of them were in sight, but we could trail them inland on the paths 
they had broken in their journeys to and fro from their lairs. It was evident that they had fed on the mass of carrion for a long time, and that it was their habit to come out at night and return to their hiding-places in the day. So at evening we brought from the ship, which lay in the offing, such guns as we had, - two fowling-pieces, one a heavy duck gun, and a rifle, and the three of us lay in wait. We knew that our station should be down the wind from the heap of carrion, but the stench there was intolerable; we therefore hid in a clump of beech about sixty yards to windward, trusting that the bears would not be able to note the little smell of man in the air full of other odor. After we had endured mosquitoes for some hours, the long northern twilight began to verge into night and we could hear bears in plenty coming through the bushy upland and swamp ground which lay behind the beach. We soon saw what seemed to be a dozen standing on a low bluff beyond the dead whale, when with the wind full of stench from it, they found suspicion of danger. They were more than a hundred yards away, and in the faint light impossible targets. The only thing to do was to wait; and wait we did, until at last one big fellow braved it and came on for his supper. We agreed to close on him and at the word to stop and fire. My comrades did as planned, but failed to hit because there was no chance to aim in the darkness. Being fairly well trained, I instinctively held until the brute in his surprise lifted up his head, so that running near I gave him an ounce ball and a lot of buckshot; this felled him. Knowing from tradition that the proper thing was to cut his throat, I set about the task, which proved difficult, for the neck seemed to be made of hickory withes. While I was bunglingly about the business, the brute recovered and managed in some way not clear to me to roll me over and fall on top of me, so that I was well rammed down upon the gruesome mass of whale. All the while I was trying to get at his interior with my good knife, but although in the fiction which makes up our tales of hunting this is always easily done, the actual doing is really hard. 
Fortunately, the bear was not attending to me; I doubt, indeed, if he knew what I was about. Though evidently hard hit, he quickly began to scramble into the swamp behind the beach, while I clung to the hair where his tail might have been if it were in Bruin shape to have such. He quickly shook me off and disappeared. We intended to track him down the next day; but, as usual, there was an on-shore gale, and we had to tack off the coast and did not find our way back. It required some days and numerous applications of alcohol to clear away the odor of the whale from my scalp.

In various places I have had contacts with black bears which have taught me that they are very harmless beasts, much less fearsome than the half-wild pigs one is apt to encounter in the woods of our Southern States, and for risk not to be compared to a little goring bull or to many cows when they have had their calves. The grizzlies may be dangerous, but when I have encountered them they have always seemed perfectly willing to share the world with me in a friendly way. They do not scuttle as the black bear does, yet they evidently prefer their own society and seek to withdraw from the presence of man. Except, it may be, for the so-called man-eating tigers, I am inclined to think that well-disposed people might come in contact with any wild beasts with no more danger than they would be exposed to in their own barnyards. To those who are of a mind to approach bears with murder in their hearts, I may give one bit of advice, based on two bits of personal experience; it is, that it is not worth while to hold on to the bear at his hinder end unless you are in search of sensations. In an encounter years after that just related I again tried the experiment, which continued for about a quarter of a mile with much damage to my skin and none to Bruin; he positively would not face about.

Another hunting incident of the Anticosti shore stays in my mind so clearly that it troubles me as I begin to set it down. Hyatt shot from the ship a female seal, of the species common on our shores. The wounded creature was taken on deck and 
lay there dying. Its eyes and its moans showed its agony; it seemed to plead with us for help. I managed to give it the coup de grâce with a bullet through its head, but that face is before me now, though it passed near half a hundred years ago. Since that sad experience I have never killed a beast. Some of my friends esteem this fanciful softness; it does not seem to me so, for if it were fit, I would slay a man and not be troubled about it further than by the regret that the conditions required the action. It is the sudden and brutal assault of the hunter on the unoffending creature which breeds this pain.

Although there were not in all a dozen people on the island, they all curiously stand out in the shadowy field of memory; perhaps because they were so few, and needed the little society we could give them. The families were too far apart-about sixty miles - for them to see each other, and so they lived quite alone. Their situation was worse than usual, for the reason that the supply ship had been wrecked the year before and they had been near two years without a chance to replenish their stores. They had enough of pork, beans, and flour, and of oil for their lamps, but all else they lacked. At the eastern light the wife of the keeper was low with consumption, - in that fearful business with only her husband and a man helper. We proposed to take her to the mainland, but there were no friends or kindred for her to go to. We gave what we had of delicacies, especially white sugar, which she curiously longed for, and also of the novels and other light reading we had brought with us. She was a reading woman of much quality, was greatly delighted with our little gifts and contented with the expectation that she would die the next winter. At the west-end light, the keeper had recently lost his wife, whose grave was near the door. He bore his loss with that grim simplicity which characterizes the seafarers who live in the expectation of bad weather. He seemed to find some comfort in firing his warning gun into the prevailing fog-bank to tell ships that death lay that way. I admired the vigorous way in which he would ram the charge and fire into the shadowy 
mist; and then for an interval of half an hour subside into meditative silence. The process seemed greatly to relieve his sorrowful mind. This good man told me a little tale of the signal gun at the light on Bad Rock. It ran that a few years before the report came from passing ships that the light was not lit. After some months a vessel was sent there to see what it meant. They found the decayed bodies of the keeper and his assistant, the only folk on the isle, lying beside the bursted gun.

The keeper at the central lighthouse was a very interesting fellow. Of nigh half a hundred of his peculiar trade I have known, all worth knowing, he was the most interesting. Like the next in note, a certain Jack Peacock of a later stage in this story, he was London born and bred, but above the working grade; in fact, he was an educated man who had books and had ranged in them and outside of them pretty far. Moreover, after the manner of the better variety of lighthouse-keepers, he was a merry fellow. His first inquiry of me was for news concerning the Franco-Italian-Austrian war of 1859, of which he had known only the beginning. He listened to my account of the campaign attentively, asked keen questions to bring out the value of the famous "Quadrilateral," seemed concerned that Venice had not been given to Italy; all of which showed me that this strangely secluded man had had a history. When I began to tell him of the Civil War in "the States," he at once politely stopped me, saying that for certain reasons he had been interested in the war he had asked me about, but he desired to hear of no others. He turned the conversation to the question of the food for his cows, which he had brought upon the island and needed to provide with some kind of forage, as the hay imported with them a year or so before was nearly gone.

This man's place was an admirable hermitage. There was a large family, a servant or two, and a number of children; a flower and kitchen garden, and over all a grace which told that the man was not of the common lot. Among the children was one, I think a little girl, who he said was a descendant of Thomas 
Jefferson. I meant to have inquired further about the little one, but the chance did not come. I tried to find the history of the fellow from others, but learned nothing. He was neither leaky nor apologetic. He took himself as he was, and in manner bade others do so.

We anchored longest at Ellis Bay, at the west end of the island ; for here there was the most of shelter, and we had sundry interesting experiences with the fishermen who resorted to the place for wood and water and overhauling of their craft. At the end of a month we came to know these people well. They were mostly from Cape Breton; for some reason we were out of the path of the "Americans." Here we noted that two or three of these vessels were following us in a persistent manner, always keeping in sight of our own little craft to the neglect of their business. Through the men on shore we found the meaning of this espionage. It appeared that the story had got about that we were on the track of buried treasure, and they took our divagations as made to throw them off the track. From their point of view the proof of our purpose was clear. We were not fishing, nor trading, nor wrecking, and as we were apparently sane, evidently not seafarers, and under a skipper who knew what he was about, the inference was plain that we were after something of value underground. Our search afoot of long shores showed clearly that we were looking for the signs left by Captain Kidd, who had been there as everywhere. "Logic is logic, that's all I say," was the sum of their considerations. Thus informed as to the state of mind of our companions of many weeks, I went to the skipper of one of the craft and told him what I had heard and what we were about. He evidently disbelieved me, though he was decent about it; so I had him on board and showed him what we were stowing away in the hold: great slabs of limestone and barrels of bits of rock of queer shapes. I tried to make him see what fossils meant to us, but he at the end slipped quietly away, convinced, it was clear, that he had escaped from a floating lunatic asylum. 
At Ellis Bay, we had much contact with the Cape Breton fishing crews. It was a fair shelter against the easterly gales which seemed the standard weather of the region. These folk interested me greatly. As compared with the New England sailors, they were miserably poor in ship's outfit and all else of the unessentials; at heart they were as sound a folk as I have ever found, largely of the Highland Scotch stock, mingled with the French of the Acadian colonies. They were essentially Celts, and many of them spoke only Gaelic. Their innate courtesy, and the fact that they did not "rub into" us the matter of the war between the States - as the Nova-Scotians and the NewBrunswickers were wont to do - helped to the friendliness we soon reached. Our relations began with a Sunday afternoon visit of a crew from a craft anchored near us. I opened to them my bag of tobacco, holding the stuff then popular with students. It did not contain much that was noxious, being composed mainly, as I had found on careful examination, of willow bark and various kinds of aromatic beans. The skipper then produced from his pocket a cloth, which, being unrolled, disclosed the remains of a dudeen with part of the stem about an inch long. After a few whiffs, he passed it to the mate; and thus it went the round of the party Indian-fashion. I did not at once see the meaning of this passage of the pipe, but found that it was the only one left in their ship. I asked them how they liked my brand; they said it was better than moss, which they had been smoking for some months. Now was the time to bring out our store of pipes and navy tobacco. Each was given a pipe and a pound of the rank stuff, - few kings have had a chance to bestow such largess. The dear fellows would not take more than a pound apiece even when pressed to do so. They said that, mixed with moss, it would serve until they were home again.

At Anticosti, and afterward at Mingan on the Labrador shore, I saw for the first time scurvy, that ancient woe of the seas and of the lands as well. Nearly every crew had cases of it, and in 
some of them all of the men were thus affected. They seemed to regard the woe as in the course of nature - to be borne as all else of their hard lives must be borne. We had a lot of antiscorbutics laid in for such use, which proved helpful. I knew little about it, yet I knew that the great need was of a vegetable diet. So I persuaded them to eat the leaves of the Rumex Acetosella, which for a long season are plentiful in all this part of the world. My patients, as I saw them from time to time in the summer, seemed to prosper. They were grateful and offered payment in fish, their only store. In fact, I gained by my medical service, which was kept well within narrow limits, a curious place with these people, who were in need of such help.

From Anticosti we went to the Hudson's Bay Station of Mingan and the neighboring part of Labrador, where we spent a week or so examining the interesting geology of the coast, and watching the Indians, who in considerable numbers had come in for their annual trading. They came out of the wilderness, through its tangle of waterways, with great bundles of furs, and, in exchange, took back their trifling return of guns, ammunition, tea, etc. It was a hard bargaining they had to do with the officers of the factory. I saw, for instance, a razeed flintlock musket, dear at two dollars, bartered for a lot of furs which would certainly have sold for a hundred in Boston. The head factor, who received us very kindly when our official letter was shown, was, as seemed to be the rule in those days in the great company, a Scotchman, as were his helpers. Apparently he had the natives in perfect control, which was kindly but of an inevitable quality. They submitted to him as well-trained children to a father. He spoke their language with fluency, settled their quarrels, cared for their maladies, was a kind of god to them. He made one insistent request of us, - that we should not trade with his people; but if we desired to bargain for anything, he would manage the trade for us. This, he said, was the one rule to which the officer of the company had to subject his guests. It was plain enough that the moderate 
profits of the company depended on keeping out competitors. It was the one instance I have ever seen where a monopoly was altogether defensible, indeed commendable, for these admirably administered trading-posts have been a vast blessing to the savages of the North. They have kept a part of the aborigines from the ruin which has elsewhere overtaken their kind. I have since seen something of the management of the same quality of aborigines in the western part of the United States; the difference between the two systems is all there can be in human affairs.

While we were at Mingan, the then Prince of Wales came there for salmon-fishing in the river of the name. One day our friend the factor said that he would be glad to take me to the place where His Royal Highness was having his sport and present me to him. I asked him if the prince had expressed a wish to see us. Finding that he had not done so, - probably he did not know we were on the planet, - I told our good friend that His Highness was doubtless glad to get out of the tiresome business of presentations, and that I had not the heart to intrude upon his solitude; so I lost the chance to see the youth who is now king.

At Mingan, I found that my reputation as a medical man had preceded me, borne by some of the crews we knew, so I was again in practice. I was glad to help as far as my limited knowledge went, and glad when the training my father had given me from childhood could be of use. Most of the cases were of a simple nature, nearly all from bad food, taking the shape of scurvy, or they were sprains, such as simple bandaging would help. In a small way I helped some of the sufferers, which gave me much pleasure; but one day a married man came to me, saying that his wife was shortly to lie in, and that he bespoke my services. I told him that we had need of going straightway to Gaspé in New Brunswick. My medical practice evidently was getting me into deep water.

At Gaspé, we were, after some three months beyond its 
bounds, again in civilization. There we found a pretty village with stores, and nice families of refined people. One household I remember where there was much music. Above all, we found a chance to buy sugar, which we had lacked for several weeks, having given away our store to the needy people at the Anticosti lighthouse. Since our keg of molasses had been in some way lost, probably washed overboard, as were the most of our provisions at one time or another in our endless threshings by the seas, we had gone without sweetening for a long time. On the general theory that we were hardy fellows well returned to the savage state, we thought that we did not need that grace to our food. But the hunger for it was much worse than that for tobacco, which was also lacking, - even the keg of "nigger head" was empty. It was evident that the hunger was not due to mere habit, but was physiological in its intensity. When we came by sugar we at once consumed about half a pound apiece of it, and for a month we were hungry for it.

The Gaspé district proved an interesting geological field, rich especially in the deposits of the Oriskany period, which abounded in fossils. Nowhere else do the rocks of that time show the seas to have been so thronged with brachiopods. Moreover, here for the first time we found the Paleozoic strata affected by mountain-building stresses. In this field we have the finish of the work done through the ages in building the various mountain-ranges of the Appalachian system. What is left of these final ridges consists of elevations having no great height, nor is the distended terrane of much width. As before noted, the strata on Anticosti, which is nearly in the line of the Notre Dame Mountains, are singularly undisturbed, nor are there any signs of a continuation of this line of dislocations on the Labrador shore. Therefore I came to the conclusion that the great eastern system of North America here found its end.

I made one or two short excursions into the interior of the Gaspé peninsula, seeking to get further information of its struct- 
ure; but the traversable ways were few. At one point not many miles from the ship was an exposure of the Oriskany section, where we obtained a great quantity of fossils. I managed to get a horse and wagon near the place and thus to satisfy the natural greed for quantity. We brought along about a thousand pounds of these treasures.

At Mingan we had heard from some Canadians rumors of a great battle between the Union and Confederate troops near Washington, but it seemed probable that it was no more than rumor; at Gaspé, however, where we arrived early in September, we learned about the battle of Bull Run and saw clearly that the two sections of the country were in the clutch. To me the situation was somewhat less exciting than to the others, for I was sure that my own state would cling to its neutrality, a course of action which I knew had been well determined on and which I individually meant to follow so long as the commonwealth did. But Hyatt, who was a Marylander, felt that the combat was near his doors. The others of the party were likewise impatient of the wilderness. So a month sooner than we had reckoned for the earliest possible start on the return, we tugged our anchor for the last time in the St. Lawrence and set out for home. For the first time in three months the winds favored us, and we had a swift straightaway run through the Northumberland Channel, close to the beautiful shores of Prince Edward Island, thence again through the Strait of Canso, now unpeopled of ships, and thence to Boston to discharge our cargo, some ten tons of fossils and much of pickled specimens. As sailors were not to be had because of the government demand for them on the improvised war fleet, I helped work the ship back to Eastport to settle accounts. I there found Stimpson, who showed his merry humor in the meeting. The tide was low when we laid the craft to the wharf, and it was near dark. Learning of our arrival, he stood above us, asked who we were, and was given other names than our own, with a yarn of our having been left behind in the wilderness. He slid down the stays and 
talked with us some time before he found out the deception. We had so changed, he said, that he could hardly recognize us. We had been through a rough changing experience. I remember that I had worn no hat for two months and found it agreeable to trust for protection to my shock of hair. Our bibulous friend called for something to drink by way of celebration. We then remembered that we had a dozen bottles of old Jamaica rum which had been presented to us at Liverpool, Nova Scotia, and which we intended to give to Skipper Small. Stimpson found it so good that he declared people who would carry such a potable for three months without touching it had no real title to it. Suiting the action to the word, he pocketed two bottles, climbed up the stays, and went away to his den with it; returned to repeat the process, and in six journeys lightened us of the lot. When begged that he would leave at least one bottle he seemed indignant at the suggestion.

On looking back over the experiences of the Labrador expedition, I now see that it was the most profitable journey I have ever made. In after years, Hyatt, who was a yachtsman, said that as we took it, it was an exceedingly dangerous expedition, and that we ought not to have come back at all. It is true the craft was unseaworthy; many times we had to climb under the hull when we had allowed the ship to ground with the falling tide, and calk the seams as best we could. Working along the harborless coast of Anticosti, we several times had a hard fight for our offing when a sudden on-shore gale came up, - and they would come out of a clear sky. But we had a good leader, who, while he was always croaking of dangers to come, was no croaker when they were on us, but a great, strong man, and we ourselves seemed to have no sense of danger.

As all those who have made hard campaigns know, discomfort, such as we became accustomed to, much lessens the love of life. In fact, that fancy for continuous existence is in some measure the product of ease and comfort, while what we call bravery is largely but merely a hard-minded state which suffer- 
ing induces even where men are not clearly conscious that they are in torment.

The most valuable results I had from my three months of adventure in the St. Lawrence was, in the first place, a bettered sense of what the world was in its larger aspects. It is one thing to behold the sea from the shore and quite another to battle with it for your desires, even for your life. From the rude life I had on that journey there came to me a sense of the actuality of the earth which has served me all my days; near to this sense of primeval earth is the sense of primitive or, at least, uncomplicated men, such as I came in contact with among our fellow seafarers. The unchangeableness of the great water extends to those whose lives are shaped by their dealings with it. Among the provincial sailors I was with the companions of Ulysses. They would have mingled well with the crews of the ships that bore the Greeks to Troy, for they had like soulswith the same valor, the same simple faiths and fears. These men taught me much of human nature. I found in them the value of the common man as I probably should have found it nowhere else; for it is so well hidden in our more organized societies that many persons far more discerning than myself fail for all their lives to see the meaning of ordinary life, and so fail to get the most important teaching the world has to give. In a way, I had been prepared for this coming revelation by my contact with the frontier type of man in Kentucky. But at his best, the man of the forests and plains cannot compare with the seaman in the even, rounded culture of human quality. As I had known him in Kentucky, he was a fine fellow of the conquering type. He had beaten his brute and human enemies and subjugated the wilderness; but he had never well learned what it was to follow a leader, to put his life in his chief's hands in a ceaseless war with a mastering deep. I count those brave, stern faces I met in the Gulf of St. Lawrence as my best teachers.

Here let me turn aside for a word concerning the grim aspect 
of our so-called education, which makes it well-nigh impossible for our youth of the higher classes to have any intimate contacts with men who may teach him what is the real nature of his kind. He sees those only who are so formalized by training and the uses of society that they show him a work of art in human shape. He thus has to deal with his fellows in terms which are not those of real human nature, and thereby much of his own is never awakened. He may live through long fairappearing years, yet fail to have the experiences necessary to humanize him fully. I have known many an ignorant sailor or backwoodsman who, because he had been brought into sympathetic contact with the primitive qualities of his kind, was humanely a better educated man than those who pride themselves on their culture. The gravest problem of civilization is in my opinion how we are to teach human quality in a system which tends ever more and more to hide it.

As for the scientific results of the Anticosti expedition, they were to me of much and enduring value. In the first place, I saw then - and the impression has stayed with me - the great interest which relates to the contact of sea and land. Something of this I had gained in tramping the shores of Massachusetts, but this journey gave me a sense of its range and scope I could not otherwise have gained. You do not gain this by mere travel; you may sail along thousands of miles of shore without winning more than faint impressions of what is going on there, but if you have to fight with the surf and in-shore currents, study harborages for their value as shelters, and learn by experience what a lee shore means, you become curiously well acquainted with the facts - you feel and do not merely see them. With this personal sense of the shores came the perception that each feature - not only the details of form, but the large elements of the geography as well - not only had a history, but was in some way a record of it. I believe that this sense of the chronicle in things, though in some measure established in my mind as a thesis, first came to me as a 
real feature during this journey. I remember being much interested in the problem of how the island of Anticosti, with its perfectly undisturbed strata, could have obtained its salience. The same question was asked me by the other islands and capes of the Gulf district. I came then to the hypothesis that the whole region had been recently much higher than at present, and had remained so long enough for broad valleys to be formed, and that these islands were the higher part of the divides between them. I recall trying from the charts to construct a plan of the ancient drainage, by extending the main St. Lawrence valley out to the sea, platting in tributary vales. In this scheme the peculiar channel of the Strait of Canso puzzled me much; I had to account for it, as for certain other features which did not accord with the hypothesis, by the supposition that glacial action had done much to change the shape of the stream topography formed before the last ice came. These speculations, fairly true, show that for a youth of twenty, in that state of geology, I reacted well on the things which came before me.

I found the fossils of Anticosti very fascinating; some of them showed themselves at a glance to be closely related to those of the Cincinnati horizon with which I was familiar, yet there were many forms entirely new to me, and some with which I was familiar had a changed aspect. Those gigantic fossil sponges found in the deposits at about the level of the vitric shale at Brating Point, forming fluted columns sometimes eight inches in diameter and six or eight feet in length, puzzled me much. Hyatt, even then concerned with the nautiloid cephalopods, judged them to be akin to the lower known forms of this group, though he afterwards abandoned that view, even before James Hall determined their affinities. These architecturally noble structures were then deemed peculiar to this field; but about fifteen years thereafter I found them in another specific form of somewhat lesser size in Nelson County, Kentucky, at about the same horizon. Certain of the peculiarities of the Anticosti species of fossils as compared with those 
found in the southern part of the Ohio valley attracted my attention. Thus at a glance it was evident that the northern forms of the lynx was far less varied than those of Kentucky. The same decrease in local variation appeared in all the other species occurring in the northern locality as I in memory compared them with the more southern kindred. I still think that this difference was well observed, and that it was due to the colder climate of the more boreal station. I have since noted in very many species in diverse groups, as for instance in the Virginia oyster, that the range in the variation of the form diminishes as the temperature of the water in which they dwell becomes lower. Something of the same nature is observable in many species of plants. It is likely to prove somewhat general in organic forms.

Probably the largest profit I found in the voyage about the shores of the St. Lawrence, came to me from the discomfort and the danger there encountered. Our conditions were in both these regards rather worse than those of the common fisherman; for in addition to the labor and trials of those who go down to the sea for fish, we had to cleave to lee shores and to fight our way through the surf to study the land. It was very hard work in fairly hard danger. We did not see it at the time, but I can recall that it made a curiously strong impression on our skipper and on the sailors we met. We had among them the reputation of being dare-devils. All this was well for us, for the best you can do for a boy is to expose him to hardships which bring him nigh to death. Being by two or three years the youngest of the party, and moreover rather delicate, I wonder that I did not suffer illness, through exposure where we were not dry for weeks at a time, when we were badly and irregularly fed, scaly and bruised all over from our hard knocks, with our legs from the knees down blue from the whacks in tugging at the old-fashioned windlass to get up the anchor, or knocked about in our surf work. Moreover, I was sea-sick in any storm, though I managed to keep up sailor's duty; I did 
not lose a watch. That this was trying, a little incident well shows. At the end of a hard "trick," I started for my bunk, but in my weariness sat on the edge of a boat which was lashed on deck and partly filled by the boarding seas; I slipped into the water and was found there by the skipper sound asleep and was none the worse for it. There were weeks at a time when we worked as men do who are fighting for life; the curious thing is we did not notice it until long afterward. 


\section{CHAPTER XII}

\section{THE FIRST YEAR OF THE WAR}

WhEN we returned to Cambridge we encountered a curious sense of change which had taken place in our three months of absence. When we left the feeling was general that the outbreak of the South was a mere insurrection which would be quieted by some small show of power on the part of the North, or, if it did not quickly subside, that there would be a spontaneous movement by the slaves for freedom, which would put an end to the revolt by giving their masters business enough to attend to at home. I knew better, for I had a nearer sense of the motives of the Southern people and of the state of mind of the slaves; though I did not think that the rebellion would develop power so rapidly, I fully expected the war to last for many years. To my friends in Cambridge the episode of Bull Run, and the evidence that the Confederates were indeed in earnest, was a surprise; it had brought out the dour element of the NewEnglander to such an extent that the look of the people on the street had visibly changed.

I found my master Agassiz greatly disturbed; all along he had taken the war as an end to his hopes. I recall how in that miserable time of the bombardment of Sumter, when we Southerners hung about the newspaper and telegraph offices all night watching for news, I found him in the gray dawn walking in Divinity Avenue weeping, almost raving in his misery. I remember how he cried, "They will Mexicanize the country," and my saying to him that we were a people who would do a lot of fighting, but come out of it all in the English way, with order and decency in the end. The fact that in a few weeks after Sumter the North settled down to the business of preparation gave Agassiz courage; but with the certainty of a long grap- 
ple which was on us in September, 1861, he again began to lose heart. The fact is, he did not see, he could not be expected to understand, the curious nature of our people. He could not conceive that the country was undergoing a process of growth of which those years of misery were but the pains.

After the collections made on the Anticosti expedition had been properly stored in the Museum I went to Kentucky for a look over the situation, visiting Frankfort and Lexington for a talk with my friends of both sides. I found that the plan of the Union men of my stripe, those who held for State Rights under the Federal bond, had been skilfully carried out, and that the commonwealth seemed tolerably sure of its neutral station for some months to come. There were serious features in the situation. The people were evidently in a process of division, in which the majority was drifting toward what was called the Union side, while a large minority, - we guessed at about twofifths, - led by the example of Breckinridge, Buckner, Roger Hanson, and a host of the able, high-placed men who had already entered the Confederate army, were leaning more and more toward rebellion. The governor was at heart in sympathy with the seceding states, but in their interest he held to his place. So far as he could, he tried to do his duty at once by his office and the law. The Unionists now controlled the Legislature in both houses by an overwhelming majority. All the measures looking toward mutual coöperation with the Union forces were promptly vetoed and as promptly passed over the vetoes. When they thus became laws, the governor would provide for their execution, or rather non-execution, by putting them into the hands of Confederate sympathizers. It was a well-played game on both sides, but our side stood to win; we had, indeed, the cards in hand that ensured success; barring folly, the end was certain.

My admiration for the way in which the anti-Secessionists of Kentucky manœuvred to prevent a sympathetic stampede of the commonwealth into the Confederacy, then great, has grown with time and the wider knowledge of the ways of men. 
The man I trusted most for guidance, my neighbor and near friend, John W. Finnell, was then adjutant-general of the commonwealth and effectively in lead of the manœuvring. He had remarkable ability in judging and guiding action, and to him more than to any other one among a host of real statesmen who have shaped the destinies of the country, the preservation of Kentucky to the Union, and the eventual success of the North, was due. I shall have more to say of him hereafter. I need here but note the state of affairs as they were in the autumn of 1861, as set before me by Finnell and by an old family friend, also one of the masters of fate, James F. Robinson, of whom there is also much to be told further on in my story.

The plan of those who at this time had control of the Legislature of Kentucky, and thus of its destiny, was, in brief, that of men who knew how to wait. They recognized that the secession of Virginia, Tennessee, and probably of North Carolina, was due to an excess of sympathetic enthusiasm, and that at all costs, even to the point of seeming cowardice, they must enforce waiting. At this stage it was evident that the attitude of neutrality, already little more than a farce, could not be maintained for many months to come. It was believed that the Confederate government would soon, and from their point of view, very properly, try to force action favorable to their cause by an invasion of the commonwealth. The aim of our leaders was to force such action under conditions which would lead the wavering people to regard the invaders as enemies. It was also seen to be good policy to allow the sympathizers with the rebellion to betake themselves to the Secession standards in the several recruiting camps which had been established in Tennessee and Virginia for their reception. Buckner, and many other officers of the state guard, a force organized to preserve the neutral position of Kentucky, had already gone to those camps, taking with them a large part of that force. This exodus, while it grimly lessened the fighting power of the commonwealth, made the end surer. 
I recall seeing in this time the parties of recruits going their several ways to their appointed places in the opposing armies, the Unionists to Camp Dick Robinson or other recruiting points in the state, and the Confederates to places beyond its lines, where the most of them were to leave their bones. In one instance I saw groups of these parting men pass on the way with salute and courtesy; we had got by the first fury of the debate, that of hot words, and were making ready for the tussle which both sides knew would be hard. It was evident that the Confederacy was to have what seemed to be - and indeed was the flower of our youth and manhood; nearly all the young men who by their qualities seemed to be the natural leaders of their generation, cast in their lot with the South. There remained a strong body of the middle-aged and the old, the abler of the generations that were passing and the youths of the plainer sort, more numerous than we then judged them to be, whose reason discounted their sympathies; for it is to be confessed that all of us were in a sense sympathizers with the South in our hearts - it was our heads that kept us in the Union. In that time it was the presumption, the fatal presumption, of Breckinridge and his advisers that this social sympathy would force all of us who were well-born to cast aside our rational part and to join with them. Thus while I was known as a Unionist of the States'Rights group, I found, from a friend who had gone South and was captured in 1862, that a place had been long kept for me on the staff of a certain Confederate general, and there was surprise that I had not turned up there. At the moment, this did not seem to me strange, though it gave me a peculiar kind of grief to think that I was parted from my friends. Nearly all those friends of my youth were then under the Southern flag, and I felt curiously lonely in being parted from them. So far as I can remember of the some score with whom I had been in intimate association only Foley, John Mason Brown, and James Jackson were on the Union side.

My survey of the situation in Kentucky led me to feel that I 
had better "stick it out" in Cambridge, and finish my work for the degree, or rather for the training I was seeking. There evidently would be time enough for the small part I was likely to play in the great contest. My ambition extended no farther than to a place in the ranks of the troops of my own commonwealth and a small share in the task of keeping States' Rights safe in the only place for their safety - the Federal Union. It was urged on me that I should go into the regular forces of the government, but this meant professional soldiery, for which I had no inclination whatever. The first plan harmonized best with my philosophy of life, which, though it may have been rather callow, was mightily helpful to me in that soultrying time, so I returned to Cambridge and set about my task of finishing up the work on which I was engaged.

It is here well to say that in my spare time from 1859 to 1862 I had done what I could to fit myself for the duties of a soldier. As before noted, I had been brought up at a military post and from before memory begins was familiar with the life. I knew, as a lad knows men, about all the officers of the regular army who came to prominence on either side, - Lee, Grant, Sheridan, Albert Sydney Johnston, and many others of the great list. All the usages and customs of military life were tolerably familiar to me, as was also the shape of arms. In my childhood I had been in an infantile way war-mad - and had recovered from it. When I went to Harvard, I felt it proper to make a nearer, man's acquaintance with military duty; so I joined a "drill club," and became familiar with the elements of infantry tactics; I worked over Hardee, so that I could manage a battalion at short notice, and I read Jomini, and found him vastly interesting. Most important of all was a training which lasted for three years at Fort Independence in Boston Harbor. At this post was an intimate friend, then a lieutenant of artillery, who had married a cousin of mine. He was in command of a company and under a Major Arnold, an able officer who had been in the Mexican War. At this time, as during a 
part of the three years in question, General Rodman was experimenting with great guns at that station. I used to go to the fort on Friday afternoons and to bide there through Saturday, working as a soldier or as a clerk, doing the diverse duties, including those of inspection and reports. In this way, by giving perhaps one hundred days to the task, I became tolerably well-instructed in the principles and practice of artillery work. There was much exercise in sighting guns and a fair amount in target practice, where I was allowed to "lay" the larger pieces, criticising the pointing of the men before they were fired, so that with my previous practice with the rifle, I could count myself fairly well-trained in the art of the gunner. All this left me, of course, below the station of the professional soldier, but it made me distinctly more competent than the novice or even most of the young men who as volunteers went into the business.

I was particularly interested in General Rodman's experiments on the pressure of gunpowder when fired. For this inquiry he had bored cylinders in the walls of his pieces, as I remember them, up to ten inches in diameter; each of these cylinders was fitted with a piston having a ridge-shaped head, which rested on a plate of soft composition metal. When the charge was fired, these cylinder-heads indented the plates in proportion to the pressure which they had received. I was allowed to take some share in these testings, which were most carefully done, and obtained through this chance a sense of accurate methods which helped me greatly. In each series of tests the gun was fired with increasing charges until it was burst; then the fragments were studied to determine the character of the metal and the seat of the rupture. So, too, after each discharge the interior of the bore was examined with the speculum, to ascertain the process of developing the incipient cracks which form long before the body of the metal gives way. The experience thus gained I found very useful in the study of dredging machinery, such as forty years afterwards I had to deal with in Montana. Rodman and his helpers had the 
strength-giving quality of the military engineers of that day; I can say of them as well that they knew how to interpret nature.

My friend, then Lieutenant Thompson, was some ten years my senior, and we were very near to one another. He was a collateral of Benjamin Thompson, and had a curious likeness to him in face and character. He was an able man in his profession, a hard disciplinarian, iron-willed, though of a very mild manner. He was for the most of the time really commandant of the fort, which, as I recall, had a garrison of two companies, composed of men of a more mutinous quality than I had been accustomed to see in the old army. His favorite punishment was "stringing up by the thumbs," and the calm, philosophic way in which he would walk around the wights thus suspended, commenting the while on their state of torment, extorted my admiration, and showed me more clearly than I had before seen how hard are the ways by which the common brutal man is broken to the soldier's trade. He was never cruel in this work, merely obdurately effective. I have never seen a higher order of care than he devoted to the inspection of his men and all that related to their well-being.

In 1862 I chanced to serve for a time under Thompson, then a major, in charge of an artillery camp of a dozen batteries. They were a bad lot, not yet well broken to harness. The way in which he battered them into shape fills me with admiration to this day. He had a capacity for objurgation which was in a way unique; unlike the one other great master of the infernal art, he made no use of the accepted classic phrases, but had invented what may be called an anecdotical method altogether his own, in which the blister, constructed in short descriptive phrases, was calculated to remove the hide of the toughest. His applications were punctuated by the grimmest laugh I have ever heard, a strange hollow cackle with no trace of mirth in it. I said to a big limberer of a battery I knew, who had just been excoriated, "Well, _ , what do you think of that?" Pale- 
faced and shrunken as by fear, he said tremblingly, "That is Satan; that is Satan." It was at least the best semblance of him I have ever seen. At this time I served for a period with Major Thompson in inspecting fortifications. One day we examined a considerable set of works commanded by a volunteer colonel. In his ignorance of his duty this officer permitted the inspection to be made in great detail, without having required of us any evidence of our authority. He had no proof save our uniforms as to our right to make it; for all the fellow knew, we might have been Confederate spies - and much such work was done by chaps who had a mind to take the risk. By the bland look of his face and his soft voice, I saw that my chief took in the situation, and meant that it should go hard with the unhappy colonel. We had given him the parting salute and were riding away before it got through his dull wits that he had made a fool of himself. When we were perhaps a hundred yards away, he shouted to us to halt. Major Thompson affected not to hear him and it was not my part to interfere. The troubled colonel then called on his guard to fire on us. As they missed, - I doubt if they intended to hit, - we went on at a brisker pace; then more shots from other guards kicked up the dust about us. By this time we were on the run and nearing an outpost where a dozen men, taking in the situation, were making ready. I was now riding by him, when I too took in the situation and said that I did not mean to be shot to gratify his fury and reined up, as he did shortly with a word of reproach for my not helping him to "break" that pretence of a soldier. He left it to me to take the orders back to the commander of the works.

Major Thompson had won his promotion at Malvern Hill, where with his battery he had broken the Confederate assault. I was told by one of his subordinates that as the charge came on supported by a heavy artillery fire, Thompson was standing by the side of a brick building watching the advance with his field-glasses and conning the fire of his gunners. A shell shook the building and in the dust and smoke he was lost to view; 
when the cloud cleared away his feet were where they had been before; he had just finished wiping the dust from the lenses and was lifting the glasses to look again. I asked him as to the effect of double canister at close quarters. He said: "It seemed as if the air was full of old clothes." This man has ever been to me the true type of the soldier. 


\section{CHAPTER XIII}

\section{MY LAST YEAR AT HARVARD}

THus far, I have said little of my life as a closet student, so that the effect of this writing may be to give the impression that my days were spent in divagations. I find no students in this day who work at anything like the rate the better part of Agassiz's following did in that time. It was my custom to get to my work by eight in the morning, and to keep at it until one o'clock; we then had dinner, and expected to be again at our desks by half-past two, working there usually until dark, or at least until five o'clock. We then went to the gymnasium or had boxing-matches, as we fancied, for half an hour. At six we supped, and then got to work in our rooms. We managed to get about seventy hours a week of pretty solid business. Once a week, or oftener, we had our club-meetings, and after them - they usually ended about midnight - we had dance-music from an old piano in our common room and a Virginia reel with shouts to wake the dead. These midnight uproars sometimes brought us near to trouble. There was no proctor in our building, for we ranked as graduates, but across the way, in Divinity Hall, proctored Mr. Sibley, the Librarian of the College, the most proper and irascible of good fellows. He often reported us for disorder, but fortunately there dwelt in a cottage much nearer a dear old gentleman, a Mr. Charles Sanders, who happily slept marvellously well and who, moreover, had not forgotten what it was to be a boy. He was always ready to testify that we were the best-behaved lot of youngsters that ever were in college. As the College had expectations from the old man, in part realized by the bequest which built the theatre, his evidence had full weight. Besides, we managed to work up the theory that Sibley was subjected to nightmares combined with somnam- 
bulism, and that the rackets he heard were really of his own making and by delusion referred to his neighbors.

Our routine work in our several subjects consisted primarily in comparing a succession of species so as to obtain a general idea of the animal kingdom; this comparison was applied first to their general morphology, as seen from the outside, and then by dissection to their internal parts. As a guide to this we took Cuvier's "Le Règne Animal," the idea being to obtain something like the general understanding of that master as to the range of forms. In this task I made a tolerably near acquaintance with perhaps two hundred species, and compared them, as far as convenient, with their kindred as shown by specimen plates and descriptions. This work was necessarily crude, but it was enlarging, because we followed the changes of shape and structure, and came to have a general understanding of animals which students rarely attain in the modern method of intense study. As I was intending to ask for my degree in geology it was my further task to trace back the history of the living groups through the geological successions, and to acquire a knowledge as to the several horizons as well as the distribution of their strata over the earth's surface. I had also to get up the history of geology, using D'Archiac's work as a foundation and to trace out the development of the several important geological hypotheses, and also to acquaint myself with mineralogy and crystallography, using Brandont's work as a basis, and helping myself from the good teaching of Professor J. P. Cooke.

Besides the general knowledge of our subjects which Agassiz required, we were expected to obtain a rather specialized acquaintance with some considerable group of animals. The group assigned to me was the Brachiopoda, which had interested me from childhood - almost from infancy. This order I came in the course of three years to know pretty well. At the end of my task I had personally examined specimens of more than three fourths of the described species, and had read practically all the literature on the subject. I believe that I could 
have given a fair account of at least ninety-five per cent of the species which had been described, and tabulated the synonymy reasonably well. I dissected representations of recent species, and did like work with some twenty species of fossil forms, by slicing specimens on the lathe and treating with acids.

My thesis was concerning the Brachiopoda in general, with a special study of the bilaterality of the group. It was an argument against the Darwinian hypothesis based on the development of the second series, in which I endeavored in the first place to show that several of the series develop at great organic cost and in a well-ordered succession of changes, features which not only cannot have any utility, but which are apparently disadvantageous, as for instance the proboscis - like extensions of the margins of the shells in Producta, the exogenation of the mixed folds in Orthis biloba, the ridges and knees of Leptina, etc. Then I discussed the development of the lateral symmetry particularly in the spirifers and Rhynchonella, endeavoring to show that the lateral balance of the calcified furrows of the so-called arms could not have been brought about by selection, but must have been the result of some other symmetry-determining influence. Incidentally, I tried to prove that the longitudinal axis of the brachiopod did not lie in the plane of function of the valves, but extended from the centre of one to the centre of the other, at right angles to both. I have not seen this thesis since it was delivered to the examiners, but as I recall it, it was a worthy piece of work, creditable to the teaching I had received. It contained some points which pleased Agassiz greatly, especially the study of symmetries. He did not like my treatment of the Darwinian hypothesis, for I did not scout it, but claimed that, while its general value was uncertain, it clearly could not account for a considerable array of facts, - natural selection in a word could not explain the development of the group; there was a suspicion of heresy in the way the matter was treated.

That work such as I did in the Museum could be done at all, 
was due to the marvellously swift way in which Agassiz accumulated collections and books in the establishment. He was blamed for his extravagance in these purchases, but it was a wise policy. He bought the cabinets or libraries of several workers, of which the most important were those of D. S. Brown. His own library was rich, and there were many valuable things in the College Library and that of the Boston Society of Natural History. Brown's cabinet and collections brought from Campeche by Lyell and others gave me larger resources to draw upon than most workers have had, and, what was most important, I used them as freely as I could have done had they been my own. In fact, I unpacked and arranged nearly all the fossils which came to the Museum while I was rated as a student. I was in effect curator of these stores. So, too, with books, - we rummaged them freely, and thereby got the habit of using them as helpers.

In our evenings it was a habit once a week to meet there together, to take up some book outside of our main pursuit. One would read and two take notes; at the next meeting, we drew straws to determine who should give a summary of the last week's reading. If in the opinion of the majority his task was not well done, the delinquent was subject to a curious fine, in that he was required to look up some subject in the library and report upon it. In this way, we read in the course of three years several important works. Of these I recall J. S. Mill's "Logic," his "Political Economy," and Lyell's "Principles of Geology." Of amusement we had not much, save the one hour of frolic before bed at midnight. Now and then we went to hear music. When I came to Cambridge I had a passion for the theatre; my father, being a wise man, told me to go as often as I desired to, with the result that I went about every night for a month, and afterward rarely, almost never, except to see one of four actors, - Edwin Booth, E. L. Davenport, Salvini, and Charlotte Cushman. Except with such actors on the stage, the theatres bored me insufferably then and ever since. 
A few years ago I was taken by a friend to a rather famous play, but had to leave in the middle of the performance and wait in the railway station for an hour for the going of my train. To operas I went for the music, generally choosing a place where I could comfortably avoid seeing the actors.

It was our custom in going to the theatre or opera to make up a gang of a dozen or more, march to the Boston Theatre, and go to the uppermost part of the gallery, which was then called in students' phrase "Olympus." Sometimes we had trouble with its denizens, for the ancient hatred between town and gown had not been forgotten. Once or twice there was fighting, but several of our side were good at it, so we were never driven out. After the performance, which on theatre nights cost twenty-five cents, and on those of opera fifty, we had a bit of supper at Brigham's oyster-shop, and then tramped home singing. Only once do I recall any trouble with the police, and that was not provoked by us. A silly "peeler" ordered us to stop singing and made a vain effort to enforce his order, a performance which led to his considerable discomfort.

Once or twice a year our gang used to go fishing. A schooner was chartered, and we sailed to some ground outside the Harbor, caught what fish happened on our hooks, and had them cooked on the shore, sometimes at some inn and sometimes in a rough way by ourselves. I distinctly recall only the last of these rather tedious outings, in the spring of 1861, and that because of a fatiguing incident. Our party was large, some fifty or more. When we rendezvoused at the wharf where the schooner lay, the tide was low and the craft aground with two hours to wait for it to float. As it was about two o'clock in the night and very chill, it was proposed that we march through the streets to keep warm, and for the fun of it we agreed to answer no questions the police would put to us, but to keep perfectly mum, even if we had to tussle with them to do it without a word. Setting out, we marched in good order; we had been in a drill club for two years or so, so we marched well. 
Presently we were accosted, but without seeming to hear the question. Soon there were a dozen of the guardians marching beside us full of wonder and of doubt what to do. We were in no wise disturbing the peace; their only evident part, therefore, was to join the procession. At the end of the five-mile tramp we came back to the ship to find it afloat. Our spokesman then thanked the officers for their services as escort, and hoped they felt better for the much-needed exercise we had afforded them.

There was very little "larking" among our lot; practical jokes were voted stupid, and only one such stays by me. There was a half-crazy impostor who used to bother us with his speeches and his solicitations to buy a copy of his poem on Bunker Hill. You had to buy the poem, for the alternative was to kill him and leave town. Threats, duckings, moderate drubbings had no effect whatever. Finally, we had our revenge by persuading the fellow that there was to be a great meeting after midnight in front of the old State House in Boston to hear him speak. A small, silent audience was provided, and also a ladder; he was taken to the place in a carriage and swiftly urged up the ladder and placed in the balcony about twenty feet from the ground. The multitude then departed, taking the ladder with them. It was so quickly done that there were no police to interfere. Their wonder was great when they found the wight in his rostrum bawling to an imaginary throng. Save in one instance, among the students with whom I had any intimate association in that day there was no vice. There were several of whom I became by one chance and another caretaker who were rakehells, but so far as I recall, they were all College or Law School men. Our general decency was, I think, due in large measure to the fact that we worked hard and that the fellows who did not do so were quickly elided. Something may be attributed to the fact that we were not watched by proctors or forced to do anything. We thus came to rule ourselves and to look after one another; it was a little brotherhood well knit together.

I had much diversion from a small collection of living animals 
which I gathered in a fenced area of about half an acre behind our club-house: a hedgehog, a porcupine, a weasel, turtles, and, above all, serpents, - all the local species, including rattlesnakes from Mount Tom, and a few foreign forms. One notable accession was a boa-constrictor of small size, about ten feet long. This collection gave me great pleasure, but some care and expense. It was much resorted to by visitors, being unhappily the only open-air free show of animals ever existing about Boston. On Sunday afternoons there would be a throng of interested people to see the little exhibition. It found an odd finish through the horror inspired by the serpents. A rumor got out that a python thirty feet in length had escaped from the collection and was winding up and down of nights, seeking whom it should devour. Fancy located it for a time under a cellarless schoolhouse in Somerville, a neighboring town. I was advised by the chief of police that I had better allay the excitement by making an end of my amusement. So the harmless creatures went into safe-keeping in alcohol.

That there was no danger from the escape of the captives is shown by the fact that but one of them got out of bounds in the two years they were kept. One night when I made the round of the cages, a hedgehog was missing. There was a tracking snow on the ground; so a dozen of us started with lanterns to run it down, and at the end of our run we recaptured it. Years afterward, my colleague the venerated Professor Henry W. Torrey used often to tell me of his sore experience with a gang of ruffians who at midnight came over his back fence and with torches searched his premises through and went on. It was evidently a painful episode in his quiet academic life, one that showed the latent iniquity of human society; the memory of it stayed by him until his death some thirty years later. The profit I have had from my little experiments with captive animals, and a lifelong close connection with our barnyard creatures, has shown me that one cannot be a real biologist without such opportunities. It is possible for a student to gain a vast amount 
of detailed knowledge of forms by closet methods, but this learning may and generally does leave out the essence of the creatures it relates to, which is the soul that has shaped and been shaped by their structure. The naturalist needs both of these modes of contact with his data, but if it be but one it had best be that which does not relate to anatomical features alone. Thus in the case of Alfred Russel Wallace, who seems never to have dissected anything, to have indeed a horror of such work, he made himself a naturalist of most excellent quality, indeed of rare discernment, by attending solely to the external shapes and habits of living things.

It may interest some of my readers to know something of my expenditures during my undergraduate days; this story may be shortly told. When I came to Cambridge I was allowed from my family out of money coming from my grandfather, Richard Southgate, the excessively large sum of fifteen hundred dollars a year; equivalent on the basis of the existing college ideals to about five thousand dollars. I managed to get rid of this money each year without what would be called extravagance, yet with no fit care to the budget. Some of it went for books, much for subscriptions for various, not unreasonable but unnecessary, associated purposes of my mates. Some of it in loans to my mates which were never repaid, mainly because the coming on of the war broke up their plans. I don't recall having wasted any part of my substance, but I had the notion that it did not befit a gentleman to be very careful of his pocket. When the war came on I had to take in sail, for the sources of means of my family were reduced and in danger of being cut off altogether. Though I had a few thousand dollars in banks in Boston and Cambridge, it seemed fit to keep this fund as a protection for those who would be helpless in case Kentucky should be swept into the ruin the South in my opinion had to face. In the last year of my residence I spent less than one hundred and fifty dollars, earned my room-rent and tuition by work in the Museum, and wore my old clothes. The club table in Zoölogical 
Hall was abandoned; there were too few left to keep it up. For a while we followed the plan of getting a dinner at a boarding-house kept by a motherly old woman, a Miss McGee. It stood on the site now occupied by St. John's Chapel on Brattle Street. To it most of Agassiz's pupils resorted, as did some of his assistants.

I think it was at this time, in the autumn of 1861 , that for a while I took my dinner at the Brattle House, then a forlorn kind of hotel where a few students went; afterward it was the University Press; like many another edifice of that time, it has vanished. At my table there was only one other person, a shy fellow of about my age with whom I tried in vain to make effective acquaintance. I took a fancy to him as I thought he did to me, but his diffidence was a bar. I learned that his name was Green, and that he came from New York way. I was piqued by my unaccustomed failure to get on with a chap I fancied, but I soon forgot all about him. Twenty years after when at a club dinner I was holding forth on the evils of self-consciousness, I described my experience with Green, presenting him as a gangling, red-headed, freckle-faced, goggle-eyed chap, who blushed whenever he was spoken to, who had probably been shamed out of activities through his preposterous sense of himself. Then John Fiske, who had been leaning across the table evidently admiring the droll picture of the vaunted Green, said, "Why, that was me!" Then it came out, what I had not before known, that for family reasons he had changed his name, and with it, it seemed, his very nature; for I could not find save in his intelligence a trace of Green in Fiske. I saw many wonderful changes in my friends who went into the Civil War, swiftly evolved in the intense environment to which they were subjected, but none equal to that which had transmuted the soft and callow youth to my solid and permanently substantial friend.

After a time, we Southerners, half a dozen in number, found that we could save still further by cooking all our meals in our rooms, and for some months we followed this plan. The result 
was that we were underfed, and suffered from it; as is shown by the fact that we got into the habit of taking a whiskey toddy before going to bed. It was, indeed, the only time in my life that I have felt the need of that whip. The hardest kind of work in the open air, when bacon and beans and the like were at hand, has never led me to feel the need of alcohol. This period of imperfect nutrition, combined with arduous study and with the exhaustion due to the Anticosti expedition, which came just before it, brought me lower in health than I had been since my childhood. I suffered very severely from indigestion, especially from the effect of the malady on the heart, in the shape of intermissions and irregularities, which often made it necessary for me to sit the night out in a chair; all this coming at a time of much worry on account of the war and because of my preparation for the examination for my degree. Except for an essential toughness which has stood me in good stead, I should certainly have broken my health in a permanent way by this combination of scanty diet and hard labor.

I had not much help from Agassiz in these last months of my preparation. He had admitted me to candidacy after going over with me what I had done, and he stated that he expected me to pass a good examination. He gave me an odd bit of warning, which was that Benjamin Peirce would probably subject me to a searching test, for the reason that they had recently once again quarrelled, Peirce questioning the character of the instruction which Agassiz gave his students as lacking in thoroughness; the truth being that Agassiz was the worst instructor I have ever known, but in diverse ways the greatest educator. These two able men were off and on the nearest of friends and the bitterest of foes; just then they were at enmity; so I had to look out for myself, for I was likely to be seized on as a horrid example of Agassiz's looseness of method of teaching. All I did to prepare for defence was to look up with care the little of geology which had at that time been subjected to mathematical treatment. I reckoned that the burthen of the 
trial, if it came, would have to be on Elie de Beaumont's "Système des Montagnes," a work I had already read attentively and abstracted, so that I knew it fairly well; but I went over it again and therefore I knew it in a way that would have made it possible to reproduce it almost verbatim; given to much training in committing to memory I could do a work of that kind passing well.

It is to be noted that in the four years I was with Agassiz, I had no kind of examination, save what he gave when he questioned and in some measure tested my training. For the rest there was nothing but criticisms of my work and discussions, endless discussions. These gave him all he cared to have as to the progress I had made. Now and then he questioned me hard. I recall by chance how he tested my knowledge of a book which I had been using in the identification of some mollusca; he sought to find how far I had compassed the work or had merely used it in a perfunctory way. He had helped me to know the difference between knowledge and ignorance and to measure my accomplishments as I went along without any kind of routine tests.

Because I needed to be away to my own parts of the country, the examinations were given me at an earlier date than was then the custom, I believe in May. My thesis was delivered a month earlier and approved by Jeffries Wyman as sufficient. This was told me before the time of the formal examination. Since this inquiry was interesting, as a type of the method used at that time in testing candidates, I will give an account of it. I had made no formal preparation for the questioning I was to meet, except to go to the shore and live out of doors for some days, putting the whole matter out of my mind, endeavoring to get into the admirable state of the little darkey who, when reproved for not caring, answered, "I doan keer, an' I doan keer if I doan keer"; with the result that when I faced my judges, it was with a sense of rather amused indifference, which I have experienced in the presence of other forms of 
danger. It was indeed an august bench, for besides Agassiz there were Wyman, Asa Gray, Peirce, Cooke, Lovering, and Horsford, as well as the then President of the University, Felton. I was placed in a seat upon the platform, which I had to occupy, when not at the blackboard, for nearly five hours with an intermission for refreshments. The performance was begun by my master, - who seemed more deeply interested in it than I felt myself to be, - with questions as to my studies. He very dexterously drew out samples of my little learning, and engaged me in disputations which would be likely to make a good impression. The dexterity of this performance took away any trace of embarrassment which the situation enforced on me. Then he made me defend my thesis with a pretty severe questioning, which, as I was now wound up, I did in good fashion. He pressed me hard on some rather recondite matters, as, for instance, in the work of Karl Ernst von Baer, Oken, etc., but he probably knew that my reading made it pretty safe to do so. I have never ceased to admire the way in which, while seeming to put me under the harrow, he was really exhibiting my paces. This part of the business kept me active for more than two hours, for the questions came swiftly.

After Agassiz handed me over to the others, there was questioning by Wyman, also most kindly but rather more searching. Gray too was most fair. Lovering's questions were evidently intended to find whether I knew something in mere outline of other subjects than biology. Cooke took me on a hard road in mineralogy, made the easier by my prompt "don't know," when I was not clear in my mind about the answer. In fact, up to the point I had scored in the game, because I never hesitated to confess the full measure of my ignorance. I took pains to have no penumbra between my light and my darkness. At the end of the second sitting came my turn with Benjamin Peirce. To my satisfaction, he shortly turned his questioning to the process of mountain-building. He produced from his pockets the three volumes of De Beaumont's "Système des 
Montagnes" and asked me to put the thirty or so questions on the board and from them to construct the "Résumé Pentagonal." The task took considerable time, but I had visualized it well, and set down the matter accurately. Then, still following the book, he asked me to criticise the work as a whole. Fortunately I had recently studied the essays of William Hopkins of Cambridge University, in which there is an effectively distinctive study of the mean, showing that, taking account of the departures of the general mountain axis from the lines described by the several great centres of comparison set up by De Beaumont, the correspondences of the position of these axes with these circles was no nearer than chance would bring about; in a word, that there was really no more mathematical order in the alignment of these features than would be found in straws thrown haphazard on a table. It happened that Peirce did not know of Hopkins's work on this subject, and though I gave the author full credit for the criticism, the sufficiency of it was impressive, and finished my examination, - save that at the end he asked me a question. I have forgotten what it was, but it appeared to me unfair. I said that I could give no answer, and asked him what the answer should be. We had a sharp colloquy, which ended in his good-natured acknowledgment that he had put the question to see what I would do with it.

I never shall forget the look of pleasure on my master's expressive face as he watched the progress of this part of my examination, which I knew was well done, for I was in an excellent state of tension for the work and felt myself in perfect command of it. He had evidently been in some anxiety as to my ability to face the questioning I should be subjected to by his colleague. I had myself no serious doubts as to my ability to meet the trial, though the purely nervous anxiety before it began was a sore infliction. I won my degree summa cum laude by the unanimous vote of my judges and that without much debate, as I was told. I was asked to wait a moment and in a minute or two the good news came to me, Benjamin Peirce being the first 
to congratulate me. My wrestle with the De Beaumont hypothesis evidently made an impression on him, in one way for me unhappy, for it gave him the erroneous notion that I was competent in mathematics, and led him, when we became colleagues, to submit many a problem to me which I could not understand for lack of adequate training, and to regard my plea of ignorance on such matters as mere make-believe.

Although I had a sense of ease in the six or seven hours of trial before my judges, it evidently was a severe ordeal. As in other instances when I have been put to proof, there came a reaction with great depression so that I could not sleep. Almost extravagantly self-possessed while under the excitement, I remember sitting in my room and shaking for an hour afterwards and winding up with a brisk fever. Rather than go to Kentucky to seek service in that condition, I took a train, alone, for the White Mountains, stayed a day or two at a curious hostel known as "Dolly Copp's" near the Glen House, and then walked over Mount Washington to the Crawford House. Three days having given me my breath and sense of balance I returned to Cambridge, to pack my effects and prepare for the next chapter of experiences. The delight I had in the solitude was the keener for the reason that I knew that what was to come would be quite other than this peace of the great hills.

When I arrived in Cambridge the news from my people was such as to make it plain not only that the neutrality of my commonwealth was broken, - that had been decided some time before, - but that the chance was that the fighting line would soon swing up to the Ohio. I therefore made haste with my preparations, packing my satchel and turning the key in my door with all my effects within. I was promised that I should hold my quarters if I lived, until I could return to care for my property. But in a few months there came a rumor that I was dead, and when I did return I found that my affairs had been summarily dealt with, so that little remained to me of my goods and chattels save a bath-tub and the frame of a bed. 


\section{CHAPTER XIV}

\section{CAMBRIDGE AND BOSTON CELEBRITIES}

As in this record I now end with my life as a bachelor student in Cambridge, it is fit to finish the story of that period with some account of the people other than fellow students or teachers with whom I had been in contact during the years I had spent there. Not many houses were open to me in Cambridge or Boston, for I had little time and not much inclination for society, yet these few houses were much to me and the memories of them are dear. First to be named of them was that of Mr. George Ticknor. As soon as the lists of students were presented which bore my name, I had a message from him through my master, saying that if I were a kinsman of Mr. William Shaler, sometime consul at Algiers, he would be glad to see me. I made haste to do his bidding, and found my way to what was in its time perhaps the stateliest mansion in Boston, at the corner of Park and Beacon streets, where its windows looked down the mall which leads to the foot of Beacon Hill. Mr. Ticknor received me in a way that made me feel that I had known him all my life. This impression was probably due to certain likeness in his manner to my grandfather, Richard Southgate. He sought to find in my appearance traits which recalled my father's uncle. On my first visit, which stays very clearly in mind, I met his wife, who made an immense impression on me; for splendor of carriage and dignity of manner, she was to be compared with my great-aunt, Abigail Stilwell. They were both dames of a vanished age. That this was no mere boy's impression, but well judged, is shown by the fact that years afterward I went to the house with Professor Bonamy Price of Oxford, who was accustomed to august personages; as we came away, 
he said that he was convinced that there was no such stateliness in his country.

I was at once made so far welcome in Mr. Ticknor's house that it required restraint not to haunt it. I never went through its door, taking the welcome look of the admirable English servant who attended it, without feeling strangely at home. It was my good fortune to be bidden there to dinner often when I was the only one from without the household, and afterward to have a talk with Mr. Ticknor. He was the most charming combination of learning, shrewdness, and simplicity I have ever known. In certain ways his thought ranged far. He had, for instance, a very deep insight into the fit conditions of a university, and from his criticisms of the conditions at Harvard, and his suggestions of betterment, my attention was drawn to academic matters. He had studied the system of the University of Virginia, had seen it under the guidance of its founder Jefferson, whom he had known. He was the first to give me an idea of what academic freedom meant. In his advocacy of the elective system, - in the better sense of that term, - his belief in the fitness of allowing a youth to choose his purpose, he was the pioneer in New England. All of us who have furthered that purpose have been his followers.

My enthusiastic admiration for my master Agassiz, as well as my criticisms of him, which he very cleverly and to my shame brought out, was one of the bonds of this singular friendship between a man already old (he must have been sixty-five, ${ }^{1}$ when I first met him) and a young student. It was partly based on this good common ground of interest in a greatness which appealed to both of us. He saw in Agassiz the majesty of his personality and was great enough to appreciate it as no common mind could. He would often say that he did not have the least idea what the master was about, but that he was great - and that was enough.

Another bond that drew and held me to Mr. Ticknor was his

1 Ticknor was born in 1791. - ED. 
sympathetic understanding of the Southern people. At that time, to most of the folk of culture about Boston, the name of Southerner was anathema. This was in a way natural. The dastardly assault on Sumner, which was as much execrated in Kentucky as in Massachusetts, was taken to be a typical sample of the slaveholders' manners. "Uncle Tom's Cabin" was still making an atmosphere of hatred; Lowell and Whittier were also contributing to it. I was accustomed to hear hard things of my people, or to have them stopped in mid-saying because they caught my ear. There was ever the sense that I was in a hostile country, where toleration was a matter of courtesy and not of right. It must be said that the manners of the Southern students were sometimes of a nature to be exasperating to those from the North. I myself shared the motives of both sections, but so much of me as was Southern evidently grated on the feelings of associates whom I liked and respected. Thus, shortly after I came to be with Agassiz, a fellow student from Salem, a good fellow from the middle-class folk, stopped me on the street when I was carrying a large bundle and asked me a question as to something I had done or left undone, and when I made my answer, said, "You are a liar"; whereupon I put aside my load and knocked him down. As he got up, apparently unruffled, he remarked, "What did you do that for?" It puzzled me much to find that my conduct was generally reprobated.

The division between the students from the South and those from the North had been made the more evident by the John Brown raid, which greatly moved the Boston community. At the moment it seemed likely that it would lead to a servile war in Virginia, which would spread to other parts of the slaveholding section. It was the natural conclusion that this was a part of an extended conspiracy for raising the negroes in arms. I have forgotten the details of the business, but there was an agreement among the Southern students to offer our services to our several states in case there was need of help. It is in my memory that a list of names was prepared and the offer of this 
help sent to the executives of our commonwealths. As I was not in control of the movement I cannot be sure that the offer was formally made, but I believe that it was so made. The rumor of it made a certain sensation at the time, and seemed to add to the sense of the iniquity of the group to which I belonged. My position in respect to slaveholding was not regarded as reasonable by my Northern schoolmates, except by Emerson. I was opposed to - I may say that I exceedingly disliked - the system; but I did not deem it iniquitous, but mainly an ancient unhappiness, which had been imposed upon my people, and that, so far as ancestors could be held responsible, the Northern folk were as much to blame for it as the Southern. I was ready to consider any natural project that could be contrived for getting rid of it. I spent a good deal of debating time in figuring that the Liberian or other colonization scheme might bring a solution; but when there was any talk of servile war as a remedy, I was ready for battle.

In my perplexities, I talked much with Mr. Ticknor. Though by nature guarded in his speech, I found that he was rather more of a Southern sympathizer than I was myself. He was not in favor of slavery as an institution, but accepted it as an existing and inevitable fact, with the belief that any project for getting rid of it was impracticable and certain to bring even worse than its presence on the country. He put aside all colonization schemes as impracticable, for the reason that they would leave the South without a laboring class; and that further we had no right to drive the negroes back to Africa, any more than they would, if in the ascendant, have a right to expel us to Europe. Moreover, he liked, as I did not altogether, the tone of the Southerners. It may have been that his studies of Spanish history and literature had developed in him a fancy for the mediæval type of man and society: he himself was clearly of that fashion. It was natural, therefore, that I went to him for comfort, when, as often in those days, I sorely needed it. 
At the outbreak of the Civil War, Mr. Ticknor was regarded as a Secessionist, and at the time when Seward was "ringing his battle bell," there was talk of imprisoning him in Fort Warren, where a number of men of distinction from the Southern states had been confined. When the sturdy Governor Andrew, the truest of Union men, let Seward understand that there were still men in Massachusetts and that his emissaries would in case of need find why they were not wanted, I, with some others, supposed that he referred perhaps to Ticknor and a small group who were known to sympathize with him, including Mr. George S. Hillard. In fact, Mr. Ticknor was not a Secessionist, nor even a Confederate sympathizer. He was, indeed, a Unionist, but he did not believe it right or wise to seek the welfare of the Federal land at the cost of Civil War. This state of mind was a judgment with no trace of passion in it. When he learned that I purposed entering the Federal army, he encouraged me to do so, on the ground that a man ought in such trials to trust to himself.

Although I had known many Europeans and not a few persons who had travelled in the old world, Mr. Ticknor was the first American who had effectively appropriated its quality. Although I did not think about it at the time, I believe that it was the feeling that he was one of my own stock who had made other lands contribute to his enlargement that most attracted me. I delighted to hear him talk of the able men he had known - he had the best of all talents, that of knowing men. He had such a pleasure in this knowledge that many provincial fclk of Boston thought him a worshipper of famous people, and after the fashion of the cheaper sort they called him a snob. In truth, he was what the provincial always finds it difficult to understand - a man who was a real discerner of man. The fact that he was willing to give much time to a rather raw lad, because he saw that the lad found pleasure and profit in his conversation, reveals the true-hearted gentleman he was.

Mr. Ticknor had a perfectly natural pleasure in his wide 
range of friendships, a most human pleasure. He gave me the letters of a number of his European correspondents to read. They showed by their tone that many discerning people took him at the large value which I from the first assigned to him. I most distinctly remember the letters he had from King John of Saxony, a cultivated man, and a very interesting correspondent. He was evidently much attracted to Mr. Ticknor; the relation was one based on the mutual esteem of two cultivated gentlemen. As I recall it, they were equally interested in Dante. In this connection, here is a bit of advice Mr. Ticknor gave me. It was that if I should become a correspondent of a sovereign, I must take care not to answer letters at once; unless they contained some specific request, it was well to wait some months before writing again, for a man of such station could not by the usages that controlled him leave a communication unanswered. He said assuringly that promptitude in answering letters and a memory for faces were the virtues of a king.

Next after two houses of my earlier life in Kentucky, that of the Ticknors gave me more than any other than my own. There was a beautiful view from the library windows; from them you looked down the charming Beacon Street mall of the Common. But from them, I now perceive, I gained a wider, nobler look on life. To this day, though that mansion has fallen from its high estate and is a place of offices, it remains sacred. I pass it often and in many moods, but never without reverence and a sense of gratitude for what came to me within its walls.

One day, early in our acquaintance, - I may indeed call it friendship, - Mr. Ticknor said to me that he was glad to have me in his house, but that I ought to know that being thus an intimate there brought certain disabilities. He went on to say that my frequent presence there would lead to my being excluded from the society of a certain group of people whose acquaintance would probably be of more value to me than his own; that I should find my way to the homes of the Lawrences, to those of Mr. George Hillard and Judge Parker and Professor 
Parsons of Cambridge, but that I should not enter those of the Lowells or the Quincys or that of Mr. Longfellow. At the time, this seemed to me the whimsy of the dear man's overmuch consideration of me, and a perhaps excessive valuation of social relations. But time proved that his reckoning was singularly correct. I quickly took my way to the houses where he said I should be welcomed, and there made valued friends, but I never was invited to any of the other houses where he told me I would find myself tabooed.

I came to know Longfellow on the street, and had many pleasant exchanges with him in our meetings; he would sometimes turn and walk with me, or bid me to go with him. We often met in the houses of mutual friends, but he never bade me to his own. In the same way I met Lowell, even more interesting. He seemed to fancy talking with me in a fine swapping of yarns and exchanging of judgments, and I always found myself at my best with him. Several times he told me that we were distantly kinsmen, as I remember it, through the marriage of an Elizabeth Shaler of Connecticut with an ancestor of his, Thomas Russell, of Charlestown. He said that this accounted for the fact that his own father and William Shaler, my great-uncle, were so curiously alike that they were gravely inconvenienced by the mistakes it caúsed. In the College faculty, he was given to seeking me for "a whack" of anecdote, and more than once he walked with me to my door but never entered it, nor was I ever in his house - and this at a time when I was in near relation with all the other folk of Cambridge whowere of the College circle. Considering that I had been in the Union army, it is hard to believe that the fact that I belonged to a slaveholding family and did not regard holding slaves as infamous should have been lifelong barriers to natural relations; yet the evidence is that Mr. Ticknor was right; he had a marvellously keen sense of human quality.

Another home where I gladly went and often, was that of my father's classmate Mr. Epes Sargent Dixwell, then the master of 
a famous boys' school in Boston, whence for many years came to Harvard a train of youths who had been well placed in the way of scholarship and imbued with the manly simplicity of his admirable nature. Like others who live with youth, Mr. Dixwell to the end of his life kept a large share of it in his soul. He and his agreeable household gave me refuge in the time when I found myself a stranger in a strange land; for at the outset New England was very foreign to me, and this though I could not discern in what the difference consisted. It was nowhere in the essentials, for at the firesides and the tables of those who were so good as to make me welcome I found always my own people, so like that I puzzled my wits to see what was the matter, and I hardly know to this day more of it than I did then; yet there is the intangible something that does not - did not then and even now does not - fit me, as does the social envelope I have found in England. I am inclined to think it is a secondary effect of Puritanism, which offsets the method of contact of man with man. Some slight, but yet important peculiarity in the way people look at or greet you or pass you on the street with no sense of your existence - matters of no weight, save for the fact that primitive-minded folk are as blindly sensitive as are dogs and other animals to the manners of folk about them. I am the more inclined thus to explain my salient, silly sense of isolation in the old days, and the remnant of it at the end of half a century of residence in New England, from some experience with folk of Quaker stock. There are to my mind no more estimable people in the world than those that owe their nurture to that sect. Among them I have found dear friends, but there is here too, though with a distinction I cannot grasp, the same sense of ill adjustment. This is but one of the many things that go to show that we feel many points in our contacts with our fellows which we do not and cannot cognize.

Mr. Ticknor's house and that of Mr. Dixwell were the only homes to which I was accustomed to resort. To Agassiz's, in my school days, I never went save on an errand; the reason for 
this, which he delicately conveyed to me, - he was a master in such art, - was that he could not take in any one of his pupils without taking all, and as he had grown daughters, it would not be fit that all the somewhat motley throng should be thus admitted. That was indeed evident. Once at Nahant, while I was wandering alone on the shore, he discovered me and led me forthwith to his summer home, taking pains by his manner to show that he was glad thus to be hospitable when it could come in the way of an accident.

It was my custom to walk much in the country about Boston, usually alone, and across lots. On Sundays, except when hard pressed for time, I usually set out in the early morning and came back at dark. At first, I tried to make friends with the country folk as I would have done at home with the certainty of a welcome and a meal, with no gratuity therefor save my courtesy. I found at once that this did not fit the time and place. I never gained an entrance to a house or to the acquaintance of a person, though I thought I was rather apt in dealing with my fellows. At the time I did not see what afterward was clear enough, - that this lack of hospitality was due to the fact that a great town was near by, and that here as elsewhere, even in the South, it had made an end of hospitality to the neighbor. In the other country districts of New England, I have observed no notable difference in this regard as compared with the Southern country, except that the stages of approach are more slowly made; there being in the North no accepted tradition that the stranger at the gate has of right a welcome. There is no difference in the human nature involved in the action; for that matter I have found, the world about, hospitality to be a characteristic of the genus Homo, having as good a categoric value as the naked hide or the withered ears.

These walks alone or with a companion, commonly Emerson or Hyatt, gave me a host of small adventures with people and things that were dear to me and helped much in my growth. At first, and until I began to get the gauge of the New-Eng- 
lander, I felt as if I were in an enemy's country and had to go carefully. This was in part because my wanderings were usually on Sunday with a deep net, a fisherman's basket, and a botanical box that showed that I was on some kind of diversion. On almost the first of my rambles, in what is now called the Middlesex Fells, I encountered on a wood road a sturdy deacon, who asked the business which took me abroad on the Sabbath. On being told I was going to church, he asked where, and when I replied that it was under the great roof of the sky where I was sure of the Lord's presence, he became angry and undertook to arrest me. Not until I convinced him that his Sunday clothes would soon be in the roadside ditch, did he give over this notion. I tried to make the fuming heathen see that he was the Sabbathbreaker; asked him to sit down and talk the matter out; but after the manner of his kind, he was not open to argument and went his way promising me, from the distance, full share of affliction in this world and the next. This deacon long stayed with me for a fair sample of the Puritan, and helped greatly to intensify my dislike, I may say my abhorrence, of Christianity. It was years after, before I came to see that he and his like belong to a group marvellously escaped from the influence of Jesus, by holding to the primitive brutal motives of man which it was the place of the Master to destroy. The fact that I could not get a "whack" with any I encountered on my walks, except with the evident pagans, did much to hinder my understanding of what religion means.

In my student days and long afterward, in Somerville, near the Mystic River, there stood the ruined masonry of a Roman Catholic convent, which had been burned by a Protestant mob in the early part of the last century, the provocation being, as I have understood, the idle rumor that a girl was imprisoned there. Although I was brought up in the English Church, it was in a tolerant atmosphere, where the Romanists were looked upon good-naturedly, as people who were not so very far off from ourselves. My grandfather Southgate, as before noted, 
was quite intimate with two of their bishops; he commended to me the prelates of this faith as gentlemen and excellent company. Moreover, Kentucky has always had a large colony of English Catholics, - some of them were near friends in my boyhood, - and I have always felt what seems to be an instinctive, affectionate reverence for nuns. From my earliest memory the sight of them has ever awakened a movement of the spirit which no religious ceremonies can bring about in me. Therefore, the spectacle of this wreck of the Charlestown nunnery helped to intensify my dislike of the Puritan motive. This was in the days when the Know-Nothing party was strong - when, probably for the last time, our race was to be revisited by the fanatical motives of the Tudor and Stuart period; so that these ruins served as an effective monument of an ancient iniquity. They were doubtless kept there by the church authorities for that purpose.

In winning a wager with some of my fellow students, I had a better view of these ruins, one that made a great impression on my mind, for they were the first of such moss-grown walls I ever saw. The place was well fenced in, and there were guards and dogs by day and night to keep people away. Therefore, of course, it was most desirable for a student to have a brick from the old walls on his mantelpiece, and there were many midnight raids to secure such trophies, - mostly failures, for the watch was good and the dogs insistent in their duties. I was asked to join in one of these ventures, but declined. Being guyed at, I wagered a dinner for the lot that I could go on a Sunday morning to the gate, and without asking leave of any one and without any violence, proceed to the ruin and bring away a choice brick. It was agreed, and a committee was sent to view the proceedings. I found the guard with his dogs, got into palaver with him; we walked together to the site of the burnt house; I chose and pocketed my specimen; he accompanied me to the gate, both of us having had an agreeable half-hour of frolic together. He knew well the game I was playing, but being a 
broth of a boy, he liked it - if a man finds that he does not get on well with an Irishman, he may know that his own human nature is not what it should be.

Another incident of my walks stays in my memory because it has an interest from the humanistic and naturalistic side. I had been collecting specimens of a Sunday morning along the banks of the Mystic River in Medford. Returning in the evening, I found a place by the old Middlesex Canal where the alewives were running up to spawn and a large gang of Irishmen were engaged in catching them. As it was the first time I had seen this anadromous fish, I was much interested in watching the movements of the sportsmen. My large collecting basket, which contained several black snakes and half a dozen or so bullfrogs, all alive, weighed upon me; so I set it down and in the course of my wandering got on the other side of the canal from it, and perhaps fifty feet away from where it stood near the fishermen. Suddenly, to my vast surprise, there came from the basket a wail precisely like that of a young child in pain. The Irishmen heard it also, and in a moment a dozen of them were gathered about it, intent on inquiry but half afraid to make it. Seeing that if they opened the lid I should lose the specimens, and fancying that it must be some ventriloquist trick, I shouted to them to leave the basket alone until I could get to it. This confirmed their suspicions; they pulled out the peg and threw the lid back, when forth sprang the frogs and snakes, - it was a hot day and they were nimble. Away went the throng in wild fright at the issue of their investigation. When I won back to the basket - it was quite a way to the place where I could cross back over the canal - my captives had disappeared; so I filled the empty basket with alewives and went home. I had lost my day's collecting, but we had fish at the club table in plenty.

Though at first I thought it possible that the babe-like cry was some trick of a ventriloquist, I was soon convinced that such a trick was impossible, for the reason that the basket stood 
at a distance from the party and there was nothing to direct their attention to it. It was clear that it came from the throat of one of the bullfrogs, the creature perhaps being frightened by the presence of the snakes. I could not find from any of my naturalist friends that such a wailing note was recognized as a sound these creatures make, nor was there any account of it in the books I searched. I tried to have the sound repeated, and for a long time without success; finally I heard it once again, not so clear as in the first instance, but sufficiently so to make the observation certain; a curiously human sound which would anywhere be taken for an infant's wail. Since then I have found two other persons who have heard it from the same species.

To me this observation is most interesting, because it shows the primitive human cry as existing in a group which is separated from us by thousands of species. The identity is due to the early establishment of the relations between the lungs, the vocal chords, and the emotions, which has in some forms remained in the series to this day. In many groups the conditions have been somewhat altered, but in nearly all the mammalian forms the young, when frightened or in pain, will give out a cry of the same general nature, one distinctly different from what comes from the reptiles or the birds. The existence of this mode of expression among the amphibia, while it is lacking in the reptiles and the birds, serves in some measure to confirm the other evidence to the effect that the mammalia were derived from amphibian ancestors.

Of all my lesser excursions, I most enjoyed those along the seashore. Watching for the lowest run of tides, I delighted to wander in the sea mud-flats, and especially among the boulders which abound in the bottom, off the cliffs of boulder clay. The richness of this life along the New England coast would not be suspected by those who do not watch for the rare occasions when the tides have the fullest swing and the wind is off-shore. I was also given at such times to searching with a boat the spiles of the bridges in the inlets about Boston, where the display 
of the sea-anemones often affords a spectacle of marvellous beauty.

In my undergraduate days it was the custom to keep aquaria in our rooms and in them to establish all the forms we could contrive to make live there. He was the smartest fellow who had the greatest number of species in the cubic foot or two of water the vessel contained. To do the work well means that we had frequently to pack fresh sea-water from the Charles River at the proper stage of the tide, and also to rig up some contrivance for aerating the water; much time and originality were spent on such devices. In these days, when some kind of histology is the aim of the naturalist, the aquarium has passed out of use. I have not seen one in a student's room in thirty years. They know much more of structure, but far less of life than in my student days. 


\section{CHAPTER XV}

\section{OFF TO THE WAR}

IN leaving Cambridge, I remember taking account of what I had done in the three and a half years that I had been a student there. Although at that day, I fully expected that three years of work would not serve as the foundations of a career, for the reason that I was going into conditions of grave stress with what seemed to be a scant measure of strength, so that I was pretty sure to find the way out in the field or in the hospital, I was yet contented with the instrument. In the three years of my connection with the University I had worked hard and continuously, and with a clear purpose, which was to lay the foundations for work in natural history with specialization in geology. Although the official instruction I had access to was scanty, almost absurd in its limitations, the contriving I had done to supplement it had been fairly successful. From Marcou, Jackson, and Rogers there had come good help, but the best, it seemed, was from my sense that I had to be untiringly vigilant in using all the opportunities which the field, the books, and the men I was so fortunate as to know could give me. Moreover, in this endeavor I had learned how to deal with men of my own group. The fact that from about the age of fourteen until I came to Cambridge I had not been in a boy's school, but with an ancient philosopher, was in certain ways a misfortune; for it left me untrained in the art of dealing with youths of my own age. The intense life of the group of students with which I had been thrown quickly made me, in the best sense of the word, a man of the world, ready to meet his neighbor in the give-andtake which is the most important feature in a college education.

The only unfortunate feature in this Cambridge student life was the narrow range of acquaintances I had a chance to make. 
Though I hungered for the society of like-minded mates, there were in all not more than two score with whom I had even the chance of such acquaintance as might lead to intimacy. There is a common notion that Agassiz had a great following of young men, but in the three years I was with him as a pupil, two of them the best of his teaching time, there were never more than a dozen youths who belonged to his group; and some of these were of a social quality that did not attract me. The most of my associates, outside of half a dozen in Agassiz's group of students, were in the other separate folds of the Scientific School; one or two with Asa Gray and Wyman, and a few with Cooke in the department of chemistry. I also came to know some of the young men who were in the Nautical Almanac office, then kept in a house on the north side of the Cambridge Common. I had also some contact with two or three young men who were connected with the Observatory, especially with Philip Sidney Coolidge, of whom I have already said much. With the youths in the College, none of us had much to do, except when, as in the case of Leslie Waggener, there were special reasons for our coming together. I had a "hail-fellow-well-met" relation with perhaps half a dozen of these academic youths, and an affection for some of them, but save in Waggener's case nothing that could be called friendship ever came from our contacts. As a group they seemed to me tiresome, with no intensity of purpose and a very limited sense of the world; at that time I had a preposterous sense of my insight into the doings of the sphere.

Looking back on myself in my undergraduate days, I am inclined to suspect that I may have been a bit priggish; yet when I remember that I was one of the noisiest, and the leader in sundry larks and with a humor for fighting, I am inclined to believe that there was a fair share of unconsciousness in my life; my relations with my mates bear this out. While I had nothing to do with their hard drinking, then a common vice with the groups I knew, nor with other forms of dissipation, our relations seemed none the worse because of these limitations. 
This was probably because my attitude towards vice was not based upon religious scruples, but was due to a primitive sense of cleanliness, a vivid dislike to certain things because they stank. I had the advantage of my mates, in that debauchery was not novel to me, as it was to nearly all of them. In the rude, unconcealed life where I was brought up, filth had always been visible, so it had no mysterious charm. Moreover, the philosophical way of looking at things which I had developed while with Escher had, by the help of inheritance, given me a certain antiquity of soul at its foundation, so that I looked upon the doings of men with an amused interest which kept me then as ever since much in the attitude of the spectator. So it fell to me, who was the youngest of the lot, to be, as I was often called, the old man; to help the roisterers out of their messes, and to see them through the stage of soda-water and repentance.

It is hardly too much to say that at three months over one and twenty I was older in spirit than I am now. In fact, I look back on myself with a certain perplexity in my efforts to account for this curious state. The condition was probably due to the fact that I had been a rather solitary child, had suffered much from illness which too early forced introspection, had lacked the good effects of public schooling, and had been too soon inducted into philosophic ways. That I was not made a prig was due to my keen interest in people, which led me to lose the over-consciousness of self which is the necessary basis of that detestable product of super-civilization.

In my training up to my majority there was very much lacking, but I had the good fortune to come under the influence of several strong men, who in some measure imbued me with their personalities and on whom directly or by reaction I was to some extent shaped. My grandfather and my father in my childhood in diverse ways opened the outer world to me; so, too, did the unhappy Marshall. Probably no drunken genius ever did so much to enlarge a lad as he. Escher had shown me the philosopher in many ways at his best and his worst; but of all Agassiz 
had vastly stimulated my intelligence and had given me the sense of the inquiring motive. To this work he brought not only a majestic and charming personality, but the body of tradition which had grown up among the naturalists of the marvellous period of the European awakening misnamed the French Revolution. His method of teaching was that of the great school wherein he had his nurture, vivified by his sympathy and his enthusiasm. More than most of his pupils, I had been made ready for his hands, and my three years with him gave me rapid development.

I would I could have set down a fit acknowledgment of my debt through all my days to the women whose influence has entered into my life and shaped for the best whatever has developed in me. I feel that I cannot do this part of my task even to myself, so it will have to remain undone. It is, however, fit to say that it has been my good fortune from the age of fifteen years on, to be always in large measure controlled by women of high character. For this I am devoutly thankful; for it kept me from the pit whereto I have seen so many go. While a man should be a man's man in quality, taking his measure from his relations with his own sex, in my opinion he cannot attain his full stature without the influence of women. Of himself alone the male human is a mere fragment of his kind; he attains to his humanity through the shaping influence of its better half.

In my "account of stock" which I remember making as I went from Cambridge to Kentucky, I found not much that was likely to be of value in the work before me. On the moral side, the equipment lacked the motive commonly noted as patriotism or love of the "old flag," that humor which is well summed up in the cry of "our country, right or wrong." This stimulating, primitive emotion appears to have been left out in my making. I felt, it is true, a certain measure of allegiance to my native commonwealth, not to its name or area, but to the people, for the reason that I knew and loved them. I firmly believed that the Federal Union was a most useful convenience 
for uniting like states for protection and interchange. But there was no such movement of the spirit as I found in others at the mention of state or nation. My interest, then as now, was in the purposes of governments, not in mere edifices. I am not commending this rather arid state of mind; it was to me a misfortune, for the reason that it set and thus kept me apart from my fellows. It is well for a man to have his adequate part of all the primitive motives, even when he has to subjugate them. I went about my business with the war not only without enthusiasm, but in a hard, reckoning way, intending to do the best I could to support the Union, as I would do the like for any business institution in which I was concerned, and at the same time to do what I could to maintain the rights of the several states.

As for the rest of my poor stock for the trade of war, it consisted in a weak body that could not be expected to withstand stress: there was no determined disease, but a general inefficiency. The extremity of this is well shown by the remark of a rugged cherry-cheeked young friend, a certain Dr. P., who was at the time of our parting also going to the Federal army. He said, "Good-by, Shaler, you won't stand the racket three months; you look like a ghost already." While I agreed with him in his judgment as to my appearance, this frank statement nettled me; so I proposed that the one who first crossed the Styx, should sit on the further bank until the other one passed over. We shook hands on that contract. If the dear fellow kept the agreement, he has been waiting for me by the dark river for four and forty years; for he who seemed embodied toughness went down at once, while the peripatetic ghost withstood far more serious trials and came forth for decades of service.

As soon as I arrived in Kentucky, I went straightway to Frankfort, the state capital, to put myself in the line of service, whatever it might be. I found there many, perhaps some score, of the men I had known, my elders as well as those of my own generation. I had from them at once a deep consolation in the 
fact that the wiser of them, all indeed but the silly fellows, were no more affected with patriotism than I was myself; they were in a business state of mind, directed to have reckonings on the hard problem before them, ready to act swiftly and together when a definite thing was to be done. They had just then made an end of the maundering Beriah Magoffin, a vastly patriotic incompetent, who had obstructed the better men since the beginning of the trouble. This they had accomplished by dint of some very patient and kindly advice and due form of law. The benevolent governor had joined the Confederacy, and by so doing had made a vacancy in the office of president of the senate. To this place, before Magoffin resigned, there was chosen Senator James F. Robinson, an admirable choice in every way. . . . 


\section{THE MEMOIR}




\title{
THE MEMOIR
}

\author{
FOREWORD
}

1859-1862

IN one of his early note-books Mr. Shaler writes, "I have kept a journal since I was twelve years old, but from carelessness I have preserved only a few pages of many hundreds; unless I pursue a greater regularity it can never accomplish the intention I design." Had he taken the time to look over this journal, fragmentary as it is, he would have found how much he had forgotten - the spiritual travel toward ideals which later were so amply developed and fulfilled, the names of books which gave him delight and laid the foundation of his education, and poems, full of sentiment, written on the spur of the moment. All these aids to memory might have tempted him to wander still farther afield in the world of reminiscence. Nevertheless in the foregoing pages nothing essential is omitted. The journal and other private papers do, however, declare more convincingly than could any retrospective chronicle the fact that in Mr. Shaler's spiritual progress there was no ground lost, but from boyhood onward a steady upward movement of mind and character. Moreover, there are many passages in this youthful record which show singular self-knowledge, and others which reveal doubts and apprehensions that were never justified. He writes:-

June 15,1859 . . . . Life is sweet to me, dearer now because I only now begin to see its glories and to know my duty; still I feel within me much want of the sterling courage so needful. I cannot float down the waters, and yet I doubt my strength for the long struggle which is before me if I live. If I live my spirit compels me to think, and that too in a tangent to the thing 
called public opinion. I believe every thought conceived in the spirit of truth demands utterance as if it were the word of all nature; so my life if ever I should come into the sphere of action would of necessity be a struggle, vehement on one side, earnest at first but soon faltering and weary on my own.

The lack of "sterling courage" was never his, nor when once convinced that his course was right did his spirit ever falter or grow weary. Fearlessness characterized his acts from the very beginning of manhood. It showed itself in his political independence; and later, though he was still a young man, in teaching the principles of Evolution at a time when the dominant scientific influence in Cambridge was antagonistic to it. For months preceding the Civil War, Mr. Shaler was subjected to a veritable cross-fire of political and rhetorical expression concerning the coming conflict. These letters, mostly written by Southern sympathizers, - indeed nearly all whom he loved best were committed to that cause, - were dictated by unselfish and generous motives and therefore are creditable to those who wrote them; but especially to him, since they bear witness to the social pressure which he resisted in taking his stand on the side of the Union. In one of his own letters, brushing aside the fine-spun speculations of his correspondent, he gives, in a few words, for one of his age a singularly discerning picture of the social situation. He writes:-

There is a civilization possible, having negro slavery for its foundation, and a cultivation not wanting in many elements of moral and intellectual beauty; but it is a civilization and society of the Middle Ages with the lighter circumstances of the nineteenth century - a feudal castle with modern furniture. Such is the society south of Mason and Dixon's Line. The North, on the contrary, is the creature of the day, never behind the march of nations but a pioneer.

After 1861 I find no trace of a journal; henceforth Mr. Shaler's observations of natural phenomena were converted into material for lectures or writings, while his experiences with men and things were transmuted into a personal philosophy, which eventually found literary expression in such books as "The 
Individual," "The Neighbor," and "The Citizen." He turned over many times the things which came to him in life, making varied applications of the lessons he learned. The emotional side of his nature, especially in early manhood, found vent whether on a railroad train, while waiting in a station, or in some lonely place, in a few lines of poetry; sometimes the thought is extended to the limits of a sonnet, but seldom further. After the moment's satisfaction of writing them these fragments were cast aside and forgotten. They are generally in the minor key, provoked by a bit of beautiful scenery, or by some fleeting aspect of nature which called forth the idea of death, an idea which was ever present with him, probably for the reason that he was often ill, and also because neither parent endowed him with the spirit of buoyancy. This was a cultivated fruit of his advancing years.

Besides Mr. Shaler's letters to his family but few have come into my hands; indeed, he was in no sense a letter-writer, and late in life those with whom he might naturally have corresponded he met in daily intercourse. Furthermore, although his handwriting was beguilingly fair, instead of a key it became almost a barrier to his thought, and for this reason, after the gist of what he had to say was laboriously arrived at, few were tempted to put aside his letters for future reading. But, even if they had been preserved, it is doubtful whether they would have furnished much of a personal nature. During one of his visits to Europe his father writes:-

... I have received an appendix to one of Sophy's letters written on a piece of paper about as big as your hand, without one word about your health, or enjoyment, or sight of places, but an engineering disquisition on the water-supply of Newport from the Licking River, which, at this time, could not water a herd of buffalo.

The fervid rate at which men lived in the early sixties of the last century may be inferred from the events which took place in Mr. Shaler's own life before he had reached the age of twentytwo. He already had taken his S.B. degree with honors; had 
become a captain of artillery; and had chosen his wife. ${ }^{1}$ This fervor of a particular period which he shared with others, eventually crystallized into a permanent personal quality, for without fervor he could never have gone out as he did to meet life on all sides. Rich experiences came to him in military and civil affairs, in his work as field geologist, mining expert, director of a state survey, member of various state commissions and of two bureaus of the national government; as traveller, prose writer on many subjects, and poet. At twenty-three he became lecturer, at twenty-seven professor, and dean at fifty.

This brief summary indicates the large lines on which Mr. Shaler might have continued his autobiography. What follows in this memoir is necessarily meagre compared with what he had in his power to communicate had it been given him to continue the narrative of his life; for, with truth, he may be likened to a ship that has gone down deep-laden with treasure.

1 He was married in the autumn of 1862 to Sophia Penn Page, the daughter of the Rev. Charles H. Page, of Virginia. The young people had known each other from childhood. 


\title{
CHAPTER XVI
}

\author{
THE WAR
}

1862-1867

REMINDED by some old letters that he came across, Mr. Shaler stated in a paper published in the Allantic Monthly, January, 1882, the reasons that led him, though Southern or States'Rights in his sympathies, to join the North. It was the fear that Southern success would make for both peoples strong, centralized, continually warring governments in which States' Rights would be completely swamped. He was so determinately a believer in the doctrine of States' Rights that he was always opposed to the Republican Party and the spirit of centralization which it embodied.

In the summer of 1862, Mr. Shaler received a commission from the government to raise what was known as the Fifth Kentucky Battery. Although the extremists on both sides had long since gathered around the flags of their respective allegiances the Confederate movement in Kentucky, under the command of Generals Bragg, Heth, and Kirby Smith at the high tide of the Civil War, brought the conservative element into full activity. There had already been an exodus of some forty thousand of the natural leaders and fighting population to the Southern army. Kentucky had also contributed its full share to the Federal forces, almost without bounties and practically without a draft; and yet there were fighting men left who sprang up everywhere eager to bar the veteran host. When Heth's army assumed a commanding position within five miles of Cincinnati, ${ }^{1}$ there was hardly a single regiment on the ground that could

1 See an account of this period in Kentucky, by N. S. Shaler, in the American Commonwealths Series. 
have been trusted in the open field. The defences consisted of a few weak redoubts where guns were like angels' visits, few and far between, "connected by rifle pits, behind which the 'squirrel hunters,' as the volunteers were termed, found a position where it was hoped they could make some resistance." Colonel Lew Wallace, who was in command, showed singular energy in the work of organization; so that the show of resistance on the Ohio in connection with Buell's movements and Bragg's dilatoriness caused the Confederates to lose a golden opportunity for doing great things for their cause. Captain Shaler's battery was called into action during this period of turmoil. His first camping-ground was at Lexington, from which the following letter was written to his wife. ${ }^{1}$

Camp Clay, Nov., '62.

... Do you remember the old grove beyond Ashland on the road from Lexington? We rode by it one morning about two months ago. Little did I then think that I should have a camp pitched under the shade of its venerable trees before their leaves had fallen. ... I am not half well, having a bad cold, severe enough to send me to the hospital were I a private in the ranks: as it is, I must try and keep on my feet for a few days until it is fully decided what the fate of my men is to be. Were I to consult my own inclinations, I should soon be out of this business, and be quite sure that the long coming winter would be spent quietly with you : but I must not consult my own inclinations. My officers and men have a claim upon me which I cannot overlook. I must secure to them fair treatment before I look to myself. ... .

A friend wrote at this time: “. . . Nat has a bad cold and I think will be unwise to stay in camp, for though the weather is pleasant, typhoid pneumonia prevails among the soldiers, most of the cases in hospital being of that character, - so, knowing his obstinacy, you had better come and look after him. He will dine with us to-day and will not return to camp until to-morrow."

His health undermined by chills and fever, Mr. Shaler succumbed to an attack of bronchitis, and was advised for a time

1 All letters not otherwise designated are addressed to his wife. 
to give up his command, which he did, again going into the field when Morgan raided Ohio in the summer of '63. Of this anticipated event he writes: "To-day there is a neat prospect of a little episode of the Kirby Smith order; can't tell what it portends, but unless all signs fail, my wife will be sewing brass buttons on my coats and looking up my epaulettes. I am in poor condition to do soldier's duty, but cannot set private claims against the call to defend home and fireside. Why the deuce don't the rascals keep t'other side of Cumberland?"

Many of his personal experiences while in this campaign are recorded in the volume of poems entitled, "From Old Fields." "The Eager Muster," "East Tennesseans," "The Georgians," "Madame B.'s Review," "The General's Yarn," "The Smugglers," are altogether reminiscent. In "A Midnight Venture" he himself was the "lank youth," "with Fate's load on his shoulders," who stood as captain.

In the hard wrestle of the Civil War,

Type of lads

Who 'fore their beards were grown and gristle set

Were burthened with the cares to weigh down men

Who've grizzled in the trade.

In the poem called "The Burial Place" it is he who, while in the family burying-ground looking for the fairest place for one more grave (his mother's), -

Where she shall bide

Who long hath striven faithfully to serve God's will on earth, -

notices on the face of his grandfather's monument a deep moss-grown scar made by heavy wheels, and tells the lad beside him, forty years after the event, the tale of how it came about when "swiftly and clear" rang the commands of "a master of hard deeds":-

But first of all to me,

To go upon the run upon this crest 


\section{NATHANIEL SOUTHGATE SHALER}

And place my pieces by this monument

Sweeping the highway yonder in the vale.

Then in a moment, forth the battery

Swept down the slope before it, broke right through

The walls and fences, then into that gulch

In seeming ruin, yet with gear unharmed

And horses stout enough to pull it out,

With spur and lash to speed them up the slope.

"The Way with Mutineers" is another record of his own experience:

If you need exploration of your soul,

Get a command of raw men - reprobates

From minstrel shows and jails. Tumble them in

Red-hot campaign to shape them on the march

And in the fight for service. You'll soon find

Their stuff and yours.

In "The Great Raid," a vivid description of Morgan's march into Ohio, he tells of good Master Greenwood's invitation to share a breakfast with him. After two days' feeding from saddle-pockets none too full, the famished youth, first stationing his orderly by the window (through which in the course of time he got his share of the victuals) to keep watch, gladly welcomed the chance to fill his hungry stomach. When the breakfast was done, the host - a maker of great guns, with also a taste for curious toys - put upon the bare floor some dolls (just arrived from Paris) to "strut and dance and quaver words of French": these so well acting their comedy as to make entertainer and guest, now on all fours, not only split their sides with laughter but forget altogether that the tide of war rolled scarce a league away. By chance they glanced toward the window, where to their consternation they beheld the orderly with "jaw-dropped wonder looking at the play."

Three leaps, and our scared leader's on his steed,

Spurring his best straightway across the fields,

To save a furlong length, cursing the fool

That harbored in his hide. 
Many years after the war, at his own table, Mr. Shaler narrated this episode to a famous teller of stories - just then the people's idol and whose hand students waiting in the library were eager to grasp. The guest listened with rapt attention, and when the tale was finished, he exclaimed: "Now that's just the kind of thing no man can invent - it is unimaginable. May I have it for my own?"

Mr. Shaler greatly admired John Morgan's military exploits; indeed, there was a spiritual affinity between them in dash and power of invention. In his history of Kentucky he lays stress upon the fact that "Morgan's subordinate officers were nearly all Kentuckians." "Their wonderful work," he writes, "is perhaps the best evidence of the military capacity of this people. More than any other it shows the people to possess fertility of invention, endurance, and the vigor in action demanded in successful war."

It was a dismal time in Kentucky during all the years '63 and '64, for although the state was no longer the pathway of great armies, many of the greatest events then happening took place in its immediate vicinity. Its fertile lands and rich supplies provoked a series of small raids which incessantly harassed the people. To these were added the still more grievous hardships of guerilla warfare. Bands made up of the unsoldierly rubbish, deserters, and outlaws of both armies, invaded the state and brought back to Kentucky the evils of Indian strife. Men again tilled their fields with their muskets by their sides, and slept in expectation of combat. The destruction of property and the depreciation of land values touched the pockets of all classes in the community, while the loss of the loved ones bowed down the hearts of the people. One after another of Mr. Shaler's intimate friends, mostly in the Confederate army, were slain by the sword or perished in prisons, so that while still a young man there were few left, outside his immediate family, who ever called him by his given name.

While waiting for the reëstablishment of his health Mr. Shaler 
carried on his studies as far as he was able; but becoming impatient of the inactivity of indoor life, he sought to occupy himself in the country by clearing a large tract of land of its timber. In order to get it into shape for the market he set up a saw-mill, but he soon abandoned the enterprise as too costly in time and money. In regard to this same tract of land his father writes some years after: "The Benton farm is doing well. You would hardly know the place where you acquired your saw-mill experience; the bottom is cleared and in grass. I have about two hundred acres of good grazing - about one hundred sheep and a fine lot of early grade Cotswold lambs feeding upon it."

Then, further along, he became collector of internal revenue. This work brought him into contact with all sorts of queer people, and, in a superficial way, made him acquainted with the material condition of the state, a knowledge which proved of advantage when he became director of the Kentucky Geological Survey. The work of "collector" at this time was hardly less hazardous than military service, for in out-of-the-way places the civil law was none too well respected, and the bearer of gold was apt to be an object of altogether too vigilant attention. The only advantage of this service over the field was his ability to regulate his movements with reference to his health; otherwise the journeys were laborious, long horseback rides, early departures and late returns. Under this discipline, whether or no, like Stevenson, he felt the need "to come down off this feather bed of civilization, to put his feet upon the floor of the globe strewn with cutting flints," he got the experience.

Although it had for some time been manifest that, owing to its malarial influence, the climate of Kentucky, so far from being health-giving, was in fact a serious menace, Mr. Shaler did not revisit New England until the summer of '64. The following letter was written immediately upon his return:- 
Parker House, Bostox, June 28, '64.

... I have been engaged during the day in looking up acquaintances and endeavoring to find some suitable place of abode for you and the little one. I met Professor Agassiz this afternoon and received from him a somewhat cordial greeting. The old fellow is in a great rage against all students, and is worn with the trouble they have lately given him. I am inclined to think that there has been much wrong done him in the way of petty spite work by the rebels of the M. C. Z. [Museum]. The students have failed to show him the consideration his age and preëminent services entitle him to receive, and have done much to embitter his declining years. I am satisfied that reasonable treatment from them would have secured an amicable adjustment. . . .

I have been out to the M.'s: received a cordial welcome, which in this land of cool greetings was very agreeable. They were packed ready to move. . . .

It is going to be very difficult to get such accommodations as we want on the seashore. Everything, they tell me, is full - four new paste-board hotels have been built this year at Hingham, a place which fashion has lately invaded. Prices are high, but not greatly above what I expected, still it will make no great difference, for when our money gives out we will go home: the higher the price the shorter the time we will have to stay.

The weather is delightfully cool and bracing, and old Boston looks magnificent. It is a great gratification to see a clean town once more after having lived in Western mud and dust for two years. . . .

In $1864 \mathrm{Mr}$. Shaler was appointed assistant in paleontology in the Museum of Comparative Zoölogy. In the following year he took charge of the regular instruction in zoölogy and geology, given in the Lawrence Scientific School. This work, owing to the continued indisposition of the Lawrence professor, remained in his hands until 1872. As in the past so in the future much of his time was spent within the walls of what was commonly known as the Agassiz Museum; therefore to pause here even at the expense of anticipating dates seems worth while. In this place he worked almost daily, often lingering late in the afternoon, that is, until daylight failed, - in the waning hours occasionally glancing out of the window in expectation of the little child and her mother who came regularly to entice him home. During these early years the life of the Museum was exceedingly 
active; the work of organizing, and collecting and classifying specimens, as well as teaching, under Agassiz's inspiring influence, awakened the energies and full powers of his pupils, for, whether they were regular assistants or not, they considered themselves such. I find among Mr. Shaler's papers the following "table of labor for the half-year ending Jan. 1, 1866": -

July 15 .

1. Essay on the intellectual relation of the four types of animals.

Sept. 1.

2. On the formation of continents.

Optional.

3. On the relation of philosophical systems to scientific methods.

Nov. 1.

4. On the changes of coast line in New England.

Dec. 31.

5. On the method of preserving recent specimens of natural history.

6. Museum Catalogue.

Lectures.

Oct. 15.

1. Either a course on geology or a course on paleontology for students, 24 lectures.

2. Five University Lectures on the growth of continents.

3. Three University Lectures on the silting up of harbors. Preparation.

Compilation for work on formation of continents.

Compilation for index universal of memoirs.

The work of organizing and arranging the Museum was arduous and fatiguing. In the autumn of ' $66 \mathrm{Mr}$. Shaler became convinced that he needed an entire change of climate, and, further compelled by the desire to visit foreign museums and scenes of geological interest, he set sail for Europe. Among the letters of introduction from Agassiz, he carried with him the following, which, with another letter from the same hand, will show something of his situation.

CAMbridge, 4th Nov., 1866.

Dear Monsieur Barrande: . . . Confident in your benevolence, I take the liberty of presenting to you one of my pupils, who has devoted himself with much success to the study of geology. Mr. Shaler is the one of my Ameri- 


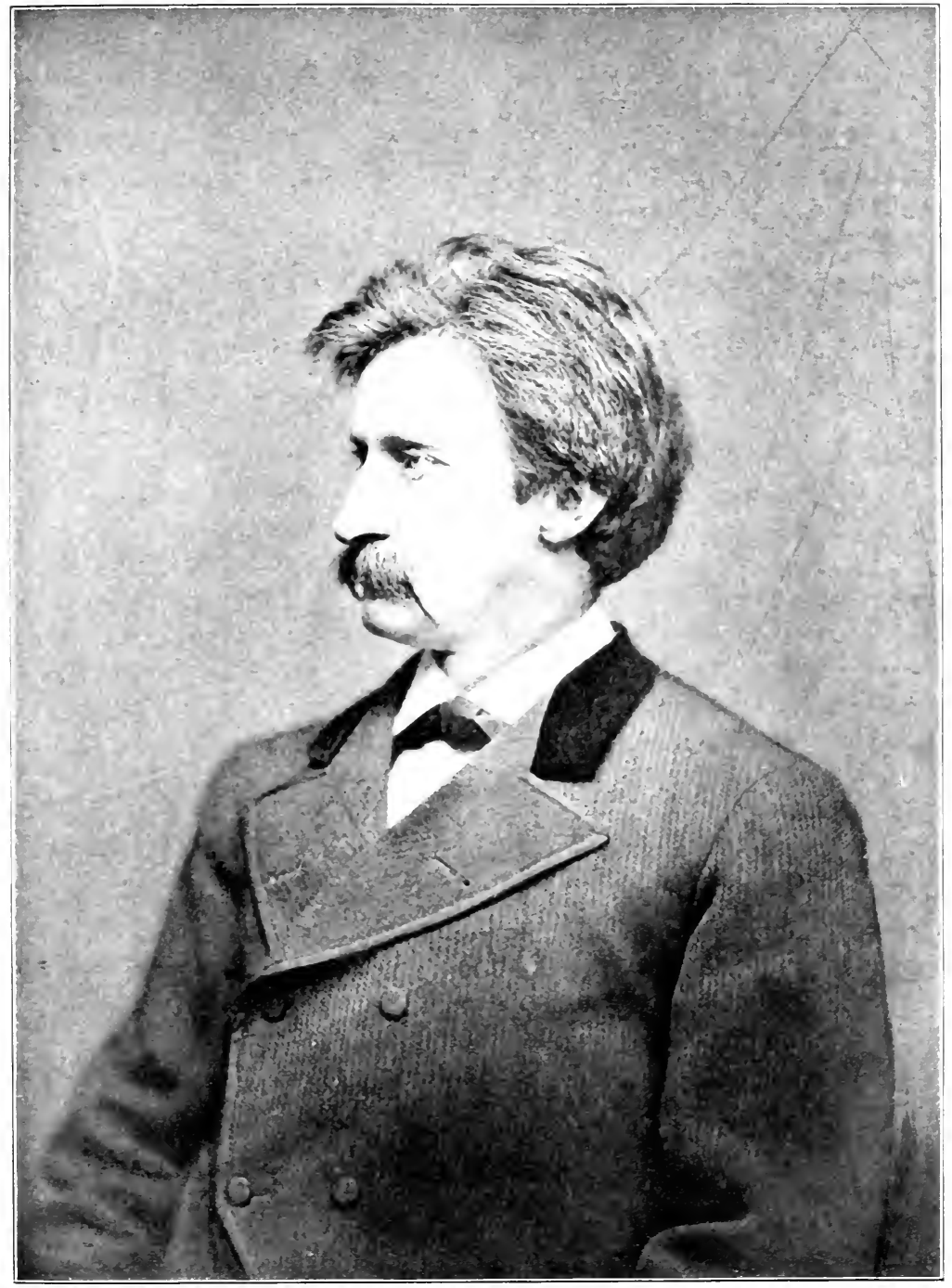

MR. SHALER IN 1 1, 


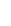


can students whom I love best. He goes to Europe for the purpose of studying the most important geological localities, for learning the recent progress of science, and also to visit the principal museums and collections, particularly fossils. I pray you give him your good counsel to aid him in the accomplishment of his object. Believe me always your very devoted friend,

LOUIS AgASSIZ.

From the same to Mr. Shaler:-

NAHANT, August 6th, 1867.

My dear Sir: . . . I have been seeking for two months, in order to answer your letter to me, your direction, which I could get from no one, never having been informed that you made Montreux your headquarters. Well, you could not have chosen a lovelier spot.

I was delighted to hear from you such good news of your health and scientific pursuits. It is my belief that you cannot do better than to go on with your present course, strengthening your health and extending your knowledge of classical geological grounds. As to your return to Cambridge, let it not interfere with those primary considerations. Nothing shall be done here that may interfere with your projects. And in this connection I would say that there are doubts entertained concerning Mr. Whitney's return to the East and that I would therefore recommend you to make yourself the more earnestly familiar with practical geology: and if you have any inclination that way and time to do it, also with mining geology. I was particularly glad to hear of the extensive collections you have been making, and also of your visiting Alpine localities. There is not an American geologist who has the slightest idea of mountain-structure on a grand scale, unless it be Whitney; certainly neither Hall, nor Lesley, nor Newberry, nor Dana know anything about it practically. All their views are purely theoretical and it is the more advantageous for you to make the most of your opportunities. Do not neglect also the glaciers and glacial traces. As to the collections you want to send home, request Mr. Francillon to make them over to some Commissionnaire and have them forwarded by sailing vessel. . . . With kindest remembrance to Mrs. Shaler, - Yours very truly,

L. Agassiz. 


\section{CHAPTER XVII}

\section{WALKS AND TALKS ABROAD}

\section{6-1868}

Mr. SHALER set sail for Europe in the fall of 1866. His stay in England was short, for already the autumn was far advanced and his object was to find a climate that offered the greatest opportunities for outdoor life. These conditions, he was led to believe, were to be had in Switzerland and thither he bent his steps. From the moment he crossed the French border heavy clouds blotted out the view of the mountains, so that when he reached Montreux, where he had for some time been expected at his sister-in-law's villa, close to the terraced banks of Lake Geneva, even if the state of the atmosphere had permitted it was too late in the evening to see anything of the hidden glory of that famous region. Nevertheless he went to bed with the uplifted sense of one girt about by grand scenery. His most vivid imaginings were more than realized the next morning when he opened his eyes and beheld from his bedroom window, whose curtains had purposely been left undrawn, the Dent du Midi's snow-capped heights radiant with the rose-light of the dawn. This was his first unclouded view of the Alps and was a vision of beauty which he never forgot.

It was not long before he began the study of mountain-structure and the movements of the ice-streams of the Alps. Already he had been imbued by Agassiz with intense interest in all that related to glaciers; he was also familiar with Elie de Beaumont's "Système des Montagnes," which had been one of the most difficult parts of his examination for his degree, as appears in the Autobiography, and with James D. Forbes's and Helmholtz's theories concerning the characteristics of ice. The fact which 
Tyndall emphasized, that ice during a thaw disintegrates so as to form rude prisms whose axes are at right angles to the planes of freezing, he had observed in the ice of the Ohio River. He explored the great Aletsch glacier, that of the Grindelwald, the Mer de Glace, and the system of glaciers between Monte Rosa and Mont Cervin. He developed a love for long tramps, but never cared to waste time and energy in trying to scale high peaks; from the lower heights he was content to attack the problem of mountain-building. At first he made his ascents under professional leadership, acquiring a great liking for the strong-limbed and brave-hearted Swiss guides. After a while, however, wishing to try his own powers, he liberated himself from their companionship and often walked alone. His senses trained to an exquisite perception of the glories of earth and air, the scent of pine and song of birds, every step was a delight. These solitary tramps, like sleep, "knit up the ravelled sleeve of care."

While in Switzerland he became acquainted with Messieurs Renivier, Pictet, and other geologists who were helpful in making known the best localities for collecting fossils. During the winter it was also his good fortune to meet at Montreux an accomplished young English geologist, Edward Tawney, with whom he travelled extensively. Tawney was a cripple, but had in his veins the blood of the heroic Lawrences, John and Henry, who saved India to England in the great mutiny. Yet, in spite of his pluck, he was in a measure dependent for assistance upon his companion, and the fact that he needed looking after awakened, as such an appeal always did, Mr. Shaler's utmost vigilance and care. Their journeys together were delightful as well as mutually profitable, and a great friendship sprang up between them, as well as a certain interchangeable guardianship; as, for instance, when Mr. Shaler's quick spirit would get him into trouble with stupid and arrogant officials - when the oft-repeated Sacrebleu, Cent Mille Diables, Nom de Dieu, made the air hiss; then Tawney would exhaust his slender amount 
of wind power by shrieking at the top of his voice, "Don't hit him, Shaler, don't hit him; kick him if you must." Tawney's longer experience on the Continent had taught him that instead of the serious punishment inflicted for a blow with the fist only a small fine was exacted for a kick.

On one occasion of a conflict with such officials, however, in an out-of-the-way part of France, neither threats nor blandishments were of avail. Suspicion happening to fall upon the contents of their map-cases, the travellers were accused of being German spies and of having rifled the secrets of French fortifications. Geographical and geological information was showered upon the gendarme without the least effect, and the two were marched off to jail. Here they were strictly guarded for some hours, until at length the absurdity of the situation induced such peals of laughter from them that the policeman himself became moved to mirth. He had wit enough to reflect that criminals were not usually hilarious, and now was persuaded to send for the chief man of the place. This functionary appeared, - a thick-headed, pursy magistrate, who solemnly turned the map-cases upside down and inside out, examined bags of specimens with the awe inspired by dynamite, then sat for a long time meditating upon the complicated plot. Eventually, under the influence of a good cigar and a potent drink from the combined brandy-flasks, he solved the problem to his satisfaction and permitted the strangers, late in the evening, to become the guests of the village inn instead of guests of the state.

Map-cases in those days were a source of frequent bother, for in the eyes of the custom-house officer every one with an unusual package was regarded as a Prussian spy, devoting his life to mastering the art of French defensive warfare. The boxes of geological specimens that were forwarded from time to time also fell under the ban of suspicion and caused trouble. And the trouble was not always confined to custom-house officers. I have cause to remember some of the specimens he 
collected at a later time in Switzerland. At the last moment before setting out for Paris to visit the exposition of 1867, after all but one of the trunks had been closed, Mr. Shaler innocently asked if he might put in a few more things, and while my back was turned accomplished the feat. When the trunk was opened at the end of the journey a lace hat and its pink roses, a holiday gown, and sundry other fine things got together for the visit, were found to be ground to powder by the weight and shifting motion of at least half a peck of stones. Mr. Shaler, however, made ample amends for the damage, and for the first time in his life (he was afraid of store clerks) voluntarily entered a drygoods shop and purchased a beautiful robe which he happened to see in the window. In compliment to him the dress was worn for many years until it seemed too gay, and then was handed down as a much-prized heirloom to his daughter.

Threats of danger, however, were not always confined to France. Once, in Tawney's own country, while the two were tramping together in the neighborhood of Manchester, some roughs welcomed the cripple by shouting at the top of their voices, "'Eave a stone at him, 'eave a stone at him, I say!" and would have perpetrated the brutal assault had not Mr. Shaler pitched into the crowd and made short work with them. His friend took the hostile demonstration as a matter of course.

Two summers and a good part of one winter were profitably spent in Switzerland, different localities being chosen as the base of explorations. These sojourns, often in remote places, away from the beaten track of the diligent tourist, furnished agreeable episodes in the serious work of the geologist. In those old days every canton, almost every village, had its distinctive customs and opinions, but with the coming of the railways miscellaneous habits and lukewarm beliefs have long since taken their place. In 1866 there was apparently no such thing as the "neutral heart," hatred and doubtless its converse love were strongly developed; at least the former passion was apparent at the target practice of the citizen soldiers on Sunday 
mornings at the little village of $\mathrm{B}$. On these occasions $\mathrm{Mr}$. Shaler won the hearts of the people by his enthusiastic applause, especially when the ball struck, as it often did, the heart of the French Zouave (a stuffed figure) which just then represented the arch-enemy across the border. His familiarity with Switzerland's heroic struggles against over-confident invaders was always the road to a friendly understanding between him and the sturdy country folk, whom he loved to compliment on their capacity to drive back at any time new foes as insolent as the old ones.

At Le Locle, the centre of the watch industry, Mr. Shaler made the acquaintance of an excellent geologist with whom he had some pleasant and instructive walks. Monsieur Jacquard was a member of a watchmakers' association, also a maker of watches himself. In his house Mr. Shaler bought a lady's watch still warm, so to speak, from the friction of the machine which engraved it. This delicate industry carried on in the homes of the artisans, uniting the domestic and the economic under such simple conditions, was to him a far more satisfactory sight than the well-equipped, well-organized, but less human manufactory at Waltham, Massachusetts. Indeed, every enterprise in which the family life was harmoniously blended, was, to his mind, the best solution of social difficulties.

It was at this same town that he had the chance of "assisting," in the French sense of the word, at a unique spectacle - a military review of the children soldiers, uniformed and equipped like their elder fighting brothers; muskets and cannon, all of a size to match their small dimensions. These young heroes at first showed themselves past masters of drill, executing the manœuvres with exemplary precision; but after the early dinner provided by the good mothers of the town, many a young warrior who had stood steadfast in the morning wavered in his alignment and stumbled in his march, while others with their hands significantly clasped over the seat of pain were led off the mimic field of battle. One little fellow who 
had feasted, if not wisely, at least more profusely perhaps than his mates, blubbered outright from the ache that too many cherries had given him, and was glad to have Mr. Shaler take him in his arms and carry him to the near-by hospital tent. The couple of francs left in his hand gave a compensating joy to his thrifty little Swiss soul.

At Salins, another halting-place which lingers pleasantly in the memory, letters of introduction from Mr. Jules Marcou to his old friends were the means of giving Mr. Shaler some pleasant geological and social experiences. Captain B. especially exerted himself to make known the local points of interest. To one spot in particular - a place of refreshment - he conducted the strangers with an enthusiasm that geological sites pure and simple had failed to awaken. In answer to an inquiry whether a luncheon had better be carried on that day's excursion, his countenance suggested a good time coming that allayed all doubts. The morning spent in driving and walking through a fair and sunny land laid the foundation for keen and appreciative appetites; therefore, at noon, the captain was asked to fulfil his earlier promise. He prodded the nag and soon there loomed in the distance a large wooden structure, bare outside and apparently empty within; but if at the sight of the barren prospect the American countenances fell, the face of the bold forager was lit with reassuring cheerfulness. Soon the appearance of a comely Frenchwoman at the door - a feminine Boniface of typical looks and manner - brought back the abandoned hope. Evidently, from the nature of their greeting, she and the captain were old and tried friends. Moreover, as good luck would have it, the déjeuner had been ordered by special messenger the day before, and did not, as was usually the case, have to be gathered together at the last moment, then wait for the charcoal to be bought, and the fire to be made before the cooking could begin.

The announcement that the meal was served brought Mr. Shaler to the foot of a staircase narrow and steep as a ladder, 
which he nimbly mounted. At the top was a large unplastered timber-roofed hall with windows opening on a fine fertile country. The potage à la printanière, the capon roasted to perfection, the green peas and asparagus fresh and succulent, the newly made butter, and bread that had been baked in an oven that admitted of no sogginess, constituted a repast that proved the captain to be a man not given to false promises. Excellent claret added to the feast, and finally a bottle of champagne, native to the region, exhilarated the spirits. This last was of so fine a quality that later, thanks to Mr. Marcou, a liberal supply was brought to America. Mr. Shaler got his share, and when it came upon the table it always reminded him of that ideal day and its breakfast, of Captain B.'s jolly company, and not the least of the beautiful Franche-Comté. He loved to revive old memories and a pleasant experience was not to be dismissed with one telling, so that guests who drank the champagne often listened to the twice-told tale. If old wine is good they were convinced that, as Mr. Shaler told it, an old story is better.

There was one walk to which he often reverted, and this was through a part of the Rhone valley leading to Zermatt. The moon was still in the heavens when the early morning start was made. There were no impedimenta to drag the steps, only alpenstocks and a knapsack holding the day's provisions. Exhilarated by the pure air, for a while the body was indifferent to time and space and the feet carelessly trod the way to the great and mystic Matterhorn. But the east gradually brightened and the sun sent its hot rays down through the thick branches across the road that till then had been dark and cool. And at last, as the day progressed, the usual feud between body and soul, which for a time had been suspended, set in, and hunger and fatigue became the imperious facts in all nature. Sitting by the roadside, beneath the shade of a great tree, Mr. Shaler emptied the knapsack of its contents - black bread, tough cheese, and sour wine. "Oh," he exclaimed, in the impatient accent that an empty stomach gives, "I would swap 
the Alps for a gallon of buttermilk and a pone of Margaret's corn bread. Out upon Brillat-Savarin, even though born at Belley! If the wine were better I would drink to the whole race of darkey cooks, now and forever." Humiliated by this animal outbreak, the travellers were inclined to beg the great monarch in the distance to forgive the lèse majesté, and finally, with the sense that carnal thoughts, though bound up with the remembrance of home, had taken the bloom off the rose, the line of march was resumed in a happy though less exalted state of mind.

In his wanderings through the Jura a discovery was made which gave Mr. Shaler almost as much pleasure as some of the facts that he gained of his science. Without reference to other considerations he chose the village of $\mathrm{X}$. as a convenient point of departure for geological excursions, notwithstanding the railway had left the village rather wide of the travellers' mark. But a good hotel, reduced to the pension stage of existence, offered comfortable entertainment. Moreover, there was no crowd, no noise, no confusion; bees hummed about the flowers, the cattle grazed peacefully on the mountain-slopes, and the church clock sounded the hours with silvery tongue, though it must be confessed it grew hoarse under the stress of announcing the twenty-fourth hour. It was a happy valley, overflowing with milk and honey. After a week spent at this restful spot, forsaking the diligence, we entered the train that was to transport us to other regions. In the same compartment there chanced to be a young English couple who, seeing Mr. Shaler from time to time consult his map, ventured to question him about the country. They seemed to be wandering about in a maze without ultimate point of destination; but the fact, which with flaunting nonchalance they endeavored to conceal, that they were bride and bridegroom, enlightened him as to their romantic needs. So immediately with his irresistible enthusiasm he described the charms of the deserted village of X., although he had to admit it was a trifle stagnant; still at this happy 
epoch in the young people's lives presumably the stream of time itself might stop. When the tale was told it was evident that in their hearts the young couple were already booked for $\mathrm{X}$. Some months after, one day while walking down the Rue de Rivoli in Paris, Mr. Shaler was accosted by two strangers, who explained that they had instantly recognized him as their fellow traveller. "We had a lovely time at X.," said the young wife, "and we sent some friends and they sent their friends; and so, on the strength of your recommendation, the little village has become a regular resort for brides and bridegrooms." And she added naïvely, "I suppose you did n't know when we met you that we were on our wedding journey."

From Switzerland to Italy was the natural transition. Mr. Shaler first saw Rome when the Pope was still unbereft of his temporal power - the old, dirty, picturesque Rome, shrunken within its ancient walls. Rome was never again the same home of the spirit to him; the ancient city smothered in the new, transformed and cheaply modernized, the street-cars bumping and screeching along the ways which to his youthful imagination had, so to speak, been profanely sacred, grew to be positively distasteful. He liked, however, to tramp beyond the city walls out on the Campagna, where he felt as light and free, as swift-footed, as though the wings of Mercury speeded his way. $\mathrm{He}$ was also at that time and during later visits to Italy supremely happy in his excursions to the small neighboring towns, where, in addition to Nature's gentle doings, he was sure to find a beautiful church, a famous picture, or a rare specimen of the silversmith's art, - beauties which he could enjoy at his leisure without the din of comment of hurried travellers. At the simple inn, too, he rarely failed of good and racy company to share with him his dinner - a jolly priest, or some sensitive crowd-detesting wanderer like himself. Ever ready to be a brother to all worthy souls, frank, guileless, and fearless, he got much of generous giving, in the way of good fellowship, from these passing comrades. 
At Vicenza the door of the hotel stood wide open and when we entered its halls were deserted. After waiting a while in its spacious vacancy, an old servant doing his leisurely rounds, surprised at the sight of visitors, disappeared somewhere into the echoing distance, and later emerged with the sorrowfuleyed master. His welcome of the guests was more like that of a sad and impoverished host than of a money-making keeper of a tavern. While waiting for the precarious getting together of dinner, he offered to show the attractions of the town. Mr. Shaler's sensitive appreciation of Palladio's work - the glory of Vicenza - warmed the Italian's poor old heart and in the waning sunlight he showed one after another of that architect's beautiful palaces. After this he led the way to the outskirts of the town, that a particular view might be had, which, for beauty, sadness, and suggestiveness of fading glory, Mr. Shaler often spoke of as one of the most impressive he remembered ever to have seen.

At Naples of course Vesuvius was the great attraction, and almost at the risk of his life he looked down into the crater, sending forth at the time lava, stones, and ashes. So intensely interested was he in what was going on that it required all the strength of his guide to drag him away at a critical moment when the danger obvious to the guide was unsuspected by the enthusiastic student. But his true volcanic spree was in the classic Auvergne region of France, where, by driving, walking, and almost climbing on his knees, like the devout pilgrims, to the Puy du Dôme and Puy de Parion, he studied the phenomena of extinct volcanoes in all their details.

In the late winter of $1867 \mathrm{Mr}$. Shaler returned to Paris. He was never over smitten with the French Capital. Indeed he liked Frenchmen none too well, and least of all their selfconstituted ruler Napoleon III, who at that time was at the height of his meretricious glory. He revolted at the forced uniformity of the city that Baron Haussmann had brought about; such imposed regularity was perhaps admissible in an American 
town, planned and executed in a day, but deliberately to wipe out the impress of the slow evolution of centuries was to his sequence-tracing mind an unpardonable sin. He gained, however, from the picture-galleries, the School of Mines, and the natural history collections much pleasure and profit. At the Jardin des Plantes he attended the lectures given by some of the most distinguished scientific men of the day. He often spoke of the small and inferior quality of the audiences, and of the perfunctory manner of some of the lecturers. His attention was not infrequently diverted by an old soldier who came at regular intervals apparently for no other purpose than to have his epileptic fit in a safe place. Another old man, whose blear eyes denoted the previous night's debauch, dropped in several times a week to refresh himself with a nap; and now and then a nurse-maid brought her baby in to profit by the warmth found beneath the academic roof. As for the alert and intelligent listeners that lecturers of equal eminence are wont to attract in America, they were not manifest.

In Germany Mr. Shaler was more at home. His knowledge of the language and literature of the country brought him into sympathetic relation with the people, and instead of searching for national differences, as in France, he was intent upon detecting points of resemblance in the Anglo-Saxon and Teutonic character. But when it was a question of manual dexterity so conspicuous in his own country, he was driven to the verge of despair. At Dresden he endeavored to have constructed the model of an invention for the ventilation of hospitals. The clumsy affair, when finished, was sent to Dr. Evans (the American dentist), who hoped to be able to introduce it in the hospitals of Paris. The effort finally languished, and Mr. Shaler himself in the course of time forgot all about it.

While at the Saxon Capital he was induced to enter a watercure establishment, where he was led to believe he would get rid of his old enemy, malaria. The heroic treatment peculiar to the place was supervised by an able though uneducated 
physician, the Herr Naturheilkundigenrath, a follower of the celebrated Priessnitz of Gräfenberg, who as a penalty for practising without a diploma was obliged to spend a couple of months each year in prison. Owing, however, to his probity of character and real success as a practitioner, he was allowed to take his punishment in instalments, and at times of his own choosing. It was a conviction in the establishment that his exile from it was coincident with Frau M.'s outbursts of temper; when these attacks threatened to last longer than usual it was observed that the doctor would coolly collect his books and other effects, and with placid countenance turn his back upon the scene of turmoil. The patients sometimes wished they might do the same, for when the kind-hearted, but quick-tempered and garrulous Hausfrau once allowed her tongue full swing, it was enough to drive the most devoted bather and follower of the "new diet" back to the unclean world of savory dishes. Under her dispensation the "dry days" especially were the hardest to bear, for eating (it was impossible to drink it) a thick pea soup, with salt for its only condiment, and stale bread for its only accompaniment, without water, beer, or other fluid to quench the raging thirst, reduced even the stalwart Prussian officers undergoing treatment to a nerveless band of resentful invalids. For moral support during these desiccated days, the patient had to depend upon the theory that the diet which produced the discomfort caused the viscous mucous coating of the inner parts of the body to be absorbed and thus to purify the system. These same Prussian officers whose haughtiness waned only on Tauchen Tagen held themselves aloof from their dyspeptic countrymen as well as from the Americans; but, unable to keep their ears closed to Mr. Shaler's entertaining talk at table, they learned that he was acquainted with the art of war and inferred that he was or had been a soldier. When the inference had ripened into a conviction, one day after dinner the chief of the party, bowing profoundly, asked if he was right in supposing that Herr Shaler had worn a sword. The 
affirmative answer led to good-natured reproaches that he had not at once made known his distinction. The bond of brotherhood was immediately established and there followed an effusive recognition by all the other dazzling sons of Mars of his belonging to a superior order of being.

Among other agreeable acquaintances made at this primitive, homelike sanitarium was that of a Cuban, who, on the first day of his arrival, presented himself at the door and announced that he had been a student at the Lawrence Scientific School and had come forthwith to welcome with open arms the teacher from Cambridge. He was a distinguished-looking and cultivated gentleman, a great lover of music, and at Vienna, where he finished his engineering education, he had the entrée of the most exclusive houses. Since he lived in the "Annex" which we occupied, we saw much of him, and, previously bored almost to death, we now had Señor N. for our guide, philosopher, and friend, who made known to us the resources of Dresden, the best places to hear music and the plays best worth seeing. Going to the theatre in those days could scarcely be called a dissipation, since the performance began at six and generally ended before ten; if, however, there was any delay the patients were sore put to it to get back before the gates of the establishment were irrevocably locked. In the effort to reach the goal Mr. Shaler always came out ahead of his companions and until the belated sprinters caught up, he with one yarn and another cajoled the custodian to postpone the final turn of the key. Since one of the party was not a patient and therefore not bound by the rules of the house, it was her province to have ready as a fit ending to the evening's diversions a modest repast, and no feast, however delicious, was ever more enjoyed than the few delicacies that were smuggled in as an offset to the peculiar dietary prescribed by the Herr Doctor. Many years after these light-hearted escapades, if such they could be called, Mr. Shaler endeavored to look up Señor N. when in Cuba. He drove to his father's once-flourishing plantation to find there neglect and 
ruin: the doors of the spacious old homestead swinging loose on their hinges; the shutters falling from the windows. In the stress of war the family, broken in fortune, had gone back to Spain. His former comrade was dead.

For the first time during this winter Mr. Shaler had the opportunity to hear fine music almost daily; he had a sensitive ear and often wished he had time to practise composition in order that he might give expression to the themes constantly floating in his head. The concerts given in the Zoölogical Garden were a source of delight to him. He liked the friendly German fashion of sitting at a table and between the pauses of the music talking over a cup of coffee with a genial friend. This custom, he said, took the strain off the attention and enabled one to avoid the mental dyspepsia which came from swallowing a whole concert at one gulp. Furthermore he was taught to associate good music with pecuniary profit: Frau M. - and she was excellent authority - insisted that the saving at home in light and fuel and sharing the cost of supper with a sociable friend made the afternoon concert an actual economy. He enjoyed watching the family life that adjourned to the Music Hall, the knitting and darning that went on among the women, and the ever-sympathetic dog who barked in unison with his master's clapping of hands - this well-to-do, selfrespecting master who wore a fur-lined coat, a symbol of luxury, and caressed it just a little when he laid it on the back of his chair, fur side out. Indeed he was enamored in those happy days of the simple, kindly German folk.

Among the scientific men of Dresden he saw something of Guinitz, and attended the meeting of the Isis Society for the promotion of natural history. It was also the first time he had ever been able to study a large number of animals in close confinement. The well-managed Zoölogical Garden inspired him with the desire to see something similar established at Cambridge, and with this end in view he often conferred with the director concerning the running of such an institution. 


\section{The following letter written to his parents shows how well pleased he was with Dresden.}

Dresden, Saxony, Dec. 31st, 1867.

... We both of us enter the New Year in better health than for a long time. Personally I am, despite bad weather, in better shape than I have ever been at this season within my memory. Stomach nearly right, no rheumatism or any other bodily ill. I should like to remain in this institution for a month to come, and would do so but that on account of the continued incapacity of the director [he was serving his time in jail] to superintend the work things are getting somewhat out of gear with the administration. On that account I expect to be again in motion within a fortnight, first to Freiberg and then to Berlin. There we will remain perhaps a fortnight before taking up our march for Paris via Brussels. We hope to get into England by the middle of March or first of April and to be on the ocean in the first days of June. . . . I am tolerably confident that by the continued use of water treatment I could safely make a lengthened visit to Kentucky. However it would be very much more agreeable for you all to come to us. So arrange your minds for the trip. I wish you could get the courage to come over to us in May and spend the summer in Europe. Epes Dixwell made the trip last summer, had a good time, and was back in season for his school. . . . I am very glad to hear of - 's improvement, but sorry to hear of his trying to study law; it is, as practised with us, a loafing, dishonorable profession in the majority of cases and success of any kind demands either high and brilliant talent or knavery of every description. I would rather see him raising garden vegetables, a thousand times more profitable and honorable a calling. I am sorry to see by the American papers that business is in bad order in the U. S. We may have some years of depression as a reaction arising from the febrile condition during the war. I am afraid the radical members of the Republican Party have killed it beyond hope of revival; no party can carry the load of negro suffrage and white disfranchisement. The second stage of abolition will, I fear, soon begin. The first was the abolition of slavery, the next will be abolition of the negro, unhappy race!

Winter is fairly upon us, and, from the sample we have already had, promises to be severe for this climate. For about a week the thermometer has been nearly to zero every morning; although about $14^{\circ}$ farther north than Cincinnati we have here less severe winters than you often have. It is nearly always cloudy, and as the sun does not rise until about half-past eight and sets about half-past three there is scant daylight. What it fails in daylight and sunshine it takes out in blowing, a half gale being a slow pace 
with the Dresden wind. I have nevertheless never seen a more agreeable place to live in than this, artificial advantages going very far to compensate for natural inconveniences. I heartily wish German immigration could be made in bulk and this old town brought to our continent.

At Freiberg, while endeavoring to acquaint himself with the methods of the Mining School, Mr. Shaler descended the deeply driven shaft and took a hand at the manual labor of the workmen. In that rich field of instruction the mineral ores were numerous, silver, nickel, cobalt, zinc, and arsenic. Often, when speaking of his stay at Freiberg, he mentioned the fact that many of the miners had the ends of their fingers eaten off as a consequence of handling arsenic, and, in some instances, their noses were also reduced in size; otherwise they were a healthylooking lot of men. But along with the practical side of the School were involved other associations of an equally interesting nature. Freiberg had been the home of Abraham Gottlob Werner, the famous geologist and teacher, whose genius had raised the Mining School from a local seminary to a great academy or university. The remarkable personal charm of this man as handed down by tradition, his enthusiasm as a teacher, his affection for his pupils and his vast influence over them, could not fail to appeal to a person of Mr. Shaler's generous nature; but while he himself likewise had the capacity to invest dry subjects with interest and awaken zeal on the part of students, his success in teaching was unattended by dogmatic preachments, such as are associated with the Freiberg professor.

While at Freiberg he made the acquaintance of Von Cotta, the well-known geologist. He was also courteously received by other professors. At one house where he was invited to supper he arrived at the designated hour, but finding no one ready to receive him, and supposing he had mistaken the day, was on the eve of leaving, when the Frau Professorin appeared full of apologies for her belated welcome. "As you have noticed," she said, "the weather has suddenly turned warm, and having a lot of pork in the house I was examining it with the microscope 
before salting it down. I have just finished the job." The professor himself soon added his welcome to hers, and, shortly after, we took our seats at the table, where, among other viands, some nice-looking slices of cold pork were partaken of with a degree of relish and confidence never before evoked by the flesh of the swine. It was soon evident that the good hostess was not only an excellent housewife but a most intelligent woman; and, later, when the daughters, who had served at table, played and sang, Mr. Shaler was charmed with the happy combination of the useful and the æsthetic that this simple German household represented. Before going, however, his gravity was somewhat taxed when his wife was asked by one of the ladies if she had ever seen a sewing-machine, and although she answered in the affirmative, the strangers were conducted by devious ways to a long gallery where a huge apparatus, apparently intended to be run by horse-power, stood against the wall. It had been constructed, as Frau Professorin proudly announced, by a local craftsman, and when she further stated that she and her daughters had much pleasure in using it, Mr. Shaler's respect for her physical strength was only equalled by his admiration of her other qualities. Truly the machine was a wonder, if not a delight, to the natives of a land where mechanical contrivances as a rule demonstrate the theory that efficiency and beauty largely consist in the purgation of the superfluous.

The principal German cities and many out-of-the-way places were journeyed to at this time - among the latter the visit he paid to Boll in Württemberg lingered vividly in his mind. It was here that he afterwards affirmed that he saw the progress of miracles from the simple origin to the inexplicable mystery. It was not, however, the search for the supernatural that brought him to this neighborhood; he came for the purpose of collecting fossils in a region famous for ichthyosauri and ammonites. On the day of arrival at the hotel to which he was directed, while registering his name, he was asked his profession. "Geo- 
log," was the reply, and not long after he was introduced to Father Blumhardt, the presiding genius of the place. At the early supper he was placed at his right hand and otherwise treated as one worthy to be his brother. The meal was preceded by a chapter from the Bible read by a young acolyte, followed by prayer and song. The next morning at breakfast the same procedure was gone through with, all of which took a good deal of time; moreover the company seemed to be made up chiefly of the halt and the blind. At the early dinner, to shorten the time spent at table Mr. Shaler concluded to evade the formidable preamble, likewise the closing exercises. The day was slipping away and as yet he had done no geologizing. Therefore, although it was Sunday, he determined to venture forth; since, however, the sentiment of the place seemed to be strictly religious, he and his wife secreted his hammer and bag for specimens and started off in the direction of an interesting locality toward which his thoughts had been travelling for many months. On his return tired and heavily laden with his treasures, he was obliged to confront his fellow pensionnaires assembled on the front verandah. Curiosity was aroused as to the nature of his burden, and when it was found to consist of rocks it flashed upon the inquirers that after all the stranger was a geolog, not a theolog as the clerk's mistake had led them to suppose. The consequence of the discovery was a considerable lowering of Mr. Shaler's dignity in the eyes of the public; he was in a measure obliterated, shifted down to near the foot of the table instead of feasting as before under the eyes of the master. He in his turn likewise received light, and now for the first time saw more clearly into the nature of his surroundings: the place was a high seat of the faith cure and Father Blumhardt was its prophet. On Mr. Shaler's left sat a youth whose eyes were so badly injured as to make it painful to look at him. He was praying daily for a miracle to be performed. Near by was a woman whose hip was out of joint: she too was waiting to develop the faith that makes whole. A sprained 
ankle which would doubtless have got well of itself in a day or two, and which recovered as quickly under the influence of prayer, was soon magnified until it was a broken limb which had healed under the miraculous touch of the inspired Blumhardt. The morning he was to depart, Mr. Shaler strayed into the little chapel and there he saw in front of the chancel Father Blumhardt, a transfigured being, standing grandly erect, his face lit up with the light of heaven; and the prayer that fell from his lips for unfaltering confidence and beseeching power Mr. Shaler always said was the most tremendous he had ever heard. Suddenly the priest stopped and took from the arms of a peasant woman, kneeling in front of him, her child, lame and sick unto death. He breathed upon it, and then went on with his invocation, asking as only a believing soul could ask, for its recovery. At last he bowed his head, gave the child back to its mother, and she with perfect faith set it upon its feet; and hand in hand the two walked out into the sunlight; the miracle (for the time being at least) had been performed. 


\section{CHAPTER XVIII}

\section{TEACHING AND EXPLORING}

1869-1873

IN the interval between his return from Europe and his next journey abroad, Mr. Shaler devoted himself to teaching, to Museum affairs, to investigations for the United States Geological Survey and the Coast Survey; work which ranged from the shores of Maine to Florida. In the summer of 1869 he accompanied Professor Winlock, Mr. Charles Peirce, and other astronomers and physicists to Shelbyville, Kentucky, to observe the sun's eclipse. He used to say that this was a profitable event for at least a part of the community, since he was called upon in the interest of his friends to negotiate for a good many gallons of Bourbon whiskey to be shipped East as a sort of trail to the expedition.

From a scientific point of view one of the most interesting episodes of this time was the unearthing of the fossil remains of elephants at Big Bone Lick. Mr. Shaler was anxious to acquire these specimens for the Museum, and with this end in view he tried to get its friends to subscribe money for carrying on the excavations. But while the treasurer earnestly desired to enrich the Museum by these possessions, money was short. Finally the owner of the thirty acres of bones gave Mr. Shaler permission to dig at pleasure. One of the tusks unearthed was eleven feet long on the curve. It may be mentioned here that these bones, which at first could find no purchasers, were later sold by the pound. Mr. Shaler told some amusing stories of the "natives" who sat on the periphery of the excavations silently watching all that was going on. One in particular referred to an old man who had been constant in 
attendance. At last one day when the fragments of a huge elephant were dug out, he exclaimed, "That knocks Moses," and, in a disgusted frame of mind, walked away, never to return.

In a letter to Agassiz, dated Cambridge, July 6, 1868, Mr. Shaler sets forth his plan of work at the Museum. Some extracts from this letter will show the general trend of his thought at an early period in regard to teaching. He writes:-

. . That I may the better explain the objects I shall have in view during my connection with the Museum in the years to come, I will consider the work as divided into two parts which need be described separately. The first relates to the teaching which I shall undertake to do. The second to the work of carrying forward the arrangement of the collection of fossils.

In setting before me a plan for my work in the first of these lines I have been guided by the desire to do all in my power to render apparent to the public generally, and especially to the authorities of Massachusetts, to whom we owe so much, the eminent value of natural history as a branch of a general education, and the extent to which our Museum, by the organization and its resources, is capable of effecting the dissemination of sound knowledge of this science. . There are two subsidiary means of giving value to our labor which seem to me to promise good results. The first is to organize lectures of such a character as the people may comprehend, to be given on Sundays, Saturday afternoons, or some such hours as would admit the presence of the laboring public; further than this, short excursions from Boston, on Sundays, if public opinion would permit, open, with certain restrictions, to the public. The other plan is to begin the formation of type collections of specimens intended to illustrate descriptive catalogues, in the form of text-books if it should be considered desirable. . . .

I see my way more clearly in all that regards the strictly scientific teaching. This should be divided into lecture teaching, which must be a process of imparting knowledge, and field teaching, which shall be so arranged as to train observation. . . . I expect to give two courses of lectures each year belonging to this plan, of about twenty lectures each. I shall avoid a text-book arrangement of the matter by the effort to embody some one object in each course. Thus the first course on geology shall be so arranged as to give preëminence to the greatest phenomenon in the history of our earth's surface, viz. the formation of the continents with the attendant differentiations of the sea-basins. Without excluding the ordinary matter of geological lectures, I expect to group my facts so that the great scheme of land and sea can be watched in its development and studied in its 
adult state. I need not say that it will be impossible to do a great deal with this subject in the present state of our science; but I hope to learn myself and teach my hearers that questions admitting of no great amount of accurate determination may still be studied with profit. In the same way I hope to make the course on paleontology serve to impress upon the student the feeling which I have acquired from your teachings and which I value above any other intellectual result: that there is an intelligence guiding the changes of nature and that the surest way to assimilate ourselves to this great guide is by patiently seeking to comprehend the things about us. With this view the leading thought of the lectures on paleontology will be the evidences of an intellectual plan in the history of the animal kingdom. . . .

During $1870 \mathrm{Mr}$. Shaler worked on the Quincy and Nahant sheet for the United States Coast Survey, and from this time on, covering a period of many years, he was continuously employed in its service; his connection with it was very close and twice he was offered the directorship, which he declined. Mr. Cleveland was almost indignant with him for refusing the office. Mr. Shaler, however, had an intense dislike to the political side of government employment. The diplomacy, verging toward intrigue, which often seemed necessary to secure appropriations as well as to maintain oneself against rival claimants was repugnant to his temper of mind. He preferred the stability of tenure at Harvard and the non-interference which characterizes the administration of that university. And yet, notwithstanding his unwillingness to become the director of a National Survey, he took an active part in furthering the organization of Government Surveys, as is shown in the following letter.

The Hon. Sir Roderick Impey Murchison, Bart.,

May 20 th, 1870.

President of the Royal Geological Society, etc., etc.

Sir: - The American Social Science Associations are endeavoring to urge upon the people of the United States the importance of a National Survey with the hope of securing from the Federal Congress the necessary legislation for the organization of a thorough Geodetic and Geological Survey together with a careful study of the ethnology and natural history of the region traversed. The society proposes to have a paper on the value of such surveys printed and widely distributed among our people. Knowing 
the influence of your name in our country, they have deputized me to write to you, begging that you will favor them with your written opinion of the value of such surveys in the development of national resources and in the furtherance of scientific investigation, and allow them to print and circulate the same with the aforesaid report.

Trusting that you will pardon this trespass upon your patience, I have the honor to remain,

Your most obedient servant,

N. S. SHALER.

Although Mr. Shaler had for some time (having received his appointment in 1868) been discharging the duties of professor of paleontology, there seems still to have been difficulty in finding room for his classes. During his forty years of teaching his classes migrated from one lecture-hall to another in quest of space and air. His largest class, Geology 4, after various wanderings found a resting-place for some time in Sanders Theatre, and finally in the large lecture-room at the Museum. Some of the letters written by Professor Agassiz at this period throw light on Museum affairs, and also show that he was interested in securing accommodations for Mr. Shaler's students.

March 30, 1870 [?].

Dear Sir: - I shall do everything that can be done to accommodate as large classes of working students as are likely to be brought together. There need be no delay about it, as our new building is up and I am willing to fit out for the purpose any part that will answer. But the thing must be done by the administration of the Museum and not by that of the College.

Ever truly yours,

L. AgASSiz.

June 8th, 1870.

My dear Shaler: - I cannot let you or the Museum alone as long as I live. Remember that the central part of the new building might have been spoiled but for my interference; as long as I breathe I mean to look after everything. It is my nature never to give up.

Ever truly yours,

L. AgASSIZ.

My dear Sir: . . I I have too much to say concerning your letter of yesterday to do it in writing. I would only request you now to see the 
President and urge upon him the necessity of connecting with Harvard at any price all the men in the country who will give character to American culture in letters and science during the present generation. Unless we do this no plan for organization or combination will avail. ... I know that unless the University follows at the rate at which the Museum advances, the Museum must stop or be separated from the University, which would be a lamentable result. And now tell Lyman that it is of paramount importance to press on the building of the Museum, since you can have no fitting accommodation for the students before our addition is completed. I shall write to him also. Until that is done I do not see how we could receive the specimens of the Harvard Natural History Society, - unless they are willing to have them boxed up and stored in one of our sheds until next winter.

Yours truly,

L. AGASSIz.

\section{Nov. 29, 1871.}

Dear Mr. Shaler: . . . If I were to surrender that room to students' work the Museum would suffer materially. ... You will remember that when I told you I could only give up one room for students' work, it was because the Museum assistants should be provided for; but only two were provided for and the others are to this day entirely without proper accommodations. I must therefore leave you for this year where you are. But be assured that I will make every proper exertion for the accommodation of your students.

Ever truly yours,

L. AgAssiz.

In 1872, among other undertakings, Mr. Shaler worked up the geology of the Sea Island district, and having an excellent opportunity to do so made a close study of the Sea Island negroes, who, because of their isolated life on the plantations there, showed, in his opinion, more plainly than any others the natural bent of the race. Many of his letters written during these geological wanderings, although they seldom allude to his scientific work, are so thoroughly characteristic that it seems worth while to give extracts from them.

OAK BlfFFs, Martha's VINEyard, June 29th, 1872.

... If it were of any use I could swear once again that the next time I had to travel you and the little ones should go along with me. The day has been hot, and, except the sea ride, quite uncomfortable. Oak Bluffs 
is a mushroom town without any oaks, except some scrubs, and little in the way of bluffs except what one gets from the super-christianized people. White pine in the shape of gothic shanties is the only forest growth I have yet found. One is shockingly reminded of the surroundings of a race-track rather than a camp-meeting. The place is not altogether bad. There are some hundreds of little box-like houses of a queer and profane architecture occupied by people of the middle classes or waiting for some one of that class to buy them. These little dabs of dwellings, about as big as boardinghouse slices of mince pie, are scattered around through the thick-set copse of oaks! (save the mark) which are not high enough to hide their ten-foot eaves. There is no visible kitchen to them, nor any outward means of existence unless they live on acorns or are fed by the woodchucks or the emaciated crows, which look old enough to have performed the work for the Syrian hermit some centuries ago.

The only substantial and satisfactory thing here is the sea that seems the greater for the weak things on its shore. It is as quiet as a baby to-night, but it looks as if it might claim this sand-heap as its plaything again some day and so make an end of it. The only place to behold the sea is from an island: the mainland seems too steadfast, a boat is too familiar, besides uncomfortable and makes a bitter end of sentiment; but here you are hemmed in by immensity, feeling like Jonah when the whale opened for him. A change of air always excites me; my young companion has gone to bed overpowered by emotions of a composite kind : affected almost to tears by the grandeur of the sea and the size of his supper. I hear his melancholy snore through the double coat of whitewash and wall-paper which form the wall of my room. I have no one to talk to and only a smoky coal-oil lamp for light, so I must try to sleep it off; I am obliged to the glacial period for having made my work at this end of the island quite simple. I go to-morrow or Monday to Tisbury, when I shall write again.

\section{S. W. HARBor, Sept. 13, 1872.}

. . Should it continue stormy to-morrow I shall not take the steamer but go by stage to Bangor and then by rail to Eastport, even though it take me another day. Safety is sometimes better than speed. I dined, or supped, as one has a mind to call it, this evening with Mr. — and his wife, Baltimore people and very pleasant. The officers have a life of dull routine, but they seem to have their hearts in it. So far the journey has been only moderately profitable. I fear that I am not fresh enough to see to the best advantage. There is not a bit of holiday spirit in the business. I want to get home and merely work because I am here for that. The Mount-Deserters are a hard set, almost as poor as Carolinians. They have a better excuse, however; 
on some tracts of a thousand acres there is not enough soil to hide the nakedness of a single acre. Bleak bare rocks channelled with all sorts of ugly scars of ice.

Southwest Harbor, Mount Desert, Thursday evening.

... I came to-day from Sedgwick, first by carriage six miles, then by fishing boat eight, then by carriage again eight to this place, saving thereby nearly two days of time. To-morrow and Saturday morning I hope to finish my work here and leave that noon for Machias, which lies about twenty miles from Eastport. Sunday I shall, if all goes well, cross that distance, and if nothing goes awry, get home on Tuesday morning. The mountains here have been wrapped in clouds nearly all day. They have fine, strong outlines, though too bleak to be beautiful. The deep inlets and lakes of the island give it a peculiar beauty. After all I am inclined to think it the most beautiful part of our shore. My ride to-day has been lonesome enough; a drizzling rain is not good company, and one tires of the unending march.

Eastport, Maive, Sept. 15.

... I have kept up well under food at all hours and all fashions; dined to-day off of potatoes and pie. Within twenty-four hours have travelled in two rowboats, one sailboat, one steamboat, one express-wagon, one buggy, besides multitudinous goings afoot with baggage and without. Eastport has burned down and been built up since I was here: the people I knew have died save one old man, who I dare say has forgotten me. Eleven years brings its changes. Of our Anticosti expedition three of the six, and the most strong, are gone.

The town is pretty, but a dreadful fog hole. It has, however, become a place of summer resort. We are getting thickly crowded when the world comes to this land of eclipse for summer. I fear I shall soon be bored with geology if it keeps me away from you and your chickens.

About this time Mr. Shaler also undertook several scientific expeditions of a more or less private nature. One of these was a journey with nine students, his family, and two men servants, as far south as the White Sulphur Springs of Virginia. The party started in wagons from Mr. Shaler's door in Cambridge, driving or walking by day and sleeping in tents at night. He did not urge the students to walk more than ten miles a day; for, when this limit is exceeded, he said, "your soul goes to your shoes and you have not nervous force enough left to be keenly appreciative of that which passes around you." 
One preliminary difficulty was found in securing a cook who could do his work by an open fire. The throng who applied in answer to an advertisement was composed, as he described them, of "broken-down actors, decayed gentlemen, ruffianlylooking foreigners of mixed nationalities, and sickly Irish boys." Since none of these could prove their efficiency, it was necessary to send to Virginia. "George — proved to be as worthy a fellow as ever turned a flapjack and fed our eager appetites with commendable patience." For some time before the departure, a number of horses bought by Mr. Shaler for the occasion (he had a true eye for the points of a horse, and could make an instantaneous decision as to an animal's merits - a few tricks more or less, and the ingredient known as "ginger," were to him unobjectionable features) were mustered in his yard on Bow Street, now the site of Westmorly Hall, where, having full range, their horseplay attracted all the small boys in the neighborhood as well as many adults, who hung like a fringe about the fence stimulating in every possible way the circus-like antics of the animals, soon to be brought down to hard work.

The experiences and results of this journey are given in a series of articles published in the Atlantic Monthly. This was Mr. Shaler's first literary venture of any importance and at once the felicity of his style was recognized. From this time on, writing upon one subject or another was an almost daily occupation with him, becoming at last, so to speak, a second nature. 


\section{CHAPTER XIX}

ENGLAND

$1872-1873$

His health again failing him, Mr. Shaler embarked on the Siberia for England, and reached Liverpool December 4, 1872. The passage was exceedingly stormy. The ship, heavily laden with grain, listed, and at times when she went over on her beam-ends, it seemed as if she would never again right herself. The lifeboats, the captain's bridge, and the bulwarks were all swept away; everything in fact that could be rent asunder by the huge waves parted company from the stanch hull. A number of the crew were washed overboard and others seriously injured. Mr. Shaler, whose nature always moved him to give aid and comfort to others at trying times, was lying prostrate, so ill that he could take for nourishment only a few tablespoonfuls of champagne. Dr. Maurice Richardson of Boston, then a young man whose laurels were still in the bud, happily was a fellow passenger, and in the forlorn state of affairs helped to take care of the baby; while the captain, a surly old sea-dog in fair weather, came often during the day and night to give courage by his presence and also to make the dreary travellers laugh at his marvellous feats of ventriloquism; but when the sky cleared, he withdrew into his crusty shell and once more became the brusque disciplinarian.

At Malvern Mr. Shaler soon got well enough to enjoy geological tramps, and to study, particularly, the black shales and holly-bush sandstones of that region. Dr. Grindrod's geological collection and his personal guidance were of great service to him. There are letters which show that he was also at his old business of instructing boys, taking the sons of friends to see the 
doctor's collection as well as to interesting geological localities. $\mathrm{He}$ often spoke of his effort at this time to find the Rev. Mr. Simons, a cultivated gentleman and a geologist, to whom he had been warmly commended. Arriving at A-, he set out for the parsonage, asking directions of the various country people he happened to meet, none of whom, however, seemed to have the slightest idea where their parson dwelt. At last two yokels more conscientious than the others stopped to think, and after a while one of them, receiving a ray of light, looked inquiringly at the other and exclaimed: "Why, man, he must mean the Squarson." Mystified as to who or what the "Squarson" was, Mr. Shaler nevertheless followed the course his finger pointed, and soon learned from Mr. Simons himself that, since he was both squire and parson, the natives, with verbal thrift, merged the titles. During his stay with this squire-parson, Mr. Shaler was charmed with the man himself and with the felicitous manner in which he discharged his combined duties - preparing the soul for virtue and both body and soul for the punishment he sometimes felt called upon to mete out.

As soon as the doctor would permit, Mr. Shaler left Malvern for London. He succeeded in finding agreeable lodgings in Regent's Park. The bedrooms were sunny, - that is, the windows admitted the sun whenever it shone, - and the grounds were enclosed with a high brick wall, which shut out the noise. The conditions were favorable both for health and comfort, and he did not fail to make physical progress notwithstanding the enormous temptation to overdo; for he not only wished to gain an insight into the conditions of social life, but also to profit by the intellectual revival which had just then put England at the head of European thought. In one of his letters to Hooker, Huxley writes, "I firmly believe in the advent of an English epoch in science and art which will lick the Augustan (which by the bye had neither science nor art in our sense, but you know what I mean) into fits." Perhaps this was the epoch he predicted, although, living in the thick of it, he did not perceive 
it at the time. Mr. Shaler felt it a privilege to meet, as he constantly did, Darwin, Huxley, Tyndall, Lyell, Galton, Proctor, Ramsay, Geoffrys, and others, and to go to the various scientific meetings, clubs, and social reunions illuminated by their presence.

Mr. Shaler rather prided himself upon being able at a glance to distinguish a Scotchman, no matter how long he had been out of his native land, from any other Britisher; moreover, wherever he went, he was struck with the potency of Scotch influence, and in illustration of this he was fond of telling of an experience he had one evening at the Royal Society (I think it was the Royal Society). Sitting at the president's right hand at dinner, he casually remarked, "I am glad at last to find an Englishman at the head of one of the great London societies." Thanking him for the implied compliment, the president replied, "I came from Edinburgh to London before I was twentyone and therefore may claim to be an English citizen, but I am not an Englishman."

At another dinner, where Tyndall was called upon to speak, having returned not long before from the United States, he proceeded to give an account of what he saw and did at Niagara Falls. In the midst of a thrilling description of a hairbreadth escape from beneath the Bridal Veil, his eyes happening to fall upon Mr. Shaler, he stood for a moment dumbfounded, and then, with a look which seemed to say "Don't tell on me, old fellow," continued in a more subdued and veracious strain. Before the evening was over he came up to Mr. Shaler and said, "I was surprised to see you here, and to tell the truth, perhaps in my story of Niagara I did stretch the long bow a little, but then you know how, at a dinner, one has got to make his speech telling"; and, shaking hands, he went on his way convinced that his American friend was not unacquainted with the cloak of charity.

While Mr. Shaler was seemingly engrossed with all the vital interest of the mother country, he was not unmindful of what 
was going on at home. He wrote back frequently, asking for information concerning scientific progress there. Moreover he was constantly tantalized by the sight of treasures which he coveted for the Museum, but which, in most instances, he was obliged to pass by, not because the director did not want them, but because he could not find the means for their purchase. The scheme for a Summer School originally intended to be held at Nantucket was also at this time much on his mind.

From London to Cambridge, according to the American reckoning of distance, is but a step, and there Mr. Shaler was at once reminded of Cambridge by the Charles. Furthermore, he was convinced that the younger town did not monopolize all the dulness or the tinge of melancholy that the poet Gray chafed under as something inseparable from his own and other colleges. It is true it was not term time, and therefore an unwonted stillness brooded over the venerable place; but if lighthearted students failed to troop through the corridors there was no barren void: the shades of the great men dead and gone spoke to the spirit.

One of the most enduring and agreeable friendships that $\mathrm{Mr}$. Shaler made while at Cambridge was with Thompson, the Master of Trinity College. Mr. Shaler happening one day in his presence to mention the celebrated Richard Bentley, Thompson asked abruptly, "What do you know about him?" "Oh," said Mr. Shaler, "I only know him in connection with the Letters of Phalaris and with Horace, as the builder of the famous staircase and the hen-house, as the man who wrung money from the doctors of divinity and in spite of the uprising of his subjects could n't be ousted from Trinity." "Well," said Thompson, laughing, "that's pretty good for an outsider. Come and see me."

A few days after, an invitation to luncheon was received. We went at the appointed time, but found the host and hostess more grave than gay, the air charged with an overtaxed and perfunctory hospitality which was not reassuring. As the meal 
progressed, greater geniality prevailed, and, finally, when the party adjourned to the beautiful garden, all barriers broke down at the recital of some amusing incidents connected with the recent visit of the Armenian patriarchs and their numerous attendants. These guests had just gone, apparently in the full odor of sanctity. Their customs, not being in accordance with Western habits, had necessitated a thorough house-cleaning, the taking down of bedsteads and the taking up of carpets. This element of confusion, together with the previous efforts to entertain their guests from the gorgeous East, had reduced the master and his wife to a state verging on a nervous collapse. The next visit to Trinity was more auspicious. Nothing could have exceeded the kindness of the famous scholar, and finally, when Mr. Shaler took his leave of Cambridge, he carried away with him various gifts as souvenirs of the great college, - engraved portraits of Newton and Milton as well as facsimiles of their writings, these showing corrections multitudinous enough to encourage even a Harvard freshman. Besides their potential use, there was another field, remote from the poet's usual wanderings, wherein practical help from him was won. In reply to some disparaging remarks made by one of the dons about Yankee pies, he insisting that the fruit pie was alien to England, Mr. Shaler proved by Milton's own statement that at the time of the plague, among other edibles, apple pies were left at Trinity Gate for the students living there in a state of quarantine.

At a memorial meeting held in honor of the late Woodwardian Professor of Geology - the kindly, witty, and vivacious Adam Sedgwick, a man of the same type as Mr. Shaler himself - there was a notable assemblage of men gathered on the platform. Among these were the old Earl of Powis, the Duke of Argyle, the Duke of Devonshire, and others distinguished for high social position, statesmanship, and learning. Mr. Shaler watched closely the faces of this picked lot of Englishmen, seeking to note what changes the race might have undergone by being trans- 
planted to the New World. So far from discovering certain alleged modifications, he recalled corresponding types of faces among his old friends in Kentucky and Virginia, and laughingly directed his companion's attention to the strong likeness between the Duke of Argyle and a respected old carpenter in Cambridge, Massachusetts. Furthermore, while talking to some of these men he noticed a similarity of phrasing; also the use of certain words peculiar to the Southern section of his own country. As regards public speaking, he was struck with the fact that the young men who had profited by the recently organized unions for debate delivered themselves more freely and to the point than the older ones, who seemed to have made a cult of a hesitating and inconclusive utterance. Mr. Shaler himself was greatly applauded whenever he spoke in public, his success at times bringing its reward, as will be seen from the following incident.

One morning while wandering over Ely Cathedral, "the most glorious shrine in Christendom," he was approached by a gentleman who introduced himself as the Dean. "I heard you speak," he said, "a few evenings ago at Cambridge and was so much impressed by your clearness of thought and statement that, recognizing you here, I was prompted to seek your acquaintance; and now," he added, "will you permit me to be your guide." And in and out of vault, choir, crypt, and Lady chapel, and down the transepts and great aisles, into the "Galilee," or western porch, he led the travellers, indicating here and there the work of the centuries as recorded in early Norman, Decorated, and Perpendicular Gothic architecture; rolling off all the while the names of founders, builders, and restorers, from St. Etheldreda to Alan de Walsingham and Sir Gilbert Scott. At last, when all had been seen that the learned doctor could show, he wound up by inviting the strangers to come home with him to luncheon. The thirteenth-century Guesten Hall of the old Abbey, which at one time had been a camp of refuge for Hereward, had been converted into a deanery; and here, at 
the very threshold, one was obliged to simulate, by bending low, the spirit of the ancient and devout monks, for the arched doorway was under five feet in height. But inside all was glorious, the ceilings rose high and the walls receded. Moreover, in this wonderful place of contrasts there was one room, a studio, holding the most modern examples of sculpture, wrought by the dean's own daughter.

This fen region, the reclaimed Marshlands (some two thousand square miles of the best corn land in England), set Mr. Shaler to thinking what might be done by draining the vast acreage of swamp in the United States. His imagination also played about the political consequences of the appropriation of this land to farming uses. He maintained (jestingly, perhaps) that the final deadly struggle between Charles I and Cromwell originated in their early disputes over this same land whether it should belong to the crown or to individuals. However this may be, the potential riches of the swamp districts in his own country were constantly in mind, and later, in addition to the actual study and reports that he made upon them, he persistently called the attention of business men to this great undeveloped source of wealth.

Mr. Shaler carried but few letters of introduction to Oxford; but after the first perfunctory civilities extended to a professor from another learned institution he received attentions which only respect and personal liking call forth. Some of the entertainments given in his honor are mentioned in a journal kept by his wife. He himself was so occupied during his travels with his geological notes and sketches that he left to her the record of lighter events. Nearly all of the incidents mentioned in the journal afterwards entered into his conversation, and therefore seem pertinent here.

Oxford, April 24th, 1873. - We dined last evening at Dr. Rolleston's (professor of anatomy). $\mathrm{He}$ is a fine-looking, quick-witted man, with a wide range of knowledge and experience. He talks well, and a great deal, upon every subject. Mr. Shaler has taken a great fancy to him and when the two 
get together they have a slashing time of it. The other day while he was examining in company with several others Rolleston's collection of early bronze implements, he (Rolleston) handed a frail but beautiful Roman strigil to a young Englishwoman to look at. Unhappily it slipped from her hands and in striking the floor was almost resolved to dust. It was easy to see the distress on the doctor's face, but he quickly rallied, and gathering up the fragments said to the frightened girl, " Don't worry, my dear, it has, I assure you, been in many a scrape before."

April 26th. - We lunched yesterday with the Master of "All Souls" College. The luncheon was served in the beautiful, high wainscoted combination room. In Professor B.'s own room, into which he took us while showing the college, we noticed his surplice hanging behind the door. Each looked at the other with the same thought in mind. Here was a man of the world much involved in its tortuous ways coming back to his peaceful, secluded college, and once more putting on the robe of his youth and innocence.

Tuesday. - We spent last evening at Dr. Acland's, a noted physician who accompanied the Prince of Wales to America. While there Mr. Shaler had a long talk with Mark Pattison - thought him cold and clammy. The Acklands, doctor, wife, seven sons and one daughter, are charming.

May 1st. - We went to a reception at the vice-chancellor's given in honor of Mr. Emerson. Mrs. Liddell is very handsome. She was dressed in a Paris gown (the wife of the vice-chancellor at Cambridge wore badly cut homemade clothes) and is unusually agreeable. He is a regular old grumpus; his opinion of himself as lofty as the tower of Christ Church, of which he is dean. I had a long talk with Max Müller. He insisted that Emerson intellectually was utterly un-American - that he was Greek in every essential. I maintained that he was the very epitome of a certain New England cast of mind, but if he was to be transplanted the "antiquity of his soul" should give him place back in the dynasties. Apparently Müller gave no credence to my statement; fortunately, however, Mr. Shaler just then joined us and squelched his argument completely. Müller is good-looking, but neither of us thought his face showed genius. During the evening the much-prized original manuscript of "Alice in Wonderland" was exhibited; it belongs to the elder Miss Liddell. The story, it seems, in the first place was told by Carroll to her and her sisters when he took them for strolls on the banks of the Isis. Supper frugal, the English apparently know but one meal dinner.

May 4th. - Dined last night at the vice-chancellor's. He gave me a charming little pen-and-ink drawing that he had made on blotting-paper, one of his many accomplishments. Nat is greatly impressed by the accomplishments of the university men and often wonders, industrious as he is 
himself, how they find time for the gratification of their tastes; for, as he says, the professors rise late, lunch leisurely, spend the afternoons in some kind of sport or exercise, dine late and well, and linger long at table. There appears to be left for work only some hours towards midnight. On the other hand he thinks, perhaps, a cloudy sky is more favorable for concentration of thought, and if perchance one does undertake mental labor in the daytime one's mind is not distracted by the allurements of the brilliant sunlight which in America makes one impatient of any but the outdoor life.

Mrs. Liddell gave Mr. Shaler an amusing account of the Emperor of Brazil's recent visit. His Majesty, it seems, is an inveterate sight-seer and showed frantic haste in going from place to place. One morning at five o'clock he roused the household that he might go to Blenheim. On the outskirts of Oxford, at a shop where a grocerman was just taking down the shutters, he stopped his carriage and bought some buns. From time to time His Majesty dipped into the brown paper bag that held them and apparently relished the buns, much to the disgust of his stately host, who for politeness' sake was obliged to swallow one. The only respite that his entertainers enjoyed during his stay was just after a visit to the Astronomical Observatory, which the Emperor stormed late one night when every one but Professor Adams had gone to bed. In his tour of observation, anxious to examine some part of one of the instruments, he knelt on the floor and on attempting to rise gave his imperial head a resounding blow. A bandage took the place of a crown, and, carried back to Trinity College, he was put to bed and advised by the doctor not to leave it until he thought it wise to let him do so. Every one heaved a sigh of relief and prepared to give himself twentyfour hours of rest at least. But next day at luncheon, just as they were comfortably seated at the table, without warning, in popped the Emperor, and shortly after activities set in with unabated fury, which lasted until the end.

Sunday. - We were invited by Mrs. Liddell to take afternoon tea with Prince Leopold. He is rather an awkward youth, his face dull, but his manners are unassuming. He was not half so agreeable or fluent in speech as his clever Irish tutor. After my talk with the prince one of the ladies asked if I had felt embarrassed. "No," I said, "he is very much like some of our own students," whereupon she looked at me as if I were demented.

It might as well be mentioned here, though recorded later, that after a few days there came through Dr. Acland an invitation from the Prince to Mr. Shaler to take luncheon with him at his villa on the outskirts of Oxford. In the afternoon, while 
strolling through the garden, the Prince took pains to say how warm was his mother's regard for America; that she had never forgotten the attentions shown his brother during his visit to the United States, and moreover her one wish was to maintain friendly relations with the country. In illustration of this, he went on to say that as a boy the first full realization he had of his mother's influence as a queen - of her power, outside her immediate surrounding - was at the time of the Mason and Slidell difficulty. "At this critical stage of affairs, I happened to be in the room," he said, "when Lord John Russell brought in a state paper for the Queen to sign. After reading it over she handed it back to him, saying, 'This will lead to war.' Again he returned and handed her the paper. Looking over it the second time, she gave it back with the remark, 'This must be still further modified.' Once more the document was submitted, and after some discussion, in which the words 'war,' 'battleships,' and 'armies' figured largely, she wrote her signature."

During several geological walks together Mr. Shaler formed a favorable opinion of the Prince, and once, while the two were going through a hospital with Dr. Acland, he was struck with the young man's disposition to efface himself. As heapproached, the various invalids tried to rise in order to show their respect for the Queen's son, but in every instance he protested against the exertion, and at last turned to Mr. Shaler and said, "This is the misery of my position; I cannot go about without being bothered by this kind of thing."

The journal for Sunday, May 5th, continues:-

Mr. Shaler lunched to-day with some gentlemen at one of the colleges (I forget which one). On his return he said he had never before been so strongly impressed with the rich associations of English life. While sitting at the table, attracted by its splendid color, he happened to look fixedly at a stained glass window just in front of him and then turning to his neighbor he made some comment about it. "Yes," the neighbor answered indifferently, " it is rather a good bit of glass; it was ordered to be put in place, you know, by Richard III when he was a student here." 
May 6, Monday. - We went to hear Mr. Ruskin lecture on the "Swallow." We were disappointed; even his drawings on the blackboard were not remarkable; more than that, Mr. Shaler was exasperated by the statement he made that men of science had given no attention to so remarkable a phenomenon as the flight of birds. On his way out he said to one of the professors, "Is it possible that Ruskin knows nothing of Marais' great work on the flight of birds? "Of course, he knows all about it, but it does n't suit his purpose to recognize it here." "Hypocrite!" exclaimed Mr. Shaler, and forthwith his sentiment was confirmed by a knowing wink on the part of the lecturer's colleague.

In spite of the disillusionment as to Ruskin's veracity, Mr. Shaler paid close attention to the Art School that he had founded. He knew that both Mr. Norton and Mr. Charles H. Moore regarded it as admirable for scope and thoroughness and without parallel elsewhere in Europe.

May 9 th. - We returned to Malvern late last evening; found our lodgings comfortable and pleasant. Mr. Shaler not well, however, and much depressed in spirits; fears he will never regain his strength. We can only hope and pray for the best.

While undergoing a mild form of treatment at the establishment at Malvern, Mr. Shaler made use of this health-giving resort as a place of departure for excursions to the surrounding towns. He also journeyed to Scotland, making a point of visiting certain classic geological localities, noting with special interest the glacial scratches which many years before had yielded his master, Agassiz, such joy as indisputable proof of his glacial theory, viz., that a great ice period had covered the surface of the earth with a sheet of ice extending at least from the North Pole to central Europe and Asia. Besides the association with Agassiz, Scotland was the home of Hutton, that man of genius whose "immortal theory" of the earth made a turning-point in the history of geology; his conception that the past history of the globe must be explained by what can be seen to be happening at present struck a responsive chord in Mr. Shaler's mental attitude towards nature. Arthur's Seat and Salisbury Crags, with their records of ancient volcanic eruptions, 
naturally attracted him, as well as the noted localities where proofs of the erosive power of running water were to be seen. The Scottish itinerary included Edinburgh, Glasgow, Sterling, Loch Lomond, and other places usually haunted by sight-seers.

May 23. - With his thoughts as much centred upon Richard III's warlike exploits at Tewkesbury, as upon the venerable abbey, Mr. Shaler and I took the third-class car, filled with good-looking country folk, for that place. It happened to be election day, and men and women were gathered in groups at the corners of the quaint old streets through which we passed. On the way from the station to the abbey, he heard a woman say to her friend, "We are having a jolly time! did you know, already one man has been thrown out of a second-story window and got smashed to pieces." While walking up the beautiful avenue leading to the entrance, we noticed in the graveyard close at hand a lot of rosy-faced children frolicking among the tombstones. In contrast with these grim tokens of age and decay they looked as bright and as ephemeral as butterflies living their happy day. At the door a number of visitors were waiting to get in, and although search had been made for the beadle, and even the vicar's house had been besieged for the keys, there seemed no way of gaining admission, for while the inner door stood open, an outside wooden gate barred the entrance. After knocking loudly to awaken the custodian, who, it was thought, might be napping in the peace of his vast surroundings, Mr. Shaler, unwilling to be balked, examined the gate; and then, calling for assistance, to the astonishment of the custom-hardened natives, he lifted it off its hinges and triumphantly led the party into the very heart of the sanctuary. Within, unmarshaled and undisciplined, we wandered through the aisles of this twelfth-century Norman church, stopping here and there to look at the tombs of the old knights, their effigies reposing at full length. Lost in this ancient world, suddenly we were brought back into the present by angry words, seemingly hurled from the far-off door, reverberating and multiplying themselves through the lofty spaces. Attracted thither, we observed the other sightseers, less smitten with the ancient glory, trying to get past the avenging beadle, who stood with outstretched hands beside the barred doorway demanding one shilling from each intruder. Appreciating the joke, Mr. Shaler rewarded him liberally for his share in the breach of beadle etiquette; and after the others had gone, by his praises of the great abbey, he so cooled the wrath within the $h$-dropping servitor that the man volunteered to go back and reveal some treasures hidden from the eyes of the thrifty. At last, exhausted by the bounty of the show, we were glad to escape. While sitting outside on a tombstone, waiting for the "fly," Mr. Shaler made a sketch of 
the abbey, drawing in the flowers growing in the high-up window of one of the towers. These flowers looked as if they had been planted by human hands, and we expected to see a tonsured monk with emaciated features (the pictorial monk) look out upon the objects of his care; but no such spectral vision greeted the eye. The tower evidently was the home of no human joy or sorrow. Nevertheless N. insisted upon spoiling the sketch by filling up one window with a broad-faced monk.

Friday. - The drive in an open carriage to Hereford led through a country of bounteous aspect. The apple orchards confirmed what we had heard about the quantity and quality of Herefordshire cider. The exterior of the cathedral was not especially impressive; but the choir and the Lady chapel were exceedingly beautiful, and Mr. Shaler was particularly impressed by the mighty Norman piers, whose capitals were more richly carved than any he had seen, also by the old map of the world, made about 1310. The secluded and peaceful garden stretching along the Wye led N. to say he would like to come and live the rest of his days under the shelter of the great cathedral, but then, he added, "I dare say familiarity, gossip, and petty cares would soon reduce even this venerable pile to the level of the commonplace." We were very tired and went to the "Green Dragon," where, paying no modest price for tea, bread, and butter, N. remarked that all English hotels should be dedicated to the Golden Fleece.

July 3. - We rose early and started for a trip down the Wye. The thirdclass car was crowded with soldiers and market-men. We concluded, in spite of the advice of English friends, to avoid the third class in the future. Mr. Shaler said if he could only rip the stuffing out of the first class, and insinuate a little liveliness into it, it would suit him better. At Ross we engaged a boat and started on the journey. The boatman was a stolid John Bull who only became talkative as the time for his tip drew near. It was not long before the rain descended, first in drops and then in torrents. Nat and I, crowding together on one bench, drew up the waterproof blanket, hoisted the umbrella, and sadly prepared to enjoy the scenery from beneath the eaves of our shelter. The longer the boatman rowed, so tortuous is the Wye, the farther we seemed from our destination. The heavier it rained the more N. tried to keep up our spirits. But at last even his succumbed, and we stopped at an inn on the banks of the river. A brief lull in the wind and rain gave a chance to reëmbark, and finally, with misty recollections of the Wye, Monmouth was attained. At the Beaufort Arms a fire was ordered, and we proceeded to dry our clothes and abuse the English climate.

We arrived at York Cathedral just in time for the afternoon service. Sitting in the great nave, we listened entranced to the music. Nat was 
especially pleased with the grand simplicity of this great shrine and with the rich-toned lancet windows. The beadle showered information upon our sated ears and strove hard to earn his fee. When at last $N$. asked him to open the door, he answered, "I will do so with pleasure; I have been shut up in this cathedral since nine o'clock this morning." Alas, it was little better than a jail to him. Nat was eager to get to the old walls of the city. There he fought over the Wars of the Roses; in imagination joined the warriors who struggled across the ditch and scaled the inner defences. He called upon the Emperor Severus in his palace, talked with Constantine and Caracalla. Altogether he voted York a place worth seeing.

At Whitby Mr. Shaler had the companionship of his friend Tawney, and together they did some splendid geologizing, filling boxes and the empty corners of my trunks with fossils. They also poked fun at one another about the customs of their respective countries. On the beach the boys and girls played almost in a state of nature; the women wore scant gowns, but the men appeared in the uniform of Eden. The whole scene, N. said, reminded him in its indecency of Naples. In revenge, Tawney picked out a bespectacled, short-skirted, heavily shod dame, striding along with a cane in her hand, as a typical strong-minded American woman. The dispute growing warm, I was sent to follow this formidable creature and find out what part of the world she came from. Happily she sat down on the sand, thus giving her pursuer a chance to catch up, and after a few minutes' talk it was possible to relieve Mr. Shaler's tension of mind by the statement that she was to the manner born.

At Durham we climbed the hill under a really hot sun and reached the cathedral tired and thirsty: but the solemn stillness and the coolness within made the pain seem small and the pleasure infinite. The massive pillars appealed to Nat's love of all that is strong; indeed he seemed more sensitive than usual to the beauty of the edifice, although, if he were an architect by profession, he could not take more interest in the structure and ornamentation of these great ecclesiastical buildings. Since the service was about to begin, fearing that the magnificent ritual would be spoiled in the manner we had sometimes heard by a sing-song delivery, he suggested that we go outside. Without, we looked for the swans that one sees in the pictures of the great cathedral, and, behold, there they were, those arched-necked creatures showing plain upon the dark waters of the river. As usual at such places, we sat on a tombstone and, besides watching the swans, watched the pious folk that came to the vesper service, and soon the music floated out upon the stillness. When it ceased, $\mathrm{N}$. beckoned to a small boy hovering near with 


\section{DURHAM SPRING-WATER}

the hope of winning a penny and sent him down to the town for a cab; another he bribed to bring a jug of water from the famous spring close by. "This cool, sweet water," he said, "should be drunk out of a gourd and from a cedar bucket." "Ah!" said his companion, "you forget you are not in Kentucky." 


\title{
CHAPTER XX
}

\author{
FIELD WORK
}

1873-1879

While he was in England, Mr. Shaler's friends at home suggested to the Governor of Kentucky that he be invited to take charge of the Kentucky Geological Survey, which was about to be set on foot again after some years of interruption. Among the many other letters sent in his behalf the two given below show in what esteem he was held by those competent to judge of his qualifications.

Cambridge, Mass., April 22d, 1873.

To His Excellency Preston H. Leslie, Governor of Kentucky.

Dear Sir: - I am so thoroughly convinced that it would be a good fortune for your state to secure the services of Professor N. S. Shaler as Geologist to direct your survey, that though he is absent and I know nothing of his intentions I take the liberty of calling your attention to his eminent abilities and perfect qualifications for such work.

I have known Mr. Shaler from the time he first began to study the natural and physical sciences. He has been my pupil and afterwards my assistant for about ten years, and more recently my fellow professor in our Scientific School in Harvard University. He is not only a thorough student and a skilful practical observer, but his ready perception of the relations of facts eminently qualifies him to direct an extensive geological survey; and your state is so constituted geologically as to require the fullest preparation and the best ability in the man who shall explore it successfully.

With great regard, very respectfully yours, L. AGAssiz.

CA mbridge, Mass., June 30, 1873.

To His Excellency Preston H. Leslie, Governor of Kentucky.

Dear Sir: - Since the receipt of your letter [asking for the assistance of the Coast Survey] of the 16th instant, I have daily expected the return of Professor Shaler from Europe, but cannot longer forego the pleasure of ex- 
pressing my own gratification at the appointment of that able man as State Geologist of Kentucky, and of assuring you, as I will also assure him, that such coöperation as may be practicable in geodetic operations by parties of the Coast Survey will be cheerfully directed.

Very respectfully yours,

Benjamin Peirce,

Supt. U. S. Coast Survey.

The request that he become the director of the Survey was sent to Mr. Shaler and accepted while he was out of the country. Agassiz again writes:-

Cambridge, Mass., June 9th, 1873.

. . . It never rains but it pours. No sooner was the conference committee of the House and Senate agreed to let me have $\$ 25,000$ with the conditions so amended that I could match it with $\$ 25,000$ already paid in than my son-in-law, Q. A. Shaw, and my daughter, Pauline, presented me with $\$ 100,000$. What I have, of course, goes to the Museum, only in this case I have not to consult either board of trustees, or corporation, or faculty. It makes me very happy, as I now see my way to give a tremendous impulse to the Museum, and I want you to make sure that there is nothing in England left unnoticed that may benefit it.

And now another question. Are you going to accept the direction of the Geological Survey of Kentucky? In your place I would, but without giving up your connection with our University. I think it would not be difficult to bring this about; and I will at once go to work in that direction if you say so. ...

\section{From the same:-}

Penikese Islaid, Aug. 17th, 1873.

... I lament that your visit to the Anderson School has been so short. I hoped for many weeks of your presence to help in the work, instead of which you have given us only a few hours. But I understand that at present your whole time belongs to the Geological Survey of your native state. Before you leave Massachusetts, however, there is one thing I want to say to you: that whatever the Museum of Comparative Zoölogy affords of resources which may foster an undertaking like that now committed to your care shall be at your disposal, whether you need specimens for comparison or men to carry on the work, and whenever I can be personally useful, you need never hesitate to call upon me.

There are already several subjects of special scientific interest which I would particularly recommend to your attention as likely to contribute to 
the advancement of our knowledge in general, and the proper solution of which may not be without practical importance. I name, first, the study of the fishes of all your rivers separately. Now that pisciculture has become an art of great practical importance an investigation into the distribution of your fishes would furnish an essential basis for the introduction of such species as may be of greater economical value than those which naturally inhabit your waters. ...

Although Mr. Shaler could spend but little time at Penikese, his interest in the theory and practice of summer schools never abated. The idea of establishing a Summer School of Geology was persistently advanced until, after much discouragement, he succeeded in putting on a permanent basis this form of teaching at Harvard University - a system now in operation throughout the country. Some of his friends were disturbed lest he fail of the credit due him for the idea, a matter about which, however, he was indifferent. The following extract is from a letter written by a friend in Cambridge in the spring of 1873, before he came back from England.

... And now about this summer school of natural history and the island which old "fine cut" John Anderson has given to Agassiz. Your friends think you ought to be on the ground when the thing is started even if you go back to Europe as soon as the first term is over. . . . It looks very much as if the "big wigs" and their satellites will rush in and bear away all the credit of the idea and as none of them know anything about "outdoor" teaching it will end in failure. It is true that at the tail end of one of his letters — did admit that his young friend Shaler had originated the idea. Now . . . if you wish to start the thing in accordance with your ideas, it would seem to me that you ought to be here at the opening so as to take your proper place in the management. . . . It makes me indignant when I see other people stealing your thunder. One thing though you must let me insist on, and that is, you must run no risks in the way of health, and in this matter I would much rather trust to Mrs. Shaler's opinion than your own. If the worst should come, you can fight the thing a year or so hence.

Notwithstanding his friend's uneasiness, Mr. Shaler's instruction in geology, including the Summer School, in the course of time became so far developed and perfected as to meet with wide recognition. 
Soon after his return to America he took up the survey work with great zest and carried it on successfully at two different periods. He enlisted the ablest men he could get as assistants, and trained a body of aids to the point where they became successful workers in that and other fields.

In the summer-time he carried on a Summer School for Harvard men, camping in such localities as seemed fittest for the advancement of the survey as well as for the training of the students. He invited some of the foremost scientific men of the day to visit the camp and give inspiration by their presence to the undertaking. A number of teachers from other colleges attended the school, which for two seasons was held at Cumberland Gap. Among the guests were a few dilettantes, a sprinkling of politicians, and some women; these elements made something of the nature of a lark of the occasion. But while there was a share of festivity, the camp was by no means a Castle of Indolence. There were the early departure and the late return - with the different states of mind shown in the accompanying illustration. Furthermore, there was no exemption from the various vicissitudes of camp life, - the long spell of rainy weather, the occasional short rations, the missing cook. The last was a good-natured, much-liked "native," whose labors were interrupted by being called to court to give a reckoning for his third murder. The excuse offered, however, was deemed sufficient to ensure his liberty. According to Jim's account, his victim (his father-in-law) was "a mighty pesterin' ole man." Among the lighter incidents was the rattlesnake episode. The students having advertised their desire to purchase rattlesnakes to be "pickled," in other words to be preserved in alcohol, forthwith the hills and valleys were ransacked by the "natives" for the largest and most vicious of their kind. The best brought at first as much as five dollars apiece; but after a while the supply increased beyond the demand, there was a glut, and the price fell as low as twenty-five cents. At this unfavorable stage of the market a belated merchant of reptiles 
brought to camp, confined in a loosely put together wooden box, one of the largest and fiercest specimens that had been caught for a long time. Mr. Shaler happening to meet the old man first, told him he was too late, and advised him to kill the snake. Nevertheless he persisted in going the rounds in the hope of selling his commodity. In the hurry of getting off on the day's tramp he was brusquely pushed aside by the young men and doubtless soon forgotten. Finally when the camp was deserted by its militant element he was observed sitting disconsolately on a rock gazing at the prisoner in the box, whereupon one of the timid sex approached and asked what he was going to do with the reptile. "I'm er goin' to let him loose," was his reply. "Surely not here." "Yes, jist right hyur, er long sides them tents. I worked turrible hard to get that thar sarpent; walked nigh on to fourteen miles over the mountain, an' now I'm goin' to have my five dollars or know ther reason why." "Come down to my tent," said the alarmed questioner, "and let's talk about it over a cup of coffee." The order was given to bring the refreshment, which, next to home-made whiskey, was the most loved by the "native," but in the presence of the dormant terror it seemed ages before it appeared.

In the meanwhile the mountaineer was enticed into telling his adventures - his moonlight search for medicinal herbs, the circumstances under which "he brought down his men," and other details of family feuds. At last the pot of coffee, together with bread and bacon, came, and the feast began. With each fresh cup, though the vaunted superiority of the snake increased, the price fell until at last it seemed likely to stick at three dollars. At this stage of the negotiation some tobacco was produced and the stiff trader persuaded to fill his pipe. After a few whiffs, he exclaimed, looking lovingly at his trophy, "He's the gamest ever I seed. I reckon he's got pison enough in them thar fangs of his'n ter kill nigh on ter er dozen folks. Yes, I tell you he's jes 'er bustin' ter git arter them studen's, and what's more, all the whiskey in creation, nor lard nuther, 
could n't cure his bite. He's er he snake, as strong as Samsin, I reckon, an' es lively es er kitten: but I say, stranger [lowering his voice], es long es it's er woman who's er dickeren I'll take two dollars cash. What do yer say to that?" At length the price of one dollar for the snake and the killing of it was agreed upon. Without further delay the slats were torn off the box and the bewildered mass of venom dumped upon the ground, and in the twinkling of an eye the hiss of a hickory stick announced that the end had come. Stretched out at full length upon the ground to show how big a bargain had been got, the creature measured nearly six feet. $\mathrm{He}$ was undoubtedly a superb specimen; all the same he was hung up as a warning and no more snakes of his particular breed were brought into camp.

These trifles emerge from the dim corners of memory; the really significant events and the important investigations are recorded in the exhaustive reports of the Survey. Under Mr. Shaler's directorship its scope could not be otherwise than wide. One of the aims most successfully carried out was to show the state in his own actions the determination and devotion that should be given to all undertakings which affect the welfare of the commonwealth. In addition to the usual scientific work, or rather in connection with it, a general description of the state - its geography, geology, and zoölogy, and its material resources of all kinds - was prepared in conformity with an emigration bill which he drew up for the Legislature. In the directing of the survey he kept his eyes pretty steadily fixed upon the development of possible business enterprises, and with this end in view furnished special information to capitalists. A very successful exhibit of the products of Kentucky was made at the Philadelphia Centennial Exhibition, which attracted wide attention.

It is needless to say that the work was laborious, involving at all seasons of the year journeys within the state and to and from Cambridge, for Mr. Shaler still discharged his college 
duties. There were also the usual troubles with the Legislature concerning appropriations, which varied from ten to twelve thousand dollars a year, - sums so small as to cramp the efficiency of the Survey and to lead to occasional outbursts of indignation on the part of those in service. One gentleman of influence writes, "If we had a little more intelligence among those who push themselves into public places there would be much more real economy." His most constant annoyance was with regard to the pay of assistants. He himself often advanced out of his own pocket money for field expenses and even to meet family exigencies, such as a marriage, a birth, or a death. Besides the many legitimate cares of the office, in connection with it was the fearful American waste of high intellectual powers upon petty details which, under a better clerical system, would be left to men of inferior grade. (In regard to this matter the writer once heard an English professor of eminence say, after a visit to Mr. Shaler's office in Cambridge, that he had been struck in America with the absence of trained assistants and the amount of clerical work done by college teachers.) Letters addressed to Mr. Shaler at this time abound with such questions as, "What shall I do with Mollie, the mare? Shall I use her or hire a team?" "How much will you take for the wagon and harness belonging to the Survey? I have a brother who is going to move to Texas. He is very poor and unless you put it at very low figures he will not take it," etc. And then come requests of the following order: "Please send at once three tents, some camp-stools, and blankets."

While there were annoyances, there were also agreeable episodes - the pleasure derived from an extended acquaintance with the people and with the rich resources of his native state. In the introduction to his first report Mr. Shaler writes:-

The thanks of the Survey are due to the generous citizens, whose names are too numerous for mention, who, by their unfailing kindness, have aided every step of its work. My own gratitude is due, in large measure, to the 
officers of the Survey, ${ }^{1}$ who, by their unfaltering diligence, have made it possible for me to do far more than I expected to accomplish with the limited means that have been at my command.

It is but justice to the Survey to say, that the means at its disposal have been exceedingly limited. The total amount appropriated for all the expenses of the years 1874 and 1875 was thirty-three thousand five hundred dollars. Out of this sum must come the costs of maintaining a force averaging twelve assistants and aids, the expenses of the state cabinet, of exhibitions at Louisville, a chemical laboratory, the outfit of camps, instruments, etc., and all the expenses of preparing the results for publication, including the making of lithographic and stereotype plates. Only the most rigorous economy has made it possible to do the large amount of field work that has been done during the last two years; and this saving has been brought about by the devotion and self-sacrifice of my coadjutors of the Survey, who have not only been willing to labor for small compensations, but have unhesitatingly adapted themselves to the rude and comfortless life which has necessarily been followed in order to secure economy and convenience in the work.

What Mr. Shaler thought of the general conditions of Kentucky is set forth in a less official manner in a letter of a somewhat earlier date written to an English friend.

My dear Mr. Lawrence: . . . I am so sorry that you could not come to Kentucky. It is by far the richest state in America, and although the people are absurdly conservative yet they present the highest type of rural life which the country affords, the only region which would remind you of the best parts of your own island. . . .

Mr. Shaler of ten laughingly alluded to an experience he had at this time with the War Department concerning some barometer straps. It was a case of red tape pushed to the extreme limits of patience. The correspondence began in 1875 and was concluded in 1877. On the back of a communication from the War Department which had travelled from one official to another is written, "What straps was he accountable for? Answer:Barom. straps nos. 2 \& 24 sent from this office June 25, 1875." On another: "Shaler N. S. says he is unable to produce the

1 Some of these officers upon whom he depended most were C. W. Beckham, John R. Proctor, A. R. Crandell, P. M. Moore, W. B. Page, C. J. Norwood, besides a number of valuable assistants. 
straps referred to in communication of 30th, but says he will either replace them with money or other straps." Still another bears the question: "What is the cost of straps?" Mr. Shaler himself writes to H. W. Howgate, War Office:-

Sir: - The straps referred to in your favor of the 30th, which the mail has just brought to me, were loaned by your office to the surveyor sent to your office to bring to my camp certain barometers, etc. At the time I supposed that they were included with the instruments, for which I gave receipt, and which have since been accounted for. I am now unable to identify them in the property of the Kentucky Survey and must ask you to allow me to give you an equivalent in money or in other straps made according to your orders in Washington. I regret this mischance, but in my little survey there is no means for keeping a careful account of small items of property; the state having failed to provide me with even a single clerk.

Very respectfully,

N. S. SHALER, Director of the Survey of Kentucky.

And at last came the first endorsement: -

Washington, D. C., Aug. 9, 1877.

War Department, Office Chief Signal Officer.

Respectfully return to Prof. N. S. Shaler, with the information that the cost of these straps to the Service is $\$ 3.00$ each.

H. W. Howgate.

The extracts below from other letters written by Mr. Shaler at different periods while in charge of the Survey, furnish a clue to his undertakings and indirectly to his opinions upon many subjects.

Frankfort, Aug. 22nd, '73.

. . . I wrote you yesterday and telegraphed. I now with sleepy eyes will try and give you a word about the day which has gone. I slept at home. They are all well, and the house is cool and charming. . . . I arose at 4 A. M. to take train for Lexington; came at 1.40 to Frankfort. Saw the Governor, a plain, blunt man, but seems direct and satisfactory. He says the Legislature is in a humor for work and will give the money necessary for its doing. I am better pleased with Kentucky than with Ohio; the surface is beautiful, horses charming, ditto cows, men able-bodied, women often have a highbred air. . . . It is very hot - stifling, old-fashioned heat. The street is 


\section{TRAVELLING IN KENTUCKY}

shaded and full of fireflies and bats. A negro band over the way is torturing a tune, starting bravely but getting thrown every time, quarreling, but returning to the charge. The house is as large as the Revere and really fine in its sturdy stone strength. Old Col. T- is dead, some friends have moved away, others have gone to the still place on the hill, so I feel like an old man. I am pretty well but dreadfully tired and homesick. . . .

Sunday Evening.

. . . So far I have made a decent headway with my work, getting things in reasonable train. I am inclined to think that the work is not above my powers, provided new sources of chafe do not disclose themselves. . . .

NewPort, Aug. 30.

. . . I am still here, but go to-morrow to see the Governor again and to get some information unobtainable by letter. I feel better to-day than for some days and think I can live along here provided you and the little ones come soon. Remember my hammer, and please pack Herbert Spencer's works. Tell M- to come along to Grayson Springs; he will have already done so, if he is not a fool. If you can, start on Monday. Fee the car servants well and make them assist at the transfers. I would come for you but I fear the journey would use me up.

RIVERTON, Kx., Oct. 21, 1873.

. . . The steamboat left me here at 2 P. M. in fair condition. The boat had no staterooms but piled the passengers into two-storied cots in one common room. A cargo of pigs down stairs sang a duet with the snorers above. However withal I am pretty well. I found C- waiting for me, which has saved me some running about. . . . I shall write again to-morrow to tell you just what my plans are, if I am so fortunate as to know them myself. Be assured I shall do my best to get home Saturday night. . . .

Mouth of the Cumberland River, ' 73.

... I came here this morning and got a little rest from the questions of the public - have been at it all day again. We have had a charming day full of spring balm. I like the people - not industrious, but decentand lawabiding in their way; they treat me kindly and considerately. . . . I am pretty well and not very tired. I have shut out the populace, and fortunately there is a murder trial on hand which diverts attention from "bating" the state geologists, which has become a favorite amusement in the state. One of the worthy citizens goes with me to-morrow to Marion and Princeton, so I have good company.

I was congratulating myself on the quiet evening when in came (without 
knocking) seven interviewers to sit an hour. They mean well and are kind, but there are too many people in the world.

Princeton [no date].

. . . This is rather a spry little town, clean and paved. The country, however, is somewhat God-forsaken; no milk to be had. When one leaves the bluegrass land one fares hardly. I think of taking a goat along - your favorite plan. . . . I am sorry to see there is no end of Kentucky in this direction. This world is a deal too big, and we have too much of it; thank God it is shrinking and in time will be a nice tight little world. I am so tired that I feel foolish - I have quite talked my brain into an addled state.

Lexington, Dec. 8th, 1873.

... I had a dull ride to La Grange, the cars were crowded, there being the whole Fifth Avenue Troop aboard. Whether it was the weight of wit or wickedness that made us fall behind time I cannot say, but we made slow progress. I have had a busy day talking to many men of many minds. It is not going to be easy to get much money ; they are disposed to be "cheeseparers," these legislators, possibly in a rattish way. It seems an intelligent body of men, much above the old average of ability. I shall soon know whether they are disposed to do well by the Survey or no. . . . I have only had six interruptions since I began this, though it is after nine o'clock, so I shall have to put out my light and go to sleep in order to secure peace.

Frankfort, Feb. 11, 1874.

... The Survey matter looks rather blue. I still hope, however, that Monday will see it well on its way and me well on mine to Cambridge. There are all sorts of cross-purposes here which require looking after almost from hour to hour. . . . I have never been so impatient of delay; I have been half sick ever since I came here. . . .

Cambridge, Friday [no date].

. . . It looks as if I might be kept here until Sunday or Monday, though I shall try to get away this evening. . . . I have arranged with Eliot that if I come back next autumn I am to have the post of geology alone, with about half the work I did before and a salary of about $\$ 3000$. I can reduce the work to about eight hours of actual work each week. [This of course he did not do.]

March 30, 1874.

. . A silent and rather sad journey down the Ohio: fair night's sleep and me voici this morning. Have done a good day's work, cleaned away a great 


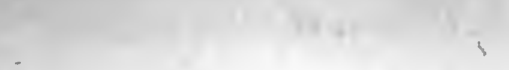

(1) 
${ }_{1}$

211

20 
-

ans

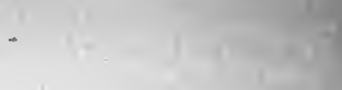

(19.1

a

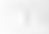

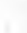
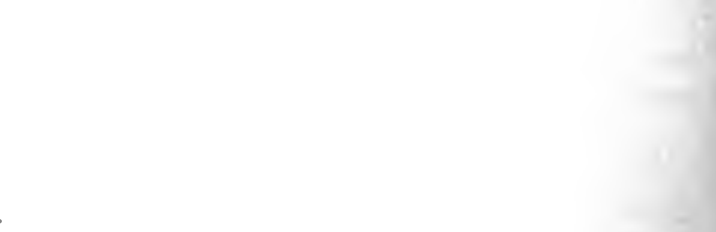
score of things, am tired but hope for a good night's sleep though the house is noisy. One month more and my roving will be done so far as Kentucky is concerned for some time. Glory for that when it comes. . . .

Louisville.

... I arrived here in tolerable order at 4 A. M. Have just had a good breakfast and am much set up thereby. Not much trouble from my cough, which goes to show that knocking about agrees with me. Please take the map which is in two sheets, - a map from the Big Sandy to Lexington, - and send by express. Be on the lookout for another roll of traced maps; look up accounts. I am sorry to be going away, but I shall turn my way home as soon as possible. ...

Hamlton, Boove Countr, June, 1874.

. . . We have reached this place, about fifty miles from Cincinnati - all well, no startling adventures. Carr is enjoying himself, having taken greatly to the tea, of which he is a famous compounder; each brew we think of you and bless your provident care.

I see already the great profit of the journey in this fashion; I have made some important observations which had quite escaped me before. We are red as boiled lobsters, sore-handed, but both quite well. No miasm observed. I think the water is healthier than the bank. I shall write each day, but you may not get letters oftener than twice a week, for the mails are rare in the small towns.

North Bexd, June 20, 1874.

... I was glad you were so considerate as to send me the overcoat, etc. You showed a fine strategic sense in your plan for intercepting us. We came quietly but slowly, making only fifteen miles this day. . . . I feel wonderfully better for the exercise of rowing. . . . I am delighted with the chance we get to see and to collect. . . . The teapot works well; we had a good brew on the boat, and C- was enchanted with the onions. To-morrow we hope to make thirty miles. I am sorry the river takes us each hour farther and farther away. ...

Camp at Bee Spring [no date].

... A plow-horse and plenty of timber brought me here before dark in excellent appetite for our camp fare. C- has several skulls and is as happy as a Carib therein. The tent stands water, which is the end of my fears. $\mathrm{S}$ - is more like the hero in "Chicken Hazard" than ever. P- has made some happy efforts at camp illustration, one in which I figure handsomely. You shan't see them (happy thought) unless you come to Grayson Springs. I shall be around here for at least a week, but unless you come by next Friday I shall saddle my horse and go deeper into the woods. 
LICHFIELD.

. . I came here yesterday to the tune of continual rain. At sundown came a clearing, and by to-morrow the streams will be fordable and the roads in a measure possible. I am going this morning to look for the young men of my party. I shall find them within fifteen miles and shall have my business done. . . . If there were anything like the railroad system of England here I could come home this evening and back on Monday. It is only 140 miles in an air line, but it inevitably takes 18 hours to make it. So one is really no better off than one would be with post horses, except as to price. Until the children are old enough to look after themselves I fear we cannot go about much together, but it will be a compensation for advancing years.

Mamuoth Cave [no date].

. . If I had not been alone I should have enjoyed myself very much the last ten days - the weather has been delightful, the sky and earth agreeing with each other. The woods are in all the tender beauty of early spring; ferns everywhere, and the perfectly dustless conditions are admirable for irritable lungs; and the cave air, uniform and clean, is so good that one even bears the want of light with patience. I should feel like inventing excuses to stay here and sending for you were it not that there is no milk to be had. A beautiful illustration of Kentucky thrift: in the sixty years the hotel has been here it has not cleared enough land for decent pasturage. Otherwise the food is bearable. ...

In the autumn of 1874 , as will be seen from the letters given below, Mr. Shaler's outdoor work, chiefly for the Coast Survey, was carried on in New England.

Coast Survey Camp, Sept. 23rd, 1874.

. . I arrived here in good order and had a comfortable night's sleep. After all I am tempted to bring you and the babies to some upper world like this, and drowse away our lives in sleepy rural content - or discontent, as the case may be. I cannot tell how long I shall be kept here, but I shall leave no stone unturned (geological joke) to get back as soon as possible. I should like to move Harvard College up to this hilltop; teaching would not be half the labor.

Coast Survey Camp, Hoosac Mountains [no date].

. . Since the morning I have done two and a half miles, or one half of the tunnel; to-morrow shall do the rest. This finishes the bad leg work, the remainder I can do on horseback or from a wagon. . . . I shall accumulate 
enough work to keep me busied with my hands: taking specific gravities and so forth, for something like fifty days. The camp agrees with me. I did a long morning's work and now feel very well. I shall try and bring my observations to that point where I shall have at most one more journey to make. . . . Be assured I shall be home as soon as possible.

Camp, Hoosac MIt. [no date].

.. . Who should turn up yesterday but Sterry Hunt? He is looking after some matters for the state and is staying at North Adams. I shall go there this evening to have a conference with him about some points which he is more competent to consider than I am. I have the satisfaction of being able to give far more than I shall receive, for he is not up in the physical questions. Chauncey Wright has been here with Charles Peirce for a day or two: he will take this down to you.

Mr. Shaler often referred to this stay at the Hoosac Mountains as one of the most interesting and intellectually inspiring experiences of his life. To come in close contact with two such broad and penetrating minds as Charles Peirce's and Chauncey Wright's was a delight and stimulus to him. In the intervals of their works their talk was persistent, lasting late into the night and often even after they had got into bed.

It is evident from the following letter that Mr. Shaler continued to be engaged during the ensuing year with other important works for the government. Professor Benjamin Peirce (director of the Coast Survey) writes:-

CAMBridge, Oct. 8th, 1875.

.. I I have read and approved your profound and ingenious report upon the geology of the coast, Boston to New York. But I do not profess to have criticised it very minutely, for it was too difficult. Your handwriting, which is nice to look at, is not easy for one to read, so I cannot make out every word. . . . [The remainder of Mr. Peirce's long letter is hopelessly illegible.]

Shaler's difficult handwriting, as we have before stated, was often an annoyance as well as a source of amusement to his friends, as will be seen in the letter given below:-

June 24, 1875.

My dear Shaler: . . I I presented your paper to the publishing committee and they considered the matter very favorably. There was but one 
slight objection, the force of which you will recognize at once. No one could read the MS. and say what was in the essay. Therefore they deputed me to request you to fulfil the usual requirements and present the paper as a communication at some future meeting. I dare say that this will annoy you a little at first, but I think after a time it will be more amusing than annoying.

I hope you have by this time entirely surmounted the first difficulties of the summer campaign.

Very truly yours,

A. HyatT.

It was doubtless his Coast Survey work that necessitated many short journeys at this time, such, for instance, as the one referred to in the next letter.

Hingham, April 23, 1875.

.. . Six o'clock found us here, about twenty-three miles behind us. We wanted to go to Cohasset, but a likely-looking hotel tempted us to give up the five miles. My companion is rather dull, not conceited enough to be amusing. I feel somewhat rested already. I can't see my letters, and the thousand and one things that solicit care are away from my hand. I shall like the road after it turns towards home much better than I do now. My horse and I feel alike, he constantly tries to turn around and evidently thinks the performance very foolish. I am not sure that he is not right.

Within a month Mr. Shaler was back in Kentucky again supervising the State Survey. He writes:-

May 15, 1875.

... We had a fatiguing journey to Grayson, the weather has been hot and the roads something frightful for stones and gullies. If the boy gets here with my horse I shall ride to S.'s camp, about fifteen miles, and, after seeing him, take a boat to Vanceburg. . . . I fear I shall not get home before Wednesday morning, for I have promised the people of Lewis to come their way, and I suppose they are in a certain sense entitled to my presence. I am tired and stewed with heat. Generally in a bad humor. I see four months of hot work ahead, but I hope to be able to go through it. P- left me to-day; he is a good fellow but a little tiresome with time, like most mortals. The room is full of dorbugs; five already in the wash-basin by their own blundering, so you may reckon the number. I wish I were home to-night, even though I should have to take up the burden of another move the next day. ... Fortunately I am tired and can hope to find some forgetful- 
ness of the rather hateful present in sleep. My friends the B- $-\mathrm{s}$ here have been very kind. They have an elegant house and are very hospitable. This endless running around makes one's life a thing of shreds and patches. I feel sick of it. . . . Eighteen hours since I sent you a despatch. No answer. ...

June 1.

. . . Our nooning, tea-drinking, bug-fighting hour comes and gives me time to write. All goes well, and we are getting along speedily towards our camp, which we hope to reach on Thursday night. . . . Our nooning reminds me quite forcibly of our Alleghany Camps - the sun, the shade, the flies, the agreeable discomforts, all help the likeness. . . .

Grayson Springs, Jnne 3rd, 1875.

... We have just arrived jaded and hungry, ever so much leaner in body and wearier in soul: thirty-six hours to rest, then I go south to look up my camp. If it were in my power I should give up all wandering that took me away from my belongings. . . .

June 4, 1875.

. . We were very tired, so the day has been given to rest and writing. ... I have written my Lexington address; it is rather scrappy, but the manuscript has the dust of forty counties on it and will need your copying hand if it is to be read at all. This summer heat is training me down in weight, but I seem to recover easily, though at times much worn. There is nothing to do but to peg away hoping for the best.

Train, June 16th.

. . . Arrived in Louisville tired, but most of the fatigue was due to reading on the train Victor Hugo's raving nonsense; it has a certain fascination for one; it is railway literature. They made me comfortable at the hotel. Some of the rooms look as homelike as an English inn. The boys at table know my leanings away from hot bread and towards milk, so I do not grow less thin. It won't be so this coming week - "Farewell, a long farewell to all my greatness," I can sing with Wolsey. There is one satisfaction, there is less to carry and less for the ticks. One is willing to be lean to starve the scoundrels. You had better bring a bottle of pennyroyal and train your nose a little. I expect to adopt it as the perfume of the camp. . . . Please look over my letters, answer those you can, and write the contents of the others. Take the auditor's check to bank - this is important during - 's sickness. I wish you could show some kindness to the poor man. I fear the 
dry-souled — will do nothing for him in an illness which promises to be long. I shall get to camp to-day if I can find a horse, mule, or other transportation. A ducking is on the bills, for I forgot my overcoat and the clouds are sulkily watching for me; fortunately I am neither sugar nor salt so I shall not melt, but will growl through it and eat my ration and drink an apple toddy (if it is not smashed) when I get to camp.

July 1st.

... A fog delays us and there is the well-known dismal tooting while the boat crawls along. This cuts me out of a day. . . . I feel very blue about diving into the woods for ten days or more, but I take courage in the hope that it will be the last time for some months. . . . In packing manuscripts, note-books, etc., be very careful so that they shall be secure. . . . I forgot my razor, so you will find me in a ferocious beard when I come out of the woods.

July 19th.

. . A pleasant journey but a weary night, the unending grind of a sternwheeler crawling over sand-bars and stumps, a wretched hotel with the din of dinner and its stench; it makes me sick, so I must seek a level place in the open if it is to be found.

Aug. 8.

. . . I am tolerably well but tired of this endless chase. Have had good luck with my geological work but bad luck with my personal effects. I hope you are gradually making ready for the trip East. Don't be anxious about me, for I have some acquaintances at Hickman who will look after me, and the hope of getting through quickly will carry me safely through. . . .

Willard, Aug. 18, '75.

.. Everything has gone to sixes and sevens, only part of our things arrived, horses sore-backed. This is a miserable chafing existence I lead after all. I hope it will soon be mended. Am pretty well despite irritation and hope to feel quite well as soon as we get into the woods. . . Shan't I be happy when we get our heads in the Cambridge Shanty! . . . I am anxious to have a quiet two weeks before the winter's dance begins.

Wednesday [no date].

... We shall sleep at Peach Orchard and make a long march to-morrow. Am quite well, sleeping soundly at night. You will see on the edge of this sheet evidence of a lamentable accident, the smashing of my quinine and iron and the inundation of my portfolio; this life of accidents is accursed. 
Wednesday night [no date].

.. . I hoped that my delay at Albany was the last, but I had a dreary wait of five hours at the Cleveland depot. . . . I have never had a more tedious and lonesome journey than this has been. It seems a month since I started and an age is laid out in the five days to come. I have half a notion that the Survey bill is fated to fail. P- has not yet got in the bill and this is much against it. He cannot act; he is a sort of McClellan in legislation. ... .

Dec. 22nd.

. . . Another day has gone and I come to my "fourthly." About the only good thing in my days at present is their going. . . . I am really tempted to resign this Survey business, but it would be cowardly at this moment. I shall have to wait until next autumn, at least then I must do something to get the load of this winter journey off my shoulders. My highest ambition is to do a [word illegible] work and do it well. I have done my share of running up and down this world, for the present at least. . . .

FraxkFort, Dec. 23.

. . . I had a charming letter from you yesterday, which quite cheered me up. . . . I did not come directly to the hotel, but went to see the Governor; so I told Jeff [the porter], who was at the station, to pick me a room. He remembered that we were here before, so, with a fineness that his white betters would not have shown, he chose this, for which I thank him. I may be able to start up the river on Sunday evening, which should bring me home on Thursday.

Louisville Hotel, Dec. 24th.

... I came here belated by the train, full of happy people going here and there to their Xmas Eve. This town is a rattle of sounds; they are merry enough, I dare say; but I am tired, so they are noise to me. . . . Have got my work in pretty good trim; it moves on fairly. . . . So far I have been quite well, but to-night I am extremely weary, I have never had a journey go more irksomely by. I have only been a week and it seems a month since I left home. . . .

Dec. $27,75$.

.. . It appears that the Survey bill is likely to pass the legislature. I am glad for the sake of my hungry young friends and sorry for our own. I am writing in the car; a drunken man is yelling like a demon and prancing like a devil - a coarse crowd, but full of a fiery animal vigor which in its way is fine. 
Frankfort, Dec. 28, '75.

. . . I am getting on pretty well save for a headache which promises me a day of misery. The Legislature meets Friday; I am to address them on Monday. The chance for the Survey seems good, but many shake their heads. I went to the governor's levee. The last I attended was seventeen years ago; nearly all the men I knew then and saw there are dead. The Governor and his wife are handsome and well mannered. The mass on the whole are a very quiet-mannered people, not a bit loud - a great change in thirty years. A fine but incongruous supper, serving its purpose, however, of feeding a lot of hungry politicians.

Dec. 30, '75.

- . . Many protests are made against my leaving on Tuesday, but I cannot stand the place any longer; it is a perfect pandemonium. To make it worse, the weather is like summer, grass and flowers growing as in spring, no frost since I came here. Confusion is made more hateful by good weather. I have seen no one but members of the Legislature, and am sick of the work, for it is the hardest I have ever had to do. . . . I shall have P- stay here after I have gone to complete the task of explanation; he fits the work, I am sick of the business. It will be a close fight, but the strongest men are for the Survey. [In regard to the answering of endless questions, he writes:] I am pretty well and rested mentally, the conundrum devil is laid for the moment at least.

Geological Cabinet, Piiladelphia, 1876.

... I had a dreary but pretty easy time to Philadelphia. Came here this morning and found much that needed eye and thought. We shall do very well for our means; though we fall behind many nations, we are not surpassed by any state in the real utility of the show. . . .

Centennial Exposition, Friday [no date].

. . . A frightful throng here to-day, marring the earth on one of our perfect autumn days. I am in fair order, and, save for weariness of soul which besets my devious ways, may be said to be well. Dr. R - of Frankfort goes with me to Cincinnati; he is a good fellow and will light the way. . . . Proctor is doing his duty manfully, and as he has his wife and children with him he will be contented. Please send my compass and telescope combined, the large opera-glass, rubber coat, and leggings to Morristown by express. Send brown case with photograph proofs within it, pamphlet on the Antiquity of Caverns and Cave Life in the Ohio Valley, to Proctor at Philadelphia by mail or express. 


\section{E. B. Tawney's letters throw further light upon this period. He writes:-}

BristoL, 1875.

. . There is a notice in Nature of a paper by you in the Atlantic Monthly: I thoroughly agree with what you say in the extract about the English Geological Survey. It fails as a teacher: it is all rule of thumb and men have to teach themselves. The reason is that the School of Mines is not intimately connected with the Survey and the School is badly treated: the professors take little interest in it, and lecture therefore without exciting enthusiasm: no love of learning is begotten and no esprit de corps such as there is in a university. . . .

. . Two Memoirs arrived soon after your letter, on "Ohio-Cavern Life" and "Recent Changes of Sea-Level on the Coast of Maine." They are a source of pleasure to me; reading them brings back pleasant remembrances, snatches of Malvern, Val de Travers walks, in the way things jump into the mind. I shall be glad to receive subsequent parts so that we may notice them in the Geological Record.

Your account of the Appalachian summer teaching of geology sounds very attractive, and if you have it on again next year I shall certainly try to run over and see how you manage things. It is such a novel idea to us and it seems as if it might possibly be imitated here; it would be very desirable to do so. Then as you say one could go to the Buffalo meeting. Many thanks for the prospectus of the Lawrence Scientific School : it appears to be a most complete system of teaching. . . . I should like to see some of your arrangements or understand more of them; you are far ahead of us, I fear.

\section{Again in Kentucky, Mr. Shaler writes :-}

Camp Harvard, July 4, '76.

... This morning finds us climbing up to the gap-shrouded camp. Seventeen days of pretty steady rain has given a natural look to things and a promise of familiar days. Everything is at odds, nothing but the tents and some food. C - has done what was expected of him, but the others have failed to do their duty. I hope to rush things at full pressure. . . . I shall get away on Saturday for a cruise to the northward; after that I shall start for North Carolina and wind up my own work as fast as possible. . . . The mail here is abandoned, at least there has been none for a week. I shall have to run my own line unless the government recovers its organization. I hope for a letter by to-morrow, as I shall send out a searcher this evening. . . . I must seek still other aid from you; send two thermometers, one for use in springs, costing say $\$ 3.00$, Safford's Geology of Tennessee, etc., etc. 
The above reference to the mail recalls the fact that at Cumberland Gap going to the post-office was looked upon somewhat in the light of a joke. On one occasion the postmaster produced a letter from some obscure corner and before handing it to the owner, scanning it closely, discovered the postmark to be Cambridge Station; seized with a thirst for knowledge, he said, "I say, stranger, is n't Boston somewhere near Cambridge?" This happy conjecture was afterward used with effect when Bostonians assumed, as they sometimes did, that Cambridge in a social way was an unimportant suburb of the larger city.

Camp Harvard, July 7, '76.

. . . The machinery of our life gives little pause for anything but utter weariness at night-time. I am glad of it, for it helps along the days. Imagine all of our troubles of last year repeated with half the people and you can see it all before you. We have a pretty good set of students, up to the average of last year I believe, but our Harvard men are not here yet; they will bring it down materially, for they can't compare in character or attainments with the teachers we have. So far I have kept quite well owing to care in eating and exercise. Several of the people have been upset just as last year because of their excessive eating. Still unending rains, but a cool air at night giving a chance for peaceful sleep. . . . I have never welcomed the going of the days as I do now; they slip away slowly but surely and I now count near one fourth of the time behind me.

Camp Harvard, July 12, '76.

I came back last night, having been absent since last Monday. At midnight I was aroused by a messenger with direful news: a Mr. C- from Minnesota, who had betaken himself to archæology, he having been much of a worker in that field, was killed by the caving-in of an excavation in a mound about twenty miles from here. I have just finished preparations for sending the body home; at least we will try, though earth may claim its own before we can get to the railway. Another man was damaged, but we hope he will live. . . . I should be more chagrined than I am, were it not that C_-'s work was no part of the school work and was the result of a sudden change of plan for which I am in no way responsible. Moreover, he was of fifty years and had been digging in mounds for years; besides he was forewarned of the danger.... I found four letters from you, which have cheered me greatly, and I need such help now. . . . 
Fravifort, Aug. 3, '76.

Another busy day behind me and night that is welcome as another stage on. Have got on smoothly with the Governor. There is still further trouble with the printing and the end is not yet. I shall have a boat-ride up the Kentucky River for ten miles with $\mathrm{J}$ - this evening. I expect it will be a bore but rather less than staying in the hotel. . . " Those to whom God wishes well," Schiller says, "those sends He forth out into His beautiful world." I used to think this fine, but Schiller was never a state geologist. I shall hurry to Morristown for letters.

Daxtille Juxction, Aug. 5, '76.

. . I I have just learned that W—was in Danville when I passed through. I spent an hour in a pelting rain trying to find him; asked at post-office, telegraph-office, of mutual acquaintances, etc., but did not find his majesty, who I suppose will be surprised that he could be lost in a town of five thousand people. However, he will doubtless feel badly enough at the result of his carelessness. This is his great fault, he cannot provide for contingencies. . . . It will be a good lesson to him. I am in a bad humor and won't write any more. I have been in a bad humor ever since I left home and fear it is getting chronic. You must prepare to treat it when we meet.

Near MIORRISTows, Aug. 8, '76.

.. Have just finished a long chase for my party, having ridden the greater part of last night. I find them all well and happy. I feel a sense of rest at having my long chase behind me. I am lean and a little overworked, but I believe the open-air life will do much to set me up again. . . . This is a pretty country, forlorn and far away, but the air is sweet and pure - that counts for much.

NEWPORT, Ky., Oct. 14, '76.

Arrived at 9 P. M. in good condition, better than usual. They seem poorly here; all climate-ridden and suffering from Centennial collapse. - has seen my lucubrations on the South and is in sore dudgeon thereat; he will recover however. I now believe Tilden can be elected unless there is a sudden access of folly in the Democracy. Indiana has gone about 5500 Democratic and can hold it in November. New York and Connecticut are safe. So there is some hope of getting out of the frying-pan whether into the fire or no remains to be seen hereafter. I rode out with Dr. R-, a welleducated physician from Frankfort. He is a diligent student and an enthusiast in his profession. Knows the use of water cure and is in successful practice with it. Found G- here; he is as dull as ever, but I believe he is not chronic. 
FRANKFoRT, KY., Dec. 7, '76.

.. I am weary with an unspeakable weariness which has grown with every hour of my journey. . . The Survey bill has made no headway yet. I shall drag it out and make it win or lose this week. It looks as if I might have to stay here until Friday to do this. I shall have to go over to Lexington to-morrow and get a quiet night at Dr. Peter's. P- and Nand the others seem absolutely dependent on the Survey and helpless if it fails. The Legislature is without an efficient leader and so does little business. I greatly doubt whether the bill gets through.

Lexington, Dec. 29, '76.

. . I I have had a piece of good fortune. $\mathrm{M} \longrightarrow$ and $\mathrm{P}-$, half buried in snow in western Kentucky, wisely decided to give up the field work without waiting for me, so I find them here. I have therefore escaped the journey to that part of the state and can fairly hope to be on my way home Tuesday evening. It is an additional reason for being grateful that we are now having a prodigious snow-storm, the heaviest in this region for fifty years. Find matters in good train here; the season's work has been good on the whole, the best yet had in the Survey. I have been pretty well so far. . . .

FraNkFort, Dec. 30 , '76.

.. I wrestled over here this afternoon in a train baffled with snow which people do not know how to deal with. I find enough bothers to keep me until Tuesday afternoon, when I hope to be away for home. . . . If $I$ have much more of this travel to do I shall take to venturing in telegraph stock so that I may feel that it is allowable to send you as many messages as I want to....

The succeeding letters close the correspondence while Mr. Shaler had charge of the Kentucky State Survey.

Frankfort, Ky., Jan. 3, 1878.

. . There is a red heat here over the senatorial election; we cannot get a hearing until that is over. I have sought for my enemies, but do not find them. I dare say they will appear in time. We count the necessary vote, however, and hope to get through in decent shape. I do not intend to come out again in February. The work is detestable.

Since writing the above, Stoddard Johnson has been talking to me for an hour to convince me of the absolute need of my giving a lecture on next Wednesday, when he believes the election will be over. I am so determined to make this my only visit that I may consider it is best to do this. I have 
two or three thousand spent dollars in the question and at least twentyfour hundred to come. If the bill passes it will not hereafter require legislative action and will not compel me to take winter journeys. It is snowing hard and I fear you are having your share as it comes from the east. I hate the thousand miles that separate me from Cambridge.

Frankfort, Kr., Feb. 13, 1878.

I hoped to have started from here to-morrow, but I fear that it will be Friday before I can get away. I shall come through New York in order to see the Tilly Foster mine. In case the ground is clear of snow I may try to get up there on Sunday to finish up my work. . . .

Homboldt, Tenv., June 15, 1878.

I left Louisville at 12.30 and had a very disagreeable ride to this place stifling heat and coal smoke making a very good imitation of hell. Dante needs come again to do justice to it. It is curious to see how far along the season is here. Peaches and plums ripe, and corn in some fields with the plume showing its yellow hue among the green. I have a few hours of waiting here in a place which surely was first named for Humboldt the patent medicine man. All the fences are decorated with Buchu or Ague Bitters advertisements. I am sure that the people have confounded the names of these two good and great men. Such is fame.

I shall be in Columbus this evening at 8 P. M., if the ague does n't shake the train off the track; the very road seems to have the ague.

I am glad to have you spared sight of this forlorn country, . . . it has an aboriginally damned look which is almost awe-inspiring. Hungry, ravaged fields which the woods cannot reclaim, scabby-looking cotton-fields, and dog-fennel pastures. It is hard to gather hope in such fields.

\section{Columbus, Kextucky, June 16, 1878.}

... We are tolerably comfortable here; the house is very clean and well kept; but it is a shifting little town on the banks of the Mississippi, where it is gridironed by the sun. The thermometer is up to 90 degrees. The landlady is "sort of kinsfolk." She is a sister of my old friend Edward T-, who long ago eat and danced himself into the jaws of death. The good woman makes a slender subsistence in keeping a little inn: the natural end of many Virginia efforts with life. I dried myself in the sun for three hours this morning; it seemed to limber me up considerably. I find myself as usual without a toothbrush. I should have three, but they seem to have a curious volatile nature in my hands. I shall have to rob the next apothecary of his stock and 
stuff all my baggage with them. . . . I now remember that it is the custom to wear short dresses at the Mammoth Cave. So you will have to provide yourself with some sort of bloomeresque costume. You must not give up the journey. It is not likely that I shall ever be called this way again. I hope to give a good deal of energy to getting through rapidly, and as I travel towards home for the first two weeks, be sure that no grass will grow under my feet.

Camp near MA FFIELD, June 20, 1878.

We get along slowly: the roads are crooked and the devil of delay in every corner. I now see to my sorrow that I cannot get back to you on Saturday. We have been quite well; the country we have traversed is healthy and high, a beautiful farming country, about the most uniformly good land in the state. . . . We must be at the Mammoth Cave on the sixth. I shall in this way get about a week away from Camp. I am utterly disgusted at the failure of my plans for getting home this week.

Camp, July 28, 1878.

I find my camp, the northern party, - for it is divided into two, - in rather poor shape, doing little save getting over the ground. Last night the other, the southern party, came to a Bull Run retreat, having managed to smash up their instruments, after which, ceasing work, they fell back upon my camp in a demoralized condition. . . . The following is my plan. . . . I have nothing to do but to tell over this plan for putting distance behind me. It is the way out of my present wilderness to the happy land of home. Please see that money is sent to me at Abingdon.

Camp at Old LAxding, July 31, 1878.

Proctor turns west this morning, so that I get a chance to send a letter which will not run the gauntlet of the mountain mails, when each five miles the letters are poured upon a bar-room table and each man takes his pick. My camp is again in working order and doing all that the weather and country will allow. ... . So far we have found an interesting country with a big-limbed, hospitable people. The camp keeps well; they are a set of bronzed savages that do me credit as a camp-master. I shall have to hire two yoke of oxen to complete my outfit, then we can creep up the hills, and along the valleys towards our goal. We are camped in a beautiful amphitheatre, with fine cliffs all around and some fine caves, where it is the fashion to hide for a while after having killed a man; this adds a little romantic touch to the scene. 
Camp near Beattrville, Aug. 1, 1878.

Let us congratulate ourselves that another month of this troubled summer time is among the shadows. We may fairly hope that another six weeks will bring us to our own roof again. We made a good march yesterday, despite a long hill that required four oxen and two horses to each wagon as well as a dozen men to steer the craft. The weather was fine and the woods charming. . . . We now go into a region of mails once a week, so, but for passing chances, we must get few letters out to mail. I believe that it will not be possible to get to Abingdon before the nineteenth of the month without wearing out men and horses or slighting work. So far the wild folk here have been very kind and neighborly, as they doubtless will be to the end of our road. . . .

Camp near Jacksos, Aug. 5, 1878.

We are creeping on, every now and then getting to a piece of road which seems impossible to wagons, but we still get on. In places it is hard to tell that there has ever been a road at all. All that there ever was here to decay is decaying, at least in the way of man's work, for the river runs pure and the woods are beautiful, the better for the worthlessness of man. The people raise just enough for subsistence and get their share of earthly satisfaction out of their feuds and whiskey; but for all their shiftlessness they are kindly and hospitable.... So far, except for ticks, jiggers, fleas, and other plagues of the kind, I have been well. There is, however, a weariness with the life coming over me which it will take all my patience to restrain. I shall reckon on getting to Cambridge on the twentieth. This is a fair-weather reckoning however.

Camp near Pexisygtoy GAP, July 9, 1879.

. . . Our camp is in very rude shape, a sad falling-off from that at Cumberland Gap. Our old tent, ragged and forlorn, is up, but it made me sad to occupy it. I was up all night with D-, who had a severe attack of cholera morbus. . . . Our plans are well matured, so I hope for quick and profitable work. "I shall let folks see how spry I be." To-day at noon I count off one third of my exile. . . .

Camp at Pexsington GaP, July 17, 1879.

... We have had a hard journey . . . and there is another sharp pull before us from this afternoon to next Wednesday, in which time we shall have to make a good many miles of travel; but I shall find them shorter than before, for I am taking great comfort from the reflection that I am in the last ten days of my absence. . . . It is possible that McKay may require my services in North Carolina: if so there will be but little time left for any 
formal rest before term begins. I don't feel that I need it more than last year. My camp life has not been very chafing, though it has been harder work than usual. You will find that the laurel leaves I send will give you good subjects for painting; they are as beautiful as flowers in their forms and colors. . . . It is not worth while to send any papers here. I have no time to read them.

\section{The next letter is written on the way to Colorado.}

On C. \& O. R. R., Aug. 23, 1879.

I have got through one of the most uncomfortable nights of the summer. No sleeping-car, and a lot of chattering idiots to cut out the sleep one might have had doubled up on the seat. Still it is one eighth of my journey done. . . . The 25th, Monday, is almost gone; I have been occupying it with my camp accounts. I have less hair on my head, but they are about straight. I don't believe I have lost this time more than fifty dollars by the wayside. . . .

Near Kaxsas City, Saturday, 1879.

The third night is behind us and we are fairly out on this western sea of earth. It is a dull, clay-sodden earth to which no tenderness of association can well cling. It seems to me a vast, broad sow fat and piggy prairie of generations of bacon and savory fatness, but not the mother earth that one loves. Men will have to live well if they are to sweeten it by deeds and make it lovely by memories. Kansas City is forlorn-looking but prosperous, a conglomeration of rich, poor, decent, vicious, such as I have never seen. The depot is a wonderful whirl of trains and on them drifts out a strange tide of wanderers. I pity the archangel who has to foresee what is to come out of this strange sowing of men in this wilderness - forty sorts of wheat and forty sorts of tares all at once. Although there is much to see I am rather bored with it all. When we see the mountains it will be a relief; but I would not swap the quarter-acre at 13 Bow Street for all this empire of plains. I shall write every day, but as the chance for mails is not good, you must not be anxious if delay occurs.

Denver, Colorado, Dec. 22, 1879.

. . I I have seen the "Rockies." The view is much like that from Montreux (you remember the first time we saw the Dent du Midi) except that in place of the lake we have the valley of the Platte River. They are majestic, but unlovely, a stern battle-front of mountains built up against the ancient seas that wrapped these plains. . . . We have here one of the owners of the mine, a fine rough fellow. I believe he is honest and that McKay will take his chance. Next Monday I hope to be homeward bound. . . . It is 
delightful here, clear, crisp, and, though cold, not chilling. I walked all the morning without needing an overcoat. The town is new and bare but full of decent people and with a great promise for the future. There is a curious absence of children. . . .

Leadville, Colorado, Dec. 25, 1879.

A merry Xmas to you and the children. I wish I could show you the view from the window where I sit. We stayed over night at a mining-camp on the hillside four hundred feet above Leadville. On the west the mountains rise into the great range that parts the waters of the Atlantic and the Pacific. At their feet lies the plain of the upper Arkansas, and on its hither side the concentrated squalor of this great camp where thirty thousand hungry, eager mortals are scratching for wealth in these ancient hills. I was on the mining-ground yesterday and am pleased with its prospect. Yet I do not feel sure that McKay will come to a contract with the owners. . . . The thermometer is 20 degrees below zero, the snow deep, and though the cold does not bite as at home, it is hard to bear. My wits seem frozen in me. I find it hard to fix my mind on work or hold impressions.

Aside from his field work, the letters from Louis Agassiz, extending over a great many years, throw additional light upon his scientific work, and the variety of the demands which Mr. Shaler met in connection with the organization and building up of the Museum; also upon the whole-souled way in which he labored to promote the interests of the institution. There were occasions when he not only had his own hands full, but the added responsibility of holding others up to the mark. In one of his letters Agassiz writes, "Keep all these people busy; make the most of them by pushing them hard." Now and then there is a fatherly word of warning lest he do too much.

". . . I beseech you," he says, "not to lend yourself towards the College to more work of lecturing than you can well bear. They are not likely in a hurry to relieve you of anything you have once undertaken. Remember that I have had to go on with zoölogy and geology together for more than twenty years, and I am afraid too much teaching will interfere with your own scientific progress. Therefore begin with the distinct understanding with the President that you will not consider 
yourself bound to do year after year what you are willing to do this year in order to make a right beginning."

And again: "After what $\mathrm{N}$ - told me just now of your days I beseech you not to undertake more than you can carry. Take my example as a warning; and look out for assistance, active and efficient, sooner than I did. You might at once prepare the ways with some of those working at the Museum."

Later, in regard to the arrangement of fossil collections sent to Dom Pedro II and a number of distinguished scientific men, Agassiz writes, "I have only praises and thanks for such work." Mrs. Agassiz, in the letters which she wrote for her husband, again and again speaks of "the comfort and peace your efficient and affectionate sympathy gives the Professor."

The letters of 1870 written by Agassiz close the correspondence so far as Museum matters are concerned. During this period Mr. Shaler went frequently at Agassiz's request to Deerfield, where he was staying, to talk over plans for the instruction of natural history, and other matters. One of these letters is significant, since the closing sentence reflects Mr. Shaler's, as well as Agassiz's, mind in regard to a subject of high import. Agassiz writes: “. . I I cannot tell you how much comfort your sympathy for my plan gives me. . . I shall have upon the wall cases of the main room busts or portraits of Aristotle, Rondelet, Linnæus, Pallas, Cuvier, and Humboldt. I should like to have Moses there as the man who wrote the first geological essay and rescue him from the false position in which Jews and Christians hold him. This little room will oblige physicists and geologists to remember that our earth is the home of spiritual and intellectual beings. ..." 


\title{
CHAPTER XXI
}

\author{
ITALY
}

$1881-1882$

IN the summer of 1881, owing to the ill health of a member of his family and also to his own run-down condition, Mr. Shaler set sail for Europe. Going first to England, by easy stages he gradually made his approach to Italy, and before the cold season closed in, established himself comfortably in a villa outside the Porta Romana at Florence. When he first saw the Tuscan city it was girt about by the ancient walls that for centuries had been its protection against its many enemies. But now on one side these walls were torn away to let the town grow freely should it fancy to expand. The barrier that once served for safety now only kept the smugglers of wine and oil from evading the duty. The brisk customs officer, with his pen over his ear and a probe to rummage in the loads of hay, took the place of the wardens of old with their trumpets and cross-bows. The old scenes were doubtless more picturesque, but through the gate the tide of life still flowed. All the wagons of the country people must stop and be searched, for everything that came into the town was taxed. This made the gate a whirlpool in the stream of life, and Mr. Shaler never passed through it, though it might be several times a day, without seeing something that was worth telling, or getting some hint as to the real nature of the people.

In his walks he was frequently accompanied by an English officer who had survived many perilous campaigns in India. Both were exceedingly critical of the Italian soldier; they deprecated his lack of discipline and especially when on duty his 
slouchy gait. At the Porta Romana the sentinel who guarded the entrance, no matter how often he was replaced, was to their minds always the same incompetent pigeon-toed fellow. The general insisted that some day in his march he would inevitably twist one foot round the other, stumble and stick his bayonet in the nearest passer-by. To be thus ignominiously despatched was a fate dreaded by the Indian veteran. He and Mr. Shaler therefore would give the soldier a wide berth and would laughingly congratulate one another whenever they escaped the threatened danger.

As it turned out, the weather for several months proved to be exceptionally fine. Mr. Shaler was thus able to indulge his fancy for long tramps and for the exploration of geological localities. In the intervals between his more extended excursions he studied Florence, - its architecture, its picture galleries, its social conditions, - and became exceedingly fond of what he called "the gloomy old city." Living in the artists' quarter of the town, he saw much of the sculptors who congregate there, and became an interested and keen critic of their work. In several instances where he had gone farther afield than they he was able to guide them to places holding some bit of precious work, hidden from those who tread only the much-frequented ways.

During the winter there came the news of his father's death, and although he was not unprepared for it, it was nevertheless a great grief to him, as the following letters show.

To his brother-in-law, the Hon. Albert S. Berry:-

Florexce, Italy, Jan. 18, 1882.

Your telegram came to me this noon. The date was lost from it, so I am not sure when the end came. If my mother bears it badly and you think seeing me would be a consolation to her, please telegraph me at any moment. . . I I cannot tell you how much I deplore my absence. If it were for any private gain I should curse the day I set my foot on ship and put half the world between me and home. The parting is harder to bear than I thought it would be. I know that he wished for death and that death was the only 
help the world held for him. Yet now that it has come I feel as if much of the good of life has gone with him. Time will wear this down, nothing is permanent with man, still a great change will always rest upon our lives who knew him for father. . . . I cannot thank you enough for your ceaseless kindness in our great trial.

To his mother:-

Florence, Italy, Jan. 18, 1882.

I would that I could have been with you when the end came. I have never so grieved over our parting as I have done this day. I hope you will make nothing of the distance, but let me come to you if I can be of any comfort to you. ... I I so hope that the end was in peace and that you have courage to bear the blow. I know that it will be hard to bear, for I feel myself that it is a sore trial, though we have so long awaited it and know so well that it is for the best. Let us take heart in the surety of that meeting beyond the earth that should help us to bear all partings here. When we parted, he told me that he longed for the end that he might no longer suffer from the confusion of mind that beset him. . . .

In his books Mr. Shaler ordinarily wrote so philosophically of death that to those who knew his devoted nature, it seemed almost as if upon such occasions he made an effort to chill his deeper emotions. It must be said, however, that in the course of his life he had been called upon to mourn those only, who, either because of disease or the limitations of years, had ended their days at a timely moment. For all the largeness of his conception of life and death we can but believe that, in face of the supreme bereavement, philosophy would have been to him, as to others, a cold comforter. In other words, when the man of science holds the pen there is a sense of the sufficiency of philosophy, but when the poet writes there is the cry of the heart. In his "Elizabeth" he speaks of -

That sorrow vast and vain for ages gone

For beauty turned to dust; for voices still That waked forgotten love to ecstasy, For all the souls we know kin to our own With whom we never can exchange a cry Across the gulf that parts us. 
In the notes which Mr. Shaler kept while in Italy is ample record of his outdoor experiences. His scientific observations and those concerned with human nature are closely interwoven, for here as everywhere the scientist and the humanist marched together. Since the lack of space compels a choice between the two, we shall give extracts dealing more particularly with men and the picturesque aspects of Italian life; for these subjects seem in a way to be nearer to him.

\section{The first walk he describes was that which led to Impruneta.}

Most travellers in Italy know Florence, but few are sagacious enough to give time for journeys in its environs. . . . Within twenty miles around there is the Italy of the middle ages with its face unchanged, as unlike the Haussmannized city as the fourteenth century is unlike our own. There are roads that look as they did when they bore the armies of Rome, and villages that Dante would find in nothing different from what they were when he saw hell beneath their pavements and a better flame in the blue sky above. . . . Let me premise that these journeys should be made afoot, or if that is not possible, in the little native two-wheeled gigs. If the stranger goes in a city carriage he carries with him an atmosphere of disenchantment a sort of cock-crow that sends the mystery away from his path. The beggar and the innkeeper mark him for their own. Every group of peasants dissolves and the people face about to gape at the English milor and speculate on him. Even the hills and walls look unnatural. The people are always sensitive to anything like obtrusive observation, for among this singularly sensitive folk the least onlooking freezes them into stolidity. . . .

I left Florence before sunrise of a winter's morning when the snow-clad hills were still sending their tides of nipping air into the green valleys below. The streets and roads of the town were white with hoar frost, and at the Porta Romana the peasants, waiting with their loads of wine and oil for the slow process of the octroi officers, were crowded around a fire of straw or dancing with antic gyres to keep their slow blood in motion. These Italian skies light wonderfully at dawn. At evening there is want of cloud to enrich the vault, but in the coming of day the light floods the upper air, which though transparent is vaporous, and seems to set it afire. This gold of the heavens came lower and lower until it caught the hilltops at Certosa two miles out; the dawn was just catching the spires and roofs in its glory while the river Arno held the night in its vapors. I have never seen this effect of sun-bathed hilltops so perfect in any other place. It turned the ancient monastery into something favored of heaven, and despite the want of favor 
for all things monkish that comes to those who know Italy well, I could not help feeling that there must be a holy ghost, a gift of things unspeakable descending in this flood of light. Near by is an avenue of cypresses that climb a long hill toward the east, going from the stream to the summit.-These Italian cypresses are the most monumental of trees; stiff as a Lombardy poplar, they want grace and give none of that sense of enduring shelter that belongs to our Northern trees, but like all trees they have a perfect fitness for their landscape. Here the best use of a tree is to look monumental. These cypresses are tiresome things when they grow wild; they look like the trees of Noah's Ark, but in an avenue they are like the propylæa of a temple.

At the bridge over the Arno I stopped to watch the stream of folk going to the city. An Italian town lives from day to day, so each morning the carts stream in full of all sorts of stores. They are vehicles of two thousand years ago, two-wheeled, of a form that we may sometimes see carved on Roman monuments; the horses and donkeys weighed down with gear that helps nothing save their picturesqueness. In a quarter of an hour I saw contributions to almost every natural need - wood, charcoal, heaps of faggots for the brief fire that the Italians use for cooking, crates of wine and oil, wagons with boards stacked up like hay in a lattice of wooden strips; and with them a host of sturdy, cold, pinched men munching their breakfast of wine and bread as they went.

In the corners of the houses where the sun's rays were coming the people huddled like barnyard fowls taking the enlivening warmth. . . . There are few small dwellings and these of rather recent date. The greater part of the dwellings are really strongholds that could easily be held even in modern war against anything but artillery. The love of strong construction that the ages of fear imposed on the people makes even the modern houses keep to the fortress type. Up on the rolling table-land I find people at work in the field. The Tuscan is as good a spader as the Irishman. He is an earthlover. There is no end to the brawny patience with which he cares for the fat valley lands where his vines and mulberry trees share the ground with grain, or gives to the rescuing of some profit from the rocky hillsides above. The men and women work together in the fields. At this season they are spading the richer spaces between the mulberry trees for their spring vegetables. A straight-handled spade, the staff six feet or so long, is driven into the ground, the handle is shaken to and fro in a rhythmic swing, and the slow, steady motion gives time for the melodious chatter that seasons all labor in this cheerful land.

In three miles of way I have passed through several clusters of villas, the summer homes of Florentines. The habit of having a country as well as a town house is older here than in any other land, and to the close association 
it brings between the town and country folk is attributable much of the good relations that maintain between the wealthy and the poor. The tenantry hold the land on the métayer system, the most perfect tenant system that has ever been devised. The landowner furnishes the land, the seed, the beasts, and the few tools that the work requires. When the crop is gathered he receives half in kind. The rest goes to the tiller. It is easy to see that this is a true partnership, and that the vexed and vexing things that come with rack-rents are avoided. If the heavens favor the crop both peasant and lord share the increase. In times of bad seasons they share the hardships. As long as a tiller is faithful to the work the proprietor has no interest in change; given the inequalities that must exist between rich and poor, this system is the best that can be found for lessening the hardships. We see its results in the easy courtesy that rules both classes. If you speak to a peasant he meets you with a smile and a bow; no cringing, no sense of difference marks your talk with him. The droll land pride of the French peasant, and the cloddy quality of the English laborer, are alike absent. There is an easy swing about his social contact that is hard to describe.

Impruneta is a village of two or three thousand people gathered about a fine old Tuscan church with solemn monumental outer walls and a fine unbroken tower, windowless up to the bell clock. Though outwardly a mean heap of masonry, the church is rich within. The town is gathered about the church, and the church is gathered about a wonderful figure of the Virgin.

At Impruneta I met by appointment my guide to whom I was commended. I had been assured that he was quite insane in a harmless way, but that he knew the nooks and crannies of the hills for many miles about; guides are rare in Italy, and except from the shepherds within range of their sheep walks, it is hard to get any advice concerning the mountain paths. My guide looked his reputation. He was an unkempt, fantastic old fellow who, from the time I appeared around the corner of the road until I left him at sundown, poured on me a torrent of rural Tuscan that was wonderful to hear. Save when I succeeded in avoiding him on some very steep hill I had no respite from the deluge of his conversation. Even then the rest was brief, for by those skilled in this liquid speech a cubic inch of air can be whipped by the tongue into an amazing lather of sound. Despite the badgering he gave me, which was the sorer because I am accustomed to walk alone, this old fellow was mightily interesting. He had patched-up opinions on everything and had a curiosity that was a devouring flame. He looked almost bloodthirsty when I failed to stand and deliver an answer to his thousand and one questions. It was clear that his insanity came from a violent accession of the philosophic desire to know. 
In the course of my day I managed to see the industries that support this well-conditioned village. The land about it is so poor that it cannot do much more than feed itself; indeed but for the Madonna there would never have been a town here at all. The burden of life is carried on straw braid. The women and children do this work; the men are busied in preparing the straw with various dyeing and softening processes for the work of the hands. There are also some potteries. It was curious to notice that the forms of the vessels have not changed since ancient times. It is only when the people begin to consider the foreign market that they get a modern flavor in their work. The great amphoræ, each big enough to hold several middle-sized thieves, particularly fixed my attention. The people of this land have never become reconciled to the barrel. One rarely sees hooped vessels of any form, and they are generally tubs. I have never seen a cask on duty that would hold over fifteen gallons, and these are of a flattened form and show that the principle of the barrel has never been understood. The same is the case with the wheelbarrow; this, though an invention of Leonardo da Vinci, has never taken in Italy. No room is found here for the machinery of life that has been invented in this century. Simple as the life is, it is cast in an iron mould.

After my tramp about Impruneta I found my way into a little country inn where a provision of bread, eggs, and sausages was after much din brought out of the darkness. My guide ate with me and had the best of the appetite as he had of the conversation. It was wonderful to see how he, though a little man, could do trencher work while he lectured me on all conceivable things. A flask of wine and half a grindstone of bread went to support his loquacity. With all his wolf-like hunger there was a certain grace in his table-manners that would have been sought in vain among Northern people of the same class. The landlord was a Garibaldian; the only picture in the house was one of this hero and when I took off my hat to it he almost embraced me. It is good to see the intensity of the devotion to this man of the people. Unfortunately devotion to him means a separation from the old rule of the church, and this rule, however evil in many ways, cannot be destroyed without leaving their uneducated minds hopelessly adrift. . . .

My guide led me to his house, entered through dark and unsavory ways and several ladderlike steps. The larger room was the place of abode, and the shop where he earns a pittance in carving out little blocks of the beautiful serpentines which I came to study. By the fireplace, where probably there had been a fire some centuries ago, before the forest was stripped away, sat two women, his wife and daughter. Both were pinched-looking and still, except that their fingers were nimbly at work pleating straw, their morning's work, several yards in length, lying in bright yellow curls at their feet. The walls black with the slow coloring that centuries give, the stone floor, 
the sunless aspect of things, made it as forbidding a dwelling as one often sees. The place seemed very old; its present inmates may have been the last of half a hundred tenants of its sombre space. The memory turns with pleasure from these tomb-like dwellings, from the momentary prisoners of the place, to the frontiersman's log cabin, or the New England wooden cottage, that thoroughly belongs to its possessor, fits his momentary needs, and is as much a part of his individuality as a snake's skin or the burrow of a rabbit. All modern Italy is in the prison of antiquity.

After I had enriched my guide by purchasing a lot of his polished stones we went again into the fields. . . . The serpentines at Impruneta are singularly varied in their structure and of wonderful beauty. In no small acquaintance with stones I have never seen more beautiful bits than can be found here. When polished they are natural mosaics. Yet they are and always have been quite unused. This people have so little sense of natural beauty that they would always prefer a Roman scarf to a rainbow.

Before the day at Impruneta was ended I climbed a hill that gave a fine view to the southwest. Travelling in the valleys of Italy one is apt to conceive it as a very fertile land; such it is near the streams and on some of the mountain-spurs, but from the highlands we look over vast wastes of sterile mountains that give only a scanty pasture to little flocks of sheep and goats. Even in this garden region of Tuscany the average fertility is less than that of New Hampshire. On my walk I fell in with some woodcutters at their mid-day meal, to which they were reclining on couches of brush; a loaf of bread in the substantial form of a small grindstone, and Florence flasks of the reddened water that does duty here for wine, was their diet. This three times a day, with some bits of pork or mutton on feast days, makes the staple of their food. Yet they are a capitally conditioned race. They are never tall, rarely misshapen, but a remarkably even, serviceable-looking lot of men and women. The women I met in my roving walks, which led us by small households, were all busy with their straw-weaving and seemed to have no household cares. The bread is baked by the baker and the wine is made once a year. This is the staple of all meals that have been eaten by the peasant since before the time of Rome. The warming of the household is carried on by means of a pot of ashes with a live coal buried in it; at the start it is urged to its fiery course by means of a small paper fan. When well alight it will give out about as much heat as a small kitten; but by nursing it in their hands and putting it under their garments the aged women seem to keep warm enough to braid straw and gossip.

The next tramp of which there are notes is in the region between Prato and Monte Ferrato. 
January 25, 1882.

. . My aim was to see some masses of serpentine that lie near Figline, a hamlet a few miles northwest of Prato. These make the mountain-mass of Monte Ferrato, or the iron mountain. Before noon I found myself shut in the bushy valleys of this set of curious hills that have furnished the decorative stone for the incrustation of the Florentine churches. Like all the other mountains of Tuscany these hills were stripped of their woods during the reigns of the grand dukes. When the Austrians came they set to work to restore the forests, but the soil had wasted away so that it was hard to regain what has been lost; still in the splintered serpentines of these hills hardy species of pines were growing in the ordered rows of a planted wood. Through them I climbed to the summit, about fifteen hundred feet above the sea. The only human interest I found was a new nunnery tucked away in the shrubby trees. After the general destruction of all cloistered places by the Italian government some years ago, a holocaust that left only a few of the greater historic places and these shorn of their ancient grandeur, there seemed for a time an end of their life in Italy, but now they are here and there creeping back into a little vitality. At the gateway of this new cloister were two figures, one of Christ and the other of the Virgin, which for artistic abominableness exceeded any human images that I ever saw. Nothing is more curious than the incapacity of the Roman Church to hold to its art traditions; when in this day, in this land, steeped for centuries in art influences, they try to present something artistic, the chance is that their work is much more hair-lifting than what we should find in Arkansas. In the whole field of human psychology I know nothing more puzzling than this utter loss of power to retain the art training which we find here. From the contemplation of this brutal Christ and stupid Virgin it was a luxury to escape to the hillsides, though a walk through a pine brushwood is not more fascinating here than elsewhere.

It is wonderful how hot a Tuscan winter noonday can be; in the morning I walked on ground frozen almost hard enough to bear up the feet, at noon the south hillsides were as hot as of a summer day, even the earth felt hot on the surface. On the top of the hill was the ruin of some very ancient building, quite tumbled to its foundations. On the old platform where it stood there was a scant grass-grown soil, and here a score of ragged sheep were nibbling while an ancient shepherd watched their hungry scrambles over the mounds of stone. It was an epitome of Italy, an aged man and an aged art, whose ruins gave a pittance to a dwarfed life. The old fellow gave me a long history of the edifice, which amounted to this: it was an old ruin and no one knew anything about it. He told his tale in a slow quaver of voice. His speech was a pure ancient Tuscan, which I thought much more like the 
language of Dante than that of the city or even the village folk. The most wonderful thing about him was his cloak. These shepherd cloaks are of the fashion set by Jacob. I believe that they may have existed as garmental entities since the time of the Cæsars, renewed each year in parts, but perennial as wholes; their system of construction gives them no natural end, they may outlast a race.

It is the time of carnival, and some special saint's day has doubled the obligation to make a noise. All the while I was upon the hills there came from the invisible villages which were crowded in the narrow valleys at their feet an almost ceaseless ringing of church bells. These narrow valleys carried a sound of bells for great distances. After you have walked for hours in hills, wild and remote looking as those of Colorado, the rhythmic beat of some church chime will start in the air about you and appear to come from every side. The effect is singularly awe-inspiring, for the sound seems ethereal, such as the skies might send down.

There are considerable quarries in these hills, but in them the modern contrivances of cranes and tramways are unknown; except that a little gunpowder is used there is no difference between the present methods and those of the most ancient days.

Descending to the east of the mountain, I came into a valley watered by a swift, clear stream. I followed the stream toward the plain, passing through the village of Figline, where there was a great crowd by the bridge, watching with bucolic interest the process of butchering some well-grown pigs. In this, as in everything else, the country people showed their utter want of contrivance. The dead beasts lay sprawled in the mud while the butchers were trying to remove the hair by wisps of burning straw, or to clean them in the same uncomfortable position. I wish the social philosophers would tell us why inventiveness increases with the latitude and finds its zero at the equator. It is not a matter of willingness to labor, for I have never seen a more devotedly industrious people than these Tuscans; they have quick minds, are pliant and fertile in speech, fairly introspective, and yet they meet the world of fact in a dumb, helpless way.

So intent was Figline on the pig-killing that I slipped through the crowd without being observed. Neither my look of northern forests - all foreigners are forestieri, or men of the woods, to these people - nor my hammer, bag, and maps caught the intent eye of the people, who usually perceive the stranger afar off. Soon after leaving the village, the brook I had followed for some miles and with which I had fallen quite in love ceased its noise and began to creep silently over the plains. On either side were dykes, at first low but growing higher until the stream stalked along on stilts with its bed of rolled stones above the level of the grain-fields between which it 
passed. This battle with the mountain streams makes the tillage of the Italian alluvial plains a costly matter - costlier than the Hollanders' fight with the sea. The root of the difficulty lies in the want of protecting forests in the hills. The rocks are soft and break to pieces rapidly, there being no mat of roots to hold them fast; while they are decaying into soil they are tumbled down by the floods in such masses that they gorge the river channels. . . . It will take centuries of forethoughtful labor to restore the forests to these Tuscan mountains, and so restore the river-systems to their natural state.

I came back from Prato to Florence in one of the slow-coach local trains. In the carriage I found a young Italian reading a German book. The sight was sufficiently rare to lead me to seek conversation with my travellingcompanion, and he proved to be a very intelligent man, one of the new Italy that is full of hope and gives one's confidence in the race a great lift; keen, clear-minded, with a desire to have his country even with the world. The young Italian, though not a frequent, is a very comfortable, spectacle to those who desire the best future of his people. . . . Farther along I made occasion to have parleys with some of the country folk I met upon the way. They are the deftest people in casual rencontre I have ever seen; they have an ease in contact with a man of strange nationality that one rarely finds among provincial peoples; in fact they are less provincial than any folk I ever saw. My Italian is very bad and my looks excessively foreign to this land, yet I never saw my strangeness mirrored in their eyes. I had a tilt in politeness with one old clumsy-looking peasant; we bowed and exchanged courtesies of grimace in which I did my best, but the ancient rustic went me better in every effort to show mutual consideration, all with the gravity of a Chesterfield. After every day spent with them in the field I come back more convinced that there is a power under the hidebound life of these people that will yet find its place in the world.

\section{Above Certosa:-}

February 3, 1882.

The Via Romana clings in the valleys for many miles south of Florence, and most travellers pass through it because of its historic associations, but they rarely take the steep zigzag roads that lead up from the banks of the Arno to the beautiful rolling highlands that lie on either hand. The day I took the road up on to this table-land was one of those when the Tuscan winter lapses into spring. It was still February, but the violets dim and the daffodils, which in England, Shakespeare tells us, " take the winds of March with beauty," were known in earth and air. From a sheltered corner a froward poppy looked out over the wheat-field that was still the soft grassy tangle that precedes the shooting stems. For some days the permanent 
leaves of the olive had been brightening their green. In the cold days of January they looked very sere, but now they were getting the sap back; they were no longer curled and twisted by their emptiness, but were as full of life as the plumage of a bird. At its best the foliage of the olive is very beautiful; the feathery, tufty masses scarcely dense enough to make a shade have a certain domesticity and peacefulness of look I know in no other tree.

On the thinner upland regions the olive replaces the mulberry. It is never trained, for it is not such a vegetable donkey as the mulberry, but must follow its bent; between these lines of trees the vines are planted. The workmen are now at work, giving the twigs of the vine their appointed attitudes in the branches. In the distance each of these binders of the vine looks like one of Lord Monboddo's caudal men, for from his back depends a fringed tail, which nearer inspection shows to be a bunch of willows for the work of sustaining the vines. Wherever a stream makes the ground moist we may see rows of willows, now very red, since the sap has given new life to their bark; each twig is as full-looking as a cow's udder.

If we look closely at the structure of the great villas that dot the landscape we can see that they are built for this peculiar agriculture; they have a vast amount of open archways and finely ventilated lofts. I like these villas as country places much more than the English country house. In the villa the utilities, in its spacious clean courts, arched granges, and other offices, pass by insensible gradations into the state and elegance of the mansion; and, above all, the dark loggia facing the north suggests this perennial freedom of the outer air. Yet there is one sore need in this nearly perfect landscape. For some time I was puzzled that amid so much beauty there should be a strange sense of desolation. This is because there is never a trace of a beast in the open air, save in labor. I have walked some hundreds of miles in Tuscany and have not yet seen a cow. Where the mothers of these stately oxen live is more than I can imagine. There is none of that charming sense of domesticity in country life that comes with the sight of the passive flocks and green pastures. We do not know how much we miss in its loss until in this country we find its value by its absence. There are no pasture fields in Tuscany. Where Nature denies everything but a few tufts of grass among the stones, the shepherd drives his sheep, which eat the little there is, and move on; the sheep go like grasshoppers over the ground, there not being enough to keep them still. Even the donkeys are more than usually cowed; their bray is a melancholy sound, and though there may be a dozen of them together they never join their voices.

I find these high hills, with a russet undergrowth of bushy oaks that hold their last year's leaves, and with their array of solitary pines, singularly 
charming. Every unnecessary branch is cut away and bound into faggots; the cones are gathered for firewood. . . .

On my way back I was startled by one of those processions that in one fashion or another tread all human ways. I was on the terrace of a villa, gazing at the distant prospect, when from the door of a house there appeared a boy with a banner surmounted by a cross; next after him an old priest with his book; then a bier on which was a slight uncoffined body, covered with a white cloth. This bier was borne by four young peasant women, dressed in their holiday attire, and each carried in the free hand a white wand, which I suppose represented the usual candle. There were no other persons; the little train went away in silence toward the parish church; their burden seemed easily borne.

\section{Monte Morello:-}

February 27, 1882.

Northwest of Florence there is a very noble-looking group of mountains known as Monte Morello. They are only about three thousand feet high, but their steep slopes lead with noble lines from the plain, so that they are grander than many mountains that labor up to thrice their height above the sea. . . . In times of storm, when the clouds enfold them and their deep ravines are full of abysmal shadows, they seem the very abodes of thunder. In the clear day their gray masses rise above the plain, with its crowd of villages and villas, an image of the stern, desolate eternity of space which wraps in this little skim of life and merriment that is borne upon the surface of the world. ... I know no greater fortune that can be given to a city than the sight of such a nobleness of unchangeable nature. The only thing is that few among its people ever look from its ways up to the throne of the Infinite that stands beyond the gates.

Alluding to a scene in a little schoolroom, where the children were learning an arithmetic lesson and at the same time keeping their fingers busy plaiting straw, the journal continues:-

This excessive laboriousness does not seem to be absolutely a thing of necessity: the children are all well clad, and outside of the cities and away from the alluvial lands they look the picture of well-fed contentment. The land system assures food even in bad seasons; every farm, nearly every field, has wine, wheat, and silk for its products, and out of these some one is sure to succeed. This ceaseless toiling is partly due to the want of other diverting activities; the mind of the people is not much occupied with politics, they 
are without the least tincture of the reading instinct, so what force they have goes to practical things.

I found my mountain hard to get access to on account of the wide fringe of walled grounds around its base. At length despairing of flanking these barriers, I asked my way at a farmhouse. At first I found only a boy of ten, who, unlike Italian children in general, was afraid of the stranger; he, however, was induced to seek his elders, and the mother, though evidently doubtful, got rid of me by pointing the way to a footpath that led through the barnyard and gave access to the hills.

The way for a mile or two was up a roaring brook, the bed of which was immensely encumbered with the wreck of the rocks; its fall was steep, and every few hundred feet there was a great masonry wall across it, some of these walls superb engineering constructions. The view was singularly perfect. Through the rocky jaws of the cliff I saw a foreground of olive orchards, vines, and fine houses; half a mile off was a ruined little castle, its single tall tower with half its battlements fallen away and its keep masked with barns and out-houses. . . .

It is rare in Tuscany that we find a picturesque ruin to fill any foreground, and the complete and abounding ruins of old castles that are so common in all northern Europe seem quite unknown here. I am inclined to think that the reason is that the nobleman, apart from the town, never existed in Italy to the extent that he did in northern Europe. Here the lord was the lord of towns rather than of castles. Individually, they were not such a militant class as those of northern countries. The little cities gave the protection that they might have afforded, and so the ruins of their strength and state do not so plentifully remain upon the hilltops. Something also is due to the want of that change in the customs of life that has caused the dominant class of the North to desire more comfortable abodes and led them to betake themselves to modern dwellings. The castles that remain here fit the fashion of the life; their darkness and sombreness do not in this land of sun and heat unfit them for the tenancy of men.

After dinner I turned myself again to the hillside. It was very steep, but a well-made though abandoned path crept for some way up the ravine. Where a little earth had been held in a cranny there was a stunted tree, planted in modern times, but for want of company it had refused to do much to help itself. It was a relief to get above these forlorn and impotent efforts of man to repair the waste of other centuries. Although the absence of vegetation gives a desolate look to a landscape, it has for the geologist much in the way of compensation. I could now see in the bare steeps the architecture of the mountain which I came to study. Looked at from the valley, the structure appeared very simple; the clearly bedded rocks seemed piled one 
on top of the other, and the whole tilted toward the northwest at a gentle angle; up here I can see that the strata have been squeezed about, twisted and overturned, until even the eye practised in dissecting such knots can hardly discern how the whole is put together. My brethren of the hammer are given to the notion that they can often make out the structure of a mountain, where the rocks are well exposed, without setting foot upon it; but they will be easily deceived, for it happens that in the mountain precipices the rocks at certain angles will mark themselves by strong lines on the hillsides, while those of other degrees of slope will be quite masked in their own débris. Here was what seemed a mile or two away a perfectly simple anatomy, turned into a problem that would require weeks to unravel when seen with a closer eye.

As I rose near the summit of the mountain the strong gale, from which I had been in a measure protected during the earlier stages of the ascent, began to baffle me. The traces of snow were still on the rocks, and the air from over the higher mountains was very cold and stifling from the force with which it beat against my face. When I came within a hundred feet of the top I could no longer stand against it, but had to grimp along on all fours, dragging my satchel and plaid as I went. It required some energy to get into a state for observation, for the wind was strong enough to blow pebbles of a dangerous size up over the ledge of the mountain. The scene was noble enough to overcome the discomfort. All around lay the mountains of Tuscany. In the west lay the fantastic peaks of Carrara, the most thoroughly individualized mountains in all Europe; they do not look like mountains, but are shaped rather like the curious frost work that forms on the moist soil of a morning in early winter; they do not belong to any of the recognized orders of mountain architecture which are well determined.

The most beautiful effect is given by the deep gorges that scar all these hills; the sun, now oblique and near its setting, filled them with purplishblack shadows, while all that lay in the sun was of a vivid reddish gray that belongs to the limestone rocks. This gamut of color is one I have never seen in any other land, and I suppose to its strangeness must be attributed the unearthliness of the effect. The lonely, sharp peak, the desolate, strangely colored landscape, the surging wind that seemed trying to sweep me off into space, all tended to raise that deep sense of mystery and fear that ever underlies our minds. The commonplace sense of our daily life usually protects us from this strangest and most terrible of all emotions, so that many know it only in dreams. Sometimes, by night on the picket line, in the face of an active enemy, when the darkness suddenly seemed to become all alive, or when exploring alone in some newly opened cavern, I have felt this sense of the terrible in the surrounding world; but though I have climbed mary 
a score of mountain-tops I never before felt it in the face of day. Turning from the serried world in the distance, I noticed that the peak on which I stood bore a curious mark of man's work: the top, including an acre or two, had clearly been levelled off and there was reason to believe that it had been some sort of a stronghold. The wind was too fierce for clear seeing, so I only note the possibility that this levelled summit had been the work of some early people. I have never climbed an isolated hill in this region without finding some faint trace of human occupancy upon it. Always before, however, these traces of man have been shown by some form of masonry however rude.

I found the mountain longer in the descent than in the ascent, for, although the Italians, like their Roman ancestors, are good road-builders, they will not build direct ways in a hilly region, as their forefathers did; even for footpaths they generally keep easy grades, and in their devious ways there are rarely any of those straight cut-off paths that people more accustomed to be in a hurry are sure to make. The result was that while doubling to and fro I saw the train for Florence clear away from the station, and had to make my way to the city in a tram-car. The Italians take greatly to streetcars; walking is to them the opprobrium of life, and even the poorest contadino will spare the two cents necessary to take him on the car. These cars move with an endless tooting of tin horns and a complicated system of supervision; still they move, and this slow world seems a little quickened as they pass. They make rather a blunt point for the edge of civilization's wedge, but I dare say in time they will bring many another of our modern complications in their train; so that this archaic, simple life will be driven away into history.

\section{Val d'Arno:-}

March 9, 1882.

I left the train at the pleasant old town of San Giovanni, in its day one of the southern bulwarks of the Florentine Republic. It seems to have been a prosperous little city, as indeed were all those towns of the fat old lake lands. The broad main street has homes more beautiful than those of most small Tuscan cities. There is a curious old podestà, or town hall, with a loggia on three sides of it.

I had to walk some miles to the country to find the guide who was to show me the geological localities. My intelligent companion, the conservator of the cabinet of San Marco, in Florence, did not know the ground we were on in an intimate way, so we had to seek out a man who spent much of his time in gathering fossils and who knew what could be found and where to seek it. The road led into the intricate valleys of the low hills, and upon it 
we met many teams of the splendid white oxen, always noble beasts, but finer here than I have ever seen before. For beauty I am compelled to give them a place above any other beasts. They are very long, their high shoulders nearly as tall as race-horses, their bodies are not over large but made as ships, their limbs are wonderfully long and clean, and their well-shapen feet the perfection of a cloven foot, which to my mind is more beautiful in form than that of the horse. Their color is creamy white, except the nose, which is of a lustrous black. The head, set upon an arched neck, is small and of a beautiful model. The eyes are large and have the same soft beauty we often find in their masters'. Their yokes are better-shaped than our own and do not seem to bear them down, - indeed, as they go along with a swinging walk that differs as much from the dull pace of our American oxen as does the step of a hunter from that of a cart-horse, they are the embodiment of animal beauty. One sees why the ancients chose these white oxen as their gifts to the gods. They are beautiful enough to gladden the heart of Apollo as they come with crowns of flowers to his altars.

Farther on we began to meet teams of another and less pleasing sort. Large two-wheeled carts laden with brushwood faggots were being tugged over the rough ways by gangs of women and girls, some three or seven making a team. The old women took the wheel-horse position; they were generally unshod, and sterner, more weather-burned creatures I have never seen. These high, toppling loads of brush, looking heavy enough for two horses to draw, urged on by these harnessed, silent old women, through ways that lay among prosperous farms and the stately villas of nobles, madea scene that was more picturesque than pleasing. They were not ill clad and they appeared well fed, but their faces had that hard, bitter look that labor gives to old women more than it does to men. Here Michael Angelo might have found the models for those stern faces of the Parcæ, for they are the faces of the embittered, yet noble-looking, type of poverty one sees so often in Italy. Besides the women with wagons, there was a yet poorer class who bore their burdens of faggots on their heads; at a distance they each looked as if a great part of Birnam Wood was on its way to Dunsinane. Sometimes their heads were lost in the stack of brushwood, and from the clutch their feet made at the ground it was evident that their burden was heavy. This is the first time that I have seen Tuscan women at work that seemed too severe for them, though elsewhere I have seen them spading.

I found my guide at his simple contadino home, of which he was the happy master. Seeing me curious about it, he very gracefully asked if I would like to look through it. This I was glad to do, so I gave the place something like a military inspection. It was clearly an average specimen of its class. The main building was about fifty feet square, two stories in height, with a ram- 
bling " $L$ " and a range of miscellaneous shed-rooms for threshing-floors and for silkworm-culture: the larger part taken up by stabling for the cows and oxen. These, all of the white variety, were amply and comfortably lodged. The stable was very dark, and the silent creatures looked longingly at the light of the open door; there was no ventilation; the air was so heavy with their sugary breath that it soon made me giddy. They, however, seemed to be in a perfect state of health. I fancy animals do not have the same imperative need of fresh air that men do, for they are not obliged to be making nervous force while they are in the house as we are.

The upper story was entered by an external stone stairway, which led to a spacious, low-roofed kitchen. At one end was a large fireplace; on either side of the fire was a space for the old to sit in, with their faces towards the room. An old crone was seated in one, with the additional consolation of a scaldino in her withered hands. The bedrooms, like all the other rooms, had stone floors, and were furnished with large, well-made, clean beds, old presses for the clothes, and long boxes of ancient but unbeautiful forms. These contadini are admirably lodged and are well fed; certainly no other peasantry of Europe are so well off. There was not a bad bed in the house, nor an unwholesome sleeping den, such as one finds in the equivalent class in Germany, France, or England.

I looked over the man's store of fossils, and spent an hour in making a bad trade with him; these fellows are as shrewd as can be in such work. When this was over we were invited to have a meal, but time pressed too much. Our host then insisted that we should wash our hands, which we did while he held the bowl with greatest civility.

We then went across the country to some mines of lignite that have recently been opened on these lake deposits. The deposit is wonderfully thick, being in many places as much as eighty feet deep straight through the bed. . . . When this lignite is removed from the bed it coheres in large blocks, which have, in fact, to be chiselled out of the mass; it is then full of water and must be stacked in long heaps until it dries. The burning quality of the material is equal to that of good pine wood.

Here, as elsewhere in Italy, one is struck with the absence of all the machinery which in America is used in such heavy work. Everything is done by hand with the simplest tools. In this pit there were no appliances that might not have been in use at the building of the Pyramids. The trouble is that the price of labor is so low that there does not seem to be the same temptation here to save it that there is in other countries. All the work is done by the piece, and the best laborers earn only about two francs a day. Yet this gives them a fairly good subsistence. Their housing has been provided by the labor of other centuries, their clothing is nearly all homespun. 
I do not think that the subsistence and clothing of these men cost on the average more than fifteen cents a day. As far as I could see, the working power of the men is excellent. Sometimes they seem to give trouble, for I heard from my guide that the overseer had shot several men since he had been there. This part of the Arno valley has a bad name for lawlessness; indeed I was warned to be on my guard, but, beyond a certain roughness of mien that faintly reminded me of a Yorkshire mining district, I saw nothing out of the way about the people I encountered.

After examining the lignite pits I had time to look about the country. A good deal of the lowland is sterile: there are, however, many patches of oaks that are valued for the mast. Every now and then we came upon a little herd of swine gleaning along the roads, each under the charge of a woman swineherd, who spins from a distaff as she goes. This is the long distaff; it is made of what appears to be a cornstalk, the space of two joints at one end being split longitudinally and forced apart so as to give a frame on which to spread the flax or hemp fibre. I was much interested in the swine; . they are long-legged creatures and are curiously marked, the fore legs and shoulders are white, while all the rest of the body is very black.

I found my guide an interesting fellow, very talkative, but with the puzzling peculiarities of speech that begin to become apparent as soon as we get south of Florence; every initial $c$ is turned to an $h$, cara is hara, cerico is harico, etc. The initial h's dropped in the air of England are all recovered here. The Italian language seems to have wronged nature in not allowing the aspirate any place, while we English give it too much share of breath. On questioning, it was clear that my companicn and my guide both thought they said cara when they said hara. My guide's rustic talk and comments were entertaining. A certain grandee was building a house in the neighborhood, making it three stories, while immemorial usage in these parts made two sufficient; this he thought a gross folly in the matter of palaces. Happening while thus remarking to pass a cemetery he said, "Behold the palace of the contadini."

Returning to San Giovanni I noticed a cart with woven rush sides, driven by some women, and drawn by a pair of beautiful white cows that went nimbly along together, looking happy with their bright burden. It struck me that the turnout would make a good design for a coat-of-arms for the woman's rights party. There were also many curious perambulating shops in the streets; a two-wheeled cart carried a platform about twenty feet long and four feet wide, on which the goods were displayed, one man easily shoving it through the streets. The dames in the windows could be led into temptation by having the shop brought before their eyes, while their ears were tickled with the persuasive assurances of the shopman. 
I came back at sundown. The whole of the majestic mass of Porta Magna was taking the last of the day, making a golden crown of it. In the tram-car was a Florentine man of trade; he spoke a poor English of which he was very proud, and he had cut his beard and his clothes in the conventional English way. It is the fashion here to gird at the English, but there is a foundation of vast admiration of that folk. The Florentine was surprised to hear that there was any profitable lignite in this valley. He complained that everything among his countrymen was done in a corner; that if a business man found a good thing he kept it so secret that until his work was laid bare by death no one would know he had made a fortune, and the business was likely to die with him. There was doubtless some truth in this tale, for secretiveness and want of mutual action and trust seem to be the evils most complained of by the intelligent natives. This does not seem to be the nature of the folk, but the product of their long struggle with the oppression that has been laid upon them. I noticed that all sorts of associations are springing up, and these seem to show by their general success that the power of combination in action is latent in the people; that in their new life they will not want for this element of power.

Having pretty well explored the immediate neighborhood of Florence, Mr. Shaler set out on a journey to the south of Italy. He writes in letters under date of March, 1882:-

Rome, Sunday Evening, March 12, 1882.

With nothing to note save my loneliness I got here at $4.40 \ldots$. I have fallen in with a nice old German scholar from near Hanover. He is bound for Sicily and wants to travel with me. So if I go to Sicily at all I shall have a very decent if rather dull company.

The old Rome we saw together is no longer here, in its place a half-Paris of a city, boulevards, etc. Even the Pantheon has been shorn of its age and looks less old than the British Museum Reading-room.

I walked up the Pincian Hill; met Miss $\mathrm{H}-$. Saw one or two other familiar faces, but spoke to no one else. To-morrow at 6 A. M. I take train for Naples. The next morning I shall go to Vesuvius, and hope to see all that I need in a day.

NAPLES, March 13, 1882.

I came here this afternoon at one o'clock, too late to go to Vesuvius. I hope to attack it to-morrow morning; it is smoking like a great chimney, in a dull, businesslike fashion. I shall not be able to fix the matter of Ætna until I find what its state is. 
The bay is as fine as ever, but it is a stage-curtain beauty, not the homely loveliness of Florence. I had a long walk this morning, and saw a lot of geology of a curious sort, much that will count me hereafter. My German is still waiting for me to go to EEtna, but I have not promised. I shall be glad to hear to-morrow that it had [word illegible] and burst, for I don't want to go farther from my belongings.

This is a swell hotel, so I shall take myself off. Every knave "speaks a little English" and will put it in the bill. The inn in Rome suited me, no English, French, or German, and low prices. I'm tired and must to bed. . . .

$P$. S. March 14. . . Have just been at Vesuvius, so that is off for another term of years.

Hotel Nobile, Naples, March 15, 1882.

Professor Guescard advises me not to try Ætna, as the things I want to see may all be covered with snow. So I shall give that up. In place of it I shall work up some problems here. I feel tired to-day; I have therefore done nothing but work at the University and search for Vesuvian photographs. To-morrow I shall be all right and shall do the Phlegræan Fields between here and Baiæ. The next day I go to Ischia. . . . I wonder where my geological eyes were fifteen years ago. It must have been some other fellow who was here.

Mr. Shaler's notes on Vesuvius and Naples were so hastily written that in most instances they are undecipherable; it has been possible, however, to make out some of them, though perhaps not the most significant. The first relates to the ascent of Vesuvius.

. . . Road to east and main observatory road, lava quite wide, yet covered with thin sheet of cinders. Aloe at 1200 feet slightly frosted. Beautiful to see the grass and flowers creeping over lava; the rapilli fill crevices and decay rapidly, because of large face and vesicular nature. Composite seem to be the best plants to begin. . . .

The mode of explosion in the crater was exactly like a large quarry mine, - the steam smelled slightly of sulphur, but was as easily breathed as ordinary steam, not at all suffocating when it thickened the air so that one could not see a hundred feet. At the minute of uprush of stones (several tons flying at once) the heat was great. At three hundred feet distance stones perceptibly red in all their first flight, and partly so when falling, sometimes splashing where they fell, again rolling up into a loop as they rushed down the slope. ... Saw no secondary explosion in stones; necessary to watch the stones so as to dodge, notes therefore imperfect. 
Darkness overtook me near San Giorgio and thence through a wilderness of lava and villages I went on to Naples. Some fête was on hand, so I found the people, save the very old, gathered in knots before small illuminations; night and dust enabled me to melt into the crowd without notice. Only one small boy found out my strangeness and announced it with a yelp. After you have got so that you fool the dogs, the small boy still scents your strangeness.

Now and then over the walls I could see the red glow of eruption on Vesuvius, but generally there was no light; only the now solid darkness to show its place. At length I got to the long sea-bound streets of Naples. The same large crowds and music of bands between silent streets, with old folk within crooning over a little fire, while I was sweating along in the tramontana. These people in their beautiful nature seem to me after all sad; they creep along with no fire in their eyes, in a weary sadness; though noisy they are not merry. I have never seen an Italian merry as a German, or even an Englishman. Here in face of this mighty nature man seems only a thin shadow.

John P_— - a Scotch gentleman at Naples who was very courteous to Mr. Shaler] was with Stephenson forty years ago at Pompeii ; Stephenson measured cart-tracks and found them to be $4^{\circ} 8^{\prime}$, and said that time was with him in his battle for the narrow gauge. $\mathrm{Mr}$. $\mathrm{P}$ — has been in Naples for forty-five years, and is the owner of a very large machine-shop, employing seven hundred hands; they are, he says, physically weak, amiable, not interested in their work, have considerable ingenuity in contriving easier methods of doing things. Saints' days once a burden are given up. Mr. P- saw Garibaldi's campaign against the Bourbons; he says that the King's troops seemed perfectly mesmerized by Garibaldi's name. If even five thousand of them could have been held to act, Garibaldi's army could have been beaten. The dependence upon the priesthood is gone; the family priest no longer exists. Once he attended to all the household, married the daughters, and saw to it that the souls of all were safely sent on their way. Once the priest was saluted by kissing his hand, now the peasantry pass him in silence. Mr. P_ gives a very bad idea of morals.

He has seen several great eruptions; he describes the roar of the lava as it came against San Sebastiano as something dreadful. He says that in the eruption of 1854 at Torre del Greco, the land rose so as to separate the ends of the rails. . . . The lava ran from Vesuvius through the town to the sea. The deaths in the Atrio del Cavallo in 1872 were from the lava surrounding the people by a divided stream that reunited; some escaped with severe burns by running over the half-solid surface. In the eruption of 1850 toward Boscenalle, the saints and pictures were brought out of the churches in the neighborhood and fixed to trees and walls to stay the flood. But it swept on despite the images. 
As I came out of Naples, Vesuvius was half hidden in a majestic army of cumulus clouds that were lifting from the sea; from one to three thousand feet was hidden by this cloud that cast a vast shadow below it. The whole mountain seemed strangely weird, a thing of speculation, the ghost of mountains that had been. Vesuvius is constantly extending its lines; as it rises higher the lava penetrates farther from the base. It will probably be not more than a century before San Giorgio Borra and Ponticelli will be in danger, and at the rate of extension Pompeii and Naples will be menaced within two hundred years. There is no reason why this great rock mushroom should not gain the size of Ætna and absorb all the region about as far as the Phlegræan Fields. The total mass of the mountain has about doubled in eighteen hundred years, and its growth in the last two hundred and fifty years has been more rapid than before. ... .

The generally good climate is shown in the ruddiness of visage and generally excellent physique of the natives. The people are small; I did not see a six-foot native nor one very brawny; the porters carry light burdens. The women have comely faces, all on one type, flat, small heads, good eyes with no brightness, small, short-fingered hands. Now and then there is a mark of African blood, no trace of Greek. It is a low population, except the gentry, which is very high. The gentry have beautiful manners; they seem to me the best I have ever seen. I asked a venerable-looking old aristocrat my way; he laid his hand on my arm and told it me in accents that were full of a certain subtle sympathy. Now and then a grand face among the poor; one of a man far gone in illness, which I saw in a window, haunts me still - a face out of the past. Naples has had no art, architecture, music, religion, or anything else. Nowhere else is nature so overpowering as at Naples, so charming and so little inspiring.

In the car from Rome another patent American in the corner; all night no sound out of him. A young fellow going away on a journey; four men and three young women to see him off, a roar of lamentation, greater than attended the going of regiments to the field. Thrice they kissed all around, thrice he descended for another bout of kissing and wailing. He was a lean, worthless-looking, dirty youth, with a large, ragged carpet-bag. When he was seated he again and again went over some photographs; when he fell asleep he rolled on the floor but apologized with much grace. Dignifiedlooking man of thirty-five, with a young woman of the harlot class, who smoked, spat, laughed, and wept by turns. He was shy and seemed ill at ease with his burden.

The Italian railway system belongs principally to the government, a large part of their debt has gone to this important work. . . . About Naples the soil is amazingly fertilized by the volcanic ashes that come upon it; the eruption of 1872 put three inches over the land for twenty miles about. 
The journey northward from Florence in March was through the lands of blossoming delight; peach, almond, and apple trees with their delicate shading of green and rose-color made the quickened earth a scene of enchanting beauty. Only near Paris we seemed to retrace the season and began with buds instead of flowers.

Besides revisiting old familiar scenes in Paris, Mr. Shaler spent considerable time at the School of Mines and other homes of science. In one of his rambles he knocked at Dr. BrownSéquard's door. The eminent physiologist at that time was engaged in making some interesting experiments on guineapigs, producing in them, by artificial means, a state of epilepsy. When Mr. Shaler was about to go, the savant asked if he would be good enough to take one of the little animals to Huxley. Since he expected to cross the channel in a few days he willingly undertook the charge. The pig was done up in a paper bag and thrust into his overcoat-pocket. On the way back to the hotel, he stopped at a bird store to purchase a cage for his little charge, and in an unguarded moment took his hand out of his pocket to point to a small wooden one of about the right size. The pig, seizing his opportunity, bounced out on to the floor : whereat the proprietress and her daughter jumped up on the counter and proceeded to scream at the top of their voices. Endeavoring to reassure them, Mr. Shaler called out, "C'est seulement un petit cochon"; the word cochon was all that they heard, and since to be called cochon in French is a deadly insult, indignation was added to their fright. In the meantime the "subject" was captured, and, its owner demonstrating his pacific intent to the crowd which had been attracted by the screams, the women were induced to descend and take their pay for their pains.

Before leaving Florence, Mr. Shaler had suggested that his family give Paris the "go-by," even offering the younger members a considerable bribe if they would stay away; but to Paris they would go, and immediately upon arrival they succumbed 
to the influenza which just then scourged the city. In the stuffy rooms of a hotel the days passed gloomily enough; so when he entered with a merry countenance and exhibited this prize there was much rejoicing. The pig was dubbed the "General," and the attentions due his rank were lavished upon him. He was fed and petted and for a couple of days flourished, then languished, and finally died. When this happened, late in the evening, his little body was put out on the window-sill, and next morning the man who came to make the fire was told to take him away. Instead of obeying he gazed at the puny object, shrugged his shoulders, and exclaimed with uplifted hands, "C'est défendu," and no persuasion would avail until, as he explained, he had got the necessary sanction of the police for its removal. Mr. Shaler, intensely amused at so great regard for legal forms, put the pig in his pocket and sallied forth. In the park he was about to deposit the "General " behind a clump of shrubbery when a policeman, as if divining some flagrant intent, fixed his gaze upon him, and instead of going about his business continued to hover near by. Several efforts to get rid of what had now become a veritable burden in some bushes in other parts of the city proving equally futile, Mr. Shaler gave up the job for that day.

The same evening at dinner by chance one of seeming authority proclaimed the fact that French law was made for French people only, and if once brought into the tribunal for any cause whatsoever a stranger seldom escaped without suffering either fine or imprisonment. Therefore, more than ever anxious to elude, if there were any informality, the guardians of the law, Mr. Shaler started out early the next morning determined to free himself of his embarras. At last on one of the bridges, seizing a favorable moment, over the wall into the Seine he tossed the little creature freighted with its pathological message which in his own person he was destined never to deliver. Ever after with a merry twinkle in his eye, he spoke respectfully of the ubiquity and vigilance of the French policeman - of his 
alert eye for broken bottles, orange-peels, banana-skins, and guinea-pigs.

At Malvern, where, as usual, Mr. Shaler stopped for a course of water-cure treatment before sailing, the world was fresh and green, but there was a desperate chill in the air and the heavily laden sky hung low, so low that one seemed literally to walk with one's head in the clouds. At Boston in the month of May we found the arch of heaven had receded; it was far off, cold, and apparently unattainable: instead of leaves, icicles hung from the branches of the trees, and the thin, shining snow that covered the ground showed, though very nearly in the same latitude, how far removed in climate Boston was from Florence. 


\section{CHAPTER XXII}

\section{SOME FAMILIAR LETTERS}

\section{2-1888}

THE ensuing summer was spent at Campobello. Mr. Shaler had previously worked up the natural features of the island and made a report upon it; he knew it well, therefore, and he was charmed with its beauty. He thought to make a summer home there, but after trying it for two seasons, the distance from Cambridge was found to be against the project, for what he had in mind was a refuge that he could easily reach and thus escape, when it became too burdensome, the pressure of life in Cambridge; indeed, he was in search of a place which at the beginning would serve for a second home, but eventually might be raised to the rank of the first in his affections and order of living. This search was to be rewarded later.

The following letters from Mr. Shaler and others reveal to a certain extent, aside from his regular Cambridge work, the happenings of these years.

Mr. Shaler writes:-

$$
\text { NewPort, KY., June 2, } 1882 .
$$

... I have been out into the country with my mother to visit some of her nephews whom she had not seen for a long time. The visit seemed to cheer her up a bit. They are all well-conditioned bucolic folk with comfortable homes and well-bred families. A pleasant spectacle to one who does not see much of his kin.

I have filled in my time with a novel of Trollope and Hamerton's "Intellectual Life." You will like the latter; it is a pleasant essay on the conditions of culture.

OLYMPIA, KeNTUCKY, Dec. 28, 1883.

I find there is a chance of decent weather, so I shall have to try my journey into the woods [he went to investigate some iron properties] much against my will. . . . I have never had an absence from home that vexed me so 
much. I fear that my humor for the outside world grows less with added years. . . . I expect to close up everything here so that there will be no need of repeating the journey.

Madison, Wisconsin, April 18, 1883.

The appointment at Helena, Montana [the occasion of this visit was to attend a mining suit], is postponed, so I spent the day here to complete my task. I hope to start back about the fifth. Be sure I shall make good fight with space and time. The people here have been most kind. Yet with all my skill in dodging I have had to make three speeches and have been kept in a whirl. Fortunately two days of silence are coming and of them I shall make good use.

CAmbridge, Thursday, —, 1883.

The train (I came by way of Rutland, Vermont) was as usual three hours late. I dined in the Vermont fashion, on a wet-flannel sandwich and a piece of white-pine pie, all out of a brown-paper parcel. I have supped on some bad ice-cream and a sort of degraded ginger-snaps (neither ginger nor snap). You will know that I am well when I tell you I am none the worse for it all. House seems all right. Cambridge, by contrast, as still as a mountain-top.

Staunton, Virginia, June 19, 1883.

I have had two red-hot days in the woods and am over the worst part of my task. I go to-day with Hotchkiss to a place called Roanoke to see some iron properties for future consideration. . . . I have found the woods very restful despite the heat and bad food. If you were here I would gladly stay all the summer. I am satisfied that in a camp one could have perfect summer conditions in the mountains.

Cambridge, Sunday, July, 1883.

I got back here last night in time for the worst continuous cat serenade I have ever heard. Summer war begins. I shall hope to extinguish the species. .. . I wish you were here, Cambridge never seemed so pleasant, almost cold and, cats excepted, quiet. ... I am looking forward to some sort of rest with great longing, for in fact I am very tired. I have my doubts about finding it at Saratoga. If not there we will go elsewhere.

Cambridge, July 15, 1883.

... I shall have to stop over a day at the Livingstone mine. . . . I mind your caution not to rush things: an inward monitor, too, tells me to go slowly that I may go surely. . . . I am more than ever convinced that a change of house is desirable. It is lonesome here. I dined last evening at M-'s. They seem as happy as two old parroquets. . . . 
LICHFTELD, March 9, 1884.

I came back here yesterday as I am sure of something to eat and a room to myself. I have made pretty good headway with the work laid out and hope to paddle homewards on Wednesday. I go to-night to [word illegible] and thence six miles to look up some matters. I shall have a trustworthy companion, so you need not worry yourself about me. This section, though settled for near a century, is still a pathless wilderness, with only here and there an acre of better land. The people are incorrigibly lazy and shiftless.

I am keeping quite well despite bad food and a good deal of work on horseback.

My old coat is going like the parson's "one-hoss shay," all at once and nothing first. So I shall be driven to shelter or shirtsleeves soon.

This is a [word illegible] land and a very uninteresting people, swampy, saturnine fellows, no life, no sparkle except the effervescence of whiskey. I really have but little confidence in any great future for our race in this shape. It must mend or make itself into nothingness. . . .

To his mother:-

CAMbridge, Sept. 22, 1884.

... You cannot imagine how glad we are to hear that you have really had your profit from your dreadful siege with the doctors. God bless them. I have been all day with my friend McKay, who has been enduring a fit of the stone (kidney form). His agony has been frightful. I have given him near two pints of ether in eight hours with only momentary effects. Now he is over it, but exhausted. . . .

I am enjoying " hay cold." There is not much fun in the crop. . . . I am much obliged to Anna for her kind letters; that I don't answer them more regularly is due to the fact that the days are short and busy with me. It is a chance to keep from under the wheels of time.

Since Mr. Gordon McKay was destined, at a later period, to play so large a part in Mr. Shaler's life and in that of the University, the above allusion to him would seem to call for a word of explanation. Mr. Shaler's acquaintance with Mr. McKay, one of Harvard's greatest benefactors, began in 1865, and from that time on he knew him intimately until Mr. McKay's death in 1903. Indeed he somewhere says he never knew any man so well or so long. For many years they were very close neighbors, and at first were drawn together by the mutual interest 
in inventions and mining problems. The side of his character which Mr. McKay presented to his friend was one of great dignity and kindliness. Moreover, his mind was constantly reaching out to large enterprises and in these excursions he sought for sympathy and suggestions from a source which he well knew would never fail him. On his part Mr. Shaler found, in many ways, great satisfaction in his business relations with Mr. McKay, who could imaginatively project himself into any large enterprise and grasp the possibilities of an unverified hypothesis, whereas with prosaic men of affairs of the average type Mr. Shaler's imagination was often a barrier. Because he saw far beyond the immediate question, they sometimes seemed to doubt his practical grasp of the concrete problem itself. Not so with Mr. McKay; he eagerly followed him in his scientific and practical quests and showed an inspiring faith in his forecasting power as well as in his capacity to meet the unforeseeable difficulty. But aside from the advice which Mr. McKay asked in mining matters, he especially sought Mr. Shaler's counsel with reference to the best uses of money intended for the public good, and particularly the conditions of his own proposed bequests were the subject of continuous discussion. So far from having a predilection for the College, he began with a serious dislike, which it was Mr. Shaler's special task to overcome. Mr. McKay, however, did believe very firmly that the men whose work tended toward applied science had better be educated with those trained in the liberal arts. This conviction remained fixed in his mind until the time came to make his final decision. After 1891 there was no longer a shadow of doubt as to the destination of his fortune, and he always alluded to Mr. Shaler as the one person of all others whom he looked to for the carrying out of his wishes.

To his sister :-

CAmbridge, March 26, 1885.

I have your two letters. Nothing could induce me to take the place of Director U. S. Geological Survey. As Hosea Biglow says, "'Taint a knowin' 
kind o' cattle that is ketched with mouldy corn." I should be a fool to give up a life position to depend on worse than "princes' favors," the will of each President and the whim of every Congress. Besides, Powell is doing very well and should be kept in office. . . . I am obliged to my friends for their interest in my political or scientific promotion, but however I may lack advancement I care nothing for it.

I proposed to come out to Kentucky this recess, but it only lasts six days this year and I am very tired after a long and hard winter, so I may not gain the courage to start. I dread the scamper out and back with only two, or, at most, three nights, to rest between. If I did not feel that Mother was after all pretty well I would certainly venture any risks to see her, but I shall have to come in May to bring her here and those days are not far off. . . . We have had a beautiful winter, except for the iron-hearted cold and endless north wind. ...

\section{To the same:-}

Casbridge, —, 1885.

It is contrary to law to send dynamite by mail, else I should feel it to be my duty to enclose a cartridge of that vivifying material for the use of the family to be taken in tonic doses. I have a great deal on hand to entangle me, but I will come out with pleasure and bring Mother on. . . . Only two weeks more lectures, then comes "blue book" and blue devil time with the examinations. We are going to Nantucket soon after you come - warranted warm and comfortable.

\section{To the same:-}

Cambridge, June 23, 1886.

I have been trying to escape from my multifarious duties here, but it now seems impossible to do so until the next month. I only know how busy I am when I try to break away from my affairs. On the first of July I am to be on Mount Washington to give a lecture from that high pulpit. On the third I am to go to Kingston, Canada, on a mining errand. On the fifth I hope to be in Washington. On the sixth at White Sulphur Springs to do another bit of mining work. On the seventh at Olympia or on train. On the eighth at home with you all. Mother can then take her time to journey East with me. We are all pretty well but waiting for the quiet that comes after the term.

\section{To his mother:-}

CAMBRIDGe, March 20, 1887.

Sophie and the children are good enough to write to you for me, thus sparing me the grip of pen and you the trial of patience which comes when 
I write myself. Of late I have taken an amanuensis who takes my work in shorthand and gives me typewritten "copy," but this will hardly do for family letters. We have won through a hard winter at last, and although a cold wind is roaring about the chimney-tops the boys are playing marbles on the dry spots on the sidewalks, the girls are buying summer dresses, and the British sparrows, daunted for a time, have renewed their impudence. These signs show that spring is upon us. Before we know it will be time for regretting the comforts of winter, though at present we are mightily glad to have it over.

We expect you on to see our flower-show. We put twelve hundred bulbs in the ground and they need your advice about coming up. If you will not come without me, you will have to come with me as soon as convenient after May first. Don't think of trying to escape the fate. . . .

St. Augustine, Florida, Jan. 1, 1888.

A happy New Year to you and the chicks. Found my way here this evening out of the continental refrigerator and into the frying-pan. Thermometer at 9 P. M. 80 and a sticky air.

This quaint old huddle of a town with some picturesque Spanish works and wonderful new hotels nearly finished. The Ponce de Leon [he had gone to see about sinking an Artesian well for its use] the greatest caravansary in the world, so they say.

The air is to me extremely unpleasant, like our southerly storms. You would not like its lifeless quality; it tastes like a doctor's prescription. So far I have felt no malaria and am well. To-morrow I start for Indian River, as far as Lake Worth, probably the southernmost point of my wanderings. The region is perfectly safe, inland navigation in small steamers. I have seen Bradley's friend and gained much valuable information from him. So far my journey has been profitable, not pleasant, for the scenery of the South is indescribably dreary, drearier than the sea. The country has made little gain in fifteen years. ...

Steamer near KeY West, Jan. 6, 1888.

.. We have had an easy passage from Tampa, a summer sky and sea, and an American palace of a boat, "extremely elegant," as they say, but I fear not very seaworthy. In two hours we shall be at Key West, where I suppose we shall have to stay to-night. To-morrow morning early I hope to be in a sailboat running up from Biscayne; this will be pleasant as it makes the beginning of my return journey. I may be subject to a detention, for although the voyage to Biscayne is through the archipelago of reefs in water generally so shoal that you can wade at any point, and, therefore, I 
assure you, perfectly safe, there is a chance of dead calm. However, I think that we shall get through Lake Worth, where we again find steamboats. . . .

My impressions of Florida are more favorable than at first. . . . The air is extremely enervating, but has a curious quality of peacefulness. The people are mostly new folk, very few of the Southern quality.

The country is a vast sand-heap (at least on the surface), a white, beachlike sand; but it grows oranges in a wonderful fashion. I have seen 2500 on one tree and 10,000 have been counted. So great is the area of gain that we shall have to double our appetites for the fruit in order to provide a market.

The principal crop is consumptives; quite half the population consists of folk who have fled from that wrath. It is the dismal side of the business of travel here. The nearer I get to the tropics the more I turn with pleasure to our grim Northern clime. This is the worst of nature full of blandishments and over-sugared things. There, it is a hard-fought field which I verily believe to be the better place. Please secure a first-class northeaster for my refreshment when I escape from this land of ease and laziness. . . .

JACKSONVILLE, FLORIDA, - 1888.

. . . I have lamented the duration of my journey each night and morning. There has been but one consolation, that when it is over I shall have a long breathing time at home.

I would write longer, but I am very very weary and have to rise again to-morrow at dawn. I have seen the sun up for thirty days or so. . . .

It was at this time, while carrying on some researches on the Florida coast, that the boat in which Mr. Shaler and two of his students were sailing was capsized in a heavy gale, and for some hours, while clinging to the upturned craft, trusting to the waves to wash it ashore, the party were in serious danger amid the heavy surges, especially since one of the men was unable to swim. It was the testimony of all who shared the catastrophe that not for a moment did Mr. Shaler lose his head or cease to cheer and encourage the others, helping each one in turn as he seemed to need assistance. The shore was finally reached, and, in a state bordering on exhaustion, without food and almost without clothing, the party set out on a long tramp for Lauderdale Station. The walk along the shelving, sandy 
beach, for unshod feet, was exceedingly painful. Mr. Shaler afterward said it was the most distressing of any experience he had ever had. But at last the Life-Saving Station, in charge of one Jack Peacock, was reached, and here they stopped for rest and entertainment, - entertainment of mind and body; for Jack Peacock, it seems, was a character, and at the moment, having rescued a cask of sherry from the sea, which he had buried in the sand, was engaged, as he phrased it, in running a race with the worms to see which should get the better of the windfall. His red nose proclaimed the fact that he was not only holding his own, but outstripping all other rivals in the race. Mr. Shaler used to give most ludicrous accounts of Jack's conversations and his philosophical reasons for keeping himself in a state of constant booziness.

After the mishap, an old student who was then in Florida wrote:-

NEw River, Feb. 5, 1888.

. . . The first calm day after you left, I was at Hillsboro and, using the mail-carrier's skiff, searched carefully for the things lost in the capsize, but without success; nor has anything more drifted ashore except a coat and one shoe. I spent nearly half a day drifting about the place of accident, as nearly as I could locate it, but the surface of the reef at that point is so broken and covered with sea-feathers, sponges, etc., that even so large an article as your valise might escape detection.

My dory was smashed by the heavy sea a few days after your departure. I am rather glad of this as it distributes the burden of the misfortune a little more evenly than at first. I sincerely hope that neither yourself nor the young men with you have suffered any ill effects from your ducking.

Very respectfully,

Chas. CORMAN.

Cambridge, April 3, 1888.

I arrived here this morning somewhat battered by the sleeping-car air. Children well?

I feel so lop-sided in my unaccustomed condition of "grass widower" that I shall get away to the Vineyard on Thursday, returning on Monday. ...

P. S. . . Mr. Stilwell turned up and to my surprise was induced to stay, so that I shall not go to the Vineyard. 


\section{LOWELL INSTITUTE LECTURES}

I am offered a course of Lowell lectures next winter, probably eight in all. It is a thousand dollars and not to be "sneezed at." I can use matter designed for magazines and so kill two birds with one stone.

These lectures on "Geographical Conditions and Life" were delivered in the winter of 1888-89. As early as 1871-72, Mr. Shaler had given a course of twelve lectures at the same place on "The Geology of Mountain-Ranges." 


\section{CHAPTER XXIII}

\section{MINE PROSPECTING AND OTHER EXPERIENCES}

\section{1-1891}

AFTER Mr. Shaler's trip to Europe in 1881, the years that followed, mostly spent in teaching and administrative work, offer few external incidents for the biographer. The monotony of his college duties, it is true, was often interrupted (that is, his lectures were anticipated, or "packed" together, as he phrased it, not "cut") by journeys, many of them undertaken, as we have seen from his letters, in the interest of various mining and other projects. During these times of travel he saw much and overcame much, and if his experiences could have been told by himself they would have added greatly to the interest of this record.

He valued these outside contacts greatly, not on account of the personal advantage that might come to him, but because they kept him in close touch with the world at large and gave opportunities for getting his students well started in business. It pleased him immensely when his "boys" succeeded, as they nearly always did; and of late years he was still further elated by the steadily increasing recognition, on the part of men of affairs, of the worth of the Lawrence Scientific School training. This was shown by constant applications for young men as civil, mechanical, and electrical engineers, to take charge of mines, and, as one of them stated, to dig coal, to wash gold, to build bridges, and bring water to dry lands.

Mr. Shaler's own work in connection with mines, water-supply for cities, phosphate-beds, mica-deposits, and so forth, took him from Nova Scotia to Florida, from the Atlantic to the Pacific Ocean. One of his chief uses as a mining expert, he was 
accustomed to say, was to keep people out of wild-cat schemes, and make them examine a "proposition" with cool and critical eyes. This he did not always succeed in doing. He writes to one of his clients: "I regret to hear that you are determined to proceed to spend money on but one test of your property. It is evident that I cannot help you by wholesome advice. Let me say once again that you are putting yourself in a position to waste money that might readily be saved. With this I will close my correspondence." It is noteworthy that his cautious, painstaking handling of the practical side of mining should so often have been preceded by a brilliant theoretic conception of the problem. The Alder Mine, in which Mr. McKay became interested and which is a part of his endowment to Harvard, was in the first place an imaginary discovery, based on a theoretic hypothesis. The minerals he had to do with chiefly were gold, iron, - the prime metal of civilization as he called it, - and coal ; with reference to their distribution he made many reports for railway companies and organized surveys for the extension of their roads. In his writings about these substances the statement of facts is, as is usual with him, accompanied by general and philosophical comments. In an article entitled "The Exhaustion of the World's Metals," he says: "It is evident that the economic side of human advance, as well as the greater part of the contriving foresight which characterizes it, depends upon the qualities of the materials men turn to account. The story of the adaptation of substances to desires did not begin with man. It is common among the bees and ants and other insects. We see it in the nests of birds, in the hot-bed in which the brushturkey lays her eggs: these contrivances generally relate to utility alone, yet often the sense of beauty guides the constructions, so that the æsthetic as well as the utilitarian motives appear to exist in the minds of many highly developed animals. ... In the case of man, each of his early and simple conquests has given a sense of the powers of the outer world, so that even the lowest savage becomes an inquirer, a man of science explor- 
ing the world with his imagination of things possible and verifying his conjectures by experiment."

His fees as a mining expert were absurdly small ; many of his former pupils acting in the same capacity asked twice and often three times as much as he. Indeed, it was repugnant to him to make out a bill at all ; it was so much easier to give outright than to put a price upon what he did. There were some features of this outside work which he especially prized - the exercise of the constructive imagination, the use of rich opportunities, the getting things going, and the contact with keen and eager wits. Besides all this, it enabled him to escape from what he considered the limitations of academic culture, from the state of mind that keeps men in the department stage of development. What he particularly wished to avoid was the one-sided experience that falls to the lot of most teachers and tempts them to set up special training, syntax, and gerunds against vital human needs.

Mr. Shaler had a great fancy for powerful, even though untrained, men, and gained singular refreshment from being with them. "Personally," he said, "I value what I have been so fortunate as to gain of acquaintance with very diverse sorts of men more highly than all else that I have won in the way of knowledge." He often spoke with pleasure of the long talks he had had with a man employed at a mine he sometimes visited in Alabama, who had reflected upon most things in the heavens above and in the earth beneath, and had worked out a universal system of his own. Mr. Shaler insisted that this type of strong uneducated man, while he had little learning, often had more light than those bred in academic places. Face to face with a real man social prejudices vanished. Whereas, as Carlyle says, Dr. Johnson bowed only to a man with a shovel hat, he bowed to a man with any sort of hat or none at all. Excessive convention, to his mind, was like the process of tanning; according to the ancient sage, the skins of the tiger and leopard when they are tanned are as the skins of the dog and the sheep. He was 
content to meet a fellow being on his own plane, - at the sealevel, if he could not breathe freely in the intellectual climate of the hilltops. On his part, the lowly person was quick to discern the good and lovable qualities of his passing associate, for whether known as doctor (the degree of S. D. was conferred in 1875), professor, geologist, or by other recondite title, he soon learned that above all else Mr. Shaler was a friend of his kind, having the dash of humor that makes comradeship easy and the knowledge and tolerance that gives wide understanding. Mr. Shaler was even indulgent to the "prospector," often a pestiferous fellow with his shiftlessness and boundless hopes. By the camp-fire he would treat him as the rich heir of all his dreams, and when he had seen a mirage, the fortune over the divide, and stated it as a fact, it was a fact then and there; but on the ground, if necessary, the mirage was ruthlessly dissipated, and the hope dispelled; yet not for long, "for the miner," Mr. Shaler writes, "is an inveterate hoper. Nothing dampens his ardor and only a few things enrage him. He knows his temporal salvation is awaiting him somewhere underground and is content to bide his time."

Nothing pleased Mr. Shaler so well during his visits to the far West as to note, in the minds of the people he met, the gradual recession of the despised "tenderfoot" and the "professor," and the emergence of the sort of man they respected: the resourceful expert and student of nature, the man who could manage a mule and get the wheels out of the rut when they were buried to the hubs in mud. The fact is, his swift divining power, his fearlessness in the presence of danger, his disregard even of the "bullet argument," his stories and outgoing sympathy, made him an idol among those people. He used laughingly to say that whatever he might be in Cambridge he was a great man in the Rockies.

On one occasion, going for the first time to inspect a certain mine in Montana, he was greatly amused, when the train stopped, at being hesitatingly saluted on the platform by a 
representative of the company,-a "practical miner,"all swathed in jet black, wearing patent-leather shoes, extremely pointed and of preternatural lustre, and a tall silk hat. The astonishment of the other party was no less acute at sight of a most unacademic-looking person. The miner afterward confessed that he expected to see a prim, starched gentleman who "put on airs and used big words no fellow could understand." This keeneyed scout once came to Cambridge and much against his will was persuaded to stay to luncheon with us. The excuse he gave for his reluctance was that he was not used to ladies' society. When the meal was over, thinking to encourage him, Mr. Shaler said, "Why, man, you did splendidly." "Yes," he answered reflectively, "but I had a hell of a time of it and I reckon I won't try it again."

So far from using big words, Mr. Shaler's language was singularly clear-cut and direct, and, as we shall see, his manner of speech contributed in no small degree to his success in different mining suits in which he was called upon to testify. Especially was this the case in a notable legal contest at Butte, Montana. He noticed that the experts on the other side seemed to take particular delight in using difficult technical terms known to the specialist, but Greek to the average man. Therefore when his time came to address the court, employing none but the plainest and most straightforward language, he was encouraged while speaking by the look of illumination on the judge's face, which hitherto had been the seat of baffled intelligence. After the trial was over the judge came to him and said, "I thank you for giving me at least a chance to understand the case. Up to the time you spoke I was completely bewildered by the abstruse statement of the geological facts which you have made so clear."

Mr. Rossiter Raymond, with whom he was associated at this time, writes as follows:-

What I remember chiefly in connection with this case is not the lawsuit itself, or Professor Shaler's testimony in connection with it, but the opportunity which it gave to me for personal association with him. During its 
prosecution, we sojourned twice in Butte, occupying rooms in the same hotel, and enjoying, after our professional day's work was done, the opportunity of friendly communion. In these hours of free intercourse, I learned much of his deepest feelings and purposes concerning, not only his contemplated contributions to physical science, but especially his responsibilities and hopes concerning the moral, as well as intellectual, development of the young men for whom, as the head of the Lawrence Scientific School, he regarded himself as responsible. It was from these conferences that I derived that sense of Professor Shaler's deep religious feeling and motive which will remain permanently associated with my memory of him. In accordance with his own request and initiative, rather than mine, we held many an informal session over the old-fashioned Bible; and I feel myself warranted in saying that, as to the eternal truths which it declares, we found ourselves, after illimitable and thoroughly fearless and unconventional discussion, not far apart.

In one of his letters, dated Butte, Montana, alluding to the above case, Mr. Shaler writes: "The question is a difficult one, but I hope to compass it without undue strain. I have had a busy day in the mine and on the surface. I shall be very glad to escape from this very tiresome place." And yet it was in the intervals of his taxing professional work there that the second part ("The Rival Queens") of the Elizabeth series was written. His window at the time overlooked a street full of vulgar and even depraved incidents of frontier life; a stalwart Norwegian working lustily at his blacksmith's forge was the only wholesome human sight his eyes met. But, as he tells us elsewhere, he was curiously independent of what are considered favorable surroundings for mental work. The poetic impulse would often come to him in a flash, even when suffering much pain, or burdened with cares. Sometimes while engaged in ordinary conversation an almost instantaneous transition of thought would take place.

This instantaneous movement of the mind in professional and other cases, where apparently there had been no time for preparation, enabled him to reach conclusions so swiftly, to pronounce his judgment so decidedly, as to awaken doubt as to its soundness. But it did not take long for the skeptic to find 
out that he was right, and that intuitively he had divined the truth, or that in his multitudinous experience he had met the same conditions before. His readiness was undoubtedly the stored-up result of persistent and almost unconscious study of the actualities and problems of life. He might well have said in the words of Daniel Webster, "There is no such thing as extemporaneous acquisition."

To go back to his Western experiences, there were few phases of mining life, camp or town, with which he was not acquainted, and his descriptions of them remain fixed in the mind. Of one of these dwelling-places, he writes: "It is curious to notice the perfect forlornness of the mountain settlement: it is distinctly a higher order of miserableness than any other region can afford. A wide range of experience in the backwoods of lower levels does not prepare one for the utter grovelling look that hangs over these shanty towns." And again: "The dilapidation that comes to these hut-towns is very rapid. Soon nothing remains but a modern kitchen-midden of broken bottles and crushed tin cans." Of the ranchers' houses, he says: "They are mostly half underground, and are a sort of gopher-holes, generally with sod roofs and with a heap of empty tin cans excreted at the only opening of the den."

Where the railways stopped and coaches took up the burdens they discharged to carry them still higher in the mountains, the caravans they formed, in Mr. Shaler's eyes, gave the most picturesque aspects of mountain life. "The teamsters," he writes, "are silent, indefatigable fellows, brutal in every outward appearance, yet, withal, patient with their difficulties and helpful of each other, unless the other is a 'Greaser.' In two hundred miles' travel, I did not hear a brutal word from one man to another, and I was indebted to them for many considerate acts. In his difficulties with his teams a man will lift up his voice and address the Infinite in a diabolical homily that would befit Milton's Satan, and then, subsiding like a geyser, remain silent for the rest of the day. At night when they gather around the 
fire in the low-walled, turf-covered ranches, they are perfectly mute: they sit on the benches as still as mummies until they slip down upon the floor and snore until morning. They often camp alone by the roadside. One night I sought directions from one of these solitary men. He was a huge grizzle-bearded fellow, whom I surprised cooking his supper by a little fire in a niche in the rocks near the team. His ugly visage stood out in the blaze of his bacon, which he was toasting on a stick. He gave me sufficient answer without looking up to see who was shouting at him out of the darkness."

On one of his journeys westward, the fertility of the soil (compared with the poor relation's share of the earth in the East) seemed to him excessively gross. "The land," he says, "loves the plow, or at least submits to it, as the ox gives himself to the yoke. There is an almost painful monotony in this utter giving up of the earth to the profitable uses of man. The soil grows fatter and more fertile as it goes nearer the centre of the Mississippi valley, until, in Illinois, it seems a perfect desert of tall withered corn-stalks and wheat stubble that stretches to the horizon. The towns have a look of squalid plenty. Corn is trodden under foot, and about the stations its grains often are as thick in the mud as are pebbles in New England. Here and there in wide fields a little rectangular patch of surface shows the roof of the master of a domain big enough for a lord. The sky, too, is prairie-like in its uniformity: it is a vacuous expanse of clearness or cloud without the diversity that a varied surface alone can give it."

Elsewhere he says: "The moon is full and the mountains show almost as well as by day. Night quiets the winds here and settles the mists and drifting snows, so that for seeing the time is almost as good as day. The walls of the gorge stand as steep as cliffs can, with their fantastic spired battlements a thousand feet above the stream (the river Platte) that winds through the ruins below. All the moods of architecture - spires, castletowers, and city-walls - are mimicked in their variations of 
shape. . . . For four hours with the throttle valve wide open and a steady panting breath, the engine toils up the steep and crooked way, gaining about five thousand feet in height, eventually escaping from the gorge into the vast mountain plains called the South Park. . . ."

And yet, notwithstanding his many entertaining and instructive contacts with men and things, - contacts such as only fall to the share of one who is on the lookout for natural phenomena and human qualities alike, - these long journeys over great stretches of the earth's surface void of historic associations of an enriching kind, after the first novelty wore off were tiresome to the last degree. There was one spiritual profit he gained from them, and that was the enlargement of his sympathies, although it scarcely seemed as if they needed further amplification. Travelling, often alone, in far-off places and lodging in strange inns served to arouse a feeling of compassion for solitary people. The isolation of most human beings, as he saw them in these wanderings, was borne in upon him, and he pitied all who were driven, either by restlessness or by necessity, from the shelter and affections of the home.

In the early days the little sleeping-cars were, as he says, "crammed with a motley lot of humanity, supercivilized and savage in all degrees." From among this miscellaneous cargo of human beings he picked up acquaintances easily. A racy character when found was a boon which served to quicken the slow-going hours. The defenceless and incompetent he befriended, especially women travelling alone, or any creature who could not well stand by himself. Often when he would fain have passed the time in silence and repose, his peace was broken in upon by people whom he had met before - old students who turned up everywhere, vigilant young men, who, in the kindness of their hearts, would make a point of keeping a close eye upon their old master, lest he be lonesome, when solitude was really the thing he most desired.

During this fruitful period of which we are writing Mr. Shaler 
did a great deal of literary work. Besides three separate books, and an important paper on the Physiography of North America, contained in the "Narrative and Critical History of America," edited by Justin Winsor, which appear on his list of publications, are a number of valuable scientific reports, among them Reports on the Geology of Nantucket, Mount Desert, Cape Ann, and Martha's Vineyard. There are also his annual executive reports of the Atlantic Coast Division of the United States Geological Survey; a preliminary report on the Coal Swamps of the Eastern United States, etc.; monographs on other scientific subjects and magazine articles too numerous to mention here. The investigations which preceded these reports exacted much of his time in the study of the geological problems of the localities and a great deal of travelling at all seasons of the year. At this period he also was doing his full share of teaching and taking an active part in the discussion of educational questions.

Indifferent health, - sick headaches and other maladies, now as always, was something to be reckoned with, its thwarting power dominated, and, instead of being allowed to take the first place in his thoughts, was reduced to a secondary, or mere menial position, wherein it served to keep his activities within bound and enforced rest at a certain time of the day, usually just after luncheon. It also prevented any waste of time, and one hour or place under its discipline became as good as another for the doing of a task. These were some of the spoils won out of the battle. Indeed, by his skilful management of his foe, reinforced by the wise counsel of his physician and friend, Dr. Henry P. Walcott, it was in a way made to dig its own grave. And yet it is impossible to reckon the inner suffering or the tax that almost constant physical annoyance put upon his patience and endurance. It made him at times exceedingly sensitive to anything like confusion or noise in his surroundings; his house, therefore, was run quietly and methodically, and as far as possible all opposition was withheld in order that no aggravating circum- 
stance might add to his nervousness, for in the outside world there was always enough to disturb the equipoise of one of his ardent temperament.

In 1886 there came about a change of residence, and the Bow Street house, now the site of Westmorly Hall, where he had spent many happy years, was sold. The street, from having been a quiet little side passage, had become the highway to boat-house and students' lodgings. The purchase of this place had been in a way the outcome of what is recognized as an ideal state of society - the condition where every man owns his own house. At least such seemed to be the case in Cambridge in 1867, for after searching vainly to find a dwelling for rent, happening one day to walk through the old part of the town, Mr. Shaler noticed an auctioneer's flag hanging from the house he was passing. Taking counsel at home, he returned in a few minutes to the site and before the next half-hour was over he had become the owner of the old-fashioned abode that for some obscure reason had been put on the market. The big chimneys were its chief attractions, built at a time when a hole in the floor was not recognized as a substitute for the family hearth. In re-introducing the open wood fire, Mr. Shaler felt that he was doing good service; the air-tight stove and furnace doubtless had their uses, but were not to be depended upon as sources of joy in the library, or any place where good fellowship was expected. He lived to see fires blazing on the hearths of most of his friends, and insisted that the open fire and the open heart were two things that naturally went together.

The Quincy Street house, overlooking the College Yard, was charmingly placed. It was sunny, quiet, and nearer to his office, especially when that was transferred from the Museum to University Hall. And henceforth all that went on within the College enclosure became a part of his life, from the ringing of the early morning bell to the "rushes" on "Bloody Monday." He had a keen scent for a fire and was always among the first to appear on the scene. His quick response to the call of the fire- 


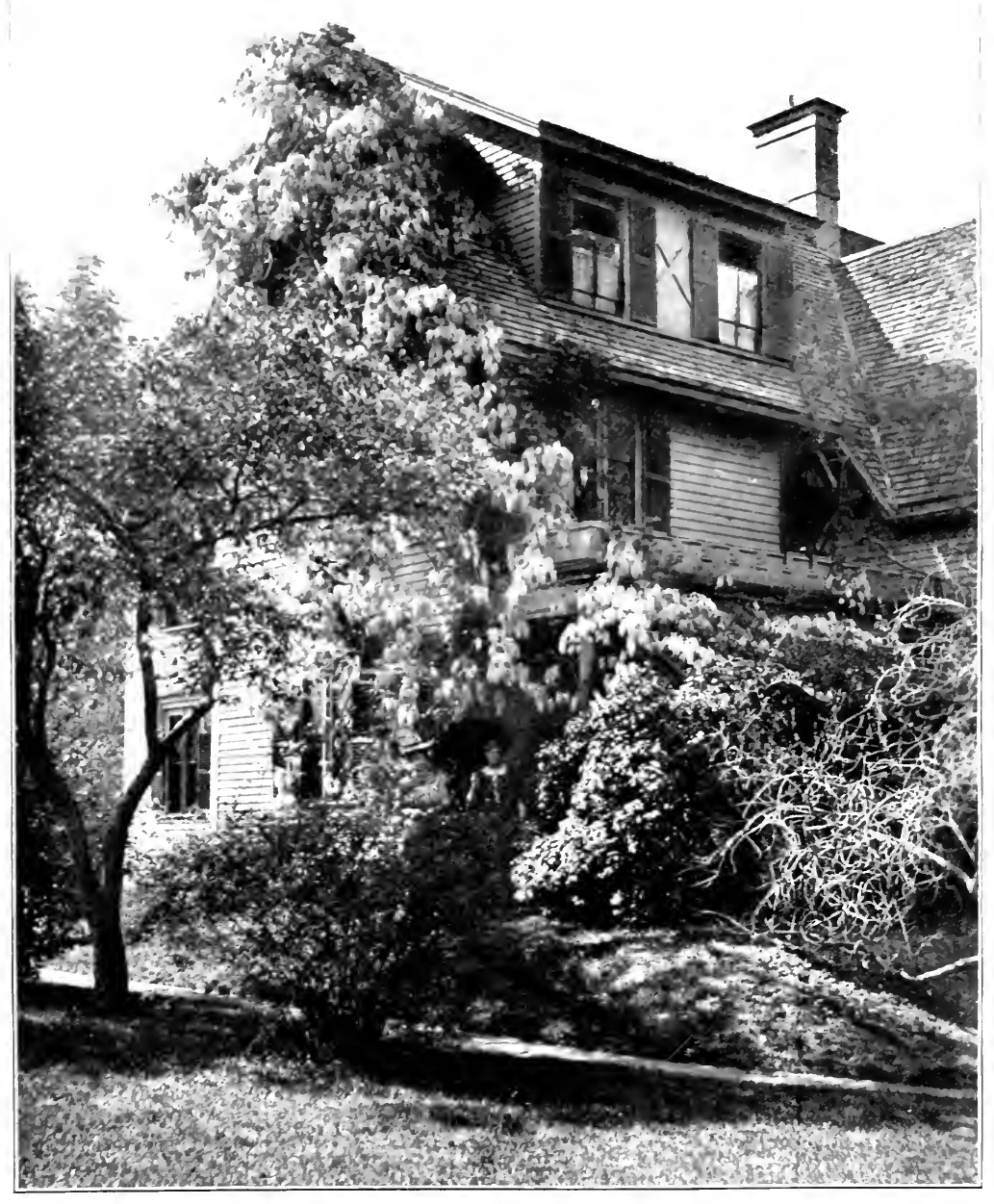

THE QUINCY STREET HOLSE IN CAMBRIDGE 


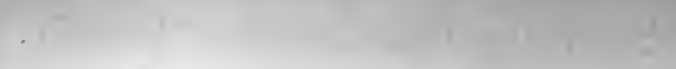

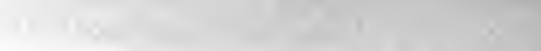

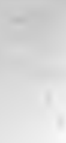


bell was a relic of his youth, when there were no paid firemen and the alarm called out the active and daring young men of the town, who vied with one another in chivalrous acts of rescue service. President Eliot was also a prompt attendant at fires; indeed one suspected an unconscious rivalry between them. At any rate Mr. Shaler rather crowed over the fact that while the President had "bossed" the fire that threatened to consume the near-by Baptist Church, he himself had an active hand in extinguishing the conflagration at the Colonial Club, while his neighbor slumbered peacefully all unconscious of the lost opportunity; and so the account eventually was evened.

For many years the house, for a sober old town like Cambridge, was a scene of comparative gayety; his daughters and their young friends, animated by the protean activities of youth, made it a cheerful place, and doubtless many who were young then but are mature now, scattered over the face of the earth, have pleasant memories of the old library, for in its retreats some of them met their "fate" - their lovers, husbands, and wives. Mr. Shaler enjoyed the Sunday afternoon receptions at his house, which became a feature of its social life. On these occasions he was most genial and solicitous that every one should have a pleasant time - the students and other friends, and also strangers who, knowing he was then at home, with or without an introduction would come to see him. This free entrance led sometimes to a curious grouping of people - a Chinaman, an Englishman, and a South American being brought into a close but good-natured juxtaposition. Between students and what were known as "grown-up people" there sometimes arose a slight feeling of antagonism, the latter maintaining that they came Sunday afternoons for enjoyment and not to do missionary work - for such they considered talking to immature youths; but on the whole, animated by good will towards host and hostess, the two elements did their best to get on amiably together.

Mr. Shaler's courtesy to every one within his doors, from the 
humblest washwoman to the most distinguished guest, was a marked characteristic. This allusion to distinguished guests reminds one of an anecdote he often told of Huxley. During the great biologist's visit to Cambridge, Mr. Shaler invited him and his wife to take a drive in the country. After passing the market-gardens out Belmont way, Huxley suddenly called out, "Stop, driver, stop. There, Shaler," he exclaimed, "is n't that tobacco growing in that field?" Receiving "yes" for an answer, he stood up in the carriage, waved his hat, and shouted three cheers for tobacco, adding in an aggrieved tone: "And to think that I should have lived forty years without knowing the comfort of the weed."

Mr. Shaler struck up quite a comradeship with Mr. Kipling when the latter visited Cambridge. The novelist was captivated by the professor's stories; those relating to Western experience, he said, were just the things no writer of fiction could ever invent. They first met at a dinner at Miss Grace Norton's, and Mr. Shaler liked to tell the story of what happened there. On their way home he said to his wife, "What were you and Kipling talking about at table? You both looked as mystified as if you had seen a ghost." The substance of the talk was as follows. In a lull of the general conversation she heard Kipling say to his hostess, "When I was at Tisbury last summer." The confusion of tongues made the rest of his remark inaudible. When the opportunity occurred she asked, "How long were you at Tisbury, Mr. Kipling?" - "Six weeks," was the answer. - "Six weeks," she repeated, "how extraordinary!" Again something was said on the other side which made him turn a deaf ear. A few minutes later he inquired, "Pray, madam, what is so extraordinary in my being at Tisbury?" adding almost defiantly, "Yes, I stayed there six weeks with my uncle and then went to Chilmark." - "To Chilmark?" she exclaimed. - "Yes, to Chilmark." - "How remarkable!" - "Why remarkable?" - "Because, to tell you the truth, there are not many people like you who go to Tisbury, 
and if I must say it, there are not many like ourselves. I should think, in a mere village, we might have met." - "A mere village? Explain yourself." And then suddenly receiving a ray of light, "Where is this Tisbury and Chilmark of yours?" she asked. - "England, of course. Where did you suppose?" "Oh, I thought you had been at Martha's Vineyard," she answered. "Our farm there is partly in the town of Tisbury and partly in Chilmark." - "That's interesting," said Kipling. "Some one from my part of the world must have given the old names to those new places. I should very much like to see them." - "Then come for a visit." — "It will give me pleasure." 


\section{CHAPTER XXIV}

\section{COUNTRY LIVING}

IN $1888 \mathrm{Mr}$. Shaler bought a tract of land on the northern shore of Martha's Vineyard, and then he bought another and another old farmstead, in order, as he said, to keep undesirable people on the farther side of the hedge, until he owned no inconsiderable portion of that part of the island. And here for many years he made his summer home, the idea gaining upon him that to cultivate a farm was a large share of the duty of man; in his own case it undoubtedly became a large share of his pleasure. The farm was a refuge from the life that cost so much in wear and tear - that life which to the casual observer seemed far removed from the feverish stir of the great world. Many a tired man of business, coming to Cambridge to look after his son, while sitting at the window in Mr. Shaler's library overlooking the college green, has commented upon the scene of beauty and repose and upon the professor's freedom from care. He knew little of the unending solicitude to make the education of his boy a pursuit of knowledge and not merely a rush for the degree. It was sequestered, but not restful.

Mr. Shaler was first conscious of the charm of the island of Martha's Vineyard when as a boy he made a geological excursion to it. Again, while doing some work for the Coast Survey he travelled from one end to the other, gaining refreshment, as he phrases it, "from the soft air, the broad, smooth fields, the rounded domes of foliage, and the unusual green, together with the drowse in which all is steeped." He learned to regard the island as "an oasis of salubrity in our New England bad climate," its average warmth being two degrees above Boston. He was also pleased to regard it as a natural asylum to be shared with worn-out sea-captains - "looking like the ani- 
mated figure-heads of old-fashioned ships" - who came there to end their days.

Since he never forgot the impression a place made upon him, the memory of the island lingered in his mind until he was ready to provide himself with a country home - not a half-acre lot, but something of the nature of a farm. The love of the country, with its actualities of animals and crops and the local independence, touching the border of exclusiveness, was strong within him; indeed, it was a tradition in his region of the country that the good of life was only to be had away from the crowded centres which hindered men from being wise and happy. What he desired was a "civil wilderness" - that is, spacious possessions tamed to comfort, but not made artificial, nor yet closely packed with humanity. He used to say he loved his fellow men - but not too near. He liked the stateliness of uncrowded fields, the sense of freedom and security from the intrusion of unsought companions while tramping over land he owned. The seclusion of the place he chose was one of its chief attractions, and the Seven Gates through which he was obliged to pass when he first took possession of it were welcome barriers between him and the dust and noise of the busy world. There was also at foundation in Mr. Shaler's nature a feudal leaning toward a large estate with numerous retainers, kinsfolk, and dependents. In the old days he would have made an ideal master, asking little service and giving much reward. And for this reason, he was never severe on the subject of abstract justice, for he could not conceive in human relations of one man taking unfair advantage of another. Slavery, therefore, was not altogether repugnant to him. He considered it a good fortune for the slave, but a taxing relation for the master. It was an institution not to be perpetuated, but gradually to be got rid of.

It was not, however, that he might pass his days in ease and isolation that Mr. Shaler sought the country. He had the naturalist's craving for contact with the earth in all possible ways; 
for a chance to solve some of the problems of agriculture with which, under his father's and grandfather's guidance, he had been more or less concerned from his youth. More than this, he had an almost sentimental affection for the earth, "knowing earth for a mother," and firmly believed that the universe of matter so far from being hostile, as the old view of nature taught, was a close ally to the world of spiritual things. He somewhere says: "With a bit of land any one may play the part of a god. ... In this day of experiments, when men see deeper in the world about them, a new field of enjoyment is opened to those who are privileged to possess the earth." In his opinion the tiller of the soil, owing to his relations to the functions of the earth, is preëminently a naturalist, and more than any other kind of man is in a position to gain the spiritual profit which may come from an intimate relation with the forces which control the development of the world. He deplored in agricultural communities the influence at work tending to separate the youth from the fields and turn his longings and ambitions away from the occupations of the soil-tiller. He urged that the master who is to teach the ways of Nature must be intimately acquainted with the work of the farmer. "My own experience," he says, "shows me how a man with moderate labor and ordinary capacities may keep himself somewhat familiar with the agricultural art and at the same time know enough of natural science to be a teacher in that department of knowledge. . . . I have never essayed the task, but I feel confident that I could take a class of farmers' sons and daughters and lead them through a course of natural science where every point and every illustration would be taken from the facts with which they are intimately familiar, without the least risk of loss of attention in the work. I believe this could be done by any fairly competent teacher."

Fortunately for his own peace of mind, he undertook no teaching while in the country. For several summers the engineering class of the Lawrence Scientific School camped on his grounds and made use of them for practice in their work. 


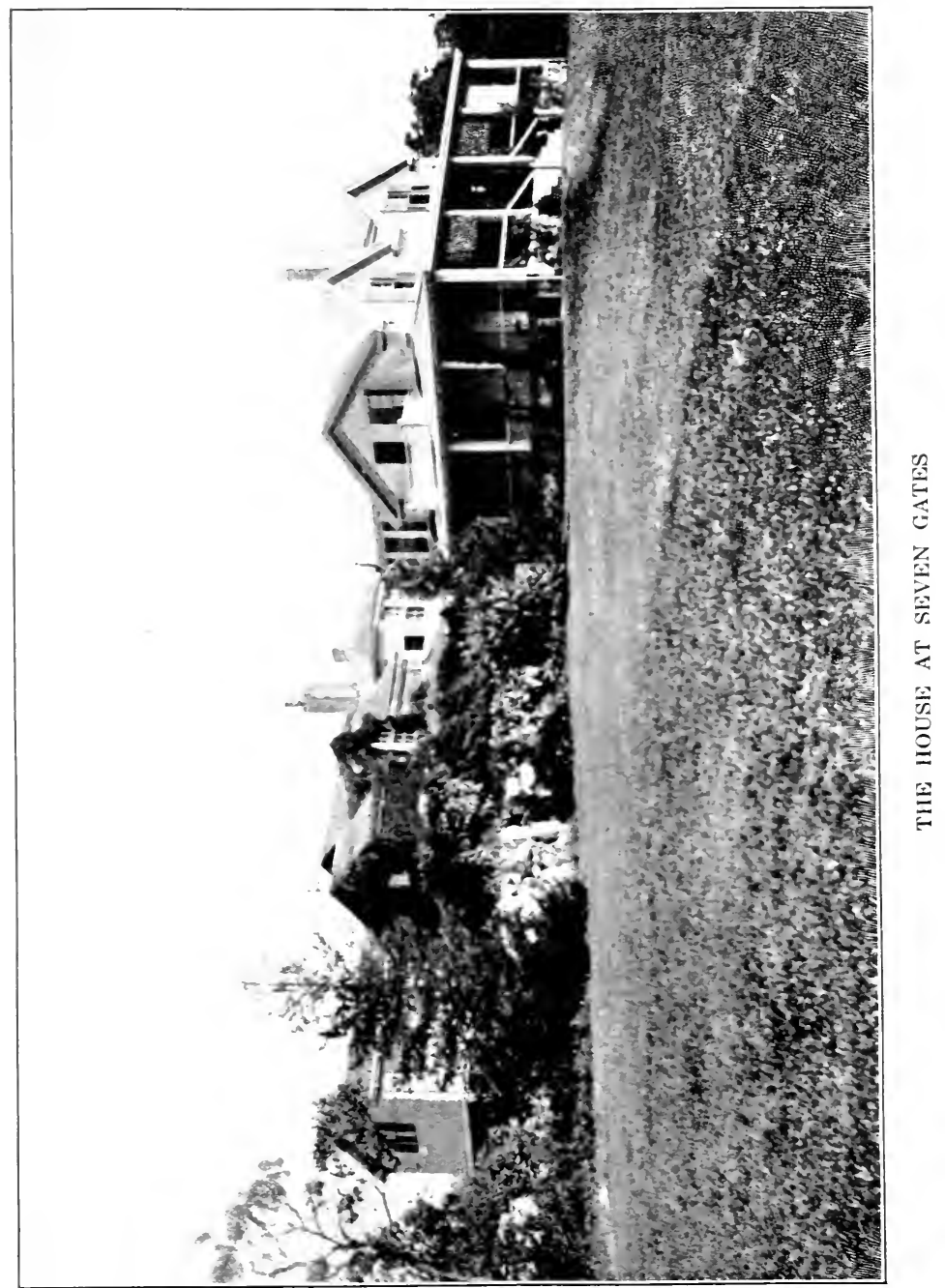



Though nominally not in charge, he could not quite divest himself of responsibility, and the very presence of a body of students so near at hand was a source of care to him, so that eventually the summer station for this branch of teaching was transferred to Squam Lake. The fascination which Martha's Vineyard had for Mr. Shaler, aside from its restorative climate, was in part due to its geological formations. There were the peculiar and brilliant beds of clay at Gay Head; on his own place, a long stretch of seashore where he could watch the work of the sea; and everywhere traces of glacial action. Unlike most farmers, he coveted the rocks as much as he did the soil; and he bought a special tract of land that he might have, as he said, a moraine of his own. His feeling in regard to these features of the landscape was recognized by his friends. Mr. W. E. Darwin writes, "There is nothing I should like better than to visit your private preserve of kames and aprons at Martha's Vineyard."

Many other stretches of land, for various assigned reasons, but mainly because he had the land hunger of his forbears, were purchased from the widely scattered children of the old folk who, in the intervals of their toiling with the sea, built bowlder walls and scratched the sterile soil for a living. Most of their houses, under stress of weather, had so fallen to decay that in some instances only chimneys and foundations remained to mark the spot where a home once had been; or flowers, - these in their season blossoming persistently in the lonely places. Among them the old-fashioned daffies seemed best to have withstood neglect; and taking this hint of their hardihood, Mr. Shaler and his companion planted thousands of new bulbs of their kind, so that in the spring, when the east winds of March invited to shelter, one was tempted forth to gather the yellow blossoms that glowed alongside of the bowlders, the old foundations, and stone walls. As the crop increased, the coming of the daffodils and their distribution in Cambridge got to be a floral event that was looked forward to by many friends. Mr. Shaler was also very much interested in the planting of 
trees, and loved to watch their growth from year to year. In addition to tree-planting at the right season, during one of his winter visits to "Seven Gates" he planted several thousand nuts with a crowbar through the snow. These were put in different soils and exposure, to see where they would grow best. He was very persistent in his efforts to acclimatize the English primrose, at last succeeding marvellously on a hillside sloping to the north and shaded from the direct rays of the sun. It was thus that the interest of his "alleged farm," as he called it, increased, and acquired a value of its own independent of being a harbor of refuge which at first was its chief excuse for being. At times the restraints and worries of his environment bore heavily upon him and the longing for space and solitude became overwhelming. Under this stress he would set out for the country with the zest of one who scents afar the perfume of green fields. The train was no sooner under way than he would toss aside his hat, shut his eyes, and take a deep breath, every line of his face showing the relief of one who had shaken off the halter. The satisfaction grew as he realized with the passing of each milestone that he was on his way to a studentless wilderness, an academic Sahara. He had frequent recurrent attacks of the rural mania, and when they came it was difficult to persuade him that there was anything else worth living for besides a trip to the Vineyard; moreover, it often required cunning stratagem to keep him from making the venture when the weather was bitter and the time inconvenient.

The visits to the farm which he enjoyed most were in the autumn just after the struggles of the college year were over, when things had in a fashion settled down to a semblance of order, when students had temporarily at least been shaken into place, the square peg got out of the round hole of elective bewilderment. In the country, also, the fervid time of reaping was at an end and the fields, with their stacks of full-eared corn, slumbered peacefully through the autumn days. Here, removed from a veritable storm-centre of contending wits, there 
was nothing to tease him out of the repose he so much needed, and gradually refreshment came to body and mind from the night's sound sleep untortured by the noise of bells or streetcars, and from the long morning's walk with hoe in hand over the bare fields, where he made war upon the thistles. In these hours of quiet and solitude life was to him a serene delight. In the afternoon, after some writing, there was another tramp, not companionless now, on the beach, or over the peaceful hills; lingering perhaps until the young moon was first seen mirrored in the waters of the little pond at the foot of the hill, or until the lamps in the laborers' windows emitted light enough to keep the feet straight in the narrow paths the sheep had made. On the way home Mr. Shaler would often stop at the spring, beneath the tupelo tree, for a draught of its sweet waters; or again, he would go out of his way to select with fastidious care a hickory log that it might give the last touch of perfection to the evening fire.

He liked to putter over the fire, having, as always, a theory to put into practice, - a method which involved the proper arrangement of the logs and the right amount of ashes to be guarded as a store of heat, details about which in Cambridge he was comparatively indifferent. Even in summer both here and in Cambridge he kept a little fire burning, not so much for the heat, but, it was suspected, that he might frequently light his unsteady pipe with a live coal, - a Kentucky habit which he cherished. To do this was undoubtedly a pleasure, but over and above its ministration to the smoker's tranquil joy, a fire on the hearth excited his poetic fancy. In one of his letters he writes:-

By a fire I am never altogether alone, but have strange company in the beings that pass as shadows are said to do in the magician's mirror; indeed the fireplace becomes as it were another window which admits our vision to the scenes of days gone by or into that dark profound we call the future. . . . Eras ago these few black lumps were the gorgeous vegetation of the tropical forests, plants stretching their luxurious foliage high towards the heavens, 
making earth glorious with their beauty. . . . Stẹp by step through every variety of change that time can bring, even while they bloomed and flourished, their present destiny was evolving, and now these dead flowers are warming a creature of yesterday and lighting my room with the sunshine of a forgotten age. I use no poetic license in saying the sunshine of long ago; for in all truth it is the light and heat of the days when the coal forests flourished which comes to me now when these relics are burning.

The country was Mr. Shaler's natural realm. At times it was difficult for those about him to realize what such a retreat meant to him; but in the fuller knowledge that perspective gives it is easy to see that it was necessary in order to keep his soul resilient beneath the load of the commonplace that found its way even into the academic world; it was the need to escape from the outer aspect that meets the eye to the inner light of the spirit, and nowhere else were conditions so favorable for the serene life of mind and spirit. It was thought by many that the days must pass dully in a region so sparsely peopled, but he was not of the dull-witted kind who suffer from quiet and demand bustle as a substitute for thought. It was impossible for one to be bored who sought, as he did, an explanation of the world about him. The power and activity of his mind left little leisure for ennui. With the good earth beneath his feet and the light of heaven above, the ceaseless pulsing of the sea and the ancient rocks to tell their story, he found himself elated. In truth, he was never lonely in company with his great friend and goddess, Nature. And yet he did not go out to her with the solemnity of "a dedicated spirit." He sought by the active use of his intelligence to interpret her truly and lovingly; but he never yielded to the mawkish sentimentality that exalts grass and stones and trees at the expense of the human interest.

But even in the remote place he had chosen for his home there was always something going on to appeal to his imagination. Vineyard Sound itself, which he looked upon from his window, was full of happenings - all kinds of craft, from the noisy little motorboats in which fishermen go to and from their nets; the 
great six-masted schooners with their sawlike sky lines; the tugs followed by their chain of sluggish coal barges; and the fast-sailing yachts that skim the water at stated seasons, all gave a far-off animation that called for no expenditure of emotion, yet at the same time kept the outgoing thought busily travelling from the Azores to the coal-pits of Pennsylvania.

Not content with the purely scientific aspect of nature, there was hardly any such aspect for one whose province it was to humanize a scientific fact as soon as he grasped it, - he appropriated the beauty of the landscape superimposed upon the skeleton of geological history, making it a part of his every-day life. It was his habit to experiment as to the best way of gaining a sense of the beauty and significance of any scene with which he was brought into intimate contact. He believed that "he who would become a lover of the landscape must accustom himself to seek it alone, and must learn to know that his mere presence at its doors will not make him free to its treasures." As a result of experiment he further became convinced that knowledge may vastly enhance the intensity of æsthetic impressions. "The evidence of the slow changes which have brought the bit of earth to its existing form, which have shaped the face which it turns to the eyes of man, has to be gained," he says, "by deliberate inquiry, so that the reading is that of a great volume in its difficulty and in the time it demands." $\mathrm{He}$ thought much upon this subject, lectured on it to the students in the Architectural School, and left many pages of unpublished material relating to it. Able himself to bring an informed intelligence to the observation of the ocean, hills, and plains, his enjoyment of their beauty was proportionally keen. Grandeur of scenery, however, never took strong hold upon him. It was the gentler scenes, linked with human interest, that pleased him most - the places where homes had been or might be, or where great deeds had been enacted. "There are," he says, "many landscapes in the unhistoric wildernesses endowed with a far greater share of purely natural beauty than that of the 
Val d'Arno or the Plain of Marathon. It is the light from the past which gives these scenes their abiding dignity; but this light does not shine forth from the pages of the guide-book; it must come from the ancient wealth of the mind." The lowlying hills and subtle gradation of outline on Martha's Vineyard were a perpetual delight to him and furnished material for study in the values of form and color. He somewhere says, "If a mountain or hill goes about it aright, it can get an amazing dignity without assaulting the heavens in its efforts." In one of his note-books he writes, "No other landscape known to me has so many contrasted slopes in an equal amount of profile; the result is the impression of height and dignity totally disproportioned to the actual altitudes: nowhere else in this country do I know anything like the variety of scenic effect that is exhibited in this hundred or so square miles."

Furthermore he discovered that, owing to the beneficent influence of the Gulf Stream, there was in southeast Massachusetts a seasonal condition akin to the Old World spring, and that people there were justified in accepting the English tradition, embodied in verse and prose, concerning the vernal time of the year. He notes the fact that on the island "spring begins in February, - the ferns awakening to the uplifting noonday sun within a month of the winter solstice. April the first always brings the daffodils; on May 15th, however, the life is at least a fortnight behind that of Cambridge. 'Seven Gates' has a real European spring which is characteristically long, with arrests which seem retardations."

Mr. Shaler might have been a good farmer, - for he was well acquainted with all the processes, - had he undertaken to supervise details. When, however, he visited his farm, he was generally weary of practical considerations and longed to escape from the application of theories as well as from the burden of administration. The intense nature of his college work entitled him to a free play of mind untrammelled by the need of looking too closely to the execution of ideas. He therefore called 


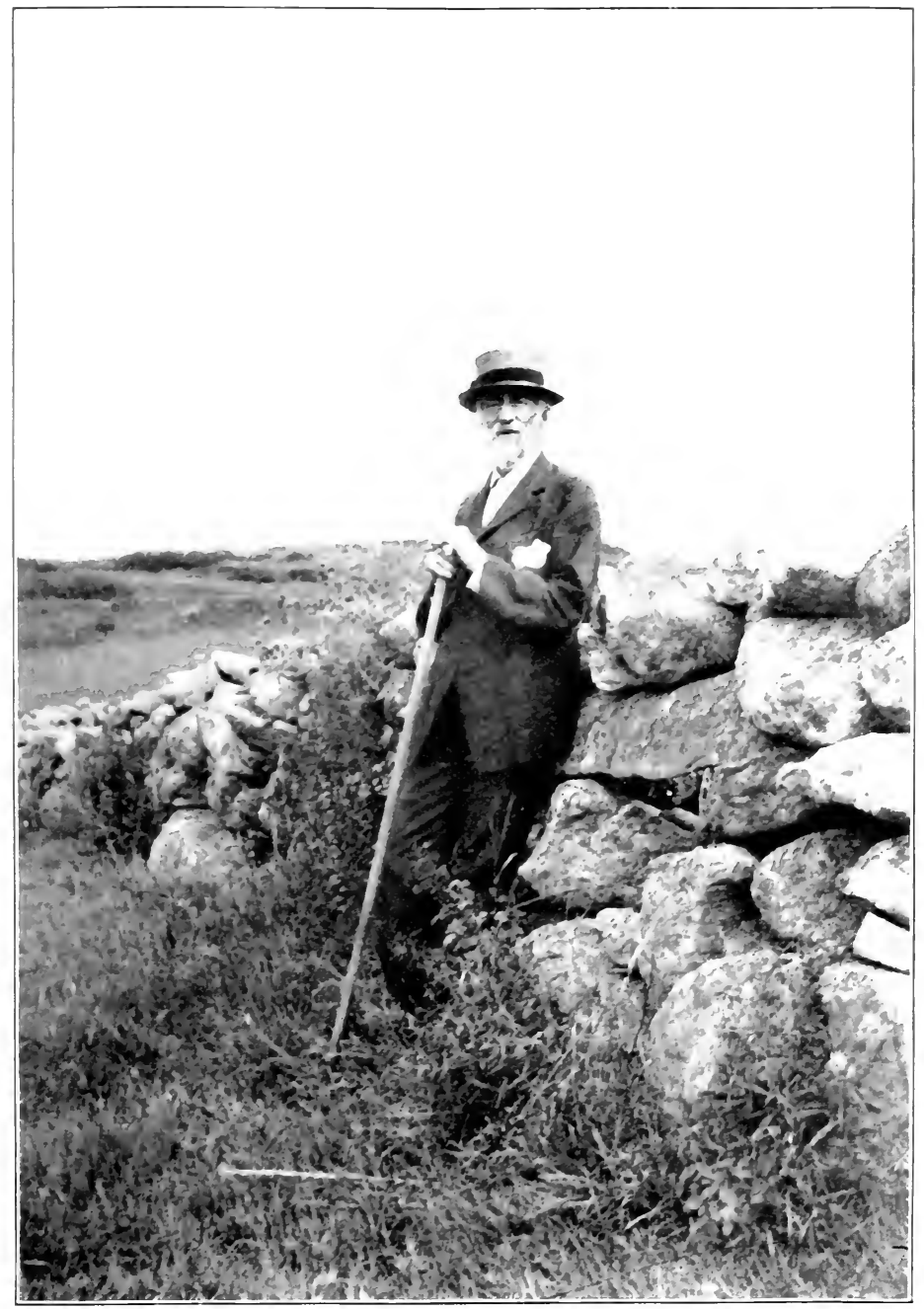

MR. SHALER ON HIS FARM 


$$
\text { , }
$$


his farm "the playground of his old age," and laid by a good deal of youthful feeling and the results of varied reflection which he proposed to make use of as a pastime when he had labored long enough in prescribed ways. The writing he had in mind would have filled up his leisure for the next ten years.

The danger of too much work of this kind was not overlooked by his friends. The letter given below from his old cousin Elias Stilwell shows his knowledge of his kinsman. In order to make his advice acceptable while suggesting that he suppress his energy in one direction, he diplomatically unfolds a scheme for its outlet in another and, as he thinks, more wholesome field.

... And you are going to your farm to work? I don't like it! You should go to reflect, and not to think. Thinking is only preparing rough, crude work for sale. Reflection gives a polished, enduring finish that will preserve the thought for centuries if well done. You are capable of it. You are doing too much. Don't wear out the machine! Go to your farm. Don't touch pen to paper. Spend the whole day in walking and breathing pure fresh air. . . . I wish you would send out West to some of our cavalry officers and obtain a few select mares from those wonderful war-horses the plain Indians use in battle. I would cross them with the fine Arab stallions General Grant brought home. You could originate the finest cavalry horses in the world. They could carry weight, require but little food, and have the staying quality of a sea-bird. I can procure here a fine pair of tame young moose, male and female. It has been thought they might be cultivated for meat production.

There was, nevertheless, one practical side of farming to which Mr. Shaler devoted himself assiduously, and that was the extirpation of weeds, especially the thistle, which generations of poor tillers of the soil had allowed to infest the fields. This business of rooting out thistles was not only a practical measure for releasing the land from a pest, but with him it grew to be a recreation. In the course of time the work becoming purely mechanical, his mind was left free to follow its imaginative way. He found so much satisfaction in his efforts to exterminate these weeds that he almost ceased to regard them as enemies or himself as an avenger. Their wide distribution led him on to the breezy hilltops, along the rocky slopes of his so- 
called "private moraine," and on the still farther uplands. On these high places, in the vales and out-of-the-way nooks, he found balm for his nerves and wisdom for his writings, as well as the stillness his soul craved.

Under his leadership the pursuit of the thistle became a family occupation and each mind was fertile in warlike invention. It was variously suggested that the flower be touched with some blighting poison; the plant be mowed and burned. Again there were those who waited, to use Mr. Shaler's own phrase, "for a critical point" in the life of the thistle - the period in which a new mode of action is suddenly introduced that will transform it from a selfish cumberer of the soil into a life-sustaining herb. The sight of one of these nuisances always provoked a warm discussion. It was claimed that one had but to cut down a full-grown specimen to evoke a circle of confident and lively little ones equally voracious for earth, air, and sun. As evidence of their possible subjugation, Mr. Shaler pointed to one hill where with his own hands he had entirely routed them, though they had strewn the ground as thick as autumn leaves. In most places, however, they were simply held back, the will to live baffling the will to destroy. The teaching value of the thistle in patience became immense; its obstinate effort to perpetuate itself the theme of acrid criticism. In love with all nature, Mr. Shaler was opposed to this hostile attitude; it was well to destroy them, he thought, but not well to harbor malice against them; they were, he claimed, expert runners in the race of life and their monumental effort to propagate themselves was worthy of admiration. It was thus that he looked off upon the universe with a sympathetic mind.

When friends, wishing to enjoy the pleasure of his company, would arm themselves with hoes and offer to go with him on his walks, the suggestion was greeted with a twitch of the shoulder and a peculiar light in his eyes, and forthwith he would start off setting a pace which he felt sure few could follow; and knowing as he did every sheep-path that led through swamps, 
thickets, and woods, he would soon be out of sight and hearing. The fact was, he wished to be alone and to follow his own train of thought uninterrupted by what he called chatter in contradistinction to good talk. Indeed what was said of another might be said of him: his library was in the house, but his study was out of doors. He preferred a companion who had nothing to say, or, if he had, would keep from saying it. He liked the one who was oftenest with him to remain within sight and speaking distance, but to guard the peace until on the way home. The time for talking was at table, or in the evening just after supper while he was smoking his long-stemmed pipe, which he filled and lighted often as a sort of punctuation to the flow of speech; at these times he delighted to expend himself in conversation. Not infrequently there were regular conversational orgies, when for instance Professor Royce, Dr. James, or other congenial men would come to visit him; then these inspiring and indefatigable talkers would only cease with physical exhaustion, for original ideas in that circle never were lacking. These occasions could not be said to be brilliant tournaments where men disported themselves for display, but each spoke from the abundance of his fertile mind to convince, to learn, or bring to light the elusive fact. It was a dead heat with frequent returns to the unsolved problem. Talks like these, and others in the library at Cambridge, with many men of many minds for interlocutors, would have made the services of a shorthand writer a desirable thing.

Some of Mr. Shaler's best thinking was done on his place at the Vineyard. Here, free from the endless interruptions of his official life, he could carry on a connected train of thought without the waste of energy that rallying the mind for fresh assauit brings. When he wanted a change he would turn from prose to poetry, in this way practising a sort of mental rotation of crops. To shed the practical work at Cambridge and enter the field of speculative thought, or the stirring world of Elizabeth's time, was leaving drudgery and soaring into the upper spaces. It was 
like the view from his study window, the bare hills standing aloof from the green fields. The act of writing was in itself a soothing occupation, and it is for this reason doubtless that one finds in his books a large and stately way of putting things rather than the dash and verve one remembers in his talk and actions.

No doubt his sojourns in the country were a solace and a moral profit. The impulse which nature gave him towards the large and noble aspect of creation was strengthened by the opportunity for peaceful contemplation. The serener air restored the equilibrium of character that was sometimes perturbed in the ardent pursuit of the projects he had most at heart. Removed from the intenser struggle, he was able to sever the essential and permanent from what was accidental and transient; his state of mind thus became calmer, and his generosity of thought and deed, his largeness of heart and tenderness, in a more pronounced way came to the surface. Always sensitive to the genial and gracious side of social intercourse, he sought occasions for the practice of a still finer courtesy in the minor as well as the more important acts of life. He could not pass through a field without gathering a bunch of wild roses for those at home, and every morning at each breakfast plate he would place the flower of the season which he plucked with the dew upon it. Often in his walks he would go out of his way to shake hands with a lonely old man whose wandering days were over. It may be that it was amid the reposeful scenes by which he was surrounded, and in the silent places he sought, that he made his conquests in the ample spaces of his soul, and fitted himself more completely to become the free champion of all that was noble. 


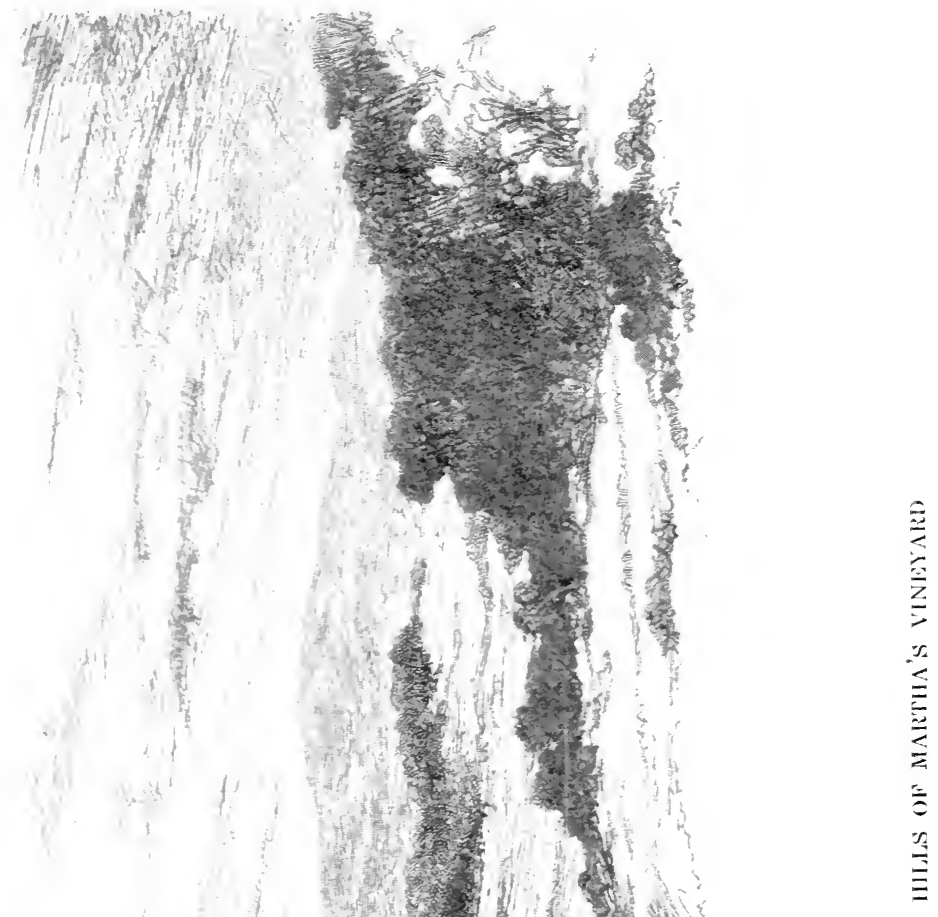




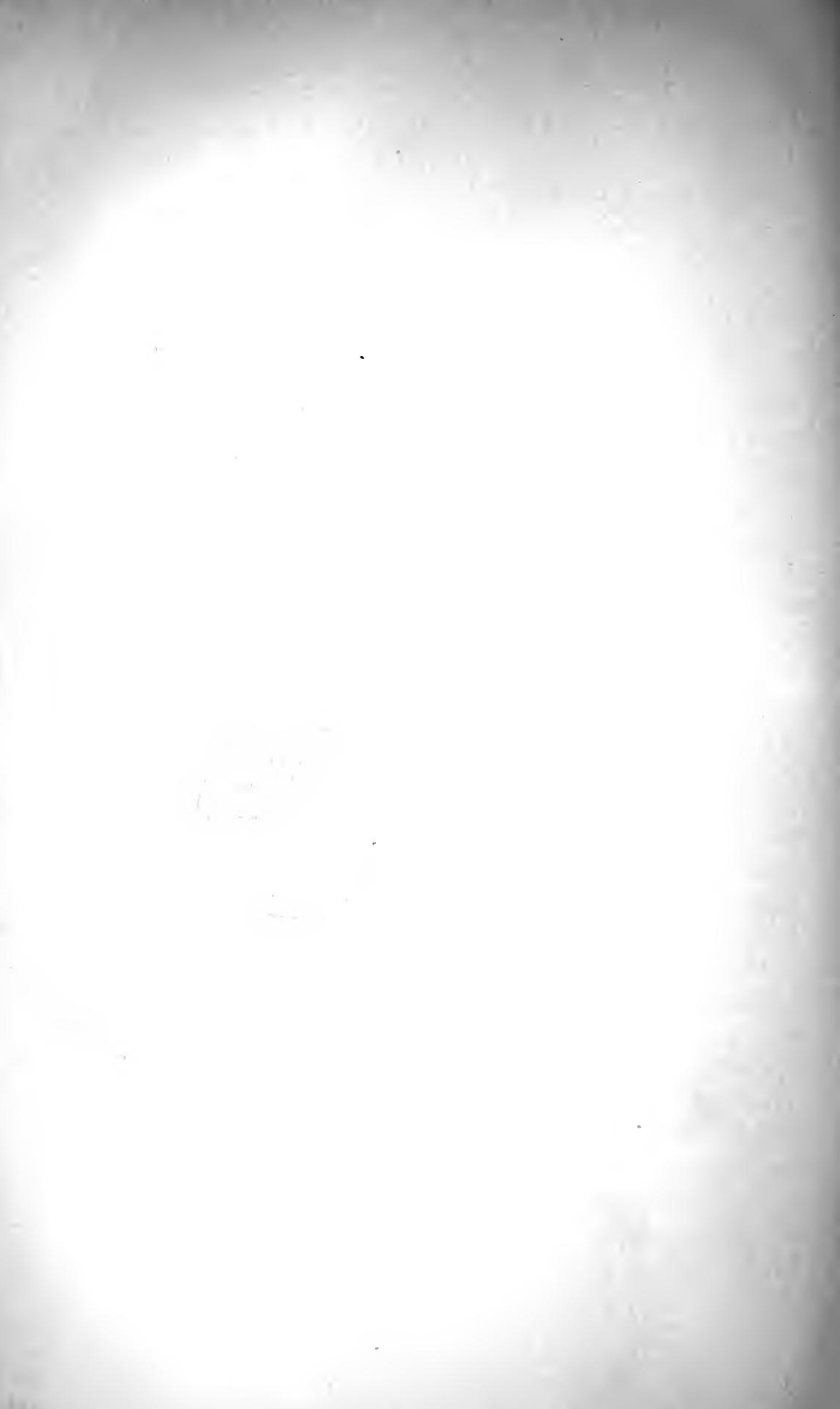

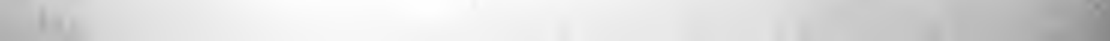




\title{
CHAPTER XXV
}

\author{
THE TEACHER
}

1864-1905

DifFICULT as it is to select the talent over and above all others for which Mr. Shaler was preëminent, one is nevertheless forced to fall back upon his teaching as the central point of his intellectual achievement, the one which in a large way, though lacking a lasting habitation, was productive of the greatest results. Although the effects of teaching are elusive, its subtle influence not to be permanently transmitted or set down in definitions, yet in the words and deeds of some seven thousand men, forty classes, there is abounding testimony to the effectiveness and uplifting quality of his work in that field. As early as 1864 he was assistant and lecturer in what is now known as the Agassiz Museum. In 1869, at the age of twenty-eight, he was made full professor of paleontology (his title eventually changed to professor of geology), and he continued to lecture with few interruptions until the end. For nearly forty years he might have been seen walking at a swinging gait and with unfailing regularity across the College Yard to and from his lectures.

Mr. Shaler chose the work of the teacher without other compulsion than that which came from within; indeed when a boy he startled some of his college associates with what seemed at the time the bold assertion that he meant to become a Harvard professor. His father and others of his immediate circle were disappointed at his choice. Without prescience of the large and noble part he was to play in the rôle of a university professor, it was thought that his talents required a wider scope: law and politics were the accepted outlets for a man of his parts in his region of the country. 
For this reason but little elation was felt when he finally decided to dedicate his life to a laborious and modest career, and to take up his permanent abode beyond the borders of his own state. The great compensation, however, was looked for in the restoration of his shattered health. On his part, having voluntarily sought New England he cast in his lot with her; she gave him opportunities that he might not otherwise have had, and he gave her the best and unstinted services of his varied talents. Indeed, he embraced the new conditions in a whole-hearted way, and if the old and new civilizations did not always mingle, they lived amicably together: only as life neared its close there was a strange longing for the one he knew first. Against the academic environment, against what was rigid, formal, and lukewarm wherever these qualities found a home, he opposed the land of passionate likings, unchastened aversions, and ancient loyalties, a land where all the elements of life mingled pell-mell and jostled one another with old-time Shakespearian freedom. And because of this full life which had so deeply entered into his being he must always have seemed to his comrades to have an exotic strain in his blood. Yet, this unappeased nostalgia, this reaching out for the other life, was more or less in opposition to his better judgment, for he well knew that he needed for the exercise of his best powers full swing in intellectual centres.

Even those who knew the conditions of his heritage sometimes wondered at the evolution of so rich a personality; questioned what the preëxistent souls were like that started on its way a nature having the sensitiveness of the poet and the vigor of the man of action. How he came by this and that spiritual and intellectual quality only those who knew the community in which he lived could in any measure grasp; to the outsider explanation is impossible, nor would the present transformed society furnish a clew. One feature of his character, loyalty to persons and ideas, may in a way be laid to the door of slavery, for it was an institution immense in its force to unite and bind together members of the ruling class. 
The Cambridge of the seventies was a very different place from the cosmopolitan Cambridge of the twentieth century. Socially, it was a compact and solid little community, skeptical of strangers and inclined to impose a period of probation more or less prolonged upon possible candidates for its favors. So far as the newcomer was concerned, if he happened to be accustomed to a certain military and social esprit de corps, there was little besides a sense of duty, a contract to be fulfilled, to bind him to the College. Outwardly, there were no close friendships among the younger men, no friendly "College teas" for the women. Notwithstanding much kindliness, nobody apparently felt himself in any way responsible for anybody else. Under these circumstances it was difficult to believe that precious friendships were to crown the coming years. It may be that this sense of social sterility - whether well founded or not, for one not to the manner born is not always a sure judge - prompted Mr. Shaler when, thanks to his natural gifts, he had made a place for himself, to endeavor to render Harvard more hospitable to the stranger within her gates; for to the stranger, as he well knew, warmth of welcome is the sum of all social virtues.

He himself did not lack opportunities for meeting interesting men. In those early days at one dinner in particular at Agassiz's, among the guests, it is possible to recall the names of Emerson, Lowell, Longfellow, Holmes, Howells, and Bret Harte, besides dimmer lights. While the meal was in progress the professor descended to his wine cellar and brought up and uncorked a cobweb-shrouded bottle which proved to be a precious, mirthprovoking bottle of sunshine. On this occasion the number of wine glasses at each plate was to some of the guests a source of embarrassment. When the maid came round with the wine my neighbor confidentially asked which glass he should present. I avowed a certain traditional knowledge of port wine, native catawba, and Bourbon whiskey, but ignorance of Swiss vintages. "Then," said he, with a merry twinkle in his eyes, "you watch Mr. Longfellow and I'll watch Mr. Lowell and we'll see what 
they do." In those days there were no despotic butlers, in Cambridge at least, to frustrate the somewhat dangerous initiative of most Americans in the matter of beverages.

So far as the College was concerned, as one looks back upon it, its educational opportunities seemed to run in a mere rill, compared with the broad stream of culture set in motion by President Eliot, into which all the tributaries of learning now flow. Mr. Shaler's connection with the College was contemporaneous with its most expansive period. That he helped in a general way to enlarge its intellectual and spiritual boundaries there can be no doubt, and it is certain that in the departments with which he was most intimately connected he vivified and uplifted them. His personality filled a void in the University, and it has been said that through him "the missing virtue of sympathy for the student forced itself in." Also by means of his enthusiastic efforts greater sympathy for the natural history side of instruction was gradually won. For many years the upholders of the scientific spirit had to fight every mile of the march toward acceptance. A stream of cold water, directed by the purely academic element, played upon nearly all of his attempts to develop and enlarge the scope of scientific teaching as well as to make its approaches possible for any but the foreordained. With the aid of his associates, a body of able men who in some instances were his former pupils, he fought his fight persistently, passionately, and so successfully that at length the value of the natural history courses met with universal recognition.

If Mr. Shaler was a great teacher it was not due merely to the accident of natural gifts. His success was also the outcome of deep meditation, and a deliberate taking account of the requirements of the vocation. In a paper entitled "School Vacations," he says: "Although the needs of the pupil control the duration of our school terms, the necessities of the teacher's work are also of a nature to demand much in the way of refreshment. The true teacher, he who goes forth to his pupils, who enters into their spirit so that he conceives their difficulties and 
helps them from near by, is called upon for duties which to the inexperienced appear simple and easily performed, but are indeed of a perplexing and exhausting nature. All sympathetic action is taxing to the strength of men. When we go forth to another, making his life our own, we attain our end by ways of exceeding difficulty, by paths which are not beaten, which can only be travelled by patient ingenuity. The teacher must clearly understand the nature of his pupil. He attains his end, if he wins it at all, by vigilant and unceasing attention to every sign which may guide his endeavors. No guide who seeks to bring his charge up the most difficult mountain need be so watchful of his actions as the teacher. He gives away his life to perform his task if he be born to his calling. None but those who have done the teacher's work know the cost of this free giving of the spirit. It has fallen to me to do many things, but none seem to take away so much from my share of vitality as the struggle to gain a hold on the mind of some youth who, by nature remote from human ways, must be firmly grasped before he can be helped."

Mr. Shaler's lecture-notes, of which there are hundreds extant, although the merest outlines of subjects, are illuminating as to the variety of topics and the philosophical and universal way in which they are treated. He seems never to have been satisfied with the mere statement of a fact, he must also make the interpretation. By way of illustrating his general trend of thought, a few extracts from his notes are here given. The first at hand have the following headings: "Importance of Historic Sense," "Importance of Conception of Energy in Operation," "Importance of Understanding the Relation of Earth to Man," "Importance of the Sense of Beauty." Others read as follows:-

Lecture on the Growth of the Study of Natural History: Importance of a study of the growth of a science. Dependence of the growth of a science upon the way the phenomena are exhibited. Dependence upon the mental characters of the races. Close likeness of the Greek scientific spirit to our own, utter diversity of Hebrew. Supernatural spirit opposed essentially to the 
investigative. Absence of the supernatural spirit among the Greeks - the cause of their scientific advance. Utter want of scientific spirit among the Semitic peoples. With all the wisdom of the Bible there is no trace of scientific inquiry - not so among the Vedas, etc., etc.

Kepler's view truer than that of him who thinks he is philosophical when he excludes all idea of plan from his conception of the actions which have made the earth what it is. The imagination and the religious instincts have their place in the investigation of nature; they give the light and show the way to those fields where the harvest is gathered with the microscope and the telescope. He who begins an investigation by excluding his imagination and his religiosity begins a difficult search by shutting out the light. He willingly gropes in the dark with the idea that he is more likely to grasp the truth by chance than by guidance. I do not advocate the use of imagination alone or the use of the religious impulse alone; I would have the whole man given to an investigation. We are intellectually argus-eyed; what folly, then, to try to see by shutting all the avenues of seeing but one! The world is vast enough to require the aid of every faculty with which we are blessed if we would read its riddles.

His tendency as a lecturer has been briefly summed up in the following words : -

It was largely from the point of unity and continuity that he revealed the order of nature to the thousands of students who attended his lectures these many years; the interaction of the sun, winds, oceans, lands, and life being the main theme in his presentation of geology, while his treatment of paleontology was directed to describing the ancient forms of life, not merely for themselves but as the ancestors of the present inhabitants of the earth. He never limited his attention closely to one line of inquiry, but was always keenly interested in a wide variety of natural and human phenomena; and one sign of this was the manner in which he would consult his colleagues on unexpected topics. He was especially fond of tracing the connections which bind together the various regions of knowledge, showing at once the naturalist's love of detail and the philosopher's fondness for large problems. ${ }^{1}$

As a teacher it was Mr. Shaler's good fortune to inspire as well as to instruct, and intellectual contact with him seemed to increase a man's capacity for knowing a fine thing whenever

1 Minute on the Life and Services of Nathaniel Southgate Shaler, Harvard University Gazette. 
it might present itself. There may have been others who stated a scientific fact as well, but there were few of his time who gave so wide an application or humanized as he did the subjects of his instruction. "Under Professor Shaler," says one of his colleagues, "the student gained a kindling vision of pretty much all the natural world"; and one of his old students writes in The World's Work : -

The dramatic points of his subjects were always brought out in his lectures with great relish. To have heard him describe the movements of the ice-cap over our continent, you would have thought he had been there, observing from a mountain-peak: and, when he wound up with the fact that he himself owned "a patch of glebe on the very moraine piled up by the edge of that creeping ice-sheet," you felt that the Creator had probably parceled it out to him as his rightful share in the great land improvement.

Another of his former pupils, now a well-known teacher, sets forth in the Journal of Geography his impressions of the teacher:

As youths, students were inspired by his wonderful exposition in the class-room, and by his deep love for all that was noble and pure; as the years went on they came to love him because of his breadth of sympathy, his versatility, and his ncbleness, which could not be appreciated in early acquaintance because their knowledge was not deep enough. Those who knew him longest loved him because of all these qualities and many others that became deeper and richer as the years advanced. . . . The large majority of students went forth from his classes broader in their mental vision, more in sympathy with Nature, more keen to analyze the problems of science presented to them daily, and with a deep conviction that they had gained a mental altitude that gave them a more human outlook on the world. Professor Shaler was a great teacher because he was primarily a broad-minded, big-hearted man, vigorous of speech, keen of mind, quick of action, versatile almost beyond belief, always interested in everything about him however remote or seemingly trivial. He sacrificed his strength in every way in the service of his fellows, but his influence will go on through the generations, by his books and writings, but more especially by the teachings of those he taught to teach by his example.

The mere mention of the course originally called Natural History Five, and subsequently Geology Four, recalls to hun- 
dreds of men - those of special scientific leaning and the mere seeker after entertainment - hours delightfully spent, listening to the wonderful tale of the world's creation. Indeed, there are many who hark back to those lectures in the way men do to the fairy stories of their childhood; others, to whom nature as yet had hardly been discovered, found them the open door to a kingdom of light, to a magnificent and unmeasurable universe.

His teaching was not confined to the lecture-room. The geological excursions which he organized, generally known as "Professor Shaler's Field Days," were notable occasions. A long line of motley-looking students, in costumes more or less complete, embellished by collars and cravats according to the morning hour when the train had to be caught, would be seen moving along the streets, over hills and dales, through swamps and across rivers, following their leader. These excursions were usually in the immediate neighborhood of Boston, though sometimes Mr. Shaler was requested to extend his tramp to other districts. The Boston Daily Advertiser's report of one of these expeditions runs as follows:-

On leaving the cars at Quincy the party walked to the top of the high hill just west of the station. Here attention was called to the widespread view of sea and shore, and to the fine mountainlike scenery of the Blue Hills. "They are called hills," said Mr. Shaler, "but in their day they formed a part of a lofty mountain-range extending from Sharon past Boston to Saugus. These now denuded and degraded mountains, presenting but a trace of their former grandeur, are very interesting to the geologist. They have not received the attention from scientific men that they deserve. . . ." Mr. Shaler then remarked that he had obtained more information concerning their history and structure from a well-known Boston lady [Miss Eliza Quincy] than from scientific works. . . Gradually the character of the rocks, and the wild, picturesque scenery they made, changed, till at last, on the shore of Weymouth River, the blue-clay slate that crowned all was reached. Here a visit was made to the only trilobite bed in New England. "These trilobites," said Mr. Shaler, "are the stony remains of the earliest life. They resemble somewhat the horse-shoe crabs so common in Boston Bay." A specimen of this crab was picked up on the beach and the two compared. Placing the dead crab fresh from the sea and his ancient 
cousin side by side, the professor said: "Here we have a fish from last summer's tide and his relation from the steaming, turbid waters of an almost shoreless sea that flowed over this spot a hundred million years ago."

Mr. Shaler would often return from the day's tramp - severe enough to tax the powers of men much younger than himself - very tired. Walking and talking, explaining and reiterating all the way were taxing occupations, and not infrequently the luncheon which had been put up for one was shared by several, thoughtless youths having forgotten to bring their own rations. But severe as was the day's work, at the end of it the young men had profound respect for their teacher's athletic capacities. Late in life he was fond of telling the story of his once having overheard two students talking together. "Where's the old man?" asked one. "Hush!" said the other, "if he hears you call him old man, he'll walk your $d-d$ legs off."

As we have seen elsewhere, Mr. Shaler early became interested in "the idea of summer instruction" and was among the first to undertake teaching at that season, making a modest effort of his own in 1868 to unite teaching with his field work in geology by taking a party of students from Cambridge to Virginia. In the summer of 1875 he organized the first course in geology at Camp Harvard, Cumberland Gap, Kentucky. The scheme in its general application was not warmly welcomed at first, and the evolution of the Harvard Summer School as it now stands with its hundreds of ardent students was somewhat precarious. In 1886 President Eliot appointed the first committee to have charge of summer courses, naming Mr. Shaler chairman, but it was not until five years later that formal recognition was given by the Faculty of Arts and Sciences to summer courses. Of the first committee appointed by the faculty Mr. Shaler was again made chairman. For nearly twenty years he gave himself with untiring devotion to the development of this phase of college work, using unstintingly his keen and vivacious intellect for the furthering of its inter- 
ests; even assuming, in times of stress, financial risks, and furthermore burdening himself with a great deal of additional work without compensation either as teacher or as chairman. Yet in spite of many hindrances his enthusiasm and zeal never flagged, and he persistently advocated the continuous utilization of the college plant - its laboratories and museums, as well as a part of the time given up to the long vacation - for the benefit of graduates, teachers, and others of both sexes.

In the paper on School Vacations, already referred to, is found the substance of his argument for summer schools of natural science. "It may be asked," he says, "how the student weary of his school year can be expected to devote a large part of his holiday to this other form of schooling; how are we to avoid the evils of overtaxing the pupil if we put a large share of his labor into the time we have found to be required for refreshment? Experience gives a satisfactory answer to this question: for it shows us that the character of the true scientific work so far differs from the labor done in the school-room that he finds a large measure of diversion in the change in the nature of his employment. . . . In the laboratory or the open field work of nature the memory is no more taxed than in the ordinary occupations of men, but the constructive imagination which is generally unemployed in the tasks of term-time is actively aroused. In the class-room the pupil is tied to print, in laboratory work he deals with natural objects and finds in his contact with them the quickening of spirit which to be conceived needs to be felt. My own experience with vacation schools shows me that ordinary students may, without suffering any tax upon their vitality, year after year devote six weeks of the summer vacation to hard work in natural-science schools."

$\mathrm{He}$ further believed that "a well-trained young man in college may with general advantage devote a small part of the year he consecrates to literary studies to some easy course in natural science; or in case his devotion is to science he may find refreshment in following an elective in music or metaphysics. . . . 
The same mind I am convinced finds profit from both these educative agents."

Another consideration he urges is "the waste of time after each vacation in getting adjusted to school routine, for the reason that the work of the student is of a nature to derive little help from inherited usage. It is therefore always difficult if he be a wholesome creature to build in him habits of study; after each break in his schooling he returns to his work with a mind disused to the tasks of the school-room, nearly half of the year is spent in recovering from the return to the primitive desultory life of the savage or half-civilized state."

In regard to the lack of inherited aptitude for study in contrast to the accumulated ancestral habit of muscular activities, he says, "the youth wrestling with the elements of language or mathematics is engaged in the same class of exhaustive labor as the author or the athlete. We cannot expect of him the persistent toil he could well give to mechanical employments which lie within the common inheritances of the race; few of our children inherit even for two or three generations the intellectual habit. School work is the creation of yesterday, while the normal energies of mind and body have been transmitted to us from the geological ages. . . . In our schools we are dealing with minds and bodies which have, perhaps happily, a vastly greater inheritance from brute and savage than from civilized life. . . . In the matter of our teaching-system, as in many other of our social problems, we seem to be always 'between the devil and the deep sea': on the one hand we have the savage and barbaric man whose lusty strength and simple nature we need to keep alive, but whose clumsy, unthinking ways we must better; on the other side, the bloodless, half-human creature which our schooling breeds. Our task is to make a middle kind of a man who retains the good of savage and scholar alike."

These views, new when he first stated them, have since become the truisms of the profession. From the beginning he 
worked with a far-seeing eye for the advancement of the Harvard Summer School, and through it for the advancement of the University. In the administration work he was greatly aided by the men who at various times acted as his secretaries: Mr. Montague Chamberlain, Professor J. L. Love, and others, who likewise spared no pains to bring the school to a high plane of efficiency. It was not the intellectual side only that was well looked after; the comfort and happiness of the students, men and women, were in every way considered. While disliking in such a connection anything of the nature of a picnic quality, Mr. Shaler was in favor of promoting social fellowship. At the reception given each summer by way of greeting to the students, he was present, whenever possible, to welcome them with a cordial shake of the hand to the ancient halls of learning. On their part, although he was unconscious of it, their attitude toward him was almost reverential. He was often greatly pleased with the delight in the attractiveness of the old surroundings expressed by those who came from the newer parts of the country; he particularly enjoyed the air of proprietorship shown by some of these scholar pilgrims, and would laughingly say, "These six-weeks students think they own the University: the women especially."

At first it was difficult to get just the men he wanted among the University corps of teachers to assist, but of late years the oldest and most distinguished professors have lectured to the large classes composed of unusually serious-minded listeners. Mr. Shaler considered the Summer School a vast instrument for the extension of Harvard's influence and the methods of teaching adopted there. Its present flourishing condition is a monument to his sagacity, and to his fostering care during times of great discouragement.

Mr. Shaler was always opposed to getting up things with too much preparation and formality - the thing was to get itself up. He often cited the Summer School as an instance of an institution coming into being almost without official authority, 


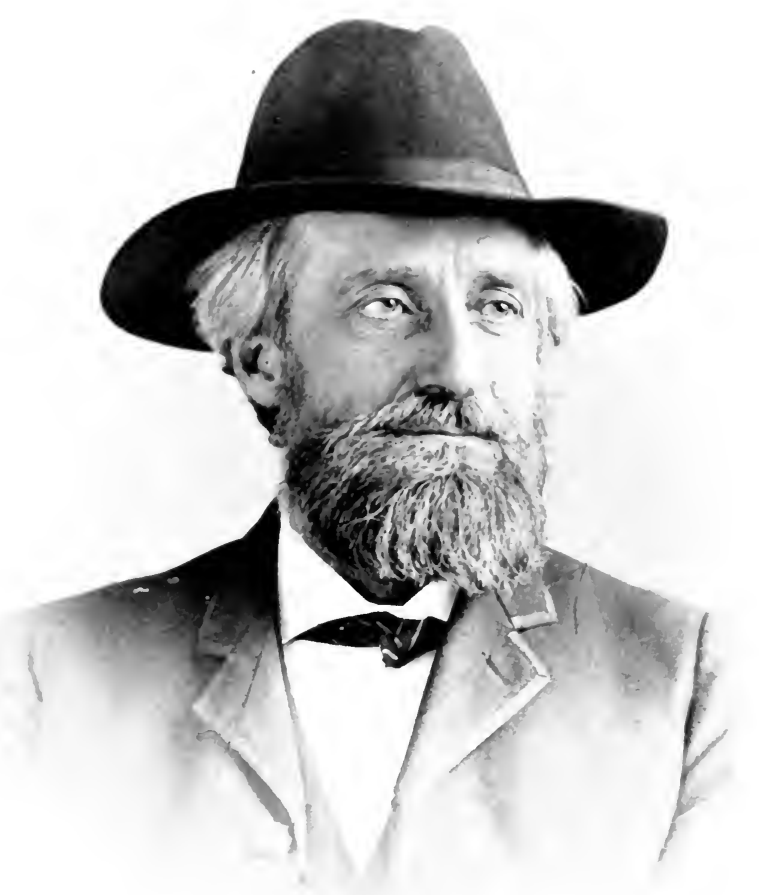

MR. SHALER IN 1S!H 
$=$

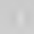

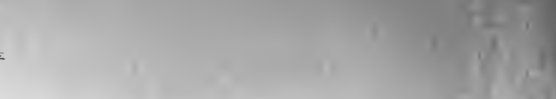

$+1$

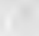


of its doing its work and gradually winning its way to success without much avowed sympathy or encouragement, indeed against a certain hostility. He would add, "The Bible grew, the Koran was made."

It may be said here that Mr. Shaler presided at the councilmeeting held at Mr. Arthur Gilman's house which took the first steps for the founding of Radcliffe College. He never taught there, for the reason that he was already too heavily burdened with his University work. While he believed that women should enjoy the most liberal educational advantages, he was not in favor of co-education, or of anything, indeed, which might take away from the poetic side of social life. He feared that matter-of-fact, commonplace contacts might do this. He never cared to have women clerks in his office, for the reason, he said, that "if there were occasion for blowing any one up for neglect of duty, he preferred to blow up a man rather than a woman."

In his teaching of teachers who came to the Summer School, as well as with his College students, so far from wishing to keep them in leading-strings or subordinate to his will he aimed to render them able to walk by themselves. He believed that the usual efforts to obtain discipline and attention through habits created from the will of the teacher impressed upon the youth, were wrong. In his opinion these essentials can be profitably won only through the exercise of the will of the pupil. If the exercise of this power arises from the mere dominance of the teacher the effect is to repress development. He sometimes reproached the kindergarten methods for fostering a limp and dependent attitude, for building up a state of mind that required perpetual amusement. He said he could always tell a victim of the system by his inability to fix his attention long on any subject or to work alone. He had far less patience with such students than with men who were simply stupid, or with those who could not even think of thinking. In the one case he trusted to a belated awakening, in the other to some kind 
of automatic response that might involve the heart even though the brain were benumbed. At any rate, stupidity he reckoned as something firmly established in human nature that had to be put up with. The confirmed in dulness he often counselled to seek their strength in manual dexterities. He by no means despised a small talent if it fulfilled its task. Nor did he overemphasize attainment. He used to say "it was not worth while for humanity to be bumptious about what it had accomplished, for the little that is done seems nothing when we look forward and see how much we have to do." This conception of the vast and unattainable field of knowledge came to him at an early age as will be seen from the accompanying extract from his journal.

Sept. 18, 1859. When one appreciates the shortness of life and the vastness of nature every moment lost to study and contemplation seems a loss irreparable; the days, weeks and months, as they glide by, are each bearing in its course a portion of our life without adding to our store of wisdom. . . . Like a wanderer in a labyrinth trying first one path and then another and hurrying with eager steps to reach the goal, one finds himself at length at the place of his departure. . . To many this view of all the end of philosophy might be discouraging, and indeed it would be if the end of all study were to gain the object of our search. But the true philosopher has more than mere curiosity to tempt him to give his life to contemplation and research, for although at last he but gains a knowledge of his own insignificance, his studies have brought him nearer his Creator.

The truth is, as time wore on, mere intellectual distinction unaccompanied by high character was held in only moderate esteem; to his mind the supreme excellence consisted in being a gentleman. But in whatever shape it presented itself, whether able-minded or dull-witted, he had great reverence for the organism called man, and was ever conscious of the immense struggle the ages had witnessed to bring him to the place where he now stands. He not infrequently quoted Emerson's saying, that it was something for man to have got up on his hind legs and shuffled off some of his animal propensities. It was this historic sense that enabled him to see the 
latent significance that lay beneath the smooth-faced vacancies of the youths that passed before him, and to such of these as would submit to his guidance he was a born director of souls. How many did submit is shown by the hundreds of letters from students acknowledging the help he had given them, the perverted ways abandoned at his stirring call to lead the clean and wholesome life. His willingness to bother, up to a certain point, with men of crooked ways, is all the more remarkable since there was no one who had less call for indulgence than he. Nevertheless, his long experience had taught him to weigh a man's errors against his temptations, and these he felt were to a certain extent involved in the previous conditions of the man's life. He therefore looked upon individuals tolerantly, with a discriminating eye as to their values and their needs, and without being sermonic he sooner or later imparted to them a sense of what was dross and what was gold - a lesson which he himself had so well learned. The fact is, his influence for good was great because he lived on the plane of right doing to which he directed others.

Mr. Shaler's relations with his students were the most vital and interesting of the contacts that came to him. Young men of all degrees and temperaments liked him, not because he spared their faults, was truckling, or sought to be popular, but because he met them on the broad level of humanity; and if in his estimate of them he sometimes gave them credit for what they should be, rather than for what they were, in the long run his judgment was as true as it was generous. The foundation of the attractive power that drew men to him was his manliness and outgoing sympathy; he had a kind word to bridge the deeps that lie between most human beings. Furthermore, when he commended a student it was with whole-hearted liberality, when he condemned him it was in a broad and catholic way. Detesting anything like mechanical treatment of a human soul, he refused to be hemmed in by rules or to raise authority to a system of oppression. Each individual was to be treated with 
reference to his capacities. "The business of the true teacher," he says, "is like that of the gardener who is dealing with hybrids, where the product of each seed is a problem to be studied at every step of its development, to be fostered by all the resources in the way of soil and climate which can be applied to it through all the resources of art."

The rough classification of men, with the assumption that all who fall within each category are alike, he regarded as gross injustice especially in the treatment of the youth. To illustrate the difference in men's capacity, he often cited the tests of the mathematical examinations in the University of Cambridge (England). Reckoning the mathematical capacity of the ordinary intelligent man at one in the scale, it would have been found that the ablest from among about a thousand youths is something like one hundred times as great.

In any difficulty he was always willing to hear the boy's story twice told and oftener if necessary, for he knew that truth sometimes has the face of falsehood; and not infrequently he exulted in snatching a boy from the punishment that had been meted out to him as he proved on misapprehended evidence. It took a great deal to blunt the edge of his sympathy, but the student who presumed upon the fact that he was tender-hearted learned to his cost that he was also tough-minded. There were some offences he would not forgive - lying, cheating, meanness, and cruelty; and to the one steeped in deception he was a terror. For the thoroughly intractable there was but one sentence: "Take him to the edge of the earth and drop him off"; or again, when a worthless man was condemned he would say, "He's nane the waur of a hanging." To have "a talk" with the Dean in his office sometimes produced a hair-lifting crisis, his energetic statement often affecting a decided betterment in a young man's future career. The man of innate and fixed evil propensities caused him bitter disappointment; he contemplated him sadly, free will and determinism struggling in the account he took of him. At times he seemed to grasp the whole 
meaning of a student's life; in his presence he became blind to the grace and beauty of youth, seeing only the unregenerate man he was to be, pitying him for writing his own sentence in the book of fate.

His solicitude for the students' welfare was not confined to the precincts of the College Yard; when they went abroad he still kept an eye upon them. He often said, "I hold it a part of my business to do what I can for every wight that comes to this place." When they got into scrapes he went to the police courts and watched the proceedings to see that justice was done them, or to give what evidence he could in their favor. He confessed that it was his habit after public days in Boston to take a look in at the Cambridge police court next day to be sure that his boys, if in any trouble, had fair play.

The hospital was also the scene of many of his beneficences. During the fifteen years that he was Dean he never failed to visit a sick student belonging to his department. In cases of serious illness he called every day; and in his afternoon walks to take in the Stillman Infirmary was almost a daily occurrence. Going the doctor's rounds in his youth with his father, his studies in anatomy, as well as his ample experience in the ways of illhealth, made him an excellent adviser; he had passed through so many phases of physical misery and come out fairly whole that he was a cheerful and encouraging friend to the sick. His very presence brought comfort to many a forlorn boy; the down-hearted he encouraged and the one who complained he rallied, telling him "to grin and bear it." During his own last illness he said with a grim smile one day, when suffering acutely, "Perhaps I have been hard on the boys inclined to whine a little after this diabolical operation for appendicitis; it is n't pleasant after all." There was no home so poor or hospital so well equipped that he did not enter, and, if anything was lacking for the comfort of the sick boy, make a vigorous protest and find the means of getting it.

In the hospital, as one of his students writes, he would pull 
up beside a bed, feel a pulse, diagnose the case, tell the boy that he heard good reports of his work, and then fall into dispute with the doctor on the effects of anti-toxin on diphtheria. He inaugurated a system of sick reports whereby a student's illness might become immediately known to the authorities and his condition promptly looked after by competent physicians. He disliked anything like haphazard methods. He urged that supervision in this and other regards be pushed to the military standard of inevitableness, for which he had a great respect, his early hauntings of a military post having given him an understanding and appreciation of order, regularity, and system.

If he was thus concerned for the sick body he was still more solicitous about the sick soul of a youth. There were few occasions when he was not accessible to a student. It is told by one of them, now a man of distinction, that time and again when he was in trouble, or when feeling the need of stimulating talk and counsel, he would go in the evening to Mr. Shaler's office and, since the door was fastened against intruders, attract attention by throwing pebbles up at his window. Not only was he never refused admittance, but, on the contrary, was cordially welcomed and given the best of fellowship and advice. Mr. Shaler's courtesy at that place and time is especially noteworthy, for he particularly enjoyed the peace of the empty building and the sense that, free from interruption, he might get on with his work.

He had intense sympathy for the lonely youth who for the first time had left behind him home and friends. He remembered the time when he too had been a stranger in a strange land and had somehow got the impression that a man from outside of New England did not count, indeed that the rest of the country was in a way superfluous. He therefore exerted himself to fortify the youth's good opinion of himself and to hearten him up as to the value of his locality, even if it was in the far West. One feature of the College administration which 
had his active support was the Students' Reception Committee, whose object it was to assist the newcomer to adjust himself to his new surroundings and give him the feeling from the first that the College was directly concerned in his comfort and success. Out of this committee, or rather because of it, there sprang up among the wives of the professors an association for giving the students a chance to meet socially their teachers and their teachers' families as well as any distinguished men who might happen to be in Cambridge. The entertainments they set on foot are known as "The University Teas," and are held in the parlor of the Phillips Brooks House every Friday afternoon during the winter months. It was realized that the afternoon tea for students, to be anything else than an exhibition of unsuccessful conscientiousness, must be entered upon with hope, faith, and verve. There were at first gentle hints that except for the concrete fact of chocolate and sandwiches this form of sociability was all moonshine, but by and by a different sentiment prevailed. The "teas" grew to be a success. The eagerness with which the students gathered about their favorite teachers showed that they did care for social fellowship with them, and the geniality of all who came, from President Eliot to the youngest usher, gave sign that the end for which they were initiated had been attained. Mr. Shaler was intensely interested in the idea, and rarely failed to go to the "teas," though he was not a friend in general of this form of entertainment. Standing before the large open fireplace, he was sure to be the centre of a group of young men who stood about him eager to grasp his hand and listen to his stories. Many doubtless have well fixed in their memories this picture of him.

In the early days, when students of natural history were few, it was easy to invite them to dinner or to a Sunday evening supper, and in this way establish some friendly relations with them; but in the course of time the numbers so increased that it would have taken almost every day of the college terms to entertain them at table, especially since Mr. Shaler would allow no pick- 
ing and choosing, all must be asked or none at all. Receptions, therefore, had to be resorted to, a very imperfect and, to many a shy student, a formidable device, for recognizing his social existence. On these occasions Mr. Shaler tried to make his guests feel at home, and doubtless succeeded, for they seemed happy, - and youths as a rule have n't the power of making believe in such matters; on the contrary, they are pitilessly indifferent to well-meant efforts that don't happen to please. At any rate, the welcome to the home was not altogether barren of results, as is proved by numerous letters and the kind words of men scattered all over the country who seem to remember with pleasure even so slight a courtesy.

Among many amusing experiences involved in the entertaining of students there was one in particular which Mr. Shaler used to relate as a sort of family joke. One Saturday afternoon he mentioned to his wife that he had invited three young men to supper the next evening. When the hostess, somewhat belated, reached the library, instead of three there were four students. In the introduction that followed the names of all but the fourth were distinctly uttered, but his somehow seemed to linger on Mr. Shaler's tongue as if he thought she ought to know it, as belonging to one whom she must have bidden to the feast. This hesitancy and presumption of superior knowledge on the part of the other was not remarkable in the academic world, since a Napoleonic memory only could successfully associate names with the constantly changing faces of the youths who formed the moving procession. One of the young gentlemen was a Japanese, and since he hailed from the farthest East he was given the seat of honor. With the usual politeness of his race he took whatever was offered him, but apparently without interest. His interest in fact had almost instantaneously become fixed upon a Japanese picture, a silk, transparent, flowery thing fastened with thumb-tacks on the wall opposite. From its contemplation neither oysters nor chicken salad had the power to allure him. At length, as if endurance had reached 
its limits, he exclaimed, "Madam, will you permit me to arrange that picture? It is upside down and wrong side out." It is needless to say, those were the days before Mr. Denman Ross had taught his fellow citizens the meaning of Japanese art; to the average Western mind it was a plexus of incomprehensible design, the lettering even giving no token; therefore the more outre the disposition of a decorative piece, the more in keeping it seemed with the Oriental plan - if plan there were in so great confusion.

The picture made right in his eyes, our young friend resumed his seat and like a Christian proceeded to eat the food massed on his plate. Still there was a sense that something yet was wrong. At this juncture the youth whose name had been discreetly slurred suddenly asked, "Shall I see Mr. P- tonight?" Assured that it was possible but not probable, he relapsed into silence, only violating it a little later to inquire if Miss — was likely to appear. Informed that it was not likely, "Well, then," he exclaimed, "where in the world am I?" Enlightened as to his whereabouts, he begged to be excused, adding that he had been invited to take supper at Mr. P- 's. After his withdrawal we once more subsided, hoping to finish the meal without further upheaval; but it was not to be. A few moments only had passed when the furious ringing of the doorbell sent Mr. Shaler in alarm to see what was the matter. $\mathrm{He}$ found the same youth back again. "I'm sorry to trouble you," he said, "but Mr. P_-'s family have gone to church; so I thought I would return and finish the evening where I had begun it."

It must be confessed that at times the student who called in the evening was a trial. To quit his books and comfortable seat by the fire and talk to a lad of no particular parts, seemed to Mr. Shaler's family a great waste of his precious time; but he seldom was willing to refuse the visitor; nor was he willing to have his wife do so either. One evening when an unusually dull youth was announced, her perverted heart inclined her to 
find an excuse. "I think," he said, "you had better see him," and when she further remonstrated he added, "Remember his uncle" (a charming and gifted gentleman). "I do," was the answer; "his uncle would n't have tolerated his nephew's company for five minutes, much less for the whole evening." "Then so much the worse for the uncle," was his final reply.

Mr. Shaler had some curious experiences in his efforts to get money for deserving students. Once he wrote to a wealthy and influential friend, Mr. Forbes, who had made a fortune in the Eastern trade, asking him to aid a young Chinese to finish his education. The choleric gentleman promptly replied that he would not give a cent to a Chinaman or to any other student, that education was being run into the ground, and so forth. Application was about to be made elsewhere when another letter came containing a liberal check with the words: "I send this money to your student with the greatest pleasure. The truest gentleman and best friend I ever knew was a Chinaman."

It was Mr. Shaler's privilege and pleasure to be much concerned with this problem of helping men to attain their education, and in the effort he spared neither time nor money. Much is said of the rich man at Harvard, but few knew, as well as he did, the dire poverty of many who entered its halls : of the close calculation in families to meet the expense of tuition, or of the outside labor of students themselves to eke out existence. Often in his visits to their homes for the purpose of seeing them when ill, or to consult with their parents, he saw much that was pathetic. Sometimes he was convinced that ambition outran capacity, and regretted the unprofitable strain to furnish a college education where manual training seemed fittest.

The Russian Jews in their desperate fight for advancement often awakened his profound admiration and sympathy. There was one student of whom he sometimes spoke as typical of many others. Observing that this young man was pale and thin, he sought to know something of his circumstances and found that he was actually suffering from the want of food. 
Moreover, in addition to keeping up with his own studies he was teaching at night a class of young Russians so that they too might grasp an education. Some money was given him with the injunction that every cent should be spent for nourishment. The answer came, "Upon these terms I cannot accept it. I give to my family half of all I get." Of course he was made to take the money and for some time was carefully looked after. At last he disappeared, but, having his address, Mr. Shaler went to look him up. The old man who opened the door insisted in broken English that no such person dwelt in the tenement. His stolid negation indeed was so persistent that the visitor was about to leave the house when a little girl who had loitered in the background exclaimed, "Why, grandpa, what do you mean? You know he does live here. Come, mister," she said, "I'll show you the way." Following his guide through a labyrinth of dark entries, he finally reached a small, badly ventilated room where the sick student was lying upon his squalid bed. After a few minutes' talk, encouraged and cheered by the presence which always brought hope and comfort into the sick room, the young man began talking of his life in America. He said: "Hard as it is in many respects, it is a paradisiacal life compared with existence in Russia." And when asked the meaning of the old man's denial, "Ah," he answered, his face flushing, "you can have no idea of the tyranny we lived under. My father could not conceive of a stranger coming to see me without some evil purpose. He undoubtedly thought you were a spy, or a policeman in disguise. He has not been long enough in America to get rid of his torturing fears, or to have the faintest idea of what freedom means. My little niece, now, was born in this country and is as fearless as an eaglet."

Another Russian student was asked to find out, if possible, why it was his young countrymen stood so well at school. He returned after a few days with the answer: "The Russian Jew needs no amusement, he does n't waste his time with games, they're nothing to him, his studies and his manual labor furnish 
all the play he wants." This account was later confirmed by a very intelligent American teacher in one of the public schools in the Russian quarter. Mr. Shaler frequently walked through this part of Boston and spoke of the sturdy looks of the children and the strong maternal aspect of the young married women. $\mathrm{He}$ also commented upon the change for the better in the appearance of the streets: the gradual recession of squalor before the march of the intrepid, strong-willed immigrants. One day he returned from his office much amused by the naïve remark of a young Russian from this same neighborhood who wanted to enter college. When questioned as to his means of support, he said that his mother kept a clothing store run on the instalment plan. "But," asked the professor, "does n't she lose a great deal of money selling her goods in that way?" "Oh, no," was the prompt reply; "she only sells to Jews." Mr. Shaler was on very good terms with many of the Jews in Boston. He was sometimes invited to their social entertainments as well as to speak at the annual dinner of the Purim Association.

There was another class of persons with whom he got on well, and this was the class known in college circles as "Mothers." With them he was always patient, even with the one who felt when she paid the tuition fee that she had bought the entire University, also the time and devotion of the teacher, to be dedicated exclusively to her son's interests, mind, body, character, and estate - for the finding of occupation for the young man when he was through with college was often an implied obligation. Mr. Shaler used to say when he wanted to get down to the bed-rock of a youth's nature that he would go to the mother; that she knew the boy infinitely better than his father, and if she would she could lay her finger on the weak spot of his character. Once, in a state of perplexity about the evil courses of a young man with whom he had to deal, he went to the mother, and, after stating certain facts, put the question, "I shall be greatly pleased, Madam, if you'll tell me just what's the matter with your boy." "Oh," she answered, "there's nothing special 
the matter with John, except that he's got no soul." "I believe you're right, and now," said Mr. Shaler cheerfully, "we must set to work to make one." And, strange to say, after a while there did appear the faint glimmerings of a soul - stirred later to warmer life by the call to arms; and then through the gates of death this feeble soul, doubtless, elsewhere won its happier chance.

Hundreds of letters from Mr. Shaler's students and their mothers show their attitude of mind toward the teacher. It is very clear that in many cases the way to knowledge was through the gateway of affection. No one knew better than he the advantages of the naturalist method of instruction. But in this instance, whatever the system, it was the man himself who drew his students near to him. The method of instruction by experiment, he says, "consists in the close relation which it secures between the teacher and the pupil and the more sympathetic nature of their contacts. . . . Very soon the student finds himself dependent upon him. Such are the depths of the phenomenal world that this mutual relation may indefinitely continue and always afford beautiful opportunities for sympathetic contact between men who are united in the work as master and apprentice."

That these "beautiful opportunities" were so freely made use of is a noble tribute to the master's outgoing sympathy and to the generous response of the apprentice. 


\title{
CHAPTER XXVI
}

\author{
ADMINISTRATIVE WORK
}

1891-1903

IN $1891 \mathrm{Mr}$. Shaler was made Dean of the Lawrence Scientific School. He accepted the office reluctantly, although he had for some years been actively engaged in furthering the development of the School ; indeed, according to one of his associates, its revival after 1886, when there were only fourteen students, was mainly his work. While foreseeing its possibilities he also had a keen sense of the labor their realization would cost. It was a task, however, which he scarcely felt justified in refusing, especially since Mr. Gordon McKay had determined to leave the bulk of his fortune to this department of Harvard University. As they had for so long a time mutually instilled into each other's minds ideas as to the kind of institution it would be well to foster, Mr. McKay naturally turned to Mr. Shaler as the person best fitted to guide it along the lines he had laid out. Therefore, weighing carefully all these considerations, Mr. Shaler found strong reasons for taking up the duties of the deanship, and, having once assumed them, with his accustomed zeal he set about making the most of the opportunity.

Under Dean Shaler's leadership the Lawrence Scientific School - a large and shapeless problem, one might almost say a "mortifying failure," when he took hold of it - rose from a more or less despised part of the University to an efficient, prosperous, and commanding position. During the fifteen years he was at the head of it the number of students doubled twice within the last decade and increased to a total of five hundred and thirty, notwithstanding the gain at times was temporarily 


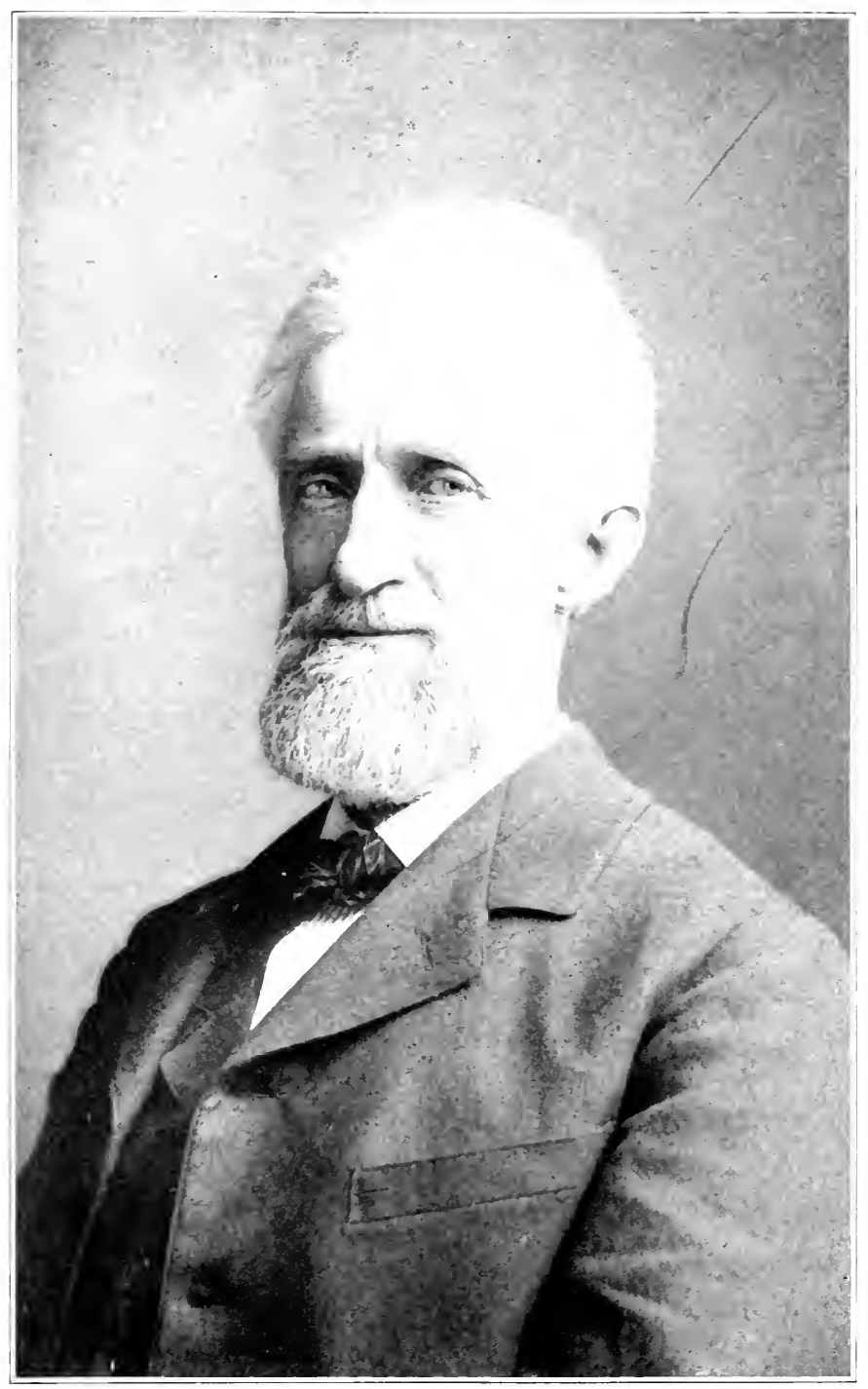

MR. SHALER IN 19 ( ) 

checked by higher requirements for entrance, this leading to the transfer of men in "general science" to the College. Surmounting great difficulties, the resources of the School were diversified and strengthened on many lines. The development was especially marked in engineering, mining, metallurgy, architecture, landscape-architecture, and forestry. In addition there were four-year programmes in chemistry, geology, biology, anatomy, and physiology. These four-year programmes under the new organization are things of the past, as also the old name, the Lawrence Scientific School giving place in the University Catalogue to the Graduate School of Applied Science. These changes are embodied in the plan of reorganizing the work of the School which Dean Shaler announced as his last official act.

While in charge of the School Mr. Shaler lifted its scholarly and moral tone, as well as its numbers, to that stage of advancement where Gordon McKay's magnificent bequest made possible a brilliant and expansive future. It was, therefore, a surprise and bitter disappointment to him, upon his return from Europe in the spring of 1904, to find that negotiations were on foot between the corporations of Harvard College and the Massachusetts Institute of Technology for transferring to the latter institution a large share of the income of the endowment which Mr. Shaler, through his friendship with the giver, had been instrumental in bringing to the service of the Lawrence Scientific School. More than this, there was the provision, as Mr. Shaler states in an address delivered before the graduates of the Lawrence Scientific School, that the institution which Mr. McKay called "his School" should disappear, and that in place of it there should be benefited another institution, not a constituent part of Harvard, but a supplement to the existing Institute with some slight semblance of joint control on the part of the governing boards of the University. The discovery of this strange and unexpected danger at the moment of fairest promise, when, by sound accomplishment, the School had reached the gateway of a great future, "perhaps," as he said, 
"the noblest that ever opened to a School of Science," filled him with the most profound chagrin.

His endeavor to maintain the integrity of the bequest brought him into collision with the authorities of both institutions. He made a strong appeal to the Board of Overseers of Harvard College to reject the project of handing over three fifths of the income of the McKay gift to the Institute. In this appeal he set forth in clear language the disadvantages to the Lawrence Scientific School and the University which would follow such a division of the fund, as well as the moral breach of the testator's purposes; for the carrying out of which he had given his personal pledge. In fact, he said, it was mainly because of Mr. McKay's request that he had accepted the post of Dean.

Besides the immediate question involved, he believed that other important problems of the higher education would be decided by the issue of the contention; foremost among these were "the respective rights," as he phrased it, "of the three estates of the School realm - the Corporation, the Faculty, and the Board of Overseers." What gave special emphasis to this question of authority was the statement that the decision on the "merger" project would be determined by the Corporation and Board of Overseers, who would be pleased to hear the opinion of the Faculty, but, whatever the opinion might be, it could have no authority whatever. In the address already alluded to Mr. Shaler called attention to the fact that the Faculty was steadily losing power.

The vote of the Corporation of the Institute and the action so far had by the Corporation of Harvard College will mean, if it be not checked, that the shaping of our great schools is not hereafter to be in the hands of experts in the science and art of education, but will be determined by men who are necessarily without other than the amateur's smattering of such learning. It means that institutions having for their province the development of experts and the extension of their high functions on which civilization depends shall in their very government deny the essential value of such training.

The meaning of this action goes yet further: it makes a radical change in the nature of these trust-keepers of our public schools. Gifts bestowed upon 
them have been made not to trustees as bodies separate from the institution as a whole, but with the tacit supposition that the faculties were integral parts of the structure, able to make themselves felt in the important questions of education. To assume that the one board, because it has the legal power, may suppress or transfer or otherwise profoundly alter the constitution, is to change the position of these schools in our societies. If these self-renewing bodies of business men are to be the sole keepers and administrators of these trusts, stolidly uninfluenced by the protests of the other and more vitally important estates, the Faculty and the Alumni, it cannot be expected that they will hereafter command the confidence of those who would send their good purposes on from generation to generation.

I have thus briefly, and most inadequately, suggested some of the considerations which are to be discussed in the debate which is before us. You see that they go far and concern questions of great pith and moment. . . . I beg of you and all the participants herein that the debate be kept to the high level of its importance. We need always have in mind the fact that those who are opposed to us are ardent, even as we, for the betterment of the institutions which they love even as we love them. . . . We are brethren, strong for the betterment of our common house: let us remember that we have in the end to dwell together under its roof and abide in its memories. This counsel of perfection need not lessen, however, the energy with which we resist to the uttermost what we hold to be evil.

The controversy which followed the "merger" proposition was bitter and determined, for upon its result Mr. Shaler believed hung the life or death of the School which he had labored so earnestly to advance. It called forth on his part a vast expenditure of force and emotion; for when he once espoused a cause he threw himself into it with passionate devotion. There is no doubt that this trying episode, this opposition to his most cherished and disinterested schemes for the development of the Lawrence Scientific School, told seriously upon his health. While petty squabblings bored him, a good big fight aroused all the powers of his mind; bold and resourceful in debate, he fought his battles with tremendous and unflagging verve. In these intellectual encounters, mercilessly hard as he hit his opponents, he hit fair, and for this reason, although in the course of his life he had many antagonists, he had few enemies, his great-hearted manliness bearing down the hostility disagreement usually 
engenders. All these qualities he showed in this particular controversy, upholding with inexhaustible fervor the material advantages and the moral right of his cause.

When at last the legal decision was delivered which made the sale of the land owned by the Institute in Boston invalid, and thus put a stop to the merger scheme, the controversy ended. Since the gift about which it had arisen was left to go where it was intended to go, Mr. Shaler in a measure was satisfied with the result, although he would have preferred to have the question fought to the end on its ethical merits. After this disturbing controversy, during which he had been warmly upheld by a large number of his colleagues and Harvard graduates, as well as by a part of the Technology faculty and alumni, he subsided to a state of quiescence and was disposed to forget the unpleasant features of the debate as well as the sometime feeling of personal injustice; this it was possible for him to do, for while he was capable of being intensely angry, he could be neither sullen nor resentful. Yet, although many of the objects he had labored to bring about in the development of the School were accomplished, or were on the way to fulfilment before the end came, it was pathetic that so near the close of his long and untiring service to the University untoward circumstances should have made him feel that perhaps after all he had built his life's work on insecure foundations.

The administrative work of the Lawrence Scientific School was laborious to the last degree. It called for unremitting attention, and was constantly present to Mr. Shaler's mind, urging him to seek in every direction opportunities for its expansion. To do justice to this one phase of his activities would require more space than can be allotted here. It may be said, however, that his object was, as far as possible, to incarnate in the students the ideals of the original founders of the Lawrence School, "who," he said, "were the first educators in America, if not in the world, to set up the ideal of the man of enlarged 
and enlarging training made as far whole in all his parts as a good general education could make him, that he might have adequate foundation on which to build his professional work." With this end in view he diversified, grouped, and so arranged the courses of instruction that they might not only yield a thorough technical training in the different branches of practical knowledge, but give also a share of culture - at least a taste for the humanistic side of learning which might be a haunting memory, a memory that would perhaps deliver men from a sordid and too exclusive devotion to business. That his aim was not wholly without result, that there was at times the sting of conscience, if not the benefit of conduct, is shown by the following anecdote, which Mr. Shaler liked to hear.

It so happened that once while waiting with a friend in the corridor of a New York hotel I was introduced in a casual way (neither one catching the other's name and I wearing rather a thick veil) to a gentleman whose appearance denoted worldly prosperity. A moment after, my friend remarked to him, "I'm sorry to hear, old fellow, you are not feeling well overworked, I suppose?" "How is it possible," I interposed, "to be otherwise than overworked in a place like this?" "That's just it," said the stranger. "I'm ashamed to confess it, but one does get submerged in the current. Yet there was a time when I had other ideals. I remember once when I was a student at Harvard, now a good many years ago, while I was calling at the house of a friend the talk turned upon the possibility of combining business with some form of liberal culture, and as an illustration of the possibility, Sir John Lubbock, the successful banker and man of science, was cited. Listening to the conversation I then resolved, young and vacant-minded as I was, that I would cling to some intellectual interest outside of the field of money-getting; but alas" - and he shrugged his shoulders. "At whose house was it?" I asked. "At Professor Shaler's; that kind of thing was a hobby of his, you know. And it was his wife who lent me the Life of Lubbock." 
But it was not alone for the benefit of his own department that Mr. Shaler strove to find the right education. He also took an active share in the discussion of every question that came before the faculty. His desire that young men should get all that the College had to give, either by voluntary appropriation or by a process of absorption, that, indeed, no chance of time or place be lost for broadening their minds on every side, led him to oppose the three-year degree. Another burning question in its time was the elective system; to this he was also, in a measure, hostile. Doubting the wisdom of allowing youths unrestricted range in the choice of courses, he advocated instead the group system as illustrated by the four-year programmes in the Lawrence Scientific School.

In regard to the part he played at faculty-meetings, where all these questions were deliberated upon, Dean Briggs writes: ". . . In all the years in which I have been a member of the faculty, I have seen no one so alertly interested in every subject that came up : nor indeed have I ever met a man so quickly and so warmly interested in every person and everything, great or small. Though there are many of us, our meetings often seem entirely different without him." Professor Wendell likewise has been good enough to set down his memories of his late colleague and of the spirit he carried into that same kingdom of debate. This is what he says:-

Boston, November 10, 1907.

During these past days, when I have been trying to gather together my memories of Professor Shaler in the faculty, I have found myself more and more aware of how deeply my relations with him there were at once of the essence of our friendship and among the chief reasons why faculty life often seems to me less professional than human. It is human, no doubt, in a very comprehensive way: it has its quarrels and its tribulations, as well as its joys and kindnesses: the very familiarity of it sometimes makes its importance seem to dwindle. But, reviewed through a vista of years, it shows itself, like the student life which came before it, a beautiful memory of fellowship.

The whole heart of this fellowship Professor Shaler embodied beyond 
any one else. My own experience can hardly have been exceptional. It was in 1884, I think, that, most unexpectedly to myself, they gave me an instructorship without limit of time. This made me a member of the College faculty - a body of which, until that time, my impressions had been the not completely cordial ones prevalent among the students of thirty years ago. I shall never forget the immense contrast of two consequent greetings. One of our elder members, with whom I had long had some manner of acquaintance, expressed the candid opinion that although I had now a right to attend faculty-meetings it was highly improbable that they would have any interest for me. Professor Shaler, whom I had never really known before, and whom I supposed hardly to have known me even by name, came straight toward me, the moment he first caught sight of me. He held out his hand, with his own wonderful heartiness, and said some word of his gladness that I was "one of us." It was almost, if not quite, the next Sunday when you both welcomed me to your house, and when we had the pleasure of meeting you for the first time. I was not yet thirty years old. The self-distrust which has beset me all my life was at its strongest. What such a welcome meant, at such a moment, it is hard to tell. The true encouragement of it sank deep - lasts still, stronger than ever now that the friendship which thus began has passed into the ideal security of almost cloudless memory.

If I had written cloudless alone, I should not have been quite true to the full humanity of its breezy vitality. There rises another memory of a few years later when in some discussion, the facts of which $I$ have forgotten, we found ourselves at variance and each expressed his own opinions with somewhat unparliamentary freedom from reserve. At the end of the meeting where this incident occurred, he looked angry, and I felt so. What is more, I felt so for two or three weeks. Then, one day, his face broke into a smile and he held out his hand again: "Wendell," he said, if I remember the words, "my head used to be as red as yours." After that, the friendship on my side stayed more delightful than ever, through the years that have grizzled my beard into something far less fiery than his was then. There were moments when each of us failed to sympathize with the other; but they passed as swiftly as clouds that are only to make the sunshine warmer. There was never a moment when I could doubt for an instant that we could always understand each other; nor yet that if any need for friendship should arise, there was no living man to whom I would turn more confidently than to him.

Once, I remember, he found me somewhere in a state of obvious depression, and asked what the matter was, in a manner that might have seemed almost blunt if it had not been so obviously kind. "Bills," I told him candidly. For the moment he said nothing. A day or two later he came to me with a sympathy fraternal - or paternal, if you prefer - in its fulness of 
heart. If the trouble was serious, if his advice or his resources would help, let him know what he could do; whatever the matter was, be sure of him. The matter proved in no wise serious, and I needed no help at all. This does not alter the gratitude which has glowed ever since that visit. He was one of whom you would always be sure.

Our last meeting was a happy climax of this constantly strengthening fellowship. You will remember how I was giving some public lectures at Cambridge - incidents too frequent there to invite, in general, much alertly cordial interest. At the close of one, you both gave a little tea-party, in my honor. He never seemed brighter, happier, more his marvellous self than he seemed that winter afternoon, telling with his vividness, which no one else could quite equal, some of his experiences in France. In the middle of his narrative something called me away from him. I never saw him again. But the last memory is so like the first that they blend for all their twenty years of separation, - big, vital, exuberant in the certainty of their helpful, inspiring humanity of friendship.

These personal memories of mine are memorable only because what was true of me was equally true of all the younger colleagues whom he welcomed throughout the years of his service to Harvard. Such stories could be told, such sentiments confessed a hundred times over. Without expression of them, without insistence on them as the chief part in one's memory of him as a colleague, the truth of this memory could never be made clear.

The more obvious phases of this memory are almost a matter of record. He prided himself very justly in punctilious performance of duty. This involved regular attendance at the meetings of the faculty, no matter how slight the business in hand; and I can remember hardly a single night meeting, when he was in Cambridge, from which he was absent. The eagerness of his temper and the alertness of his mind combined to make whatever was the subject of discussion appear for the instant paramount. So he spoke oftener, and with more energy than most of us. This habit, which rather strengthened with the years, involved a somewhat unexpected result. Above the custom of most men he thought aloud concerning whatever problem was before us. His remarks were often rather a statement of his current mental process than an assertion of his deliberate conclusions. Yet, often, I had almost said always, he expressed himself with that concrete precision of momentary finality which was so characteristic. In consequence, particularly during his later years, he sometimes impressed the younger men as not quite stable, as prone to perplexing inconsistency. To understand what this really meant one had not only to know him affectionately, but also to experience that gradual enlightenment which reveals the true office of debate in the Harvard faculty. We are an unwieldy deliberative body with consider- 
able party legislative powers, and wholly without party organization. The incessant speeches there have very little, if any, persuasive effect; they are essentially expressions of sincere intelligent opinion, to be taken at the moment for what it is worth. Each year, young men fancy that they are admitted to something like a parliament; each year, we older ones understand better that we are really sitting in something more like a Homeric council. So the young fail to comprehend the old, while the old begin to forget what their dreams and fancies were in the days when they were of the young.

And yet, through it all, there springs to memory one of his utterances there, ten years ago. Just what his own words were I have quite forgotten, except that they were so completely characteristic of his peculiar bravery, and some note of just that spirit was what I most wanted, at that moment, for the verses which I was trying to write. So here is the form they took in my "Ralegh in Guiana," where - as I told him more than once - his remarks concerning himself and ourselves gave my forgotten play a touch of such spaciousness as makes inspiring that old Elizabethan world he loved so well: -

"This cloudy monster, circumstance, Affrighting common folk, doth melt to air Round them that, plunging in her maw, dare vex Her misty bowels."

Mr. Shaler's heart-felt desire that the doors of the University should never be closed against one who showed any disposition to profit by what it had to give, sometimes led to misapprehension and the charge of shielding students from merited punishment. The truth lies in the manly statement contained in the letters given below from one of his colleagues. Although these letters belong to a later date this seems in a way a fitting place for them. The first is addressed to President Eliot.

CA Mrbridge, Dec. 19, 1905.

Dear Sir: - In the brief word which I had with you after the meeting to-day, in regard to the administrative board of the Scientific School, I was conscious of not having made my meaning clear to you, and in justice to myself I beg you to allow me to add a word of explanation.

My object was merely to correct one misapprehension in regard to a matter of fact about which I have had ample opportunity for observation. In the course of your statement to the faculty you said that complaints had come to you from members of the Board to the effect that the Board had felt 
obliged to admit certain students this year, against its own judgment, merely on account of representations previously made to those students by the Dean of the Scientific School. I have attended every meeting of the Board this year, and I can state positively that no such case has arisen. The Dean has been exceedingly scrupulous to avoid bringing any pressure of this kind on the Board. I remember one case at least in which the Board rejected a student who had been very properly granted "provisional registration" by the Dean - and this action met with absolutely no protest from him. In the only case in which the student was "given the benefit of the doubt" in view of possible misunderstanding of certain correspondence with the Board, the Dean had nothing to do with the case, and expressly stated to the Board that the Board should not feel in the least hampered in its action.

It is true, Mr. President, that the Dean often moves the Board by eloquent, sometimes personal, appeals on behalf of some boy; but it is not true that he has ever, since I have been on the Board, based his appeal on the ground of previous representations made by him to the boy. I am as sensitive as any member of the Board to the unsatisfactory character of much of our action; but in respect to this one item of your statement to the faculty there seems to have been some misapprehension, which I trust you will allow me, in this manner, to correct.

Respectfully yours,

EDWARD HUNTINGTON.

From the same to Professor Shaler, after referring to the letter to President Eliot, a copy of which he sent:-

I am free to say that I have often disagreed with your side of a case presented to the Board, and voted against it; but the idea that you have ever exercised any "discretion" in admitting students - other than the persuasive force of your own eloquence - is certainly devoid of foundation, and I hope the President will pardon my telling him so. If the members of the Board have yielded more often than we think we should have yielded to your persuasion, that is surely our fault and not yours! For myself, I regard it as one of the privileges of my academic life to serve on the Board under your chairmanship, where the fight, when there is a fight, is at least a fight in the open.

Other administrative work outside the faculty room and Mr. Shaler's office, which was run with great system and punctuality, he had at this time in abundance. The different state boards (the Highway, the Metropolitan Park, and the Gypsy 
Moth Commissions) upon which he served, and the mining organizations with which he was connected, filled up most of the hours left over from his college duties.

That Mr. Shaler was working too hard at this period of his life was evident to those immediately about him, as also to others who saw him less frequently. In a letter relating to some question in which he was interested that had come up for discussion at the National Academy of Science, his friend Professor N. M. Storer writes:-

May 10th, 1894.

. . Y You should not, ought not, must not work so hard. No one can say but that you made things merry in your time; but there are those who wish to have the sweetness long drawn out. ...

Various mining enterprises continued to call for long journeys which, as we shall see from his letters, became each year more burdensome. He writes from near Cleveland:-

9 A. s., Saturday, '97.

One of the days of exile is over; the train is on time and will, I trust, put me in Newport to-night. And the evening and the morning will be another of these cursed days.

I had a fairly comfortable night, a lot of baby music in the next section, but it seemed rather familiar and domestic. It rained into my window and made me sloppy, but the air was fresh and even the water refreshing. This morning the land is a deluge and streams hurrying about in a crazy way, apparently bewildered in their new-found freedom. The grass is growing and the wild ducks are going north. The people are waxing grimier, and now and then an old hat in the window; all of which means that I am getting on towards the sunny South.

Near Chicago (on the road to Virginia, Montaxa).

One more of the days is done. It is the same old West in summer, hot, dry, and dusty, rich in all good things, but a weary land to the wayfarer. I have been paying for my continued spree with coffee, but a bit of starvation promises to set me right again. Mr. B. is with me; as he is a silent man I have some rest.

Near Salt Lake Citx.

This is the fourth day of this dusty furnace. Since yesterday noon it has been a monotonous desert, as hard as original sin. Here and there a patch 
of Mormons and of cultivation, or rather crop-getting, for the Mormon is only a higher kind of Digger Indian.

The thermometer has been near a hundred every day, but we have kept pretty well in a dirty, miserable way. The time to come is June. Page joined us at Denver and goes to Virginia. He is the same dear boy, though he is becoming gray-headed and solemn. . . . Fine as these mountains are, they are very mechanical things, no grace in them. At this season the land is a dusty circle in the Inferno.

Junction near Virginia, Montana, July 30, 1897.

I find that I stand the work well, better than do my companions, who appear to suffer from the heat. The conditions are rude, but there is enough to eat of a rough kind, and a chance for a bath in the ditch, good mountain snow water. A splendid landscape, but one that is curiously uninviting from the lack of the human quality.

Butte, Montana, July 26, 1898.

I am pretty well through with the blessed underground, with its dirty business, and am now doing the surface, trying to extract information from the [word illegible] of dust which wraps this wealth in. The place is a dry hell, but far away are the snow-tipped mountains. . . . The task is interesting, so too, in a way, are the people. A Britisher who is my guide is a good fellow. The mass is Irish and the civilization inexpressibly so. Every shanty has its back yard in the front street. A priest-ridden, labor-ridden, politicsridden horde of laborious vagabonds.

CAMbridge, 1899.

... I had to go yesterday morning to Nashua. This promises to be my only divagation until we go to the island. ... We are waiting the arrival of the Sunday afternoon contingent. We hope there will not be many to be disappointed by your absence.

Later. The people have come and gone, a bare dozen. The new were a lecturer on irrigation from the West, an able man. Another, an Englishwoman, a patent crank. She is not permanent. And a gentleman from South America. . . . I would there were some news to tell you, but the town is like us in being dull.

Friday, 1899.

After lecture I had to go to town, to see McKay on business; to vary my walk, I came back through Charlestown, - a rather long way - so I am tired, having had no rest. I shall, therefore, take the sleep cure upstairs early.

There is no news except that the I $\longrightarrow s^{\prime}$ boy, I have been looking after, 
seems to have a rather better chance of life, and there is a lunch at the Pickerings' to-morrow. I shall go, to meet Prof. Young of Princeton.

The Brooks House "tea" seemed more successful than the last. more people and merrier.

As the years sped on, in spite of remonstrances Mr. Shaler kept up his activities to the full extent of his powers. In the hours left over from his prescribed tasks, to be sure, he took a share of recreation, - as much, at least, as he wanted. Indeed, it was only an imaginary line that divided his work from his play. This consisted now, as always, in long walks, and visits, sometimes; concerts also, but the theatre rarely. His chiefest delight was found in writing poetry.

The return to this ideal realm, which he had so long forsaken, was a happy inspiration. It gave a momentary pause to performance; sweetened his life and opened up a retreat from discouragements and vexations. Even during the "merger" controversy, which stirred him profoundly, he was still able to create his own utopias. In his work-room in the third story, away from interruption, he could throw himself at will into another world. There his battle with dulness and the commonplace was over; the irksome tasks of life, if done at all, were done vicariously. There, too, he could conjure back lost loyalties and virtues and all manner of nobleness; not that he was a complainer of men or of the present times: in fact, he was rather persuaded that the golden age lay not behind but before us. In this shelter from the din and stir of competitive life, as he said, he could consume his own smoke - that is, get rid of nervousness. As an aid to this process his long-stemmed pipe was an invaluable resource; also, at times, a few minutes' sleep. Half an hour spent in this peaceful atmosphere was usually sufficient to compose his mind and smooth out of his face any lines of irritation.

Not the least of his cares after 1902 was Mr. McKay's unhappy physical condition. Besides the need for business conferences with him, the old gentleman leaned upon Mr. Shaler in 
many ways, and not infrequently summoned him by telegraph at most inconvenient seasons - at the end of a hard lecture day, or of other appointments of a taxing nature. These hurried visits to Newport were exceedingly depressing, for, with a failing body, Mr. McKay could not be other than a devitalizing companion. At these meetings his mind grasped eagerly at business details, or dwelt upon the future scope of the Lawrence Scientific School. To talk about such outside matters freed him for the moment from the gloomy consideration of his decrepit state.

Each year, Mr. Shaler hoped to break away and give himself a rest, but the seasons, as they came and went, brought ever new responsibilities, so that the time never seemed just right for taking the much-needed holiday. As the following letter shows, he thought seriously of going to Europe in 1901.

Sept. 22, 1900.

Dear old Shaler: - It's either post-cards or nothing with me, so you will excuse the shabbiness. I have thought of you almost daily since July 15th, 1899, when I left home, and longed for your inspiring presence, as the myriadminded and multiple-personalitied embodiment of all academic and extraacademic Kenntnisse and Gemüths bewegagen. For Heaven's sake keep alive till I get back, and don't embark on your own sabbatical year just as I shall be returning, early I hope next summer. To stop the gap, I send you this greeting at the beginning of the New Academic Year, which I hope will be replete with happiness and activity for you and all of yours. It's a good thing to have a place to belong to, and not to leave it for too long. I regret to say that I am still laid on the shelf and don't know when they 'll take me down to use me. Send me a post-card some time. Warmest regards to Mrs. Shaler.

Yours sincerely,

WM. JAMES.

Although utterly indifferent to many of the honors that men so eagerly strive for, - such, for instance, as honorary degrees and offices in learned societies, - indeed shirking the latter whenever possible, - his heart was warmed by the storm of applause from students and visitors that greeted him when, at the Commencement exercises in 1903, President Eliot conferred 


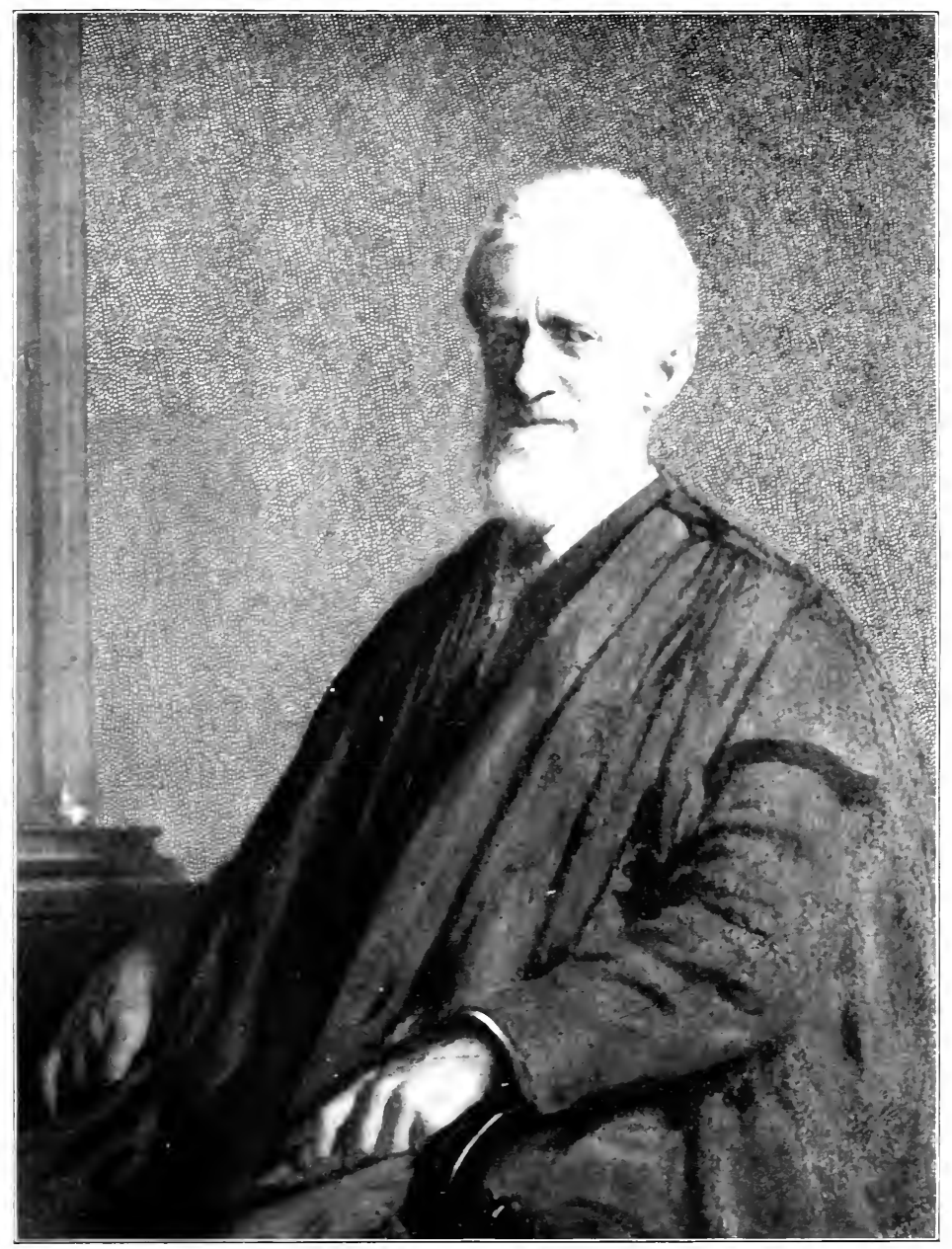

PORTRAIT OF MR. SHALER BY JOSEPH DE CAMP 

upon him the Harvard degree of LL. D., with his usual felicitous characterization addressing him as "naturalist and humanist."

At all times Mr. Shaler was flooded with invitations, especially during these later years, to speak at colleges, schools, institutes, societies, and clubs; but, though the list of his addresses is long, aside from subjects relating to his profession, touching world interests as divergent as those which appealed to the Congress of Religions and the Military Historical Society of Massachusetts, only a comparatively small number of these invitations did he ever accept. Speaking in strange places and before miscellaneous audiences was never agreeable to him. On the occasions when he attended the Harvard Club dinners in different cities he always said afterwards that he had had a "good time" with the boys.

Twenty-one years after he gave his first course of lectures before the Lowell Institute, Mr. Shaler delivered his last (1902-03), on the subject of "Dynamic Geology." All of these elements of work and play must in a general way enter into the picture we would give of the busy years included within the dates of this chapter. 


\section{CHAPTER XXVII}

\section{LAST YEARS}

1904-1905

IT had been nearly twenty-three years since Mr. Shaler had had other than the briefest vacations; he therefore resolved to take a "sabbatical," and early in January, 1904, set sail on one of the Mediterranean steamers for Egypt. He was very tired and longed to rest his eyes upon new scenes in regions that he knew only through his readings. He was not, as a rule, a good sailor, but the seas were tranquil and he reached his destination without much physical discomfort. Knowing as he did its geological and human history, he found every bit of land that he passed in the Mediterranean mentally stimulating. The landing, however, at Alexandria, that ancient seat of schools and philosophies, was such as to banish all feeling of reverence. The scuffle among dragomans and boatmen, the sort of Donnybrook Fair at the station where belated luggage was weighed and mislaid, the general demoralization of officials, a legacy doubtless of the " unspeakable Turk's" misrule, filled him alternately with mirth and indignation. Nor was he specially moved at Cairo. The grandeur of the Pharaohs was veiled behind the veneer of Western civilization. Even the sight of the Pyramids failed to arouse any great emotion in him. Somehow he did not seem able to get en rapport with these aged landmarks of vanished aspirations. Indeed the antiquity of Egypt, which to most persons is so overwhelming, to the naturalist, whose considerations are based upon eons, - from eternity onward to eternity, - is of no great moment; a few dynasties more or less add little to his conception of the element of time.

The whole life of the past as represented in the temples and 
symbols seemed alien to Mr. Shaler's spirit. Rameses the Great, bragging his way down through the centuries in stone and graven images, became actually repulsive to him. Yet when he afterward gazed upon the well-preserved face in the Museum at Cairo and observed its strong resemblance to the portrait busts of Cæsar, he was more inclined to take him at his own exalted valuation. Nevertheless there were times, while travelling up the Nile, when he regained his imaginative power of projecting himself sympathetically into far-away scenes and transactions. The burnished mountains that had melted into the sands of the desert, the swarthy fellah at his immemorial task of lifting water from the Nile, in his changeless work and attitude to Mr. Shaler's eye a pathetic link in Egypt's immutable chain of custom, the ancient idols and superstitions, - all set his fancy spinning. The story told of the weeping and wailing of men and women on the banks of the Nile when the mummies of their great kings, disturbed in their long rest, were conveyed down the river to Cairo, was a picture of spiritual desolation that lingered in his mind.

The great irrigation works that the English were constructing interested him immensely, while the geology of the banks of the Nile and the neighborhood of Cairo offered a profitable field for study. The results of his observations he afterward made use of in his lectures at Cambridge.

Yet in spite of a lack of enthusiasm for the land of Egypt, the slight touch with its spiritual motives gained in some weeks of travel could not fail to affect one of his receptive nature. The ages during which these people warred with death, seeking salvation of the memory of the individual to himself or his kind, was to him exceedingly impressive. Under the influence of this persuasive and elaborate effort at self-perpetuation he began while there to write his autobiography.

Greece affected him very differently from Egypt. It was like a smiling return to an intellectual home. He had much the same feeling that a graduate has when he goes back to his beloved 
Harvard. For while by accomplishment Mr. Shaler was no classicist he had to the core the humanistic spirit. Moreover, he was thoroughly familiar with Greek history. As a boy he had studied Grote from beginning to end, had made notes and abstracts of the "History," so that every inch of the land and the deeds that had been enacted thereon were known to him. His Xenophon he knew almost by heart and the great tragedians he had read in translations.

While at Athens he spent a part of every day at the Parthenon. The weather was fine so that he could sit indefinitely, taking in from every point of view the beauty of its surroundings. The study of the Parthenon was not wholly an artistic exercise. The fallen pillars that strewed the ground suggested a practical engineering feat for Harvard men. German archæologists had seen to the lifting and putting in place, with considerable expenditure of time and money, it was said, of several of these columns. From his examinations and from all that he could learn of the difficulties of the task, he was convinced that it was not beyond the power of Scientific School students - of an Archimedes of the West - to reinstate quickly and economically, by the use of labor-saving devices, these dismembered parts of the great temple. Firmly persuaded of their capacity for this work, he resolved upon his return to America to put the case before some rich man in the hope that he might make the gracious deed possible. So many other matters, however, pressed upon him when he returned, that it is doubtful whether he ever made any effort in this direction.

In modern - fatally modern - Athens, where the small present dwindles beneath the weight of a great past, it was often difficult to lead the dual life that its historic associations called for. Mr. Shaler would sometimes stop abruptly and say: "Perhaps it was at this very corner that old Socrates stood and asked his vexing questions. Bless his ugly mug!" Or, "Perhaps it was here that the so-called "vain and chattering Aristotle' looked about him with the piercing eye of inquiry." It 
was thus that Athens was repopulated and that the naturalist by keeping him well in mind paid his long-accumulated debt to the greatest of all scientists. Other torchbearers he kept in sight as he wandered in and out among the streets of Athens. Mr. Shaler became deeply engaged in building up to the mind's eye out of their ruins a picture of the ancient splendors of temple, Areopagus, and theatre; succeeding in an unusual degree, for the constructive imagination so constantly exercised in the field of natural phenomenon served him in this world of suspended art and human glory.

Deviating from the usual line of travel, Mr. Shaler visited the Peloponnesus and other parts of Greece, seeing enough of its charm to make him wish to return and go all over it at his leisure. Indeed, he thought seriously of a camping-expedition under the guidance of Miss Stone, the archæologist, who already had smoothed the way and made light much that otherwise would have been left in darkness. With charts in hand they studied out the details of ancient structure. As for the new ones, he was able to judge for himself; the new Stadium - built of dazzling marble, the offering of a native who beyond the boundaries of his own country had prospered well - Mr. Shaler frequented, sometimes making comparisons that were not altogether favorable to the Stadium at Cambridge. The public spirit of the Greeks was a surprise and a pleasure to him, for he was not prepared to find an almost American generosity in the giving of libraries, colleges, and other buildings for general use.

From Greece to Corfu, thence to Naples, to Sicily, and finally a visit to Rome, were included in this itinerary. Etna was the chief call to Sicily. At his earlier visit, more than twenty years before, Mr. Shaler had given up the journey because of the snowsheet on the volcano, and even now in the month of April its cone was white; but the lower portions and the extinct craters were uncovered for observation, so that he was able to make the long-coveted study of this great mountain. While at 
Taormina he got much pleasure from long walks up the sheer mountain-sides on roads that tapered off into zigzag footpaths, seldom trod. He was loath to turn away from this paradise of natural beauty, this library of human history where almost every tongue in its time had been heard; but each day the snowcap on Etna was growing less, the grateful warmth had turned to heat, and the body had begun to feel a warning languor. He therefore turned his face to the North.

At Rome Mr. Shaler began again his old habit of long tramps into the surrounding country. More than once he went to Rocca di Papa to study its geology, its fortress, and Hannibal's old camping-ground; to Monte Cavo; to Nemi and Subiaco, and there met good company at the albergo, where he and a Catholic bishop exchanged ideas on the cardinal virtues, Mr. Shaler paying his tribute in coin to the chiefest of all, charity : its symbol at the moment a new church just then mounting heavenwards in the bishop's diocese. Other points of interest tempted him abroad. Probing for the heart of humanity, he hobnobbed with the simple people, ate with them in the village trattoria, talked with them on their own level of interests, and trusted them in every way. And yet for all that, he fell among thieves, and a handsome gold watch and chain which he valued was stolen from him. Still, it must be said, this happened not in the country, but in Rome itself.

The city had little persistent attraction for him. "The potshards of a great world flung around " were too closely pressed in by flimsy new structures. It was too populous, and its life pitched on too strident a key. All this shut down on the perspective. In the uproar he found it hard to put the breath of life, as he would have liked, into the great past. He could better patch together the fragment of ancient glory, recall to the mind "the great free people, the voice of the orators, the procession to the Capitol," outside of its walls than within.

In the month of May roses and nightingales were everywhere ambushed behind the garden walls, the one loading the air with 
perfume, the other with a great "din," "poor stuff," as Mr. Shaler phrased it. The "din" kept him awake at night and lowered his opinion of this European nonpareil. To his mind the Philomela of poets was not worthy of his reputation. He claimed that in America we had songsters whose notes were far sweeter - that we had the bird, but we had n't the poet to celebrate its music in words still more melodious.

As the train drew off into the country, a glimmering glory of sunlight rested on the Imperial City, and for the last time Mr. Shaler looked upon Rome. Travelling to Naples, he took a farewell view of Vesuvius, and thence sailed for America. Circumstances had shortened his vacation and made him anxious to get home. England, which he counted upon visiting, was left for another time, and along with it many other undertakings, for as yet no warning voice had spoken, and life, so far as planning was concerned, might have been in its first quarter, as always the waxing, not the waning time of things was what he oftenest thought of, such being the privilege of his energetic soul.

Within a few days' sail of New York, while taking his daily "constitutional," - so many times the length of the vessel,he lost his footing on the slippery deck and broke his left arm just above the wrist. The ship's surgeon set the bone, but from the beginning there were signs that the work was not well done, and therefore, with the sense that it would have to be repeated when he came ashore, the pain was less easy of endurance. But from the very first he refused to yield to the infliction and endeavored to do everything for himself. And this, it may be said, was a characteristic that often gave pain to those nearest to him; he would not allow them to do for him what their love prompted. This strong motive of self-reliance was founded upon the heroic element of his nature which, at all hazards, would beat down and dominate whatever was soft and feeble; la mollesse was the quality of all others for which he had the greatest contempt. Therefore to those who knew how much he 
often suffered and overcame, in spite of the proverbial disillusionment of the valet he grew by nearness to be more the hero, rather than less.

If there was any perceptible physical change during these later years, it was perhaps an increased tendency to vertigo, the old enemy with which he had struggled for a large part of his life. Even while lecturing it would sometimes assail him like a flash of lightning, and but for his habit of holding himself well in hand during any physical stress he might easily have succumbed. The only outward sign he gave of the disturbance was a blanching of the face and a momentary interruption of the flow of speech. He was accustomed to pull himself together so quickly that few noticed the break. The attack, short as it might be, nevertheless produced very painful sensations, and he often spoke of it as "a living death." Sick headaches which had tortured him from his youth were now less frequent, though sometimes he labored through a day of hard work, even a lecture, while borne down by them. The stress they had laid upon his body and spirit all during his earlier manhood could not be estimated, nor the firmness of will that led him to reject the valetudinarian habit of life. He had sufficient cause to have lapsed into self-indulgence and indolence had he allowed himself, but he set his face against these qualities, and at whatever cost of will-power and suffering he lived a manly and selfexacting life. To feel disinclined to do a thing was with him good reason for doing it. He often said that his physical ailments had strengthened his will and done more than anything else to make a man of him, and for this reason he gave to pain a high place in the work of spiritual education. Indeed, he was of the nature to give the rack or thumb-screw a word of praise.

The summer of 1904 he spent much as usual, the Summer School claiming in the early part its usual allotment of time and care; and later he went to Montana to look after the Conroy Mine, of which he was the president. On the way to Montana he writes:- 
Near Chicago, Aug. 3, 1904.

The first day is now over. Good weather - train not overcrowded. I thought I was alone and so wrote you yesterday, but as I went to mail the letter, behold two of the "old boys," and since then others; so that it has not been so still as I hoped. At 6.30 this evening I shall be off for St. Paul and the further distance.

I like the plan of the balcony to the new part of the house very much. On the whole the plans seem to me good. See that Willoughby [his son-inlaw] rests a bit. The train is about to start and the road is too rough for writing. ...

The plans alluded to in the above were some which he had seen in Boston for the remodelling of the house at the Vineyard. The balcony was intended as a surprise; it was made to connect with Mr. Shaler's upstairs study so that he could at any time when weary of writing go out upon it and refresh his eyes with the sight of the Sound and the near-by woods, of which he was very fond.

The two succeeding years were spent very much as usual; mainly in the discharge of college duties, which were neither more nor less exacting than heretofore; but even if they had been Mr. Shaler would probably not have cared very much, for, having about made up his mind to withdraw from teaching at the first convenient moment, he was possessed of the calm that comes with the sense of work almost completed. Only, as we have seen, the merger scheme occasioned serious perturbation. The reorganization of the Lawrence Scientific School also called for the expenditure of much thought and care. After these important questions were disposed of he settled down to a state of comparative repose. His daughters being married (the elder to Mr. Willoughby Lane Webb and the younger to Mr. Logan Waller Page) and gone to their own homes, the house was left very quiet. The time of fervid striving had passed; a serenity seemed to pervade his spirit; his engagements were less pressing, or, perhaps, it was that he was beginning to take things more calmly. So the days passed pleasantly and peacefully. The evenings he spent by the library fire, abandoning the habit 
of going for a part of the time to his upstairs "den." He had so much that he wanted to write about that he looked forward with infinite pleasure to the unburdening of his mind at his own choice of time and place. He hoped to spend more of his days in the country, with an occasional dip each year into the life of the great cities; so he proposed.

On the twenty-second of February, 1906, according to an old custom a reception was given to the Southern Club. He always enjoyed these commemorative entertainments and commended the arrangements for this one, into which some humorous features were introduced, as more successful than usual. He did not, however, seem as vivacious as was his wont; indeed he complained of not feeling well, but since he was suffering from what was supposed to be a slight attack of indigestion, no importance was attached to the circumstance. It was obvious, however, that the passing days did not bring his usual vigor. It was not many weeks after this that he walked to Corey Hill, in Brookline, to see a sick friend in the sanitarium there who had been operated upon for appendicitis. After the visit the wife of his friend insisted upon his driving home and lunching with her, and later she commented upon the chivalrous feeling which prompted him to say, "No, I would like to, but if I stayed away my wife would be lonesome." A hard crust of snow on the ground made the walk more taxing than he expected, and when he reached home he complained of great weariness, and of other sensations worse than fatigue. The doctor was sent for and discovered alarming symptoms. The next morning the operation for appendicitis was performed. At first all went uncommonly well; but after a while pneumonia set in, and the fight for life began. Along with those about him he struggled heroically to keep at bay the terrible foe. It would seem from the resisting power his body had always shown that he might have had much to endure before death came; such, however, was not the case. The combat was hard and sharp, but it was short. Then just before the end, on April the tenth, he dwelt 
for some hours in the twilight region. If life is great he might have said, death perhaps is greater. He did say, "All things do prophesy the life to come." More than this, the prayer he uttered when a mere youth had been amply fulfilled: "O Power who has given me being, grant to me the strength to live as becomes thy creature. May I stand amid the changes that whirl around me untouched and unbroken, and when it shall please thee to end my days, may I not have lived in vain."

The announcement of Dean Shaler's death awakened profound sorrow in the whole community. By common impulse the flags on the students' clubs and on the city buildings were hung at half mast, and on the afternoon of the funeral the shops in Old Cambridge were closed. At the meeting of the four undergraduate classes it was decided that the entire undergraduate body, both of the College and of the Scientific School, should assemble and thus express their appreciation of the great and noble work performed by Dean Shaler while connected with the University. And in this manner, between two continuous lines of undergraduates, his remains, borne on the shoulders of eight students, were carried from his house to Appleton Chapel. There Bishop Lawrence read the Episcopal burial service, and immediately after interment took place at Mount Auburn Cemetery.

Nothing would have touched Mr. Shaler's great heart - the heart that burned with love and sympathy for them - more than the sorrow of the young men who waited in line to give this last token of affection to their true and valiant teacher, or the grief shown by his associates and fellow townsmen among whom he had lived "unsullied with his journey of the day." Into his grave was poured the mingled love of youth and of friendships old and tried. 


\section{CHAPTER XXVIII}

\section{PERSONAL CHARACTERISTICS}

Physically Mr. Shaler was well made, lithe, and muscular. The description given of him in a passport at the age of thirtytwo was correct. Stature five feet eleven inches, eyes gray, inclining to blue, nose aquiline, mouth medium and it may be added, delicately moulded and sensitive. Face thin, complexion fair. His hair, described as "sandy," was unusually abundantso abundant that one naturally expected it to defy the thinning touch of time. He disliked very much the idea of growing bald, and the only regard for his personal appearance he ever showed were some precautions which he took the last year or two against this disfigurement. He was of such just proportions that few realized how tall he was. He described an experience he had when he first entered the drill class at Cambridge in 1861. The drillmaster, it seemed, spent at least ten minutes trying to place him; beginning low down in the squad, he shifted him step by step until within two of the top; he, knowing where he belonged, enjoying the joke all the while. His body broadened with years, but he had never an ounce of flesh to spare. He held in great dislike the accumulation of adipose tissue and the physical inertness that is apt to go with it. He regarded increase in girth of waist as a mark of degeneration, a sign that a man was eating too much and walking too little. When he saw a comrade getting pursy, he took it seriously and would exhort him to more exercise. He commented regretfully upon the fact that only one other teacher besides himself went regularly to the gymnasium.

In youth, at least, his face failed to show what was in him; it was alert and sensitive, but did not bode the strong-willed, dominant personality that time revealed. These qualities, 
shrouded by evident self-consciousness, could be read neither in the look nor manner of the young man. In the course of time, however, his interest in his work and in his fellow men delivered his soul of this burden, and he became the most self-forgetting and self-sacrificing of men. The centre of his thoughts was so successfully shifted from himself to the universe that he often seemed to be lost in the vast field of time; and again, he would shelter himself in a sort of humorous detachment from the paltry and commonplace, deeming them as part of the infirmity of poor human nature - poor, but none the less lovable. More and more he looked upon all the elements of life, however small, as involved in the great whole, as different actors in different parts. His mind thus occupied with large conceptions, his appearance could not fail in a measure to reflect his thoughts. One saw in his face that his ideal of what a man should be and the right way of looking at things had done their work there; when in repose its expression was lofty and noble; it showed both kindliness and wisdom, that final crown of attainment.

Mr. Shaler had great power of endurance, and though often assailed by sickness he was no example of "lamed misery." $\mathrm{He}$ rallied quickly and went about his business as if nothing had happened. This ready recovery was partly due to natural resiliency, but more especially to the will to be well. Recognizing the danger of hypochondria to one gifted with an active imagination, he set himself against the impulse to yield to its manifold suggestions of evil, and thus fought his way out of the Slough of Despond - the borders of which he touched, though its depths he did not enter. He did his duty thoroughly by his body, except perhaps by overtaxing it at times, but even this was in accordance with a theory and not the result of carelessness. He believed that it was well to use one's powers, mental and physical, up to their full limit, and to vary occupations when weary rather than suspend labor altogether. He exercised regularly and persistently, preferring long walks off in the country, but if these were not to be had he walked in and out of 
Boston when called there on business, or around Fresh Pond in all weathers. A day without at least a six-mile tramp was burdensome to him. He was a good fencer, a good swimmer, and an exceptionally fine horseman, having in his day mounted every kind of beast, under all sorts of conditions, and yet never been thrown. As for sports, he had taken his turn at the bat, with the oar, and at football, but he cared little for them or for any set amusement. Nothing made time pass heavily, he said, but pastime. He got stimulus and diversion from so many sources within himself that prescribed forms of entertainment or violent efforts in that direction made no appeal to him. He could take his sensations delicately; it was not necessary to be supersaturated with glaring sights, loud sounds, strong tobacco, or highly seasoned food. He drank a glass of wine with the same relish he would have shown for any other ingredient of a good dinner. He did not need wine as a stimulant; it might have been well had he taken it more freely as a sedative. He often spoke of a delightful "spree" he once had with two congenial spirits at the Cosmos Club in Washington which lasted from eight in the evening till one o'clock, - the jollity sustained by Apollinaris water and crackers. He was capable of becoming thoroughly exhilarated with good talk and sometimes better on an empty stomach than a full one. Coffee was his favorite beverage; it was one, however, he could not freely indulge in. It was his habit to have it for breakfast on lecture mornings and in consequence these were regarded by the family as red-letter days. On other mornings the cup of tea was not one that cheered; on the contrary, Mr. Shaler always found it too strong or too weak, too hot or too sweet, until at last it would be necessary to remind him that tea was not coffee. "Alas! that it is not," he would exclaim, and without further criticism empty his cup.

His youth had been spent much among men who in a way were high livers; he therefore was accustomed to see both whiskey and wine consumed freely. His father often sent him, 
when a student, wine from his own vineyard, and yet he never formed the taste for intoxicating liquors. Indeed, sometimes he was at a loss to know what to do with the strong beverages sent to him from Kentucky. Especially was this the case with some gallons of apple jack which proved altogether too potent for his palate, and which would have remained unused had not the housekeeper, seized with a happy thought, resorted to it, instead of wine, for the flavoring of jelly. The success of the experiment was such that this particular refreshment became a feature of Sunday evening suppers whose popularity grew as the season advanced, for however dull the meal might begin it was sure to be gay after the jelly was served. The hostess was flattered by requests for its receipt, and by the relish with which the confection was eaten; but alas, when the apple jack was consumed, the complaint arose that while the mould was the same, the sensation was different.

Whatever may be said of the lost art of conversation, so far as Mr. Shaler was concerned it had not passed away, for he was not afraid to say what he thought; and what others might think had no terror for him. Overflowing with anecdotes and reminiscences, brilliant and cheerful, his talk was an inspiration, and the happy phrase which with most persons is an accidental prize was with him habitual. He delighted in hearty intercourse with people of vivid thought and feeling, with such as had something worth saying, though it might sometimes be difficult to say it; for unless his interlocutor was unusually good at "tongue fence" he was apt to get belated in the race. Mr. Shaler's fortyodd years of lecturing had doubtless confirmed in him the habit of pretty continuous verbal expression. It has been said that Lowell could talk in paragraphs; with equal truth it may be affirmed that Shaler could talk in chapters. His conversation swung free, any subject serving for the deliverance of his versatile mind. There was, however, no preaching, no "pontificating": what he said was spontaneous, epigrammatic, and in accord with the occasion. With quip and joke he enlivened the 
homely facts of life, or on easy wing ventured beyond the bounds of the self-evident and prosaic.

In his contact with men Mr. Shaler seldom struck the minor key; conscious of an underlying tendency to melancholy, he encouraged himself in the practice of cheerfulness, shutting his lips upon anything like complaining or self-pity. He had not only accepted the Universe, but had become reconciled to it and although no one at times was more alive to the tragic consequences of man's deeds, his poetic imagination enabled him to endow the hard facts of life with rich compensations. The unity of all created things in the plan of the Universe was an abiding thought - a thought which made it possible for him to believe that society at large might become so united by sympathy that the inherent isolation of the individual could to a certain extent be overcome. As a consequence of his sympathetic outlook upon the vast spectacle of ongoing life, his talk was optimistic, - not the complacent sort that tries to drug laziness by good humor with the times, but of the type which endeavors to master difficulties, - cheerful and full of courage. It was this highsounding note of valor that made him so uplifting a companion. It may be said here that while in the act of talking Mr. Shaler's face wore a vivacious, half-amused expression; when he listened his look was intense and penetrating, as if he would allow nothing to escape his attention.

With callow youths his quick insight in the choice of subjects that would interest them - ranging from adventures by sea and land to football tactics and baseball curves - held them spellbound, while the absence of anything like professional pose, his friendliness and his eager desire to see the good that was in them, won their enthusiastic and abiding affection.

For all Mr. Shaler's unfeigned interest in his fellow men he never descended to petty gossip, or encouraged it in others. The truth was, a certain inner stateliness of soul made him not scornful, but indifferent to the valet side of a man's life.

Mr. Shaler was neither clubbable nor lionizable. From good 
nature he joined many clubs, but he seldom attended their meetings. He went perhaps more frequently than to any other to the Thursday Club, where he often spoke. But he cared little for cut and dried social expedients; and as for the rôle of lion, the artificiality of it was as repugnant to him as the iron cage to the free-breathing animal from the jungle. He was nevertheless very social, and although he growled at having to go to dinnerparties, when once launched he enjoyed them exceedingly. Of late years there was one house in Boston in particular where he dined often - its mistress the daughter of an old Kentucky friend. The warm-hearted hospitality of both host and hostess made him feel very much at home, and the talk about old times and the friends of other days rejuvenated him. To get into simple, kindly relations with people without any fanfaronade was what delighted him most. Much as he enjoyed meeting his friends in their houses, nothing pleased him better than to see them in his own. If a stranger brought a letter of introduction he was most scrupulous in his welcome. Even when the individual was merged in a crowd, such as a learned society and so forth, he could still meet successfully the collective demand.

The worst part of dinner-parties was the getting ready for them; he was so impatient a subject of conventional appearance, or any form that failed to represent a worthy outcome of social experience, that the tying of his white necktie was a serious undertaking. And when several ties had wilted under his fiery touch and his wife was called upon to finish the work, it was to both a moment of extreme tension. When it was over he would heave a sigh of relief and execrate the petty details of fashions that stole a man's time from better things. He was careless about his dress, but so far as his body was concerned cleanliness was next to godliness, and two baths a day often were none too many to meet his self-exacted requirements. He took heed for a while to an admonition of President Eliot's, who, on their way to chapel, good-naturedly reproached him for walking on the wet grass while the morning's "shine" was fresh on his 
boots. For several days after he was seen to pick his way carefully on the gravelled walks. In regard to his next-door neighbor, whom he admired very much, although it was seldom they agreed, he used laughingly to say: "Now Eliot is too much like George Washington for us ever to be able to keep step long together." Speaking of his other colleagues, many of whom he loved dearly, he would often make use of the phrase "He's a dear boy," or "He's the dearest creature alive." This expression was oftenest on his lips with reference to Dr. James, Professor Palmer, and Professor Royce; and in his lifetime Professor Child would call forth the same spontaneous words of liking. Like himself, Professor Child was of a testy nature and they often disputed acrimoniously in faculty-meetings, but they would no sooner get home than a note would fly from one to the other full of contrition and tender atonement. So far as his relations with the men in his own department were concerned, they were cordial, liberal, and encouraging. Professors Davis, Smyth, Wolff, Woodworth, and others had been his old pupils and were endeared to him by long association. He was also most considerate of the clerks in his office, and almost without exception they adored him.

Mr. Shaler was a very constant friend ; for, after all, his impatience was rooted in patience, and he would put up with the backslidings and misdemeanors of a person with whom he had once had friendly relations beyond the usual endurance. It was rare that anything could happen bad enough to shake his loyalty to a tie once formed, and an appeal, however exacting, was seldom unheeded. On one occasion when the discovery that a German woman, who for years had been befriended on account of her extreme poverty, had stored in bank six hundred dollars which, she said, she was saving to pay her son's gambling debts in case he had any, awakened indignation, he merely remarked, "What did you expect? Besides, when you undertook to help her you should have realized that it was for better or for worse." The friend who was so 
fortunate as to have him for an ally in any difficult situation was sure to be powerfully and intensely sustained; indeed it would have been hard to find a better backer in a mortal quarrel.

This was a characteristic feature even of his early manhood, and was strengthened, not diminished, by time. In 1870 his friend Professor Hyatt writes:-

Boston Society of Natural History.

... I shall never be able to express my obligation to you for the friendly manner in which you worked for me. Perhaps no one was more surprised than your humble servant at the sudden bold swoop with which you threw the first bomb. I could compare the effect of your speech to nothing else. The applause that followed was as astonishing to me as to our opponents....

He often went far afield to help a friend, nor did he consider that by so doing he was wasting time and energy, for the sympathetic and human realm in his opinion claimed the foremost place in the minds of men. "There were other things in life," he said, "besides beating a little learning into a student."

If it had been possible to spoil him in his youth, he certainly would have been spoiled, for he was the constant object of pride, solicitude, and affection on the part of his parents. In his turn he was a devoted son, showing great tenderness for his mother; ready to go to her at all times, in the depth of winter or the heat of summer, that he might give her cheer and comfort, especially after his father's death. His resemblance to her side of the house was strong - to her brothers in particular, two of whom were brilliant men, witty, ready phrasers and much sought after for their social qualities. In his own state of Kentucky the tongue was almost as mighty as the sword and the man or woman who could flash forth an aphorism or a quick repartee was. exalted. The witty retort was native with his father, but Mr. Shaler's brilliant conversational powers came from his mother's side of the house. His mother's love for him amounted to idolatry. When he was with her she lived in his shadow; everything he did was right; every object about him was transmuted 
into something fine and precious. Even the food at his table had a better flavor than any other.

It may be said in this connection that his attitude toward women was exceedingly chivalrous, and for the elderly of fine character he had profound reverence. And yet, as a rule, his affections having become early centred, so far as he was concerned, women only existed in a generalized way and not as objects of definite personal interest. There was a time in his life when he was apt to take the absence of beauty in a woman as a personal affront, and if one of his "boys" married a plain girl he was indignant. Farther along, however, this, in a measure, ceased to be the case, he was content to find in their faces a good, motherly, feminine expression.

Mr. Shaler's well-recognized irascibility was partly owing to physical causes and partly to an exceedingly sensitive nature. His emotions, both pleasurable and painful, were singularly acute, and when thoroughly aroused his tongue was sharp and trenchant. But at foundation he was so noble and large-hearted, so willing to pardon and forgive the offence which had aroused his ire, that the sting, received and given, was soon over. Only meanness and indirection he neither would nor could forgive. He strove very hard to overcome his excitability. Yet, working as he did to the full stretch of his capacity and a little beyond (doing many things easily, he had little present feeling of the amount of work he accomplished), the pressure under which he lived was too great for one of his nervous temperament. Nothing less than superhuman powers could have coped with the physical and mental stress that his varied activities imposed, or have allayed the nervousness for which they were indirectly responsible. There were periods when his doing-power was extraordinary. In contrast to it, do what they would, those about him seemed to be mere cumberers of the soil. The last years of his life, however, in this respect were somewhat calmer. The unanswerable quests of the soul, the permanence of matter, and the persistence of force, in other words, the profundities of the 
natural world, a subject ever uppermost in his mind, taught him at last a sort of belated patience as well as tolerance in others of less strenuous efforts than his own.

The best antidote to nervousness he found lay in his longstemmed pipe with its small bowl, holding scarcely a thimbleful of the lightest and most delicately scented tobacco-a mixture of his own, its aroma too faint for the nicotine-steeped senses of most smokers. His friends often complained that instead of smoking tobacco he smoked matches, so frequently did he light the dying ashes. However this may have been, he pulled at his pipe pretty steadily. With his pipe in his mouth and his pencil in hand, he soon became lost in the large mental territory he owned, where he ranged at will oblivious of all vexing cares. This world of his thoughts grew to be more and more sufficient, and therefore forced marches into remote geographical realms, instead of being recreative, were even thought of with positive aversion. All he asked of life, in these last years, was to be left alone by his fireside to do what he pleased, not to labor necessitously, but only to draw his pension and to restthat is, to work in his own way. In fact, he was now willing to let the struggle pass on to others, "holding himself in reserve for an occasional onslaught if necessary."

Mr. Shaler's work-table was a heaped-up mass of papers - an epitome of the world's interests. There were blue-books, theses, manuscripts of his own and others, social letters, business letters, maps, mining-reports, newspapers, and books of reference. How he found his way through this chaos it was difficult to understand, but if his table was left unmolested, neither straightened nor dusted, he got on very well; a foreign touch, however, produced distressing consequences, making him lose the thread that guided him through the tangle. For many years during the early growth of the Lawrence Scientific School, and even after, he answered personally every inquiry, thus putting a severe tax upon himself; but it was just these personal communications that made all the difference between failure and success. 
His indefatigable performance of this dull clerical business was pathetic to those who watched him thus engaged, and gave them the impulse to throw (in many instances) the illiterate application into the waste-paper basket, to save his precious strength.

Away from his work-table he was methodical to a marked degree. He rose a few minutes before the ringing of the College bell, took a short walk before breakfast, going for his newspaper, possibly stopping at the fruit-vender's to exchange a few words of Italian while selecting his oranges or grapes, and would also look in at his office for a moment to see that the day was well begun. After breakfast he went to Appleton Chapel. The morning service there he regarded as a gate to better health of mind; the reading of the Psalms and the short and pointed address were as a spiritual bath, he said, which prepared a man to run the day's course. From the chapel he proceeded to his college appointments. The sequence of his acts was almost unfailing. He kept his engagements with persistent punctuality; disinclination, sickness, or other solicitation to shirk the prescribed task was treated as non-existent; not unfrequently he would get up out of a sick bed, find his way to the lecture-hall, and by sheer force of will talk through the hour. The order of his life in other directions was equally well maintained. On election days he went to the polls early, his vote always being among the first half-dozen that were cast. This political duty he never neglected, and while a Democrat, when it was a question of the better man, he did not stick to his party, but voted for the one who promised to discharge his duties best. His own sense of duty toward town, state, and nation was always keen. In travelling, except for delays, he usually outran his schedule, so that letters directed to be sent to different places at special times were apt to be returned through the dead-letter office. Furthermore the housekeeper who undertook to have repairs done in his absence, or the house cleaned, was almost sure to be caught with the task only half accomplished. 
Nothing but the unfailing regularity of his days enabled him to accomplish what he did. It was not, however, an inhuman regularity that excluded the play of life; he found time for this, too. Owing to the habit he acquired of intense concentration, he was able to make use of spare moments for reading or writing when other men would have thought of nothing save their cares and fatigue. In these fragments of time he would peg away at his regular work or almost instantaneously lose himself in his own world of entertainment. He was glad to have those near him enter this world if they would, but he never thrust his compositions upon them, and while engaged in writing anything of a serious nature he was averse to talking about it. On the whole, he was singularly independent of criticism; he wrote because he had something definite to say and was content to say it once for all and forget it. With his poetry it was different; he was less confident and asked advice of some of his colleagues of reputed literary judgment.

Mr. Shaler's personality was such that he became the subject of a whole world of anecdote and reminiscence in the College circle. These were communicated by word of mouth, or understood by nod and gesture by the initiated; as, for instance, when students called him "Uncle Nat," the sobriquet suggested how often they were saved by timely application to him from a visit to the "Uncle" with the three balls for sign of willingness to accommodate. But these current sayings and the performances that gave rise to them, like all unrecorded things, even though there were a cloud of witnesses, have gone or are going the way of oblivion. The other side of his character happily lives on in his books. 


\section{CHAPTER XXIX}

\section{LITERARY WORK}

As we have seen, Mr. Shaler began to write in his youth. He did so, however, without intending to make literature, in other than a secondary way, any part of the serious work of his life; in truth long after he was fairly committed to the writing of books he insisted that such work should with most authors be a side issue, the spilling over of a full life; a recreation rather than a deliberate purpose. The hard drill which a man received in the exacting field of his avowed profession would, he thought, do away with amateurish results. Furthermore he believed that a well-educated man could apply his talents as well to one thing as another and could write on any subject of ordinary human interest. Owing to his own varied intellectual activities it is difficult to associate Mr. Shaler with a special branch of knowledge or industry, for there was hardly a subject on which he could not throw an unexpected light; and for this reason his literary work falls in with no ready-made classification either of subject or intellect. Apparently no irresistible impulse led his mind away from what seemed at the moment the thing best worth doing, nor when accomplished could it detain him longer. It was possible for him to enter into the floating interests about him, ${ }^{1}$ and yet keep his energies in the steady stream of his appointed tasks; always faithful to the hour and minute of their discharge, never shirking the fatigue or monotony of their smallest detail. The different ideas which beset him, strange to say, were not combatants. In passing they saluted one another and went on their way, each patiently biding its time for fuller recognition and development. In this respect his life was pe-

\footnotetext{
1 As is shown by the multitude of magazine articles he wrote on current subjects of interest, - such, for instance, as the Silver Question, the Negro Problem, Red Sunsets, the Law of Fashion, Hurricanes, Immigration, etc.
} 
culiarly rich, for in his mental house there were many mansions into which at will he could enter. Whatever struggle there may originally have been between poetic imagination and scientific research, the two were not only reconciled, but during the last fruitful years of his life fused into one in such books as "The Interpretation of Nature" and "The Individual." It was not only when his mind travelled into the realm of poetry that time and eternity, the vast and the mysterious, were present with him. These phenomena ever underlay his thought, and because of this solemn undertone often there was a note of pathos in what he wrote - markedly so in early manhood; and later his pen continued to obey the dictation of a subconscious sadness, a sadness which in a measure was lost in the world of activity, where he practised a self-sufficing stoicism, but which, in the world of reflection, showed itself continually.

So far as the actual process of writing was concerned, Mr. Shaler could write at any time and anywhere; he was unfamiliar with the coaxing habit indulged in by some authors. He knew nothing of "moods" or "atmospheres," nor did he make ostentatious preparations for the act. All he wanted was his Morris chair, a tablet, a lead pencil, and his long-stemmed pipe. He did not care for what is known as "the frippery of erudition" and was without the solicitudes of those who strive for faultless lines; indeed he produced too rapidly to keep his mind for long at the critic's level. What erasures he made were done at the moment with the rubber end of his pencil, a labor-saving contrivance to which he was wont to sing a hymn of praise. His writings are seldom cumbered with quotations, and if any came to his mind he was apt to brush them aside in his effort to express himself. He wrote freely and easily, but no amount of talent, unsupported by his steady-pulling diligence, would have enabled him, amid so many distractions, to fill out the long and varied list of his writings.

Mr. Shaler's first published scientific works of any importance were his list of Anticosti Brachiopods, and later, in 1876, The 
Fossil Brachiopods of the Ohio Valley. His researches in this field were warmly commended by Agassiz, and at once gave him a place among his contemporaries in science. Although he early began to publish in scientific journals, in Government and State Geological Reports, a letter which he wrote to his father while in England shows that he was by no means satisfied with what he had already done.

Loxdox, May, 1873

S- wrote you all the news Sunday last. We are all much as then. I did too much last week and so am compelled to do less this; but I am getting along quietly. I do not expect ever to be able to do very hard work again; yet I think it is probable that I have a good deal in me yet which can be got out with careful management. I shall always run the risk of setting up the old irritations. My plan is to come back to Cambridge for the next year. If my Nantucket scheme for summer school goes forward this year I shall try to get there in July; it will involve only a little supervising work and in exchange therefor I shall get two months' rest in the winter. I intend to have two assistants, which will cost me $\$ 1000$, leaving me $\$ 3000$ from the university. I shall do a little less than half my usual task for the coming year and see how that does. I mean also to come back to horseback exercise, which is more diverting and less wearing than foot exercise. In this fashion I hope to live at least twenty years of useful work. I am anxious to have some repose in order that I can begin to get my scientific results in order. I have done a good deal of work which should be published, but have as yet got very little on to paper and into print.

While Director of the Kentucky Geological Survey (1874-80) Mr. Shaler's annual reports and other contributions, written by himself or with the aid of his assistants, required a great deal of his time. These writings relate to the natural resources of the state, as well as to purely scientific subjects. The whole of Volume III, new series, was written by himself. His first independent book, "Thoughts on the Nature of Intellectual Property," was published in 1878; "The Geology of Boston and its Environs" (Memorial History of Boston, edited by Justin Winsor), in 1880. "Glaciers," with W. M. Davis as collaborator, appeared in 1881. His next venture, "The First Book of Geology," was published in 1884, and "Kentucky: A Pioneer 


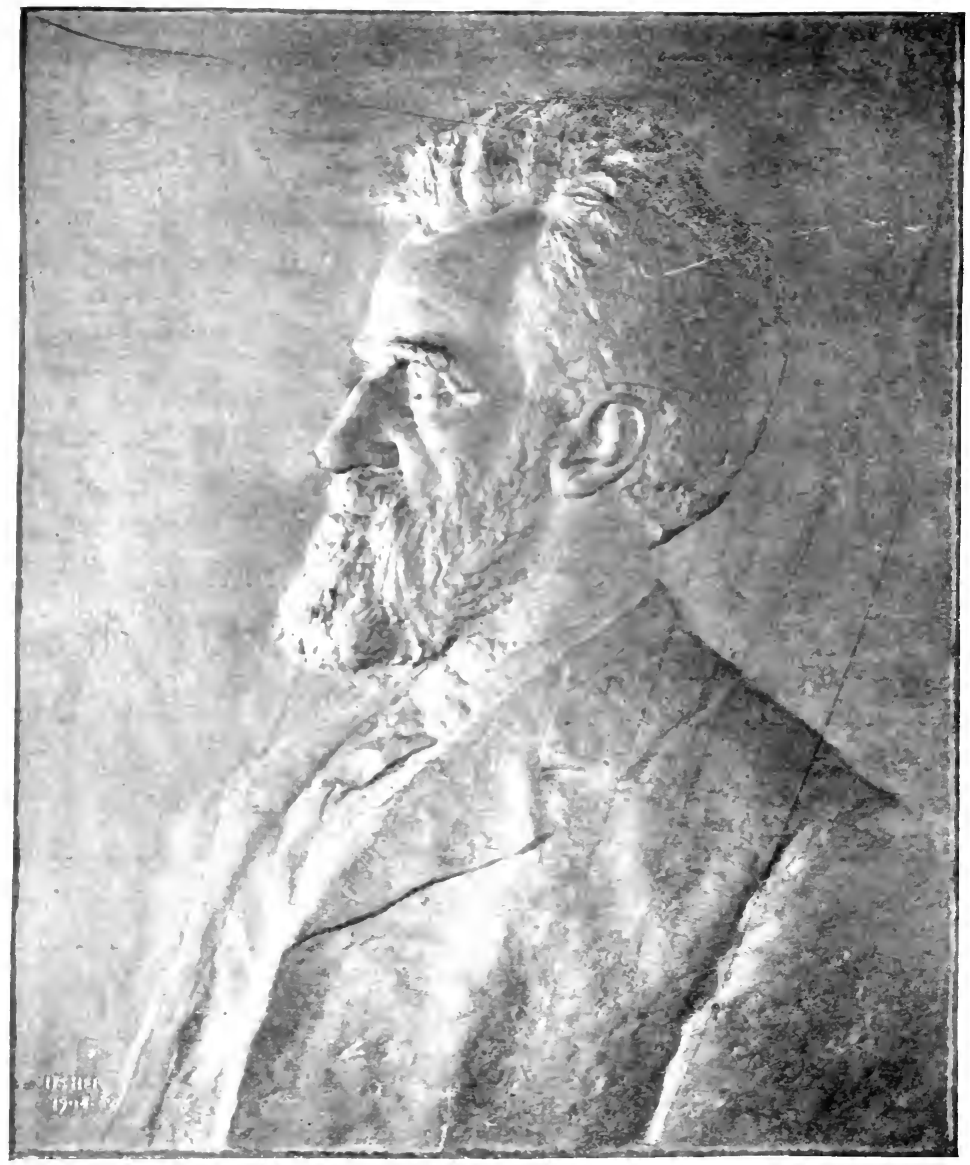

BAS-RELIEF OF MR. SHALER 
, 
Commonwealth," the same year. Thereafter his books were sent forth in rapid succession and about in the order in which they are mentioned here. "Physiography of North America" (Narrative and Critical History of America, edited by Justin Winsor), "Field Geology" (published serially in Popular Science News), "Aspects of the Earth," "Nature and Man in America," "The Story of Our Continent," "Sea and Land," "Valor" (a poem), "The United States" (edited by N. S. Shaler), "The Interpretation of Nature," "Domesticated Animals," "American Highways," "Outlines of the Earth's History," "The Individual," "The Moon," "Elizabeth of England" (5 vols.), "The Neighbor," "The Citizen," "Man and the Earth," "From Old Fields." In addition to the above-list of his principal writings there are twenty-one long and valuable publications contained in the United States Geological Survey Reports, also others in the Reports of the Coast Survey, and a long list of papers in the Proceedings of the Boston Society of Natural History, and in the Annual Reports of the Curator in the Museum of Comparative Zoölogy at Harvard College. Mr. Shaler's contributions to learned societies, to scientific journals, and to magazines, and his book reviews alone would fill many volumes.

The "First Book of Geology" was gratefully received by teachers and was so well appreciated abroad that in the course of time it was translated into the German, Russian, and Polish languages. It was also embossed in print characters for the use of the blind. From the hundreds of letters sent to both publishers and author after the appearance of this little book one learns of the satisfaction felt in getting hold of something which was untechnical in style, entertaining, and scientifically true. One teacher writes: "The interesting way in which you treat of all even the most abstruse questions would vivify a stone, to say nothing of the receptive mind of an average pupil." This book was the beginning of a series which he had in mind. Again and again he was requested by publishers to write the more 
advanced volumes. He, however, postponed doing so, meaning in the end to give to it his ripest knowledge and experience. Mentally he was entirely prepared - indeed he had written out a large part of one of the higher text-books - to finish the undertaking at the first leisure period, that is, when his life should be disengaged from the cares of administration and the actual work of teaching, to which he, in thought at least, had already set the limit. In addition to a geological series he also considered the writing of some science readers. "The Story of Our Continent" is, strictly speaking, the only book of the kind he finished; nor was the scheme of a family library, upon which he pondered a great deal, brought to fulfilment. Like most of his conceptions, it was outlined on a large scale. Publishers dwelt upon the subject with fascinated interest, only in the end to abandon it because of the amount of labor and energy it would have required.

Of Mr. Shaler's exclusively scientific writings there are others more competent to write than I. One of these, who knows whereof he speaks, has said, "He was always a thoughtful observer, an independent inquirer, and a most ingenious speculative theorizer." It may also be affirmed that in almost every instance his scientific investigations were associated with the literary charm which made them attractive to the lay reader. There are at hand a dozen or more letters relating to a single monograph on the "Origin and Nature of Soils" which bear witness to this quality. A teacher writes from Trenton, New Jersey: "I have read 'The Origin and Nature of the Soil' in the United States Government Report. For felicity of expression, beauty of style, and rhythmic movement, as well as the insight it gives into the operations of divine law, it stands unequalled. It deserves an honored place among the classics."

The best evidence as to the interest of his scientific writings is the following line from that fastidious author, T. B. Aldrich, who perhaps exceeded even James T. Fields in his detestation of "a damned instructive lecture" or article either:- 
Aug. 25, 1881.

My dear Sir, - I think that nothing of yours has ever escaped my reading or failed to reward it; so I am very glad that you have consented to prepare the paper on Hurricanes.

Yours very sincerely,

T. B. AlDRICH.

His book on "Domesticated Animals," illustrated by Seton Thompson, called forth many enthusiastic letters from people having pets and pet theories, who overwhelmed him with anecdotes concerning the various animals that figure in its pages. He himself always insisted that many of the attributes which constitute a gentleman had passed over to the dog. "We may look upon the dog," he says, "as affording the first step on the path to culture which was to lift man from his primitive selfishness to the altruistic state to which he had attained. In his intercourse with this creature man first learned to develop his altruistic motives beyond the limits of his own kind."

"Man and Earth" is the last contribution to human knowledge based on scientific inquiry that Mr. Shaler gave to the public - the last of his lifelong efforts to interpret the facts and mysteries of nature which he had so lovingly pondered. In this volume he undertook to forecast the future of the globe from the study of its past history. Among other important suggestions its pages hold a warning against despoiling the earth of its treasures. He believed that the present reckless use of nature's supplies would eventually transfer to Manchuria and other parts of China the opportunity to furnish the world with its coal and iron, and that the state which commanded the mineral stores of that kingdom might find its way to master the world even more effectively than did Rome in her time.

In natural science, in short, as in all his work, Mr. Shaler was an innovator and a pioneer, and this is no more markedly evident than in the field of his writing upon the preservation of our woods and waters. His reports on Swamp Lands, and the Origin and Nature of Soils, prepared for the United States Geological Survey, are among the most notable papers bearing 
on the conservation of our natural resources, and the lines of action which he laid down in them have since met with general approval and acceptance, while his reports on the Geology of Roads and on Road-Building Stones have proved of great practical importance.

Mr. Shaler's earliest work in the field of general literature is to be found in the Atlantic Monthly so early as 1869 . He began to contribute to that magazine with a series of five papers upon Earthquakes, which attracted much attention; but as time went on his writings for this magazine became less strictly scientific, and passing from such subjects as a "Summer's Journey of a Naturalist," "The Moon," and "How to Change the American Climate," he came in later papers printed in the magazine in the course of the next fifteen years to the discussion of such themes as the "Natural History of Politics," the "Use of Numbers in Society," the "Negro Problem," the "Law of Fashion," and similar topics of wide general interest when passed through the alembic of his vigorous mind.

These papers in the Atlantic were greatly liked by the readers of the magazine, and highly valued by its editors. One of these, Mr. Howells, writes, "I have been reading the history of your gipsying with greatest pleasure, - the whole most charming and instructive." And in the correspondence which ensued between them during the years of Mr. Howells's editorship of the magazine there were numerous expressions of cordial appreciation that notably aided in stirring the literary impulse in Mr. Shaler's writing. There are other letters, too, that came to him as the result of these contributions to the Atlantic that were both pleasing and stimulating, - among them this from Oliver Wendell Holmes:-

May 16, 1879.

Dear Professor Shaler: - I have never thanked you for your article on "Sleep and Dreams," but I do thank you at last heartily. I have read it with much interest and have been struck with some of its ideas - especially with the original suggestion of the possibility of the transmission of concrete 


\section{A CURIOUS DREAM}

thoughts. I told my parlor audience at New York a week or two ago that your suggestion would be an admirable one in the case of a clergyman who had delivered a sermon just like a printed one of a famous divine. - His father probably heard it and having a very retentive memory recollected it and transmitted it with his virtues to his cruelly wronged offspring.

I may possibly have thanked you before, but no matter. My table is laden with what the Western people call a "boom" of pamphlets, and I sometimes forget whether I have acknowledged a particular one, as I mean to do with the very best of them at least.

Very truly yours,

O. W. HoLMes.

Mr. Shaler was observant of his dreams and would often entertain the family at breakfast with some fantastic experience of the kind he had had the night before. His dream about the white elephant that he found in his bed would make him laugh until the tears ran down his cheeks. Among his notes is the record of the following curious dream. He told it to Sir Arthur Sullivan when he was in London, and always believed that it gave the musician a hint for the plot of his opera "Ruddygore." He writes: "In the fancy which I shall tell as it came to me I was sitting with a friend one evening talking of the portrait of an old warrior which hung on the wall. Suddenly the likeness became living and the figure stood upon the floor. He told us that he was prisoned by enchantment in the picture centuries ago, doomed to wait until some one should pronounce certain words which would break the spell. These words we had spoken. He besought me to make the sign of the cross upon his forehead that he might go to his rest, for which he was the more eager for his centuries of waiting. This I did, when at once he was gone. On the wall still hung the vacant canvas - all of one hue. This curious dream could be made the basis of an effective tale. I do not remember ever to have read a story with such an incident."

In other than scientific fields the first book by Mr. Shaler to be widely read was the history of Kentucky in the American Commonwealths Series, which was published in 1884. This was in a measure a labor of love, and it was an undertak- 
ing for which he was peculiarly fitted. The knowledge he had gained of the state and its people, during the years when he travelled from one end of it to the other in discharge of his duties as Director of the Kentucky Geological Survey, served him to good purpose in vivifying the historical record. He knew the people intimately, the wealthy planter of the blue-grass region, the small farmer, and the poor mountaineer, finding among all classes characteristics which awakened his admiration. He had a keen sense of the reserve power, the unused-up force that in many cases lay dormant in the different grades of society. ${ }^{1}$

Furthermore, while a Union man himself, Mr. Shaler's understanding of the motives of those who cast in their lot with the Southern cause enabled him to treat of the Civil War period with larger comprehension than fell to the lot of the mere partisan writer. The proof-sheets of his book were subjected to the criticism of some of the ablest men in the state, and as might have been expected there was one point about which there was a diversity of opinion, viz., the exact meed of praise due the Union and Confederate soldier. One of his friends, Mr. John Mason Brown, writes, October 24, 1884:-

In reading over the estimate of the troops during the Civil War, it is difficult to resist the conclusion that your historical opinion is, that the Union forces of Kentucky were composed merely of such material as were left after skimming off the cream of the state into the churn of Morgan's cavalry. This is hardly gratifying to one who thinks so strongly to the contrary as myself and my friend Speed. It however suits Durrett and Collins to a dot.

It is barely possible that Mr. Shaler may have been induced by the representation of his critics, whom he greatly respected,

1 He was fond of telling of men whom he had met in out-of-the-way places, who had interpreted, of ten in a wise way, the phenomena of nature. Others had the same experience. Mr. Edward Atkinson writes to him: "You once told me that you found an old farmer up in the mountains of Kentucky who had worked out a true theory of erosion. I enclose letters from a farmer in Henderson, Kentucky, who appears to have worked out from his inner consciousness what would be substantially the theory of Quesnay and the physiocrats. I wonder how many farmers of this type are to be found in Kentucky. They ought to rule the state." 
to modify his first estimate of the men engaged on the Union and Confederate sides; but it is certain that he never materially changed it. His judgment was based not alone upon the exploits of Morgan's cavalry ; the record of the First Kentucky Confederate Brigade appealed strongly both to his reason and to his imagination. He felt that those men by their soldierly qualities and endurance did credit to the race, and among the last of his writings was a short poem called "The Orphan Brigade" celebrating their remarkable deeds. It was "arms and man" he sang and not a political party; nor war itself, for it was his firm conviction "that all armed struggles are monstrous ills which permanently weaken and degrade the states that wage them."

"The Interpretation of Nature" contains a course of lectures delivered in the Andover Theological Seminary in 1893. This book was in a way the forerunner of "The Individual," and many of the considerations there presented in relation to the critical points in the continuity of natural phenomena and the resultant occurrence of the unexpected, were to be more fully elaborated in the later volume. It also shows the same note of faith in a continual progress toward a higher life as well as the conviction that the world is governed not by blind force but by purposeful intelligence. These conclusions, together with the simplicity and directness of statement, made the book a delight to many readers. Furthermore, in those parts which deal with personal religion, it is in a fashion a piece of self-revelation.

He himself says in the preface to "The Interpretation of Nature": "My first contact with natural science in my youth and early manhood had the not uncommon effect of leading me far away from Christianity. Of late years a further insight into the truths of nature has gradually forced me once again towards the ground from which I had departed." Indeed in his journal there is a corroborative paragraph relating to this youthful phase of experience which is not without significance.

1860. Time was when all the fearful doctrines of the so-called Christian church were rooted in my mind. Great Nature! I thank you it is no longer 
so. I believed all that I now shudder at. I have heard ministers denouncing pangs inconceivable to little children whose life had passed like the fading of some springtime flower, promising woe of ten thousand deaths, all concentrated into one and lasting forever, to feeble and worn mortals tottering on the change. While I could not shake off the toils which were knit round me I still felt within that it was a lie; there was no answering voice that it was true coming from my inner nature such as I have ever felt when truth came to me. How I escaped from this net I cannot in detail say. Partly my escape from what was called the "House of God" was accomplished through the study of nature, no, study it was not, rather contemplation of nature (a feeling which I am not sure is not higher-souled than the study which came to me at this time; my age forbade deep study and I believe that it was better so). Without the absolute severance which I made with the dogmas of religion I never could have thought. . . . The church is opposed in its dogmas to the advancement of man whether it be through the ways of science or agency of political changes. What the church of Rome has been to Italy, to Spain, and to others of those most beautiful spots on earth, so are the modifications of the same institution in its thousand names in every land; it makes men miserable or careless of those great problems of existence which men are not born to solve but must strive nevertheless to understand.

This feeling of revolt against the old hell-fire punishments, as their letters indicate, was shared by others among Mr. Shaler's associates. At that time, it is true, a youth often felt called upon to work in a dash of skepticism to show that he had, as it were, put on his mental toga virilis; but beneath this bravado there was with them a heart-felt repugnance to many articles of the prevailing belief. Yet despite his inability to accept many dogmas of the orthodox, his frank expression of his views, his clear and candid thought, was found wholesome not only by the laity but by many of the clergy. The Rev. Leighton Parks writes:-

I have just finished reading "The Interpretation of Nature" and am moved to thank you for it. My only excuse for bringing myself to your notice is that as one of the preachers to the University I am profoundly interested in the spiritual life of the young men of the day. I know what an influence you have in the College and with what admiration you are regarded, and I rejoice that you have been able to accomplish such work as this. If your 
book did nothing more (and it will do far more) than to make the men with whom the future of the country lies feel that religion is worthy the consideration of thoughtful men, it would have been worth your while to write it.

"The Individual," "The Citizen," and "The Neighbor" form a trilogy of scientific and philosophical thought which seemed to meet the public need, one might almost say the public craving, for some such exposition of the eternal problem of man's relation to the Universe and his fellow beings. These books follow one another without any formal plan, the one growing spontaneously out of the other, or perhaps it is truer to say that the later ones were sent on their way by the letters which came to the author after the publication of "The Individual."

In many instances these letters are pathetic in their revelations of the comfort the writers extracted from its pages. In the welter of modern thought so thirsty were these souls for some spiritual staff to lean upon that they seized with eagerness, and as if they were demonstrated facts, upon the hints and suggestions of immortality so judicially expressed. Like much else that he wrote, these books were partly the outcome of the author's need to reduce to form the thoughts which thronged upon him. The sympathetic motive upon which he so persistently dwells in their pages was strong in his own case and was of no recent origin; from early manhood the subject had constantly beset him. In some of his first letters he emphasized its importance and often expressed surprise that it was so little thought about and discussed. "Its light," he said, "had in the beginning radiated from the family," and therefore the purity and warmth of all family relations he especially cherished. The curious thing about Mr. Shaler's mental work was that his different intellectual interests were never divorced from the actual problems of existence, and that subjects like the above, although removed from the practical questions of his profession, lived side by side with them.

Letters written to an author sometimes reveal the various states of mind awakened by his writings,- showing the good 
as well as the stony soil upon which the seeds of his thought have fallen, - and indirectly throw light upon his character. Here are a few of the many he received about "The Individual." The first extract is from a letter written by a woman:-

... You can regard this merely as a word of appreciation, of gratitude for the light and comfort I have got from your book "The Individual." I wanted to talk with you and ask you questions, feeling that one, to use your words, who sees so far on dark ways must be able to penetrate the mysteries of life and death, and make the Universe plain. At least I was inclined to feel that way. No doubt I shall get something from you that is not in your book, as that is confined to the scientific, but what a wonderful outlook you give. . . I want to tell you what comfort I had from the chapter on the relation of parent to child - I don't know how you know about it, unless you love a child not your own, but I know what you say is true. I have not seen it or heard it expressed before - it has always been taken for granted that no one can love a child as does its mother. I know I love my sister's children as if they were my own. . . I have much comfort in the truth that what we see is not all that is to be known. That " much may take place in the revolution that evidently occurs in dissolution that we do not see at all."

Here is another that gave him pleasure:-

My dear Stranger-friend and "Brother Man": - I've just finished reading your exceedingly interesting "Individual." I feel sure that I, in a measure at least, appreciate and "absorb" it. Will not the "solidarity" of organized society in this century apply the peaceful, fraternal teaching of the Christ to their daily life? What a vast theme it all is! I feel cheered, animated, exalted and more full of myself, as capable of being uttered. Most heartily do I thank you for this work.

Gratefully and appreciatingly yours,

T. F.

But most interesting of all, perhaps, was this from William James:-

Dear Shaler:-Being a man of methodical sequence in my reading, which in these days is anyhow rather slower than it used to be, I have only just got at your book. Once begun, it slipped along "like a novel," and I must confess to you that it leaves a good taste behind, in fact a sort of haunting flavor due to its individuality, which I find it hard to explain or define. 


\section{A LETTER FROM WILLIAM JAMES}

To begin with, it does n't seem exactly like you, but rather like some quiet and conscientious old passive contemplator of life, not bristling as you are with "points," and vivacity. Its light is dampened and suffused, - and all the better perhaps for that. Then it is essentially a confession of faith and a religious attitude, - which one does n't get so much from you upon the street, although even there ' $t$ is clear that you have that within which passeth show. The optimism and healthy-mindedness are yours through and through, so is the wide imagination. But the moderate and non-emphatic way of putting things is not; nor is the absence of any "American humor." So I don't know just when or where or how you wrote it. I can't place it in the Museum or University Hall. Probably it was in Quincy Street, and in a sort of Piperio-Armadan trance! Anyhow it is a sincere book, and tremendously impressive by the gravity and dignity and peacefulness with which it suggests rather than proclaims conclusions on these eternal themes. No more than you can I believe that death is due to selection: - yet I wish you had framed some hypothesis as to the physico-chemical necessity thereof, or discussed such hypotheses as have been made. I think you deduce a little too easily from the facts the existence of a general guiding tendency towards ends like those which our mind sets. We never know what ends may have been kept from realization, for the dead tell no tales. The surviving witness would in any case, and whatever he were, draw the conclusion that the universe was planned to make him and the like of him succeed, for it actually did so. But your argument that it is millions to one that it did n't do so by chance does n't apply. It would apply if the witness had preëxisted in an independent form and framed his scheme, and then the world had realized it. Such a coincidence would prove the world to have a kindred mind to his. But there has been no such coincidence. The world has come but once, the witness is there after the fact and simply approves, dependently. As I understand improbability, it only exists where independents coincide. Where only one fact is in question, there is no relation of "probability" at all. I think, therefore, that the excellences we have reached and now approve may be due to no general design, but merely to a succession of the short designs we actually know of, taking advantage of opportunity, and adding themselves together from point to point. We are all you say we are, as heirs; we are a mystery of condensation, and yet of extrication and individuation, and we must worship the soil we have so wonderfully sprung from. Yet I don't think we are necessitated to worship it as the Theists do, in the shape of one all-inclusive and all-operative designing power, but rather like polytheists in the shape of a collection of beings who have each contributed and are now contributing to the realization of ideals more or less like those for which we live ourselves. This more pluralistic style of feeling seems to 
me both to allow of a warmer sort of loy $y$ to our past helpers, and to tally more exactly with the mixed conditio $\mathrm{n}$ which we find the world as to its ideals. What if we did come where we re by chance, or by mere fact, with no one general design? What is gained, is gained, all the same. As to what may have been lost, who knows of it, in any case? or whether it might not have been much better than what came? But if it might, that need not prevent $u$ s from building on what we have.

There are lots of impressive passages in the book, which certainly will live and be an influence of a high order. Chaps. 8, 10,14, 15, have struck me most particularly.

I gave at Edinburgh two lectures on "The Religion of Healthy-Mindedness," contrasting it with that of " the sick-soul." I shall soon have to quote your book as a healthy-minded document of the first importance, though I believe myself that the sick soul must have its say, and probably carries authority too. ... .

Ever yours,

WM. JAMES.

Late in life there was a resurgence of the poetic impulse, so well fulfilling itself that one is tempted to ask what might have been the result, if, in the fashion of a Wordsworth or a Tennyson, Mr. Shaler had set himself in youth deliberately to develop the talent. But to such painstaking care as they lavished upon their work he was altogether averse. Once when I repeated to him Dorothy Wordsworth's answer to an inquiry concerning her brother's health: "William is not at all well, he has been laboring all day to find an adjective to go with "cuckoo," he laughingly exclaimed, "What a galoot! He deserved to have his head punched." There are passages in the "Elizabeth" and other poems which give rise to the belief that if, instead of using the gift merely as a pastime, he had employed it with serious intent, a very great name might have been added to the list of American poets.

But vain as are these speculations now, the fact remains that the return to the poetic exaltations that beguiled the golden hours of his youth gave him infinite delight. In "The Individual" there is a paragraph which may be construed as personal. Writing of the latent capacities in people which in mature life 
often assert themselves, 1 says: "To the oldish person who is a bit weary with the repeti "ons of his days, to whom the best of his profits have already a iresome sameness, the effect of a new accomplishment is magical. . . . It brings again the joy of youth, for the most of the pleasure of that time lies in just such excursions into the great unknown of the self." He had so great respect for the creative habit of mind that he urged those about him to make an attempt at something of the kind, no matter in how humble a vein. Such an attempt he believed would at least lead to a keener appreciation of the art of those who had won the great prizes of fame.

Although few of his friends had failed to recognize the poetic side of Mr. Shaler's nature, they had not suspected him of skill in metrical composition. It was therefore a surprise when the typewritten copy of the "Armada" was first passed from one to another. The dramatic romance, "Elizabeth of England," of which the "Armada" is a part, - the first that was written, - was begun, the author says in the preface to that work, "to test the truth of a common statement as to the effect on the mind of long-continued application to tasks such as occupy men of science." Mr. Darwin's experience in the loss of the æsthetic sense gave point to the argument, also the lack of literary skill on the part of many eminent investigators. "These instances," he says, "have led to a general belief that there is something in the quality of scientific work which inevitably leads to a loss of imaginative power." This charge of the essential incompatibility of science and the humanities Mr. Shaler took very much to heart. He believed, on the contrary, "that the work of the naturalist in interrogating his world of facts differs in no essential way from that of the poet in elaborating his fancies - both alike using the constructive imagination." With this conviction he set to work to make a personal experiment which might have some measure of critical value. He further states that it was difficult to make a beginning, but after a few hundred words had been set down in an automatic manner the writing began 
to take shape, not in a kind of measured prose such as he had thought to use, but as heroic verse, "which at once proved to be an easier and more sustaining mode of expression than prose - far easier to frame and more helpful to the mind than the prose I am now writing."

The impression that developed into the impulse that produced Mr. Shaler's cycle of Elizabethan dramas is to be found noted in his Journal as far back as 1858.

. . . The works of Charles Kingsley will often bear even the investigation of the most hypercritical without danger; so clear, so healthy is the mind of this author. It had been nearly a year since I had read a novel and it was half my resolution not to read another when accident threw in my way a single line from his "Andromeda"; it was a verse worthy of Homer.

"Boomed in their wave-worn hills as they champed at the roots of the mountain."

Curiosity impelled me to read the poem whence comes this remarkable description; then to seek some other work, "Westward Ho," from so admirable a pen. The author has been fortunate in selecting for his plot an age more than any eventful to the world. The reign of Queen Bess, the decline of the Spanish power, the Armada, the last struggle of an effete yet mighty nation to retain the headship of the world. And then the impulse of "Westward Ho" gives a wide scope to the imagination.

Forty years later, in "The Armada," his own imagination reconstructed that age "more than any eventful to the world."

The success of the endeavor naturally produced a feeling of elation, for Mr. Shaler was not one to be twitted with impunity; as his associates must have known, he was ever ready in any debate to give a Roland for an Oliver. But aside from the momentary triumph in the success of this essay he had found a mode of literary expression that was to be a source of great and unexpected pleasure, serving as an outlet for his own varied emotions - enough at any time to vivify a five-act drama. The characters he chose in which to embody his ideals became intensely real and the hours he spent in their company a veritable delight. The moment he dropped his serious labors he could at 
once enter this kingdom of poetic imagination and there feel himself secure from the aggressions of vexatious cares.

The choice of subject for his drama was thoroughly characteristic; for with all his love of humanity in its high and its low degrees, the circumstances and motives of the aristocratic class - men born to responsibility and leadership, having the oldtime grace of manner and spirit - most readily engaged his interest and affection. But above all, aristocracy, for him, meant that the strong should serve the weak, and should also represent, as Aristotle explained, "ancient wealth and excellence."

Imaginative work was to have furnished relaxation from the more taxing tasks Mr. Shaler had planned for the future; it was to have been, so to speak, the musical accompaniment of his declining years, for as yet his pen had but begun "to glean his teeming brain." In his power to maintain his own world of thought irrespective of the casual surroundings, he proved his kinship with the poets of the Tudor times. Had there been the right kind of a tavern - a Mermaid Tavern - or a coffeehouse in Cambridge, he might have written there, or wherever vivid men crowded together. In a paper in which he describes his mode of writing, he says:-

In my earlier experiences, as before noted, the lack of continuity was marked, every suggestion came to an end in a few lines, rarely more than a score. Now, with the dramatic purpose before me, the rush of conceptions was almost baffling and their persistence such as to perplex me when engaged in other tasks. To give an instance, one of many, showing the curious persistence of these dramatic conceptions where they did not belong, I will tell the story of how the picture of the progress of the Spanish Armada up the British Channel came into the conscious field. I had written some days before the part of the third play of the "Elizabeth" up to the end of the scene on Tilbury Field, and here put the work aside with no idea of what should come next. I should have said that the whole business was quite as much out of my mind as a chapter of the "Arabian Nights," for I was engaged in looking after the affairs of a public dinner over which I had to preside and act as toastmaster. In the middle of the feast, while, so far as I could judge, 
my mind was intensely occupied with the matter in hand, the scenes of the channel fight came out of the darkness. I had to do my toastmaster's business with the preposterous din of that action in the background. This disturbance lasted for about an hour; when the dinner was through the scenes, though well remembered, were no longer present to sight and hearing as before.

It is interesting to note that the persons who appear in the dramatic conception come apparently in a sudden manner before the mind, in my experience, even where they are historic personages about whom I have read and formed opinions as to their appearance and character. When they are visualized in action they are often quite unlike the images previously formed of them. To take a leading example of this, that of Queen Bess herself, what I had read of her led to a notion, not at all dramatic in its intensity, but entirely clear, that she was a hard, calculating, cruel woman, vastly vain, redeemed only by a large measure of political shrewdness. The conception of her appearance was distinctly forbidding. "Old wooden petticoats" I remember often calling her. When she appeared it was rather as a tender lass with a self-sacrificing motive, and the other notion, formed on reading and portraits, never returned to me. So with a dozen other of the characters of the known people, none of them appeared as I had historically conceived them or as I should have delineated them in prose.

The publication of the five volumes of "Elizabeth of England" brought Mr. Shaler many appreciative letters from those best qualified to measure his achievement, and the cycle was widely recognized as a work of large significance, showing the essential unity of the poetic with the scientific imagination on its highest level. What Macaulay wrote of Bacon has a singular applicability to this other deep delver in natural lore:-

In truth, much of Bacon's life was passed in a visionary world, amidst things as strange as any that are described in the Arabian Tales, or in those romances on which the curate and barber of Don Quixote's village performed so cruel an auto- $d a-f e$, amidst buildings more sumptuous than the palace of Aladdin, fountains more wonderful than the golden water of Parizade, conveyances more rapid than the hippogryph of Ruggiero, arms more formidable than the lance of Astolfo, remedies more efficacious than the balsam of Fierabras. Yet in his magnificent day-dreams there was nothing wild, nothing but what sober reason sanctioned. He knew that all the secrets feigned by poets to have been written in the books of enchanters are worthless when 
compared with the mighty secrets which are really written in the book of nature, and which, with time and patience, will be read there.

Two other dramas, "Alfred the Great" and "Curtius," written at this period, were never published. "Valor," a poem delivered before the Phi Beta Kappa, June 26, 1902, was warmly appreciated by those who heard it. As to his manner of speaking, the accompanying letter from the then teacher of elocution at Harvard gives the best and most competent representation:-

You perhaps know that I hurt my knee a short time ago, and for some days I was unable to walk. This morning, I am glad to say, I could hobble over to Sanders Theatre to hear you. You were so real, and so entirely individual in your delivery, as well as in your matter, that I found myself thoroughly absorbed in your thought, and forgot entirely about your manner. That to my mind is the greatest praise that can be given to a speaker. Your form of speaking was indeed a true reflection of the man back of it, whom to know is to honor. An old war veteran who sat near me said that you did not fire Gatling guns in your talk, but you dwelt on the happy and peaceful side of the relations of our people, which he said to his mind was the side to dwell upon. This morning you quoted one of the Scriptural sayings that I use a good deal in talking of my work - "What does it profit a man if he gain the whole world, and lose his own soul?" Your soul was in the topmast of your being.

"From Old Fields," the last volume Mr. Shaler ever wrote (published after his death), took even stronger hold upon the author than any of his previous poetic writings. This collection of short poems is the record, in many instances, of personal experiences. In writing them he lives over the grim days of the Civil War, qualifying the youthful ardor by the sad reflection time brings to the man who revives the dead passions, who hears the voiceless call of the dead past. Of these last poems Dr. William James writes:-

Dec. 25, 1906.

Dear Mrs. Shaler: - I have been waiting, ere I wrote to you, to finish reading the Poems of the Civil War which you so generously sent. I read the last line only night before last, so that my letter falls, most felicitously, 
upon Christmas Day. I imagine that if Shaler had seen the whole thing in proof, and revised it himself, certain little verbal and versical roughnesses would have been smoothed out, but they make no difference in the grand effect. It is a most moving and grasping work, with a great epic wind of sadness blowing all through it in spite of so many lively individual touches. These all seem to me cut on a vast background of landscape, and human multitudes fulfilling what was fated, that dim twilight in which the memories of those early 60 's lie now in so many of our minds. There are "anecdotes" in plenty, but they all swim in that atmosphere of landscape and historic fate, and moral sadness in the life of man. It is very striking that Shaler, who had so many notes in his mind, should have struck this note so strongly and (it seems to me) so exclusively in these poems. They are entirely unique, copying no special model, and their emotional atmosphere is unique too - it shows how strongly he was subject to those sentiments of vastness. The mixture of breadth of effect, of dignity and grandeur of tone, with vulgar realism in much of the detail is very extraordinary. And of course the note of magnanimity and humanity everywhere, so characteristic of him! I am sure that the six volumes of poems will outlast in fame all his scientific prose - especially this last one.

Affectionately yours,

WM. JAMES.

\section{A month earlier Charles Eliot Norton had written:-}

You have given to me a very precious gift in sending to me a copy of "From Old Fields." These poems would have extraordinary interest even if one knew nothing of their author. But to us who knew and loved Mr. Shaler they make a quite exceptional appeal. He lives in them. I see and hear him as I read them. His heroic spirit, his tender heart, his quick and generous sympathies, his nature full of reverence for nobility in man and woman and quick to discern it under whatever disguise, his simplicity and readiness to feel and express emotion provided only it became a man, and his uncompromising resolution to see things as they really are, - all tilis and much more is manifest in these poems. It is the work of most poets that chiefly interests us, but here it is the poet and not his poems: as fine as they are, he is finer. Hereafter, when I am asked, "What manner of man was Shaler?" I shall reply, "You may know him by these poems."

This volume can draw no more fitly to its close than with a paragraph from a letter from Professor George Herbert Palmer, Mr. Shaler's neighbor and intimate friend for many years. In it there is the phrase "the great powerful creature," which, with 
the added words of "brave" and "generous," is, when all is said, perhaps the truest key to Mr. Shaler's character. The facts set down here, which lead us the general way he trod, reveal but a tithe of his soul's adventures; in his nature there is still a large territory that remains unexplored, and, though steeped in his personality, it has been beyond my power to give the true measure of the man who marched along under the sign of the Universe, of one who was close to nature, close to the affairs of the world, and deeply involved in the poet's realm of fancy. This memoir therefore goes forth giving an inadequate picture of the life of a great and good man. Mr. Palmer writes:-

Thank you for this delightful volume. All of Mr. Shaler's writing is highly characteristic. In every sentence of his one hears his voice. But I think he has nowhere more completely expressed himself than in this book. Here is his chivalry, his adventure, his public spirit, his perpetual humor, his wide sympathy, his profound religiousness. Through his escapade with Elizabeth, too, he has acquired ease in blank verse. So that he seems himself to be muttering these tales and setting his lips hard together after the climactic passages. How many such yarns has he spun to me in equally picturesque prose! Some of these poems, too, I had already seen. He brought them to me in manuscript, and in my ruthlessly critical way I pulled them to pieces and told him to go to work at them longer. Now they are precious. I long to tell him so and to say over the love and admiration which then seemed unnecessary. Fortunately he was big enough not to need our approval. I think he knew how many of us loved him, and deep within was glad. But the great powerful creature strode along his noble and independent path while we little fellows scrambled after, hardly near enough to make our delight in him audible. How large your companionship with him was your words in this volume, and elsewhere, show. Happy woman to have been so blest, and happy we who were allowed to know you both! 



\title{
LIST OF PUBLICATIONS ${ }^{1}$
}

\author{
BOOKS, ETC.
}

Kentucky Geological Survey, new series (1874-1880). Reports of Progress, Memoirs of Survey, and Bulletins by Director and Assistants. Vol. iii by Director alone.

Question Guide to Environs of Boston, for Beginners in Geology in Harvard University. I: Somerville and Cambridge. Cambridge: C. W. Sever, 1875.

Thoughts on the Nature of Intellectual Property. Boston: James R. Osgood \& Co., 1878.

The Geology of Boston and its Environs (Memorial History of Boston, edited by Justin Winsor). 1880.

Glaciers, with W. M. Davis as collaborator. Boston: James R. Osgood \& Co., 1881.

The First Book of Geology. Boston: Ginn \& Heath [1884]. (There are also German and Polish editions of this text-book.)

Kentucky: A Pioneer Commonwealth. Boston: Houghton, Mifflin \& Co., 1885.

Physiography of North America (Narrative and Critical History of America, edited by Justin Winsor). Boston, 1887.

Field Geology. (Published serially in Popular Science News.) 1887.

Aspects of the Earth. New York: Charles Scribner's Sons, 1889.

Nature and Man in America. New York: Charles Scribner's Sons, 1891.

The Story of Our Continent. Boston: Ginn \& Co., 1892.

Sea and Land. New York: Charles Scribner's Sons, 1892.

Valor. Harvard Graduates' Magazine, 1892.

The United States, edited by N. S. Shaler. New York: D. Appleton \& Co., 1893.

The Interpretation of Nature. Boston: Houghton, Mifflin \& Co., 1893.

Domesticated Animals. New York: Charles Scribner's Sons, 1895.

1 This list does not pretend to completeness. Many scientific notes by Mr. Shaler appeared in the Proceedings of the Boston Society of Natural History and elsewhere, and many reports on mines, railroads, etc., are to be found in printed documents. Mr. Shaler also contributed scientific articles to Johnson's Universal Cyclopedia and edited the geological terms in the Standard Dictionary. A very full bibliography of his writings, compiled by Prof. John E. Wolff of Harvard University, appears in the Bulletin of the Geological Society of America for March, 1908. 
American Highways. New York: Century Co., 1896.

Outlines of the Earth's History. New York: D. Appleton \& Co., 1898.

The Individual. New York: D. Appleton \& Co., 1900.

The Moon. Smithsonian Institution, 1903.

Elizabeth of England. Five volumes. Boston: Houghton, Mifflin \& Co., 1903.

The Neighbor. Boston: Houghton, Mifflin \& Co., 1904.

The Citizen. New York: A. S. Barnes \& Co., 1904.

Man and the Earth. New York: Fox, Duffield \& Co., 1905.

From Old Fields. Boston: Houghton, Mifflin \& Co., 1906.

\section{MISCELLANEOUS REPORTS}

Report on Phosphate Beds of South Carolina. Coast and Geodetic Survey, 1870.

Report on Geology of the Sea Island District. Coast and Geodetic Survey, 1870.

Report on a special investigation of lunar phenomena, dated Sept. 25, 1872. Annals of the Astronomical Observatory of Harvard College, vol. viii, pp. 50-53. 1876.

Report on the Delaware Gravel Beds, containing chipped pebbles. Peabody Museum American Archæology in connection with Harvard College, vol. ii. $1876-77$.

Report on The Unfinished Work of the Survey of the Commonwealth under Dr. David Dale Owen. Frankfort, K .: Yeoman Press, 1877.

Report on Lunar and Terrestrial Geology. Observatory, Harvard College, 1878.

The Island of Campobello. Preliminary Report. Cambridge, 1881.

Report on The Fossil Brachiopods of the Ohio Valley. (Geological Survey of Kentucky.) Cincinnati: Robert Clarke \& Co., 1883.

Preliminary Report on The Geology of Cobscook Bay, District of Maine. American Journal of Science, July, 1886.

Annual Report of the Commissioners of the Massachusetts Topographical Survey for 1887.

Report on Fluviatile Swamps of New England. American Journal of Science, March, 1887.

Report of Massachusetts Commissioners of Topographic Survey and Map, with F. A. Walker \& H. L. Whiting. 1890.

Report of Massachusetts Gipsy Moth Commission. 1890.

Report on Tertiary and Cretaceous Deposits of Eastern Massachusetts. Bulletin of Geological Society of America, vol. i, 443-452. Plate 1. 1890. 
Report on The Topography of Florida. 1890.

Report on The Inundated Lands of Massachusetts. Massachusetts Board of Agriculture, 1891.

Report on Marshes and Swamps of Northern Long Island, between Port Washington and Cold Springs Harbor. 1902.

Report on Plans for the Extermination of Mosquitoes on the North Shore of Long Island, between Hempstead Harbor and Cold Springs Harbor, pp. 64-76. New York: Styles \& Cash, 1902.

\section{REPORTS CONTAINED IN UNITED STATES GEOLOGICAL SURVEY PUBLICATIONS}

Report: Atlantic Coast Division. U. S. Geol. Surv., J. W. Powell, Director, 6th Ann. Rept., 1884-85, pp. 18-22. Washington, 1885.

Preliminary Report on Seacoast Swamps of the Eastern United States. U. S. Geol. Surv., J. W. Powell, Director, 6th Ann. Rept., 1884-85, pp. 353398. Washington, 1885.

Report: Atlantic Coast Division of Geology. U. S. Geol. Surv., J. W. Powell, Director, 7th Rept., 1885-86, pp. 61-65. Washington, 1888.

Report on The Geology of Martha's Vineyard. U. S. Geol. Surv., J. W. Powell, Director, 7th Rept., 1885-86, pp. 297-363, pls. 19-29. Washington, 1888.

Introduction: Nature and Origin of Deposits of Phosphates of Lime, by R. A. F. Penrose, Jr. U. S. Geol. Surv. Bull., vol. 7, pp. 483-494, no. 46. Washington, 1888.

The Geology of Nantucket. U. S. Geol. Surv. Bull., vol. 8, pp. 601-653, 10 pls., no. 53. Washington, 1889.

Report: Division of Coast-Line Geology. U. S. Geol. Surv., J. W. Powell, Director, 8th Rept., pp. 125-128. Washington, 1889.

The Geology of the Island of Mount Desert, Maine. U. S. Geol. Surv., J. W. Powell, Director, 8th Rept., pp. 987-1061, pls. 64-76. Washington, 1889.

Report: Atlantic Coast Division. U. S. Geol. Surv., J. W. Powell, Director, 9th Rept., pp. 71-74. Washington, 1889.

The Geology of Cape Ann, Massachusetts. U. S. Geol. Surv., J. W. Powell, Director, 9th Rept., pp. 529-611, pls. 32-37. Washington, 1889.

General Account of the Fresh-Water Morasses of the United States, with a Description of the Dismal Swamp District of Virginia and North Carolina. U. S. Geol. Surv., J. W. Powell, Director, 10th Rept., pp. 255-339, pls. 6-19. Washington, 1890. 
Report: Atlantic Coast Division. U. S. Geol. Surv., J. W. Powell, Director, 10th Rept., pp. 117-119. Washington, 1890.

The Origin and Nature of Soils. U. S. Geol. Surv., 12th Ann. Rept., pt. 1, pp. 219-345. 1892.

The Geological History of Harbors. U. S. Geol. Surv., 13th Ann. Rept., pt. 2, pp. 99-209, pls. 22-45, figs. 7-15. 1893.

Preliminary Report on the Geology of the Common Roads of the United States. U. S. Geol. Surv., 15th Ann. Rept., pp. 259-306. 1895.

The Geology of the Road-Building Stones of Massachusetts, with Some Consideration of Similar Materials from Other Parts of the United States. U. S. Geol. Surv., 16th Ann. Rept., pt. 2, pp. 277-341, pls. 18-24. 1895.

Origin, Distribution, and Commercial Value of Peat Deposits. U. S. Geol. Surv., 16th Ann. Rept., pt. 4, pp. 305-314. 1895.

Geology of the Cape Cod District (Massachusetts). U. S. Geol. Surv., 18th Ann. Rept., pt. 2, pp. 503-593, pls. 97-104, figs. 86-92. 1898.

The Glacial Brick Clays of Rhode Island and Southeastern Massachusetts, with J. B. Woodworth and C. F. Marbut. U. S. Geol. Surv., 17th Ann. Rept., pt. 1, pp. 957-1004, pls. 61-62, figs. 34-43. 1896.

Geology of the Richmond Basin, Virginia, with J. B. Woodworth. U. S. Geol. Surv., 19th Ann. Rept., pt. 2, pp. 385-520, pls. 18-52, figs. 90-116. 1899.

Geology of the Narragansett Basin, with J. B. Woodworth and A. F. Foreste. U. S. Geol. Surv., Mon. xxxiii, 402 pp., 31 pls., 30 figs. 1899. (Reviewed in Journal of Geology, vol. 8, pp. 377-378. 1900.)

\section{MUSEUM OF COMPARATIVE ZOÖLOGY REPORTS}

Report on List of Brachiopods from the Island of Anticosti. M. C. Z., June, 1865, pp. 10.

Report on the Collection of Brachiopoda. Annual Report M. C. Z. 1864 (1865), pp. 41-42.

Reports on the Palæontological Collections. Annual Report M. C. Z. 1865 (1866), pp. 28-30.

Report on the Department of Palæontology. Annual Report M. C. Z. 1866 (1867), pp. 33-35.

Report on the Collection of Fossil Remains in General. Annual Report M. C. Z. 1868 (1869), pp. 41-45; 1869 (1870), pp. 26-30.

[Reports on Instruction in Geology and Palæontology.] Ann. Rept. M. C. Z. 1870 (1871), pp. 24-26; 1871 (1872), pp. 28-29; 1872 (1873), pp. 28-31; 1875 (1876), pp. 29-30; 1876 (1877), pp. 12-14; 1877-78 (1878), pp. 20-21; 187879 (1879), pp. 11-12; 1879-80 (1880), pp. 12-13; 1880-81 (1881), pp. 10-13; $1883-84$ (1884), pp. 19-20; 1884-85 (1885), pp. 19-20; 1885-86 (1886), 
pp. $12-13 ;{ }^{1} 1886-87$ (1887), pp. $10-13 ; 1887-88$ (1888), pp. $12-14 ; 1888-89$ (1889), pp. $12-15 ; 1889-90$ (1890), pp. $11-14 ;^{2} 1890-91$ (1891), pp. $12-17 ;^{3}$ 1891-92 (1892), pp. 17-19; 1892-93 (1893), pp. 19-21; 1893-94 (1894), pp. $19-24$; 1894-95 (1895), pp. 20-26; 1895-96 (1896), pp. 20-25; 1896-97 (1897), pp. 10-17; 1897-98 (1898), pp. 8-12; 1899-1900 (1900), pp. 19-28.

Report on the Geology of the Cambrian District of Bristol Co., Massachusetts. M. C. Z., October, 1888, pp. 30.

Report on the Occurrence of Fossils of the Cretaceous Age on the Island of Martha's Vineyard, Mass. M. C. Z., June, 1889, pp. 10.

Report on the Topography of Florida. M. C. Z., March, 1890, pp. 20.

Report on the Conditions of Erosion beneath Deep Glaciers, based upon a Study of the Boulder Train from Iron Hill, Cumberland, R. I. M. C. Z., January, 1893, pp. 42.

\section{MEMOIRS OF MUSEUM OF COMPARATIVE ZOÖLOGY}

Vol. IV: (No. 10) The American Bison, Living and Extinct, by J. A. Allen, in connection with the Geological Survey of Kentucky; preliminary note by $N$. S. Shaler. May, 1876, pp. 246.

Vol. VIII: (No. 3) North American Reptiles, by S. Garman, in connection with the Kentucky Geological Survey; preliminary note by N.S. Shaler. July, 1884, pp. 200.

Vol. XVI: (No. 1) Notes on the Taxodium distichum, or Bald Cypress. June, 1887, pp. 16. (No. 2) Notes on the Original Connection of the Eastern and Western Coal Fields of the Ohio Valley. June, 1887, pp. 12.

\section{SCIENTIFIC MEMOIRS}

Proposition concerning the Motion of Continental Glaciers. Memoirs Boston Society Natural History, June, 1875.

Notes on the Cause and Geological Value of Variation of Rainfall. Id., October, 1875.

On the Antiquity of Caverns and Cavern Life in the Ohio Valley. Id., February, 1875; ii, 355.

Propositions concerning the Classification of Lavas considered with Reference to the Circumstances of their Extrusion. Id., 1880.

1 1881-86 with W. M. Davis.

2 1886-90 with W. M. Davis and J. E. Wolff.

s 1890-91 with J. D. Whitney, W M. Davis, and J. E. Wolff.

- 1899-1900 with W. M. Davis, R. T. Jackson, and R. DeC Ward. 


\section{MISCELLANEOUS ESSAYS AND SCIENTIFIC PAPERS}

On the Formation of Mountain Chains. Geological Magazine, London, 1868.

Earthquakes. Atlantic Monthly, June, 1869.

Great Earthquakes of the Old World. Id., August, 1869.

An Account of Specimens from Ohio and Kentucky, presented to the Peabody Museum, Harvard University (a letter to Jeffries Wyman). Peabody Museum Reports, i, 1214. Cambridge, 1869.

Earthquakes of the American Continents. Atlantic Monthly, October, 1869.

Earthquakes of the Western United States. Id., November, 1869.

California Earthquakes. Id., March, 1870.

The Time of the Mammoths. American Naturalist, May, 1870.

An Ex-Southerner in South Carolina. Atlantic Monthly, July, 1870.

Father Blumhardt's Prayerful Hotel. Id., December, 1870.

The Effect of Pressure on Rocks. Proceedings Boston Society Natural History, January, 1872.

Notes on the Origin of our Domesticated Cat. Id., April, 1872.

Notes on the Effects of the Upright Position of Man. Id., June, 1872; vol. xv, p. 188.

Rattlesnake Hypothesis. American Naturalist, April, 1872.

On the Geology of the Island of Aquidneck and the Neighboring Parts of the Shores of Narragansett Bay. Id., September, October, and December, 1872 .

Effects of Extraordinary Seasons on the Distribution of Animals and Plants. Id., November, 1872.

Notes on the Right and Sperm Whales. Id., January, 1873.

The Summer's Journey of a Naturalist. Atlantic Monthly, June, August, and September, 1873.

The Moon. Id., September, 1874.

Notes on Some of the Phenomena of the Elevation and Subsidence of the Continents. Proceedings Boston Society Natural History, December, 1874; vol. xvii, p. 288.

Martha's Vineyard. Atlantic Monthly, December, 1874.

North American Climate. Proceedings Boston Society Natural History, 1875.

Notes on Cause of Geological Value of Variations in Rainfall. Id., October, 1875 ; vol. xviii, p. 176.

Some Considerations on the Possible Means whereby a Warm Climate may be produced within the Arctic Circle. Id., January, 1875; vol. xvii, p. 332. 
A State Survey for Massachusetts. Atlantic Monthly, March, 1875.

The Harvard Summer School of Geology. American Naturalist, January, 1876.

On the Prehistoric Remains of Kentucky, by Lucien Carr and N. S. Shaler. Cambridge: University Press, 1876.

How to change the North American Climate. Atlantic Monthly, December, 1877.

Notes on the Age and Structure of the Several Mountain Axes in the Neighborhood of Cumberland Gap. American Naturalist, July, 1877.

On the Existence of the Alleghany Division of the Appalachian Range within the Hudson Valley. Id., October, 1877.

The Mountain Axes near Cumberland Gap. Id., July, 1877.

The Silver Question Geologically Considered. Atlantic Monthly, May, 1878.

Reelfoot Lake. Id., August, 1878.

Notes on Certain Evidences of a Gradual Passage from Sedimentary to Volcanic Rocks, shown in Brighton District. Proceedings Boston Society Natural History, January, 1879.

Notes on Submarine Coast Shelf or Hundred Fathom Fringe. Id., May, 1879.

Note on Value of Saliferous Deposits as Evidence of Former Climatic Conditions. Id., 1879.

The Natural History of Politics. Atlantic Monthly, March, 1879.

The Use of Numbers in Society. Id., September, 1879.

Precious Metal Mining in the United States. Kansas City Review, vol. iv; 1880.

Future of Precious Metal Mining in the United States. Atlantic Monthly, June, 1880.

The Future of Weather Foretelling. Id., November, 1880.

On the Recent Advances and Recession of Glaciers. Proceedings Boston Society Natural History, vol. xxi, p. 162; March, 1881.

A Winter Journey in Colorado. Atlantic Monthly, January, 1881.

The Value of University Records. Harvard Register, April, 1881.

Hurricanes. Atlantic Monthly, March, 1882.

Improvement of the Native Pasture-Lands of the Far West. Science, March $23,1883$.

The Floods of the Mississippi Valley. Atlantic Monthly, May, 1883.

American Swamp Cypress. Science, July 13, 1883.

The Red Sunsets. Atlantic Monthly, April, 1884.

Altruism. A lecture delivered at the Harvard Divinity School. Christian Register, May, 1884.

On the Origin of Kames. Proceedings Boston Society Natural History, vol. xxiii, p. 36; February, 1884. (Also separately.) 
The Negro Problem. Atlantic Monthly, November, 1884.

Humanism in the Study of Nature. Science, July 24, 1885.

Race Prejudices. Atlantic Monthly, October, 1886.

The Swamps of the United States. Science, March 12, 1886.

On the Formation of Mountain Chains. Geological Magazine, London, vol. 5, pp. 511-517. 1886.

On the Parallel Ridges of the Glacial Drift in Eastern Massachusetts. Id., London, vol. 8, pp. 27, 28. 1886.

On the Needs of American Universities. Harvard Monthly, February, 1886.

Series of Twenty-five Colored Geological Models and Twenty-five Photographs of Important Geological Objects, accompanied by letter-press descriptions, with the assistance of W. M. Davis and T. W. Harris. Boston: D. C. Heath \& Co., 1886.

Field Geology. Popular Science News, May and August, 1887.

The Stability of the Earth. Scribner's Magazine, March, 1887.

The Forests of North America. Id., April, 1887.

Caverns and Cavern Life. Id., October, 1887.

The Instability of the Atmosphere. Id., August, 1887.

The Supply of Natural Gas. Forum, May, 1887.

The Earthquake in the Riviera. Epoch, March, 1887.

The Law of Fashion. Atlantic Monthly, March, 1888.

Animal Agency in Soil Making. Popular Science Monthly, February, 1888.

On the Study of Nature. Popular Science News and Boston Journal of Chemistry, April, 1888.

Volcanoes. Scribner's Magazine, February, 1888.

The Crenitic Hypothesis and Mountain Building. Science, June 15, 1888.

Rivers and Valleys. Scribner's Magazine, August, 1888.

The Work of Underground Waters. Chautauquan, December, 1889.

College Scientific Expeditions. Id., 1889.

The Sense of Honor in Americans. North American Review, August, 1889.

Discipline in American Colleges. Id., July, 1889.

The Athletic Problem in Education. Atlantic Monthly, January, 1889.

The Problem of Discipline in Higher Education. Id., July, 1889.

School Vacations. Id., December, 1889.

Effects of Permanent Moisture on Certain Forest Trees. Science, March 8, 1889.

The Common Roads. Scribner's Magazine, October, 1889.

Chance or Design. Andover Review, August, 1889.

Knees of the Bald Cypress. Garden and Forest, January, 1890.

Nature and Man in America. Scribner's Magazine, September, 1890. 


\section{LIST OF PUBLICATIONS}

The Use and Limits of Academic Culture. Atlantic Monthly, August, 1890.

Science and the African Problem. Id., July, 1890.

The Negro Race Question. Arena, November, 1890.

The Peculiarities of the South. North American Review, October, 1890.

Critical Points in Continuity of Natural Phenomena. Unitarian Review, January, 1890.

Rock Gases. Arena, May, 1890.

Soils of Massachusetts, a lecture delivered at the annual meeting of the Mass. State Board of Agriculture, 1890.

Note on Glacial Climate. Proceedings Boston Society Natural History, vol. xxiv, p. $460 ; 1890$.

Individualism in Education. Atlantic Monthly, January, 1891.

College Examinations. Id., July, 1891.

T'he Interpretation of Nature, a lecture on the Winckley Foundation, Andover Theological Seminary. 1891.

The Antiquity of the Last Glacial Period. Proceedings Boston Society Natural History, May, 1891.

The Betterment of Our Highways. Atlantic Monthly, October, 1892.

The Border State Men of the Civil War. Id., February, 1892.

Sea and Land. Scribner's Magazine, May, 1892.

The Depths of the Sea. Id., July, 1892.

Icebergs. Id., August, 1892.

Caves. Id., April, 1892.

Sea Beaches. Id., June, 1892.

Regulation of Professions. Engineering Magazine, October, 1892.

United States Geological Survey. Id., November, 1892.

Relation of Animals and Plants. Harper's Magazine, April, 1892.

Faith in Nature. International Quarterly, December, 1892.

Our Costly Geological Survey. 1892.

European Peasants as Immigrants. Atlantic Monthly, May, 1893.

Relations of Academic and Technical Instruction. Id., August, 1893.

Undiscovered Mineral Wealth of the World. Donahoe's Magazine, May, 1893.

High Buildings and Earthquakes. North American Review, March, 1893.

Geology, What is it? Chautauquan, December, 1893.

The Geology of Niagara Falls. In Howells (W. D.), etc., "Niagara Book," pp. 65-92. 1893.

Beasts of Burden. Scribner's Magazine, July, 1894.

The Dog. Id., June, 1894.

Geological Science. Chautauquan, November, 1894.

The Horse. Scribner's Magazine, November, 1894. 
The Transmission of Learning through the University. Atlantic Monthly, January, 1894.

Distribution of Earthquakes. Proceedings Boston Society Natural History, vol. xxvi, pp. 246-256; 1894.

Domesticated Birds. Scribner's Magazine, September, 1895.

The Direction of Education. Atlantic Monthly, March, 1895.

Training of Engineers. Engineering Magazine, September, 1895.

Relation of Science to Industry. Chautauquan, October, 1895.

Conquests of Geology. Id., December, 1895.

March of Invention. Id., November, 1895.

Aspects of the Negro Question. Public Opinion, February, 1895.

The Last Gift of the Nineteenth Century. North American Review, December, 1895.

Beaches and Tidal Marshes of the Atlantic Coast. American Book Company, 1895.

Conditions and Effects of the Expulsion of Gases from the Earth. Proceedings Boston Society Natural History, vol. xxvi, pp. 89-106; 1896.

Natural History of Warfare. North American Review, March, 1896.

Relations of Geologic Science to Education. Science, April 24, 1896.

Environment and Man in New England. North American Review, October, 1896.

Erosion of the Soil. National Geological Magazine, October, 1896.

The Scotch Element in the American People. Atlantic Monthly, April, 1896. Autumn. Chautauquan, November, 1897.

Nansen's Heroic Journey. Atlantic Monthly, May, 1897.

Elective Studies. Educational Review, May, 1898.

The Landscape as a Means of Culture. Atlantic Monthly, December, 1898.

The Changes of the Seasons. Chautauquan, April, 1898.

The True Measure of Valor. Harvard Graduates' Magazine, December, 1898.

Future of the Negro in the United States. Popular Science Monthly, July, 1900.

The Negro since the Civil War. Id., May, 1900.

The Transplantation of a Race. Id., March, 1900.

Influence of the Sun upon the Earth's Surface. International Quarterly, July, 1900.

Thomas Henry Huxley, Life and Letters. Critic, March, 1901.

American Quality. International Quarterly, July, 1901.

Future Supply of Gold. Id., November, 1901.

Proposed Appalachian Park. North American Review, December, 1901.

Nature of Volcanoes. Id., July, 1902. 
Teaching Geology. New Educational Association, 1903.

Plant and Animal Intelligence. Harper's Magazine, July, 1903.

Human Personality. Independent, May, 1903.

Natural History of War. International Quarterly, September, 1903.

A Comparison of the Features of the Earth and Moon. Smithsonian Contributions to Knowledge, vol. xxxiv; 1903. 

INDEX 


\section{INDEX}

Abolition and Abolitionists, 79, 82, All Souls College, Oxford, Eng., 262. $85,86,112,113,242$.

Acland, Dr. Henry W., 262, 263, 264. Adams, John Quincy, 78.

Administrative work, Shaler's, 386401.

Etna, 318, 319, 321; study of, 405406.

Agassiz, Louis, 90, 92; Shaler's first meeting with, 93 ; personal quality of, 94 ; his ease in captivating men, 94-95; his methods of teaching, 95-96, 103-104; his laboratory, $95,96,97,98,100,127,128$; Shaler's first work under, 97-99; quality of his lectures, 101; a note of Shaler's on, $103 n$.; bouts with William B. Rogers, 105, 116-117; 106, $107,110,111,113,114,115,118$; some students of, 119-129; distress of, at outbreak of the Civil War, 170171 ; work of his students, 179,180 , 181 ; swift accumulation of collections and books for his establishment, 182; 188, 189, 190, 191, 194, $195,200-201,208,209,225,226$; letters by, 226-227, 250, 251, 270, 271, 297-298; letters by Shaler to, 248; a dinner party at his house, $363 ; 426$.

Agassiz, Mrs., 298.

Agassiz's glacial theory, 265.

Agassiz's museum. See Museum of Comparative Zoölogy.

Albany, Ky., 287.

Alder Mine, the, 335.

Aldrich, Thomas Bailey, 428, 429.

Aletsch glacier, 229.

Alexandria, Egypt, 402.

"Alfred the Great," 443.

Algiers, William Shaler's Sketches of,

7; memorial of William Shaler in, $7 ; 193$.

Alps, 228; great glaciers of, 229 ; 234 , 235.

"American Highways," 427.

American Social Science Associations, 249.

"Americans" vs. Provincials, 143, $144,158$.

Anderson, John, 272.

Anderson School, 271.

Andover, Me., 136.

Andover Theological Seminary, 433.

Andrew, Gov. John A., 197.

Animals, Shaler's early interest in, 49; childhood studies of spiders, insects, and birds, 49-50; first acquaintance with a menagerie, 52; playing with the elephant and the camel, 53; companionship with dogs, 53,180 ; a small collection of living, 184, 185; study in Dresden Zoölogical Gardens, 241.

Anticosti, island, expedition to, 139160 ; description of, 150-152; collecting fossils on, 152-153; bearhunting, 153-154; an unpleasant adventure, 154-155; another hunting incident, 155-156; loneliness of life on the island, 156; the lighthouse-keepers, 156-157; tale of the original gun on Bad Rock, 157; an admirable hermitage, $157 ; 158$, $159,160,162$; scientific results of the expedition, $166-168 ; 171,188$, 253, 425.

Anticosti lighthouses, 162 .

Appalachian system, 162.

Appleton Chapel, 411, 422.

Aquaria, 206.

Archæan district of Canada, 54 .

Architectural School, 355.

Argyle, Duke of, 259, 260.

Aristocracy, a landed, 33. 
Arkansas River, 297.

“Armada Days," 439, 440.

Arno, the river, 302, 303, 309.

Arnold, Major, at Fort Independence, 174.

Arthur's Seat, 265.

Artistic abominations, 307.

Arts and Sciences, faculty of, 369 .

Ashland, Ky., 220.

"Aspects of the Earth," 427.

Astronomy, Shaler's boyhood interest in, 55,56 .

Athens, 404; study of the Parthenon and an engineering feat for Harvard men conceived, $404 ; 405$.

Atkinson, Edward, $432 n$.

Atlantic Monthly, articles by N. S. Shaler in, cited, 219, 254, 289, 430.

Atlantic Ocean, 297, 334.

"Aunt C_-," Shaler's maternal great-aunt, description of, 20-21.

Autobiography, 3-212, 218, 228; begun in Egypt, 403.

Auvergne, 237.

Azores, 355 .

B., Captain, of Salins, 233.

B- - s, the, 285.

Baiæ, Italy, 319.

Bailey, anti-slavery editor in Kentucky, 85.

Bangor, Me., 252.

Bar Harbor, 134.

Barbecues, 41.

Barlow, telescope-maker, 56.

Bay of Fundy, 141.

Beacon Hill, Boston, 193.

Beacon Park track, 94.

Beacon Street, Boston, 193, 198.

Bears, black, on the island of Anticosti, 153-154.

Beaumont's, Elie de, "Système des Montagnes," 190-191, 192, 228.

Beckham, C. W., 277 n.

Bee Spring, Camp at, 281.

Belmont market gardens, a story of Huxley, 346.

Bentley, Richard, 258.
Benton Farm, the, 224.

Berkenridge New Ferry, 4.

Berry, Albert S., 300.

Big Bone Lick, 247.

Big Sandy River, 281.

Billings, Elkanah, 139.

Bird Rock, 145-146; an adventure upon, $146-147 ; 148$.

Birds, early interest of Shaler in, 49; mating pigeons, 50 ; training gamecocks, 50-51.

Biscayne, Fla., 330.

Blue Hills, the, 368 .

Blumhardt, Father, 243, 246.

Board of Overseers of Harvard College, 388.

Boll, Württemberg, 244; a faith-cure hotel at, 245.

Bond, William Cranch, 104.

Boone, Daniel, 33.

Booth, Edwin, 182.

Border states, 86.

Boston, 68, 69, 103, 104, 109, 114, $115,116,117,120,121,136,139$, $160,163,183,184,185,186,193$, $194,197,200$; walks in the country about, 201-202, 204, 205, 248; 255, 283; "Boston somewhere near Cambridge," 290; 324, 348; field days in neighborhood of, $368 ; 377$, 384, 390, 417.

Boston Basin, The, 115.

Boston Bay, 368.

Boston celebrities, 193-199.

Boston Common, 198.

Boston Daily Advertiser, quoted, 368.

Boston Society of Natural History, 104, 105, 110, 116, 182, 419; Proceedings of the, 427 .

Boston Theatre, 183.

Bostonians, 290.

Bounty-catchers, 135.

Bow Street, Cambridge, 254, 296, 347.

Bow Street, No. 13, 254, 296, 344.

Boxing, Shaler's bouts with his tutor at Harvard, 91.

Brachiopods, 100, 180 ; the Anticosti, 425 ; fossil, of the Ohio Valley, 426. 


\section{INDEX}

Bragg, Gen. Braxton, 126, 219, 220.

Brattle House, Cambridge, 187.

Brattle Street, Cambridge, 187.

Breckenridge, Elder, 73.

Breckenridge, John C., 73, 86, 171, 173.

Briggs, Le Baron R., 392.

Brigham's oyster-shop, 183.

"Bristoe," a slave, 38-39.

Broadhorn, 84.

Brown, D. S., cabinet and collections of, 182.

Brown, John, the, raid, 195.

Brown, John Mason, 173, 432.

Brown-Séquard, Dr. Charles Édouard, 322 ; adventures of a gift to Huxley from, 322-323.

Brussels, 242.

Buckner, Gen. Simon B., 171, 172.

Buell, Gen. Don Carlos, 220.

Buffalo, N. Y., 68, 289.

Bull Run, 163, 170.

Bunker Hill, Battle of, an ancient with memories of, 136 .

"Burial Place, The," 221.

Butte, Montana, notable legal contest in, 338,$339 ; 398$.

"Button, Bill," 13.

C—, 281, 289.

C- a Mr., of Minnesota, 290.

Cairo, Egypt, 402-403.

Calhoun, John C., 82.

Cambridge, 44, 69, 79, 90, 96, 100, 107, 109, 120, 121, 125, 136, 170, 174, 182, 186, 192, 193; the College circle in, 199, 207, 216, 240; proposed Zoölogical Garden in, 241; the Shaler homes in, 253, 254, 286, 296, 344, 345, 348, 359; 258, 260;

"Boston somewhere near Cambridge," 290; 293, 351, 353, 356; the Cambridge of the Eighteenseventies, 363 ; a dinner party at Agassiz's, 363-364 ; 377; entertainment of students, 379, 403; 411, 412, 426, 441.

Cambridge celebrities, 193, 199-200.
Cambridge, Eng., 191, 258, 259, 260, 261, 376.

Cambridge University, 191, 376.

Camp Clay, 220.

Camp Dick Robinson, 173.

Camp Harvard, Cumberland Gap, 369.

Campbell County, Ky., 17, 33, 36.

Campobello, island, 325.

Camps and camping, in Mount Desert, 134; in the Umbagog Lakes country, 135-137; Camp Harvard, Cumberland Gap, 273-275, 289290, 369; elsewhere in Kentucky, 281, 294, 295; on Hoosac Mountain, 282-283; Alleghany camps, 285; on Martha's Vineyard, 350; at Squam Lake, 351.

Canada, 54, 83, 139.

Canada Survey, the, 139.

Cape Ann, report upon the geology of, 343 .

Cape Ann fishermen, 143, 144.

Cape Breton fishermen, at Anticosti, 158; compared with the New England sailors, 159; courtesies exchanged with, 159.

Card-playing, old time, in Kentucky, $72,73$.

Carolinas, the, 66, 252.

Carrara, peaks of, 313 .

"Carroll, Lewis," and "Alice in Wonderland," 262.

Catskills, 68.

Celebrities, Cambridge and Boston, 193-206.

Centennial Exhibition, Philadelphia, 275, 288.

Certosa, Italy, 302, 309.

Chamberlain, Montague, 372.

Channing, Dr. Walter, 12.

Charles River, 206, 258.

Charlestown, 199, 203.

Chickamauga, 123, 124.

Child, Francis James, 418.

Chilmark, Mass., 346, 347.

Chilmarks, the English and American, and Rudyard Kipling, 346-347. 
Christ Church, Oxford, Eng., 262.

Cincinnati, $31,32,43,44,55$; Mitchel's observatory in, 55; 56, Connecticut, 150, 199, 291.

58; notable group of Germans in, Connecticut Valley, 4, 125.

$62 ; 63$; Harriet Beecher Stowe in, Conroy Mine, 408.

85; fortifications of, 88-89, 219, Cook, Caleb, 97. 242, 281, 288.

"Citizen, The," 217, 427, 435.

Civil War, Kentucky Unionists in the, $14 ; 41,43,46,73,74,75$; Kentucky's losses by the, $76 ; 82,86$, 88,120 ; a story of the, $123-124$; $126,127,141,157,159,163$; first year of, 170-178; situation in Kentucky at the outbreak of, $171 ; 186$, 187, 188, 197, 207, 216; Shaler's battery in, 219, 221-223; Shaler's treatment of, in his "Kentucky," 432 ; his poems of the, 443.

Clay, Cassius M., 85.

Clay, Henry, 82.

Cleveland, President Grover, 249.

Cleveland, Richard Jeffry, his "Narrative of Voyages and Commercial Enterprises" cited, 5.

Cleveland, O., 68, 287.

Coal Swamps of the Eastern United States, report upon, 343.

Coast Survey. See United States Coast Survey.

Coast Survey Camp, 282, 283.

Cock-fighting, 50, 51, 52 .

Cohasset, Mass., 284.

College companions, 118-129.

College gymnasium, 97.

College library, 182.

"College teas," 363.

College Yard, the, $344,348,361$, 377.

Colonial Club, Cambridge, 345 .

Colonists of Kentucky, 33, 76.

Colorado, 296, 297, 308.

Columbus, Ky., 293.

Confederacy. See Southern Confederacy.

Confederate army, 121, 163, 171, 173, 219, 220, 223; the Confederate soldier, 432 .

Cooke, Josiah P., 111, 124, 180, 190, 208.

Coolidge, Philip Sidney, 121; story of, 121-123, 124, 208.

Corey Hill, Brookline, 410.

Corfu, 405.

Corman, Charles, 332.

Cosmos Club, Washington, D. C., 414.

Cotta, Bernhard von, 243.

Country living, 348-360.

County fairs, 41.

Covington, Ky., 79.

Crandell, A. R., $277 n$.

Crittenden, J. J., 73.

Cruising and Camping, 130-138.

Cuba, 5, 7, 12, 240.

Cumberland Gap, summer school at, 273 ; incidents of, 273 ; a rattlesnake episode, 273-275;289-290, 295, 369.

Cumberland River, 279.

"Curtius," 443.

Cushman, Charlotte, 182.

Cuvier's "Le Règne Animal," 180.

Daffodils, cultivation of, at "Seven Gates," 351, 356.

Dana, Edward S., 227.

Danville, Ky., 291.

Darwin, Charles R., 257, 439.

Darwin, W. E., 351.

Darwinism, 105, 110, 128-129, 181.

Davenport, E. L., 182.

Davis, Jefferson, 88.

Davis, William M., 418, 426.

Debating society, Kentucky, discussions of States' Rights in, 8687.

Deerfield, Mass., 298.

Democratic party, 291.

Dent du Midi, 228, 296.

Denver, Col., 296; in 1879, 297; 398.

Devonshire, Duke of, 259. 
Digger Indian, 398.

Divinity Hall, 121, 179.

Dixwell, Epes Sargent, 69, 90, 199200, 242.

"Domesticated Animals," 427, 429.

Douglas, Stephen A., 80.

Dredging expeditions, 130-133; incidents of, 131-132.

Dresden, 238; water cure in, 238240, 242; the Zoölogical Garden in, 241; the Isis Society, 241; 242.

Drill Club, in Cambridge, 174, 183.

Duel, the, in Kentucky, 42-43; challenge received by Shaler, 46; second in, 47; maxims of, 48.

Durham Cathedral, 268-269.

"Eager Muster, The," 221.

Eagle Lake, Mount Desert, 134.

Earthquakes, papers on, 430.

"East Tennesseans," 21.

Eastport, Me., 132-133, 139, 141, $163,252,253$.

Edinburgh, 257, 266, 438.

Egypt, visit to, 402, 403.

Elephants, fossil remains of, 247.

Eliot, Charles W., 251, 280, 297, 345, $364,369,379,395,396,400,417$, 418.

Elizabeth Islands, 145.

"Elizabeth of England," quoted, 301; $427,438,439,441,442,445$.

Ellis Bay, Anticosti, 158, 159.

Ely Cathedral, 260-261.

Emancipation party, 86.

Emerson, George, 124-127, 196, 201.

Emerson, Ralph Waldo, 262, 363.

England, 41, 200, 228, 229, 231, 242 ; visits to, $255-269,270,271,272$, $299 ; 309,407,426$.

English Geological Survey, 289.

English hotels, 267.

Entry Island, 145.

Escher, Johannes, 'a Swiss tutor, 60, 61; teachings and philosophy of, 61 ; inducts young Shaler into the mystery of Hegel, 62; 90, 91, 102, 209.
Europe, journeyings in, 228-246, $247,265,299,312,313 ; 400$.

Europeans, 197, 198.

Evans, Dr. Thomas W., Paris, 238.

Evolution, Shaler's early teaching of the principles of, 216.

"Exhaustion of the World's Metals, The," cited, 335.

Expeditions, along the Maine coast, 130 ; to the Gulf of St. Lawrence, 139-149; on the Labrador shore, 160-163; various scientific expeditions, 253; on the Florida coast, $330-331$.

Faith cure at Boll, 245-246.

Far West, 41, 337, 341, 378.

Federal army, 120, 123, 124, 163, $173,197,199,211$; N. S. Shaler in, 219-223.

"Federalist, The," 86.

Fen country, Eng., 261.

Fencing, Shaler's training in, 43-44, 45; a bout with Agassiz, 96.

Felton, Cornelius C., 69, 190.

Feudal system, in the settlement of Kentucky, 32-33; 349.

Field Days. See "Professor Shaler's Field Days."

"Field Geology," 427.

Field work, 1873-1879, 270-298.

Fields, James T., 428.

Fifth Avenue Troop, 280.

Fifth Kentucky Battery, 219, 220, 221.

Fighting and fighters, 34; fighting propensities of early Kentuchians, 41,42 ; anecdote of Sam McLaughlin, fighter, $42 ; 44,49,119$.

Figline, Italy, 307, 308.

Finnell, John W., 172.

"First Book of Geology, The," 426; translations of, 427.

First Kentucky Confederate Brigade, 433.

Fishing ships, types of, 144-145.

Fiske, John, a little story of, 187.

Florence, Italy, 78, 299 ; walks in and 
about, 299-300; 302; tramps into its ancient environs, 302 ; along the way to Impruneta, 302-304; town and country folk, 304, 309; 311, $314,317,318,319,322,324$.

Florida, 247, 330; impressions of, 331; an adventure in, 331-332; 334.

Foley, of Kentucky, 119-120, 135, 173.

Forbes, James D., 228.

Forbes, - 382 .

Foreword, 1859-1862, 215.

Fort Independence, Boston Harbor, $174,175,176$.

Fort Warren, Boston Harbor, 197.

Fossils, 100, 153, 229, 244, 247; collections sent to Dom Pedro, 298; in Italy, 314, 316; 426.

France, 228; incidents of travel in out-of-the-way parts, 230; 231, 237, 238.

Franco-Italian-Austrian War, 122, 157.

Frankfort, Ky., 46, 70; description of, in Shaler's boyhood, 71-72; $73,74,75,171,211,278,280,287$, 288, 291, 292, 293.

Freiberg, 242; School of Mines in, 243; a German household, 243-244.

French Revolution, 5, 210.

Frenchman's Bay, 131, 133

Fresh Pond, 414.

"From Old Fields," 221, 427, 443, 444.

Frontiersmen, 34, 41; Kentucky type of, 165.

Galton, Francis, 257.

Game-cocks, 50; young Shaler's interest in battles of, $51 ; 52,53$.

Garibaldi, recollections of, 320 .

Gaspé, 161-162; an interesting geological field, 162-163.

Gay Head, 115, 351.

"General's Yarn, The," 221.

Geodetic and Geological Survey, 249. Geoffrys, 257.
Geological excursion. See "Professor Shaler's Field Days."

Geological Record, 289.

Geological Reports, Government and State, 426, 427, 428; 429, 430.

Geological Surveys, Kentucky, 224; United States, 247.

Geology, Shaler's early speculations in, 53-54; study of, under Agassiz, $100,101,111$; field work, $115 ; 117$; on the coast of Labrador, 160 ; in Gaspé, 161-163; 180; Shaler's methods of instruction in, 225, 248, 272,280 ; various reports upon, 275, 283, 343 ; Agassiz's instruction, 297; Shaler's lectures to his students, 365-366; "Natural History Five," afterward "Geology Four," 367-368; " Professor Shaler's Field Days," 368-369.

"Geology of Boston and its Environs, The," 426.

"Geology of Roads," report on, 430.

George, the cook, 140, 141, 147, 152, 153.

"Georgians, The," 221.

Germany, 90; travels in, 238; visits to Dresden, 238-243; to Freiberg, 243-244 ; to out-of-the-way places, $244,245$.

Gilman, Arthur, 373.

Glaciers, 228; great glaciers of the Alps, 229 ; Shaler's book on, 426 .

Glasgow, 266.

Glenn, William, 118.

Gloucester fishermen, 143, 144.

Goebel, Gov. William, 73.

Gould, Augustus A., 109.

Gould, Benjamin Apthorp, 104.

Government post, Newport, Ky., 27, $31,39,55,59$.

Government Surveys, 249.

Graduate School of Applied Science. See Lawrence Scientific School.

Grand Manan, 132, 133.

Grant, Gen. Ulysses S., 174.

Gray, Asa, 104, 105; Shaler's relations with, 110; 113, 190, 208. 
Grayson, Ky., 284.

Grayson Springs, 279, 281, 285.

Great Britain, 139.

"Great Raid, The," 222.

Greece, visit to, 403-405.

Green. See Fiske, John.

Green Mountain, Mount Desert, 134.

Greenfield, Mass., 79, 125, 126.

Greenland, 140.

Greenough, Horatio, 69.

Greenwood, Master, 222.

Greylock, 68.

Grindelwald, glacier of, 229.

Grindrod, Dr., of Malvern, 255.

Guescard, Prof., in Naples, 319.

Gugerheimer, in Agassiz's laboratory, 97.

Guides. See Italian guides, Swiss guides, and Tuscan guide.

Guinea-pig, adventures with a savant's, 322-323.

Guinitz, Prof., Dresden, 241.

Gulf of St. Lawrence, expedition to the, $139-169 ; 142,144,145$; results from the expedition to, 165-168; discomforts and dangers of the expedition, 168-169.

Gulf Stream, 356.

Gut of Canso, 142, 143, 144, 163.

H., Major, 48.

Haddam, Conn., ancestors of Shaler there, 4.

Hall, James, 227.

Hamilton, Ky., 281.

Hammond, Surgeon-General, 14.

Hannibal's old camping-ground, 406 .

Hansen, a Swede, learned in Scandinavian languages, 118.

Hanson, Roger, of Kentucky, 171.

Harte, Bret, 363.

Harvard alumni, 389, 390.

Harvard Club dinners, 401.

Harvard College and University, N.

B. Shaler in, 12,$69 ;$ N. S. Shaler in, $13,43,44,75,79,90-163 ; 111$, 117, 121, 126, 135; Shaler's last year in, 179-192; 193, 194, 208,
209; the College circle, 199; the faculty, 199; 200, 207, 249, 250, 251, 270, 271, 272, 275, 282, 297; Gordon McKay's gift to, 328,335 ; $363,364,369,370,372,373,378$, $379,382,386,387,388,391,395$, $411,434$.

Harvard corporation, 387, 388.

Harvard Divinity School, 69.

Harvard faculty, 388, 389; part played by Shaler in meetings of, 392-395; 396.

Harvard Law School, 184.

Harvard Medical School, N. B. Shaler in, 53,69 .

Harvard Natural History Society, 251.

Harvard Observatory, 121, 208.

Harvard Summer School, 258, 272; organization of, 369 ; advancement of, $369-370,372$; the opening reception, $372 ; 373,408$.

Harvard University Gazette, quoted, 366.

Hasty Pudding Club, 97.

Haussmann, Baron, 237 ; Haussmannized Florence, 302.

Havana, William Shaler consul at, 5,$7 ;$ N. B. Shaler physician in, 12.

Head, Low, 139, 142.

Heidelberg, 90.

Helena, Mont., 326.

Helmholtz's theories, 228.

Henderson, Ky., a wise farmer of, $432 n$.

Henry Clay Whigs, 82.

Hereford, Eng., 267; Herefordshire cider, 267; the ancient cathedral, 267.

Heth, Gen. Henry, 219.

Hickman, Ky., 286.

Hillard, George S., 197, 198.

Hillsboro, Fla., 332.

Hinde, Dr. John, 19-20; surgeon in the British navy, 19; in Virginia, 20 ; with Wolfe at Quebec, 20; figured in Benjamin West's painting, 20 ; anecdotes of, 20 ; his 
death at nearly a hundred years, his wife then ninety, $20 ; 22$.

Hinde, Mrs. John (born Hubbard), 20. Hingham, Mass., 225, 284.

Holmes, Oliver Wendell, 363, 430.

Hoosac Mountain, 282, 283.

Hoosac Tunnel, 282.

Hopkins, William, 191.

Horsford, Eben N., 124, 190.

Hospitality North and South, 201.

Hotchkiss, 326.

"How to Change the American Climate," 430.

Howells, William D., 363, 430.

Howgate, H. W., 278.

Hubbard. See Mrs. John Hinde.

Hudson's Bay Station, 160; Indian trading at, 160-161.

Humboldt, Tenn., 293.

Hunt, T. Sterry, 283.

Hunting, 66 ; bears on Anticosti, 153154, 155.

Huntington, Edward, 396.

"Hurricanes," 429.

Hutton, James, 265.

Huxley, Thomas H., 256, 257, 322; his visit to Cambridge, anecdote of. 346.

Hyatt, Alpheus, 79, 97, 120-121, 124. $126,130,139,141,155,163,146$. 201, 284, 420 .

\section{Iceland, 140.}

Illinois, 80, 341.

Impruneta, Italy, a tramp from $\mathrm{Flo}$ rence to, 302 304 ; description of, 304; a unique Tuscan guide, 304 , 305,306 ; primitive industries of the peasants, 305 ; serpentines at, $305,306$.

Indian River, 330.

Indian wars, with the Illinois Indians, 40 ; tales of old Indian fighters, 40-41.

Indiana, 291.

Indians, 39 ; how to "manage an Injun," 40 ; 41, 151 ; trading, of Labrador, $160-161$.
"Individual, The," 217, 425, 427, 433, 435, 436, 438.

"Infant Hayes," 120.

Inns, a French country inn, 233234 ; English inns, 285; Italian village inn, 305 ; in Rome, 319.

Insects, boyish studies of, 49, 84, 96 . "Interpretation of Nature, The," 425, 427, 428, 433, 434.

Ironbound Island, 131; an amateur Grecian at, 131-132.

Ischia, Italy, 319.

Isis Society, Dresden, 241.

Italian country and farm life, 303, 304,305 , 306, 308, 310, 311; Tuscan women drawing heavily laden carts, 315.

Italian guides, 304 ; character of, to geological localities, $314,315,317$.

Italian patois, 317 .

Italian peasantry, 303, 304, 305, 306, $309,310,311$; a typical contadino home, $315-316$; 317 ; old and modern customs of, in Naples, 320.

Italian shepherd, an ancient, on a hilltop. 307-308.

Italian soldier, the, 299-300.

Italian villages, 302, 304-306, 307, 309,320 .

Italian villas, 303 ; as country places, 310,315 .

Italy, 62, 78 ; visits to, $236-237,299-$ $3: 1$.

Jackson. Charles T., 12, 53, 69, 100, 104. 105; qualities of, 109-110; 207.

Jackson, Gen. James, duellist, 46; ancedote of, 46-47.

Jackson, James, of Kentucky, 173.

Jackson, Ky., 295.

Jackson Purchase, the, 32.

Jacksonville, Fla., 331.

Jacquard, Monsicur, 232.

Jamaica, ancestors of Shaler there, 4.

James, William, 359, 400, 418; letter of, on "The Individual," 436-438; on "From Old Fields," 443-444. 
Jardin des Plantes, 238.

Jarvis Street, Cambridge, 97.

Jefferson, Thomas, 16, 121, 158, 194.

Jews in Boston, 384.

Johnson, Stoddard, 292.

Johnston, Gen. Albert Sydney, 174 .

Journal, Mrs. Shaler's, 261; quoted, 261-263, 264, 265, 266-269.

Journal, Shaler's, quoted, 215-216, $374,433-434,440$.

Journal of Geography, quoted, 367.

Jura, the, 235.

\section{Kansas City, 296.}

Keene. N. H., 92, 93.

Kentuckians, 141, 223.

Kentucky, 12, 14, 19, 31; settlement of, 32 ; the feudal system, 33 ; resemblance of the tenant whites to the English cotter class, 34, 35; slave-owners in, $36 ; 48,49,56$; eastern Kentucky, 66; some Kentucky magnates, $71-79$; 80 ; political life in, immediately preceding the Civil War, 82 ; customs of the early days in large households, 83; "living within yourself," 83 , $84 ; 86,87,94,96,119,123,126$, $138,139,140$; situation in, at the outbreak of the Civil War, 141, $171-172,173 ; 165,168,186,192$, $195,198,203,209,211,219$; the war in, $220-223 ; 224,242,247,260$, 269 ; geological survey of, 270-271, 273-281, 282, 283, 289-296 ; 329, $369,415,417,419,426,431,432$, 433.

"Kentucky: A Pioneer Commonwealth," cited, 219 n.; 223, 426, 431-433.

Kentucky farmers, $432 n$.

Kentucky Geological Survey, 224, 270 ; Shaler director of, 271, 273281 ; Reports on, $275,276-277,426$; episodes in the work of, 276-278; letters written during its progress, 278-282, 284-288, 289-296; 432.

Kentucky habit, a, 353 .
Kentucky Legislature, 275, 276, 278, 280, 287, 288, 292.

Kentucky mountains, $432 n$.

Kentucky Resolutions of 1798, 86.

Kentucky River, 74, 291.

Kentucky Unionists, the, 14.

Key West, 330.

Kidd, Capt., treasures of, 158.

King John of Saxony, 198.

King's Mountain, 136.

Kingston, Canada, 329.

Kipling, Rudyard, in Cambridge, 346; a little story of, 346-347.

Know-Nothing party, 203.

La Grange, Ky., 280.

Labrador, 144, 150, 159; expedition in, 160-163, 164.

Lake Erie, 68.

Lake Geneva, 228.

Lake Worth, 330, 331.

Lamb, —, 97.

Lancaster, Mass., home of Abigail Stilwell in, 9; N. B. Shaler at school in, 12, 68 .

Landscape, Shaler's love of, 355-356.

Lauderdale Station, 331.

"Law of Fashion," 430.

Lawrence, Mr., 277.

Lawrence, Bishop, 411.

Lawrence Scientific School, 95, 105, $106,110,111,117,120,126,208$, $225,240,270,289,334,339,350$; Shaler made dean of, 386 ; his administration work in, 387, 390-391; Gordon McKay's bequest to, 387; the proposed "merger" with the Mass. Institute of Technology, 387, 389,390 ; change of name, to the Graduate School of Applied Science, 387 ; 392, 395, 396, 400, 404, $409,411,421$.

Lawrences, the, John and Henry, 229.

Lawrences, the, of Boston, 198.

Le Locle, 232.

Leadville, Col., 297; mining-camp near, 297. 
Lectures, Shaler's courses in the Lowell Institute, 333, 401; notes for his college lectures quoted, 365-366; his course "Natural History Five," afterward " Geology Four," 367-368; course at the Andover Theological Seminary, 433.

Lee, Gen. Robert E., 12, 174.

Lesley, J. Peter, 227.

Leslie, Gov. Preston H., 270, 278, 279, 287, 288, 291.

Letters, by Shaler, quoted, 216, 217 ; from camp in the Civil War, 220; 225; from Dresden, 242 ; 248 ; from Martha's Vineyard, 251-252; from Mount Desert, 252, 253; during the Kentucky Geological Survey, 277, 278-282, 284-288, 289, 290-296; the Coast Survey in New England, 282, 283, 284; from Colorado and other mining regions, 296-297, 397398,409 ; from Italy, 300, 301, 318319; familiar letters from various places, 1882-1883, 325-327, 328$331,333,426$; to Shaler from Agassiz, 250-251, 271, 297; 283. 284, 289; to Shaler from Prof. James, 400, 436-438; to Shaler from others, 429, 430, 432, 432 n. 434, 436.443 ; to Mrs. Shaler, on Shaler's spirit and work, 392-395, 443-444. 445.

Lewes, G. H., "History of Philosophy," 63.

Lexington, Ky., 17, 56, 85, 171, 220. $280,281,285,292$.

Liberian colonization, 82, 196.

Libraries collected by Agassiz, 182.

Lichfield, Ky., 282, 327.

Licking River, 31, 36, 66, 79, 217.

Liddell, Rev. Henry George, 262.

Liddell, Mrs., 262, 263.

Life Saving Station, Florida, 332.

Lignite mines in Tuscany, 316; methods of mining, 316-317, 318.

Lincoln, Abraham, 79-81.

"Little Giant," the. See Douglas, Stephen A.
Liverpool, Eng., 255.

Liverpool, N. S., 142, 164.

Livingstone mine, 326.

Loch Lomond, 266.

London, visits in, 256-258, 426, 431.

Long Island, 68, 69.

Longfellow, Henry W., 199, 363.

Louisville, Ky., 47, 277, 281, 285, 287, 293.

Louisville Journal, 47.

Love, James Lee, 372.

Lovering, Joseph, 190.

Lowell, Rev. Charles, 199.

Lowell, James Russell, 111; characterization of, $112 ; 195,199,363$, 415.

Lowell Institute Lectures, 333, 401.

Lowells, the, 199.

Lush, Miss, of Albany, New York, married to Wright Southgate, of Virginia, 16.

Lyell, Sir Charles, 116, 182, 257.

Lyman, Theodore, 97, 251.

M., Frau, 239, 241.

McGee's, Miss, boarding-house, Cambridge, 187.

Mckay, Gordon, 295, 296, 297; Shaler's associations with, 327-328; death of, 327 ; bequest of, to the Lawrence Scientific School, 335, $386,387,388 ; 398,399,400$.

Mclaughlin, Sam, fighter, 42.

Machias, Me., 253.

"Madame B.'s Review," 221.

Madison, Wis., 326.

Magoffin, Gov. Beriah, 212.

Maine, 37, 130, 135, 247, 252, 253.

Maine lumberman, the, 138.

Malvern, Eng., 255, 256, 265, 289, 324.

Mammoth Cave, 47, 282, 294.

"Man and the Earth," 427, 429.

Manchester, Eng., 231.

Manchuria, 429.

Marcou, Jules, 100, 104; description of, 114-115; 116, 207, 233, 234.

Marion, Ky., 279. 
Mars, Captain, 44.

Marshall, Humphrey, 74, 75.

Marshall, John, 74, 75.

Marshall, John, the jurist, 75 .

Marshall, Thomas F., 74, 75; curious relations of Shaler with, 77-79; 87 , 209.

Martha's Vineyard, 115, 251, 332 ; report upon the geology of, 343; 347; "Seven Gates," the Shaler "Farm" on, 348-354, 359; geological formations of, $351 ; 356$, 360, 398, 409.

Maryland, 120, 163.

Mason and Dixon's Line, 216.

Mason and Slidell affair, 264.

Massachusetts, 68, 110, 120; shores of, $166 ; 195,197,248,260,271$; southeast Massachusetts, 356.

Massachusetts Gypsy Moth Commission, 396.

Massachusetts Highway Commission, 396.

Massachusetts Institute of Technology, 117; corporation of, 387, 388; "the "merger" with Harvard project, $387,388,389,390$; faculty of, 390 ; alumi of, 390 .

Massachusetts Legislature, 271.

Massachusetts Metropolitan Park Commission, 396.

Matterhörn. 234.

Mayfield; 294.

Medford, Ha 204.

Mediterranesil voyaging on the, - 402.

Memoir, The, 215-445.

"Memorial.History of Boston, The," 426.

Mer- dë Glaxế; 229.

Mercantile 'Library, Cincinnati, 55, $56^{\circ} \circ$

"Merger" controversy; the, 387,389 , $390,399^{\circ} .409$.

Mexican boundary survey, 114 :

Mexican

Mexico, 41, 74, 122.

Middlesex Canal, the old, 204:-
"Midnight Venture, A," 221.

Mine prospecting, 326, 334; Shaler as a mining expert, 335,336 ; his attitude toward the "prospector," 337; a Montana incident, 337-338; 339.

Mingan, Labrador, 159, 160, 161, 163.

Mining in Italy, 316, 317.

Mining camps and towns, 297, 340341.

Mining life, 340.

Mining School, Freiberg. See School of Mines.

Mississippi, 47.

Mississippi River, adventures of William Shaler on, 6, 81, 293.

Mississippi Valley, 41, 341.

Missouri, 33.

Mitchel, Ormsby McKnight, 55.

Monboddo, Lord, 310.

Monmouth, Eng., 267.

Monongahela River, 84.

Mont Cervin, 229.

Montana, 175, 326; mine prospecting in, 337; 338, 397, 398, 408.

Montauk Point, 69, 70.

Monte Cavo, 406.

Monte Ferrato, 306, 307, 308.

Monte Morello, 311; the climb to the summit, 312-313, 314 .

Monte Rosa, 229.

Montreux, 227, 228, 229, 296.

"Moon, The," 427, 430.

Moore, Charles H., 265.

Moore, P. M., $277 n$.

Morgan, Gen. John H., 74, 221, 222, 223.

Morgan's cavalry, 432, 433.

Mormons, 398.

Morristown, N. J., 288.

Morse, Edwäd S., 97.

Morton, Sam, 82.

Morton, Dr. William T. G., 169.

Moses, "the man who wrote the first geological essay;" 298.

Mount Auburn, 411.

Mount Desert, camp journey in, 134- 
135 ; 252, 253; report upon the geology of, 343 .

Mount-Deserters, 252.

Mount Tom, 185.

Mount Washington, a tramp over, 192, 329.

Mountain structure, study of, 116 , $190,228,229$; in Italy, 307, 312313.

Müller, Max, 262.

Murchison, Sir Roderick Impey, letter to, 249-250.

Murchison's "Silurian System," 55.

Museum of Comparative Zoölogy, nucleus of, $97,98,100 ; 101,102$, $103,114,118,139,171,181,182$, $186,225,247,248,250,251,258$, 271, 297, 298, 344, 361; Reports of the Curator of the, $427 ; 437$.

Mystic River, 202, 204.

N., Señor, 240, 240-241.

$\mathrm{N}-, 298$.

Nahant, 97; Agassiz's summer home at, 201,$227 ; 249$.

Nantucket, 258; report upon the geology of, 343; proposed summer school in, 426.

Naples, 237, 268; notes on, and the Neapolitans, 319-321; second visit to, $405,407$.

Napoleon III, 237.

Narragansett Basin, 110.

Narragansett Bay, 110.

"Narrative and Critical History of America," 427.

Nashua, N. H., 398.

Nashua River, 10.

National Academy of Science, 397.

National Survey, a, 249.

Natural history, Shaler's early interest in, $92 ; 93,98$; plans for instruction of, 298.

“Natural History of Politics," 430.

Nature, Shaler's love of, 350, 354, 358.

Nature, 289.

"Nature and Man in America," 427. Note-books, Shaler's, quoted, 215;
Nautical Almanac office, 208.

Neapolitans, the, 321.

"Negro Problem, The," 430.

Negro-traders, 31, 36, 38.

Negroes, of Sea Islands, 251. See Slaves and slavery.

"Neighbor, The," 217, 427, 435.

Nemi, 406.

New Brunswick, 143, 161.

New-Brunswickers, 159.

New England, 85, 92, 125, 138, 143, $144,145,151,159,194,200,201$, 224, 262, 282, 348, 362, 368, 378.

New England climate, 348.

New England coast, 205; geology of, 283.

New England fishing ships, 144, 145.

New England sailors, 159.

New England wilds, 138.

New-Englander, 125, 170, 201-202.

New Madrid earthquakes of 1811, phenomena connected with, recorded by William Shaler, 6 .

New Orleans, 32.

New York, 32, 83, 283, 291, 294, 407, 431.

Newberry, John S., 227.

Newport, Ky., 3, 12; characteristics of, before the war, $31-32 ; 39,54$, $66,85,217,279,291,325,397$.

Newport barracks, $14,27,28,39,55$, $57,59,174$.

Niagara Falls, 257.

Nightingale, the, 406-407.

Nile, the, 403.

North, the, $82,84,88,170,172,195$, 201, 216, 219.

North Adams, Mass., 283.

North Bend, O., 281.

North Carolina, 34, 41, 172, 289, 295.

Northern States. See North, the.

Northerners, 196.

Northumberland Channel, 163.

Norton, Charles Eliot, 265; letter of, on "From Old Fields," 444.

Norwood, C. J., $277 n$. 


\section{INDEX}

kept in Italy, 302, 318; on Vesuvius, 319,$321 ; 356$.

Notre Dame Mountains, 162.

Nova Scotia, 142, 143, 144, 164, 334. Nova-Scotians, 144, 159.

Nullification doctrine, the, 86 ; attitude of the men of Kentucky on, 86.

Oak Bluffs, Martha's Vineyard, 251252.

Observatory, Mitchel's, 55 ; Harvard, 121, 208.

Ohio, 84; Morgan's raid into, 221, $222,278$.

Ohio River, 17, 18, 27, 31, 32, 33, 36, $50,54,55,59,84,88,192,220,229$, 280, 281.

Ohio Valley, 17; geology of, 54, 139, $168 ; 426$.

"Ohio Cavern Life," 289.

"Old Daniel," negro slave exhorter, 57-58.

Olympia, Ky., 325, 329.

Open fireplace, the, 344, 353, 379.

"Origin and Nature of Soils," 428, 429.

"Orphan Brigade, The," 433.

"Outlines of the Earth's History," 427.

Oxen, the Italian white, 315.

Oxford, Eng., 193, 261-264.

P., Dr., 211.

$\mathrm{P}-$, 281, 284, 287.

$\mathrm{P}-$ _ John, Scotch gentleman, long resident in Naples, recollections of, 320.

Pacific Ocean, 122, 297, 334.

Page, Rev. Charles H., 218 n.

Page, Mrs. Logan W., 409.

Page, Sophia Penn. See Shaler, S. P. Page, W. B., 277 n., 398.

Palmer, George Herbert, 418, 444, 445.

Paris, 231; Exposition of 1867, 231; visits to, 236, 237-238, 242, 322.

Parker, Judge, 198.
Parks, Rev. Leighton, 434.

Parsons, Theophilus, 199.

Pattison, Mark, 262.

Peabody Museum of American Archæology and Ethnology, 97.

Peach Orchard, Ky., 286.

Peacock, Jack, a character, 157, 332.

Pedro, Dom, anecdote of the visit of, to England, $263 ; 298$.

Peirce, Benjamin, 104; memories of, $113 ; 188,190,191,283$.

Peirce, Charles S., 247, 283.

Peloponnesus, 405.

Penikese Island, 271, 272.

Pennington Gap, 295.

Pennsylvania, 116, 355.

Perryville, 46.

Peters, Dr., of Lexington, Ky., 292.

Phi Beta Kappa, Shaler's poem before the, 443.

Philadelphia, 275, 288. See Centennial Exhibition.

Phillips Brooks House, 379, 399.

Phlegræan Fields, the, 319, 321.

"Physiography of North America," 427.

Pictet, François Jules, 229.

Pioneer life, tales of, 84.

Pioneers, in Kentucky, 19; differences between, in Kentucky and Ohio, $32 ; 33,84$.

Pittsfield, Mass., 68.

Plain of Marathon, 356.

Platte River, 341.

Platte Valley, 296.

Poems, reminiscent of the Civil War, 221, 222.

Political debates in Kentucky between 1858 and 1861, 87-88.

Pompeii, 320, 321.

"Poor Whites," 33, 34, 36, 41.

Popular Science News, 427.

Porta Magna, 318.

Portland, Me., 135.

Powell, John W., 329.

Powis, Earl of, 259.

Prato, Italy, 306, 307, 309.

Prentice, Courland, 47. 
Prentice, George Denison, 47.

Price, Bonamy, 193.

Prince Edward Island, 163.

Prince Leopold, 263 ; observations of, 264.

Prince of Wales, 161, 262.

Princeton, Ky., 279, 280.

Proctor, John R., 277 n., 288, 294.

Proctor, Richard A., 257.

"Professor Shaler's Field Days," 368-369.

Proslavery party in Kentucky, 86.

Province ports, fishermen of, 143.

Provinces, the, 144.

Provincial sailors, 165; value of "the common man" found in them, 165.

Provincials vs. "Americans," 143, 144.

Prussian officers at the Dresden water cure, 239-240.

Prussian spies, Shaler and Tawney seized as, in a French town, 230.

Purim Association, the, 384.

Puritans and Puritanism, 109, 125, 127, 200, 201, 203.

Putnam, Frederick W., 97.

Puy de Parion, 237.

Puy du Dôme, 237.

Quaker stock, 200.

Quebec, 20.

Quincy, Edmund, 112-113.

Quincy, Miss Eliza, 368.

Quincy, Mass., 249, 368.

Quincy Street, Cambridge, 34.4.

Quincy Street house, the, 34.4: memories of the old library, 345; Sunday afternoon receptions, $34.5 ; 348$, 359 ; hospitalities to the stranger in Cambridge, 363 ; entertainments of the natural history students, 380-381; 391, 398; Shaler's workroom in, $399 ; 409,410,437$.

Quincys, the, 199.

R——, Dr., of Frankfort, 288, 291

Radcliffe College, 373.
Ramsay, Sir Andrew C., 257.

Ramsbottom, - , 133-134.

Raymond, Rossiter, 338.

"Recent Changes of Sea-Level on the Coast of Maine," 289.

Renivier, Swiss geologist, 229.

Reports, Geological. See Geological Reports.

Reports of the Curator in the Museum of Comparative Zoölogy, 427.

Republican party, 219, 242.

Revere House, Boston, 279.

Revolutionary War, 4; a pensioner of the, $39 ; 41,136$.

Rhode Island, 110.

Rhone Valley, the, 234.

Richardson, Dr. Maurice, 255.

Richmond, Va., 17.

Ringgold's Battery, 28.

Riverton, Ky., 279.

"Road-Building Stones," report on, 430.

Roanoke, Va., 326.

Robinson, James F., 172, 212.

Rocca di Papa, 406.

Rocky Mountains, 296, 297, 337, 341, 342.

Rodman, Gen. Thomas J., 175; his experiments with great guns at Fort Independence, 175-176.

Rogers, Henry D., 100, 116.

Rogers, James, 100.

Rogers, William B., 104; debates of, with Agassiz, 105, 116-117; qualities of, $117 ; 207$.

Rolleston, George, 261-262.

Roman nightingales, 406-407.

Rome, 236, 302, 306; second visit to, 318,320 ; third visit to 405 ; tramps into the surrounding country, 406 ; $407,429$.

Ross, Denman, 381.

Ross, Eng., 267.

Royal Geographical Society, 249.

Royal Society of London, 257.

Royce, Josiah, 359, 418.

"Ruddygore," the opera, 431. 
Ruskin, John, 265.

Ruskin School of Drawing, 265.

Russell, Lord John, 264.

Russell, Thomas, 199.

Russian Jew student, the, 382 ; hardships of, 382-383.

Russian quarter, the, in Boston, 384. Rutland, Vt., 326.

\section{$\mathrm{S}-281$.}

Safford's Geology of Tennessee, 289. Sag Harbor, 10, 69.

St. Augustine, Fla., 330.

St. Clair's defeat, 41 .

St. John's Chapel, Cambridge, 187.

St. Lawrence River, 151.

Salem, Mass., 127, 195.

Salins, 114, 233.

Salisbury Crags, 265.

Salt Lake City, 397-398.

Salvini, Tommaso, 182.

Sanders, Charles, 179.

Sanders Theatre, 179, 250, 443.

Sanford, Col. John, 73.

San Giovanni, Italy, 314, 317.

San Jacinto, battle of, 10 .

San Marco, cabinet of, Florence, 314.

Saratoga, 326.

Sayles, Milton, 44.

Scherer, fencing-master, 43 ; Shaler's relations with, 43-44; anecdotes of, $44-46 ; 51,91$.

Scherer's school of arms, 91 .

"School Vacations," essay, cited, 364, 370.

School of Mines, Freiberg, 243.

School of Mines, London, 289.

School of Mines, Paris, 238, 322.

Scotland, 41; visits to geological localities of, 265.

"Sea and Land," 427.

Sea Caves, 145.

Sea-fowl, 147.

Sea Island district, geology of, 251.

Sea Island negroes, 251.

Secession and Secessionists, 82, 86, 88, 171, 172, 197.

Sedgwick, Adam, 259.
Sedgwick, Me., 253.

Serpentines, in Italy, 305, 306, 307.

Settlers of Kentucky, quality of, 33.

"Seven Gates," 348, 349; development of, 351-352 ; 356 ; life at, 357359 ; conversational "orgies" at, 359 ; the house at, 409.

Seward, William H., 197.

Shaler, Captain, at sea when a lad, 8 ; early master of his own ship, 8; merchant in New York city, 8; privateer in the War of 1812,8 ; his ship finally vanishes from the sea, $8 ; 9,11,24$.

Shaler, Ann Hinde Southgate, 3, 12; forbears of, 16-21; description of, $21-22 ; 23,28,56,68,80$; death of, $88 ; 90,221,300$; Shaler's letters to, 301, 327, 329-331, 419, 420.

Shaler, Elizabeth, 199.

Shaler, Nathaniel Burger, 3; forbears of, 3-11; description of, 1116 ; in Harvard College, 12 ; in Harvard Medical School, 12; practising physician in Havana, 12; settlement and marriage of, in Newport, Ky., 12 ; surgeon at Newport Barracks, 14 ; death of, $15,16,300 ; 18$, $23,24,27,29,35$; views of, on duelling, 42-43, 46 ; interest of, in mineralogy, $49,53-54$; $56,59,60$; college mates and friends of, 68,112 ; $69,88,90,140,182,209,217,224$, $350,377,414,419,426$.

Shaler, Nathaniel Southgate, birth and birthplace of, 3 ; forbears of, on the name side, in England, 3; in America, 4; first on the island of Jamaica, then in Connecticut, 4; farmers with a propensity for fighting, 4 ; great-great-great-grandfather quarrying the red sandstone of the Connecticut Valley, 4 ; greatgrandfather at Berkenridge New Ferry, 4; in the Revolution, 4, 8; grandfather, Capt. Shaler, seafarer, merchant, and privateer, 4, 8; great-uncle, William Shaler, 
navigator, scholar, diplomat, 4, 5-7; great-aunt, Abigail Stilwell, a great dame, 9-10; father, Dr. Nathaniel Burger Shaler, physician in Kentucky, 11-16; ancestors on the maternal side, the Southgates, in England and in America, 16; first settled in Virginia, 16; great-grandfather, Wright Southgate, Virginia merchant and planter, 16; grandfather, Richard Southgate, lawyer, early established in Kentucky, 17; 18-19, 21; grandmother, daughter of Dr. John Hinde, surgeon in the British navy, a large figure in her time and place, 19; mother, Ann Hinde Southgate Shaler, 21-22; inheritances from these ancestors, 23-24; recollections of childhood, 26-48; first memories, 27 ; playing at war, 2829 ; fight with a bully, 30-31; passing from childhood to youth, 31 ; becomes an expert rifle-shot and fencer, 43 ; a memorable fencingcontest, 44-46; the duelling code, 46-48; desultory education, 49-66; early interest in objects of natural history, 49, 52, 53; interest in game-cocks, 50-52; introduction to geology, 53-55; turned toward astronomy, 55-56; early attitude toward religion, 57-58; awakening love of nature, 58-59; formal schooling first at the barracks school, in Newport, afterward with a Swiss tutor, 59-63; youthful love of philosophy, 63 ; first visits from home, 66-70; a journey to Massachusetts with his father, 68-69; first visits to Frankfort and impressions of it, 71-75; a friend of his youth, Thomas F. Marshall, 77-79; a brief contact with Abraham Lincoln, 79-80; member of a debating society discussing States' Rights, 86-87; at Cambridge under a tutor, 90-92; first meeting with Agassiz,
93 ; becomes a pupil of Agassiz, 95; his examination, 96 ; first work in the laboratory, 98-100; the Zoölogical Club, 103 ; relations with scientific men in Boston and Cambridge, 104-111, 113-117; some college companions, 118-129; cruising and camping, 130-133; geological expeditions, 139-169; in the Gulf of St. Lawrence, 139-149; on the island of Anticosti and the Labrador coast, 150-169; fitting for the duties of a soldier, 174 ; at Fort Independence, Boston Harbor, 174176; last year at Harvard, 179192; work and play of student life, 179-184; economies of the Southern students, 187-188; examinations for his degree, 189-192; off to the war, 207, 210, 211; in the Federal service, captain of the Fifth Kentucky Battery, 219-224; return to Cambridge in 1864, 224; his first university appointment, 225 ; takes charge of the regular instruction in zoölogy and geology in the Lawrence Scientific School, 225; first visit to European scenes of geological interest, 226, 228; walks and talks abroad, 228-246; study of mountain structure in the Alps, 228229 ; acquaintances with Swiss geologists, 229, 232; tramps with Edward Tawney, English geologist, 229-233; in Italy, 236-237; in Paris, 237-238; in Germany, 238246 ; teaching and exploring, 247254; investigations for the United States Geological Survey and the Coast Survey, 247, 249; unearthing fossil remains of elephants at Big Bone Lick, 247-248; plans for developing the work at the Museum of Comparative Zoölogy, 248; various scientific expeditions, 251 , 253, 254; abroad again, 1872-1873, 255-269; visits to London, Cambridge, Oxford, 257-265; in Scot- 
land, visiting classic geological localities, 265-266; in various old English places, 266-269; field work, 1873-1879, 270-299 ; appointed director of the Kentucky Geological Survey, 271; Camp Harvard, summer school at Cumberland Gap, 273, 274-275; progress of the survey, 275-278; letters written during this work, 278-282, 284288, 289-296; on Coast Survey work in New England, 282-284; in Colorado, 297; constantly promoting the interests of the Museum of Comparative Zoölogy, 297298 ; third visit to Europe, 1881-82, 299-325; in Florence, 299; long tramps for the exploration of Italian geological localities, 300 ; record of, from notes kept while in Italy, 302-321; again in Paris and in England, 322-324; relations with Gordon McKay, 327-328; urged to head the United States Geological Survey, 328; researches on the Florida coast, 321; mine prospecting and other experiences, 1881-1891, 334-347; as a mining expert, 334-340; writing a poem in the intervals of his taxing professional work, 339 ; remarkable output of literary work and scientific reports, 342-343; homes in Cambridge, 344-346; country living, 348-360; on Martha's Vineyard, 348, 351, 356; life at "Seven Gates," his "Farm" there, 349, 351-359; his love of landscape, 355-356; as the teacher, 1864-1905, 361-385; social life of the Cambridge of the Eighteen-seventies, 363 ; lofty view of the teacher's vocation, 364-365; his lecture-notes, 365-366; geological excursions with his students, 368-369; establishing the Harvard Summer School, 369, 372 ; concerned in the founding of Radcliffe College, 373; relations with his students, $375-378,382-$ 385; the "University Teas," 379 ; the Sunday evening students' receptions at the Shalers' house, 379382; administrative work, 18911903, 386-401; appointed dean of the Lawrence Scientific School, 1891, 386; large development of it under his direction, 387; his attitude upon the McKay bequest and the "merger" project, 387-390; his active part in faculty meetings, 392-396; work on Massachusetts State boards, 396-397; hard work and long journeys, 397-398; Lowell Institute lectures, 401; last years, 1904-1905, 402-412; a "sabbatical" abroad, 402; in Egypt, Greece, Sicily, Italy, 402-407; at home again and his duties resumed, 408; closing of his life, 409410 ; death and burial, 411 ; personal characteristics, 412-423; nature and variety of his literary work, 424-442; his dramatic romance, "Elizabeth of England," 439-443; his last volume, "From Old Fields," 443; appreciative tributes, 443-445.

Shaler, Sophia Penn Page, 55 n., 218 $n$.; letters to, quoted, $220 n$., 225 , 443-444, 445; 227, 242 ; journal of, quoted, 261-263, 264-265, 266269 ; 272, 287, 391, 445.

Shaler, William, 5; story of, 5-7; early master of his own ship in foreign trade, 5; involved in the French Revolution, 5; voyage about the world with the "merchant-navigator" Cleveland, 5; adventures in South America, 5; in government employment, 6 ; United States consul at Algiers, 6; aids the French in the expedition against Algiers, 7; consul at Havana, 7; death there, 7 ; his personality, 8-9; his library in the Boston Public Library, 10; 12, 24, 193, 199. 
Shaler, William, second, 11.

Shaler's battery. See Fifth Kentucky Battery.

Shaler's journal. See Journal, Shaler's.

Shaler's letters. See Letters.

Shaler's note-books. See Note-books.

Shayler, or Shaylor, family in Warwickshire, 3.

Shaw, Pauline Agassiz, 271.

Shaw, Quincy A., 271.

Shelbyville, Ky., 247.

Sheridan, Gen. Philip H., 174.

Siberia, the steamship, 255.

Sibley, John Langdon, 179.

Sicily, 318, 405; study of Etna, 405; at Taormina, 406.

Silk culture, domestic, in Kentucky, 83,84 ; in Italy, 316.

Silk-manufacture, in Kentucky, 83, 84.

Silurian system, study of the, 139, 150, 152.

Simons, Rev. Mr., a squire-parson, 256.

Slave-traders. See Negro-traders.

Slaveholders, 170, 195, 199.

Slaves and slavery, 21, 26, 27, 32, 33, 34 ; theories of Kentucky slaveowners, 36 ; status of the slaves in Southern households, $36-37 ; 38$, $57,80,82$; fugitive slaves, $83 ; 84$; growth of a proslavery party, 86; $112,170,195,196,199,216,242$, $349,362$.

"Sleep and Dreams," 430.

Small, Skipper, 140, 141, 143; the skipper and the gulls, $147 ; 148$, 152, 153, 164 .

Smith, Gen. Kirby, 219, 221.

"Smugglers, The," 221.

Smyth, Henry L., 418.

Social systems in settlements on either side of the Ohio, 32-33.

Somerville, Mass., 185, 202.

South, the, $82,84,87,155,170,173$, $186,195,196,197,201,216,260$; Shaler's papers on, 291.
South Carolina, 86.

South Park, Col., 342.

Southern Club, 410.

Southern Confederacy, 171, 172, 173, $212,433$.

Southern people, the, 195.

Southern States. See South, the.

Southern students at Harvard, 195; division between them and the Northern students, 195.

Southern sympathizers, $86,173,196$, 216.

Southerners, 170, 187, 196, 219.

Southgate, Ann. See Shaler, Ann Hinde Southgate.

Southgate, Henry, 21.

Southgate, Richard, of Virginia, 17; at William and Mary College, 17; becomes a lawyer and moves to Kentucky, 17; practises his profession and amasses a fortune, 17; death of, 17; an example of the old class of Virginia gentlemen, $18 ; 19$, $21,23,35$; treatment of his slaves, $37-38 ; 47,49,60$; farm of, $66 ; 80$, 83,84 ; supposed to have figured for "St. Clare" in "Uncle Tom's Cabin," 85; 90, 186, 193, 202, 209, 221, 350 .

Southgate, Mrs. Richard, 19 ; qualities of, 19.

Southgate, William, 21, 74 .

Southgate, Wright, the emigrant in Virginia, 16; becomes a merchant and planter there, 16; marries Miss Lush of Albany, N. Y., 16; his principal shops in Richmond, 17; 19.

Southgate family, in London, 16; origin of the name, $16 ; 23$; in Kentucky, 34 .

Southgate, town, 50 .

Spain, 241.

Spanish Main, buccaneers on the, 23.

Spiders, Shaler's boyish studies of, $49,96$.

Squam Lake, 351.

"Squarson," the, 256. 
Stadiums, the Harvard and the Grecian compared, 405.

Stage-coaching, 47.

Stallo, John B., 62.

"States'-Right" view, the, 86, 87, 171; States'-Rights group in Kentucky, 173; 174, 211, 219.

Staunton, Va., 326.

Sterling, 266.

Stillman Infirmary, 377.

Stilwell, Abigail, 5, 7; stately home of, in Lancaster, Mass., 9, 10; an example of the great dame, 9 ; her family stories, 9 ; her children and grandchildren, 10;11, 68, 193.

Stilwell, Elias, 357.

Stilwell, Elias Millard, 10-11.

Stilwell, Mr., 332.

Stimpson, William, 97, 104, 127; qualities of, $128-129 ; 130,132,133$; incident of his merry humor, 163164.

Stone, Miss, archæologist, 405.

Stone River, 123.

Storer, N. M., 397.

"Story of Our Continent," 427, 428.

Stowe, Harriet Beecher, 84, 85.

Stuart, David, 10.

Stuart, Elizabeth (Stilwell), 10.

Stuart, Gen. James E. B., 74 .

Students' amusements, 182 ; marching in gang to and from the play and opera in Boston, 183; fishingparties outside Boston Harbor, 183; a little fun with the Boston police, 183 ; revenge on a bore, 184 . Students' Reception Committee, 379. Subiaco, 406.

Sullivan, Sir Arthur, 431; hint for the plot of his "Ruddygore," 431. Summer School of Geology, 272, 273. Summer School of Natural History, 272.

Summer Schools, 258, 272, 273-275, $277,281,289-290,294,295,369$, 408; proposed, 426.

"Summer's Journey of a Naturalist," 430 .
Sumner, Charles, 195.

Sumter, 170.

Sunday afternoon receptions at the Shalers', 345, 346.

Sutherland, Lee, a gentleman vagabond, 38-39.

Swamp lands, report on, 429.

Swiss guides, 229.

Switzerland, travels and geological explorations in, 228-229, 231-236; incidents of sojourns in remote places, 231 ; target practice in the village of B., 231-232; a unique spectacle in Le Locle, 232-233.

T—, Col., of Frankfort, 279.

T-, Edward, 293.

Taliaferro, Richard, pioneer, 84.

Tampa, Fla., 330.

Taormina, 406.

Tawney, Edward B., 229; Shaler's adventures with, 230,$231 ; 268$.

Taylor, Edmund, 71.

Taylor, Gen. Zachary, 88.

Taylor family in Kentucky, 34.

Teacher, Shaler, the, 361-385.

Tenantry in early days of Kentucky, shiftlessness of, 34-35; homes of, 35.

Tennessee, 172, 289.

Tennessee mountains, 66.

Tennessee River, 32.

Tewkesbury, Eng., 266; the abbey church, 266-267.

Thompson, Benjamin, 176.

Thompson, Lieut., later Major, artillerist, at Fort Independence, 176 ; a hard disciplinarian, 176 , 177; coolness of in action, 177; the "true type of a soldier," 178.

Thompson, William H., 258, 259.

"Thoughts on the Nature of Intellectual Property," 426.

Thursday Club, 417.

Ticknor, George, 9, 139, 193; Boston home of, 193, 194, 198; quality of, 194, 197; 199, 200.

Ticknor, Mrs. George, 193. 
Tilden, Samuel J., 291.

Tilly Foster Mine, 293.

Tisbury, Mass., 252, 346, 347.

Tisburys, the English and American, and Rudyard Kipling, 346-347.

Torrey, Henry W., 185.

Trading ports in Labrador, 160-161. Travers, Val de, 289.

Treat, Captain, of Eastport, 139.

Treat, Upton, sailor, 140.

Trenton, N. J., 428.

Trenton Point, 133, 134.

Triassic sandstones, 145.

Trilobite bed, the only, in New England, 368.

Trinity College, Cambridge, Eng., 258, 259.

Tuscan guide, 304 .

Tuscan mountains, 307, 309.

Tuscany, garden region of, 306; tramps in, 302-318; mountains of, 307, 309; on Monte Ferrato, 307, 308 ; in winter, 307, 309; 310; Monte Morello, 312-313 ; 314, 315; lignite mines and their working, 316-317.

Tyndall, John, 229, 257.

Umbagog Lakes, 135; sport at the, 136-137.

"Uncle Tom's Cabin," 84, 85; characters of, supposed to have been drawn from Newport, Ky., and its neighborhood, 85; Richard Southgate pictured in St. Clare, Legree sketched from a neighbor, 85 ; the incident of Eliza's flight drawn from an old local tradition, 85; 195.

"Underground Railroad," 83.

Union, the, $82,87,88,142,172,173$, $174,210,211,216,433$.

Union soldier, the, 432 .

Unionists, in Kentucky, 171, 172, $173,197,432$.

United States, 32, 73, 91, 157, 159, $161,242,249,261$.

"United States, The," 427.
United States Coast Survey, 247, 249, 270,271 ; work on, in New England, 282-284; 348; Reports upon, 427.

United States Geological Survey, 247, 328; Reports upon, 343, 426, 427,429 .

University of Texas, 124.

University of Upsala, Sweden, 11.

University of Virginia, 194.

University Catalogue, the, 387 .

University Hall, 344, 437.

University Press, 187.

"University Teas, The," 379, 399.

Ursuline convent, 202, 203-204.

"Use of Numbers in Society," 430.

Vacation schools, $369,370$.

Val d'Arno, 314, 317, 356.

"Valor," 427, 443.

Vanceburg, Ky., 284.

Vaughan, teacher in the Newport Barracks school, 55; anecdotes of, 55 n.; 56.

Verrill, A. E., 97, 139.

Versailles, Ky., 79.

Vesuvius, 237, 318; notes on the ascent of, 319-320; 321; a farewell view of, 407.

Via Romana, 309.

Vicenza, 237.

Victoria, Queen, 264.

Vienna, 240.

Villas, Italian. See Italian villas.

Vineyard Sound, 354-355.

Virginia, 16; colonists of Kentucky from, 19, 34, 84; Virginia system of land grants inherited by Kentucky, $32 ; 36,41,66,116,172,195$, $218 n$.; 253, 254, 260; 293, 369, 398.

Virginia mountains, 326.

Virginia oyster, the, 168.

Volcanoes, extinct, studying the phenomena of, 237.

Waggener, Leslie, 121; a story of, after the Civil War, 123-124; president of the University of Texas, $124 ; 208$. 
Walcott, Dr. Henry P., 343.

Walks, in the country about Boston, 201-205, 368-369; along the seashore, 205; abroad, 228; among the Alps, 229; through a part of the Rhone Valley, 234; out on the Campagna, 236; in Italian towns, 236-237; in England, 255; in and about Florence, 299-300; from Florence to Impruneta, 302-304; 305-306; between Prato and Monte Ferrato, 306-309; about Martha's Vineyard, 353, 358, 360; 399; in the country about Rome, 406; 413.

Wallace, Alfred Russel, 186.

Wallace, Col. Lew, 220.

Waltham, Mass., 232.

War Department, 277, 278.

War of 1812, Capt. Shaler a privateer in, $8 ; 41$.

Warren, Dr. John Collins, 12, 53.

Warwickshire, Eng., ancestors of Shaler there, 3.

Washington, D. C., 163, 329.

Water cure at Dresden, 238; acquaintances made in, 239-240.

"Way with the Mutineers, The," 222.

Webb, Mrs. Willoughby L., 409.

Welsh, German drawing-master, 58.

Wendell, Barrett, memories of Shaler in the Harvard faculty, 392-395.

Werner, Abraham Gottlob, 243.

West, Benjamin, 20.

West Point, 10, 90.

Westmorly Hall, 254, 344 .

Weymouth River; 368.

Wheatland, Richard, 97, 127-128.

Wheeler, Gen. Joseph, 74.

Whigs, 82.

Whitby, Eng., 268.
White Mountains, a tramp over Mt. Washington, 192; 329.

White Sulphur Springs, Va., expedition from Cambridge to, $253 ; 254$, 329.

Whitney, Josiah Dwight, 227.

Whittier, John G., 195.

Willard, Ky., 286.

William and Mary College, 17.

Winlock, Joseph, 247.

Winsor, Justin, 343, 426, 427.

Wolff, John Eliot, 418.

Woodworth, Jay B., 418.

World's Work, The, quoted, 367.

Wright, Chauncey, 283.

Wye, the river, 267.

Wyman, Jeffries, 104; characterization of, 105-107; 109, 111, 189, 190, 208.

Wyman, Dr. Morrill, 107; characterization of, 107-109.

Wyman, Rufus, qualities of, 109.

"X," a collaborator of Agassiz, 114.

Yankee, the, of caricature, 85; Yankee life, 128; 143, 144.

York Cathedral, 267-268.

Zermatt, 234.

Zoölogical Club, 102, 103, 116, 119, 120, 186, 204.

Zoölogical Garden, Dresden, 241.

Zoölogical Hall, 102, 106, 119, 120, 186.

Zoölogical Museum. See Museum of Comparative Zoölogy.

Zoölogy, studies in, 100, 101, 111, 117, 127; Shaler instructor in, 225; 275, 297. 
(Che thiurerido preg

CAMBRIDGE - MASSACHUSETTS

$\mathrm{U} \cdot \mathrm{S} \cdot \mathbf{A}$ 



ing

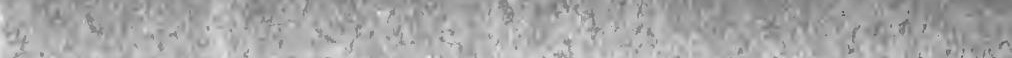
2.

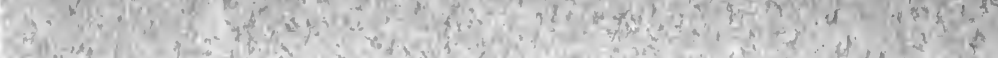

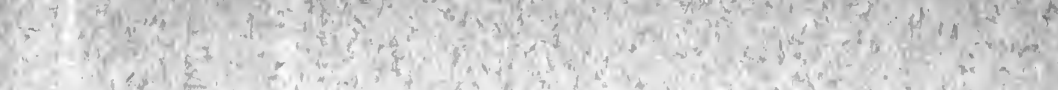

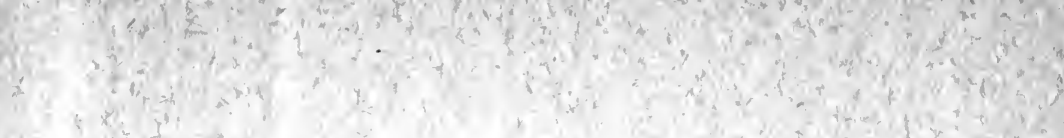

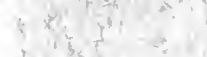
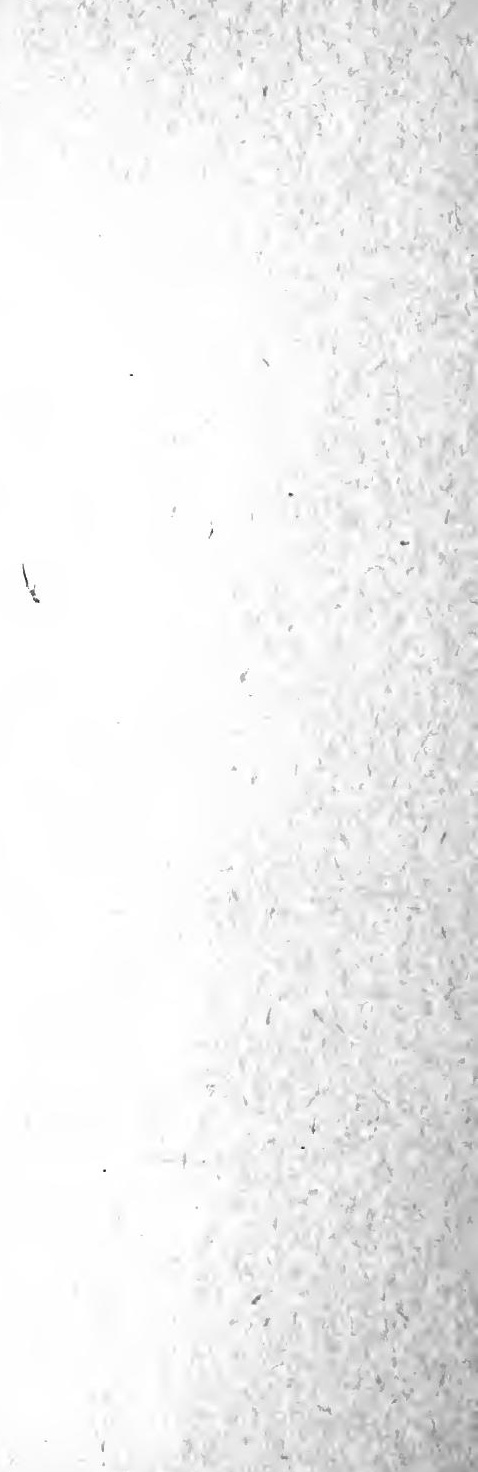

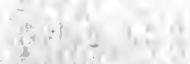

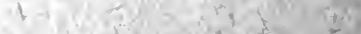

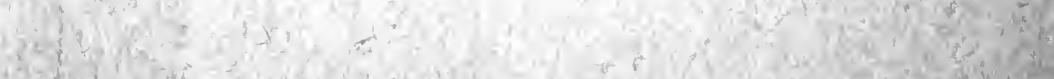

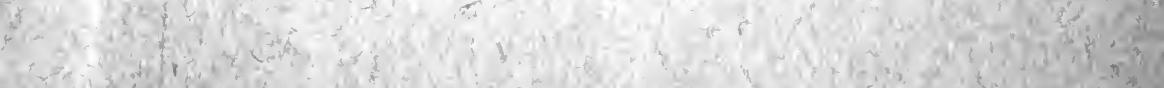
(1) 
